2. To: (Receiving Organization)

Remote System and Sensor Applications

5. Proj./Prog./Dept./Div.:

Sensor/Analytical Technology Projects

8. Originator Remarks:

Documents contain 1971-1974 data record inventory logs for BY-Tank Farm.

11. Receiver Renarks:

3. From: (Originating Organization)

Remote System and Sensor Applications

6. Cog. Engr::

F. R. Reich $818800 / N 2183$ (2)
4. Related EOT No.:
$N / A$
7. Purchase Order No.:
$N / A$

9. Equip./Component No.:

$N / A$

10. System/Bldg./Facility: $N / A$

12. Major Assm. Dwg. No.:

$N / A$

13. Permit/Permit Application Mo.: N/A

14. Required Response Date: $N / A$

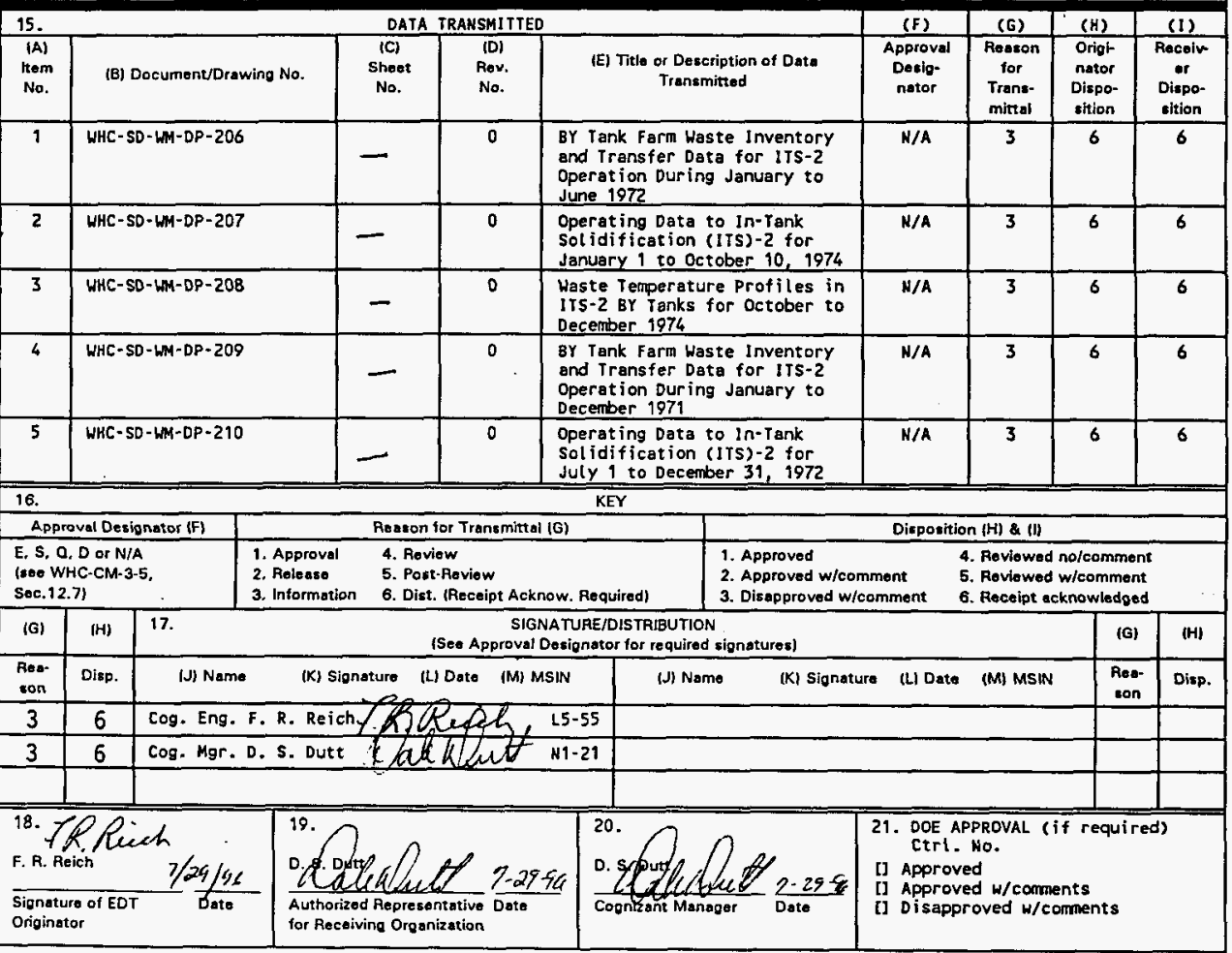

BD-7400- $772-2(04 / 94)$ GEF097 


\section{Operating Data to In-Tank Solidification (ITS)-2 for January 1 to October 10, 1974}

F. R. Reich

Westinghouse Hanford Company, Richland, WA 99352

U.S. Department of Energy Contract DE-AC06-87RL10930

EDT/ECN: 617410

Org Code: 8 A800

B\&R Code: EW4010000
UC: 721

Charge Code: N2183

Total Pages: 203
$279 \mathrm{~m}$

Key Words: ITS-2, BY tank temperatures/data, waste solidification data, operating data, pressure, temperature, profile

Abstract: Data sheets containing date, time, feet above bottom, temperature, comments. Operating data to In-Tank Solidification (ITS) -2 for January 1 to October 10, 1974.

\section{BEST AVILABLE COPY}

TRADEMARK DISCLAIMER. Reference herein to any specific comercial product, process, or service by trade nane, trademark, manufacturer, or otherwise, does not necessarily constitute or imply its endorsement, recomendation, or favoring by the united states Government or any agency thereof or its contractors or subcontractors.

Printed in the United States of America. To obtain copies of this document, contact: WHC/BCS Document Control Services, P.O. Box 1970, Mailstop H6-08, Richland HA 99352, Phpne (509) 372-2420; FBX (509) 376-4989.

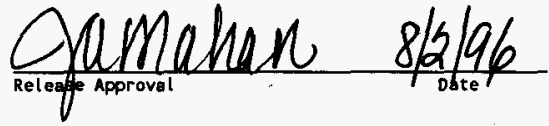

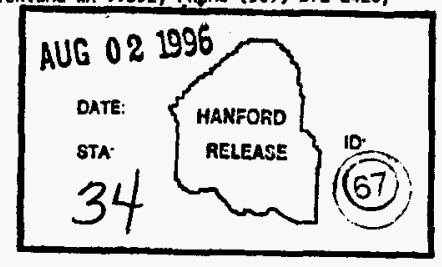

Release Stamp 
Document Date: None given

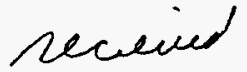

Document Number: None given

RHA Box Number: 58099

File Number: None given

Title:

DATA SHEETS TITLED PROFILE TEMPERATURES IN ITS-2 BOTTOMS TANKS

Description:

APPROXIMATELY 400 DATA SHEETS IN NON-TITLED PRESS BINDER

Comments:

DATA INCLUDES DATE, TIME, FEET ABOVE BOTTOM, TEMPERATURE, COMMENTS. DATES FROM $1-3-73$ TO $10-8-74$

Addressee, Company:

Author:

Company:

Tank \#:

241-BY-102

241-BY-103

241-BY-104

241-BY-106

$241-B Y-107$

241-BY-109

241-BY-110

241-BY-112

Keywords:

PROFILE TEMPERATURE

References: $N$

\# References: None given

Action Required: $N$

Topic: None given

Action Taken: None given

User: RL HORNE

User Datë: 03-20-92 07:33:51

Reviewer: ULBRICHT RS

Review Date: 03-05-92

Checked By: SCHWARZ RM

Checked Date: 03-05-92

WTS Key: 870

Document Type: DS 
Title:

PROFILE TERPERATURES IN ITS-2 BOTTOMS TANKS

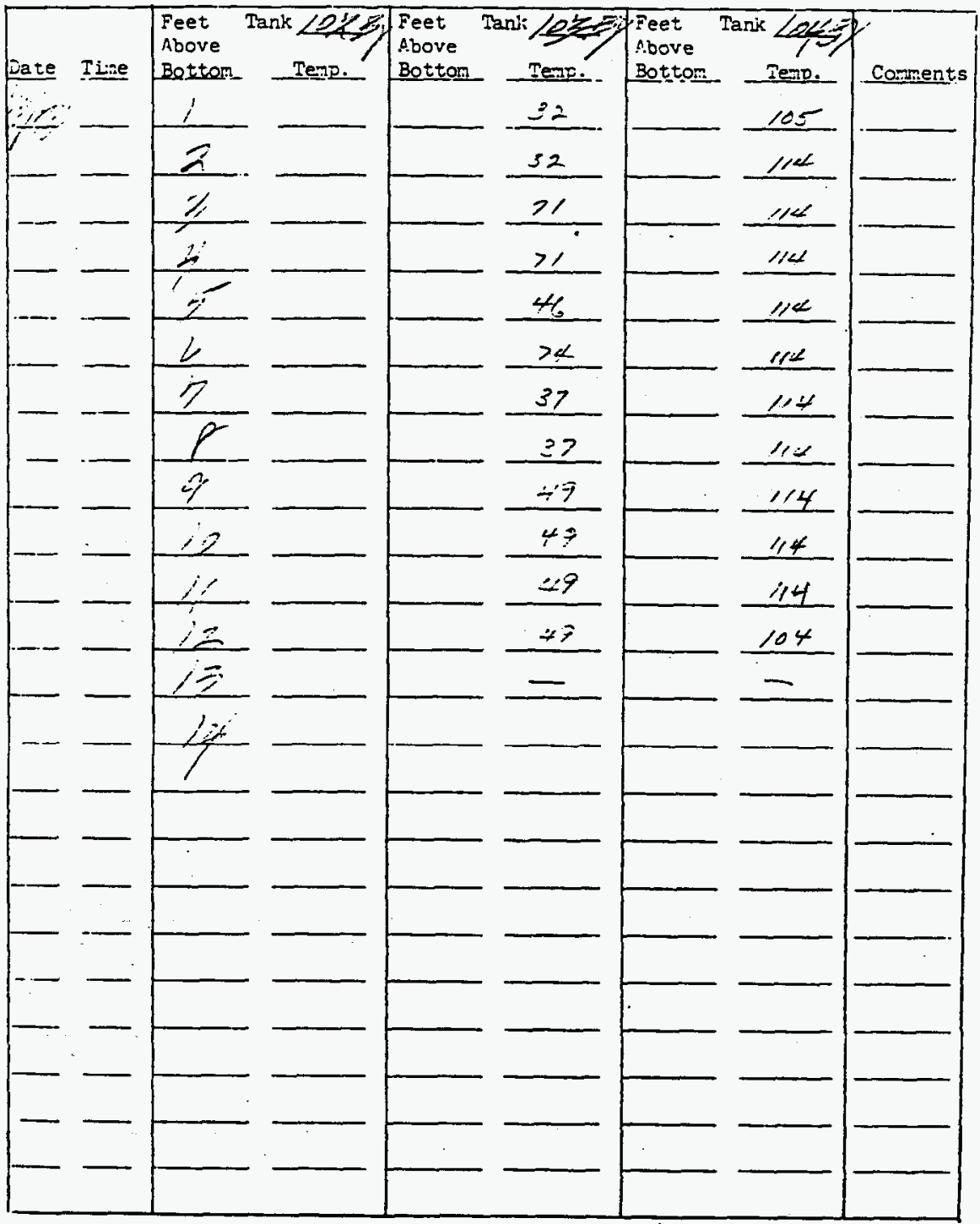

Ins:r:itions or coments: - Take profile temperatures weekly in each bottoms tank. Attach completed form to Mondi $Y$ and Thursday's Dats sheets. 
Title:

PROFIIE TEMPERATURES IIT ITS-2 BOTTOMS TAIKS

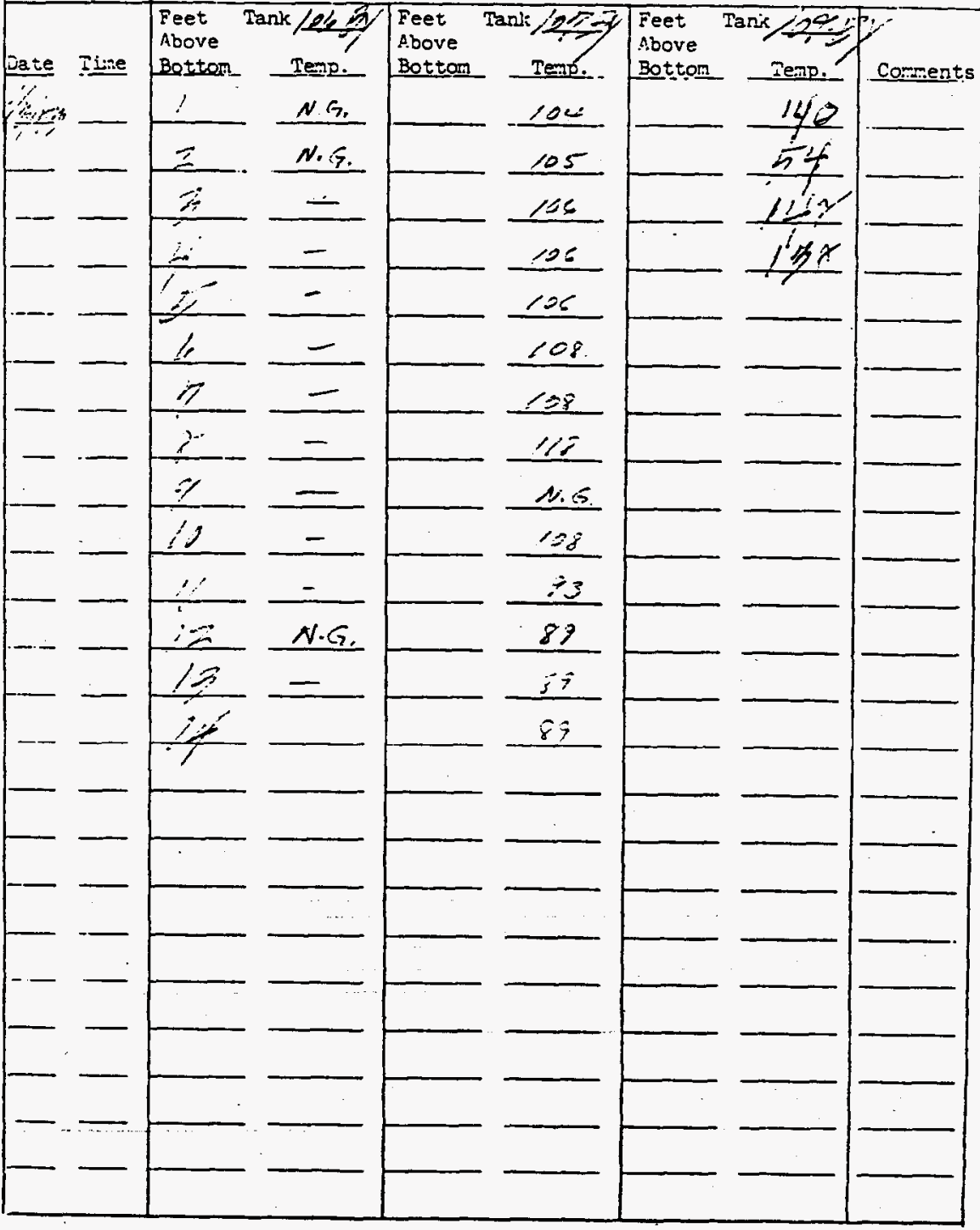

Instrictions er coments: -Take profyle temperatures weekly in each bottoms tank. Attach completed forn to Monday and Thursday's Data sheets 
Title: PROFTLE TEIPERATURES IN ITS-2 BOTTOMS TANKS

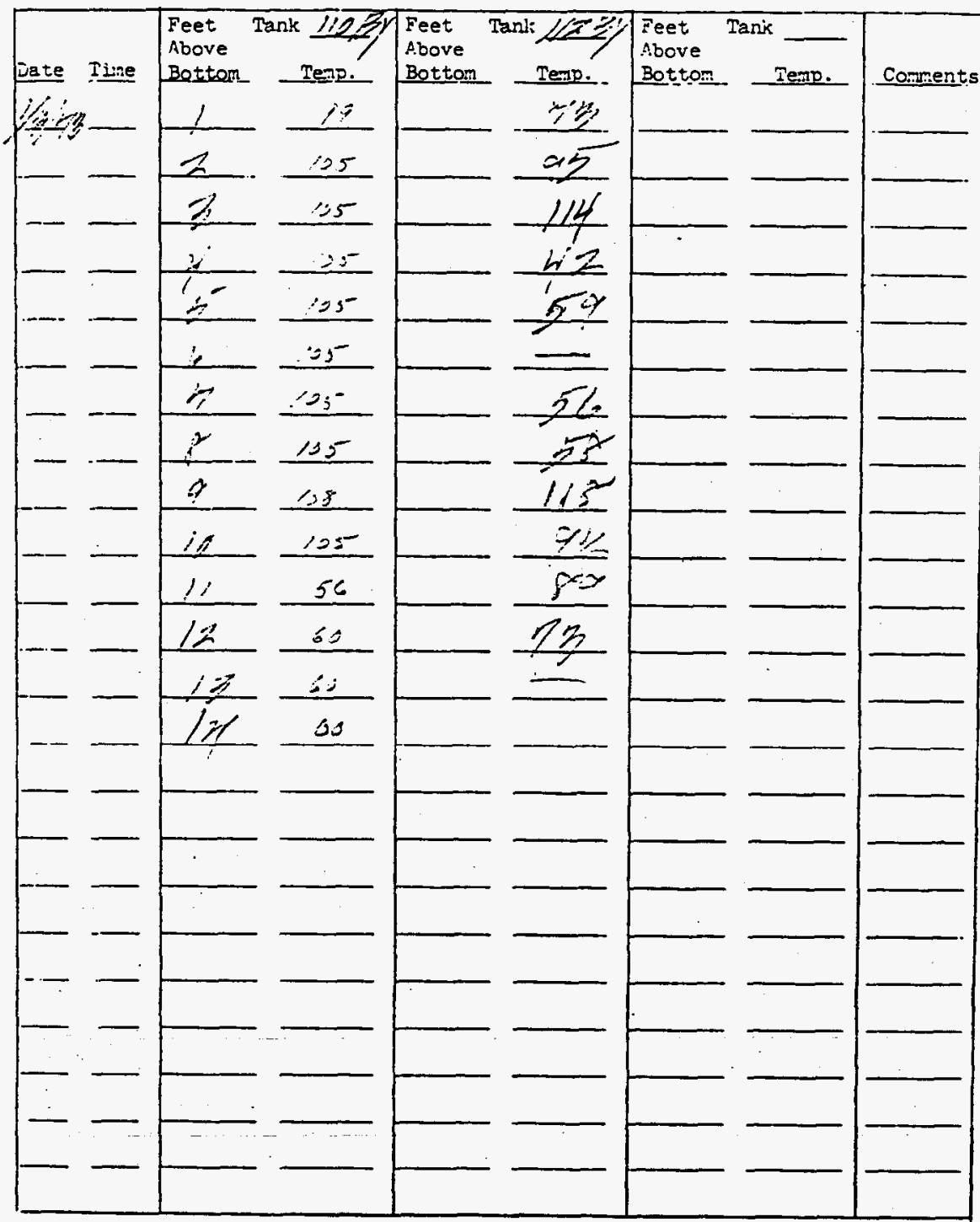

Irjtrictions or co:meats: - Take proflie temperatures weekly in each bottoms. tank. Attach coapleted forr to Monday and Thursday's Data Sheets. 
Title:

PROFILE TETRERATURES TI ITS-2 BOTTOMS TANKS

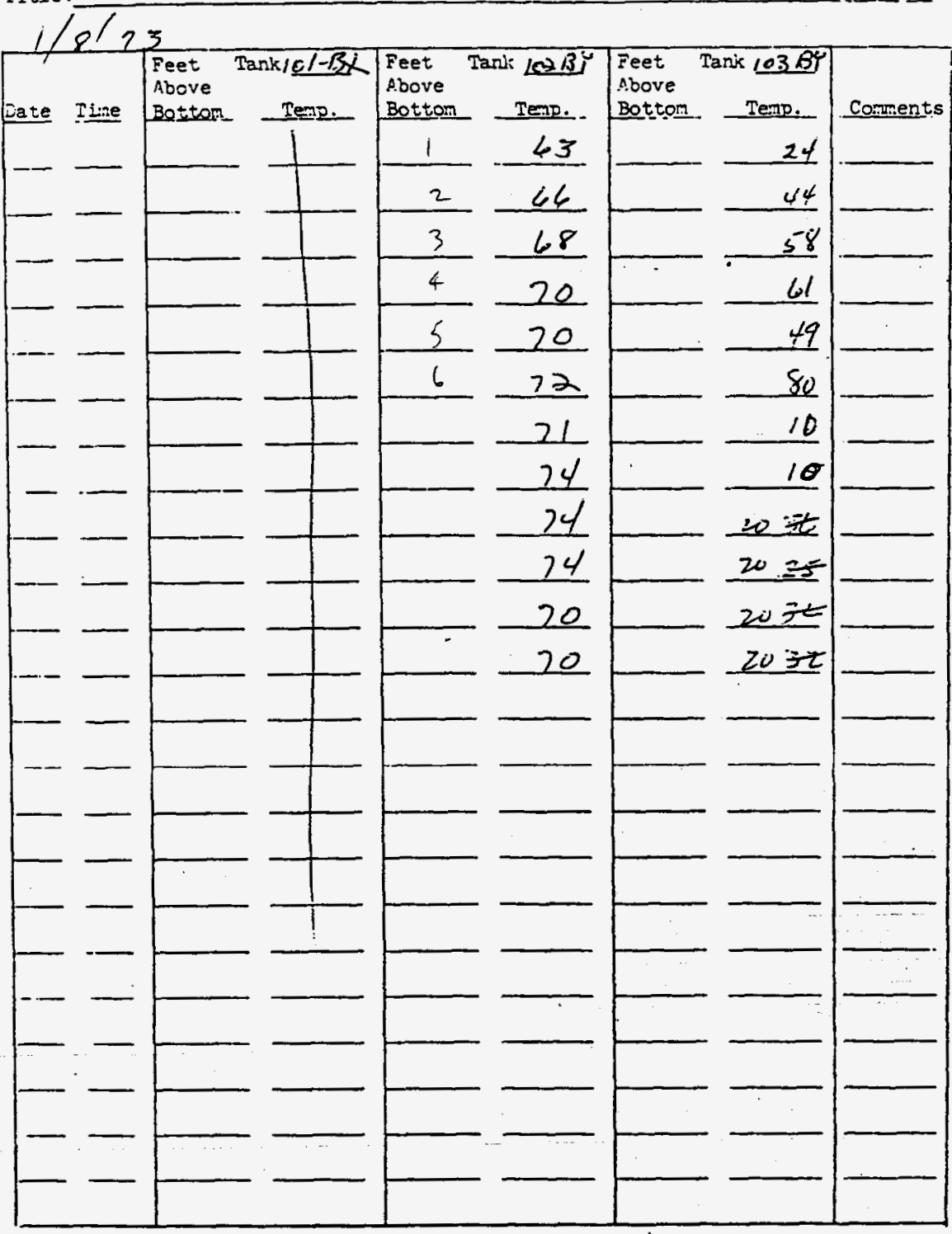

I-3:ristisns or coments: Trake profile temperatures reekly in each bottoms tank. Attach conpleted form to Monday and Thursday's Data Sheets. 
Title:

PROFILE TEMPERATURES IN ITS-2 BOTTONS TANKS

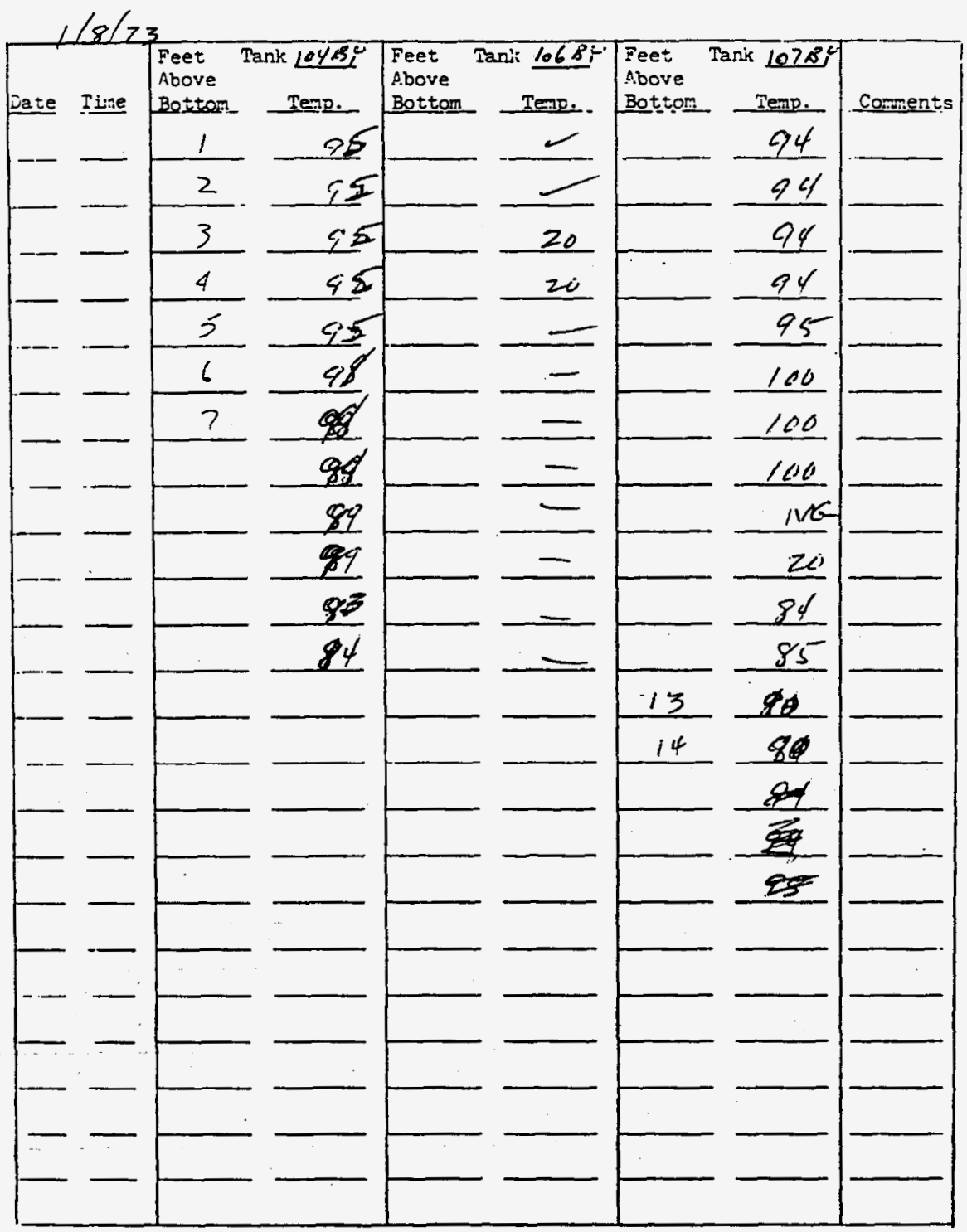

Irstriftions er coments: Take proflle temperatures yeekly in each hattoms tank. Attach completed form to Monday and Thursday's Data Sheets. 
Title: _ PROFIIE TERERATURES IN ITS-2 BOTTOMS TAITKS

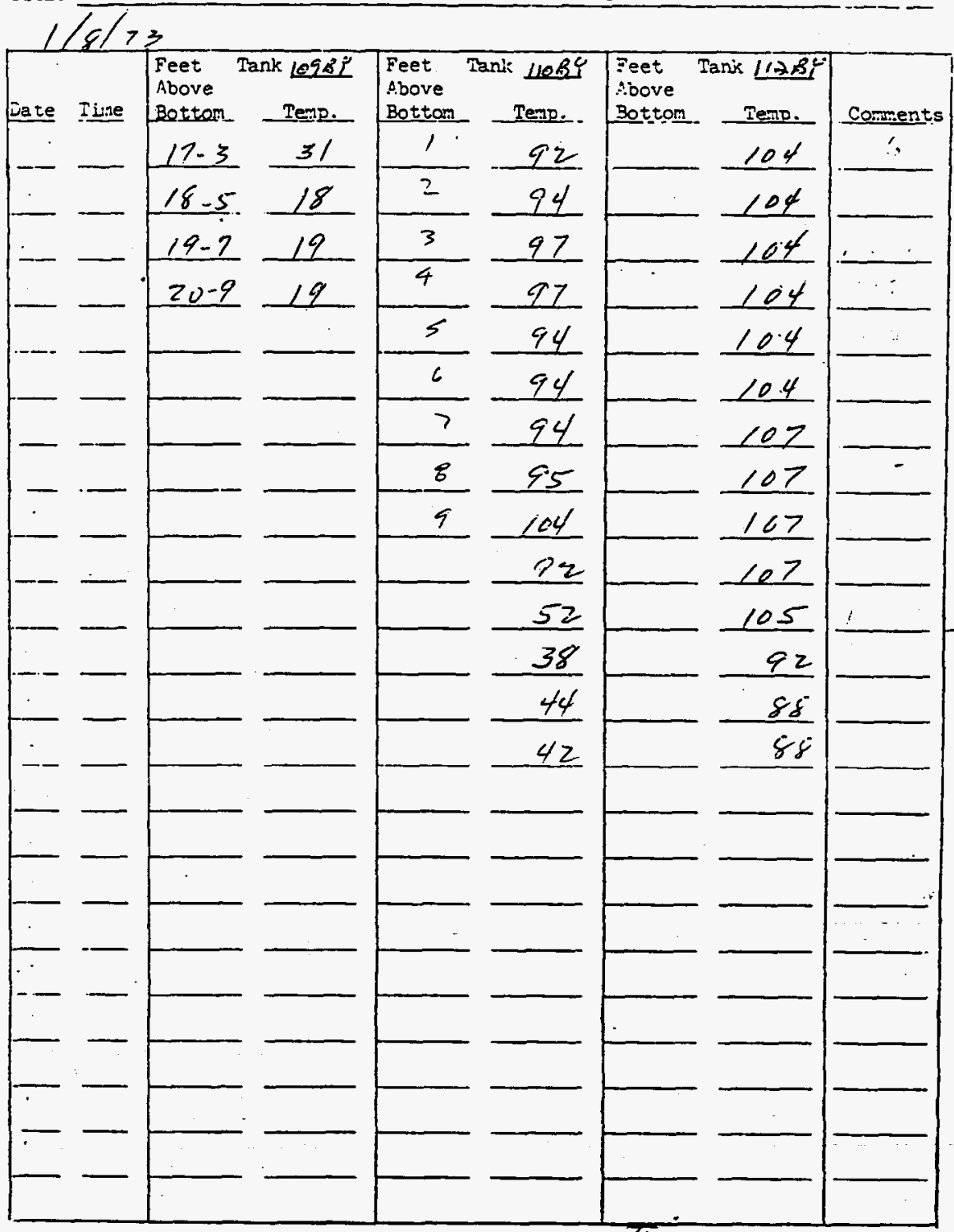

Ir:iristions or coments: - Take profile temperatares weekly in each bottoms tank. Attach coapleted form to Monday and Thursday's Data Sheets. leportany Rerecalues above 
Title:

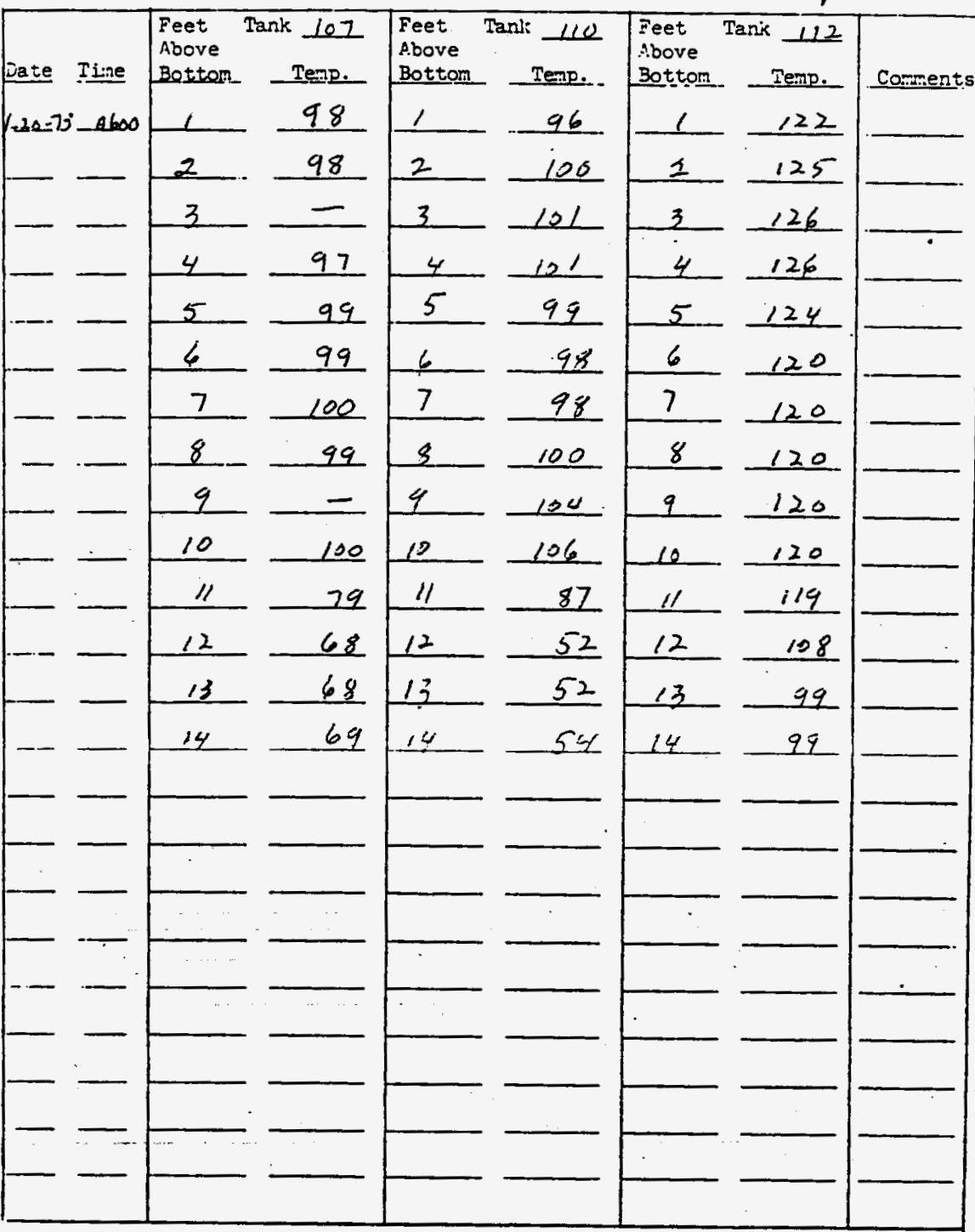

I:3ir:sions cr coments: Take profile temperetares weekly in each nottoms. tank. Attach completed form to Monday and Thursday's -Data Sheats 
Title :

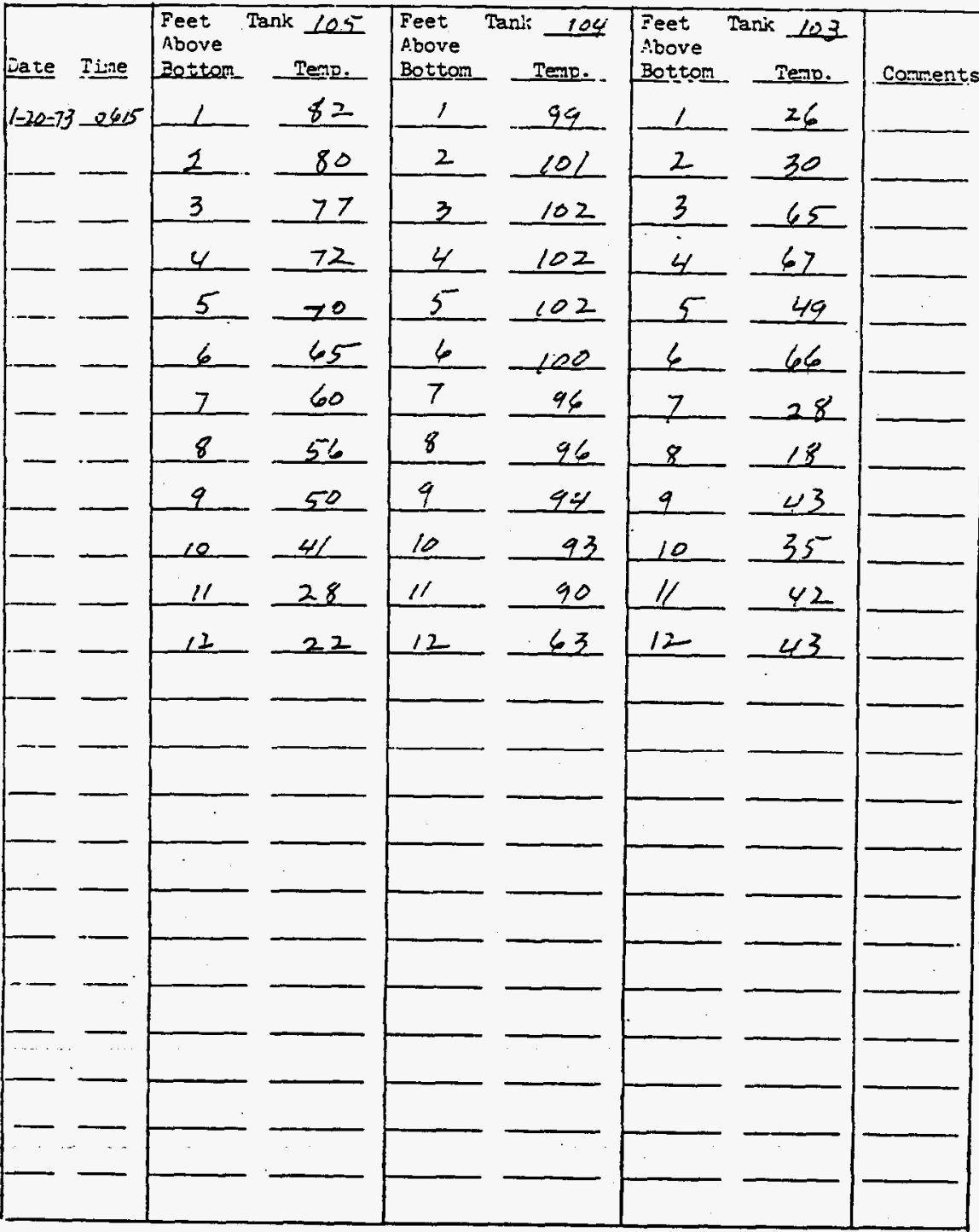

Instriations or connents: -Take proflle temperatures reekly in each hattoms tank. Attach conpleted form to Monday and Thursday's Data Sheets 
Title: PROFILE TERAPERATURES IN ITS-2 BOTIOMS TANKS

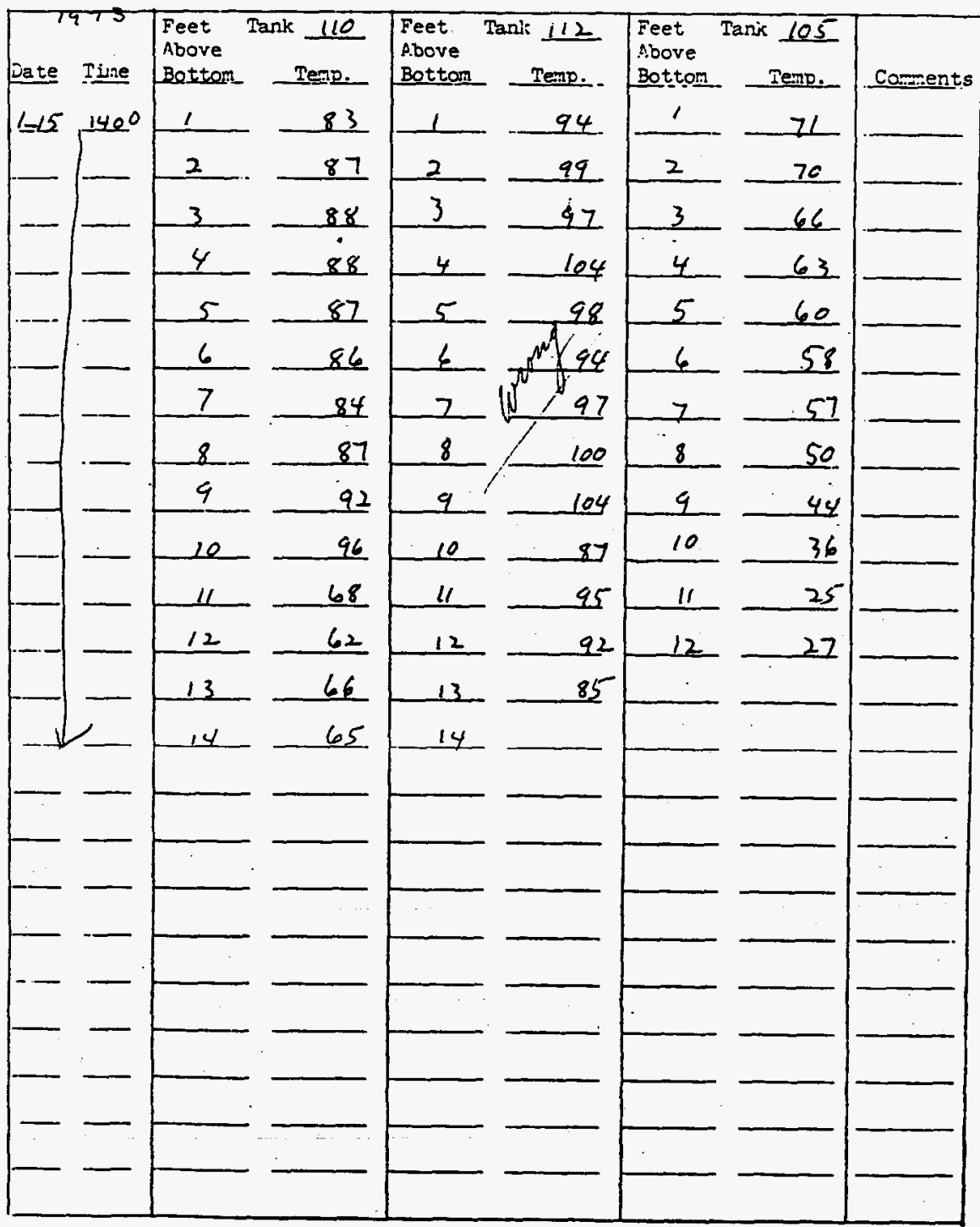

Instristions or coments: - Take proflle temperatures veekly in each bottons. tank. Attach completed form to Monday and Thuesday's Data Sheets. 
Title: PROFIIE TEMTERATURES IN ITS-2 BOTTOMS TANKS

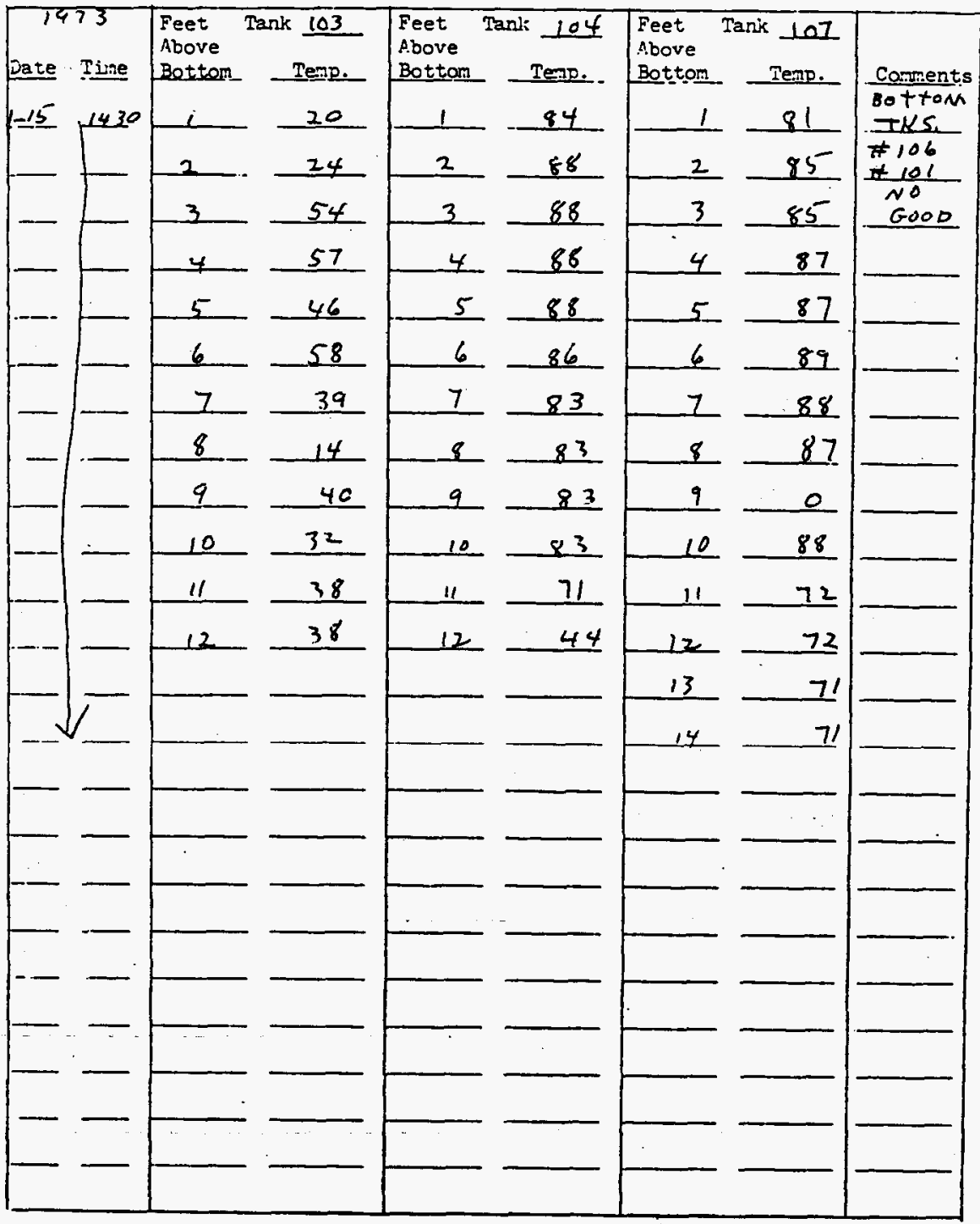

Ir:stristions or cormenis: Pake profile temperetures veekly in each bottoms tank. Attach congleted form to Monday and Thursday's Data Sheets. 
Title: PROFILE TERERATURES IN ITS-2 BOTIONS TANTS

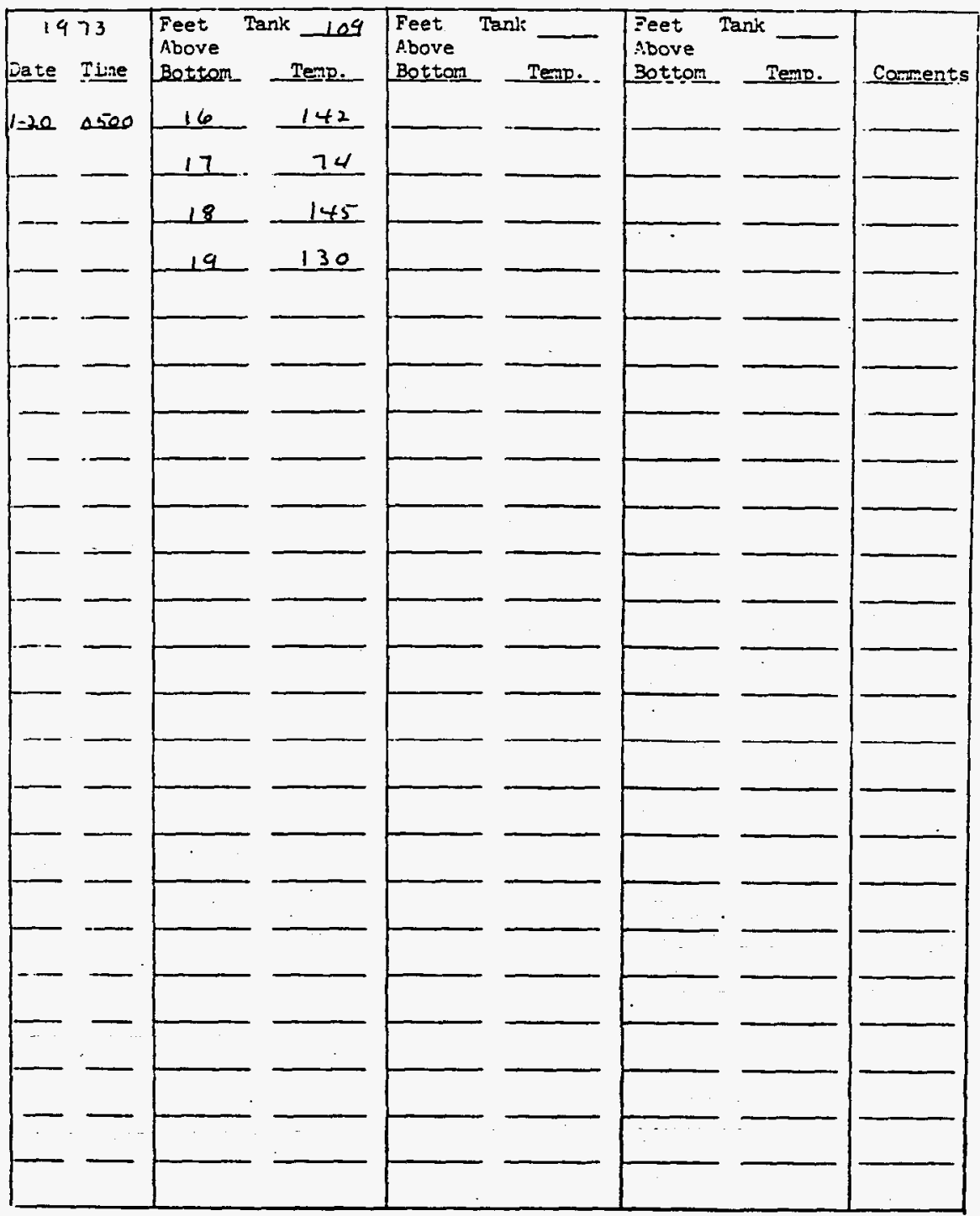

Irsiristions ar coments: Take profile temperatures veekly in each bottoms tank. Attach canpleted form to Monday and Thursday's Data Sheets. 
Title: PROFIIE TMPMERATURES TI ITS-2 BOTTONS TAIKS

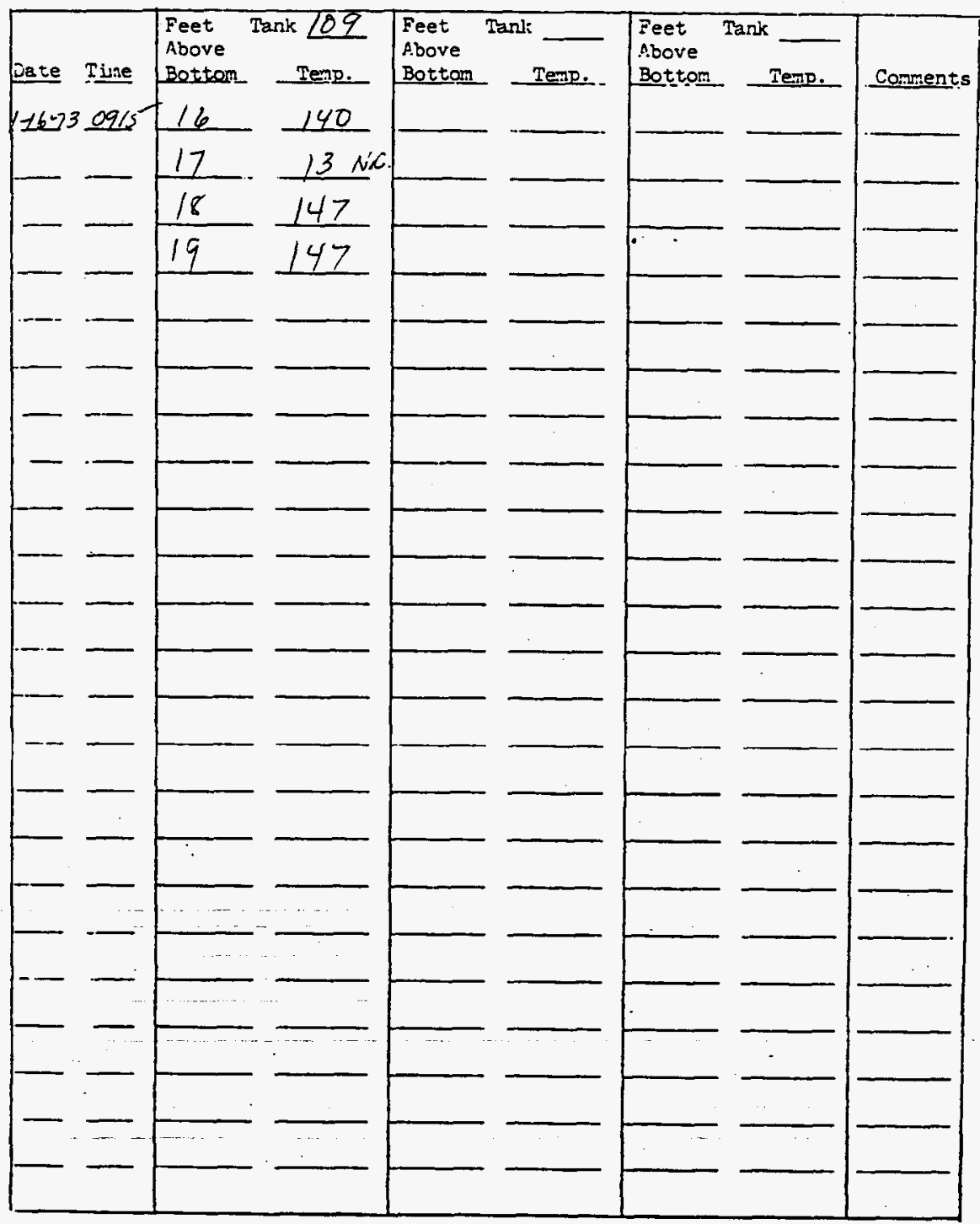

Ir:jiriotions or coments: -Take profile temperatures veekly in each hottoms tank. Attach conpleted form to Monday and Thursday's Data sheets. 
Title: PROFIIE TEYPERATURES IN ITS-2 BOTMONS TAYKS

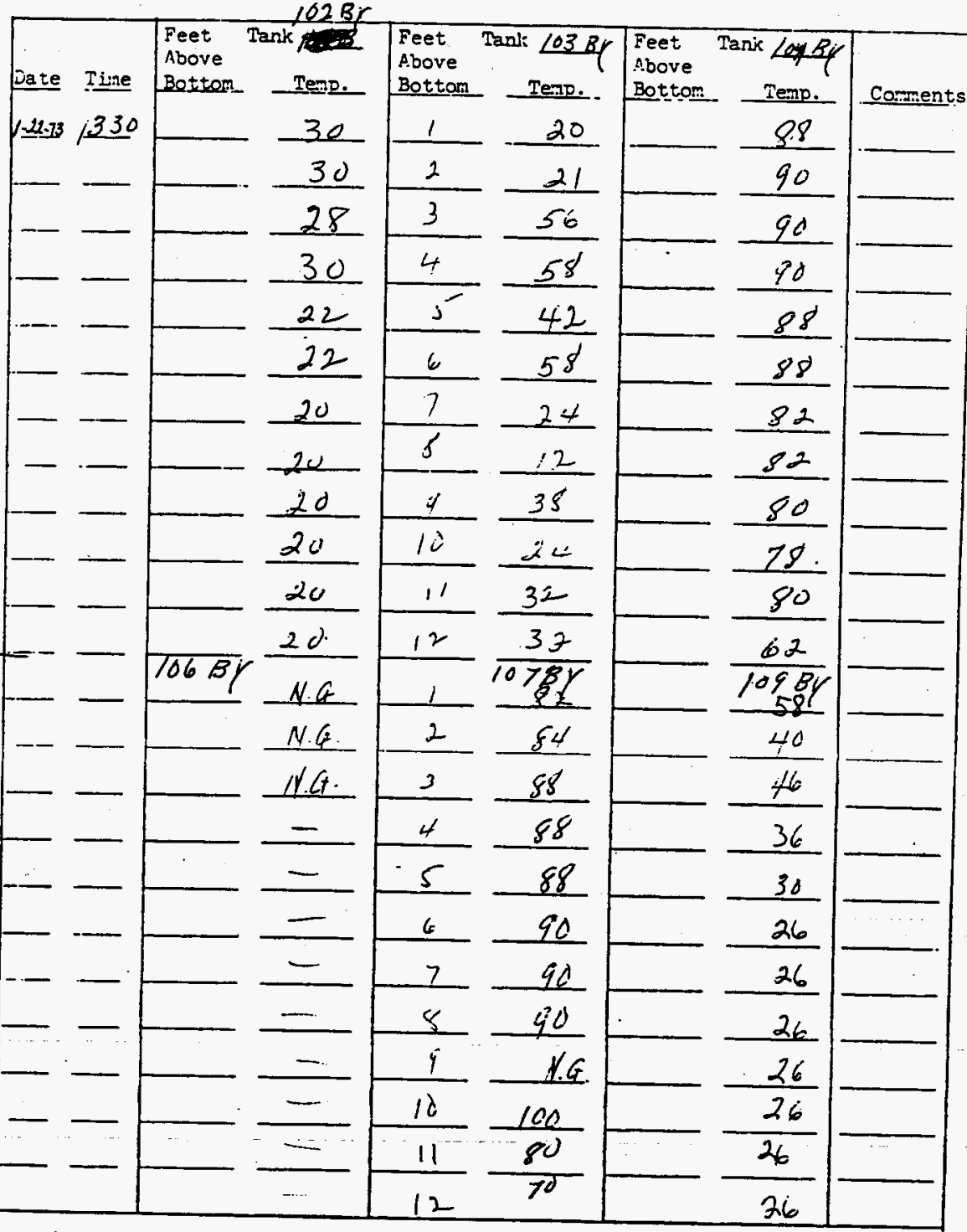

Irsiristions or coments: - Pake profyle temperatures reekly in each bottoms tank. Attech completed form to Monday and Thursday's Data Sheets. 
Title: PROFIIE TERIPERATURES DI ITS-2 BOTTONS TAINS

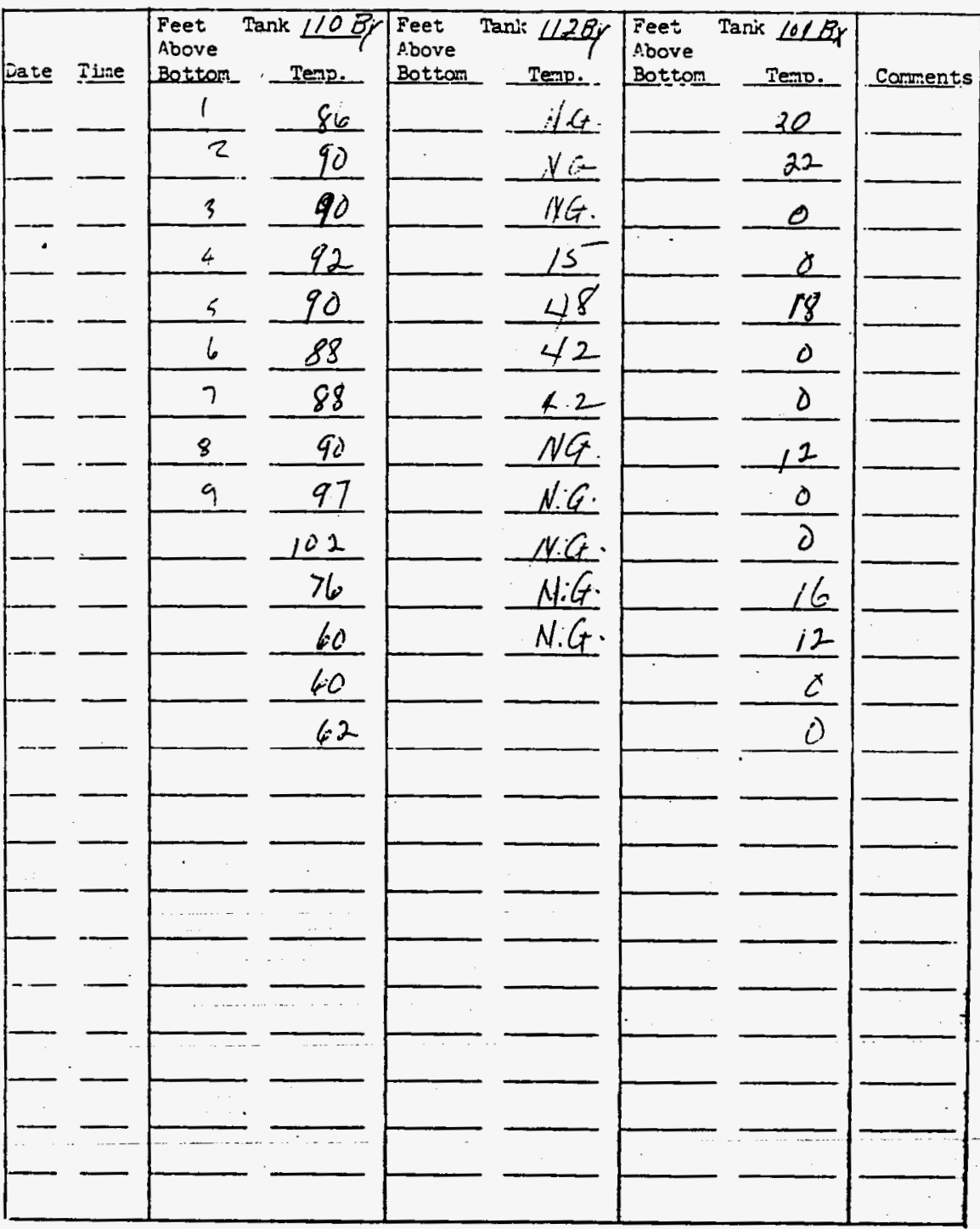

Irjtractions or coments: - Thke profile temperatures veckly in mach hottoms tenk. Attach conpleted form to Monday and Thursday's Date sheets. 
WHC-5D-WH-DP-207, Rev. O

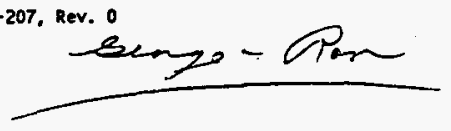

$$
\begin{aligned}
& 11-3 y
\end{aligned}
$$

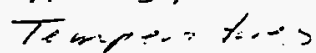

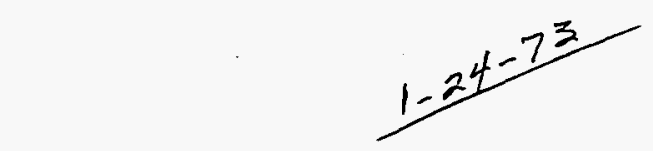

PT

${ }^{\circ} \mathrm{C}$

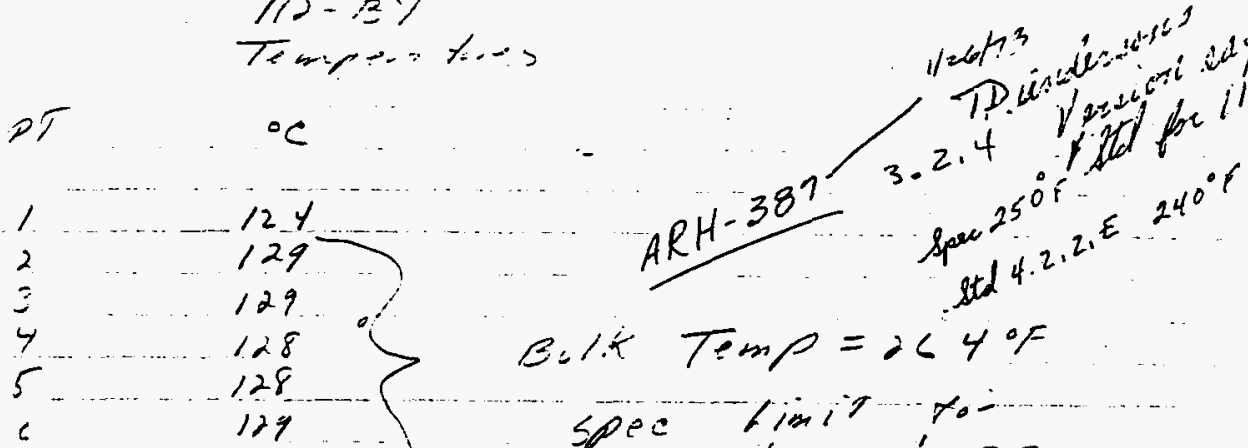

\%

127

130

$\Rightarrow$

$\therefore$

130

130.

spectionit to

By Trnks = Y yop?

$\begin{array}{ll}\because & 115 \\ \therefore & 112 \\ 17 & 105 \\ & 105\end{array}$


WHC-SD-WH-DP-207, REV. 0

$1 / 26 / 23$

$r \quad 0600$

$542^{11}$

Duste

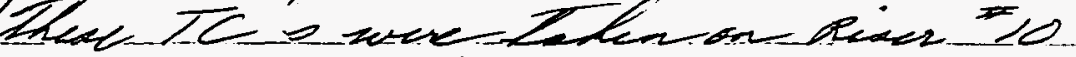

(I) (Ine)

risent $(12)$

$$
\begin{gathered}
1-121 \\
2-125 \\
3-125 \\
4-125 \\
5-125 \\
6-123 \\
z-123 \\
8-123 \\
9=123 \\
10-123 \\
11-121 \\
12-116 \\
13=100 \\
14-100
\end{gathered}
$$

BEST AVAILABLE COPY

16 


$$
\begin{aligned}
& \text { DON'T SAY IT ... Write It! } \\
& \text { Dusfy: } \\
& 0 \text { Date } 1-24-23 \\
& \text { FROM_ELECleie } 1455^{5}=1.1
\end{aligned}
$$

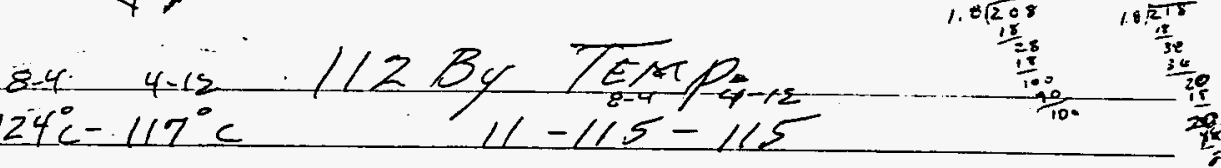

$$
\begin{aligned}
& 2.129-119 \quad 12-112-101 \\
& 3-129-120 \quad 13-105-96 \\
& 4-128-120 \quad 14-105-96 \\
& 5.128-119 \quad 15- \\
& 6-129-121 \\
& 7-129-121 \\
& 8-130-120 \\
& 9-130-120 \\
& 10-130-120^{\circ} \\
& \text { "SAFETY PAYS WHEN YOU'RE CAREFUL; YOU PAY WHEN YOU'RE NOT" }
\end{aligned}
$$


WHC-SD-WW-DP-207, REV: O

112 BY CHRISTMAS

TREE T.C. READINGS

$$
\begin{aligned}
& { }_{124} r_{132}^{1-25-73} \\
& \text { 2. } 129-138 \\
& \text { 3. } 129-137 \\
& \text { 4. } 128-137 \\
& \text { 5. } 128-137 \\
& \text { 6. } 129-137 \\
& \text { 7. } 129-138^{\prime} \\
& \text { 8. } 130-138 \\
& \text { 9. } 130-136 \\
& 18.130-134 \\
& \text { 11. } 115-130 \\
& \text { 12. } 112-115 \\
& \text { 13. } 105-106 \\
& 7 \% \quad 105-106
\end{aligned}
$$

$$
\frac{72 p}{1.8+264}
$$

Parchese, $1-5.23$ Pats which te will idect ayedid

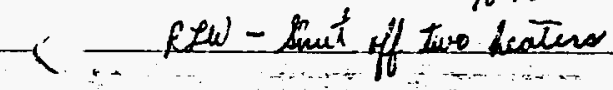


WHC-SOFWH-DP-207, Rev. : O

( C4R POx-D- T4k4i2s

(1) $122 \quad 121$

(B) $126 \quad 123$

(d) $128 \quad 124$

(4) $130^{\circ} \quad 123$

(5) $122 \quad 123$

(b) $128 \quad 124$

(8) 128

(8) $128 \quad 127$

(9) $128 \quad 123$

(10) $128 \quad 122$

(1) $123 \quad 119$

(2) 112

106

e) $104 \quad 92$

(19) $104 \quad 96$

$1-25=23$
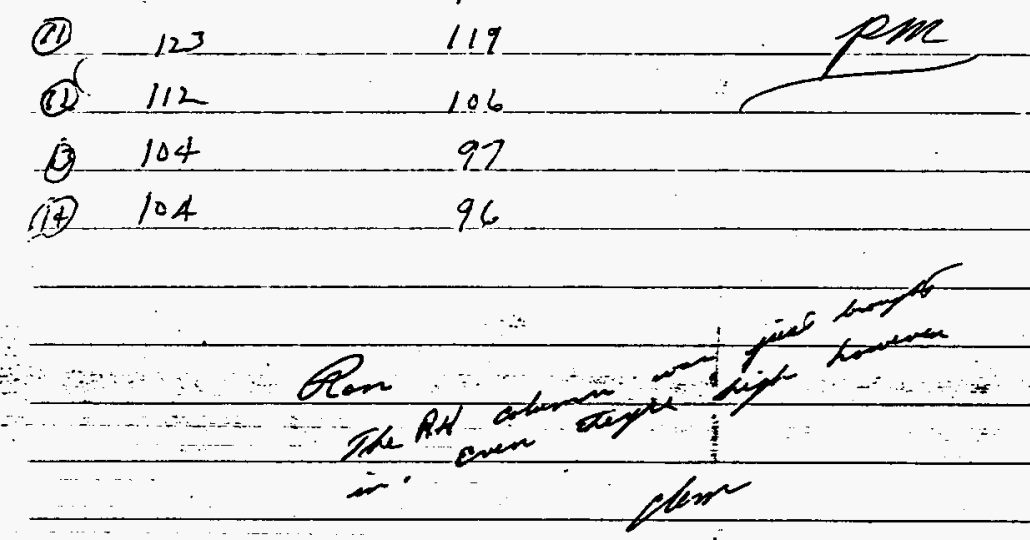


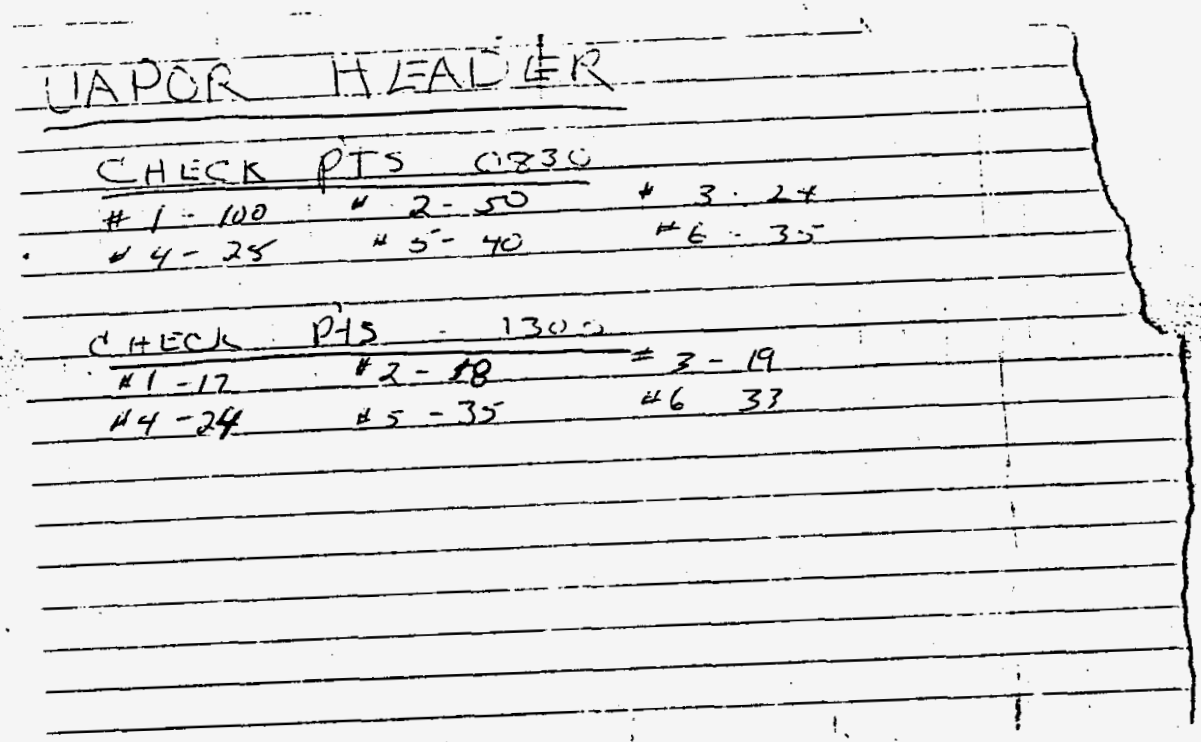




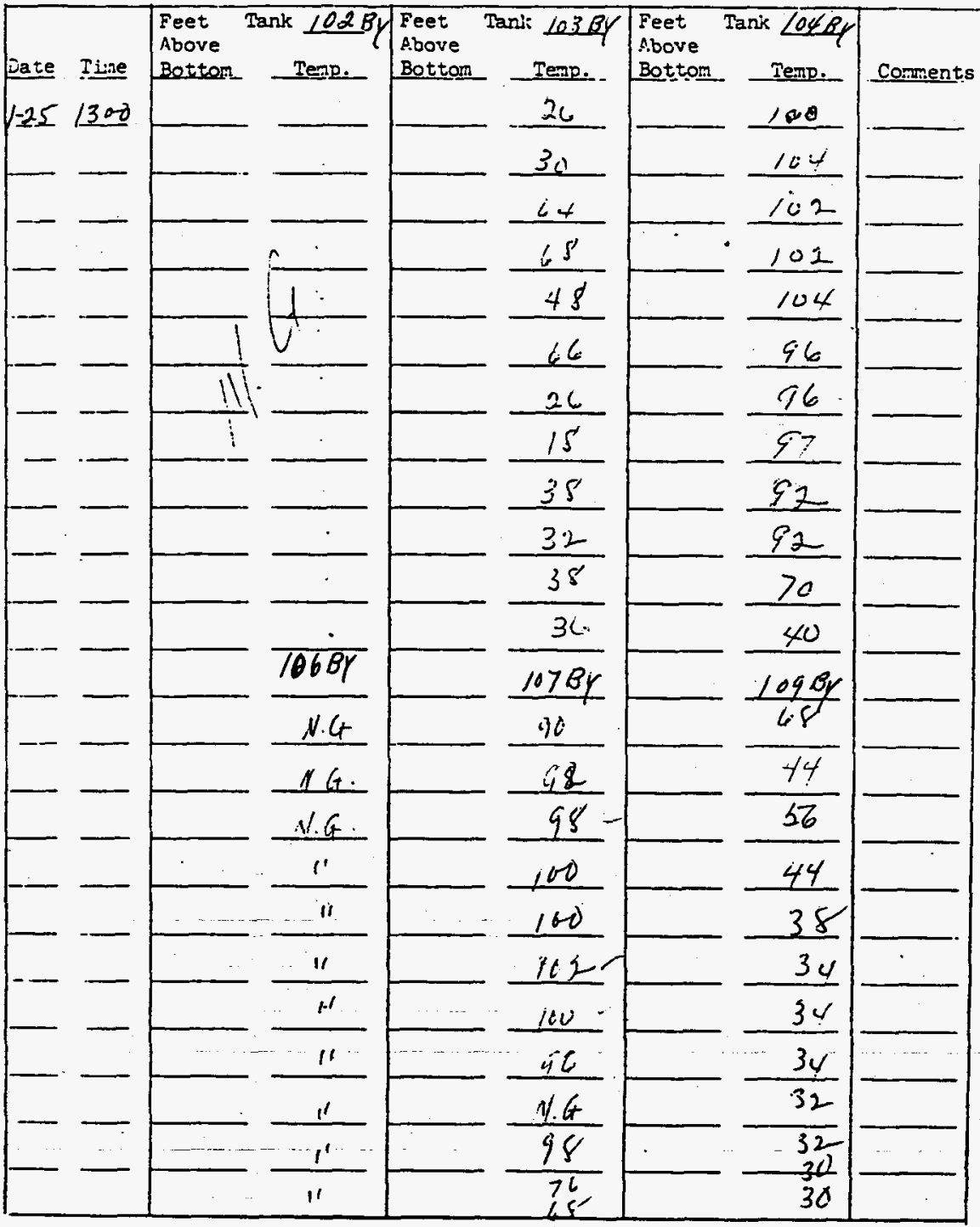

Irjtrictions or coments: - Take profile tempopares veekly in each hottoms tank. Attach completed form to Monday and Thursday's Data Sheets. 
Title:

PROFIIE TMIPERATURES IN ITS-2 BOTTOMS TANKS

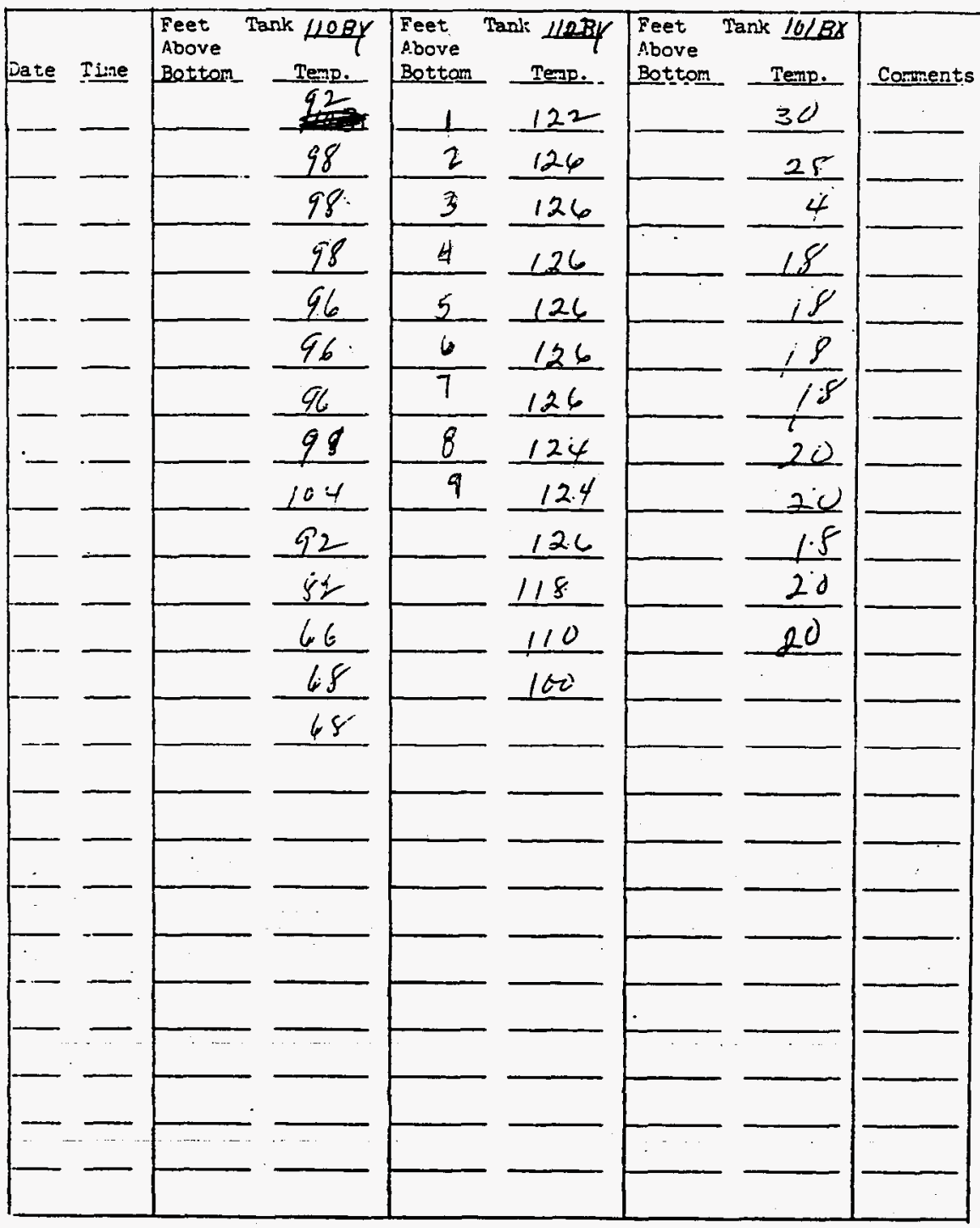

Ins:ricitins ar coments: Take profile temperatures veekly in each bottoms tank. Attach completed form to Monday and Thursday's Data Sheets. 
Title:

PROF IIE TPQPERATURES IN IIS-2 BOTTONS TANKS

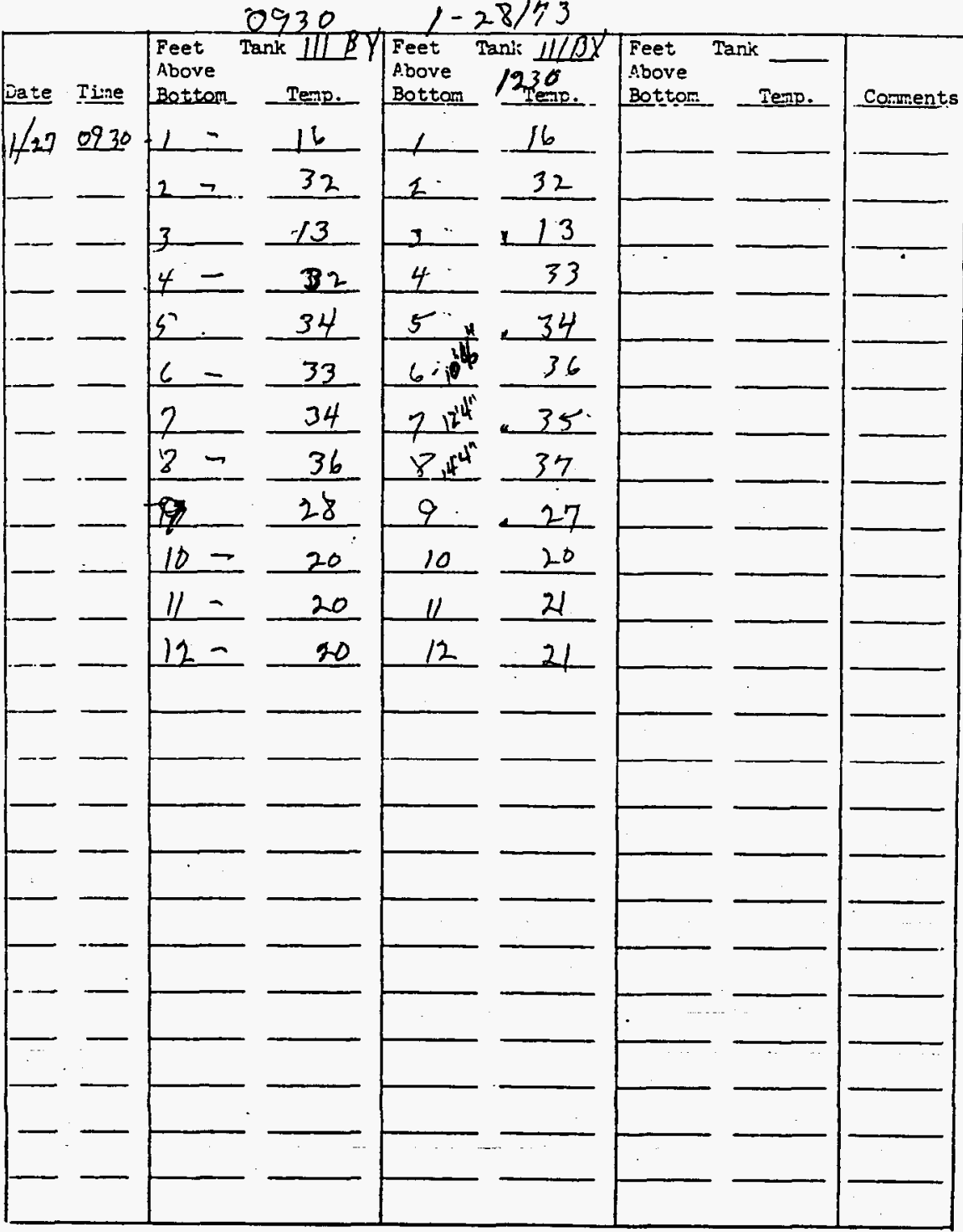

Irsiristions or coments: - Pake profile temperatores weekly in each bottoms tank. Attach conpleted form to Monday and Thursday's Data sheets. 
Title: PROFIIE THIPERATURES IN ITS-2 BOTTOMS TAMKS

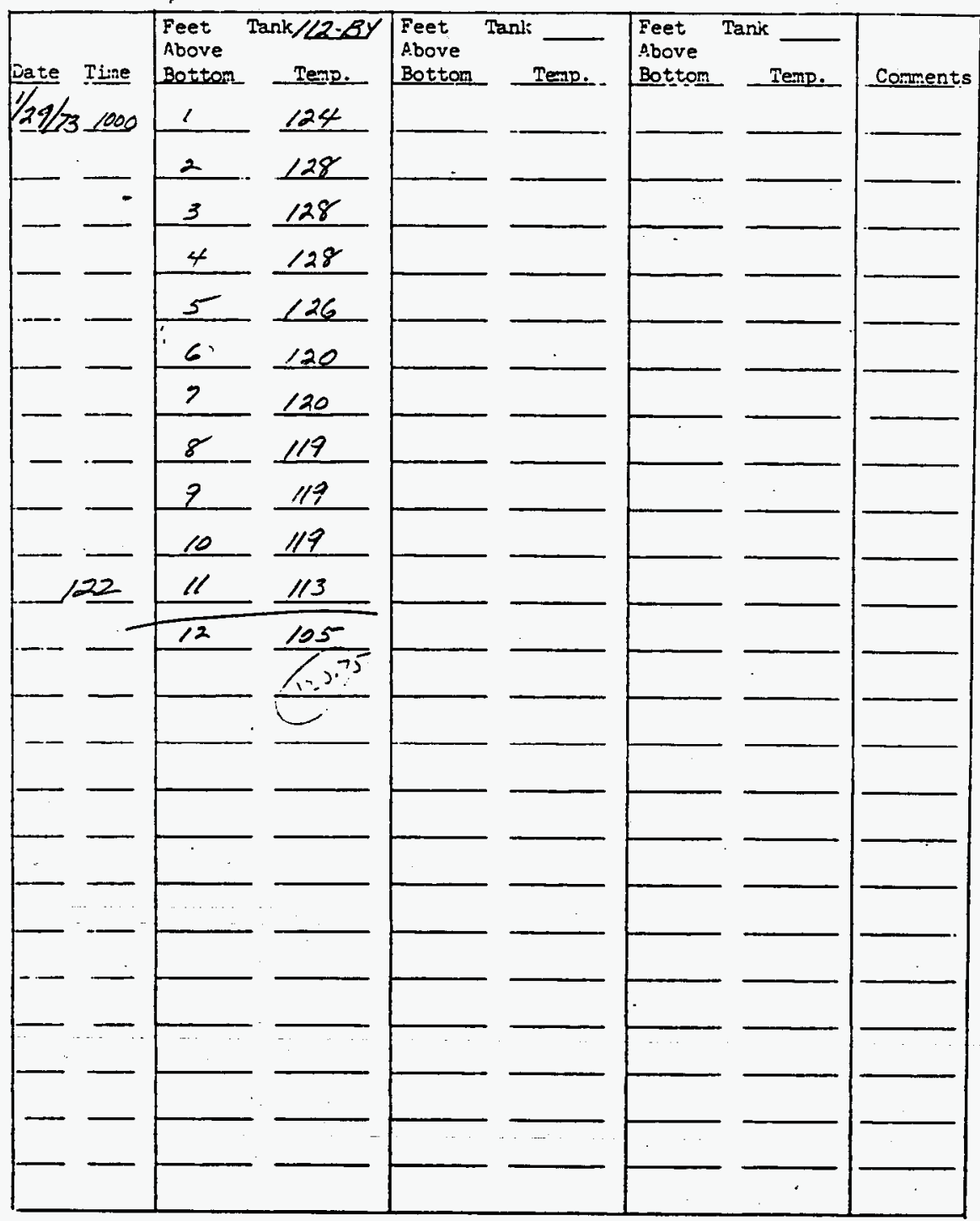

Insiricitions or coments: Take profile temperatures veekly in each bottoms tank. Attach completed form to Monday and Thursday's Data Sheets. 
Title: PROFIIE TERERATURES DI ITS-2 BOTTONS TANKS

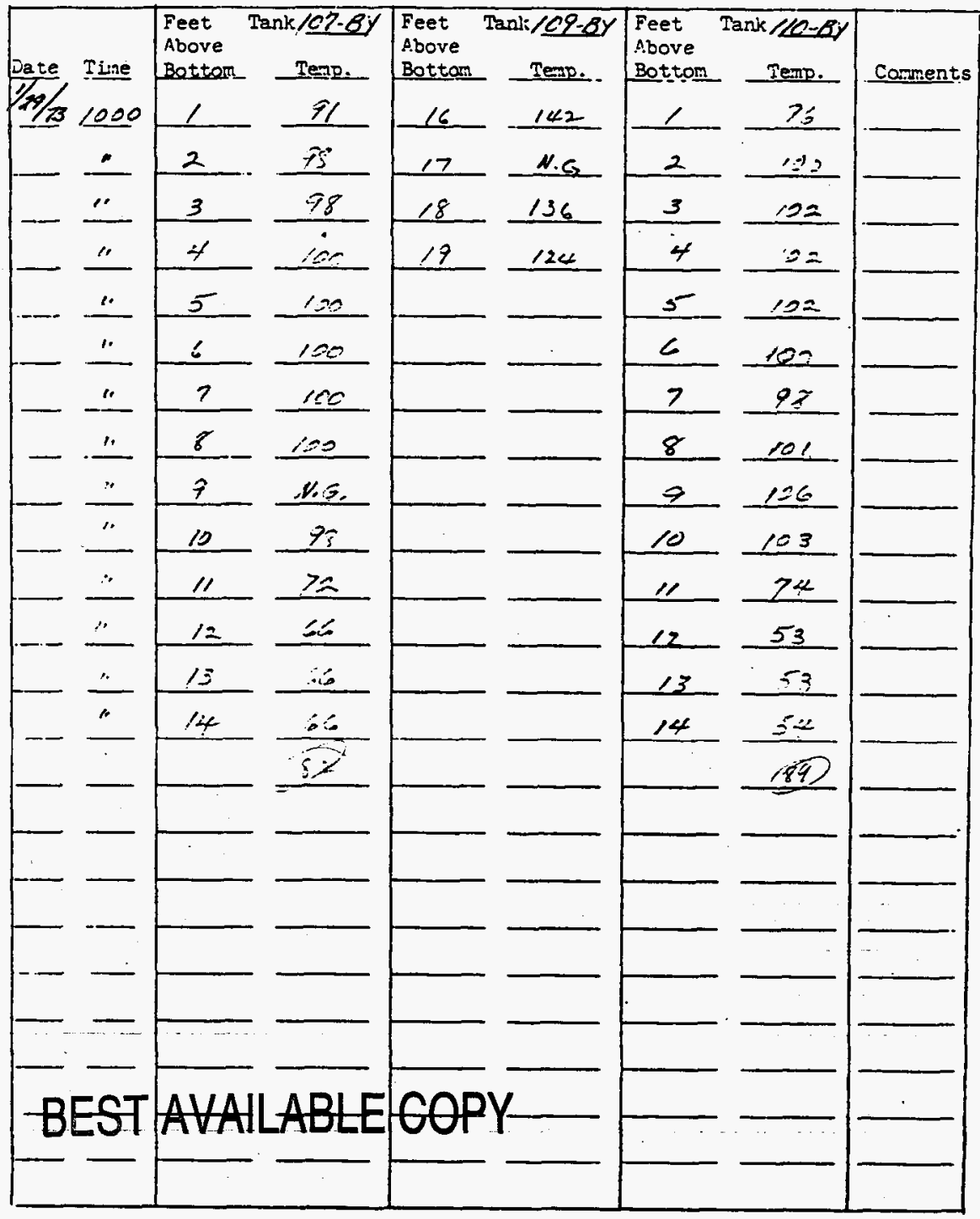

Ir:striations ar coments: Pake prof lle temperetures veekly in each hattoms tank. Attach conpleted forn to Monday and Thursday's Data Sheets. 
Title: PROFIIE TERTERATURES IN ITS-2 BOTTOMS TAITS

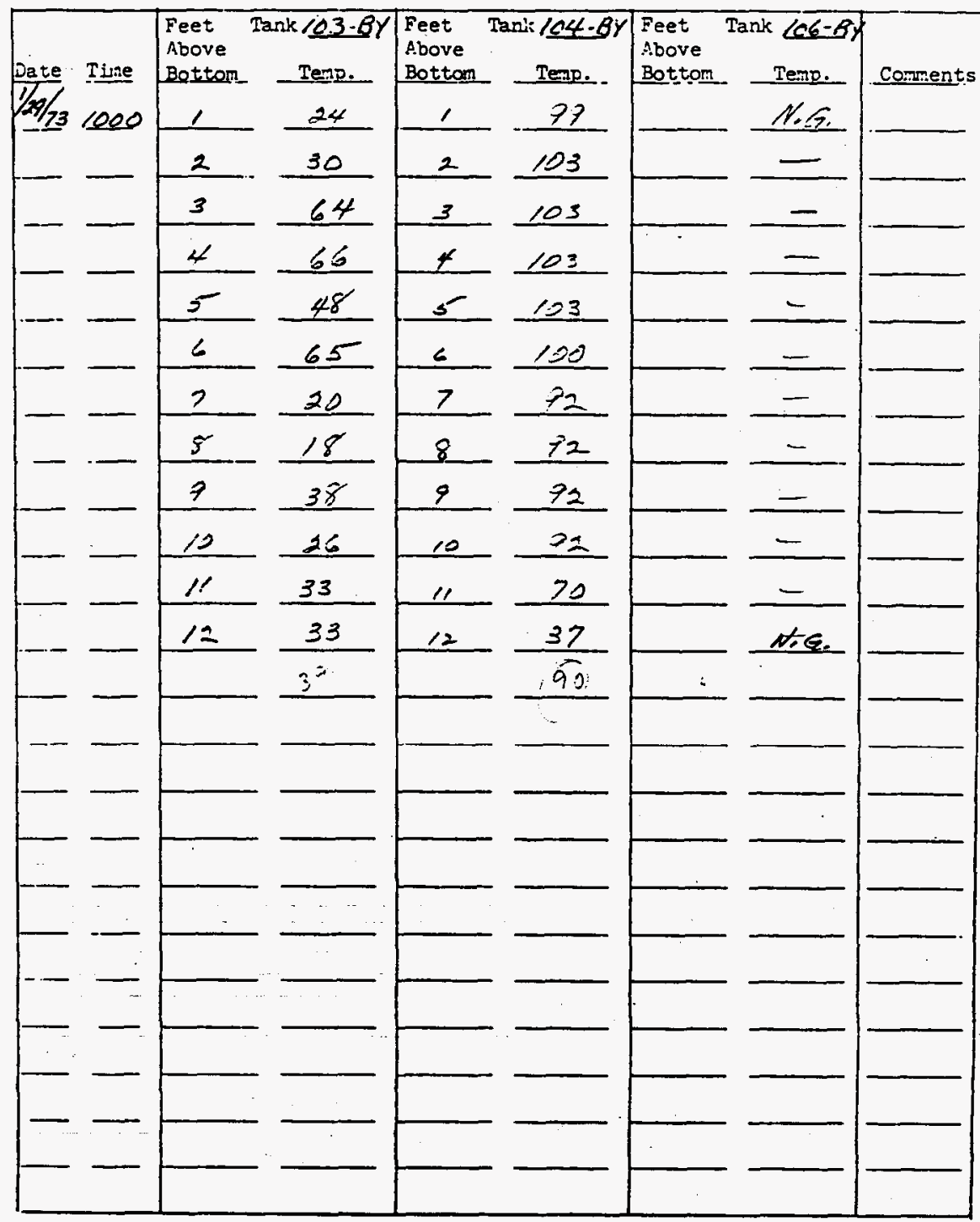

Irstristions er coments: Pake proflle temperetures weekiy in each bottams. tank. Attach conpleted form to Monday and Thursday's Data sheets, 
Title: PROFIIE TERIPERATURES IN ITS-2 BOTMOAS TANKS

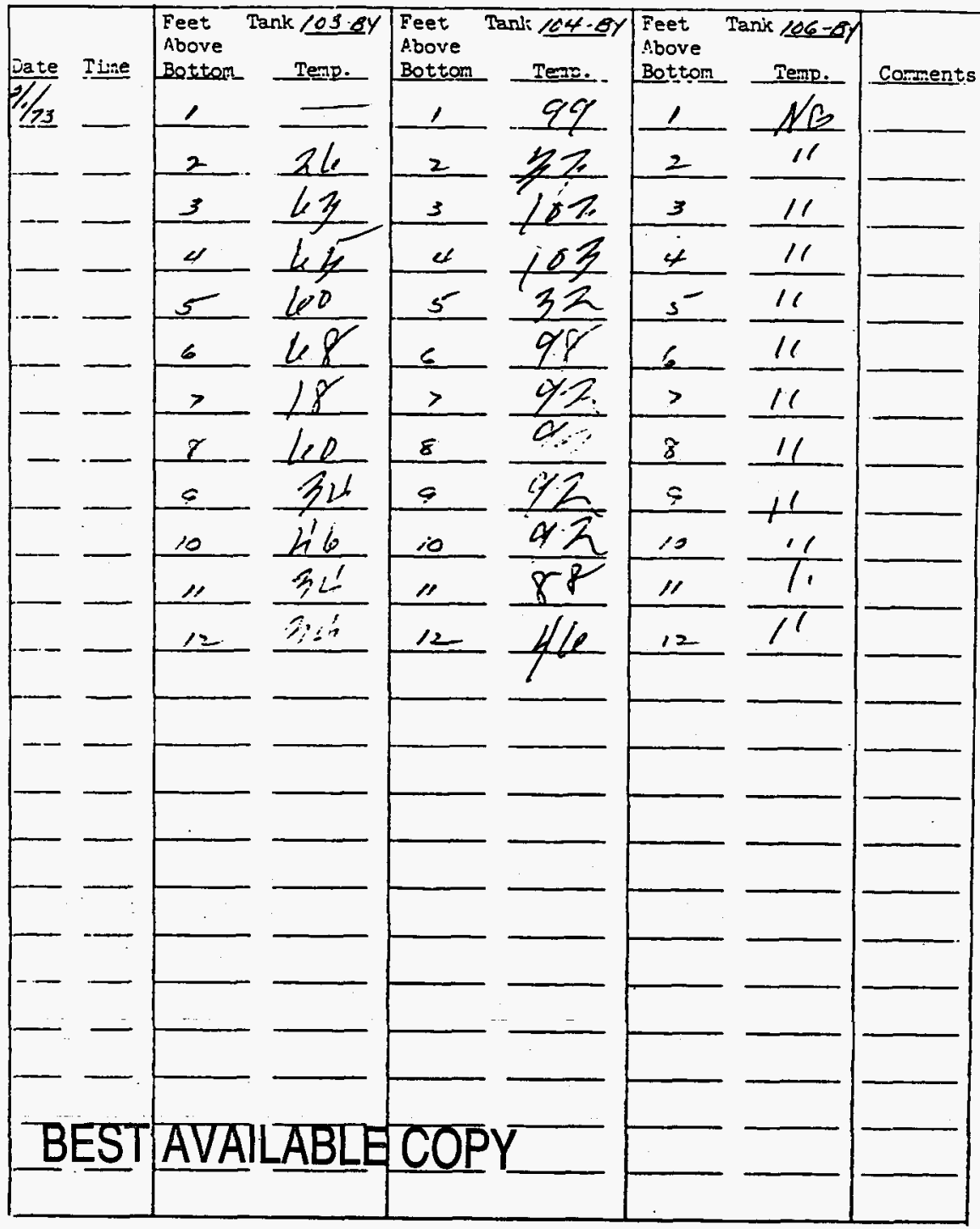

Instr:stions or coments: - Pake proflle temperatores weekly in ench bottoms 
Title: PROFIIE TERPERATURES IN ITS-2 BOTTOMS TANTS

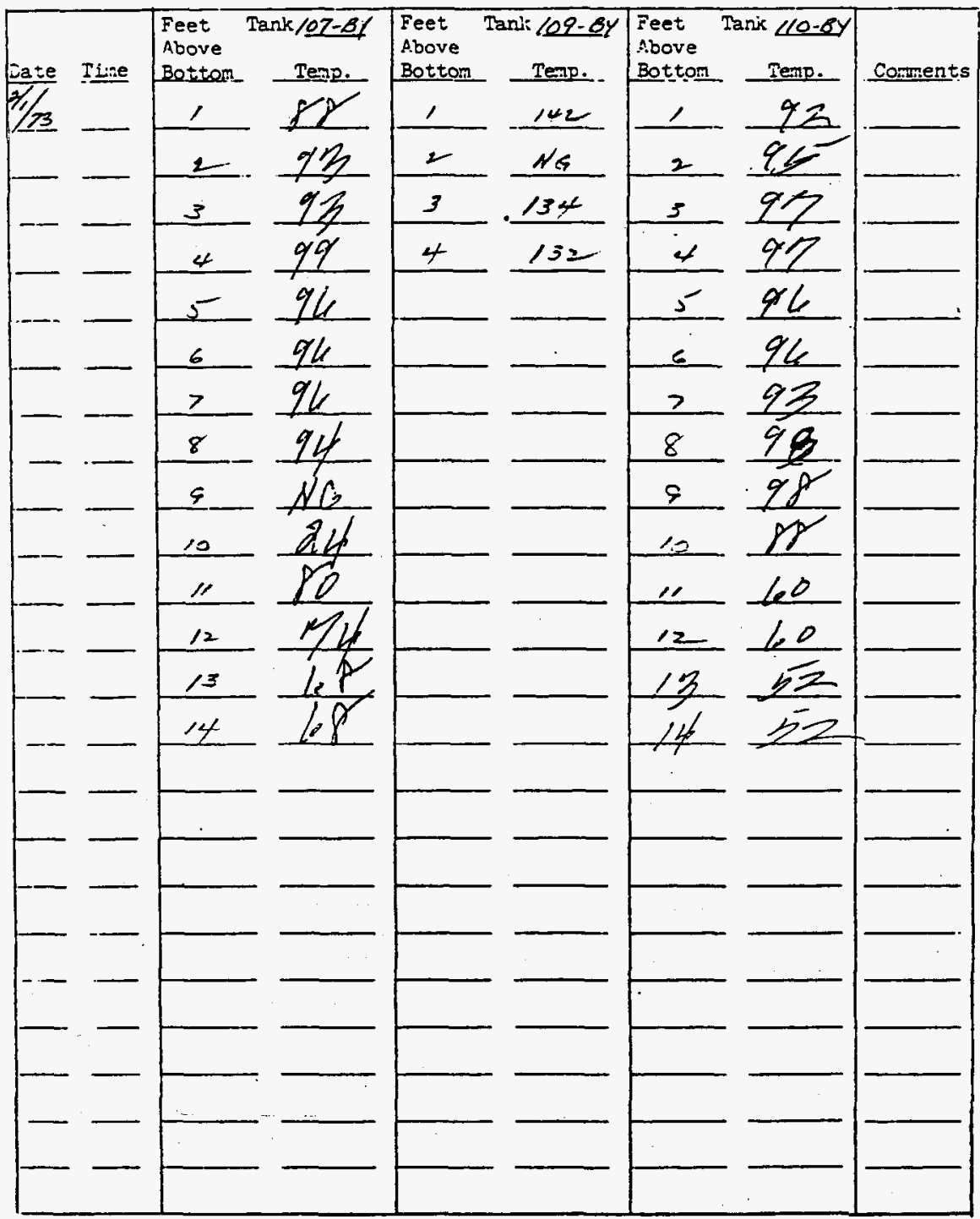

Instrations ar conments: - Take proflle temperatures weekly in each battoms tank. Attach conpleted form to Monday and Thursday's Data sheets. 
Title: PROFILE TERTERATURES IN ITS-2 BOTTOMS TAIKS

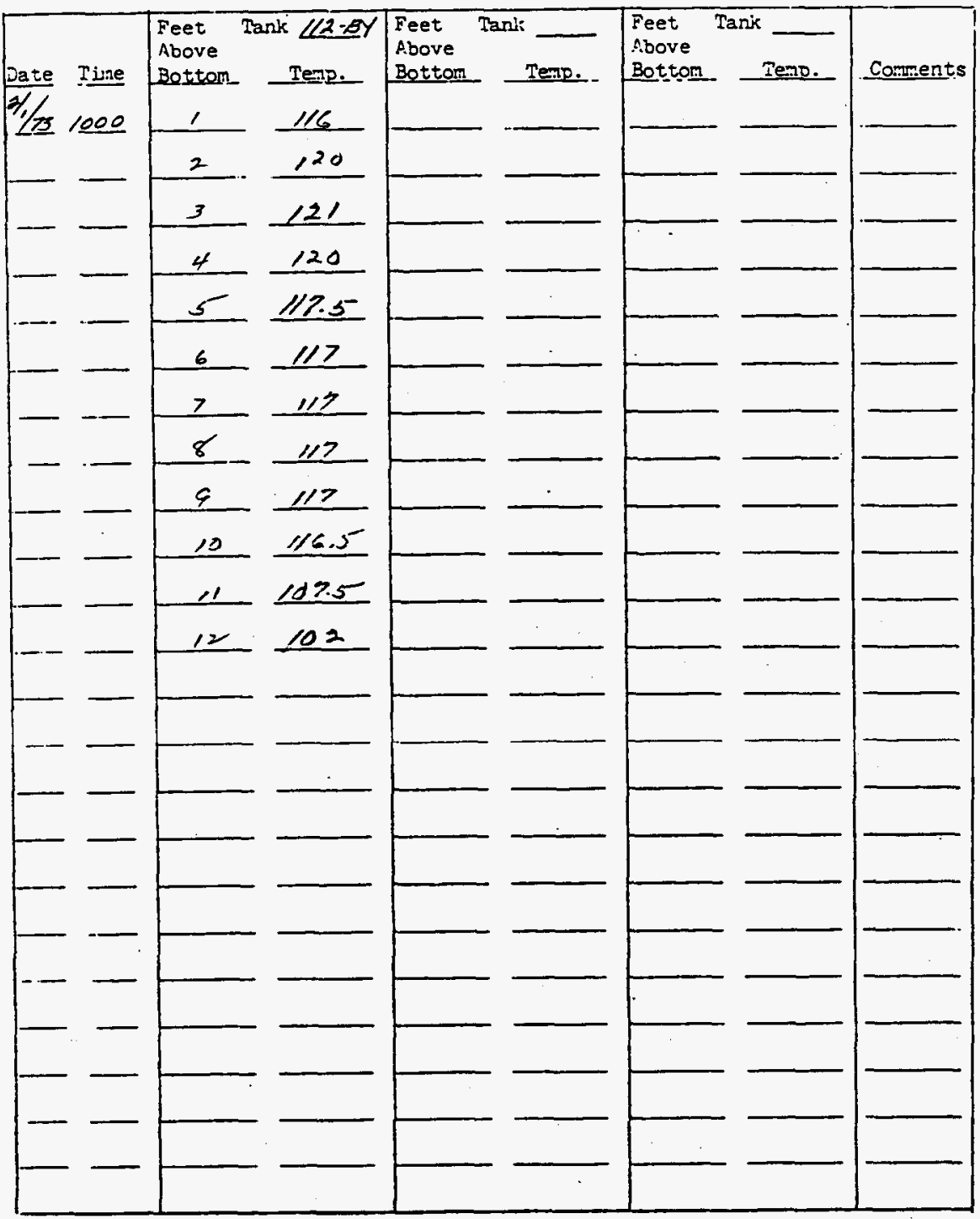

Ir:sir:ations sr corments: Take proflle temperatures weekly in aach battoms tank. Attach conpleted forn to Monday and Thursday's Data Sheets. 
Title:

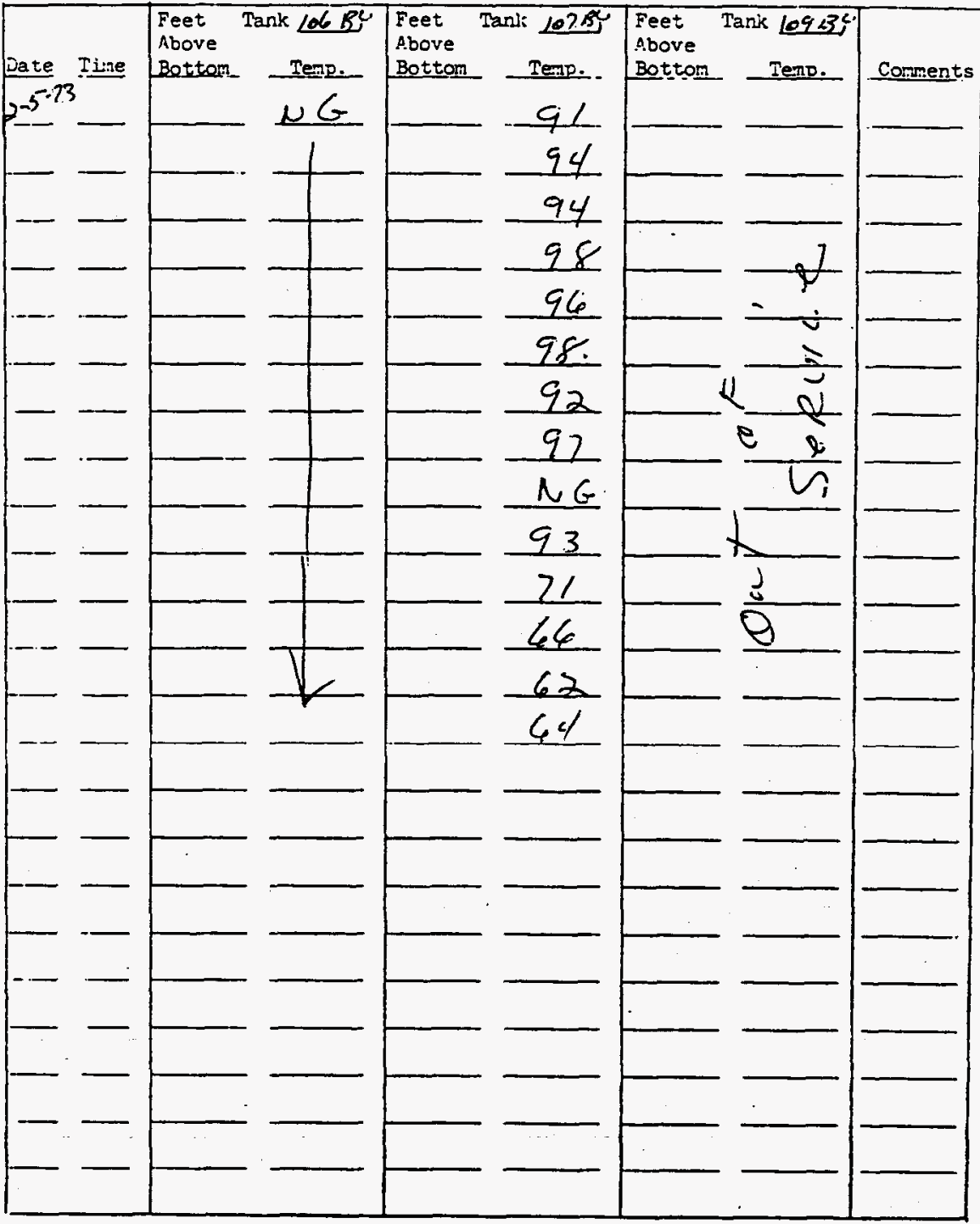

Injtriations or coments: Take profyle temperatures veekly in each bottoms tank. Attach carpleted fors to Monday and Thursday's Data sherts. 
Title:

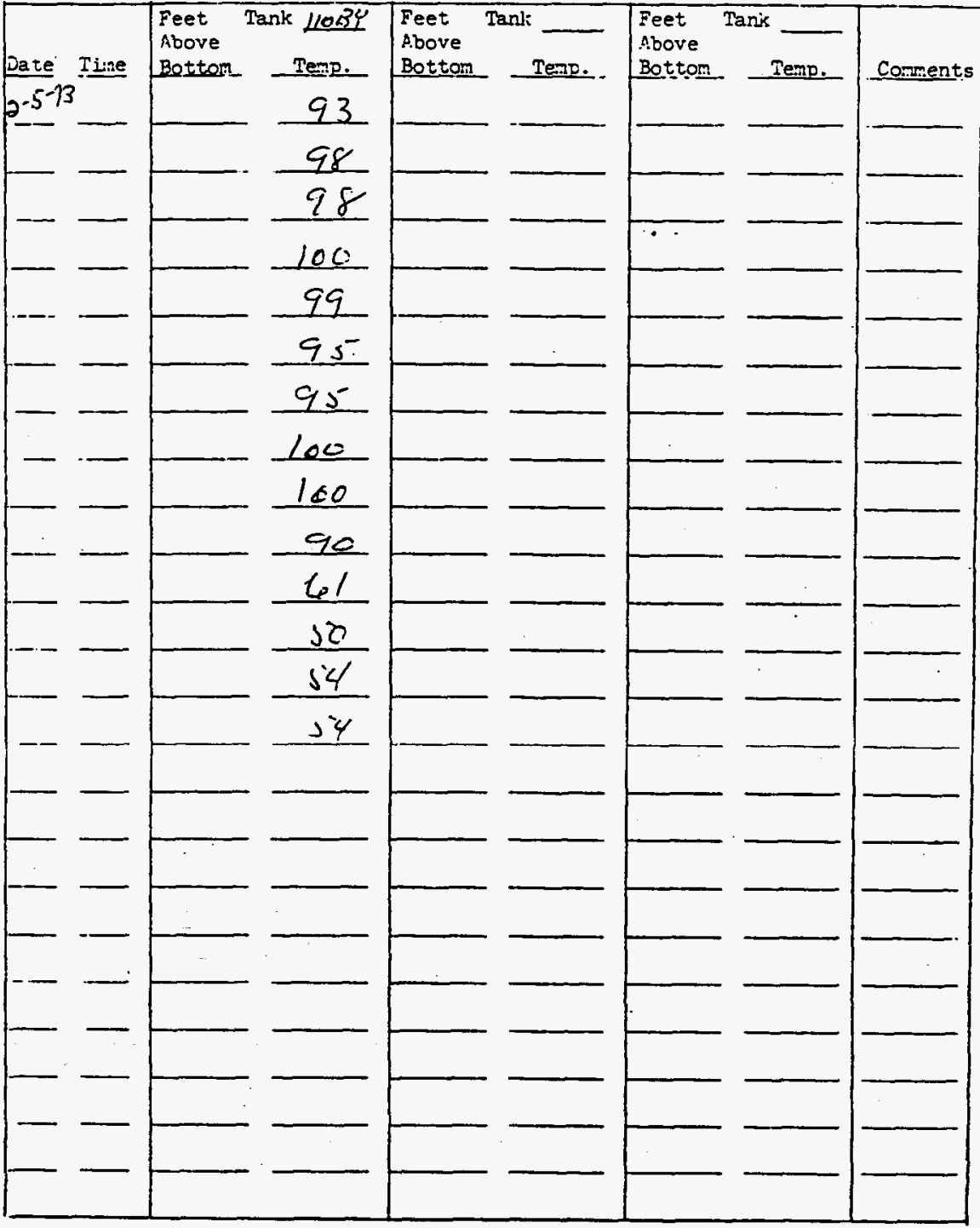

Irstristions ar coments: - Take proflle temperatures weelcly in each battoms tank. Attach conpleted form to Monday and Thursday's Data Sheets. 
Title: PROFIIE TEPERATURES DN ITS-2 BOTTOMS TANKS

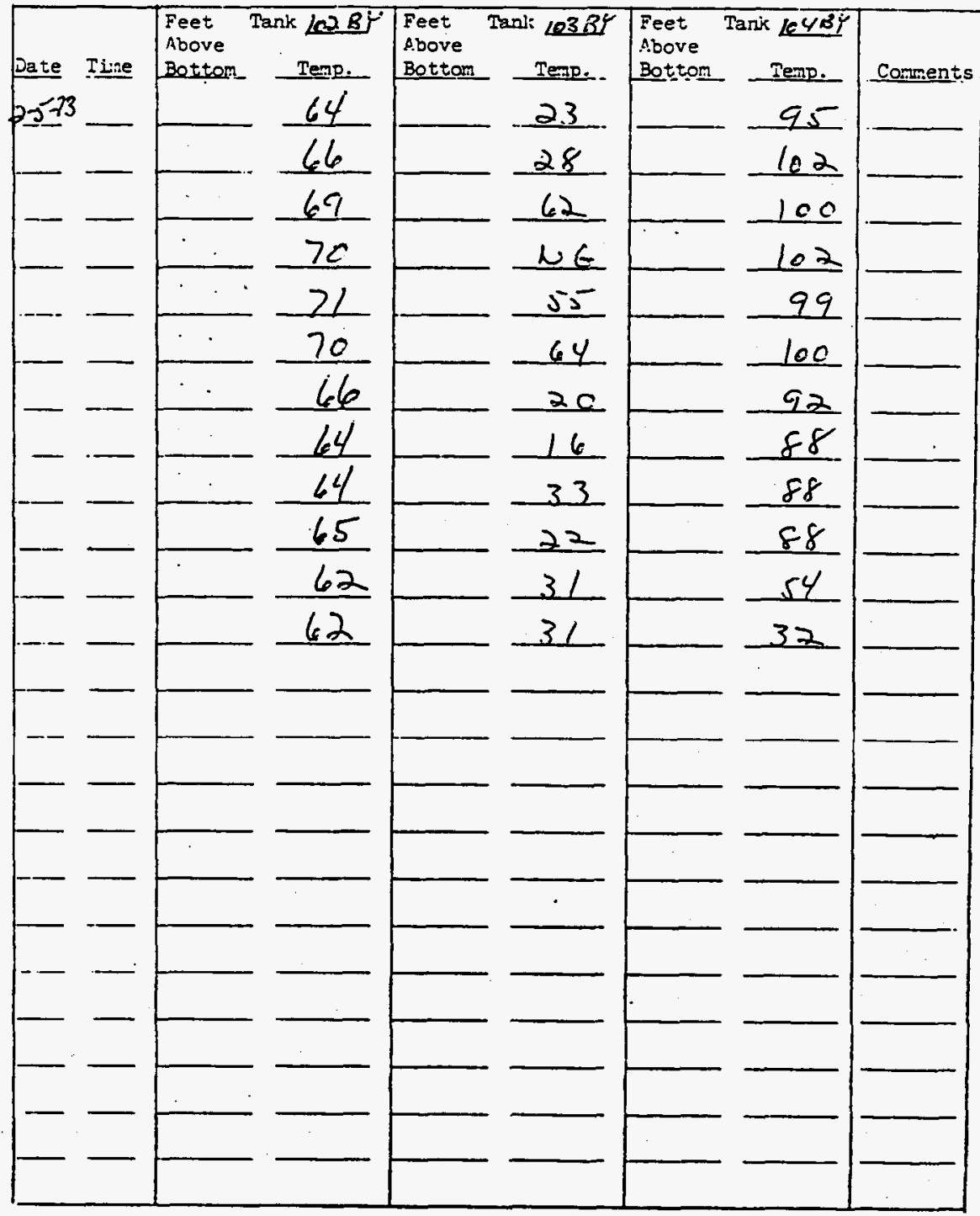

Irstristions or coments: Take profyle temperatures weelely in each bottoms tank. Attach conpleted form to Monday and Thurgday's Data Sheets. 
WHC-5D-WH-DP-207, Rev. 0

$2-6-73$

r. 104 BY XIMAS

TREE TEMPS

${ }^{\circ} \mathrm{C}$

1. .96

2. 99

3. 99

4. 99

5. 98

6. 96

7. 88

8.88

9. 86

11 81

11. 49

12. 30 $10^{\circ} 7$ BY Xmps

TREE TEMPS

OC

1. 92

2. 98

3. 96

4. 101

5. 100

6. 100

7. 98

8. 96

9. $O P=N$

10. 95

11. 72

12. 65

13.65

14. 64

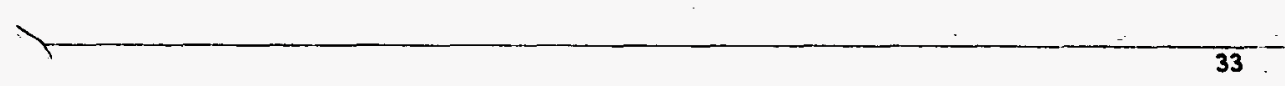


Title: PROFIIE TEIPERATURES II ITS-2 BOTTOMS TAIKS

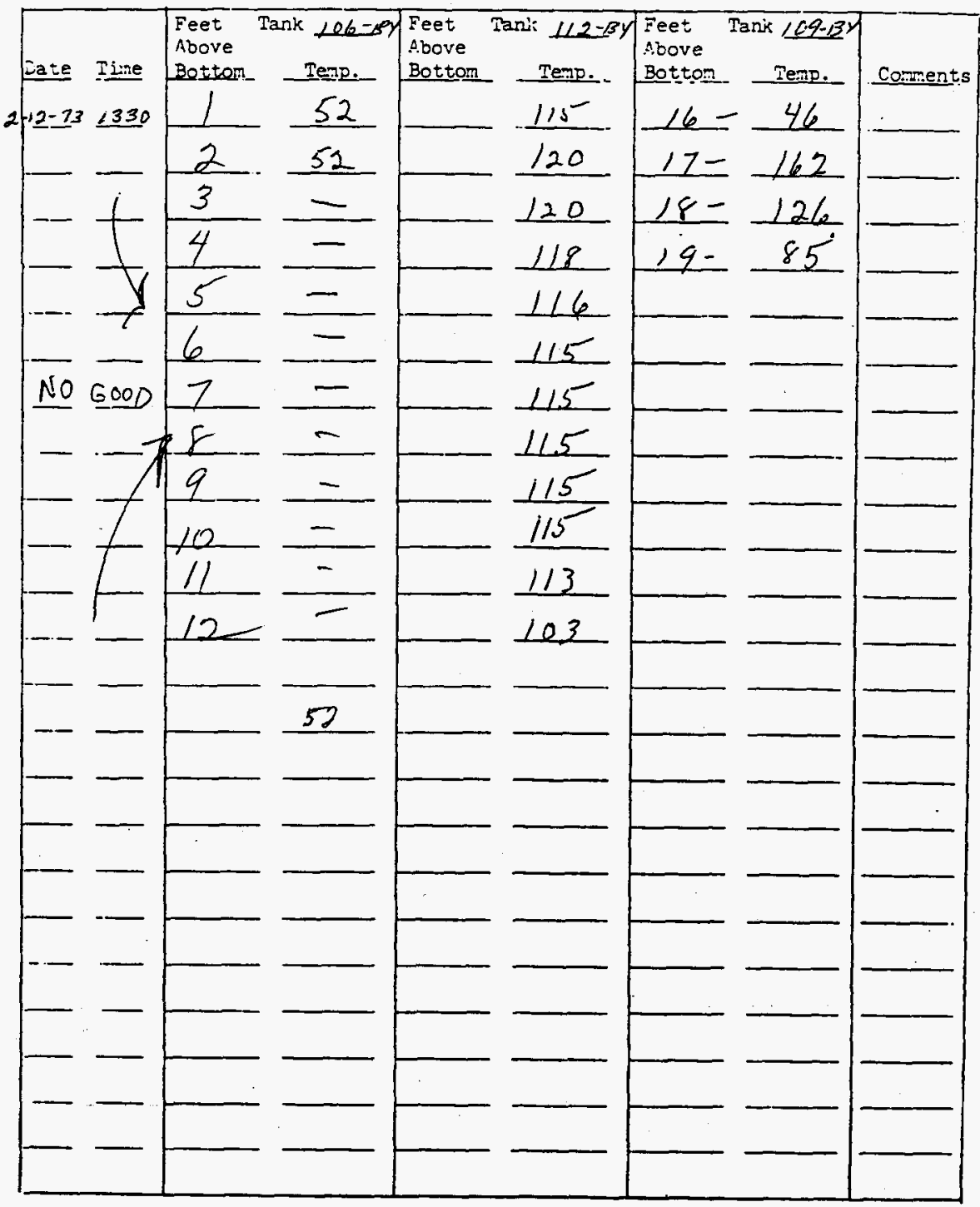

Instristicns sr coments: - Take proflle temperatures weekly in each bottoms tank. Attach completed form to Monday and Thursday's Data sheets. 
Title : PROFILE TERIPERATURES IN ITS-2 BOTTOMS TANKS

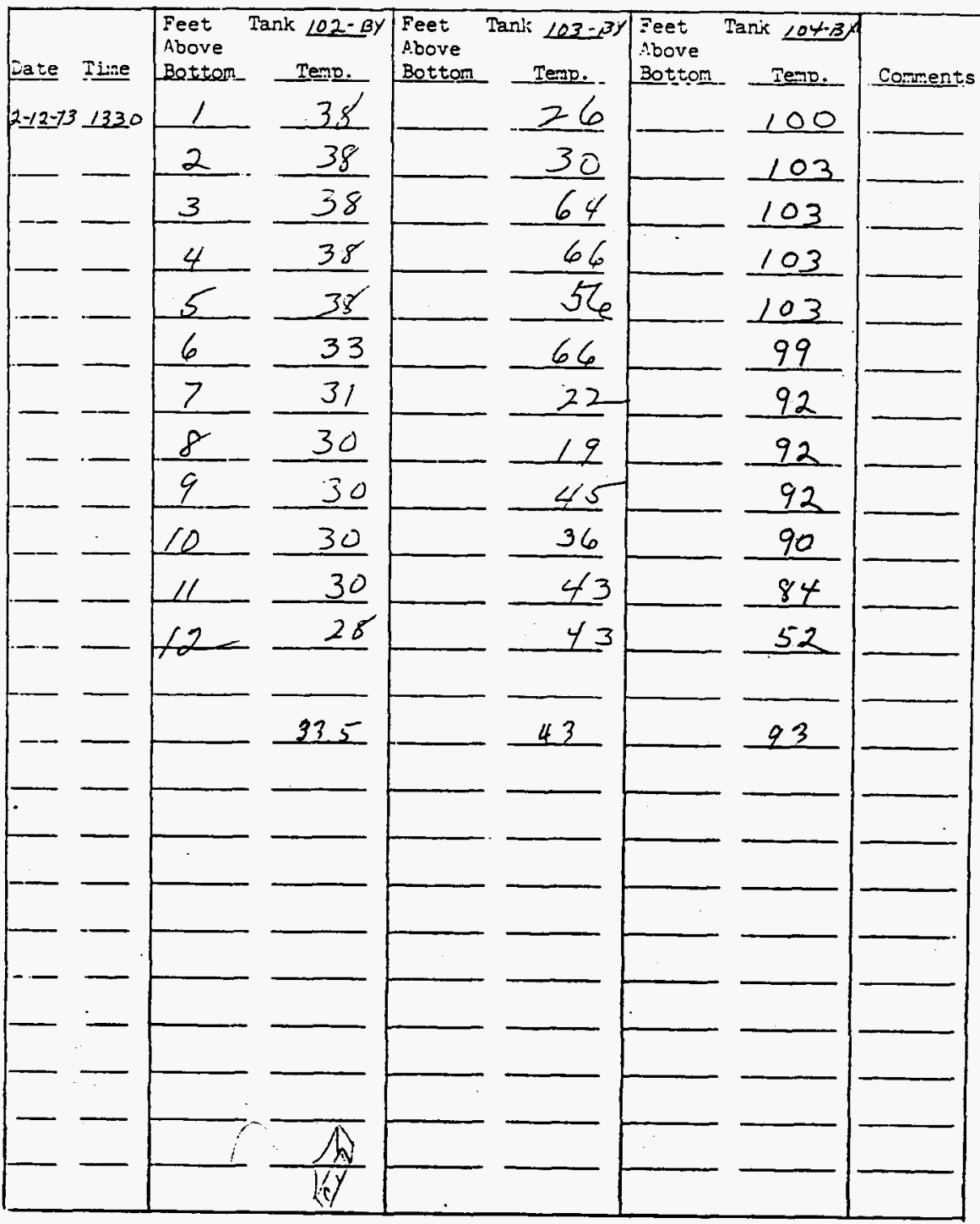

Instriftions ar coments: - Take profule temperatures weekly in each bottoms. tank. Attach completed form to Monday and Thursday's Data Sheets. 
Title:

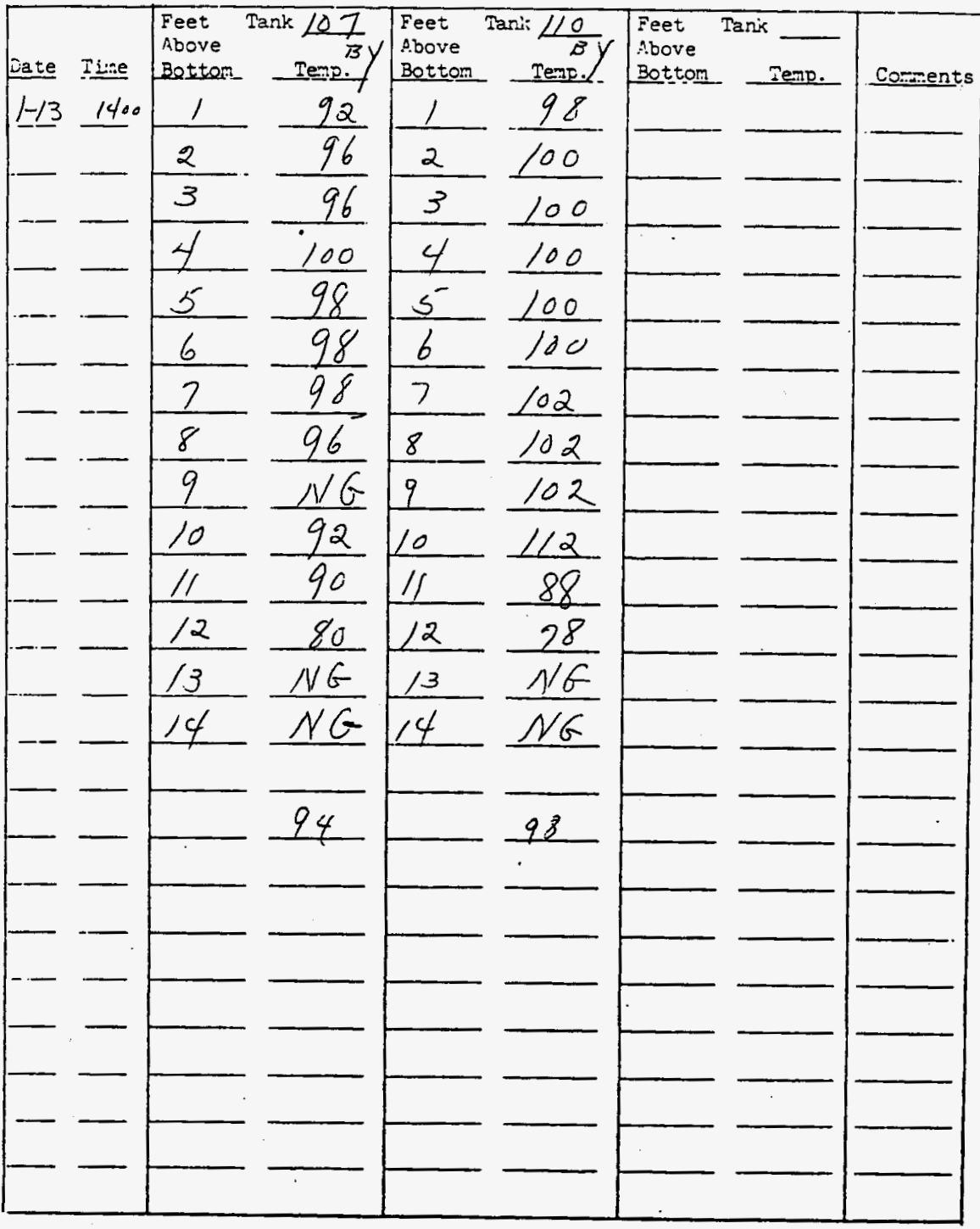

Injtrictions or coments: - Pake prof lle temperatures weekly in each bottons tank. Attach corpleted form to Monday and Thursday's Data Sheets. 
WHC-SD-WM-DP-207, REV. 0

Title:

PROFILE TRPERATURES IN ITS-2 BOTTOMS TANKS

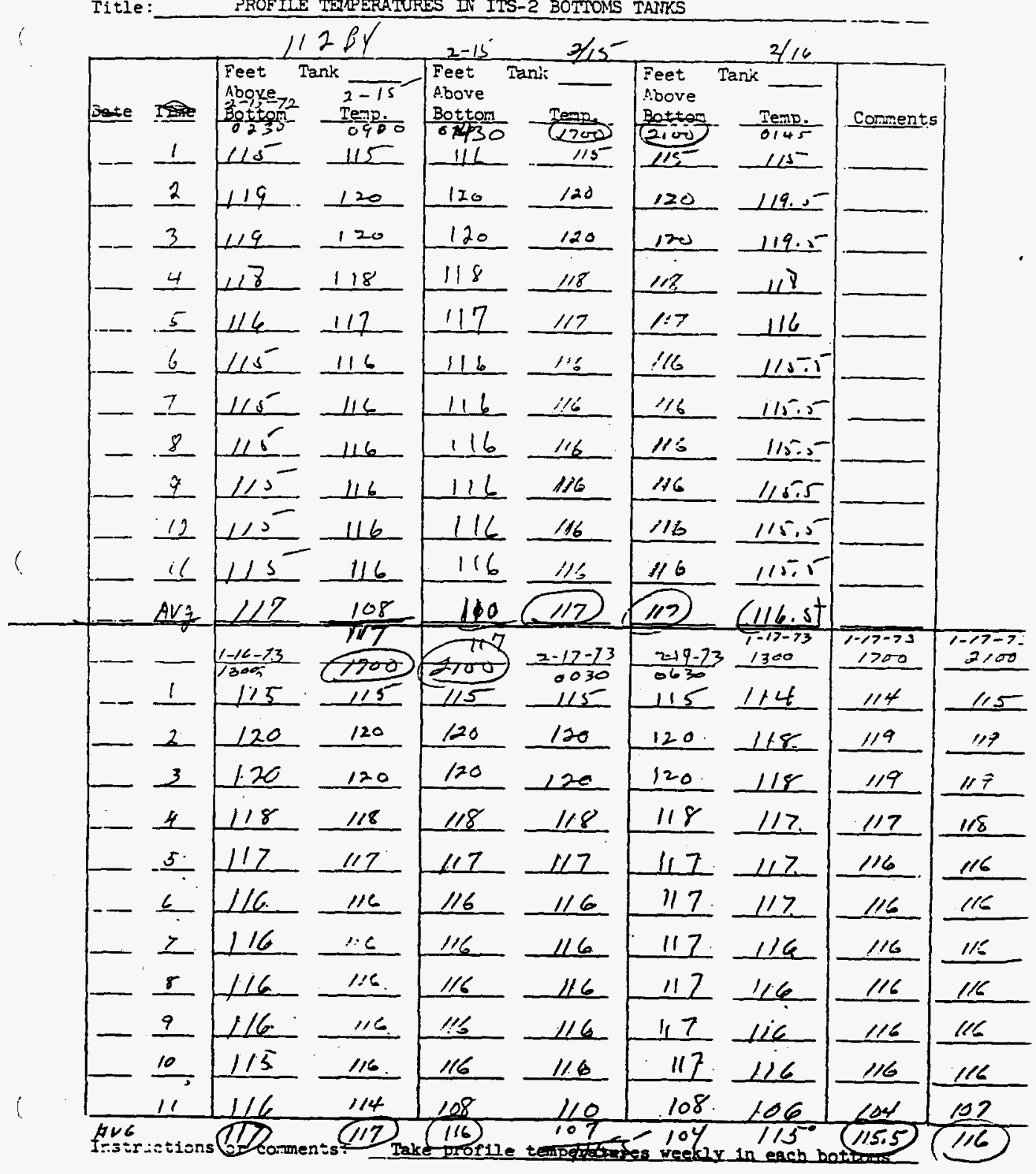

tank. Attach completed form to Monday and Thursday's Data Sheets.

37 
Title : PROFITE TEPERATURES IN ITS-2 BOTTOMS TAIKS

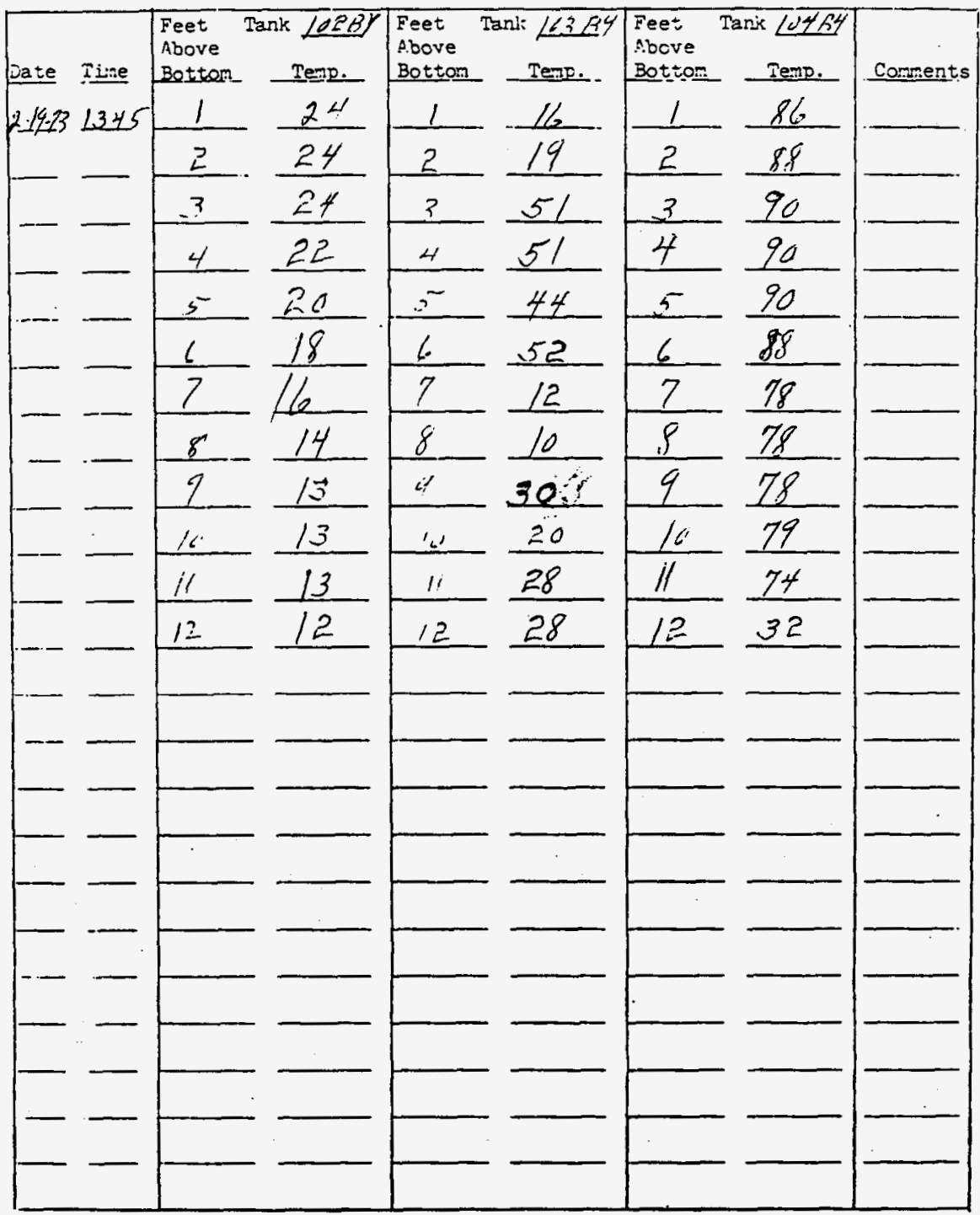

Ir:sir:isions or canments: - Take proflle temperetures weekly in each bottoms tank. Attach coraleted form to Monday and Thursday's Data Sheets. 
Title :

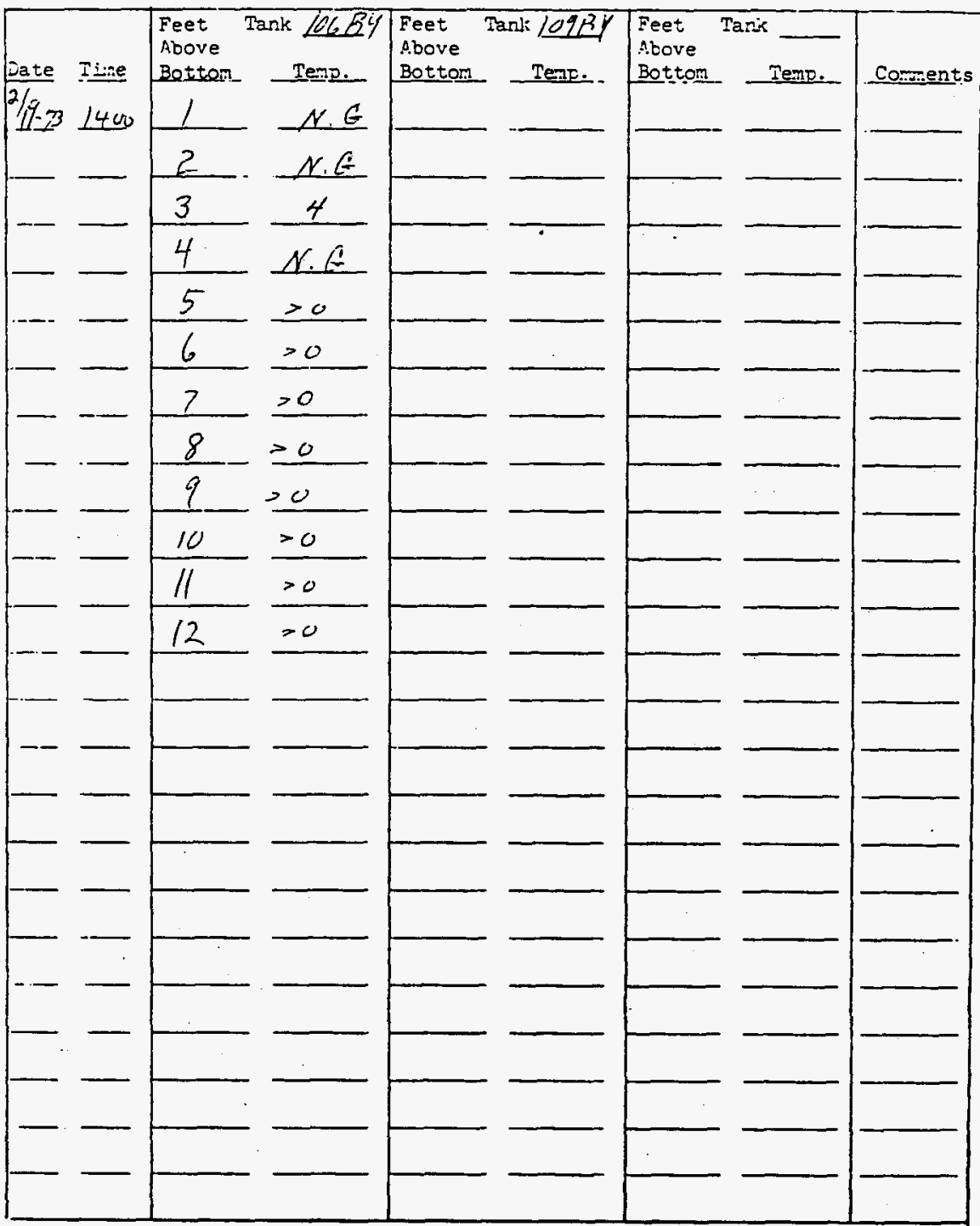

Instr:ations $=r$ coments: - Take proflie temperatures veekly in each bottoms tank. Attach conpleted form to Monday and Thursday's Data sheets. 
Title: PROFIIE TERPERATURES IN ITS-2 BOTTOMS TANKS

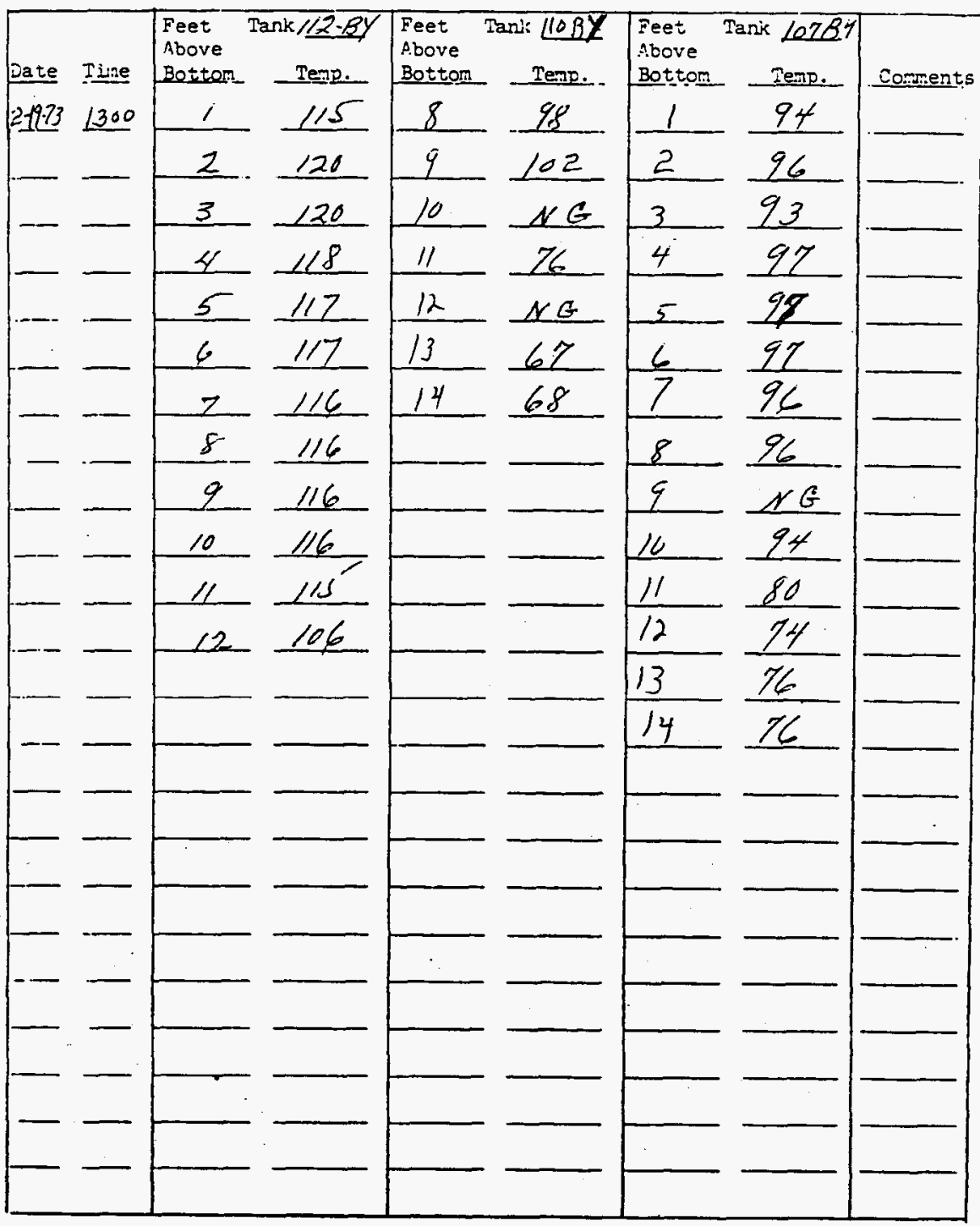

Instrictions or conments: - Take profile temperatures weekly in each bottoms tank. Attach completed form to Monday and. Thursday's Data Sheets. 
Title: PROFILE TEIPERATURES IN ITS-2 BOTIOMS TANKS

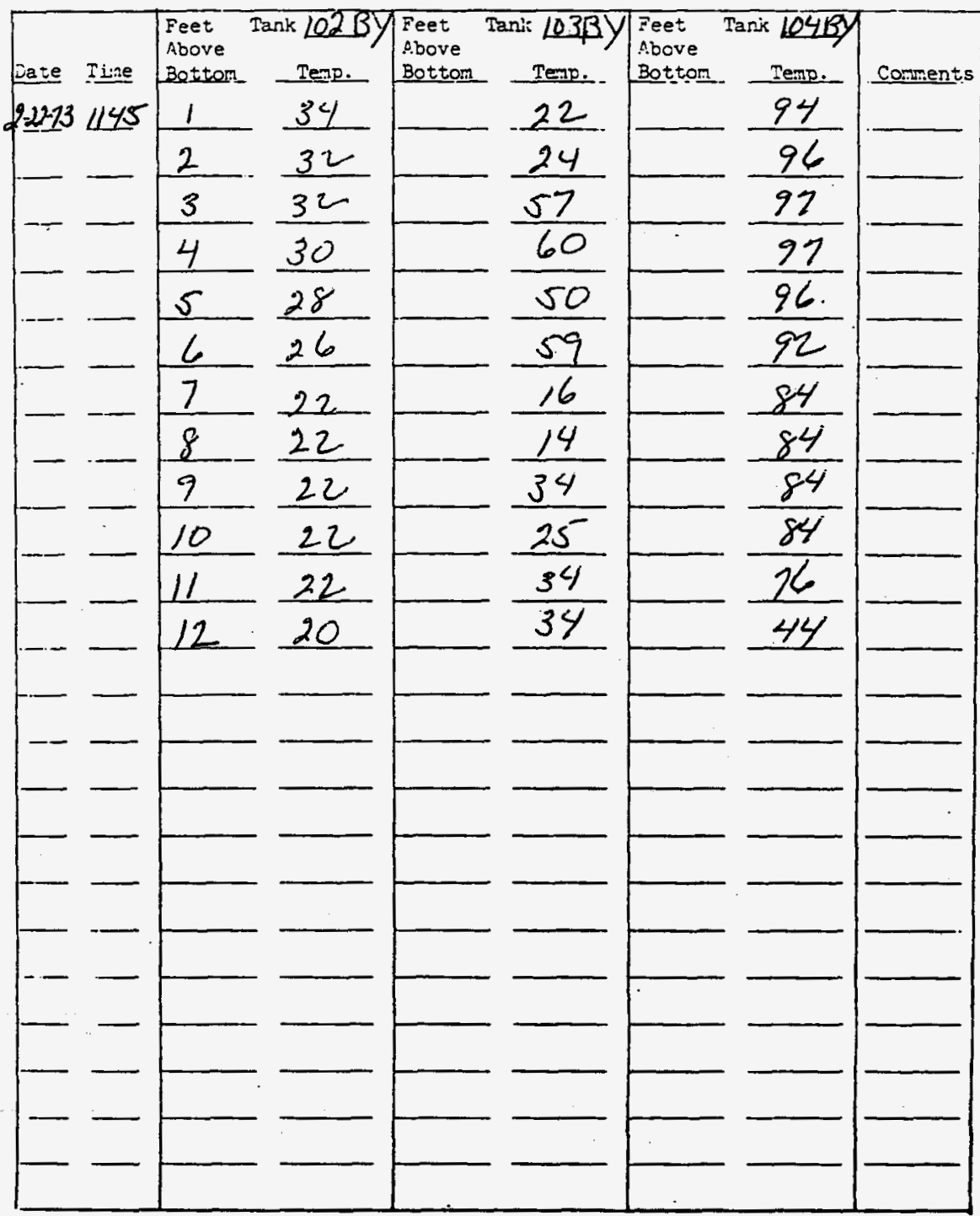

Instristions or coments: - Take proflle temperatures weekly in each bottons. 
Title: PROFILE TEIPERATURES IN ITS-2 9OTTOMS TAIRS

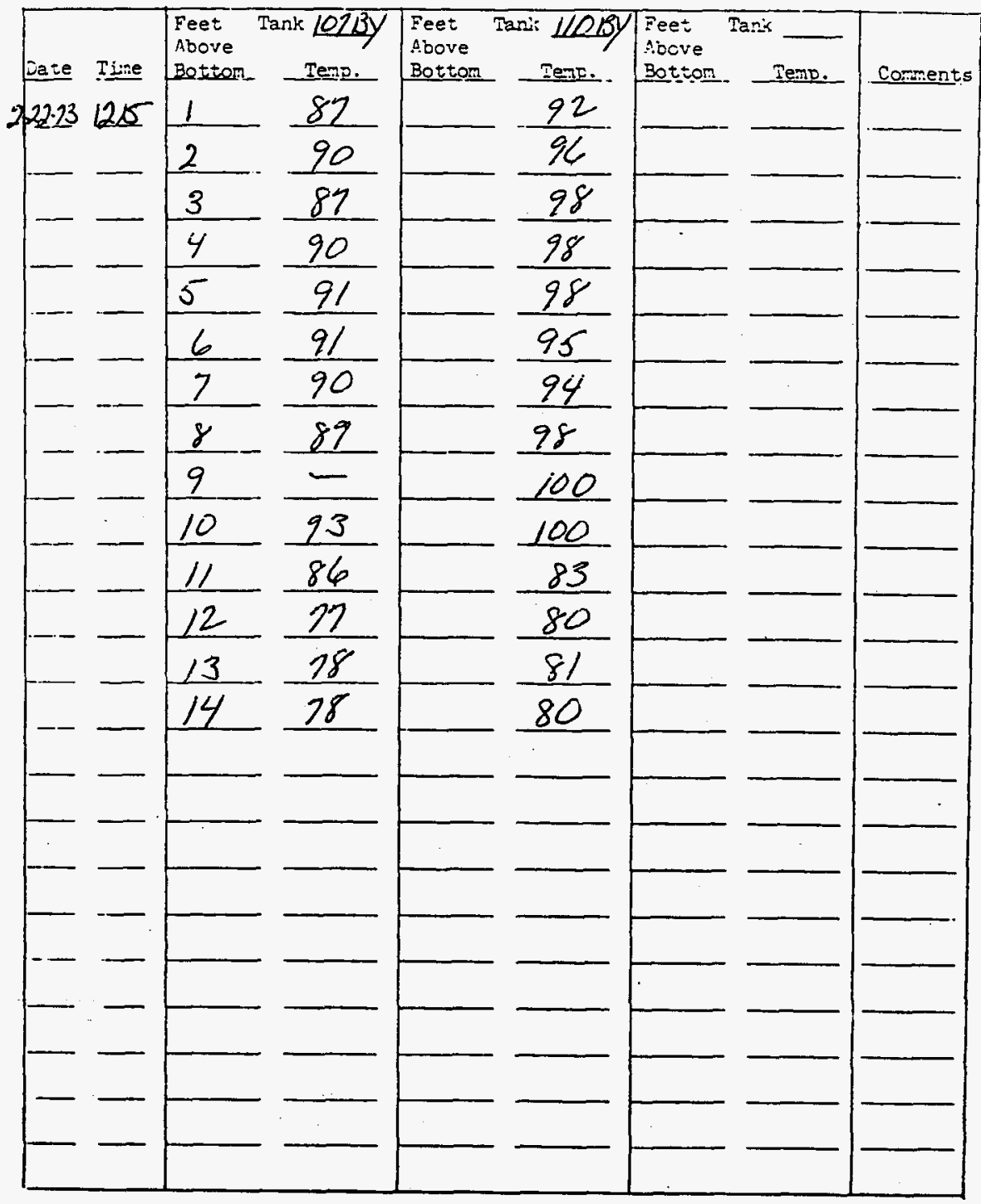

Ir:3tr:etions or coments: -Take proflle temperatures veekly in each bottoms tank. Attach corpleted form to Monday and Thursday's Data Sheets. 
Title:

PROFILE TEMPERATURES IN ITS-2 BOTTONS TANTSS

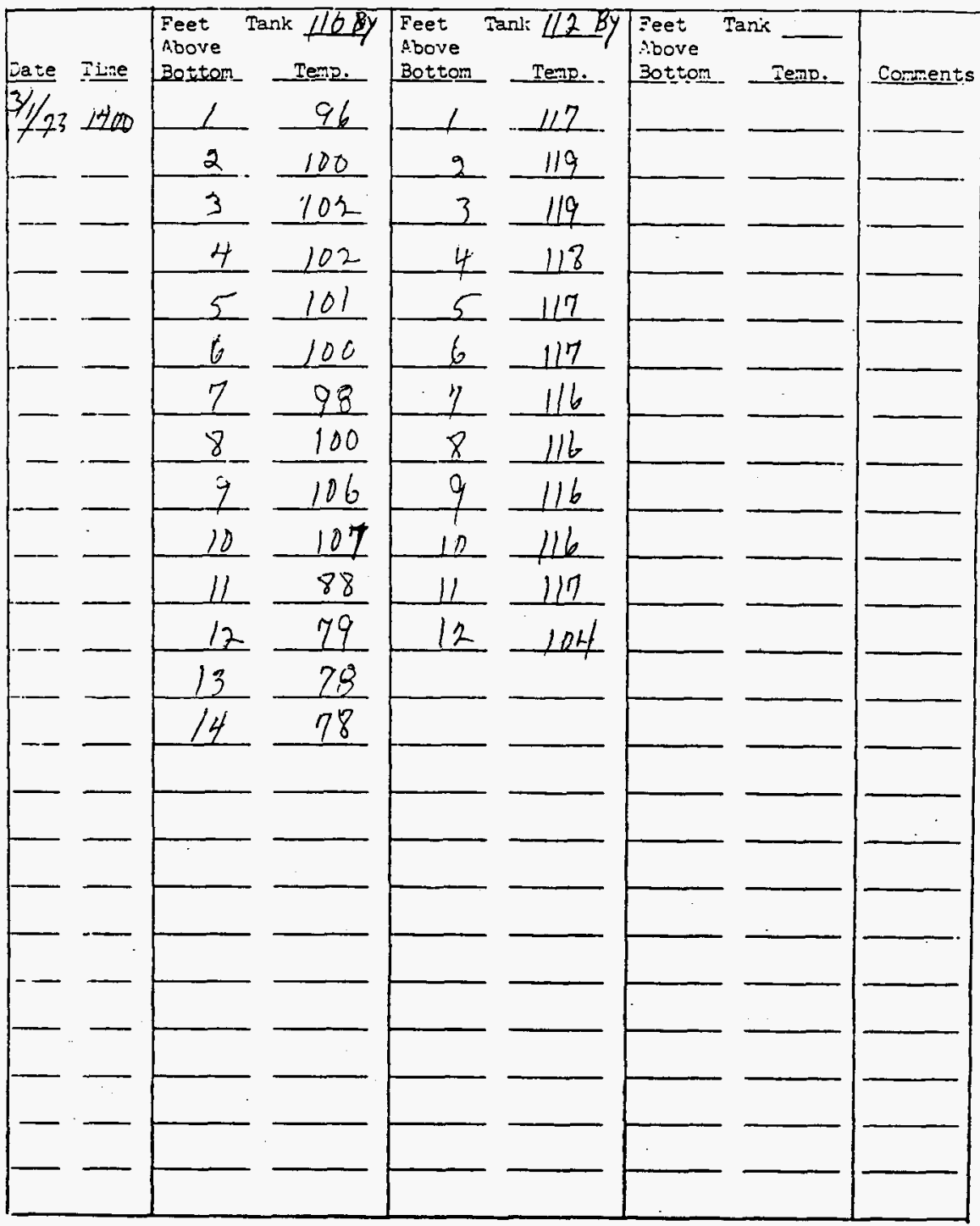

Irstr:atisns or caments: - Take proflle temperatures veekly in each bottoms tank. Attach conpleted form to Monday and Thursday's Data Sheets. 
Title: PROFILE TEIPERATURES TI ITS-2 BOTTOMS TAMKS

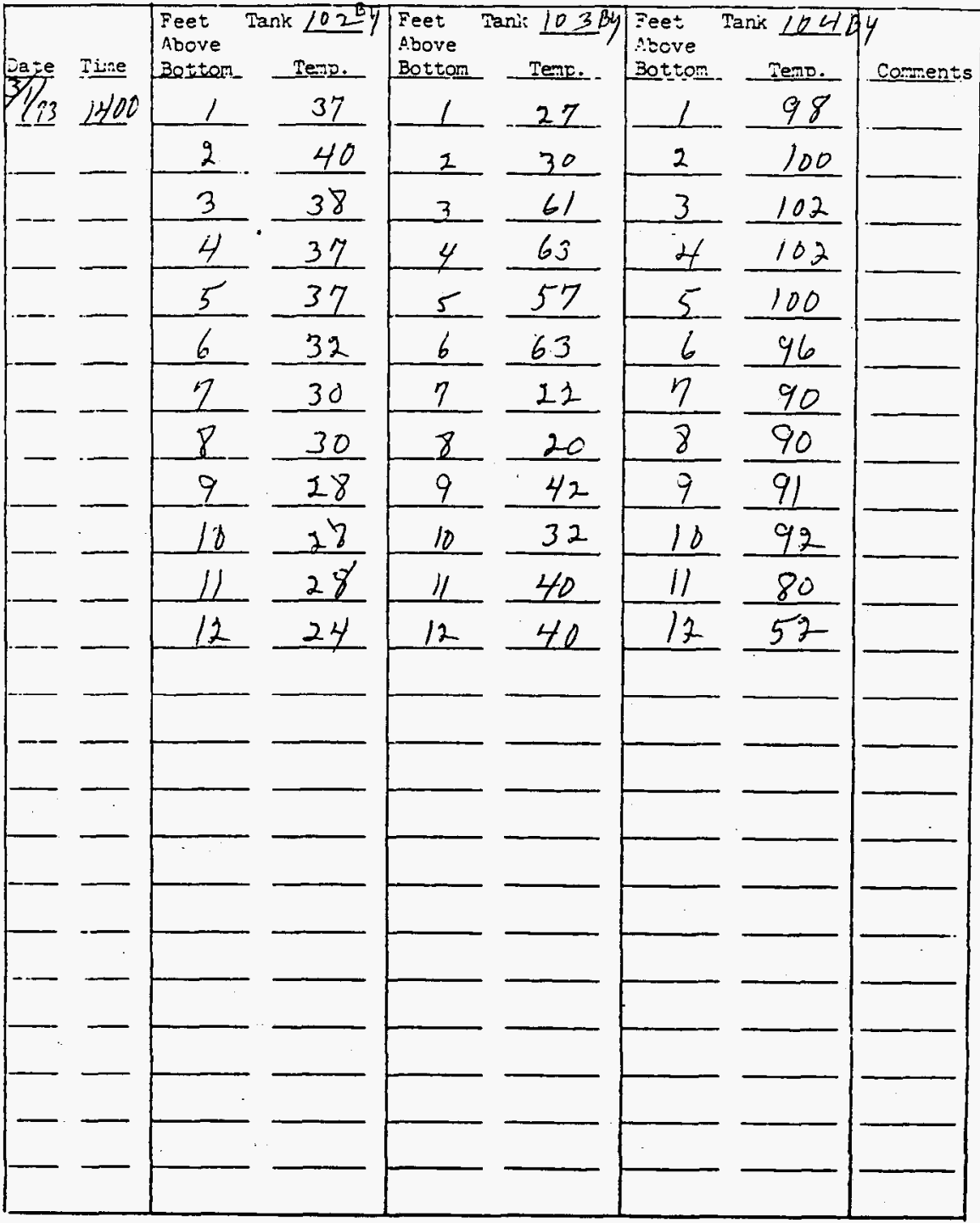

Irstristions or corments: - Take profile temperatures weekly in each bottons tank. Attach completed ford to Monday and Thursday's Data Sheets. 
WHC-SD-WM-DP-207, REV. 0

Title:

PROFIIE TEPQPEATURES II ITS-2 BOTTONS TAIKS

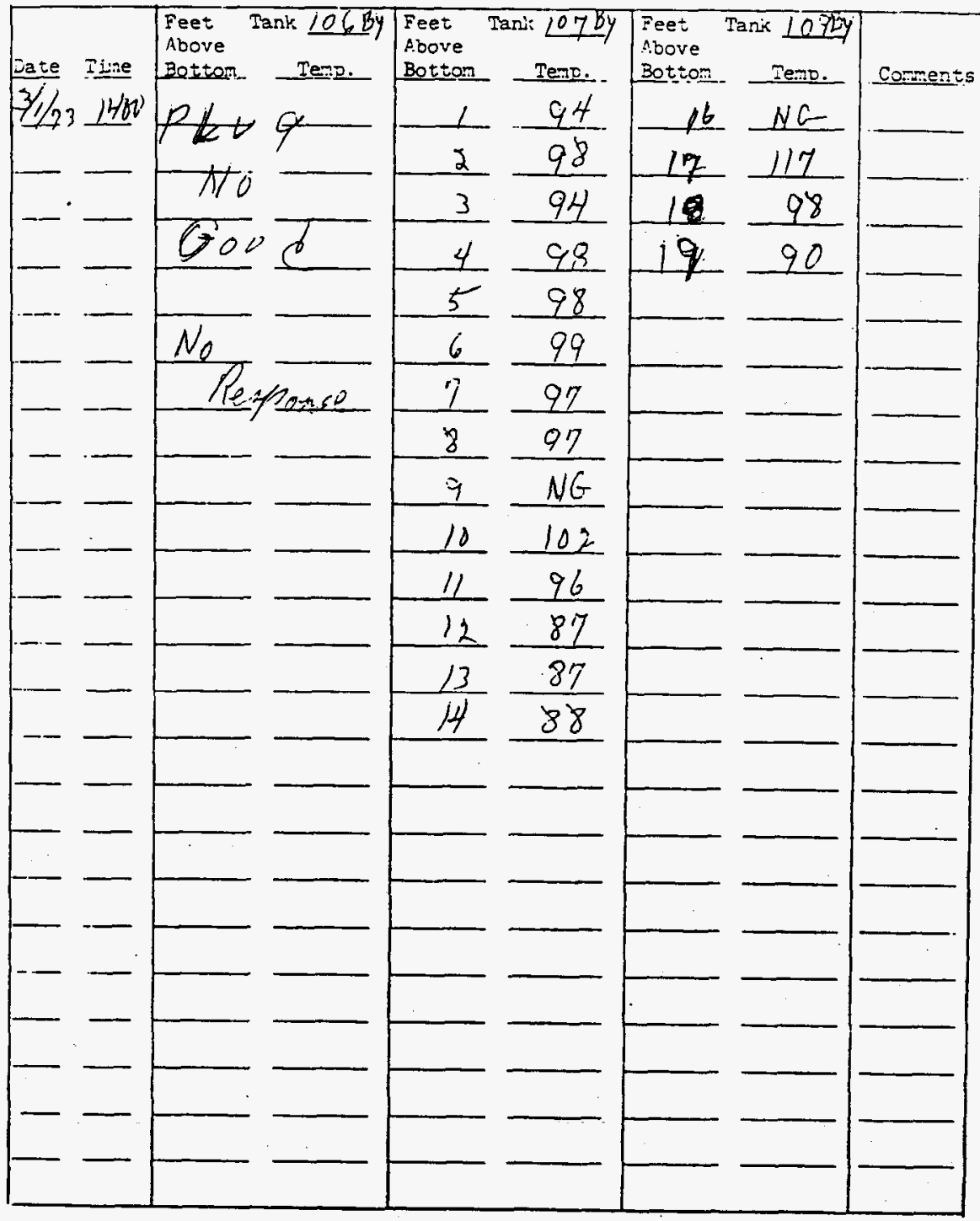

Insirisisions or conments: -Take proflle temperatures veekly in each bottoms tank. Attach conpleted forn to Monday and Thursday's Data Sheets. 
Title: PROFILE TERTERATURES IN ITS-2 BOTTOMS TANTSS

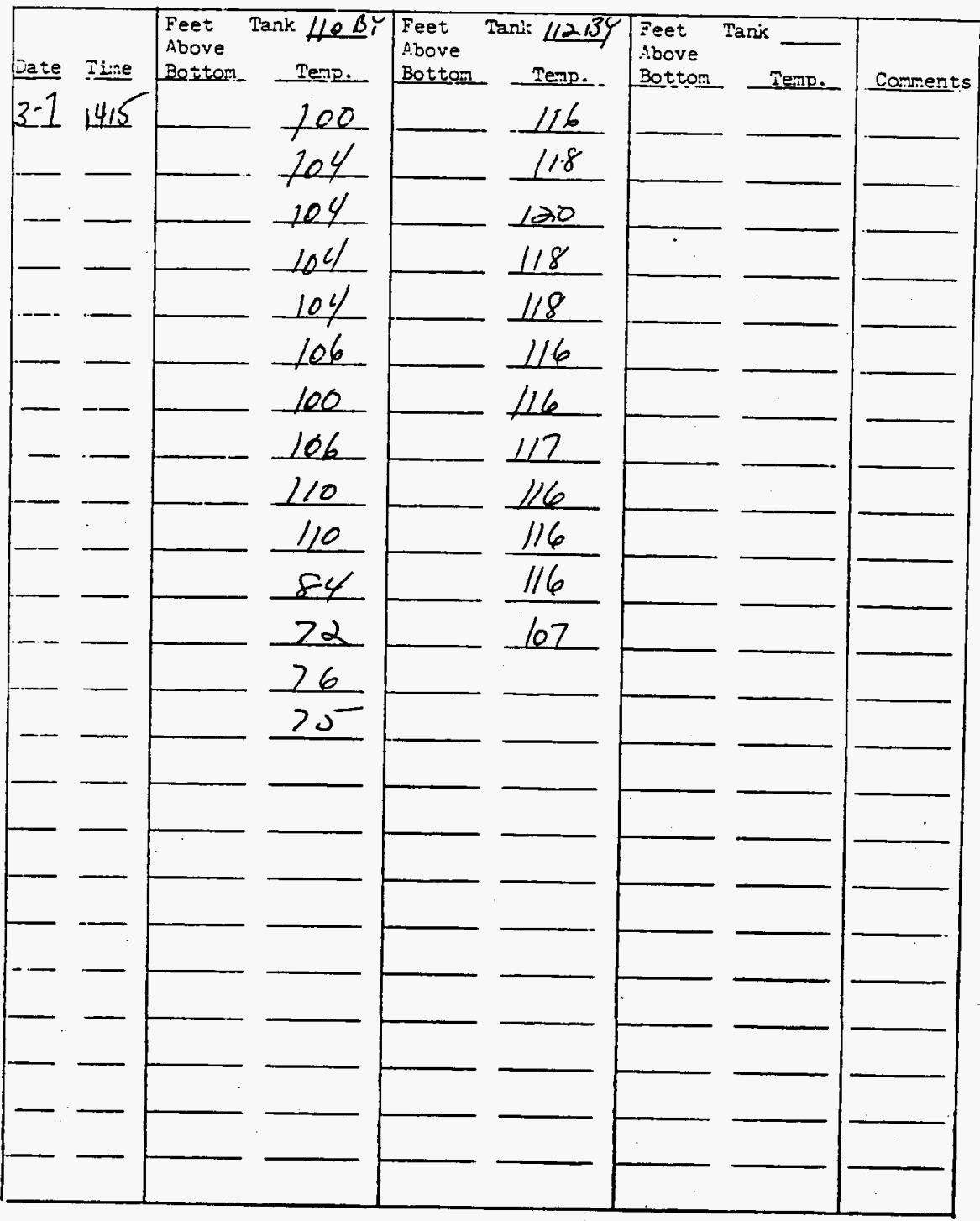

Irstristions or coments: - Pake profile temperatures weekly in each battoms tank. Attach completed form to Monday and Thursday's Data sheets. 
Title :

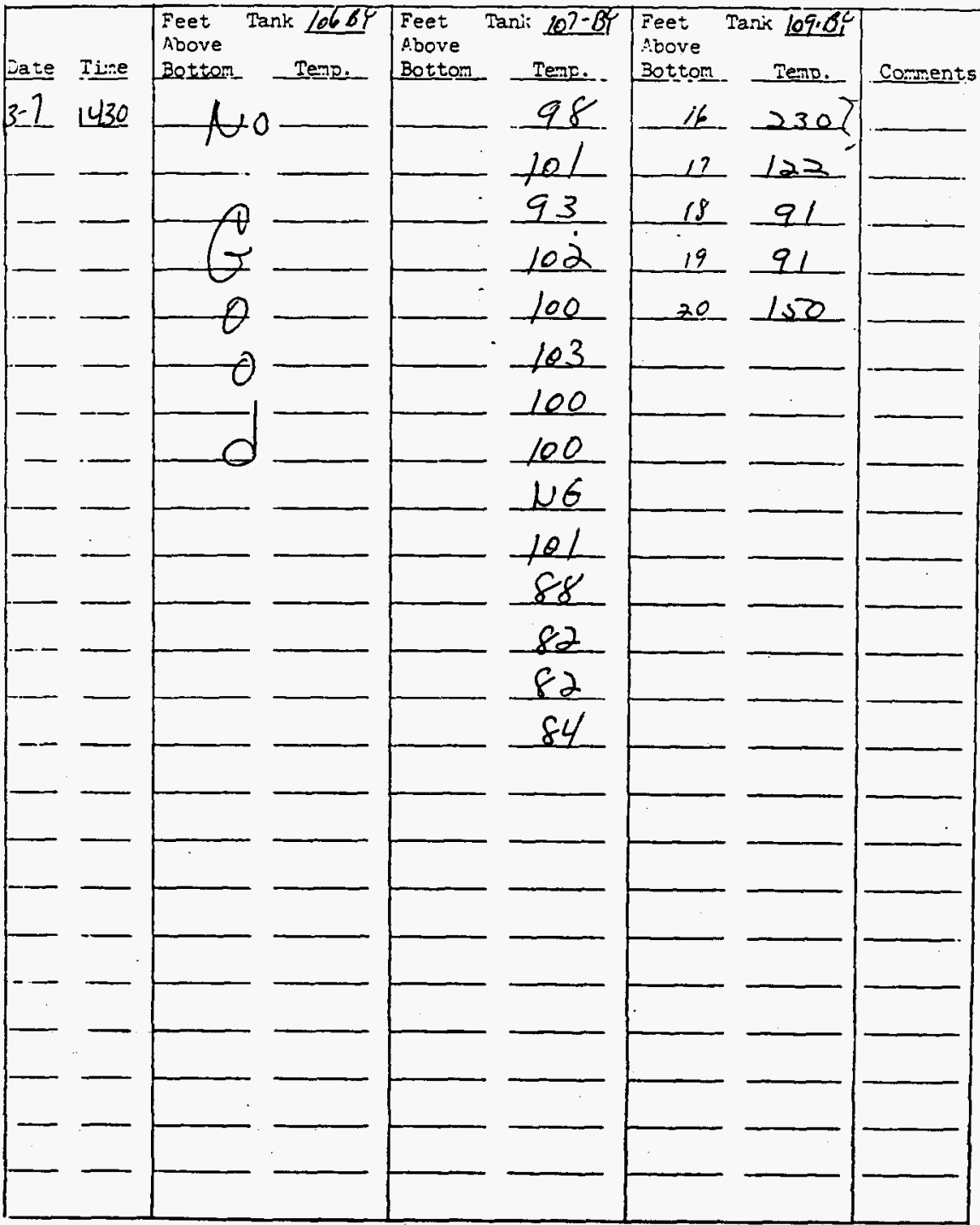

Inserditisns or conments: - Take proflle temperatures weekly in each bottoms tank. Attach conpleted forr to Monday and Thursday's Data Sheets. 
Title: PROFILE TEPERATURES II ITS-2 BOTTOMS TANCS

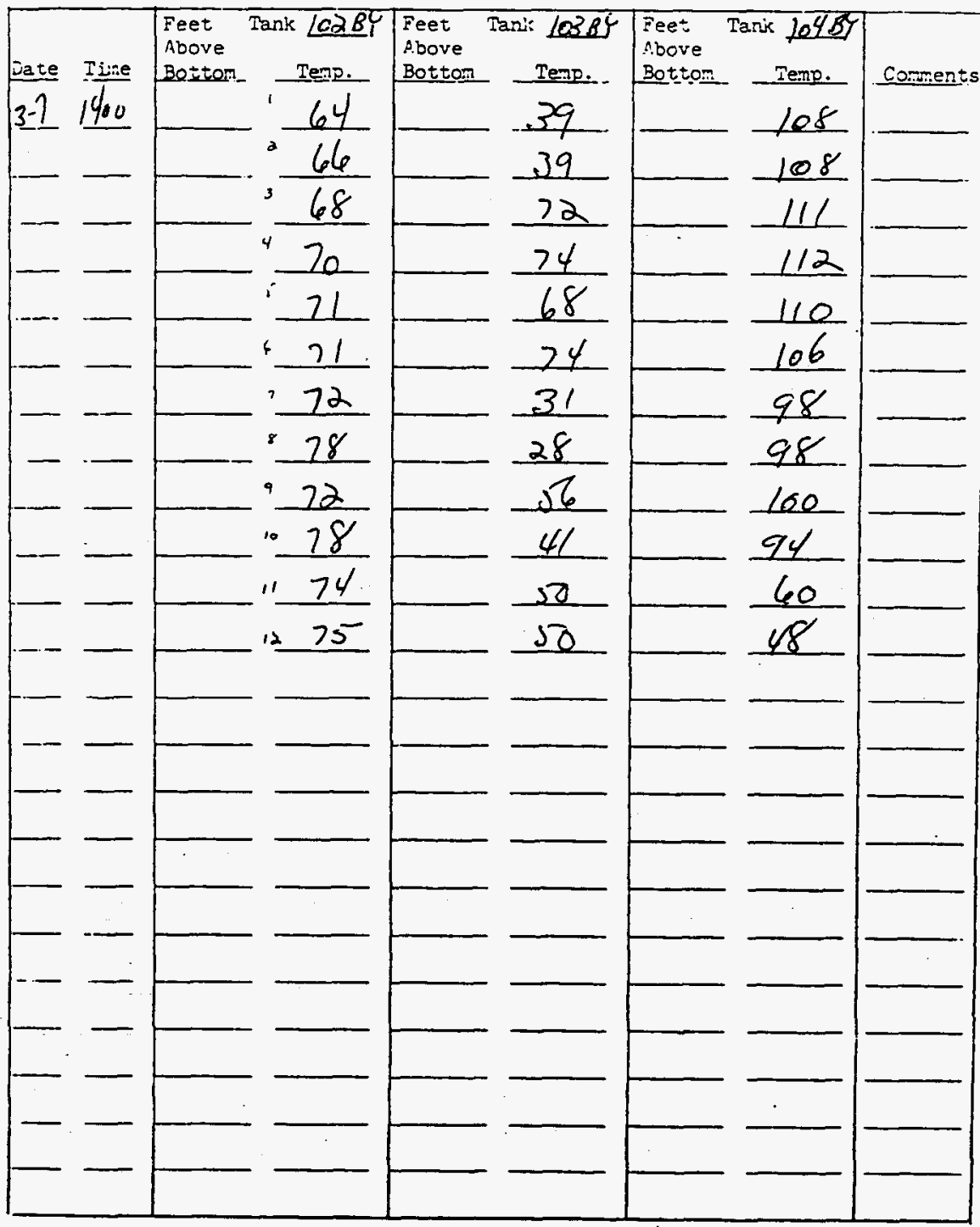

Instrisitions or coments: - Take profile temperatures veekly in ench bottoms. tank. Attach conpleted forn to Monday and Thursday's Data sheets. 
Title:

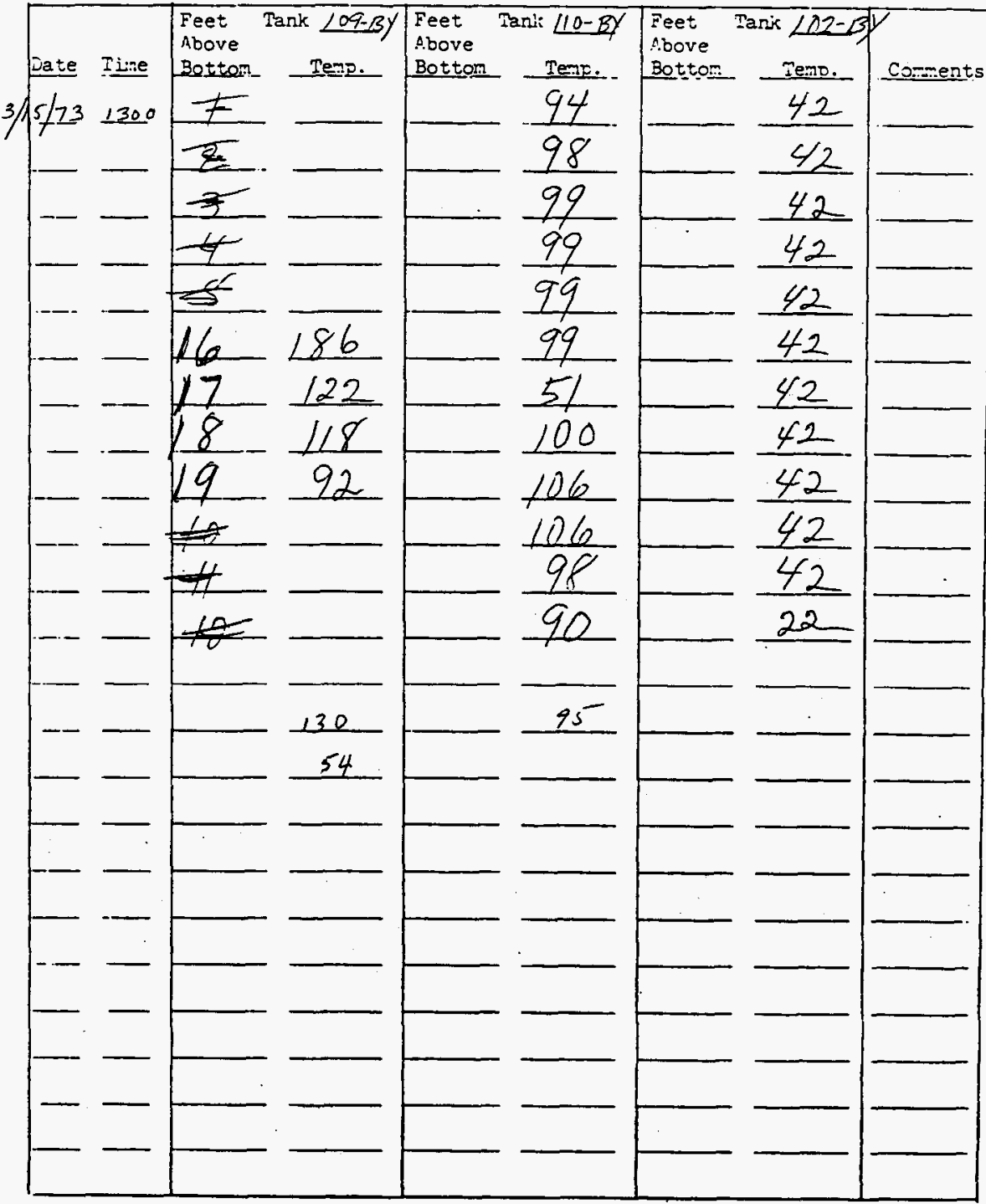

Instristions or coments: - Take profile temperatures weekly in each battoms tank. Attach conpleted form to Monday and Thursday's Data Sheets. 
Title:

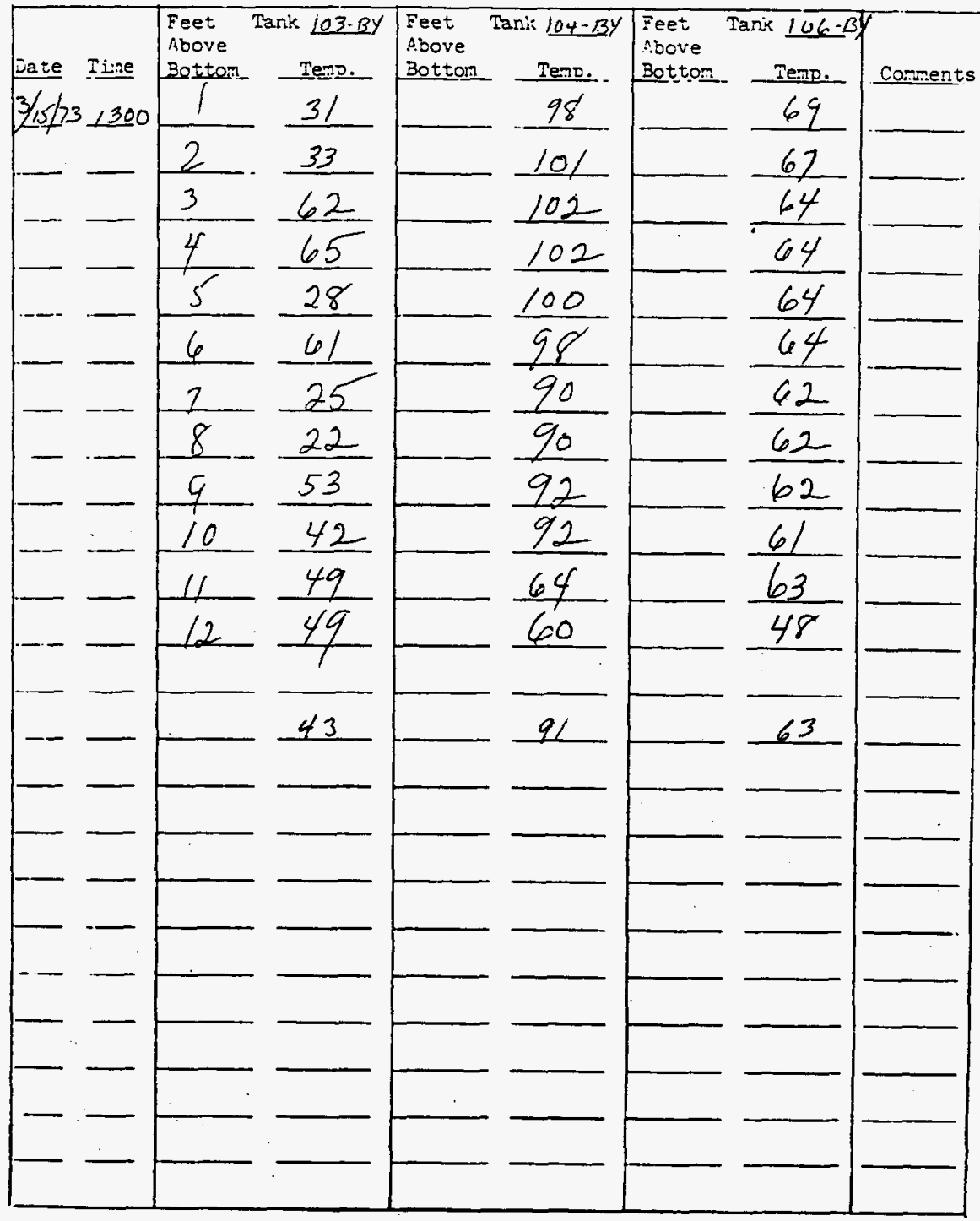

Instrictions ar coments: - Take profile temperatures veelcly in each bottoms tank. Attach conpleted form to Monday and Thursday's Data Sheets. 
Title: PROFTLE TERPERATURES IN ITS-2 BOTTOMS TANKS

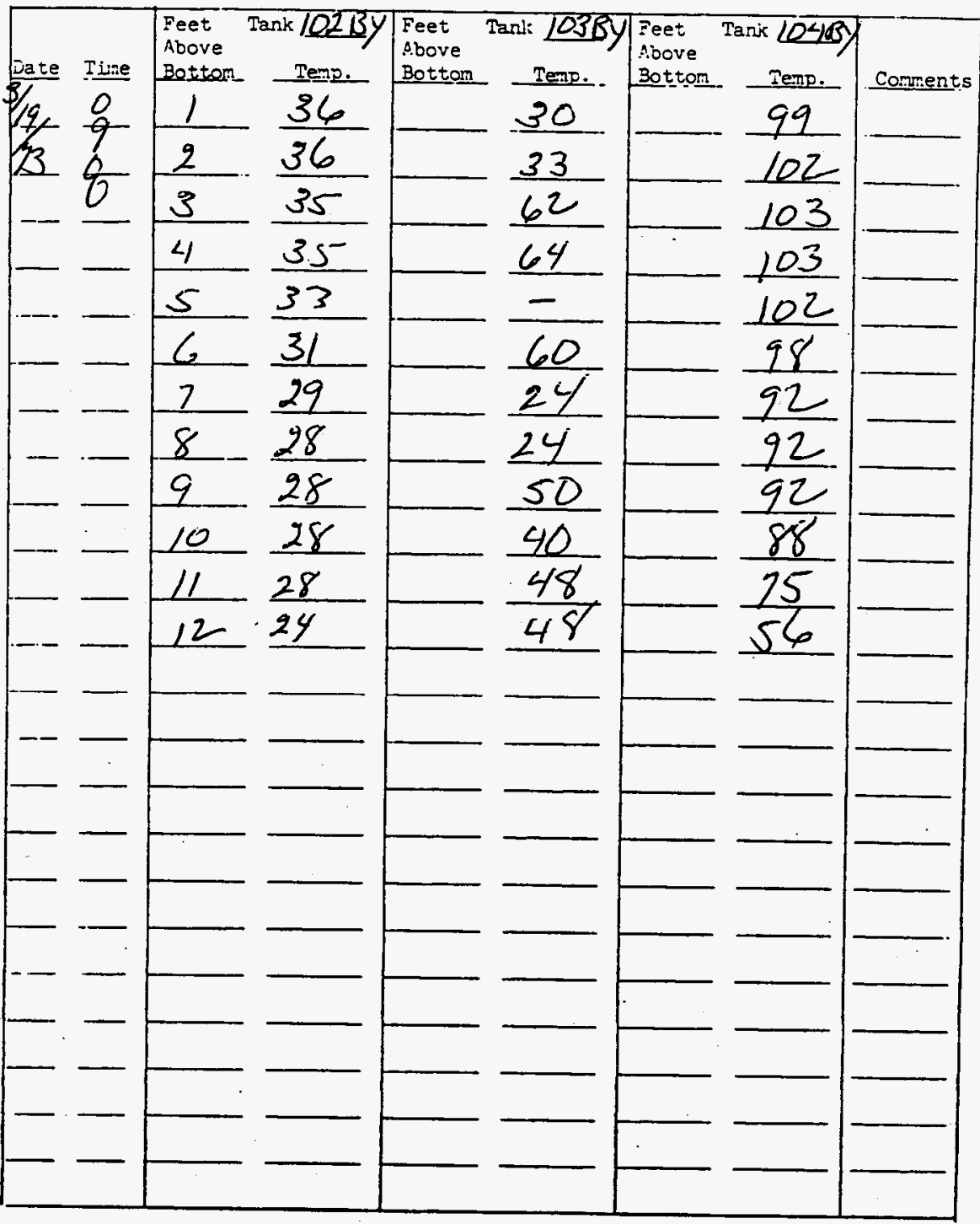

Instrictions or coments: - Take profille temperatures weekly in each bottoms tank. Attach completed form to Monday and Thursday's Data sheats. 
Title: PROFILE TERERATURES IN ITS-2 BOTTOMS TANKS

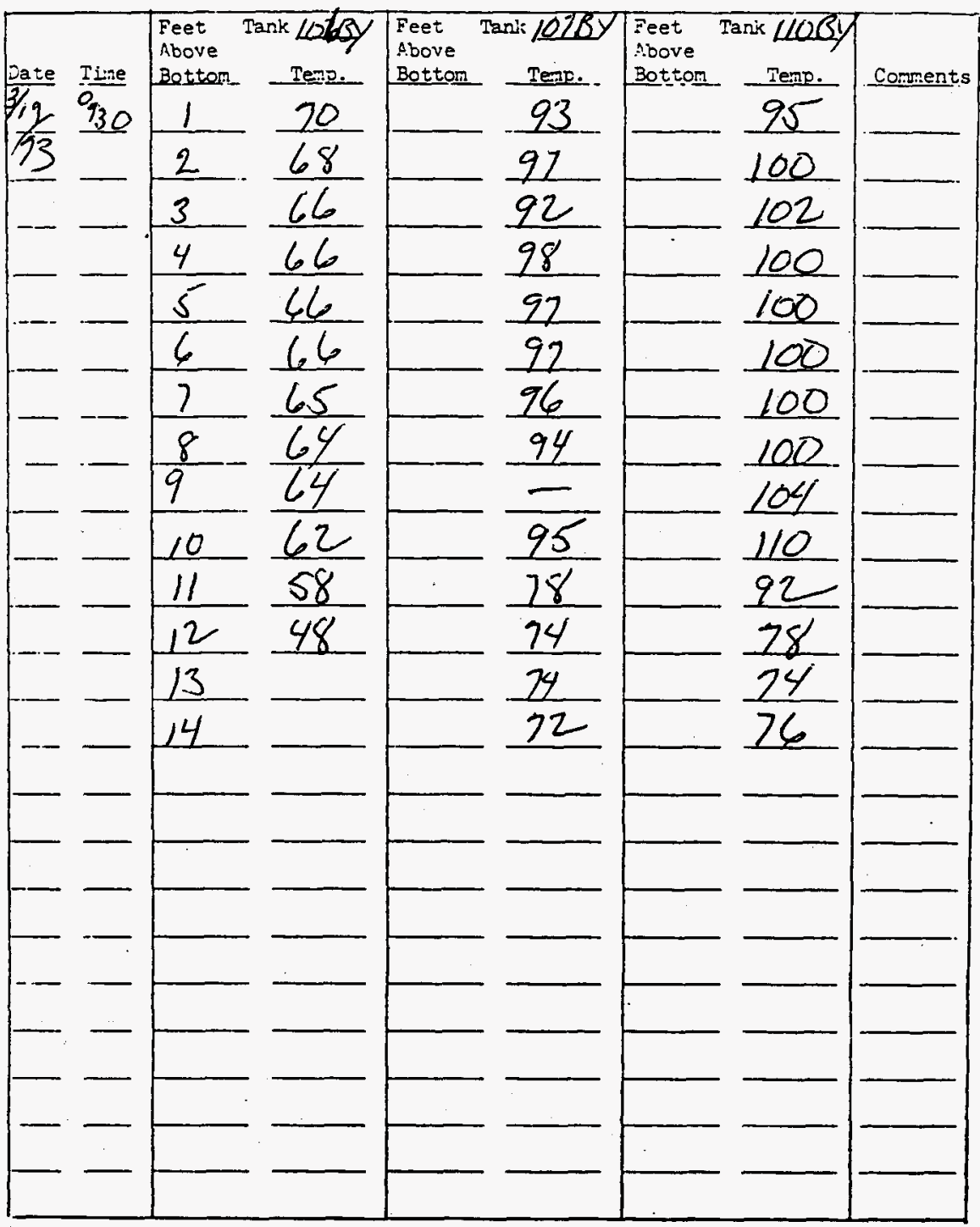

Instr:etions or coments: - Take proflle temperatures veelely in each battoms tank. Attach conpleted form to Monday and Thursday's Data sheets. 
Title: TROFILE TERRERATURES INI ITS-2 BOTTOMS TANKS

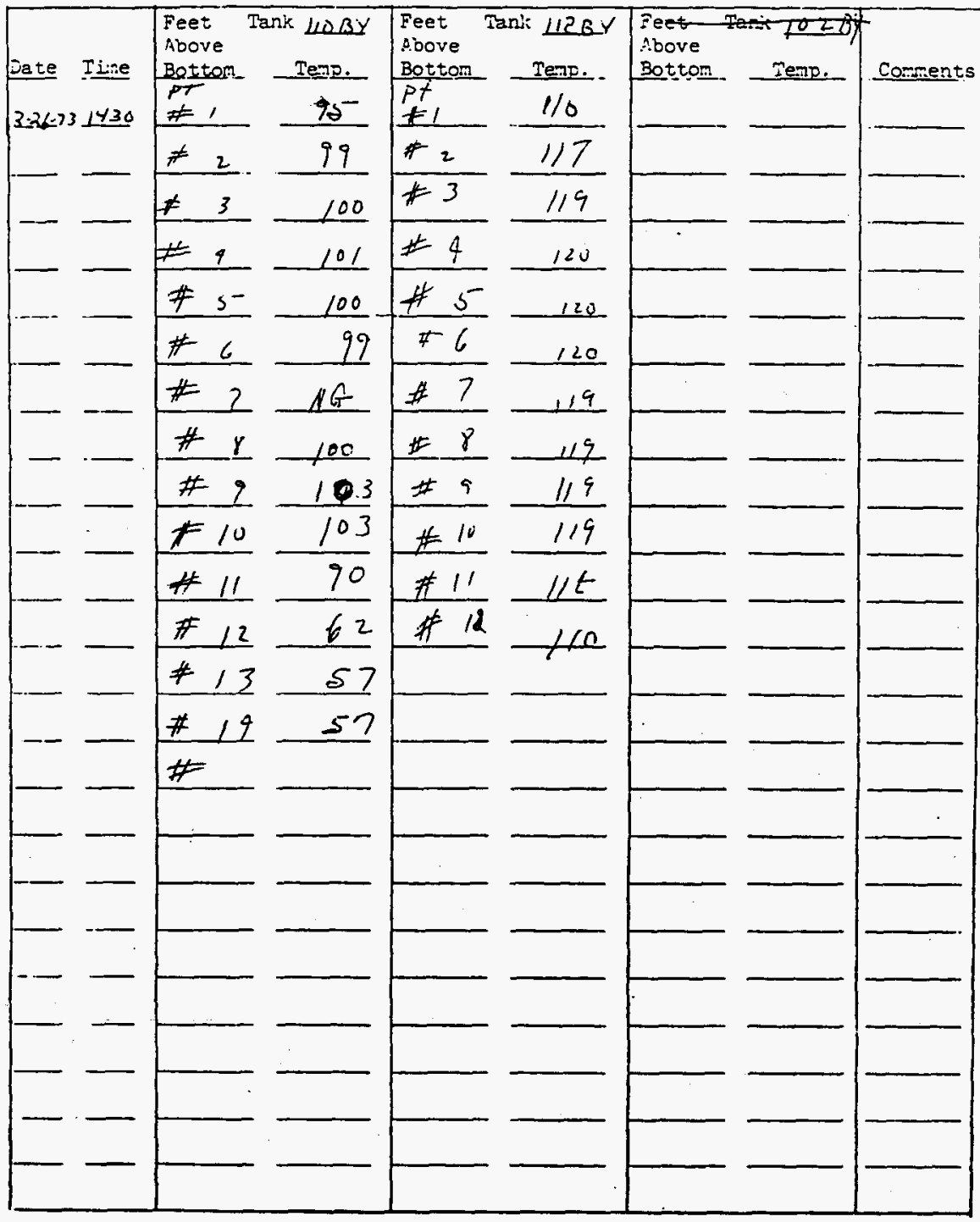

Irstrietions ar caments: -Take profile temperatures weekly in each bottoms tank. Attach conpleted fors to Monday and Thursday's Data Sheets. 
Title : PROFILE TETIPERATURES MV ITS-2 BOTTOMS TANKS

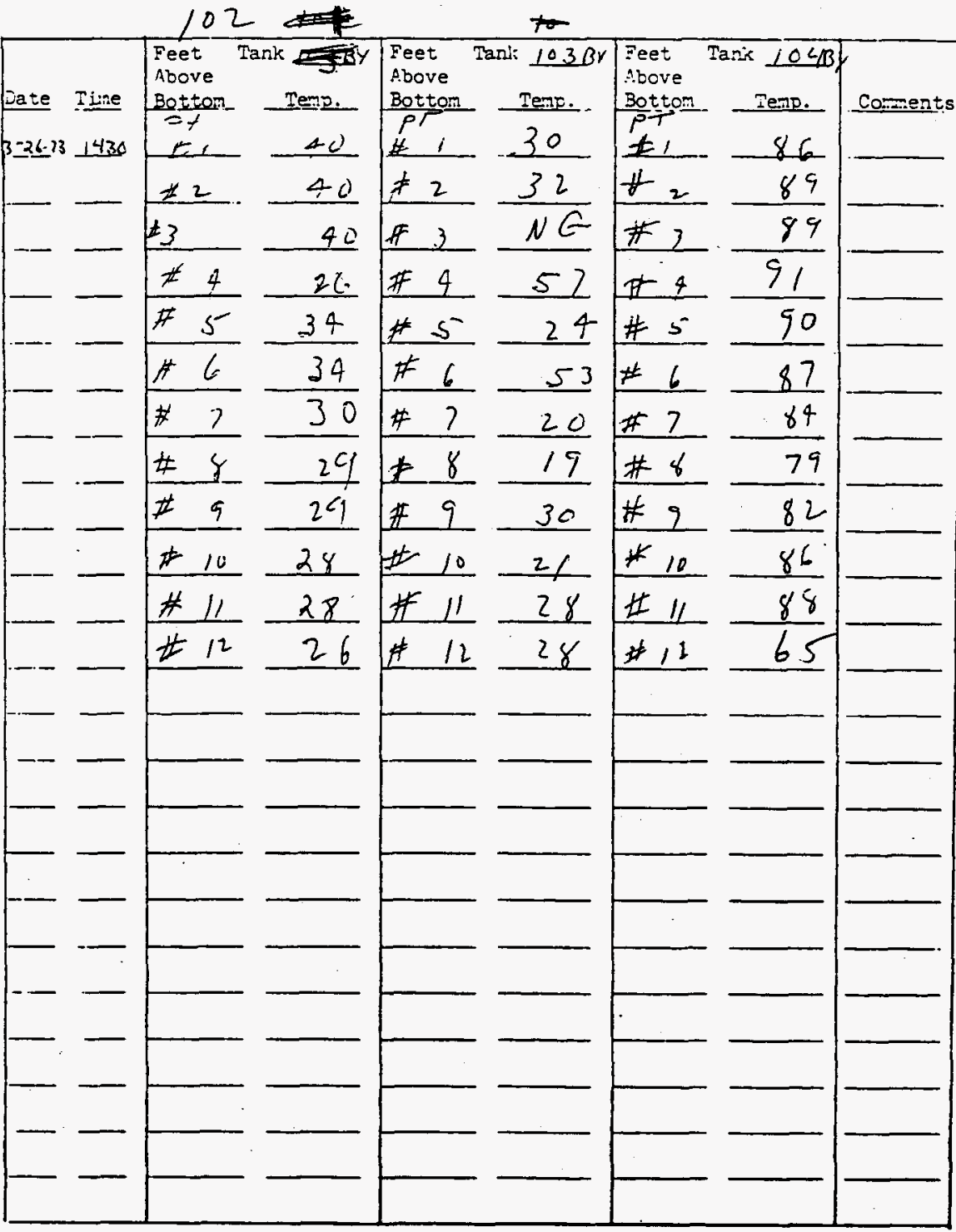

Irstristions or comenss: - Take proflie tomperatures reakly in each battoms tank. Attach conpleted form to Monday and Thursday's Data Sheets. 
Title:

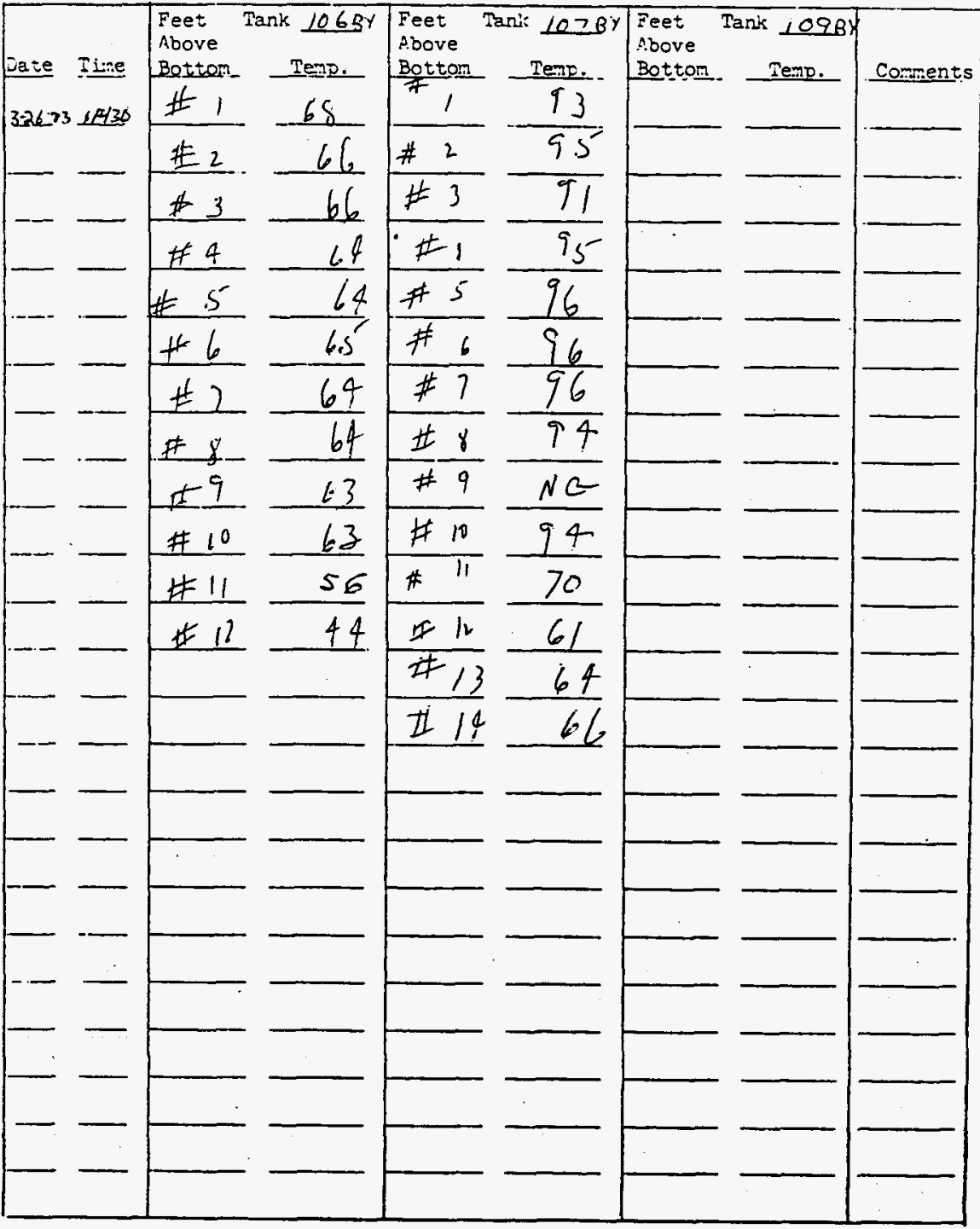

Insiristions or comments: - Take prof lle temperatures veekly in each battoms tank. Attach conpieted form to Monday and Thursday's Data Sheets. 
Title : PROFIIE TEMPERATURES IN ITS-2 BOTTOMS TAITSS

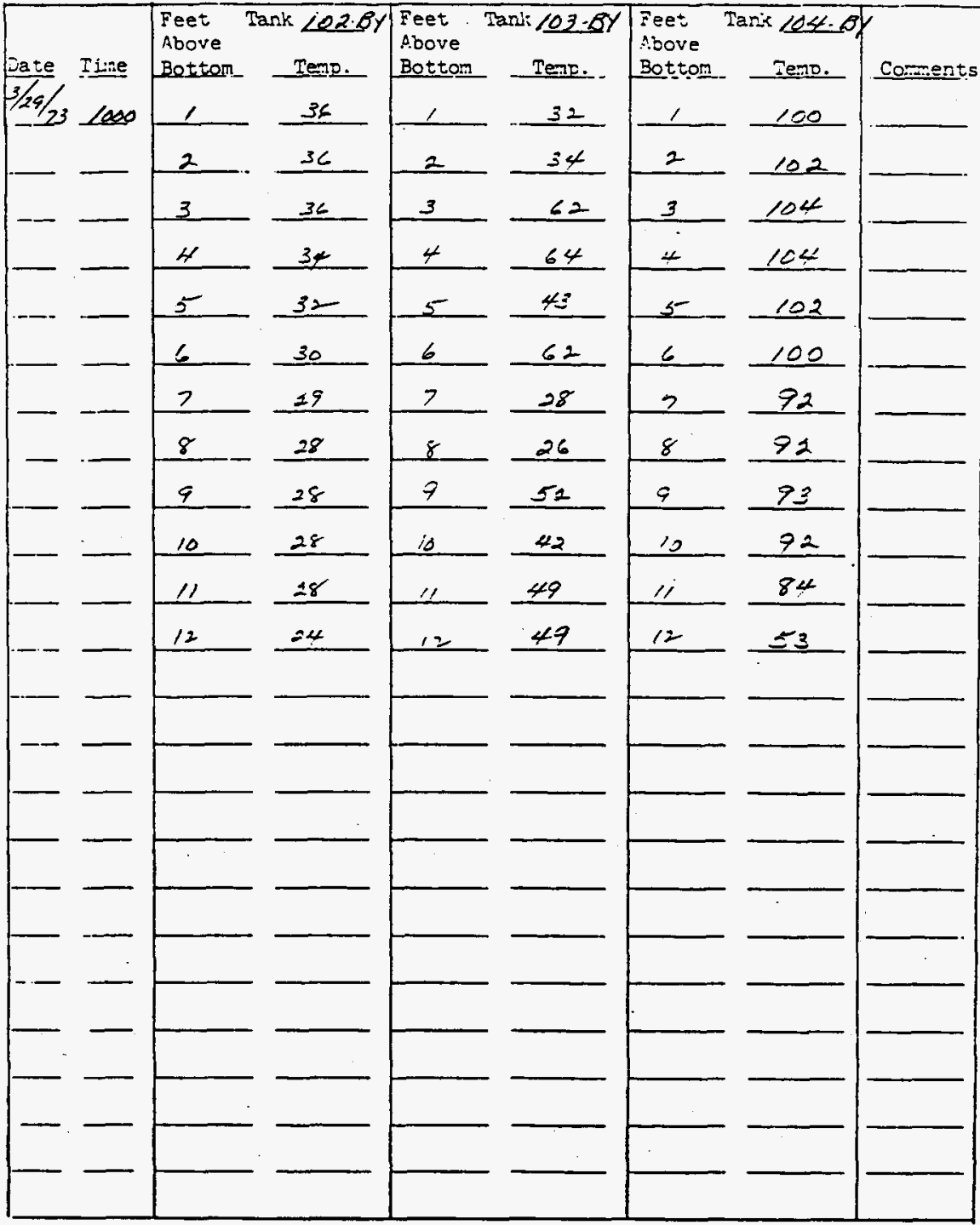

Ir:siriations or camenis: Take proflle temperatures weekly in each bottoms tank. Attach conpleted form to Monday and Thursday's Data Sheets. 
Title: PROFILE TEIPERATURES TR ITS-2 BOTTOMS TANKS

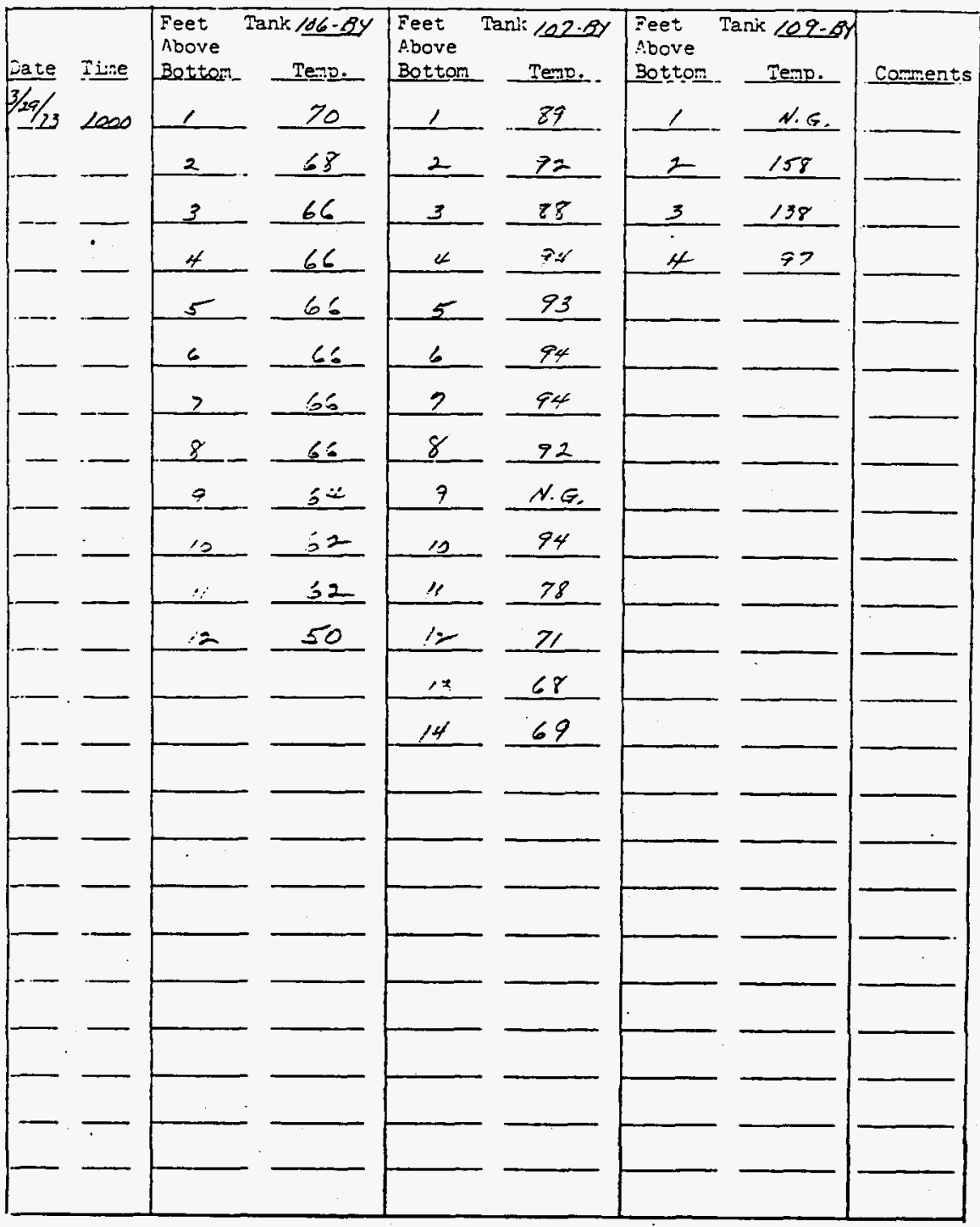

I:3traiticns or conments: - Take profile temperatures weekly ia each bottans tank. Attach corneleted form to Monday and. Thursday's Data Sheets. 


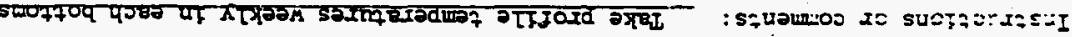

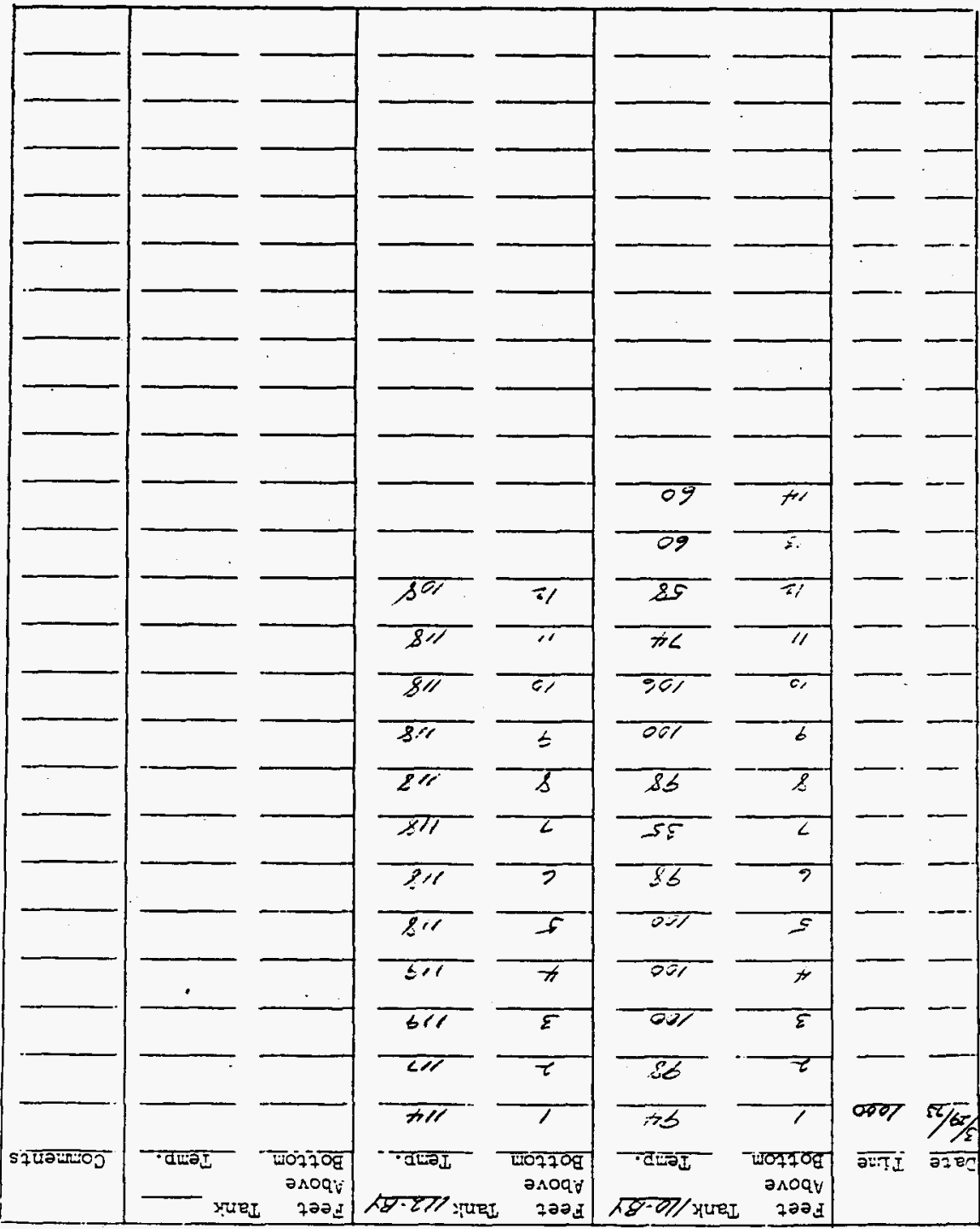


Title:

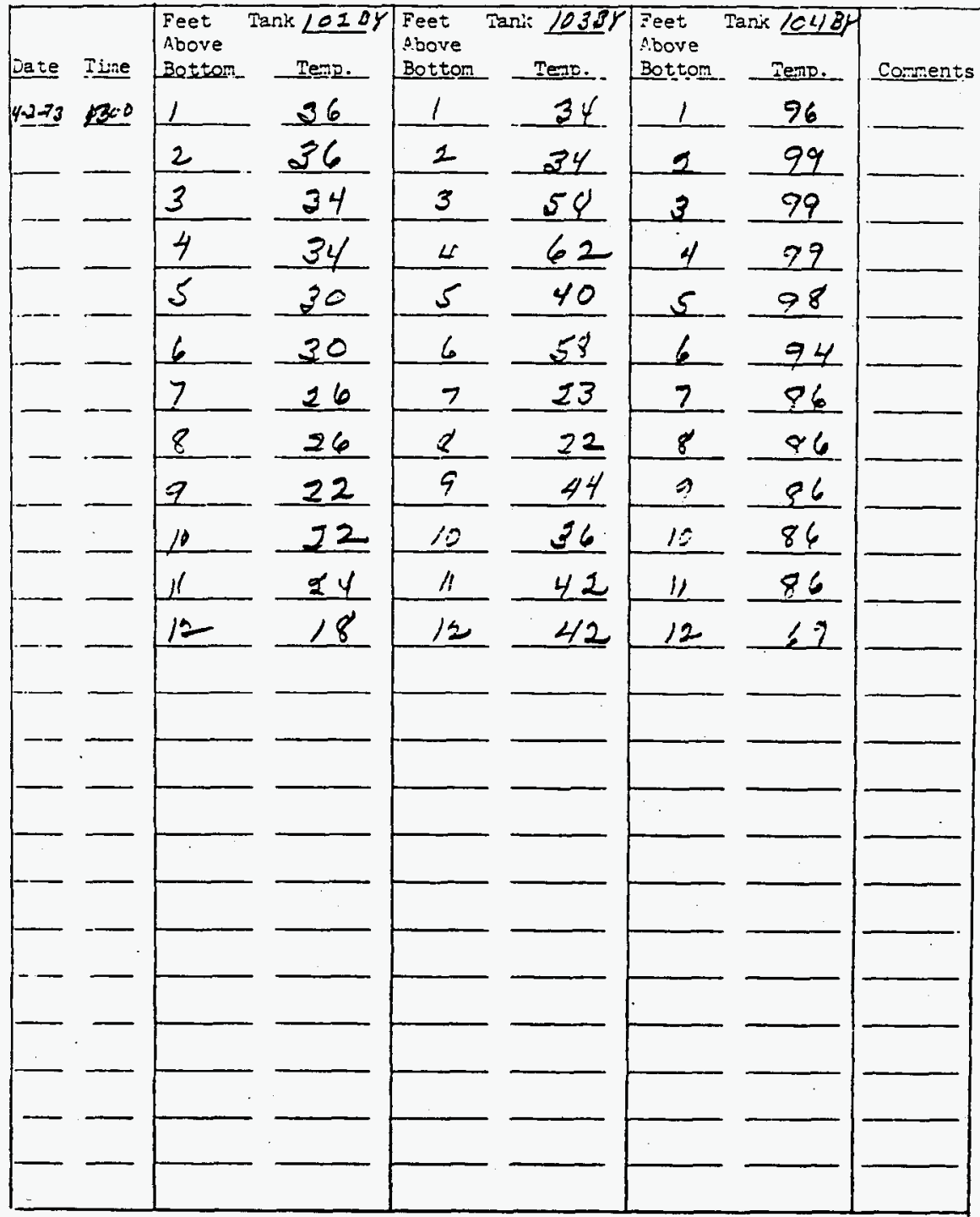

Irstr:itisns =r coments: - Take prorile temperatures veekly in each bottons tank. Attach completed form to Monday and Thursday's Data sheets. 
Title: PROFILE TEPERATURES DN ITS-2 BOTTOMS TAITS

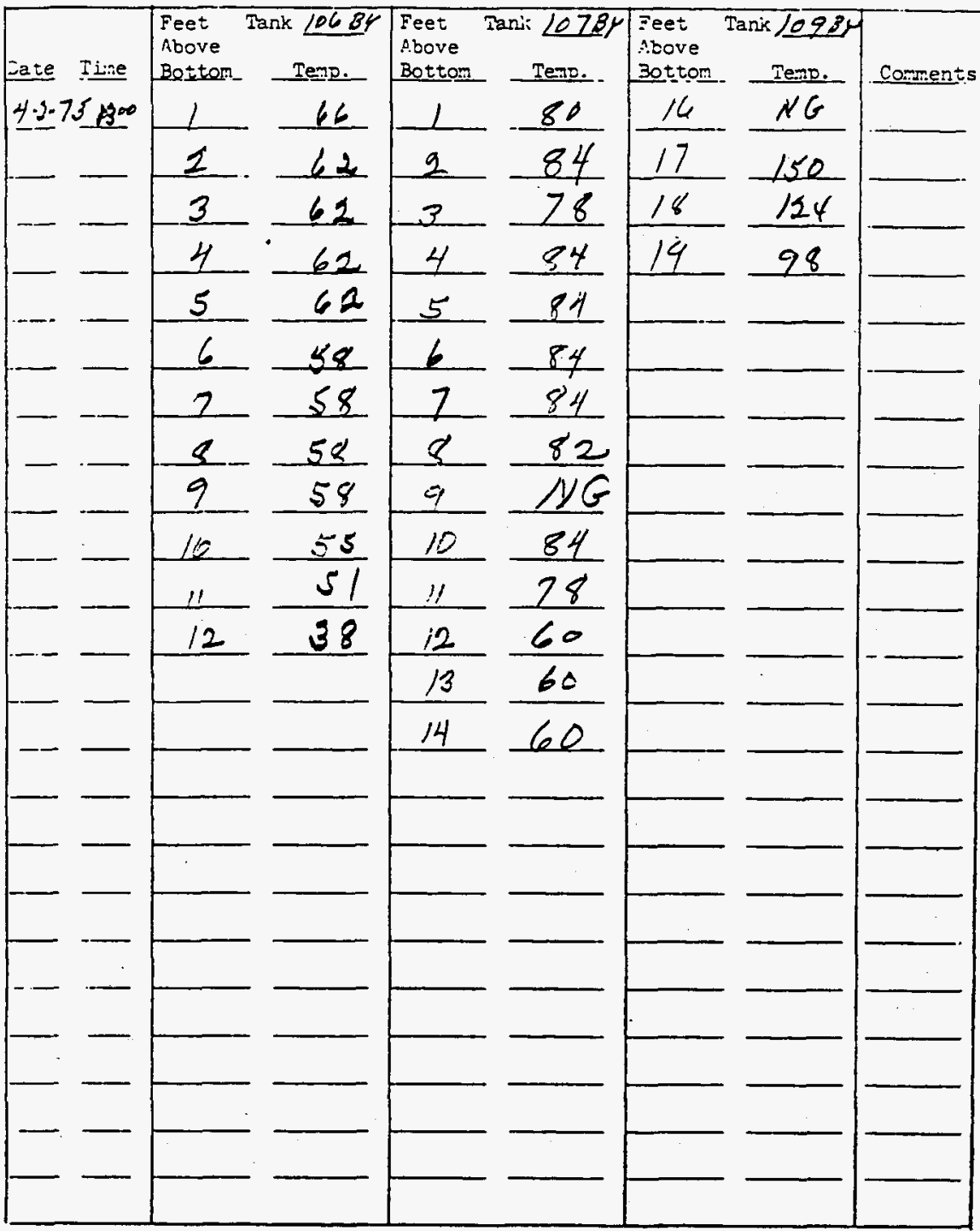

I:3:risticns or comen:s: Taise profile temperatures veekiy in each bottoms tank. Attach conpleted for to Monday and Thursday's Data sheets. 
Title: FROFILE TEBPERATURES IIV ITS-2 BOTTOMS TANKS

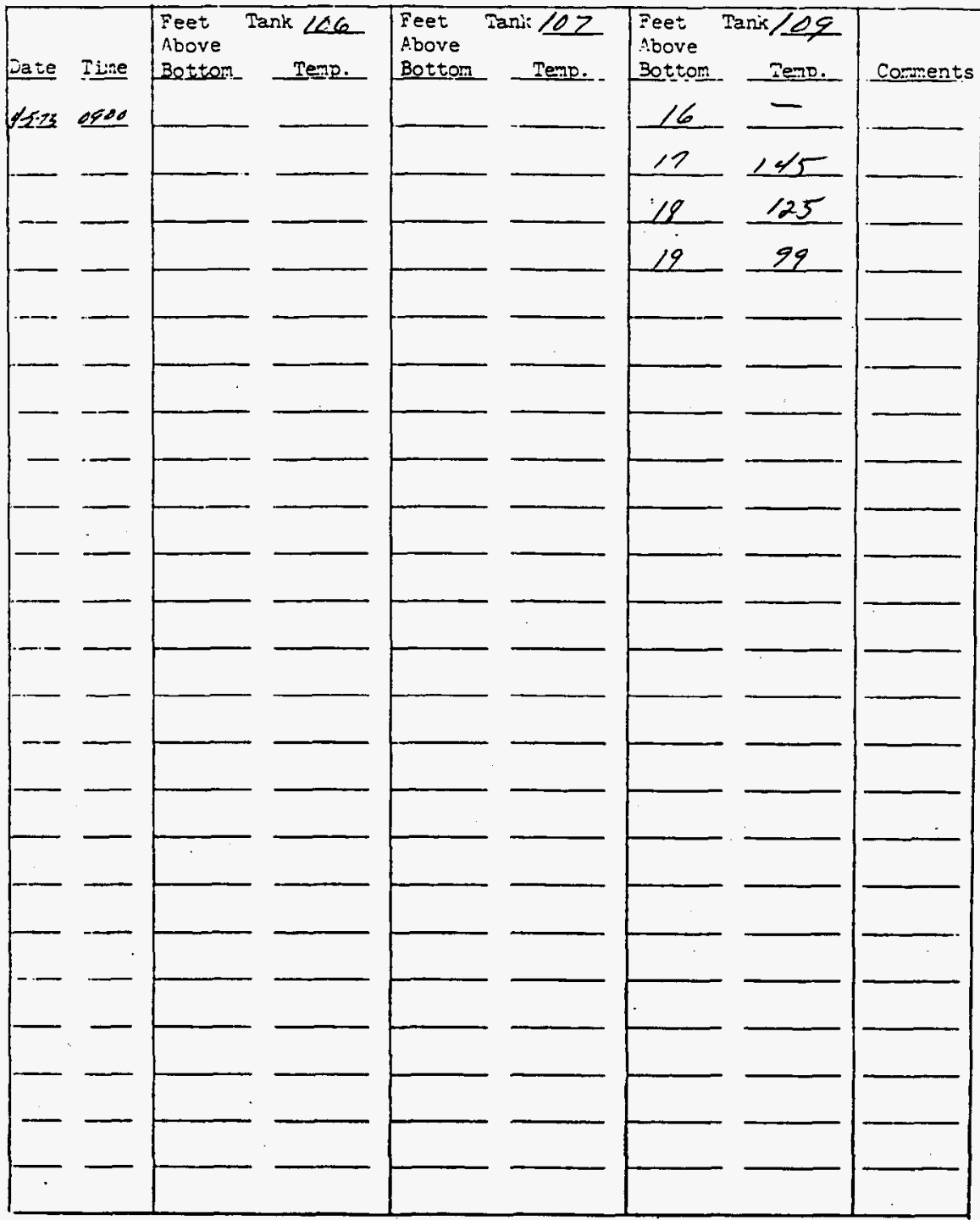

Irstrictions or coiments: - Take prof lle temperatures weekly in each hottoms 
Title: PROFIIE TERPERATURES IN ITS-2 BOTTOMS TAIKS

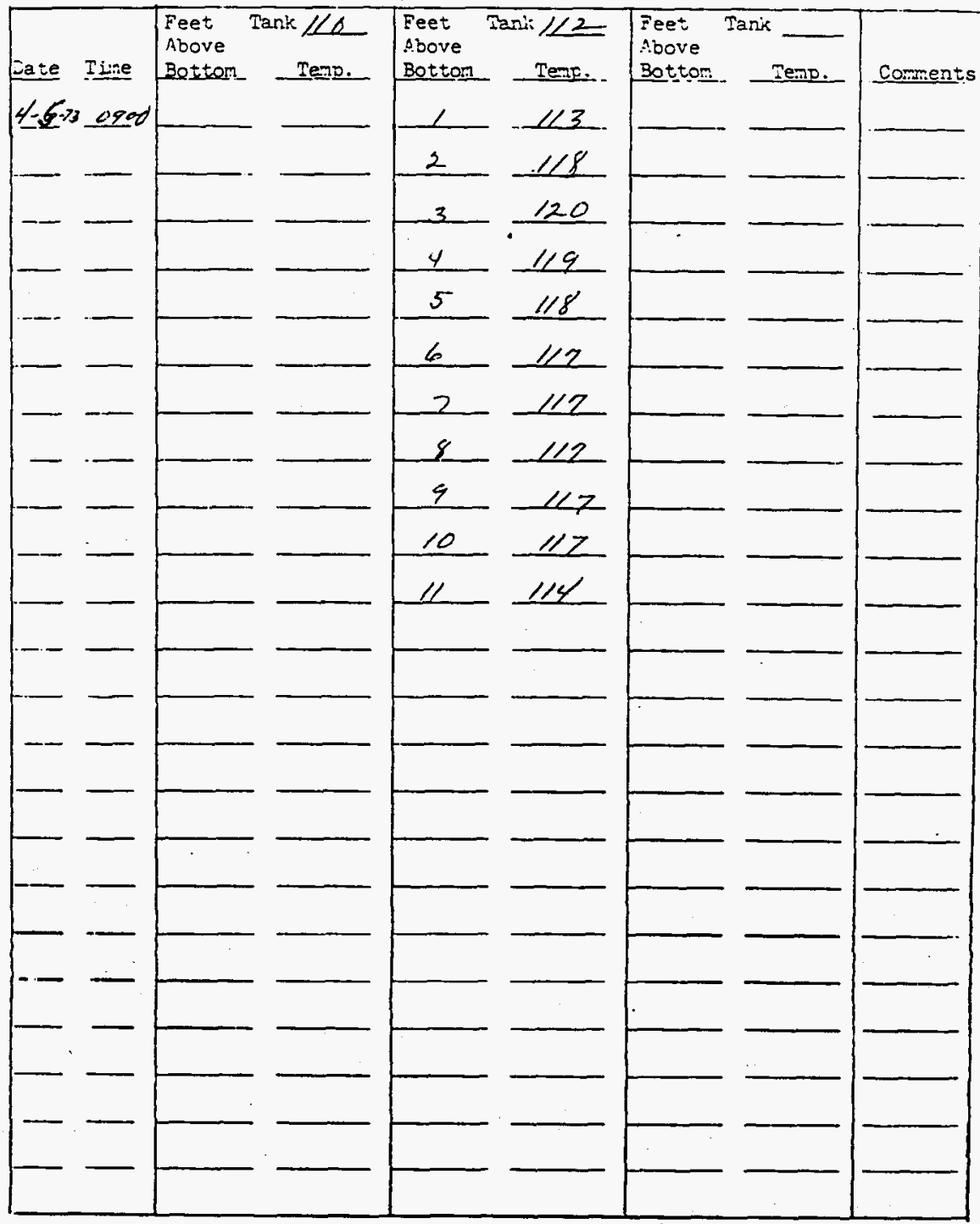

In:sin:tions or coiments: - Take profile temperatures veekly in each bottoms tank. Attach completed fore to Monday and Thursday's Data Sheets. 
Title: PROFILE TERERATURES II ITS-2 BOTTOMS TAMKS

$B Y$

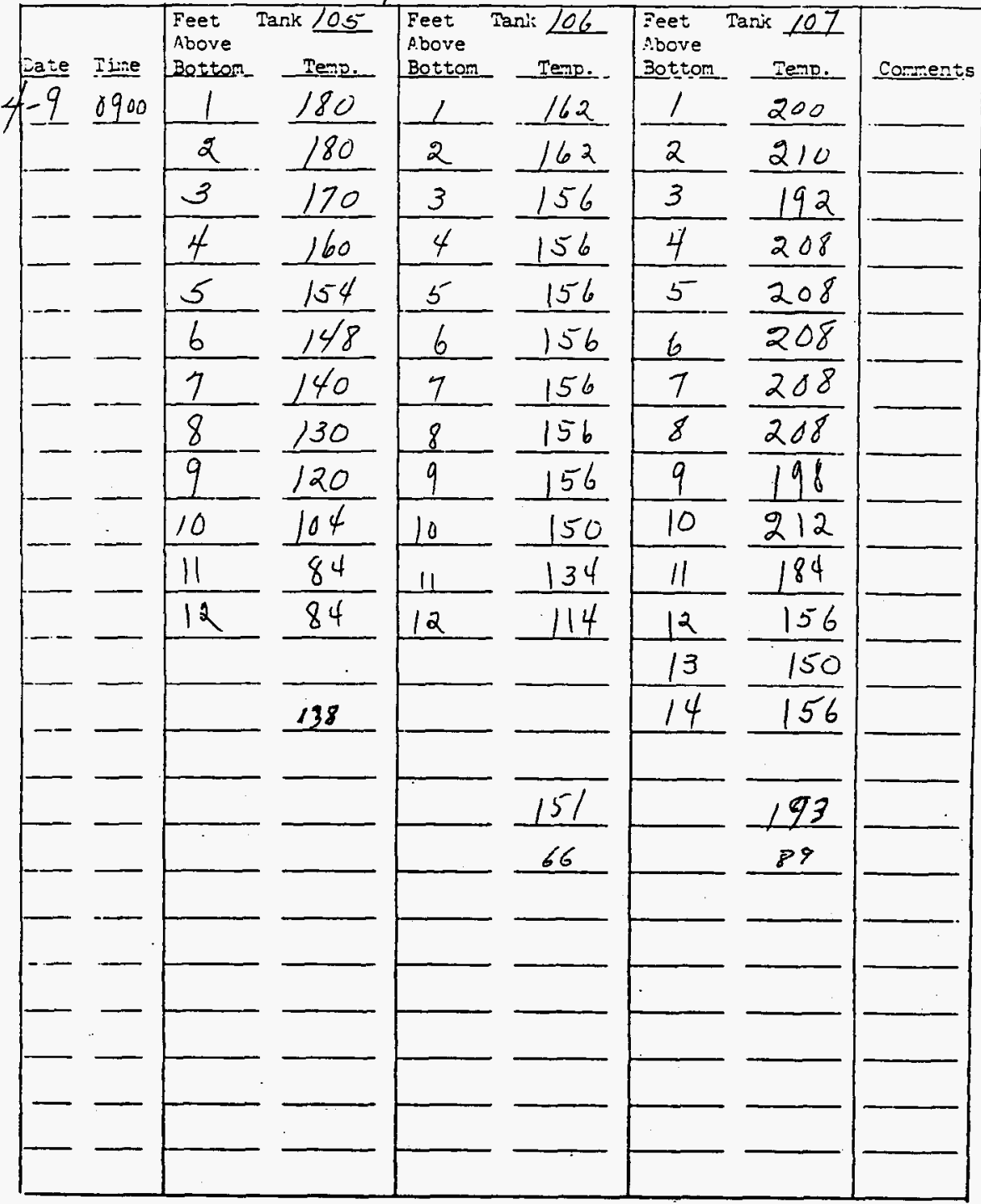

Instriciions or coments: - Take proflle temperatares weekly in each battons tank. Attach corpleted form to Monday and Thursday's Data Sheets. 
Title: PROFILE TEPERATURES IN ITS-2 BOTTOMS TARTS

By

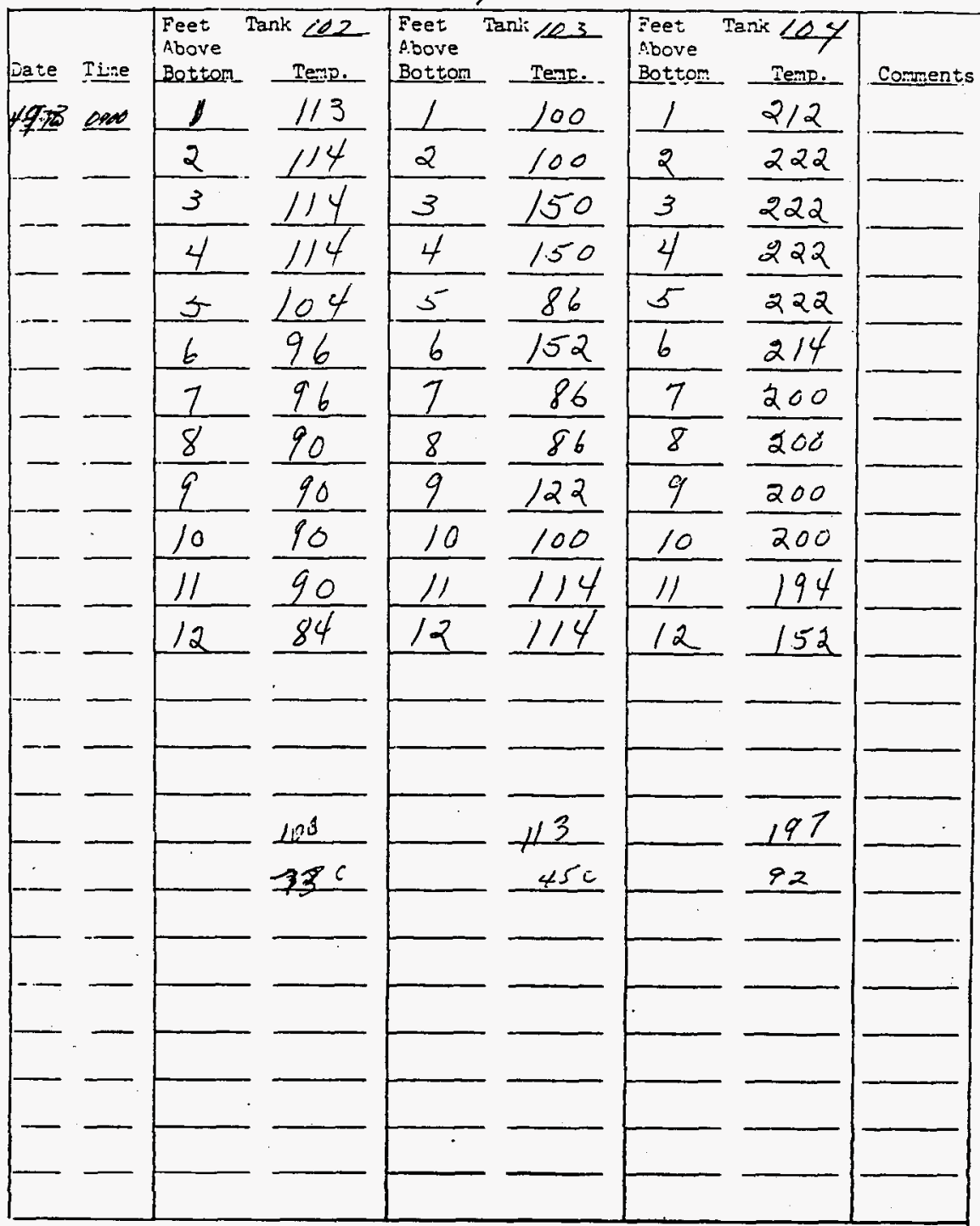

Instristions or coments: - Thke profile temperatures veekly in each battoms tank. Attach completed form to Monday and Thursday's Data sheets. 
Title:

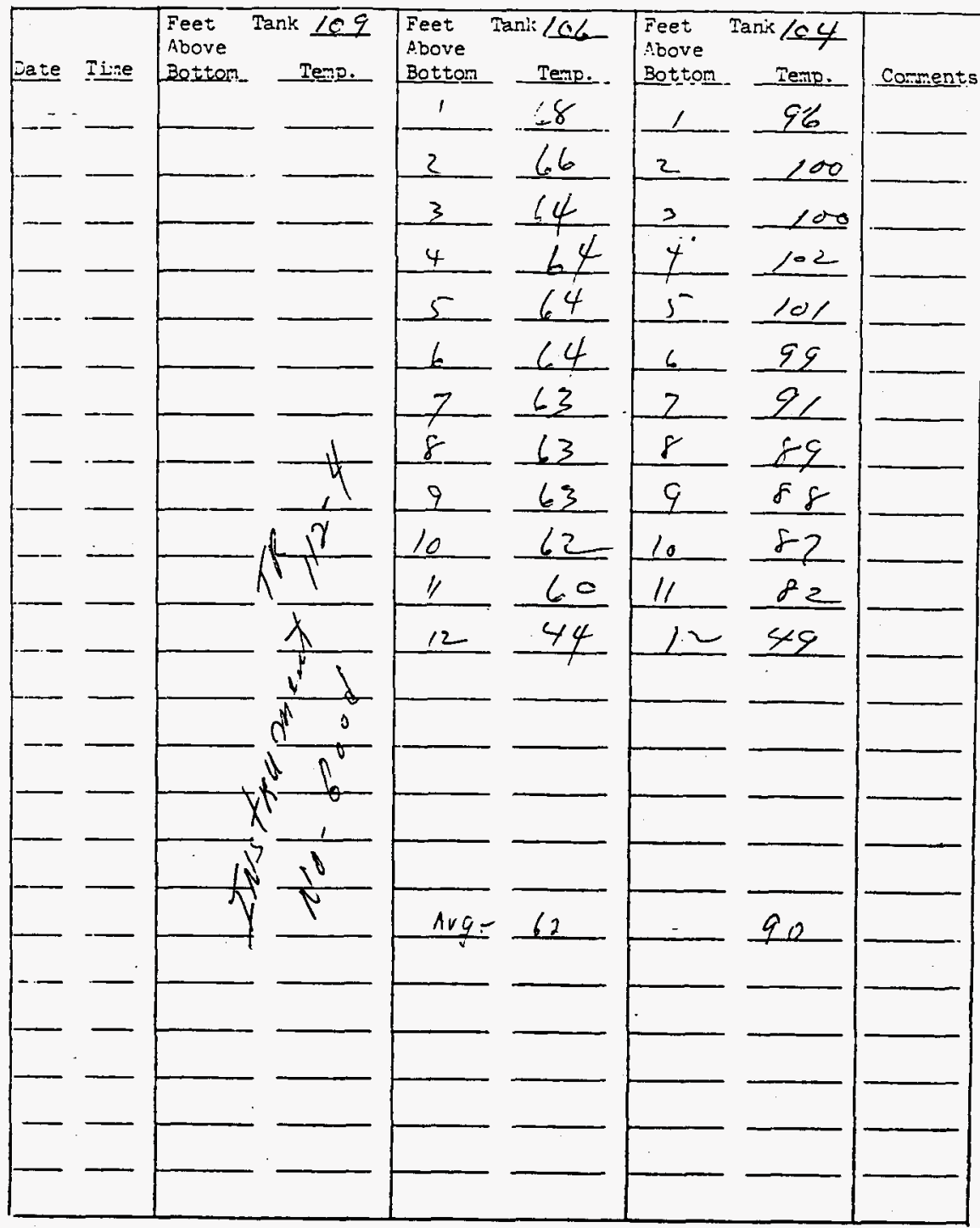

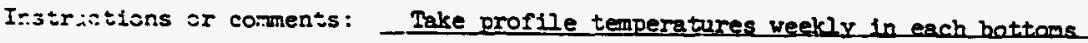
tank. Attach conpleted forf to Monday and Thursday's Data Sheets. 
Title: PROFIIE TERPERATURES IN ITS-2 BOTTOMS TANKS

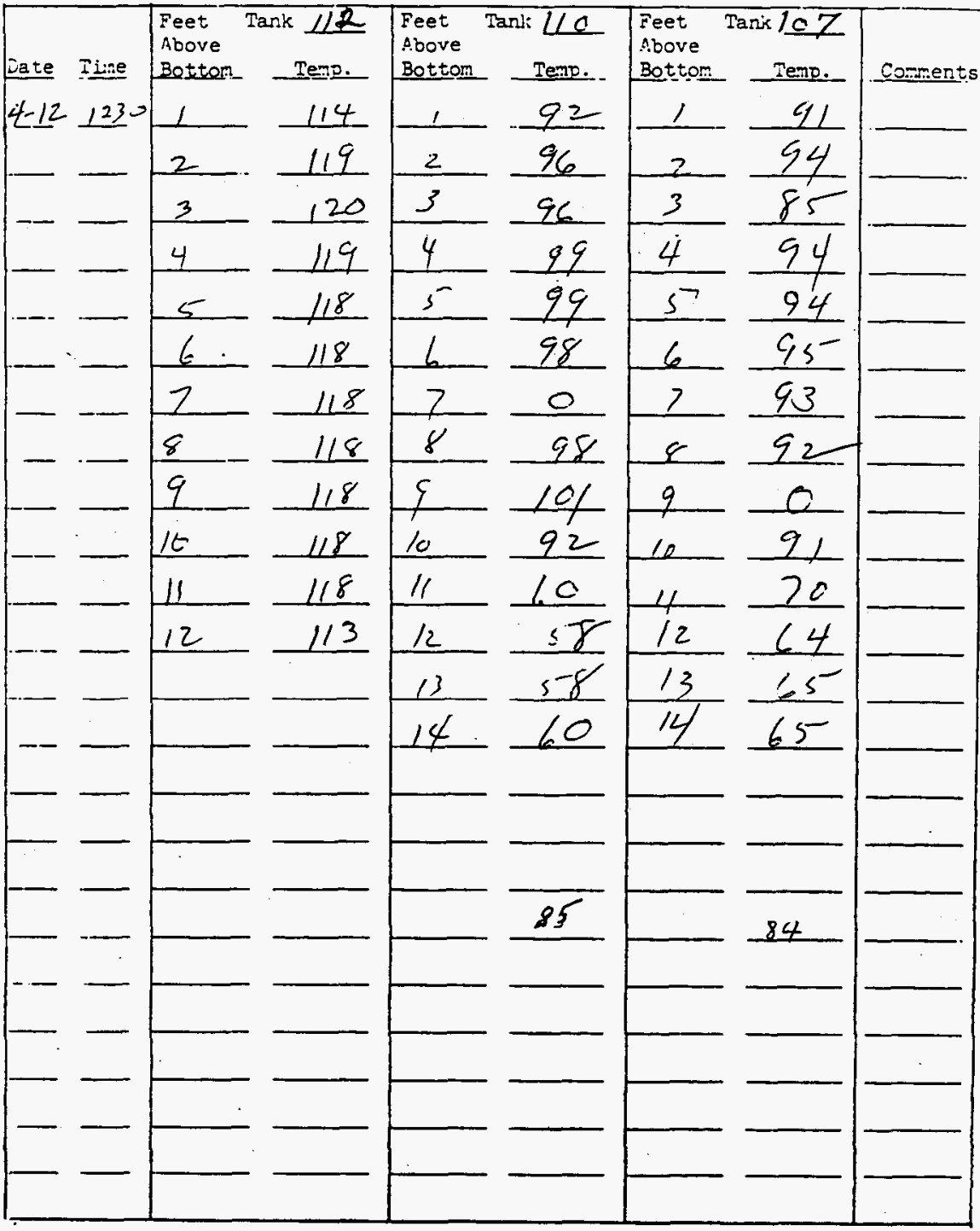

Instrictions or conments: - Take proflle temperatures veelely in each bottans tank. Attach completed form to Monday and Thursday's Data Sheets. 
Title: PROFILE IERTERATURES IN ITS-2 BOTTOMS TAIKS

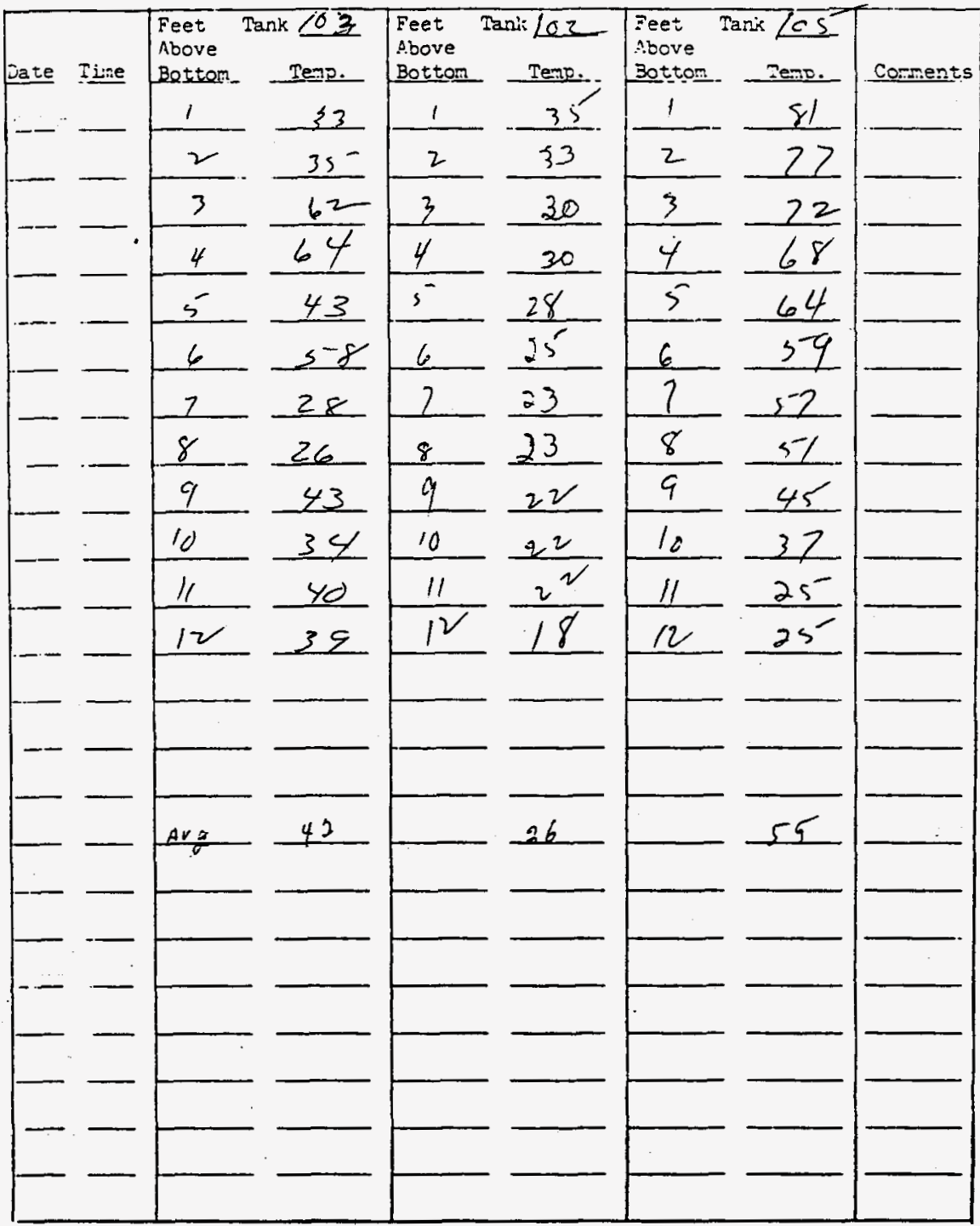

Instristions or connents: - Take proflle temperatures veekly in each bottoms. tank. Attach conpleted form to Monday and Thursday's Data Sheets. 
Title: PROFIIE TERERATURES IN ITS-2 BOTTOMS TANKS

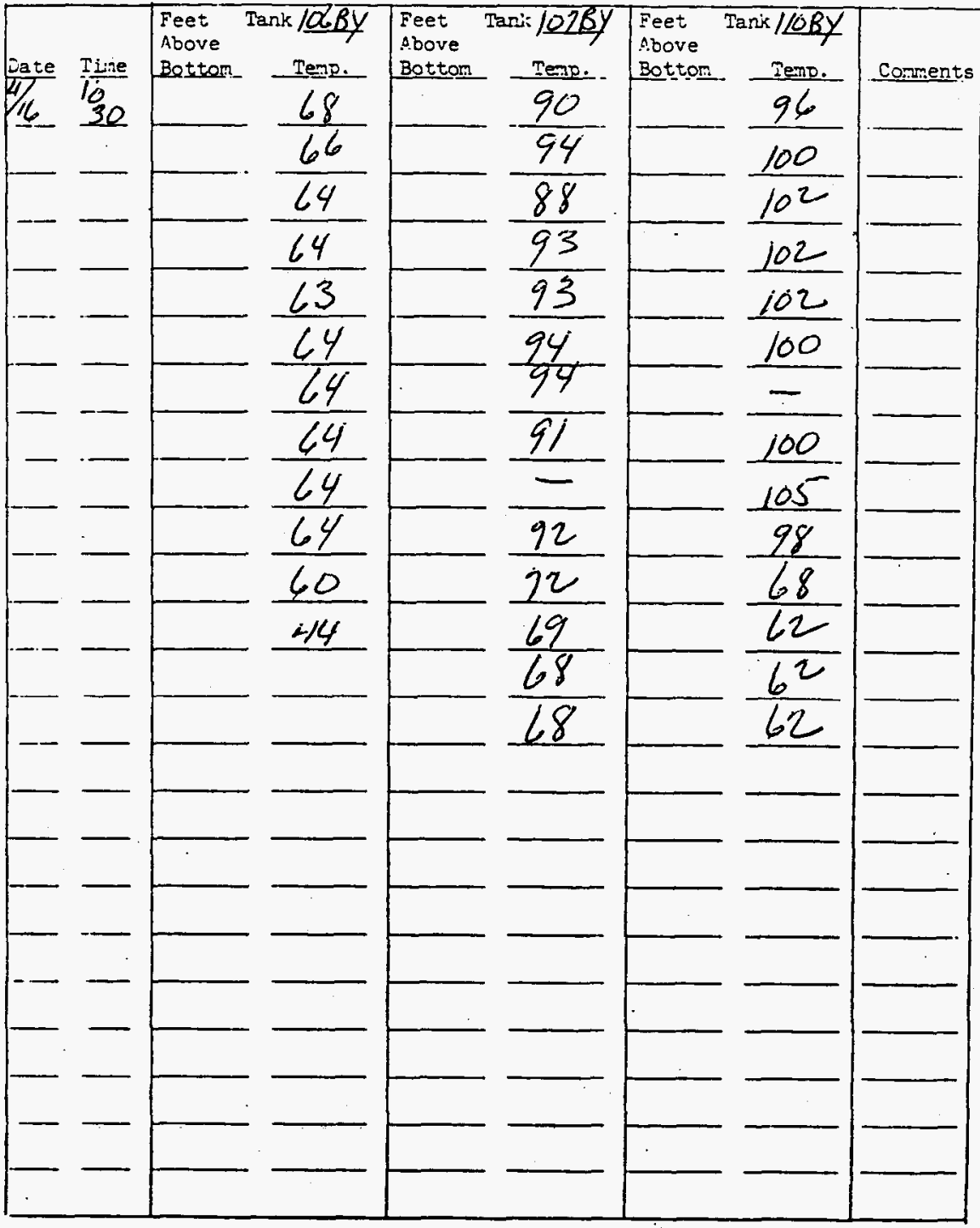

Irstristions ar corments: Take profile teaperatures weekly in each bottoms. tank. Attach conpleted forn to Monday and Thursday's Date sheats. 
Title: PROFILE TERPERATURES IN ITS-2 BOTTOMS TANKS

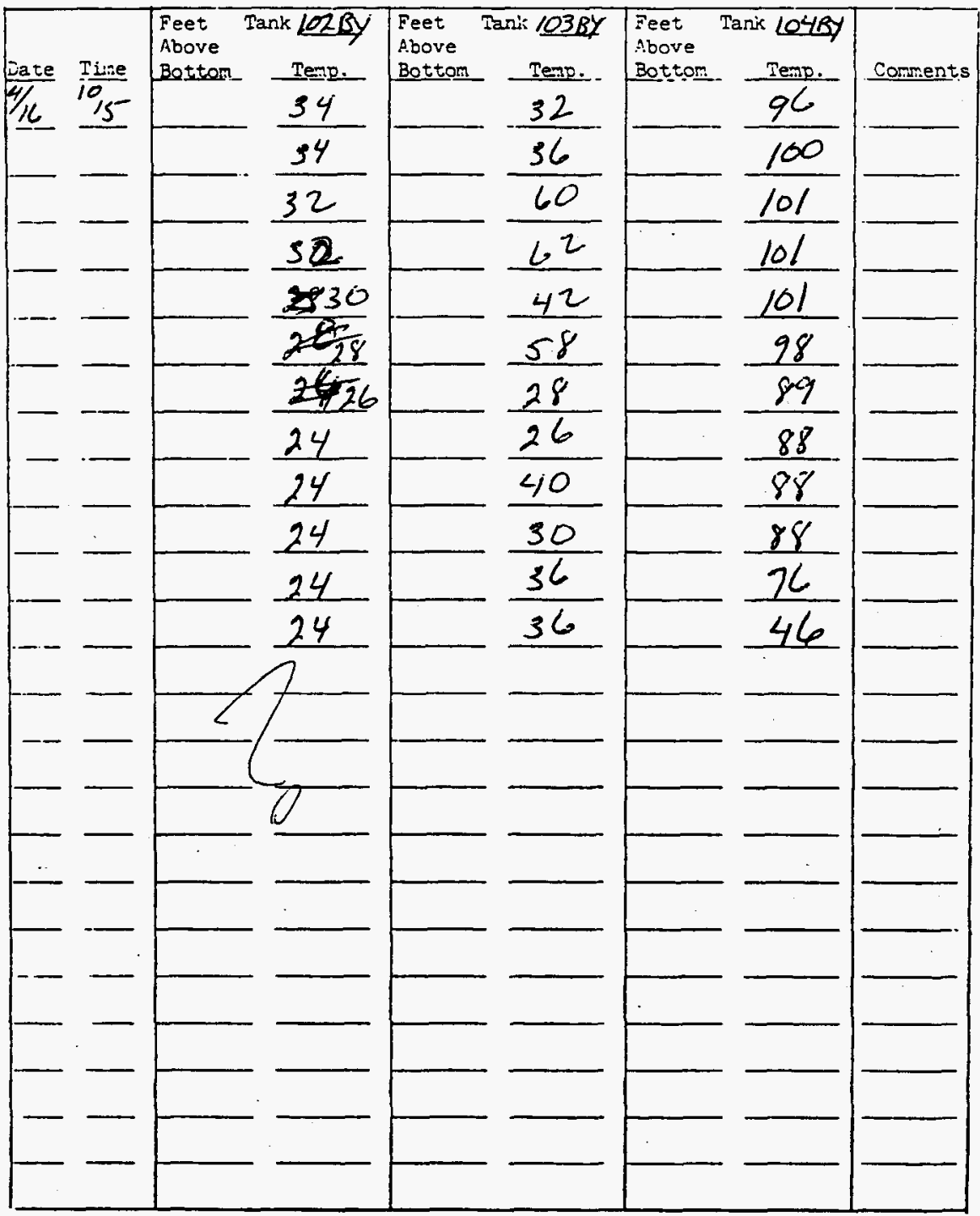

Irstristions ar conments: Take profile temperetares veekly in each bottoms tank. Attach corpleted form to Monday and Thursday's Data Sheets. 
Title:

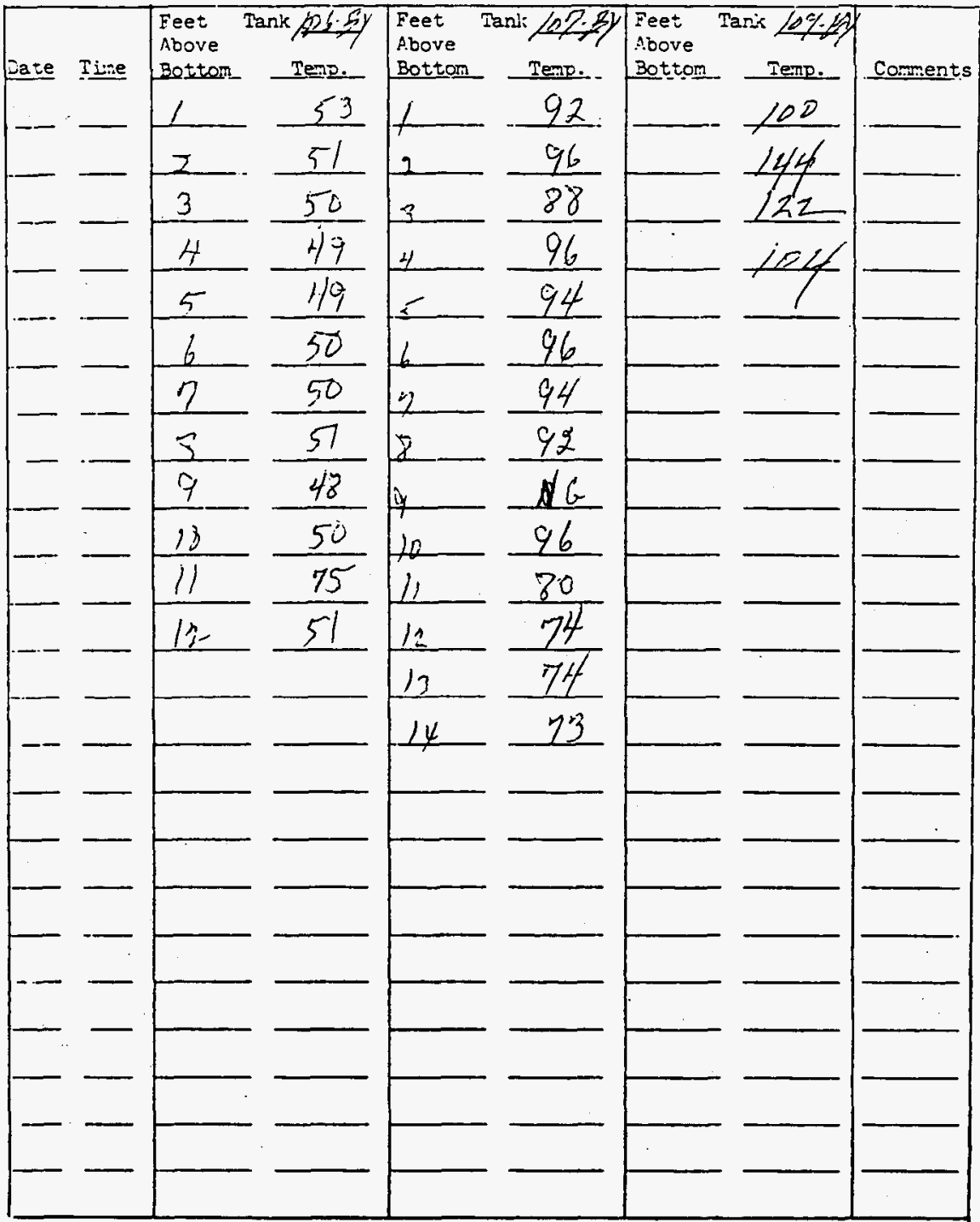

Instristions or comments: -Teke proflle temperatures veekly in each bottoms 
Title:

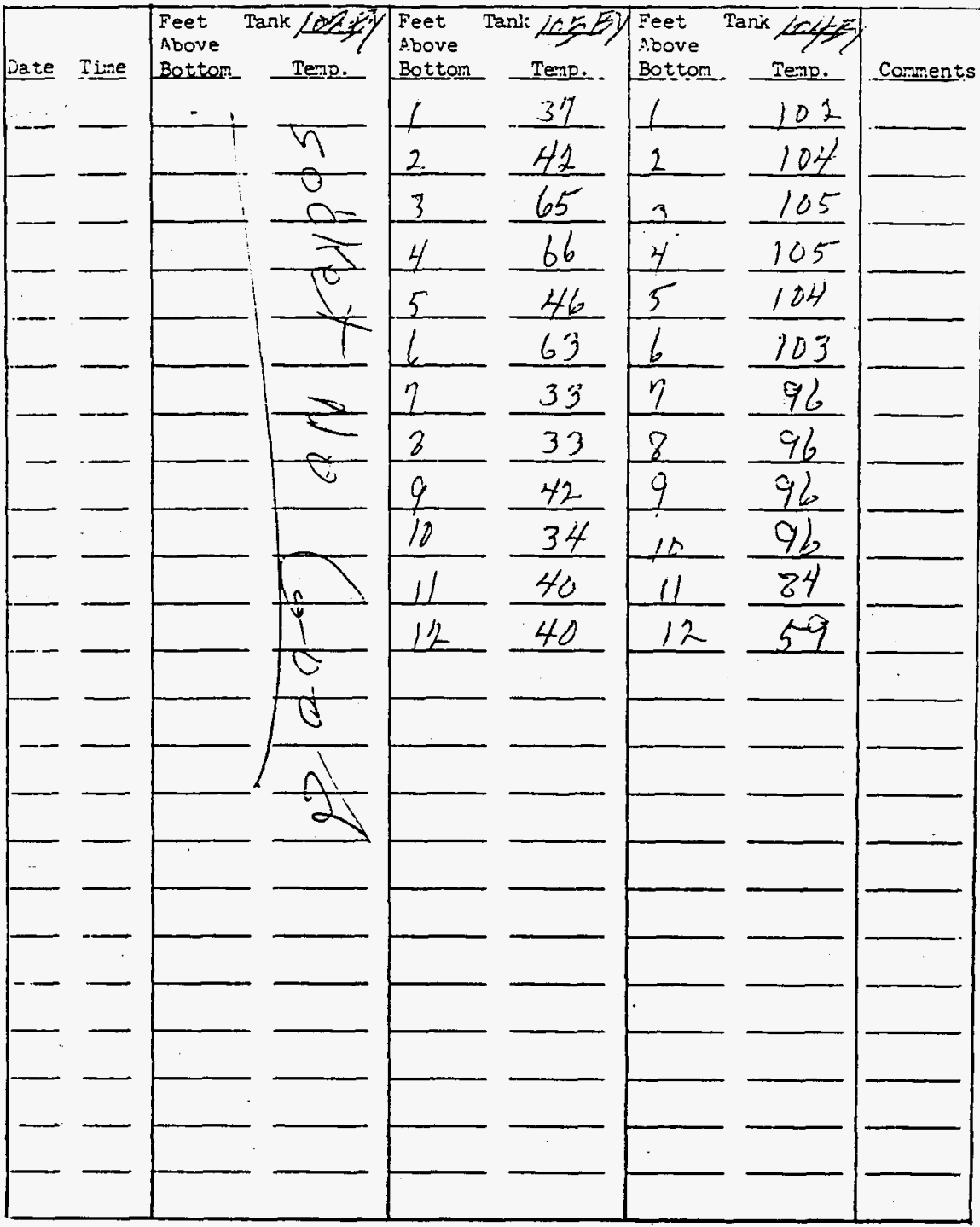

Irstrictions or coments: - Take proflie temperezures weekly in each bottoms 
Title:

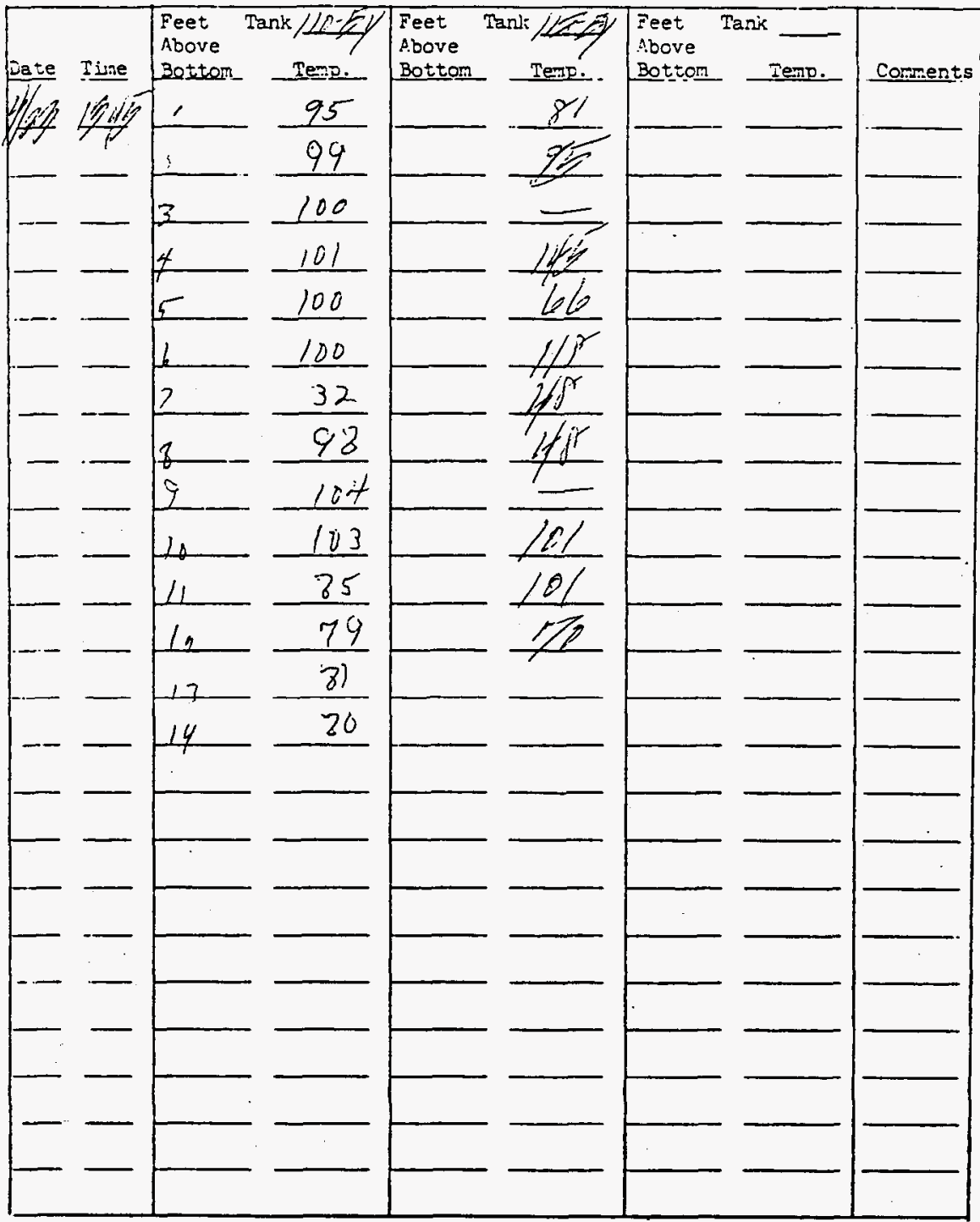

Instristions or conmen:s: Pake profile temperatures weekly in each bottoms tank. Attach conpleted form to Monday and Thursday's Data sheets. 
Title:

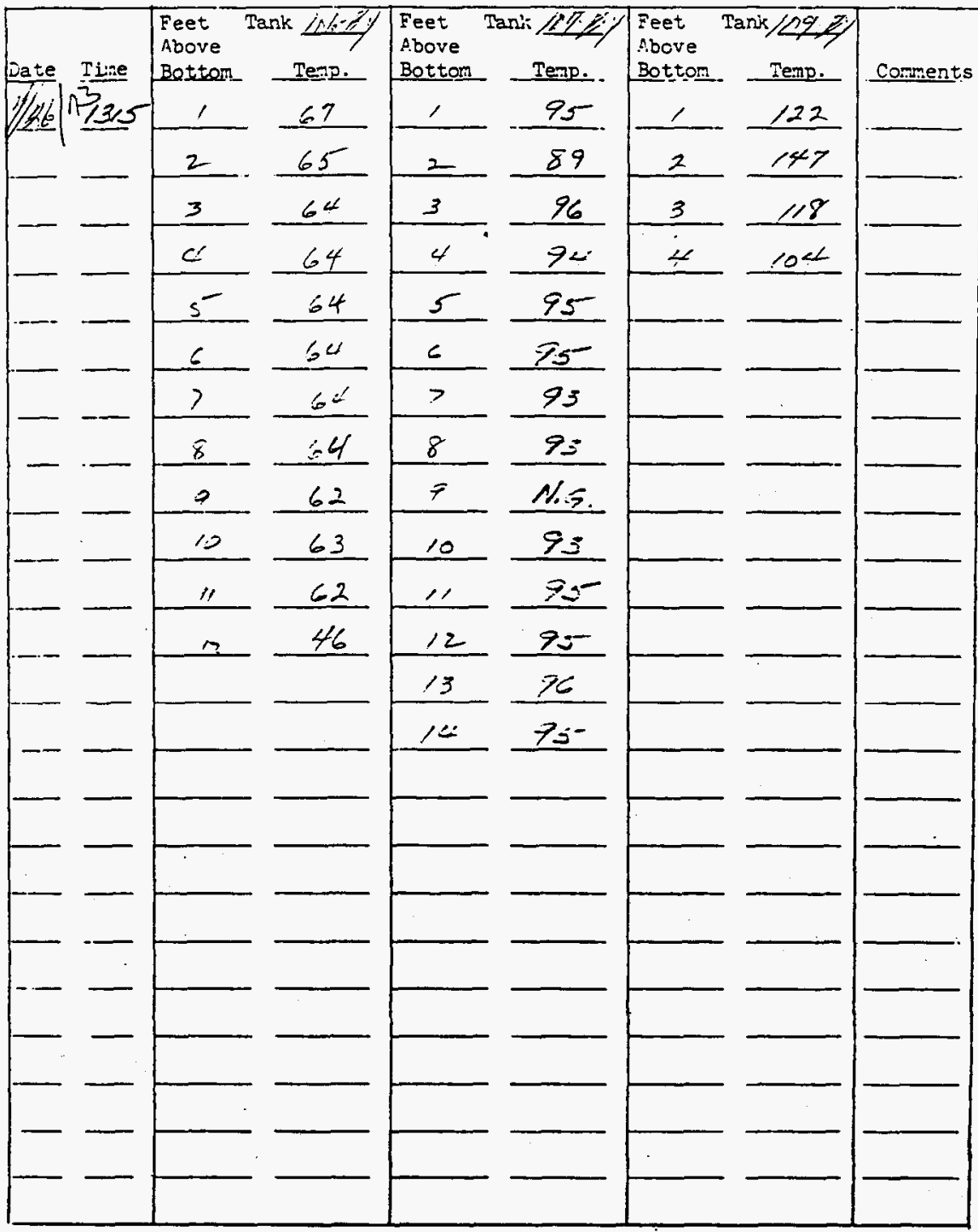

I:3tr:0tisns or coments: - Take proflle tenperatures veekly in each hottoms tank. Attech conpleted form to Monday and Thursday's Data sheets. 
Title: PROFIIE TEZPERATURES IN ITS-2 BOTTOMS TAIKS

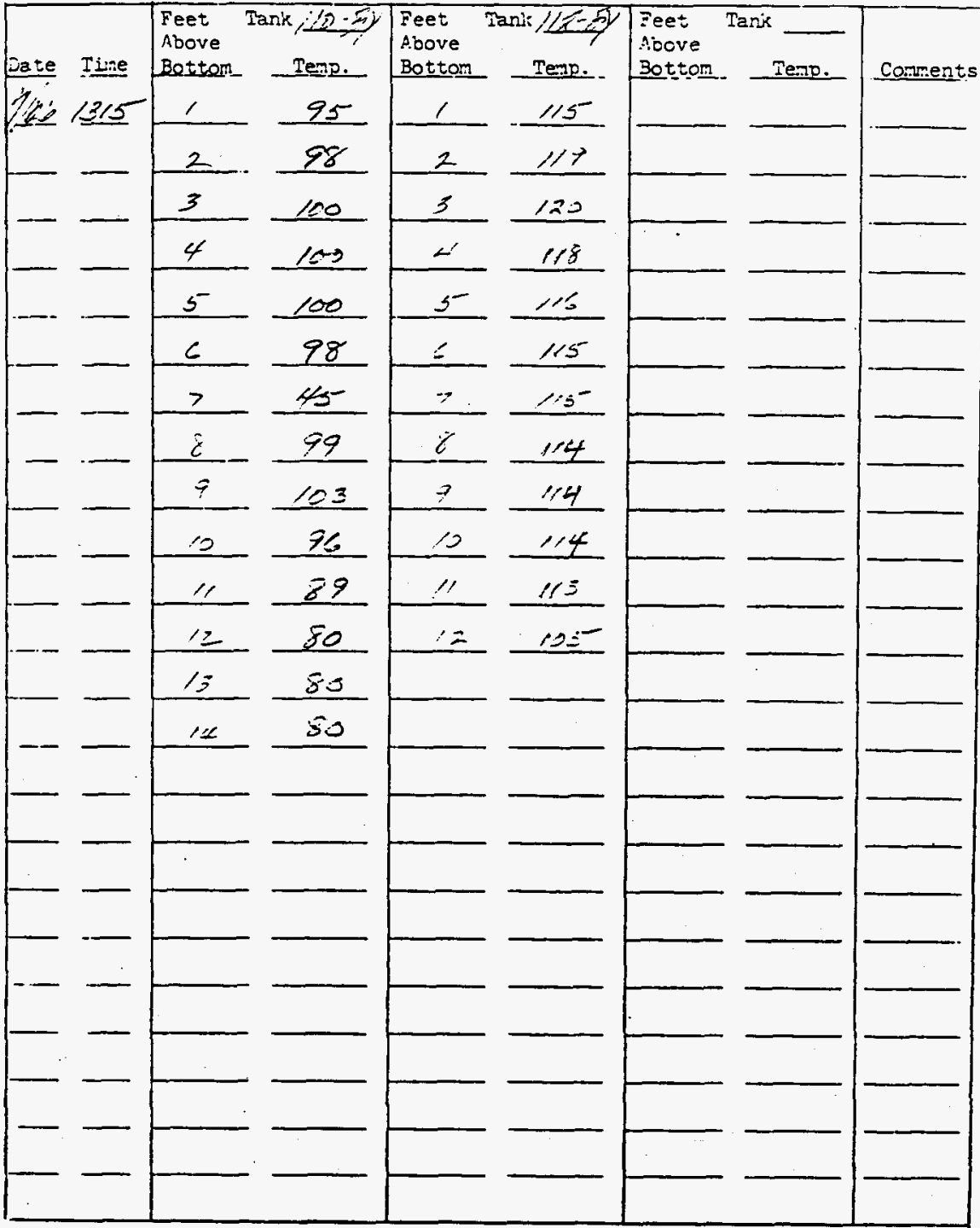

Irjtrietions or corments: Pake proflle temperatures veekly in each battoms tank. Attach conpleted form to Monday and Thursday's Data sheets 
Title : PROFILE TEMPERATURES IN ITS-2 BOTTOMS TANKS

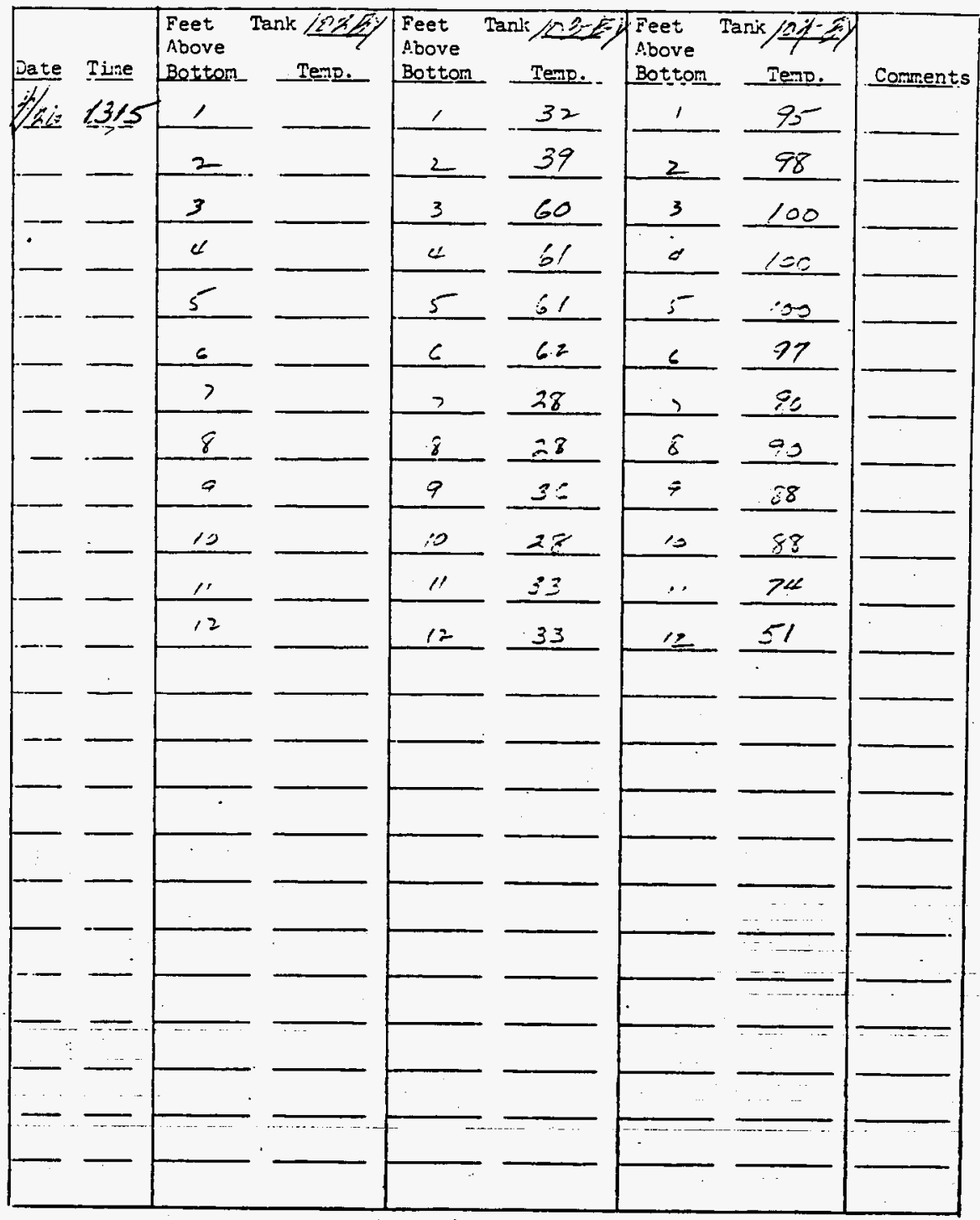

Irsisistions or corments: The proflle temperetures weekly in each bottoms tank. Attach completed forn to Monday and Thursday's Data sheets. 
Title: PROFILE TETPERATURES II ITS-2 BOTTOMS TANKS

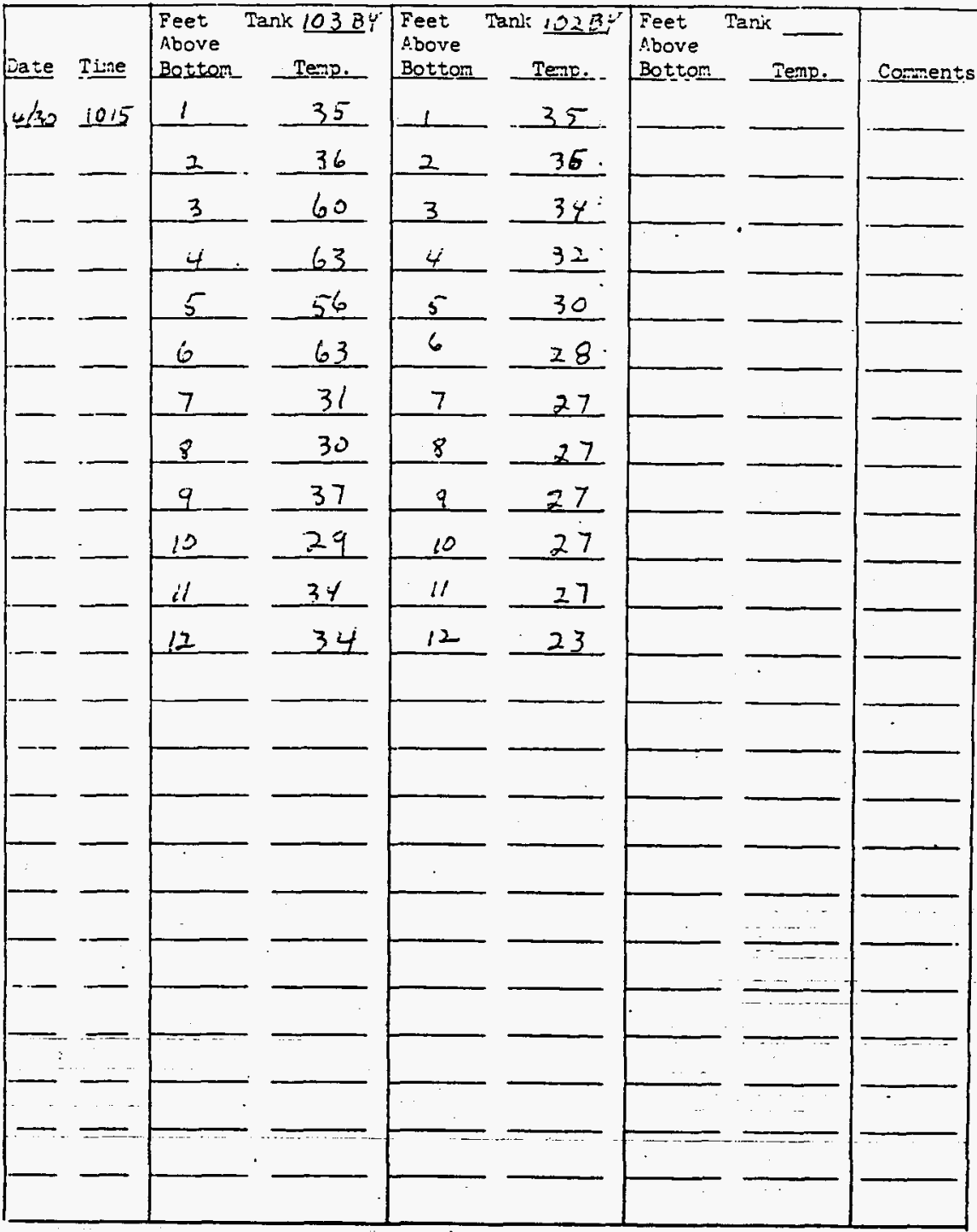

Instrictions or caments: - Take prof tank. Attach conpleted form to Monday and Thursday's Data sheets 
Title: PROFILE TEPERATURES IN ITS-2 BOTTOMS TANKS

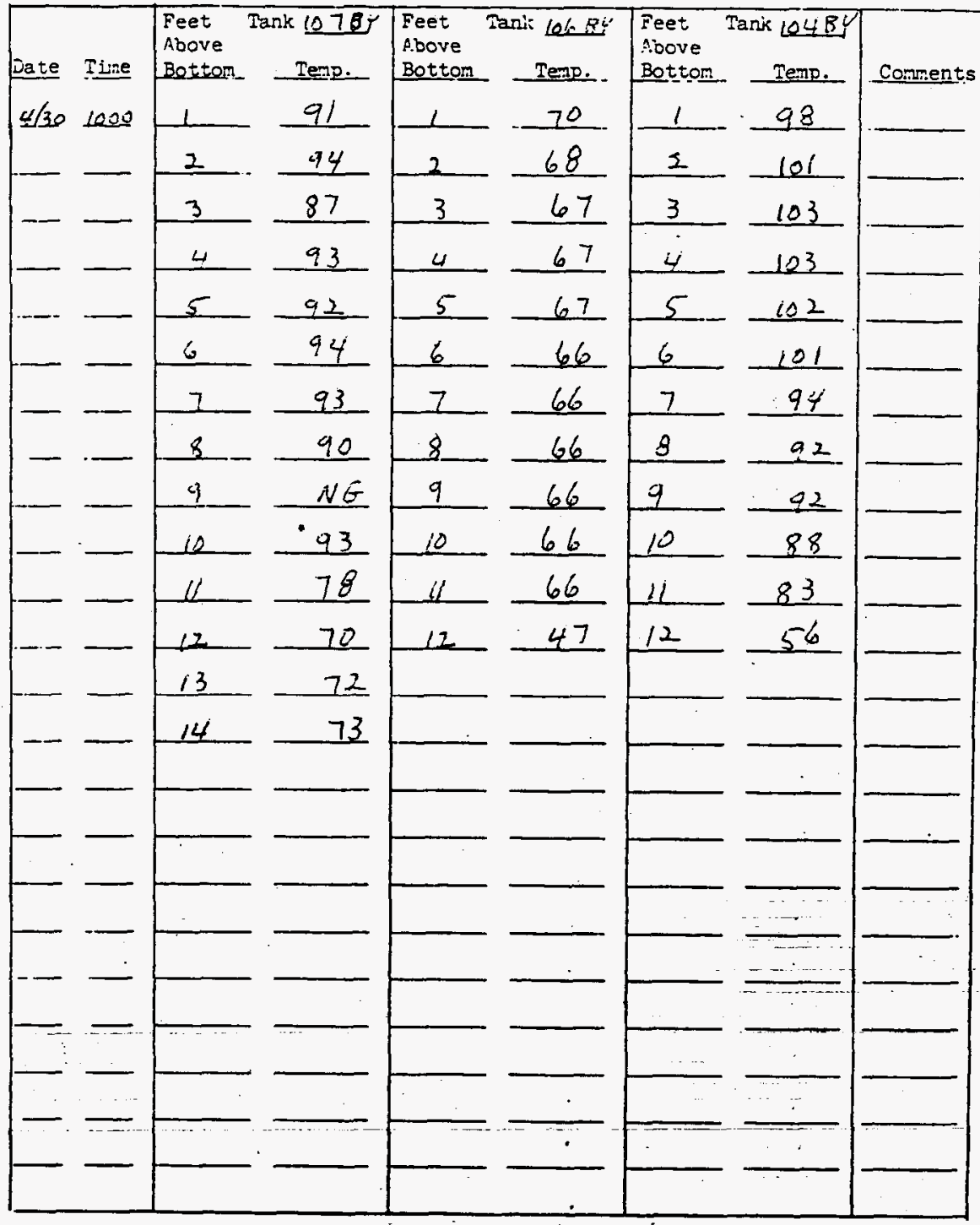

Instri:tions or coments: Take profile temperatures weekly in each hottoms tank. Attach completed form to Monday and Thursday's Data Sheets. 
Title:

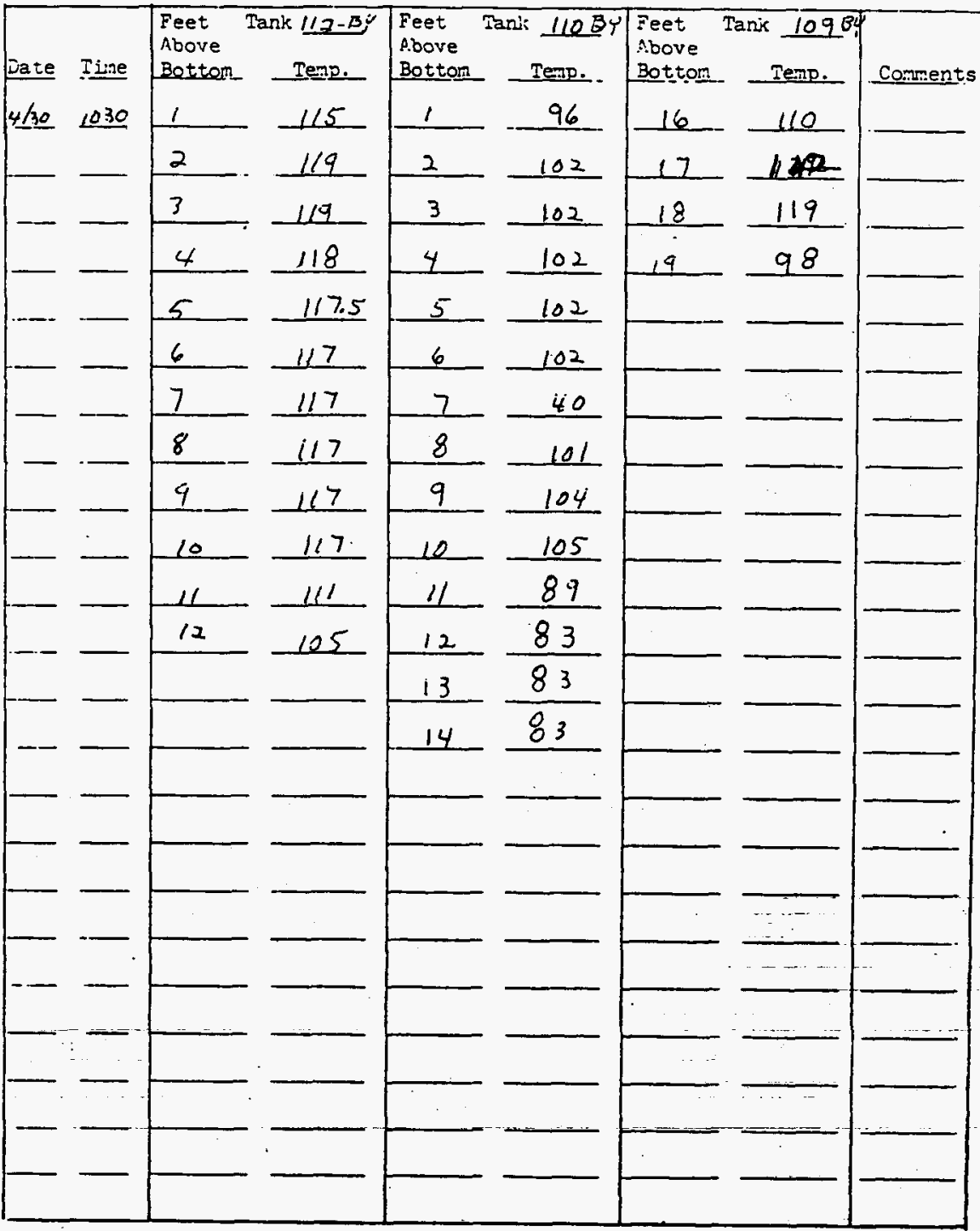

Instrictions or coments: Take profile temperatures veekly in each battoms tank. Attach completed form to Monday and Thursday's Data Sheets. 
Title: PROFIIE TERERATURES IN ITS-2 BOTTOMS TARTS

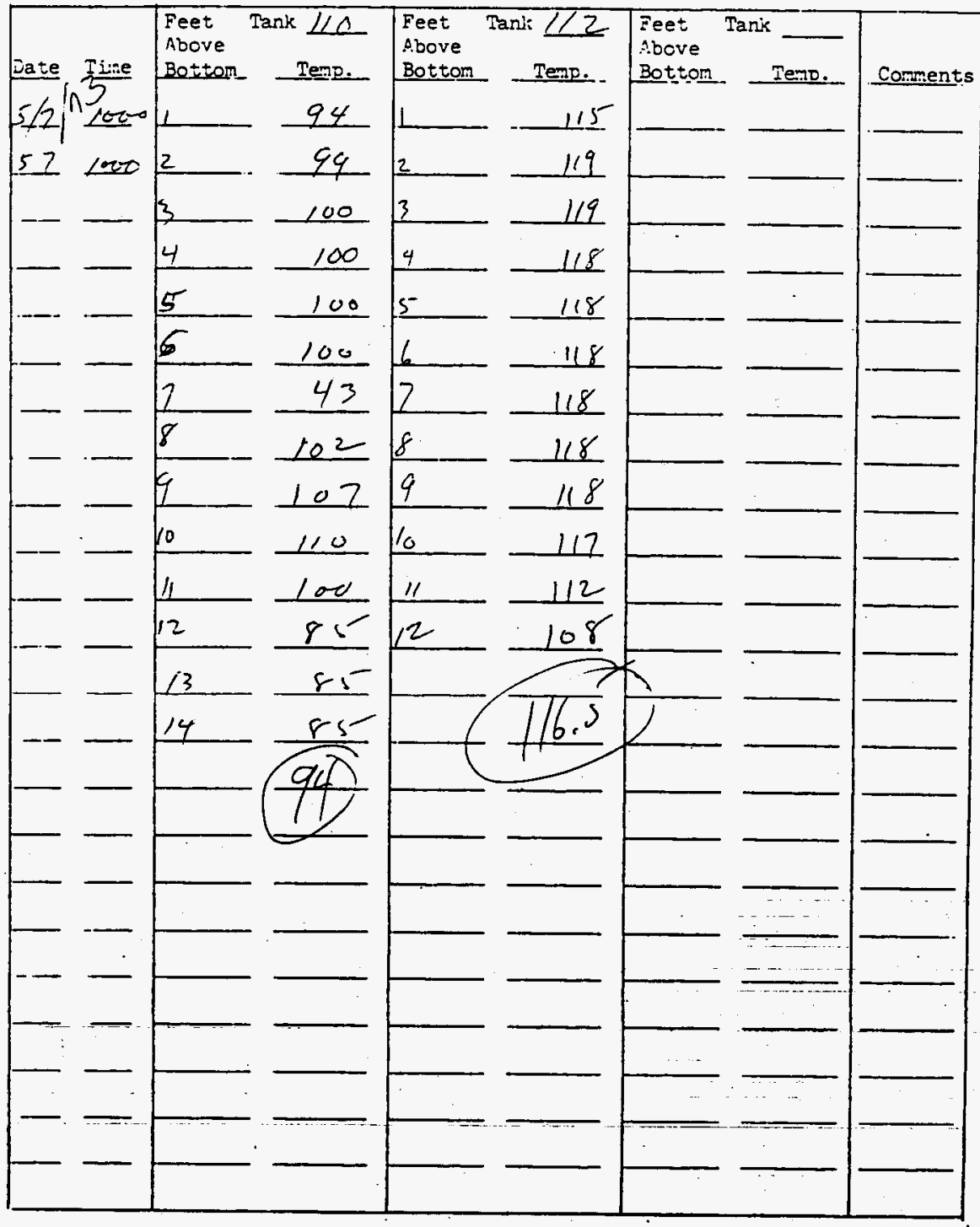

Instrïstions sr comments: - Pake profile temperatares weekly in each bottoms 
Title: PROFIIE TERPERATURES IN ITS-2 BOTTOMS TANKS

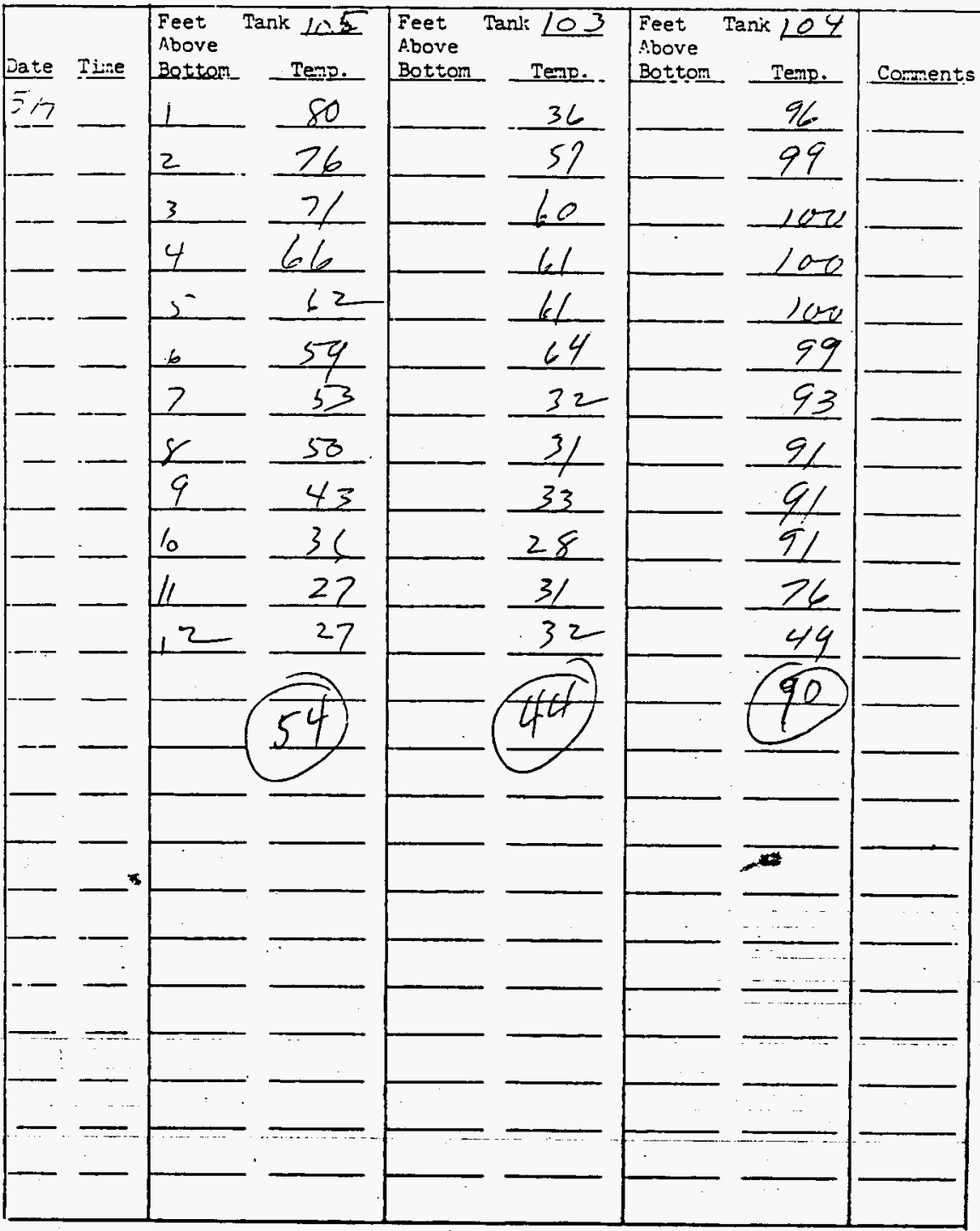

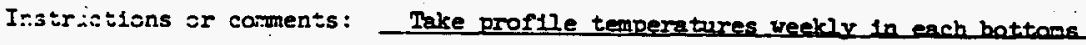
tank. Attach completed fors to Monday and Thursday's Data Sheets. 
Title: PROFILE TEIPERATURES IVI ITS-2 BOTTOMS TANKS

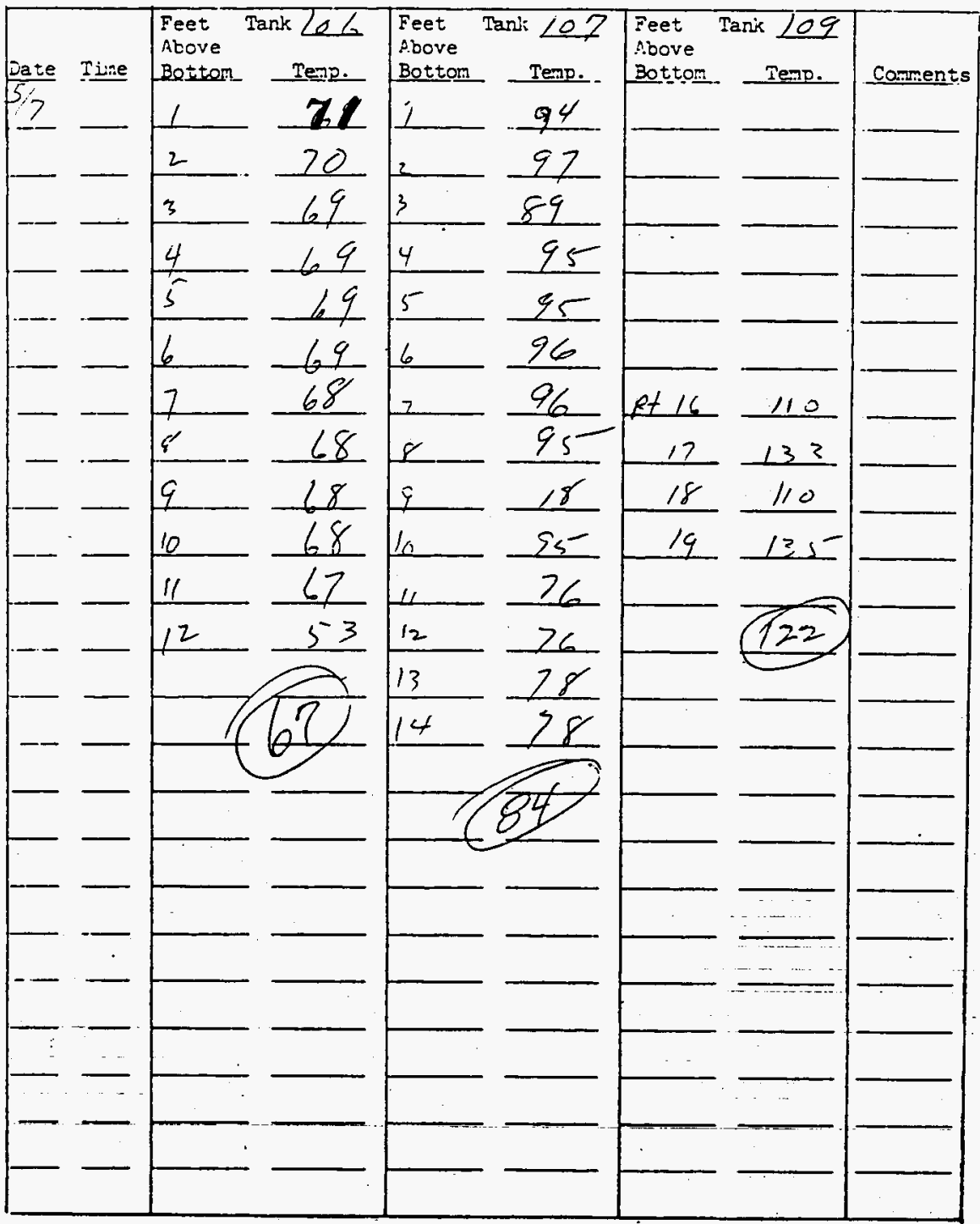

Irstrictions or coments: - Take profile temperatures veekly in each battoms tank. Attach completed form to Monday and Thursday's Data Sheets. 
Title: FROFILE TEFERATURES IF ITS-2 BOTTOMS TAIKS

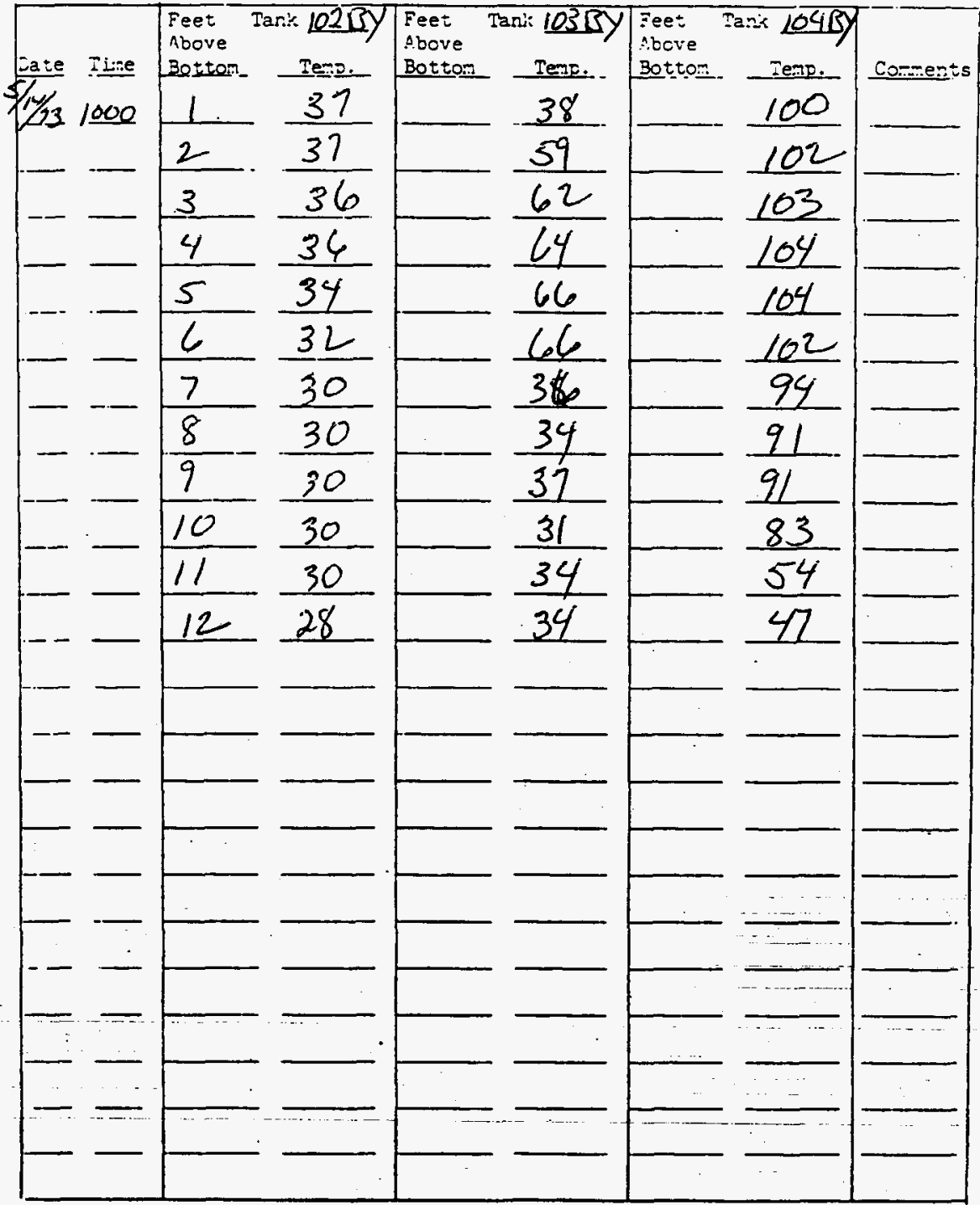

I:3tr:Ations or coments: - Take profile temperatures veekly in each bottoms tank. Attach conpleted form to Monday and Thurscalay's Data Sheets. 
Title: PROFILE TEFERATURES II ITS-2 BOTIONS TAIKS

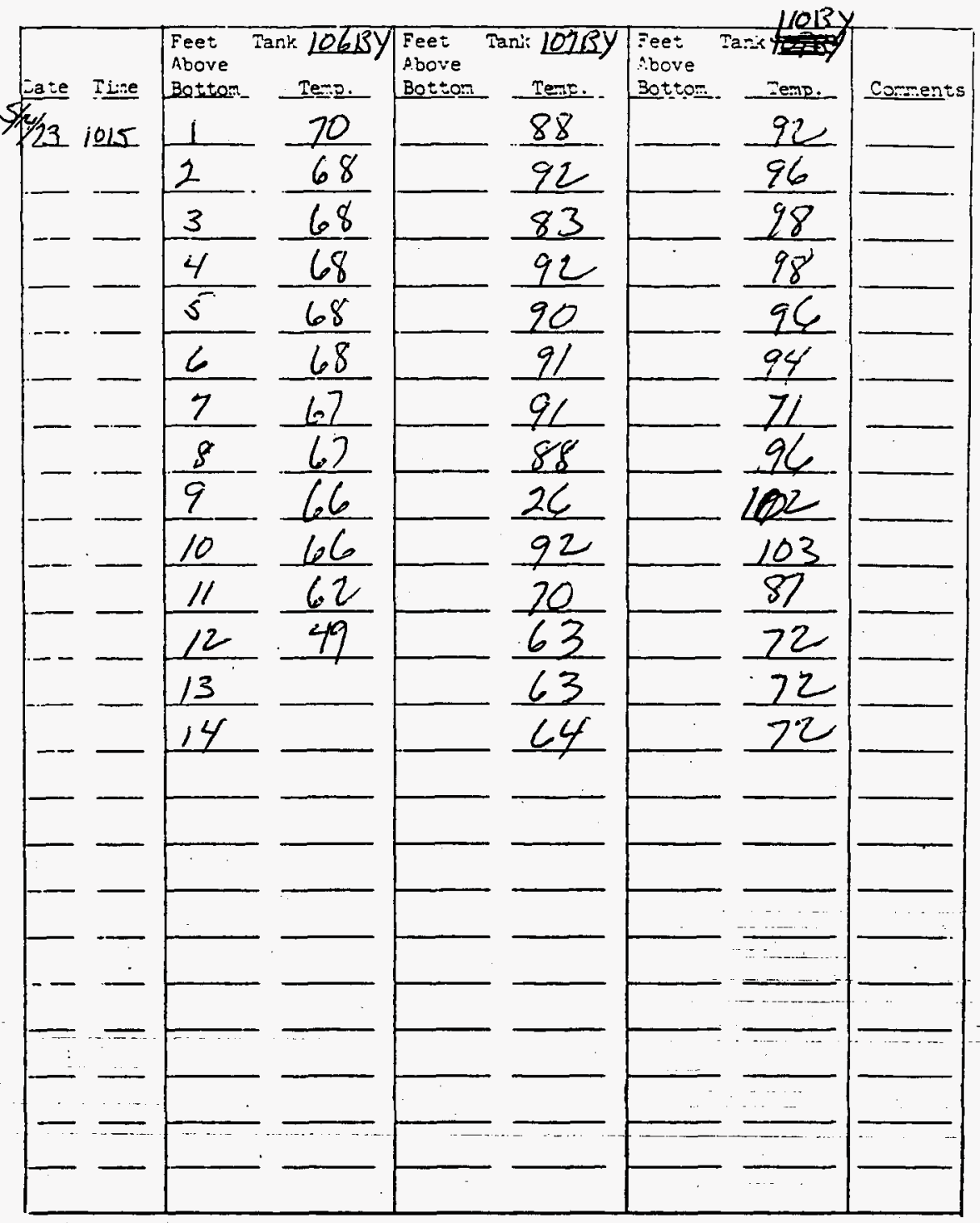

Ir:35r:stions or comen's: - Take proflie temperatares weekly in each bottoms tank. Attach conpleted forn to Monday and Thursday's Data Sheets. 
Title: PROFILE TERPERATURES DI ITS-2 BOTTOMS TAMTS

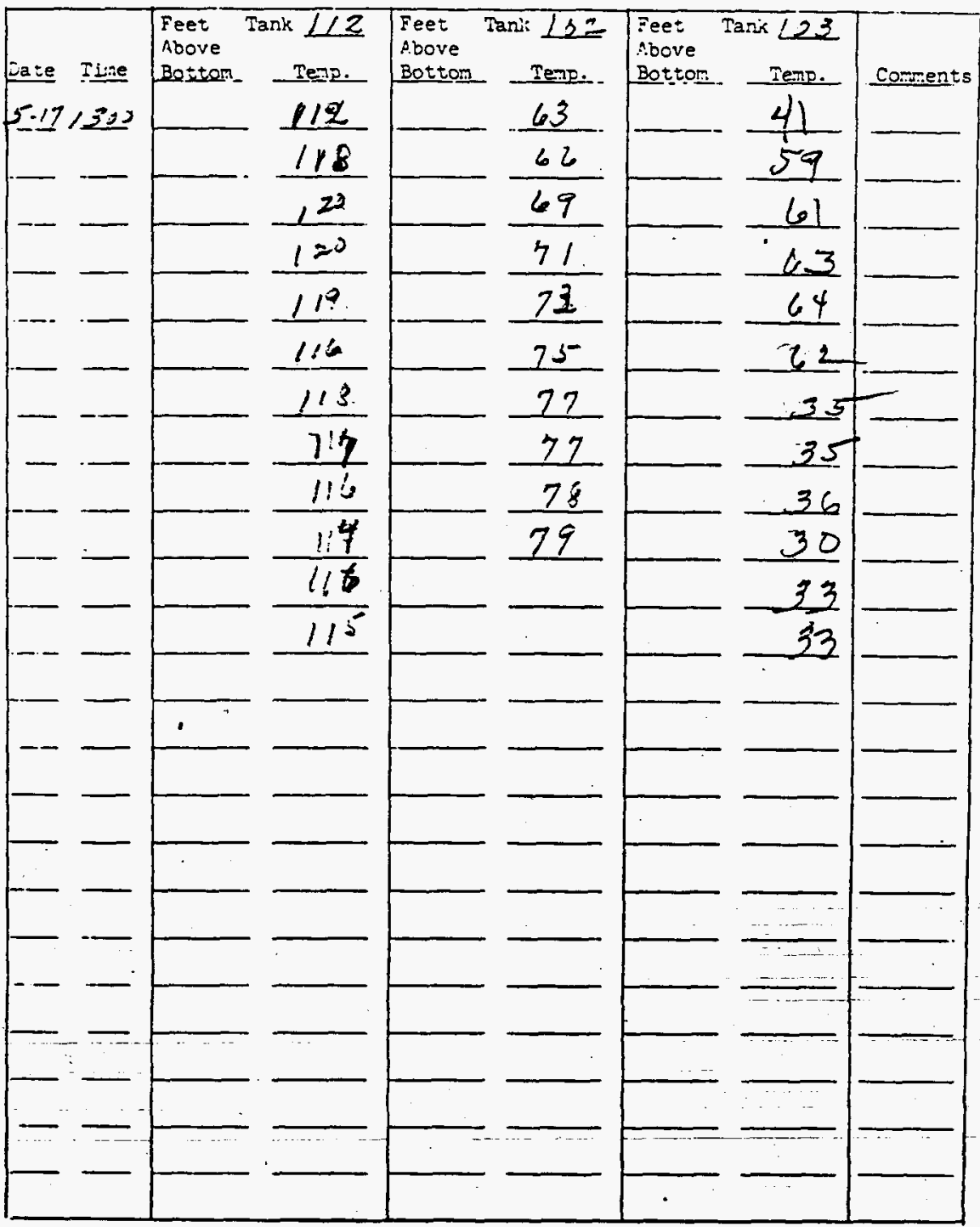

Instritifiss ar comens: - Take profile temperatures yeekly in each bottoms tenk. Attach conpleted forn to Monday and Thursday's Data Sheets. 


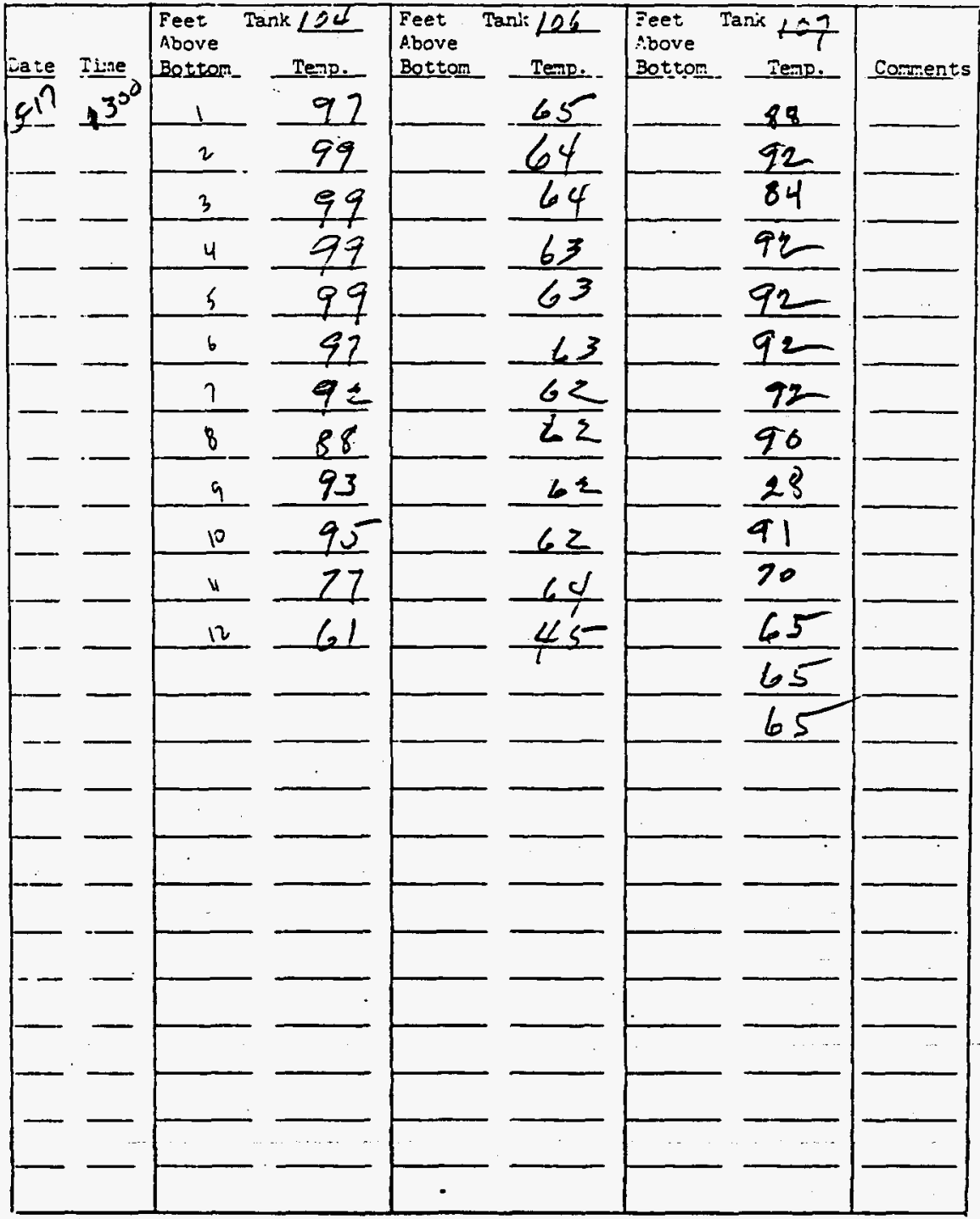

Ir:35r:5itsns or coments: - Take proflie temperatures veekly in each bottoms tank. Attach corpleted fora to Monday and Thursday's Data Sheets. 
Title:

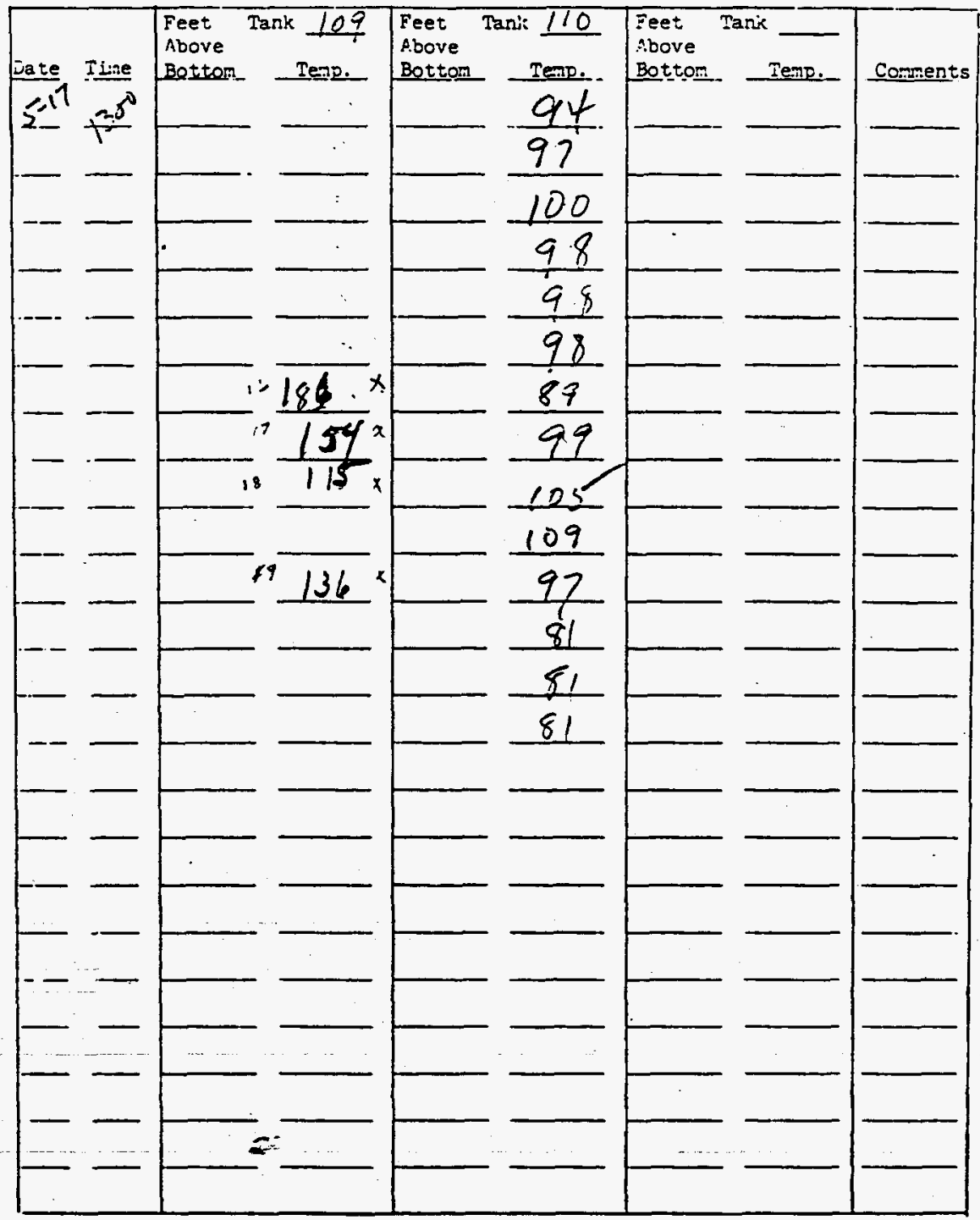

Instr:ntisns sr comien's: Take profile temperatures veekly in each bottons tank. Attech completed form to Monday and Thursday's Data Sheets. 
Title: PROFILE TERERATURES II: ITS-2 BOTTOMS TANKS

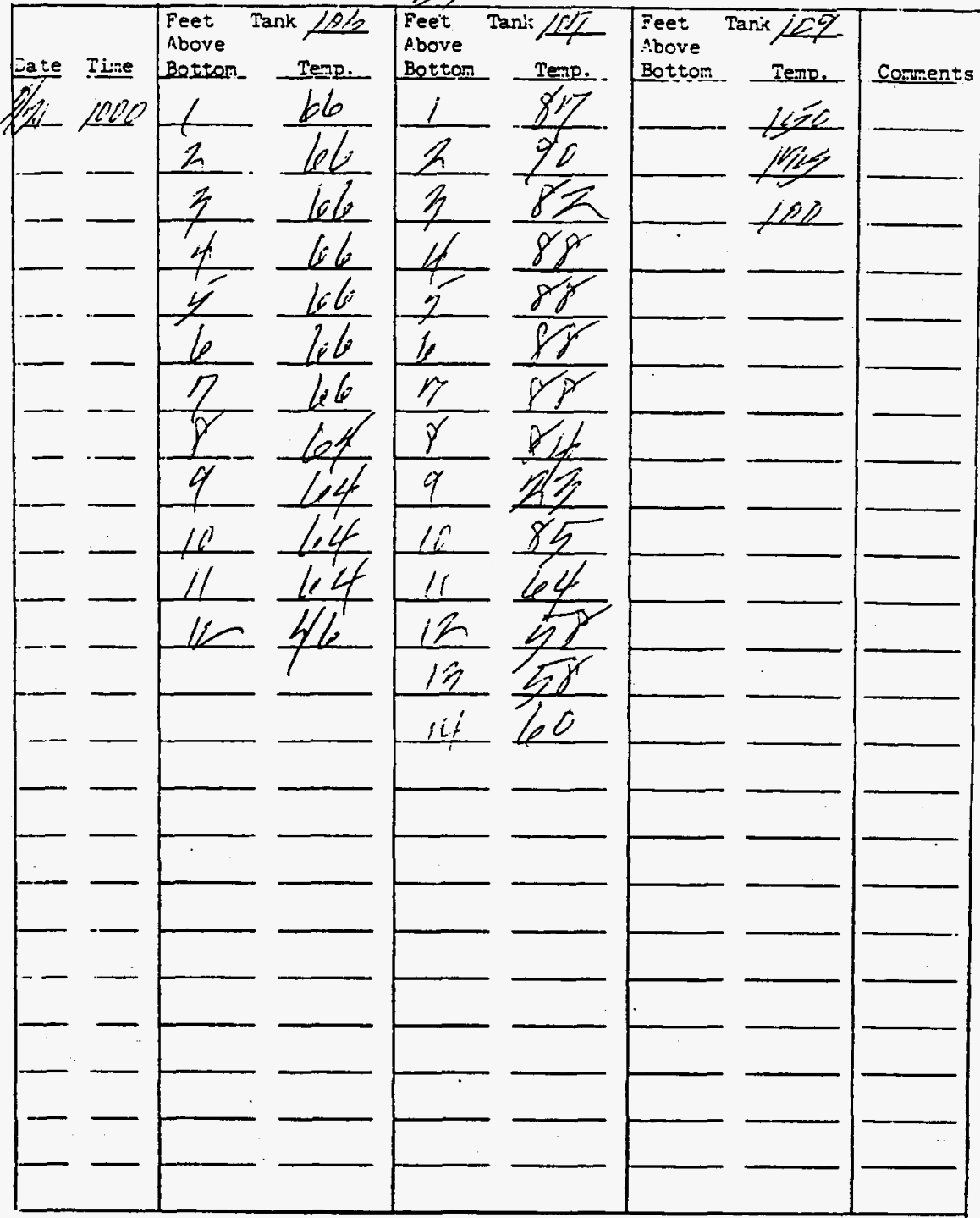

Ir3trisisons or comen's: - Take prorelle temperatures veekly in each bottoms tank. Attach conpleted form to Monday and Thursday's Data sheets. 
Title: PROFILE TERERATURES IN ITS-2 BOTTOMS TANTS

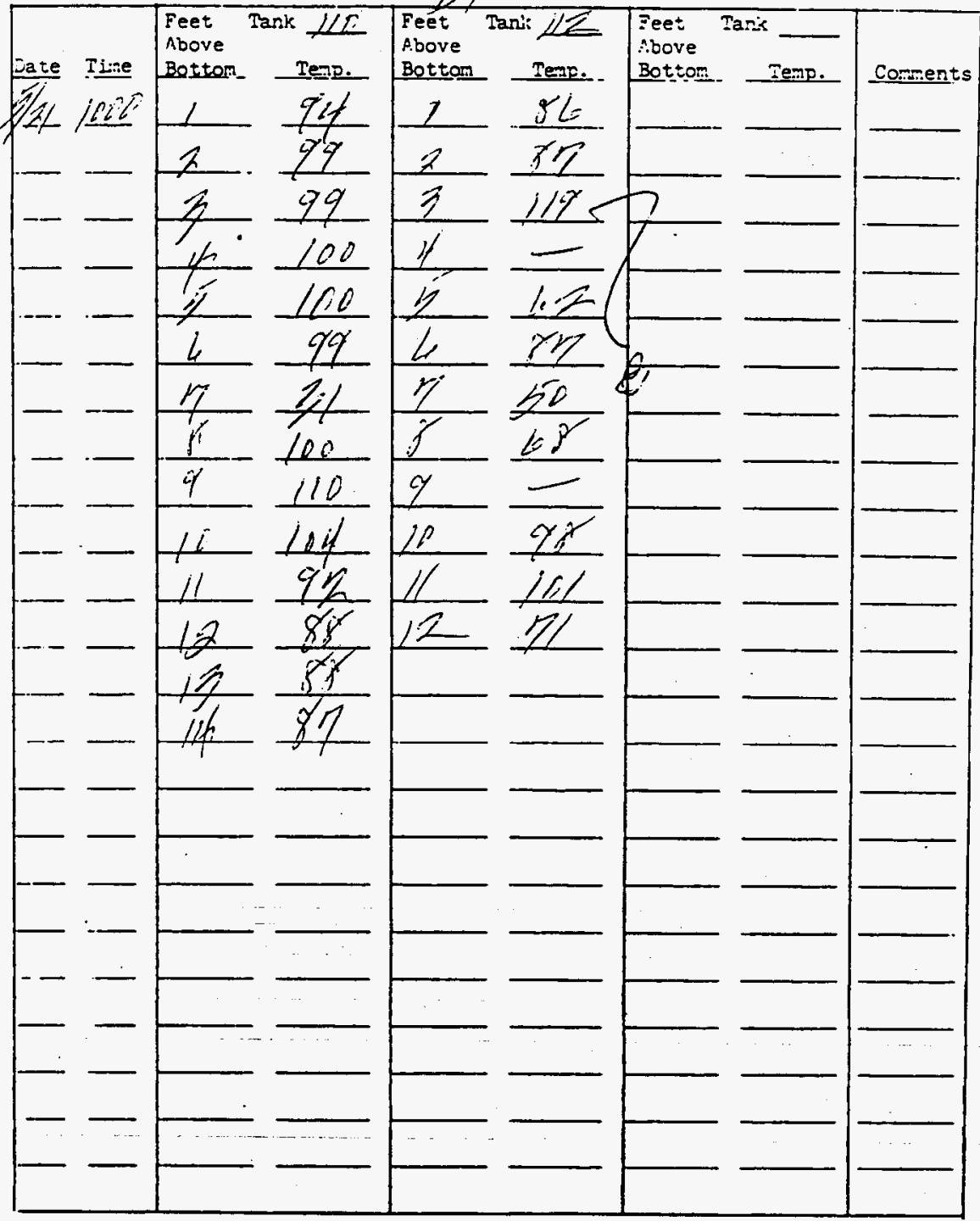

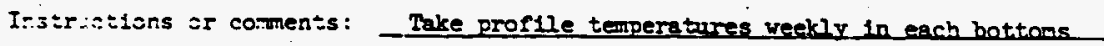
tank. Attach conpleted fora to Monday and Thursday's Data sheets. 
Title: FROFIIE TEQPERATURES IT ITS-2 BOTTONS TAIKS

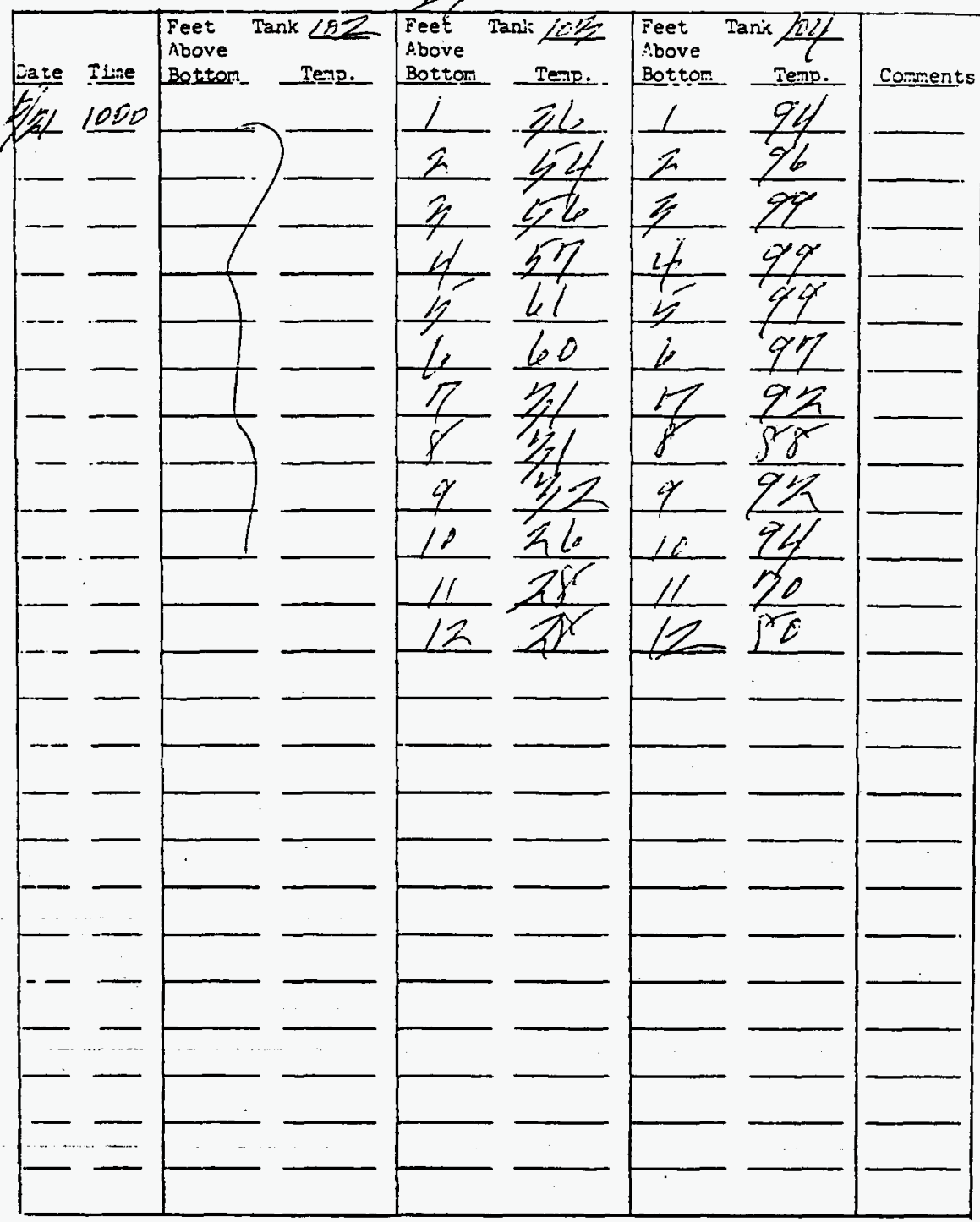

Instrietions sr coments: - Take proflle temperatures yeekly in each battoms tank. Attach conpleted form to Monday and Thursday's Data Sheets. 
Title :

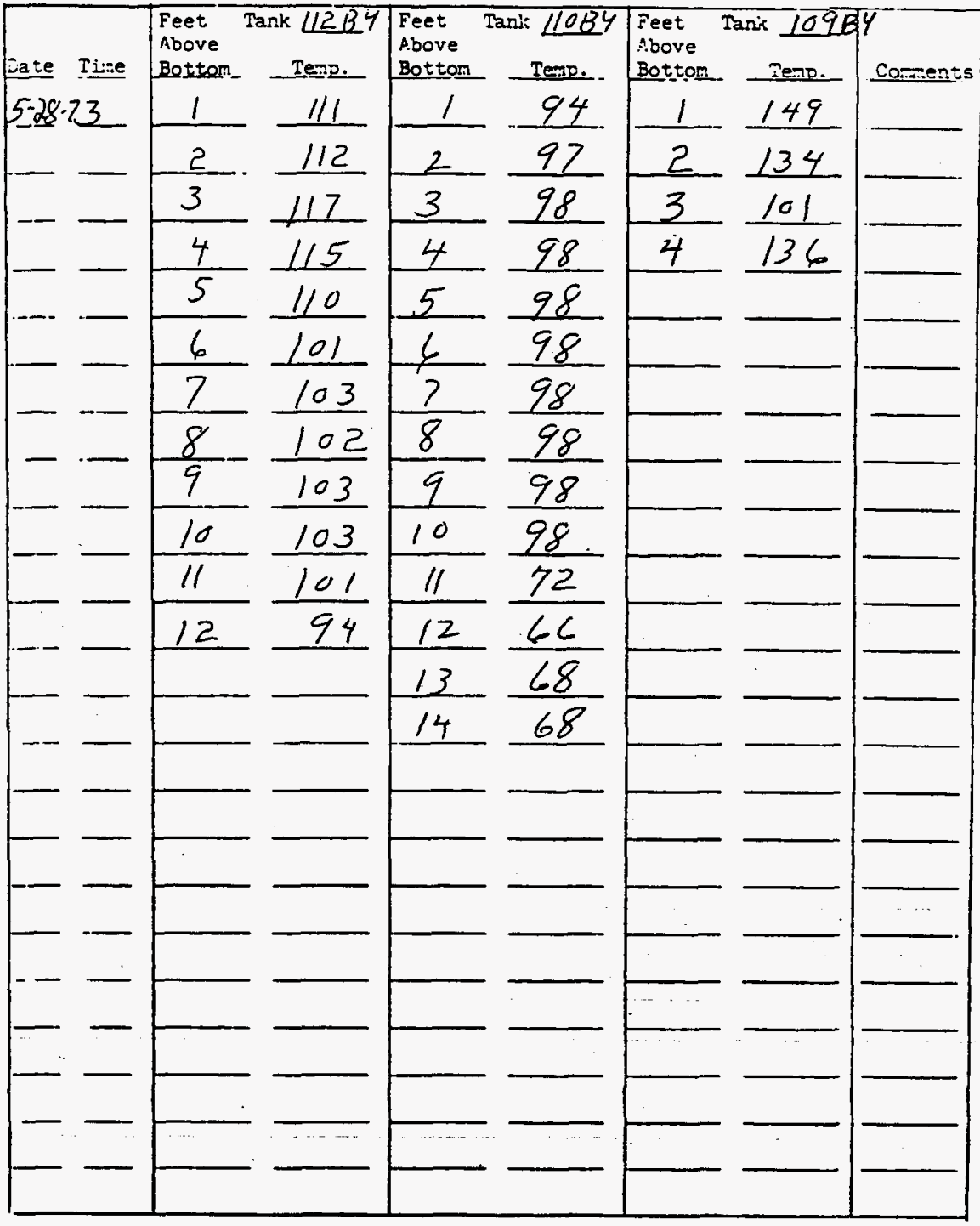

Instr:Aisiss =r coments: - Take proflle temperatures veekly in each bottons tank. Attach completed form to Monday and Thursday's Dato sheets. 
Title: PROFILE TDIFERATURES IVI ITS-2 BOTIOMS TANTS

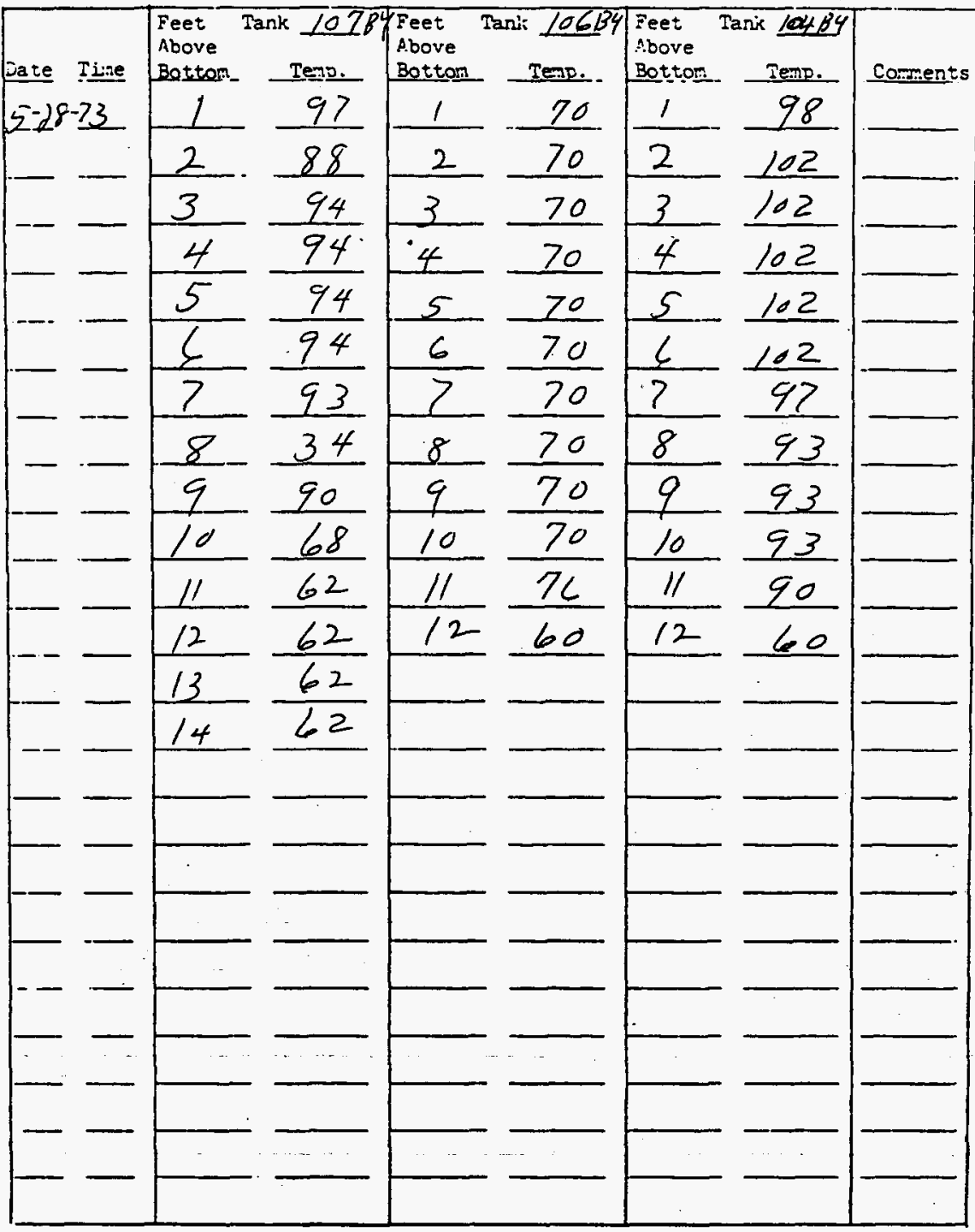

Ir:3:r.:i:isns or coments: - Take profile temperatures reekly in each bottoms tank. Attach completed form to Monday and Thursday's Data Sheets. 
Title:

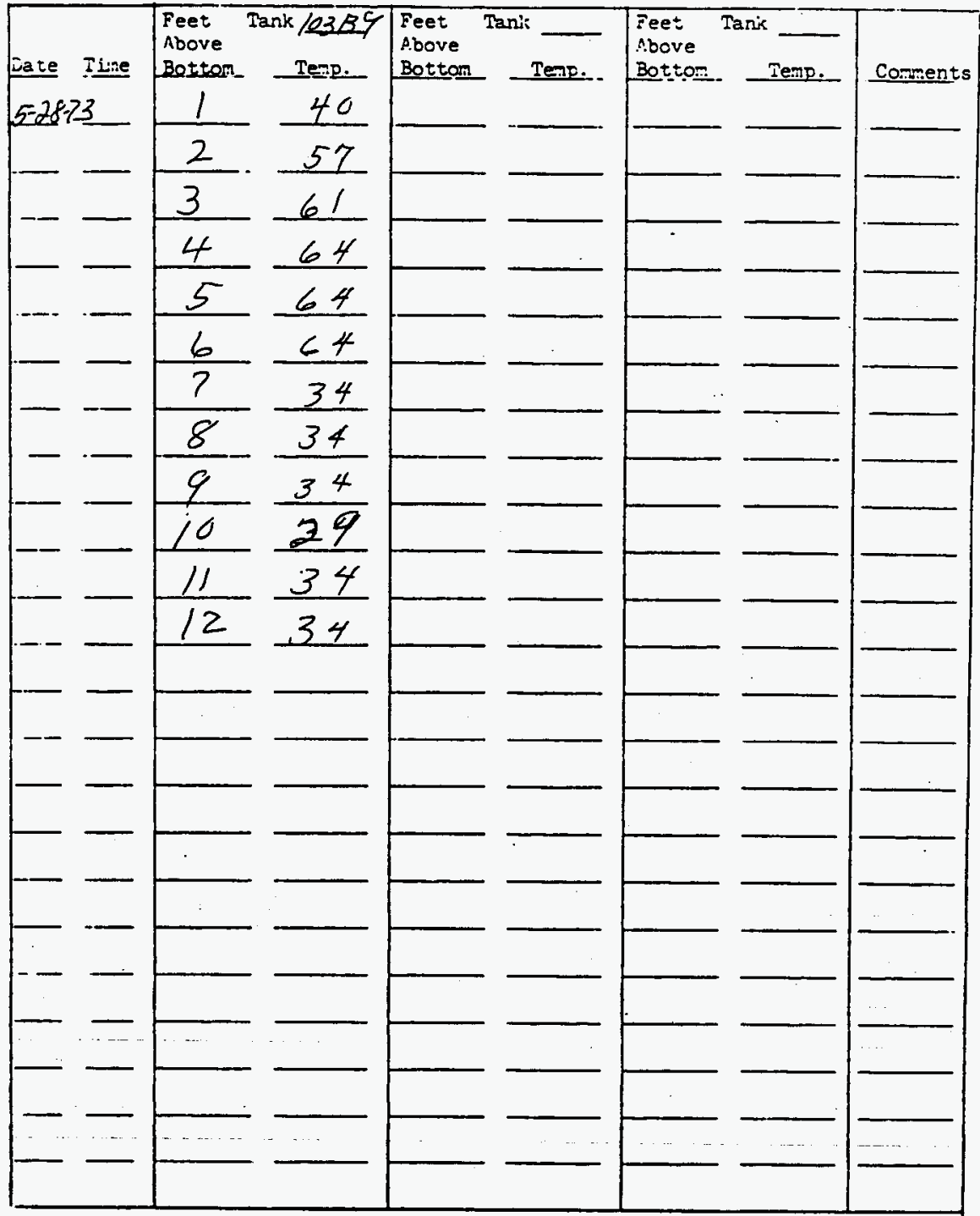

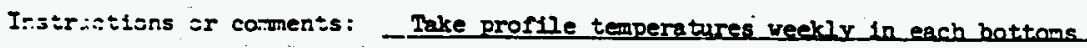
tank. Attach conpleted form to Monday and Thursday's Data Sheets. 
Title: PROFILE TEPERATURES TR ITS-2 BOTHOMS TAIKS $\ddot{\prime \prime}-8-4$

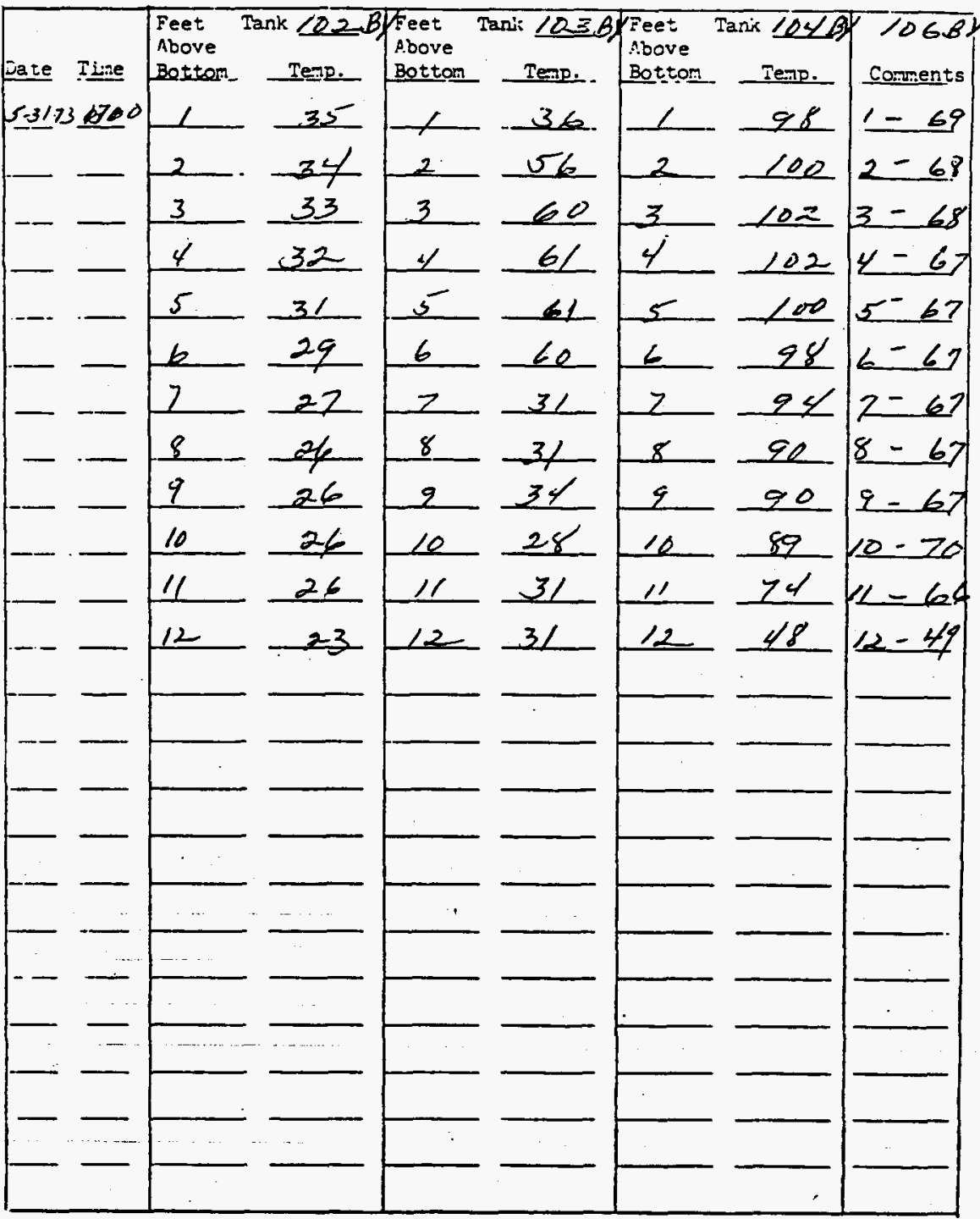

Irstr:ations sr coments: - Take proflle temperatures yeekly in each hottoms tank. Attach conpleted ford to Monday and Thursday's Dats Sheets. 
Title: PROFIIE TEIPERATURES IN ITS-2 BOTTOMS IAIKS $A " A=8-4$.

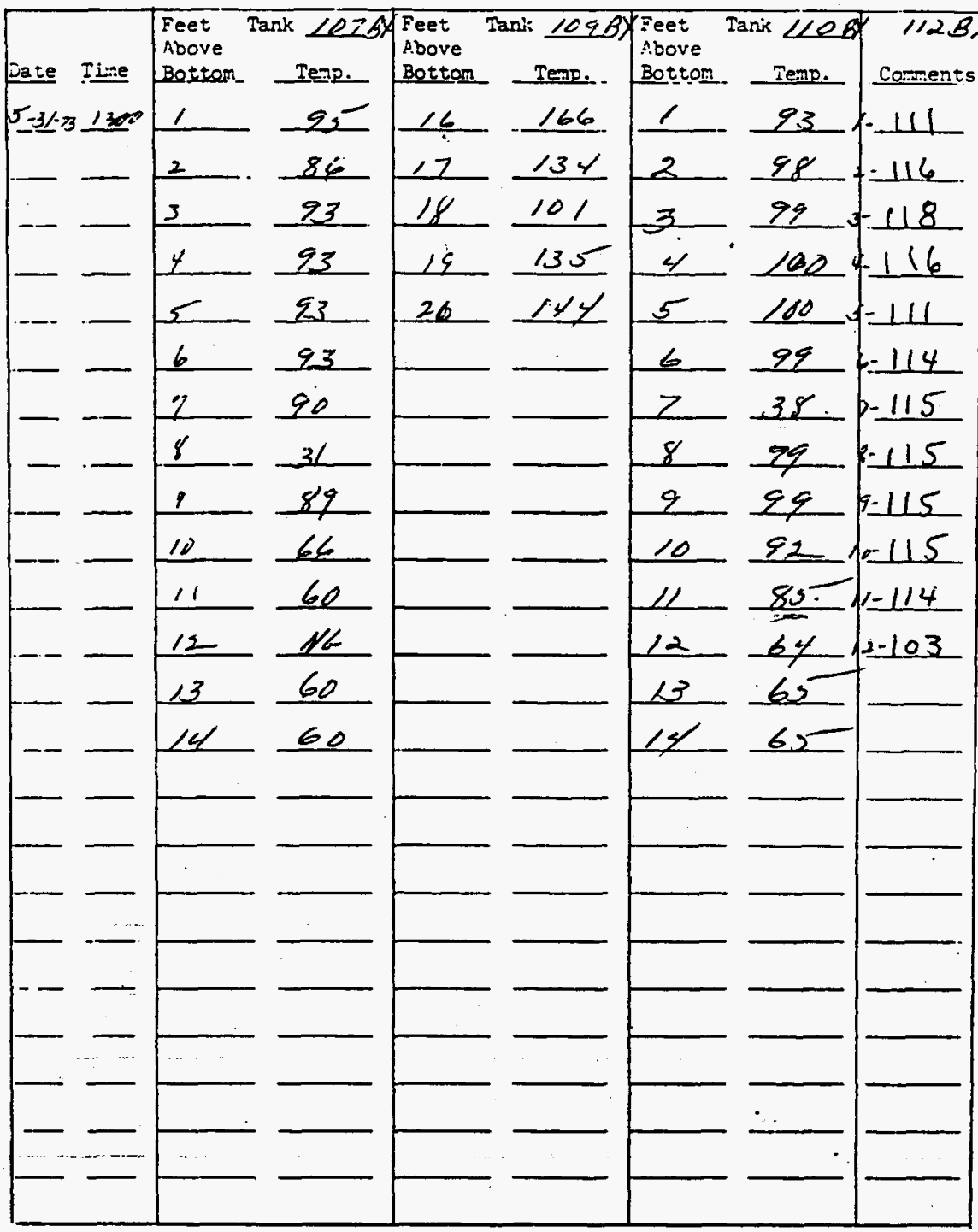

I::s:r:atisns ar coments: - Take profile temperatures weekly in sach bottoms. tank. Attach completed fora to Monday and Thursday's Data sheets. 
Title: PROFIIE TIPRERATURES IN ITS-2 BOTTOMS TANKS

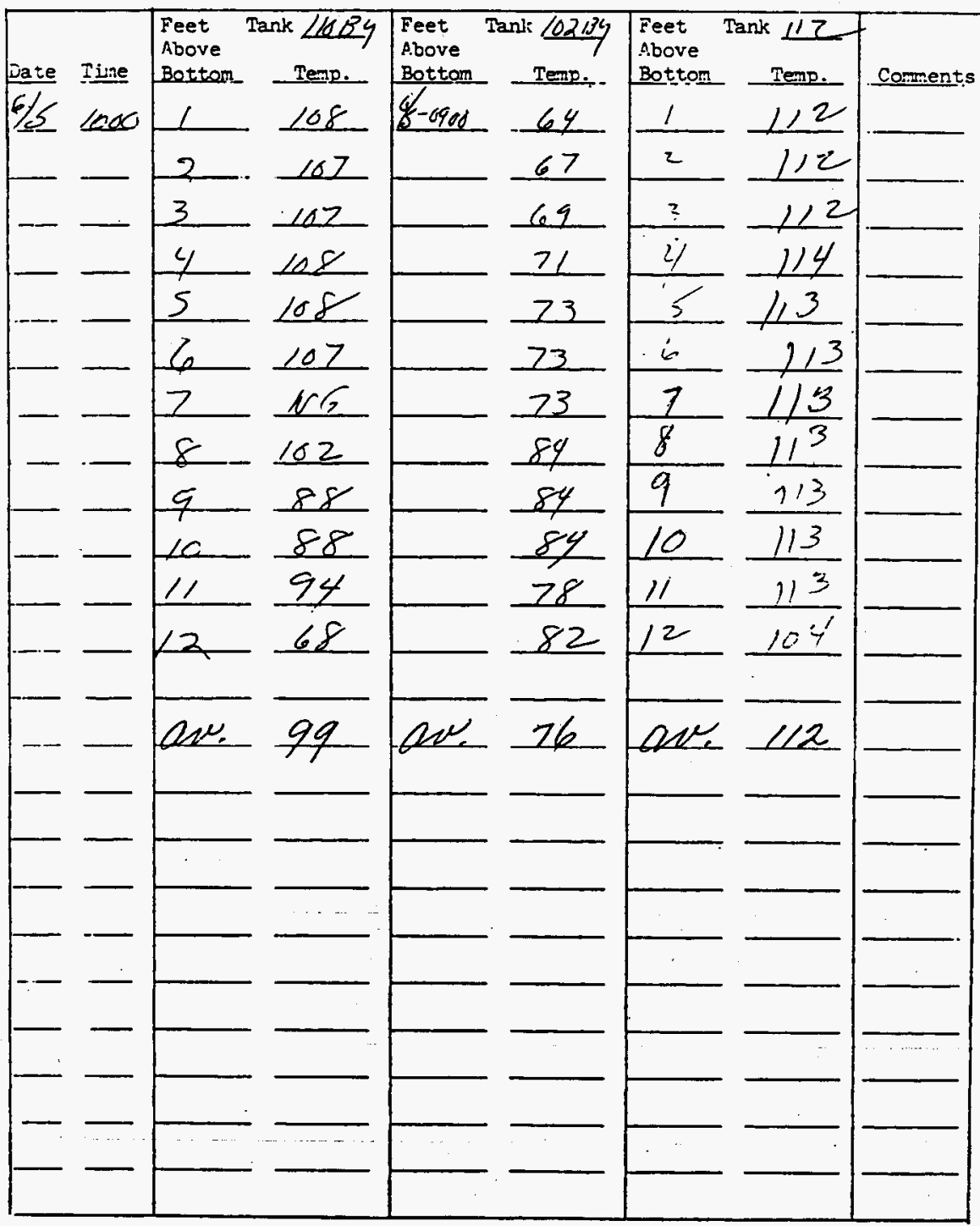

Instrietions or conments: - Take proflle temperetures weekly in each bottoms tanik. Attach conpleted form to Monday and Thursday's Data sheets. 
Title:

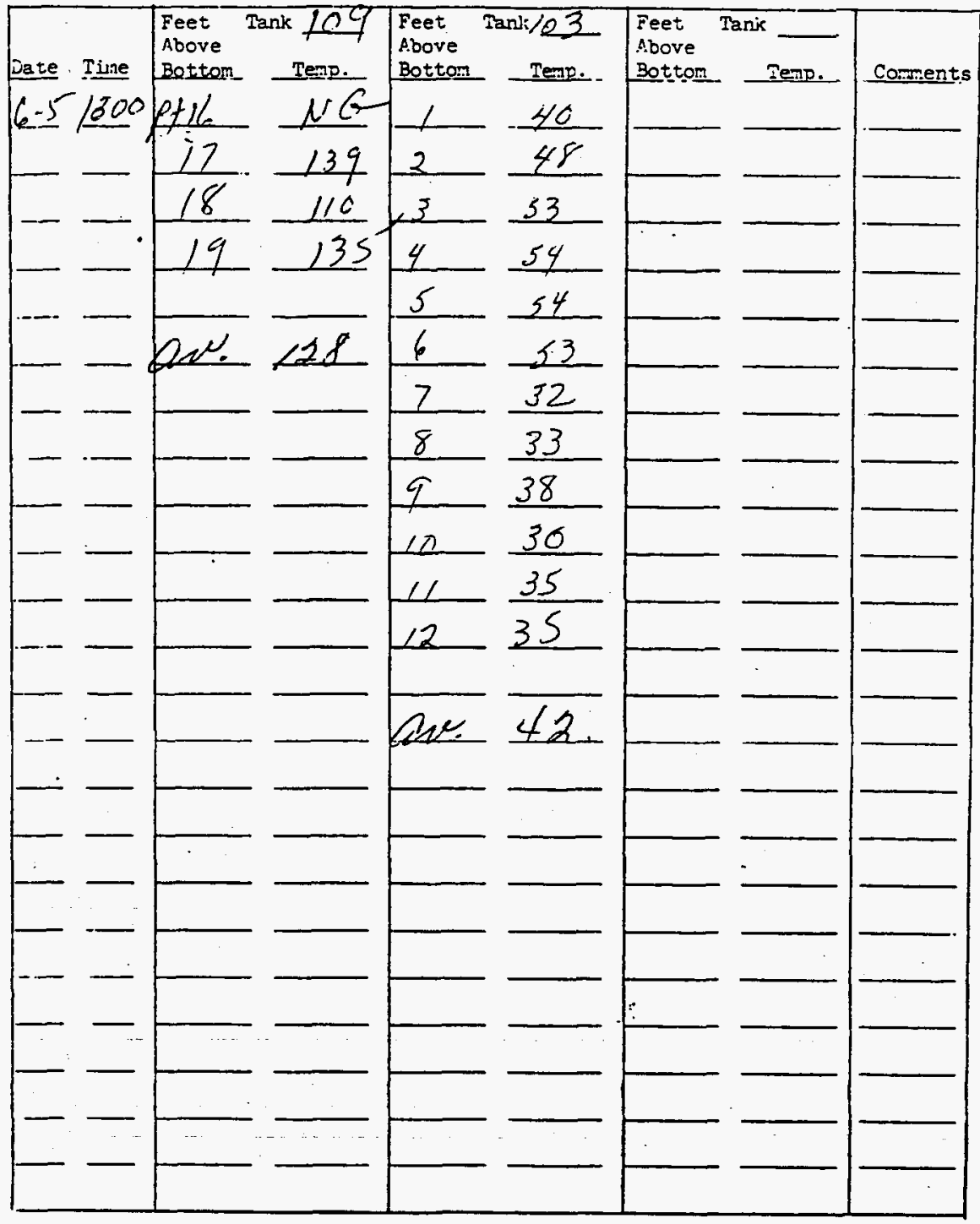

Instrietions ar corments: Take profyle temperatures veekly in mach bottoms tank. Attsch conpleted form to Monday and Thursday's Data Sheats. 
Title: PROFIIE TEYPERATURES IN ITS-2 BOTTOMS TAIKS

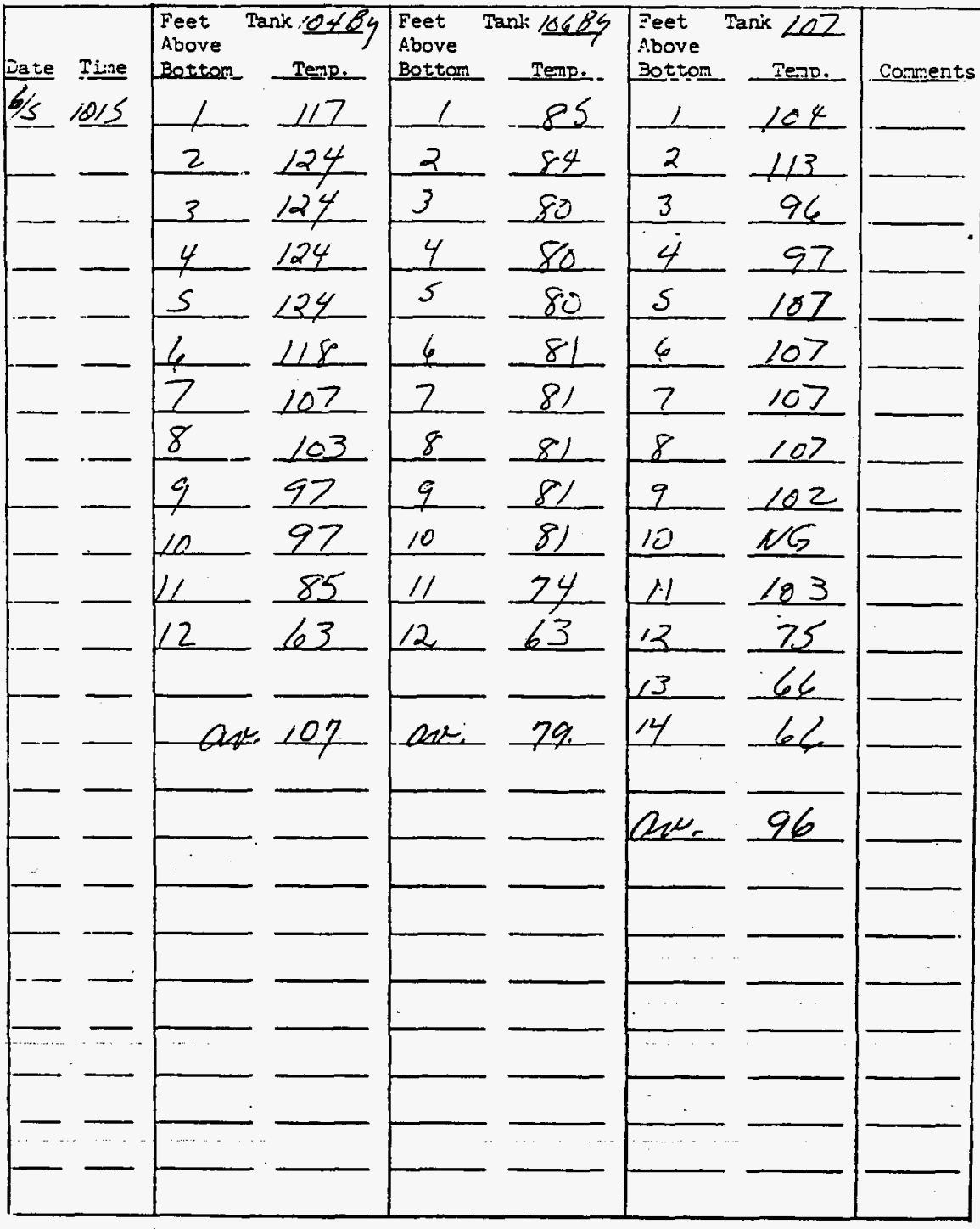

I:3 tr:stions or conmenis: - Take proflie temperatures veekly in each bottoms tank. Attach completed form to Monday and Thursday's Data Sheets. 
Title:

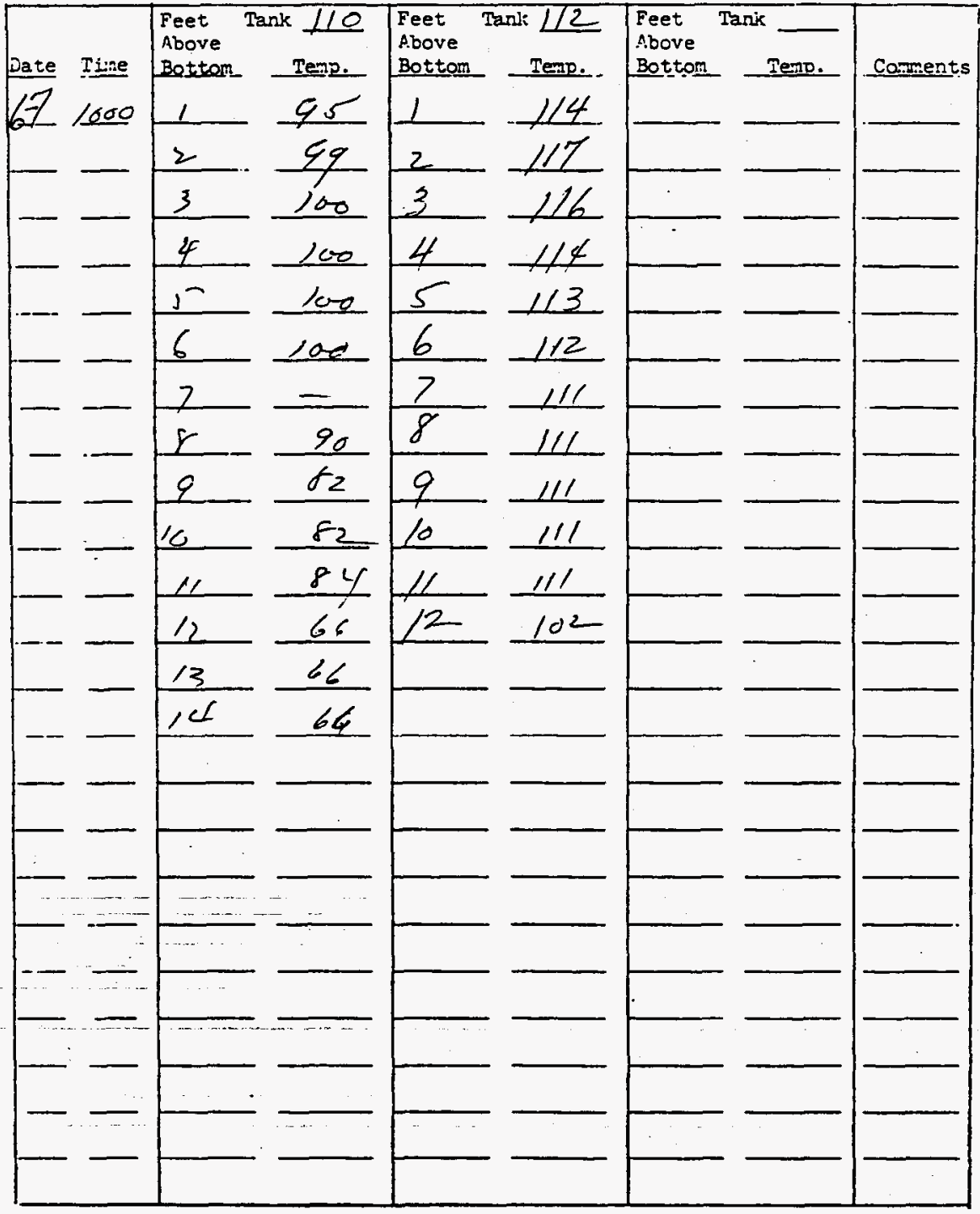

I::3:r:ettons sr coments: Take proflle temperatures weekly in each bottams tank. Attach completed form to Monday and Thursday's Data Sheets. 
Title: PROFIIE TERIPERATURES II ITS-2 BOTIOMS TARTS

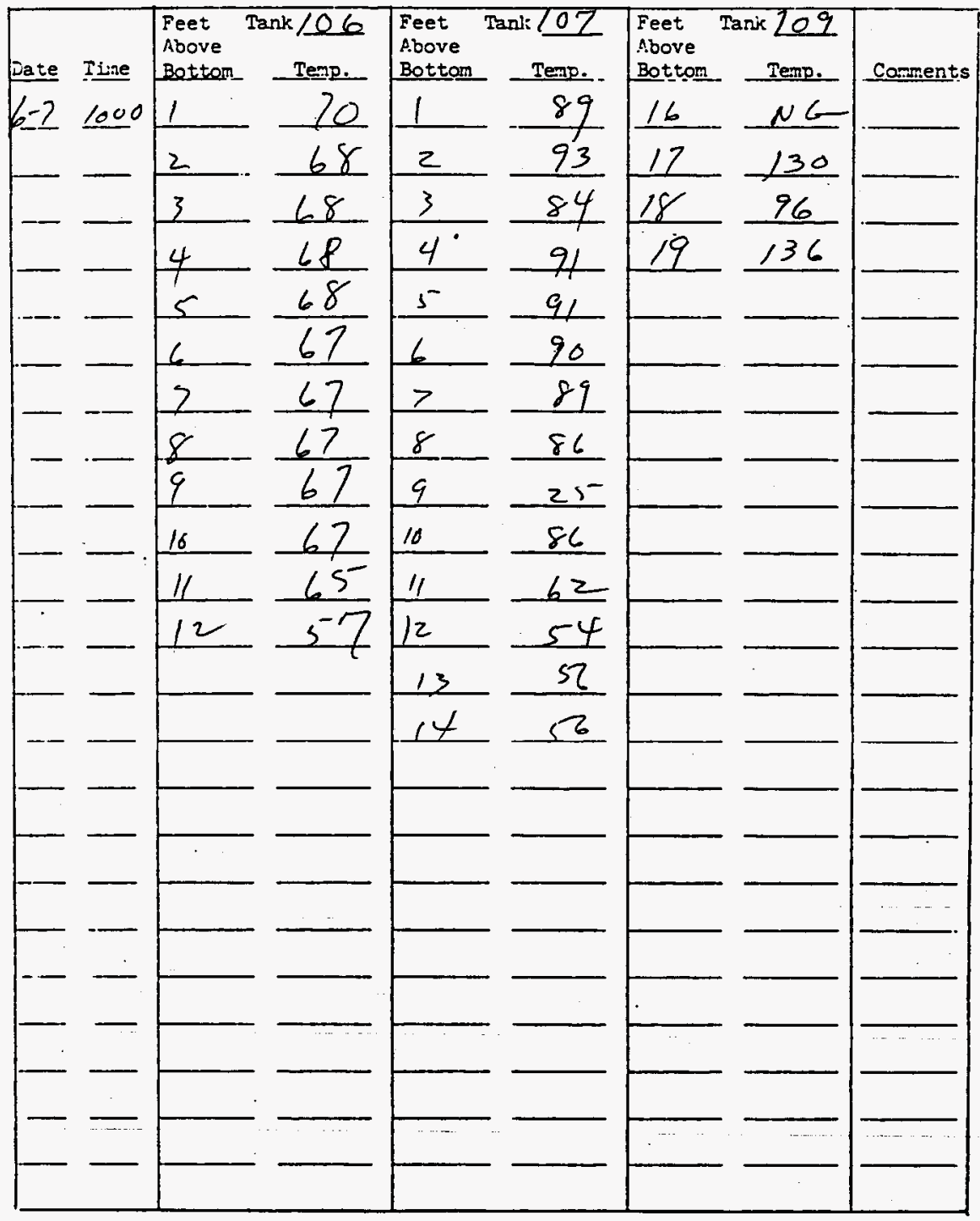

Irstriations or comments: - Take profile temperatures reekly in each hottoms tank. Attech conpleted form to Monday and Thursday's Data Sheets. 
Title:

PROFILE TIITPERATURES IN ITS-2 BOTTOAS TANKS

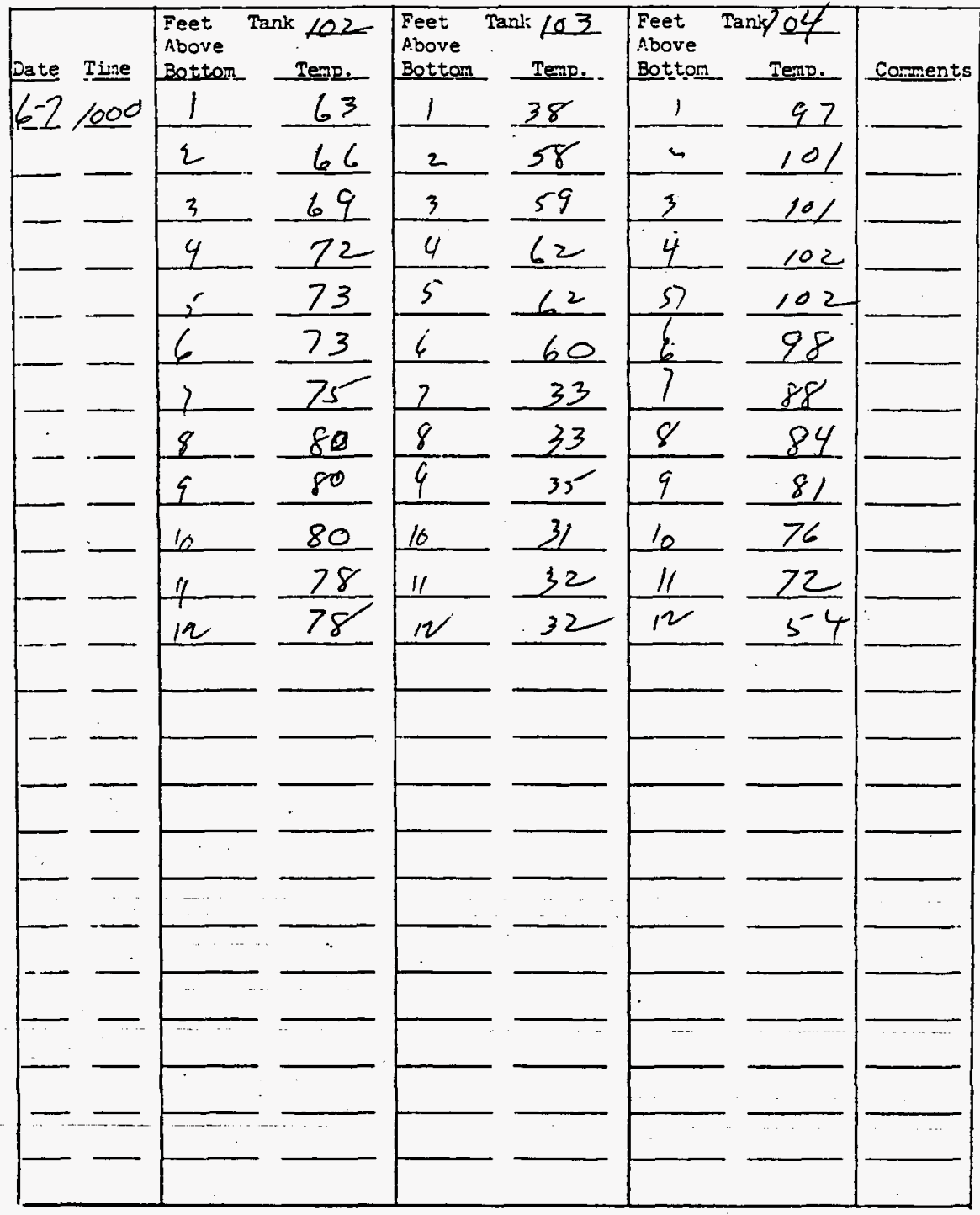

Injtrictions or coments: -Take prof lle temperatures weekly in each hottoms tank. Attach completed form to Monday and Thursday's Data sheets. 
Title: PROFILE TERERATURES $\mathrm{CI}$ ITS-2 SOTIONS TAIKS

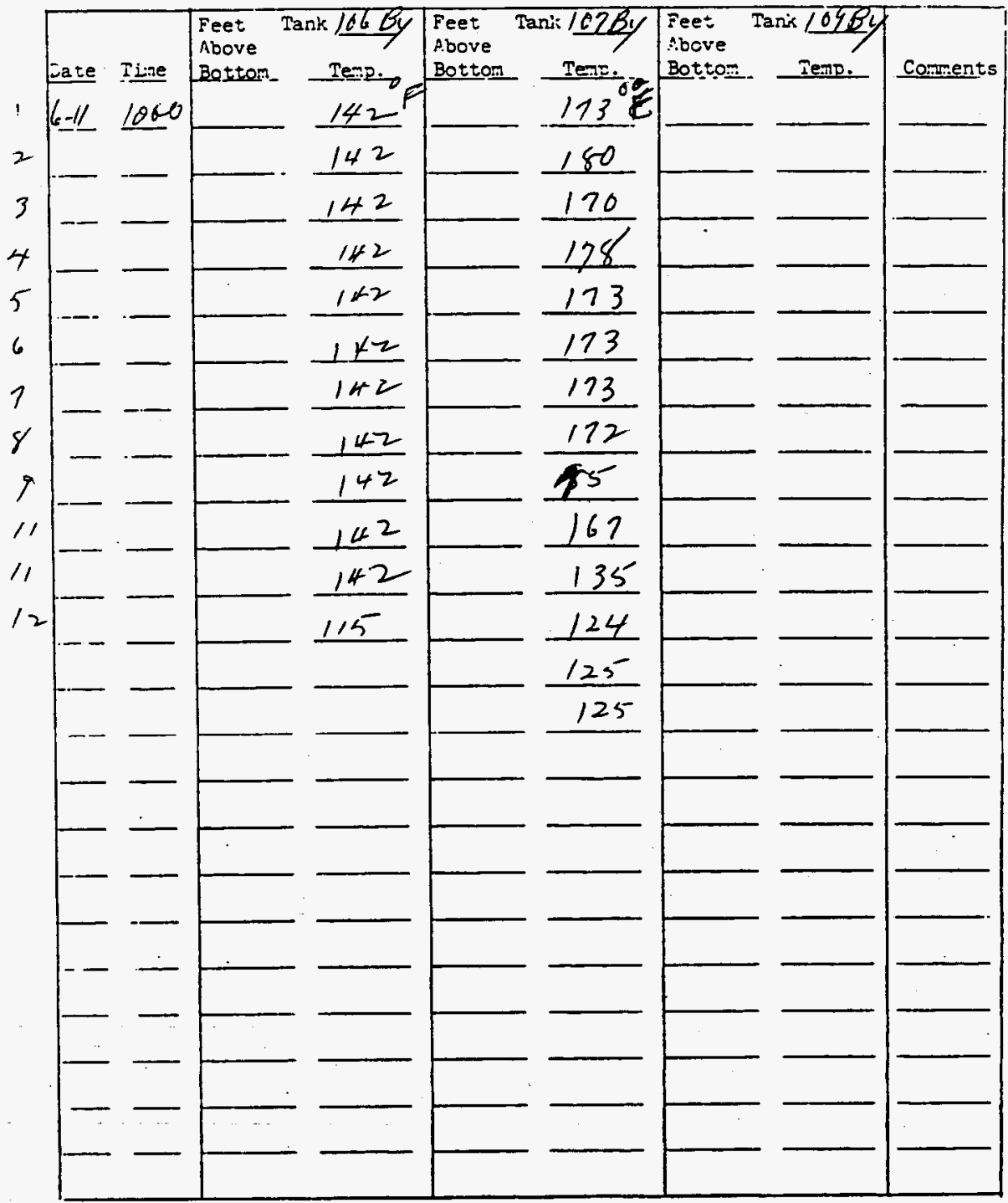

I:3:r:4:isns sr coments: - Take profile temperatures veekly in each bottoms tank. Attach completed form to Monday and Thursday's Data Sheets. 
Fitle: FROFILE TOTERATURES Li IIS-2 SOTTONS FARTS

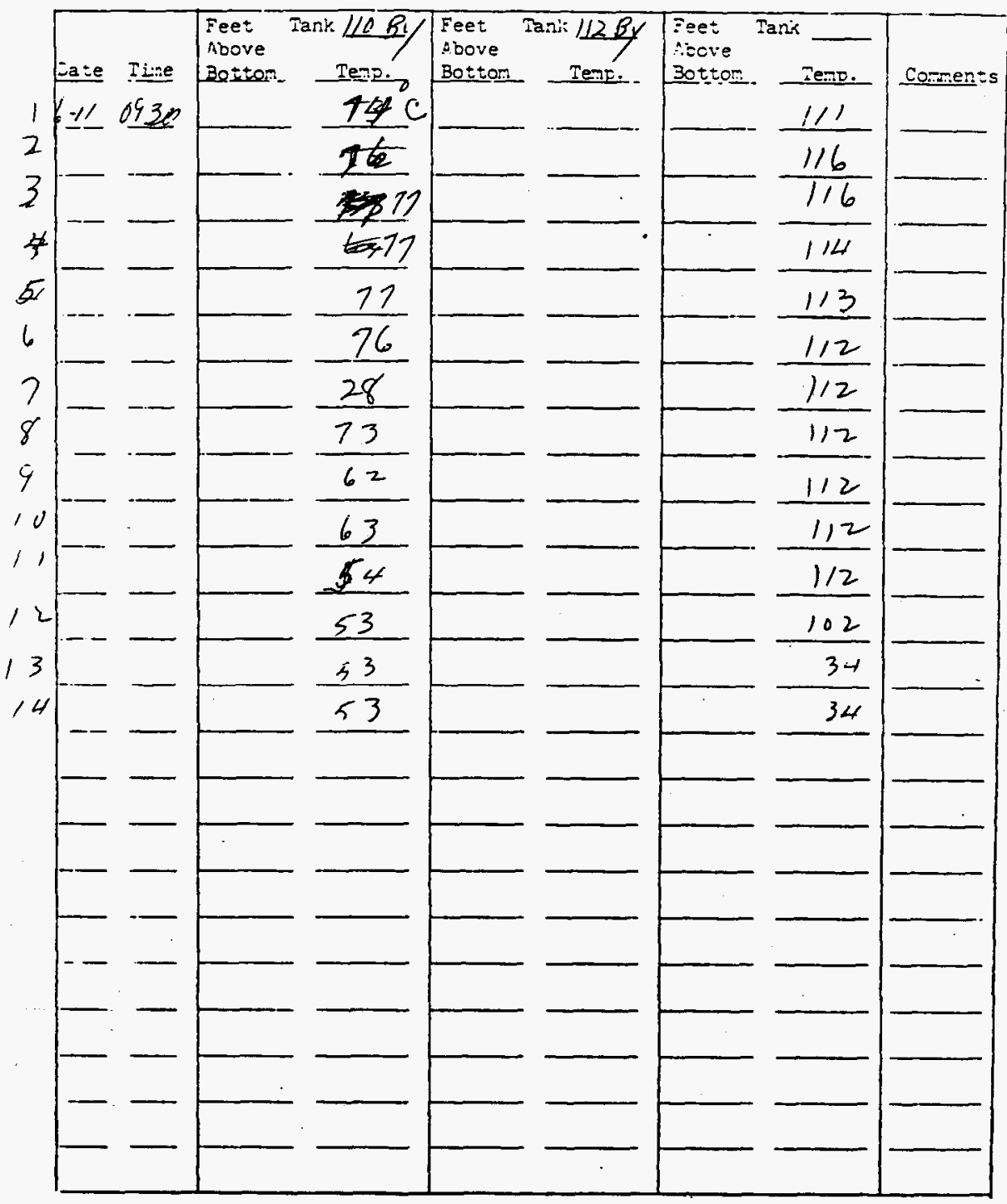

IF3:r:sticrs ar coments: - Take proflle temperatures weekly in each bottons. tank. Attach conpleted form to Monday and Thursday's Dats Sheets. 
Title: PROFIIE TD.PERAIURES IV ITS-2 SOTTOMS TAIKS

-ise Feet Tank/QD-By

Ea:e Iine Above Botton- Temp. Feet Tani $163-B y /$
above
Boted

$\$ 11 \quad 1060$ $\frac{92}{92} \frac{92}{92}=$

Tene. $_{0}$ Botto- Iemp. Coments

7

$$
\begin{aligned}
& 1 \\
& 3 \\
& 4 \\
& 5 \\
& 6 \\
& 7 \\
& 8 \\
& 9 \\
& 10 \\
& 1
\end{aligned}
$$$$
\text { - }
$$

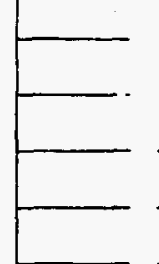


Title:

PROFIE TMIPERATURES IN ITS-2 BOTTOMS TANKS

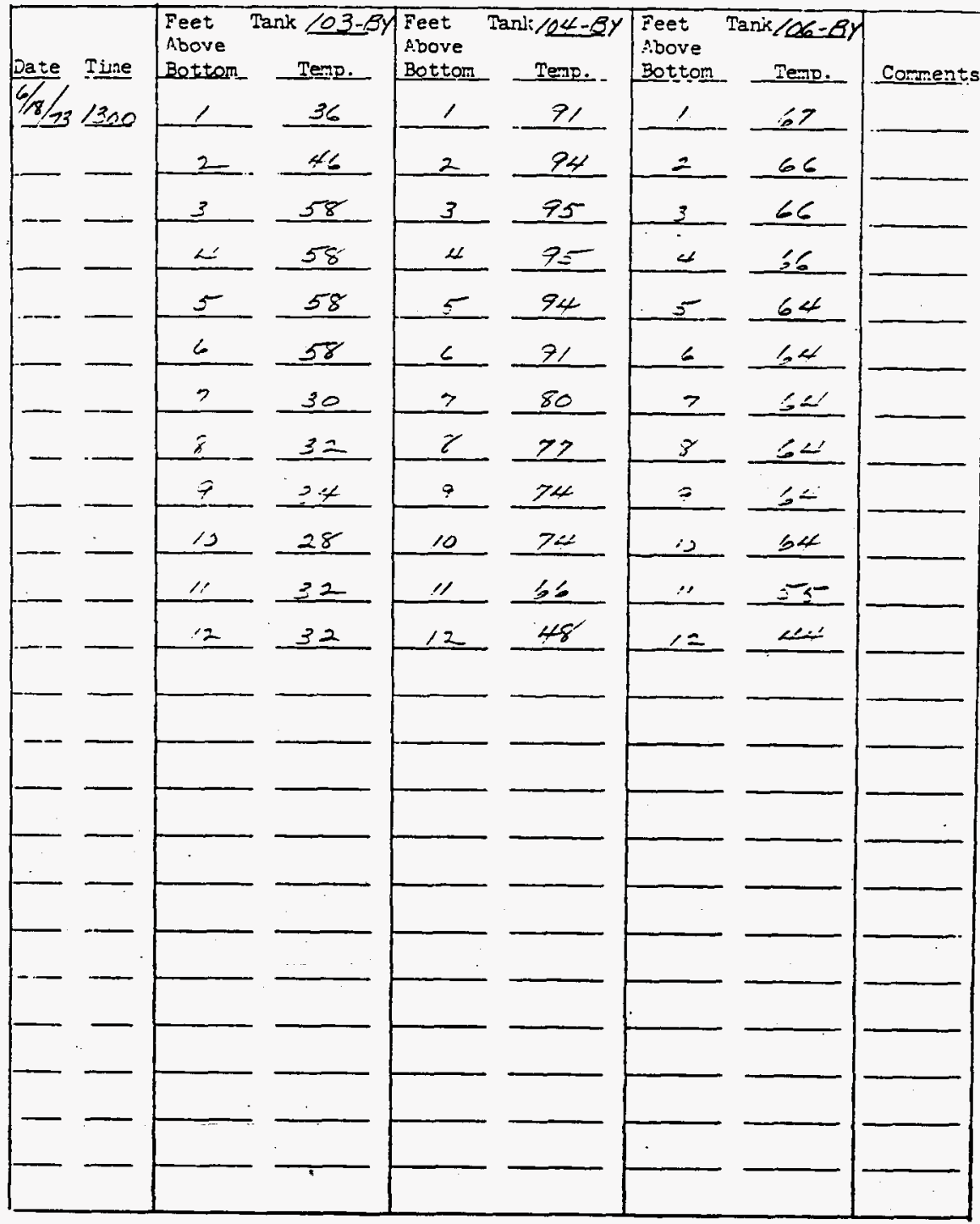

Instristions or comenis: The prorlle temperetures weekly in each bottoms tank. Attach conpleted form to Monday and Thursday's Data Sheets. 
Title: PROFIIE TERERATURES IN ITS-2 BOTTOMS TANKS

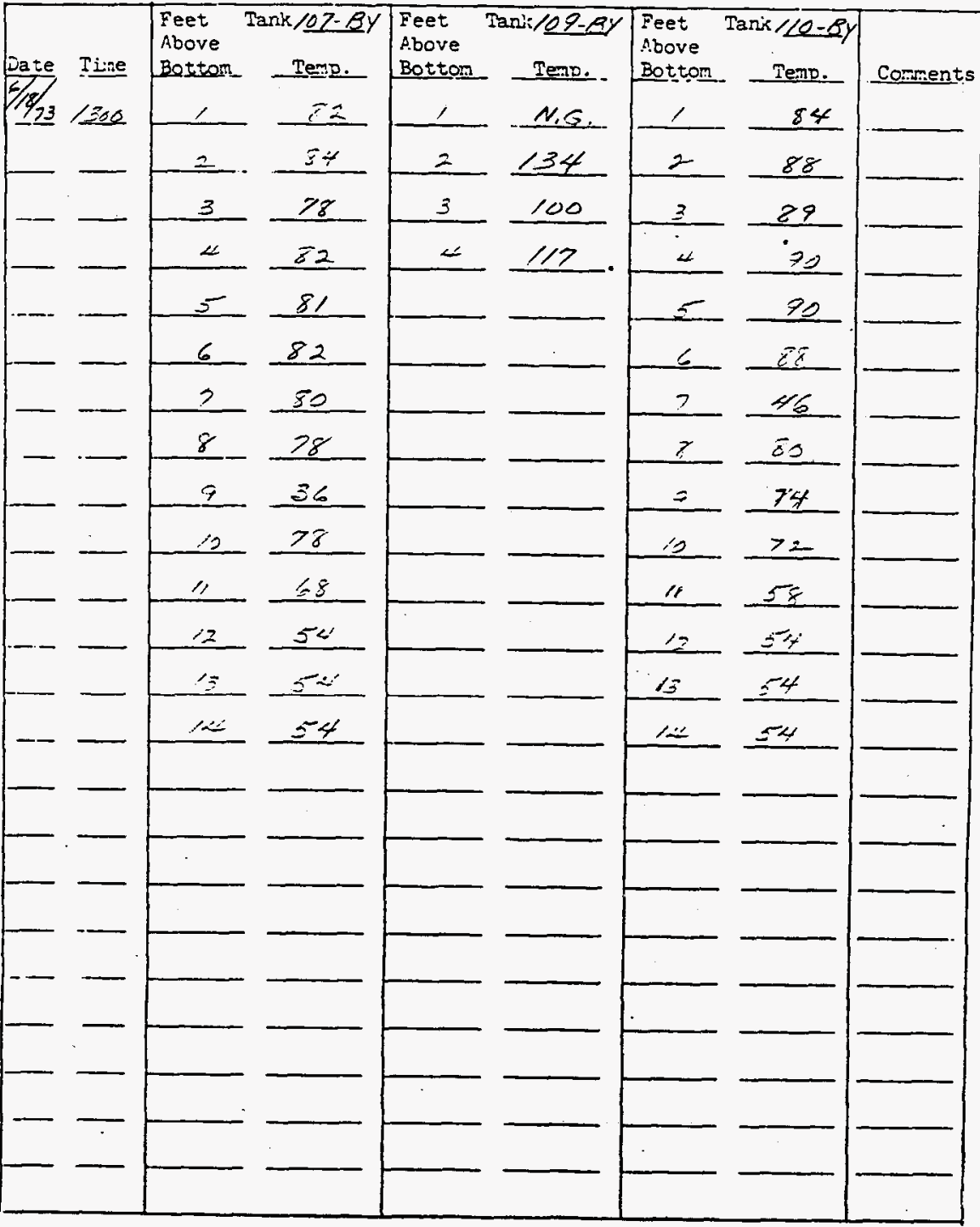

Instriations ar conments: Take prof lle temperatares weekly in each bottoms tank. Attach canpleted form to Monday and Thursday's Data Sheets. 
Title:

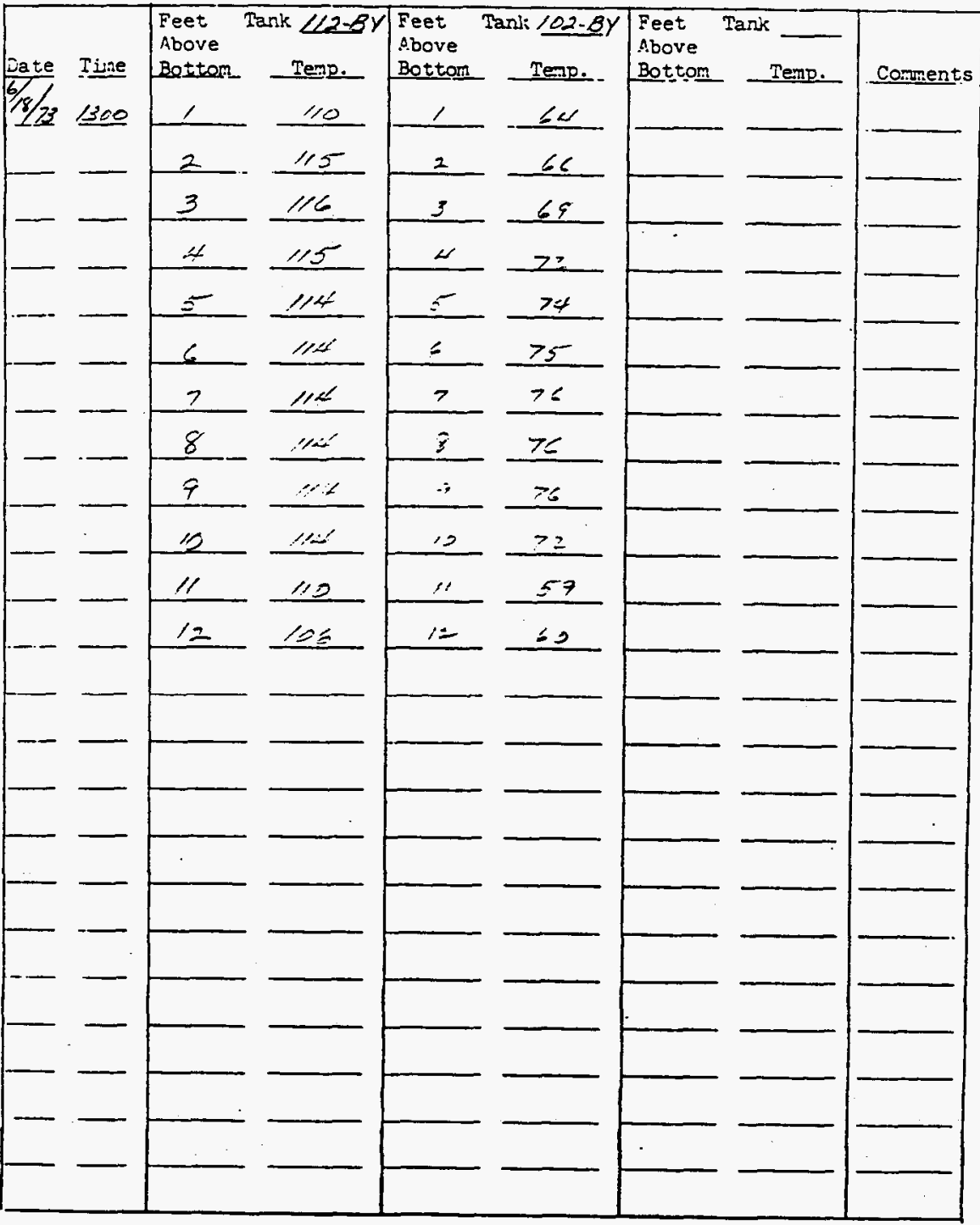

I-3tr:stions =r coments: Pake profile temperatures weekly in each bottons tank. Attach coaplieted form to Monday and Thursday's Data sheets. 
Title:

?

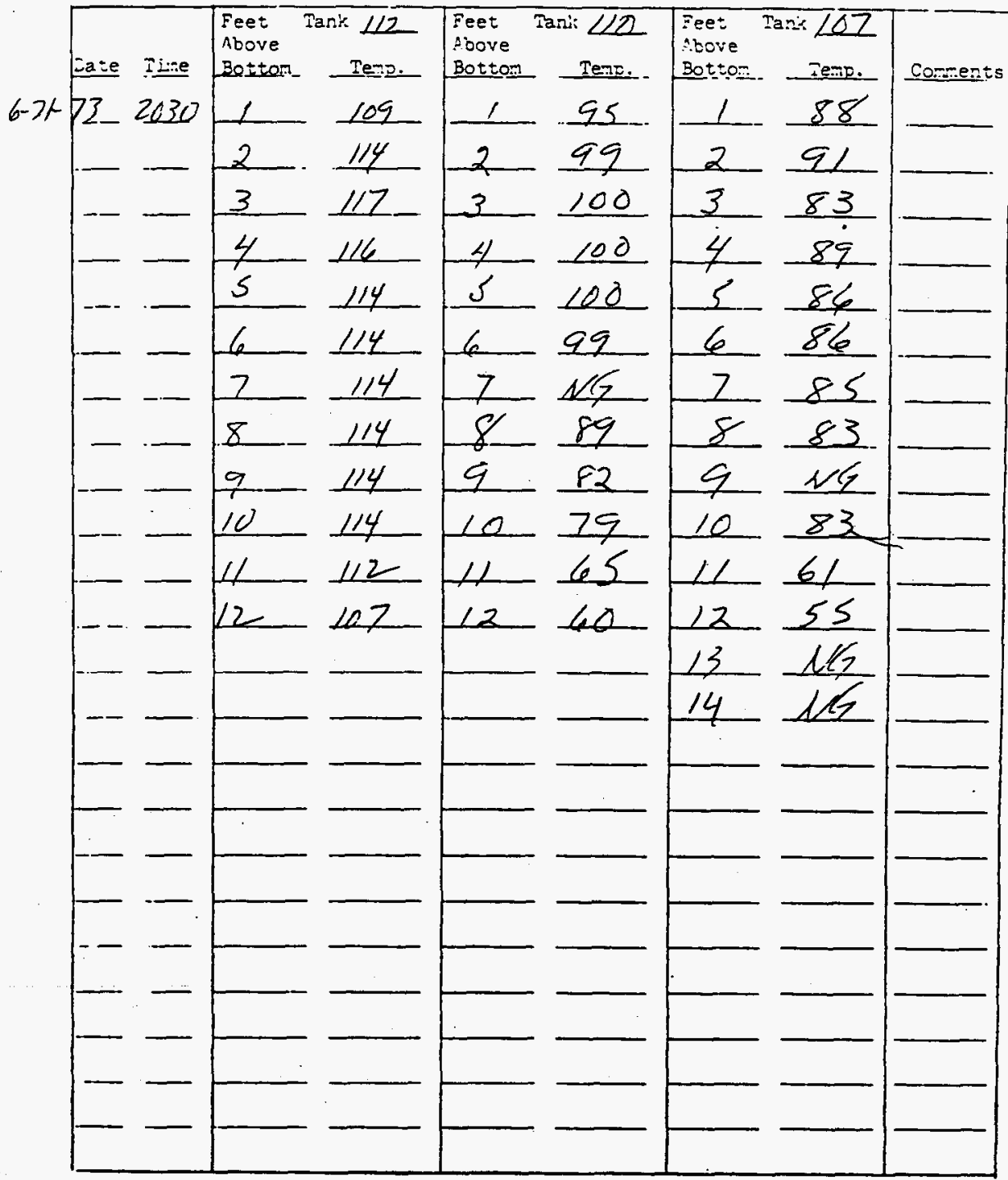

Irstr:t:isrs sr comenss: - Take Erorile temperatures veekly in each bottoms. 
Iitle: PROFILE TEFERATURES IV ITS-2 BOTTOMS TAIKS

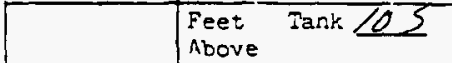
Eave Iine Bottom, Te:p. $6-12-23$ 2100 1 -

$---$

$2 \cdot 77$

$-1 \frac{3}{4}$

$--$

$\ldots-\frac{63}{5}$

$-\cdots$ $6-\frac{60}{5}$

$-\cdots \frac{7}{\frac{8}{9}} \frac{51}{45}$

$--9 \frac{45}{32}$

$-=\frac{10}{11} \frac{37}{27}$
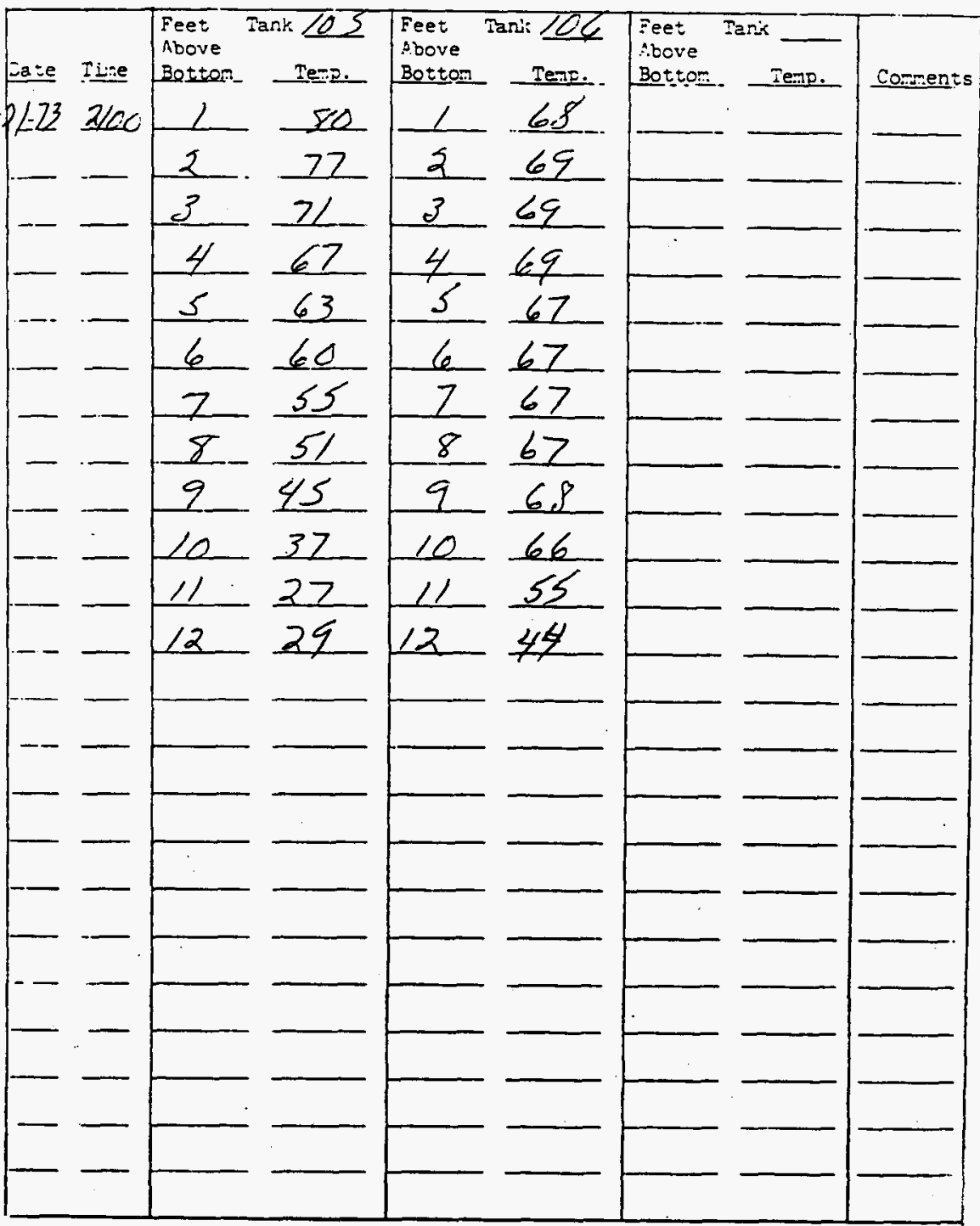

Irsir:otions ar comens: - Take prorlle temperetures weekly in each battoms 
Title: FROFILE TETERATUES IV ITS-2 BOTTOMS TAHKS

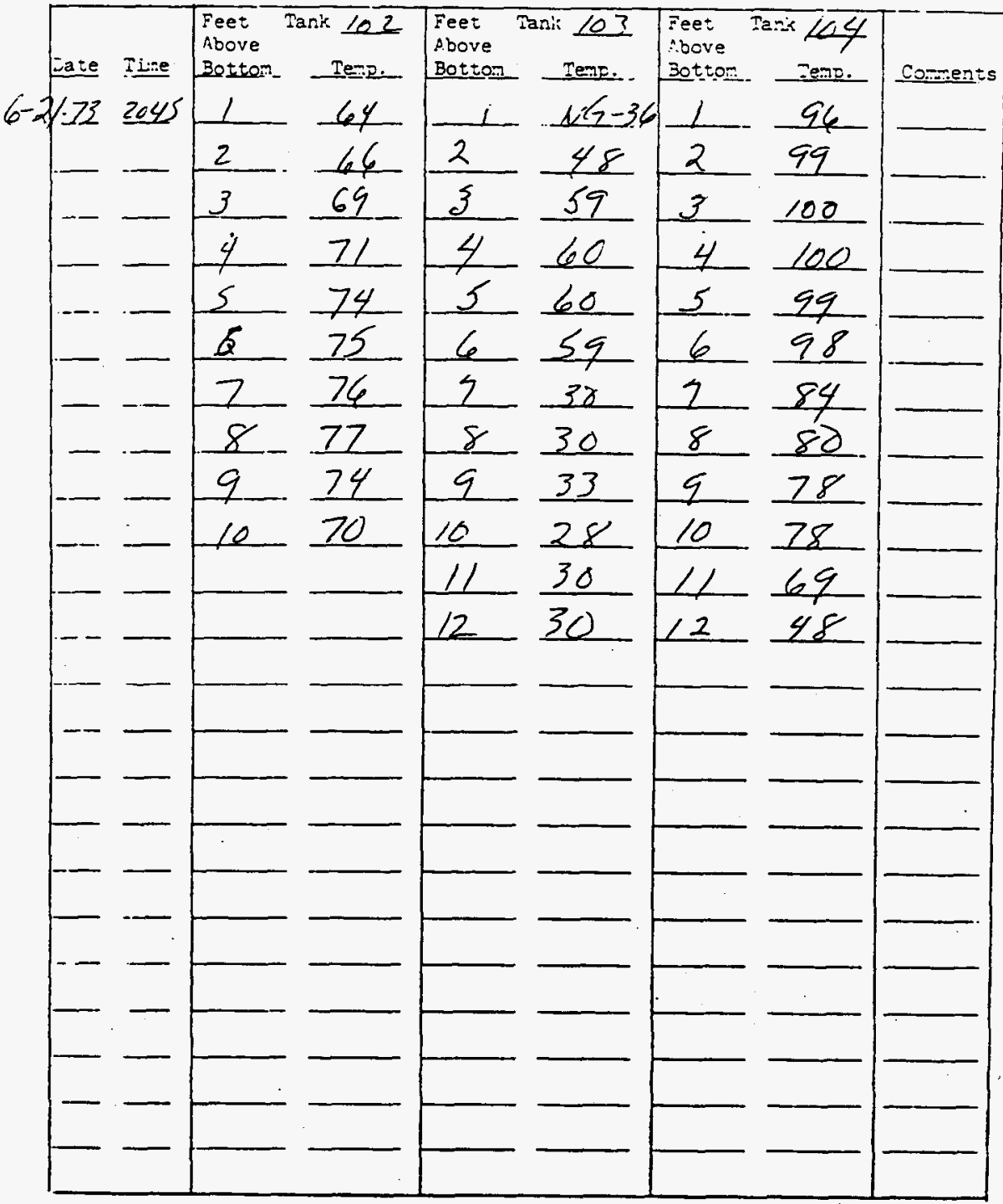

Ir:3tr:atisns or coments: - Take crorile temperetures weekly in each botioms 
Title: PROFILE TEFERANUES IN ITS-2 BOTOMS TARTS

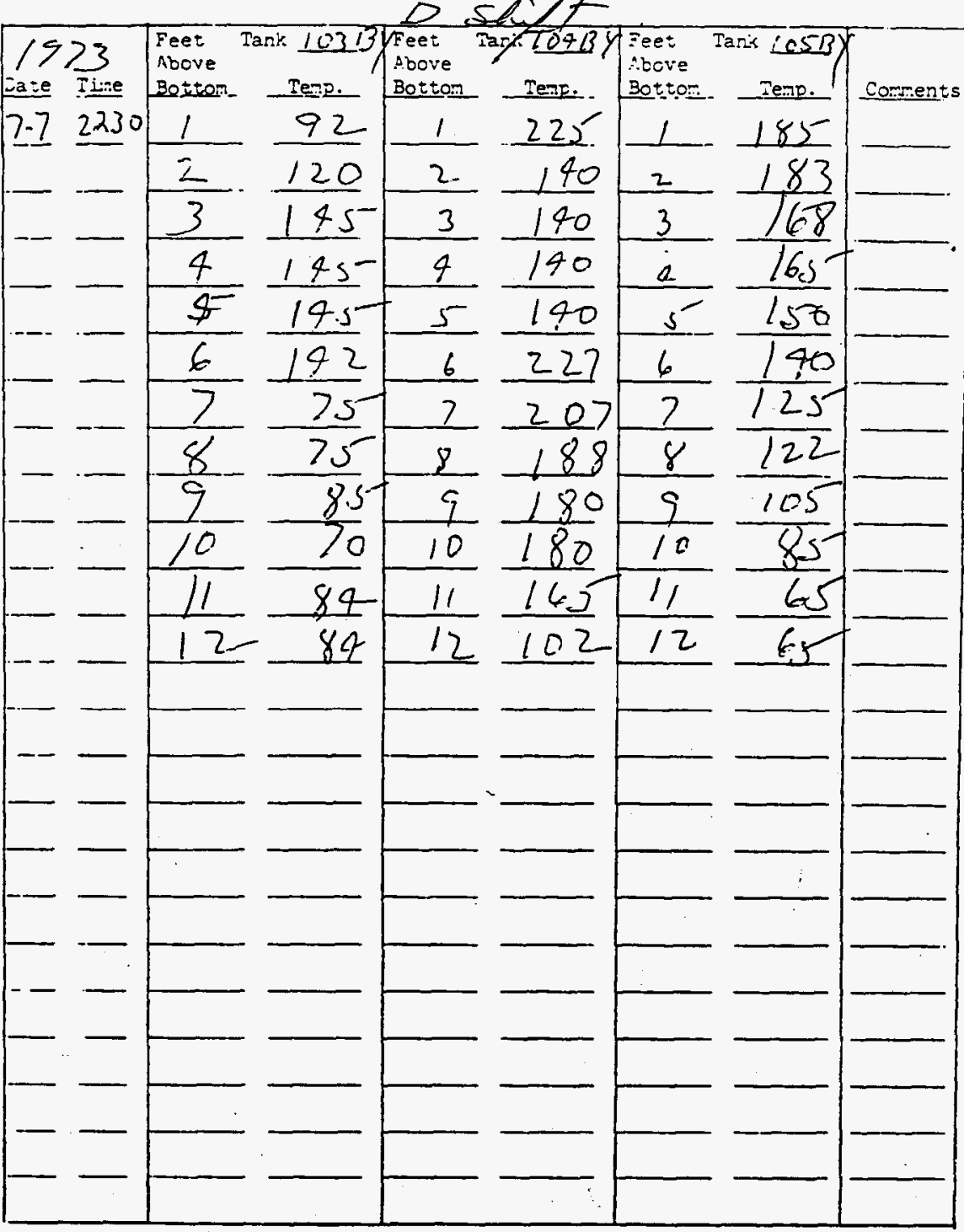

Injtr:sions sr comen's: Take frof 11 e temperatures weekly 10 each battams 
Iitle : PROFILE TEFERRIURES EN ITS-2 BOTTONS FAMTS

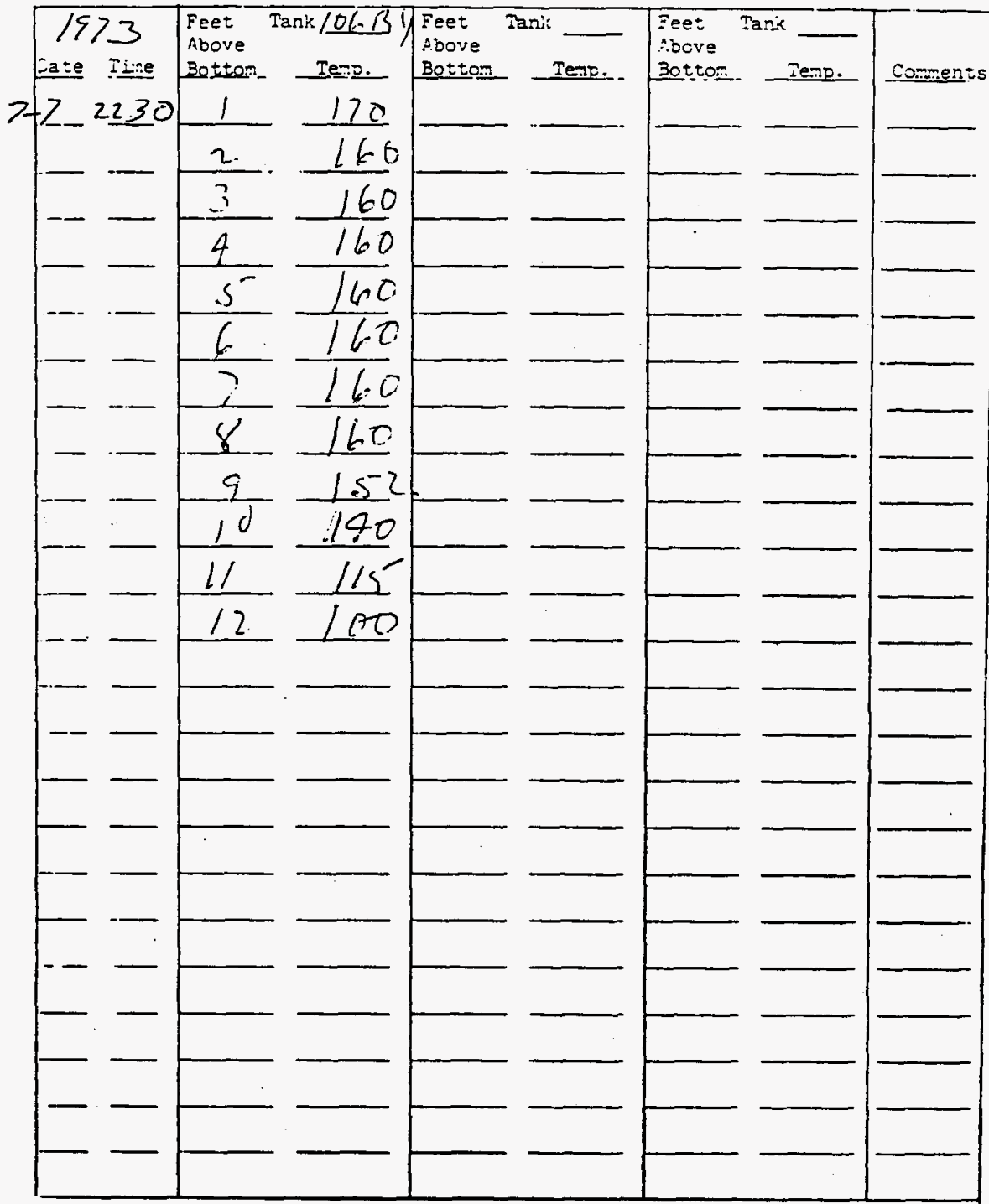

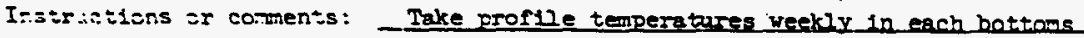
tank. Attach completed forz to Monday and Thursday's Data Sheets, 
Title: FROFILE TEEERATEES I: ITS-2 BOTTONS IATKS

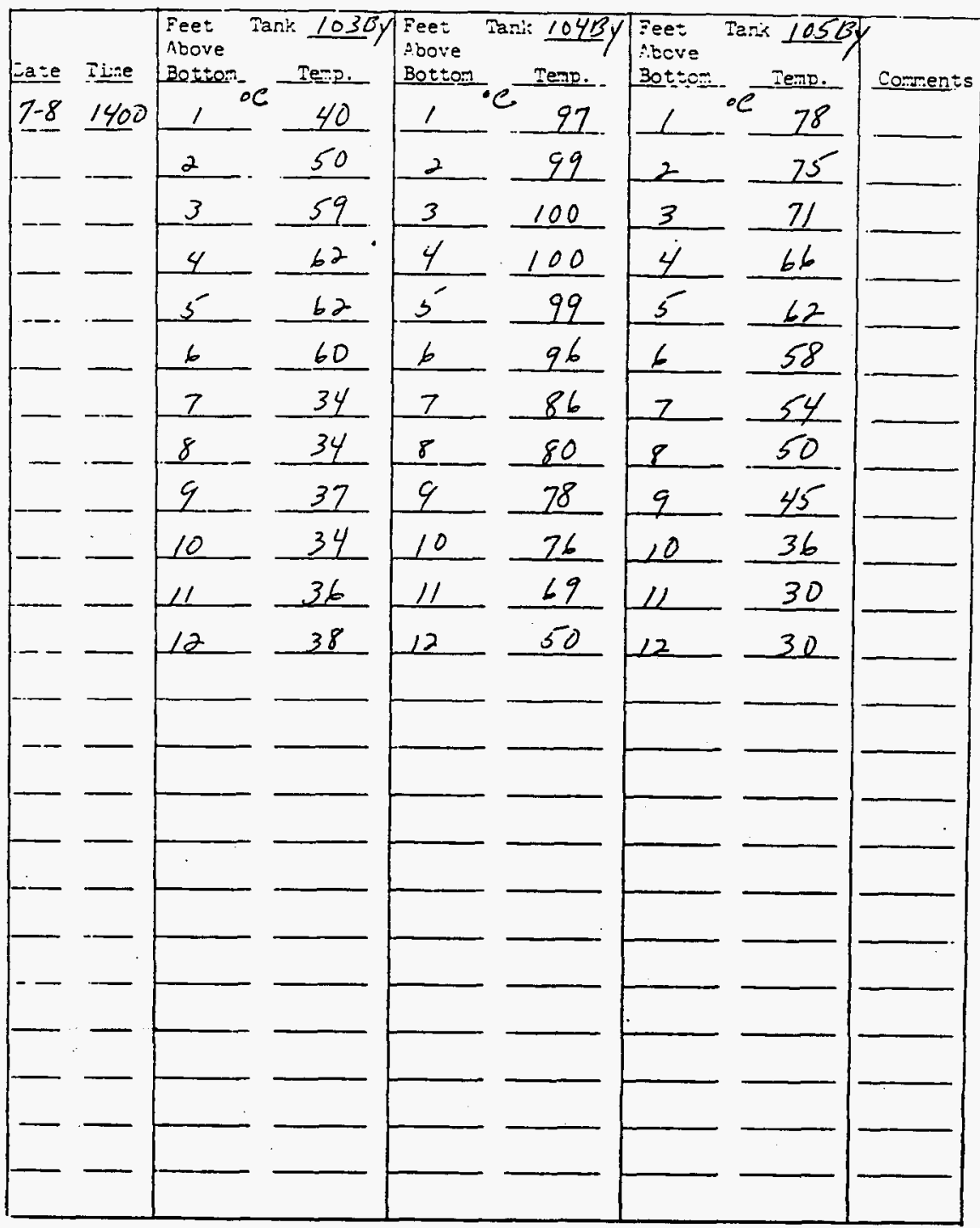

Instr:otisns or comen:s: - Take profile terperatures veekly in each battoms. tank. Attach completed form to Monday and Thursday's Data Sheets. 
ritle:

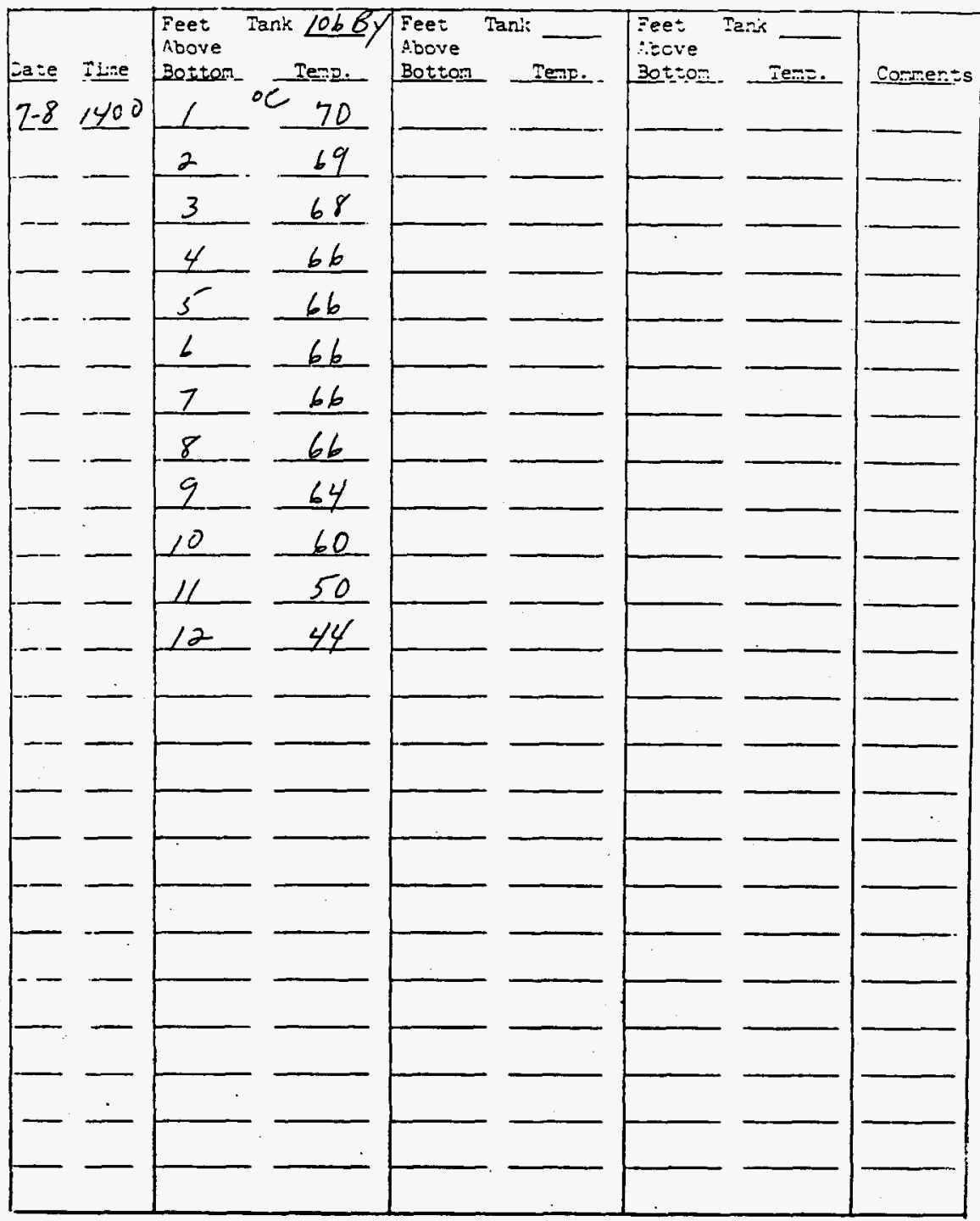

I::3tristions ar coments: - Take profile temperatures veekly in each bottoms 
Title:

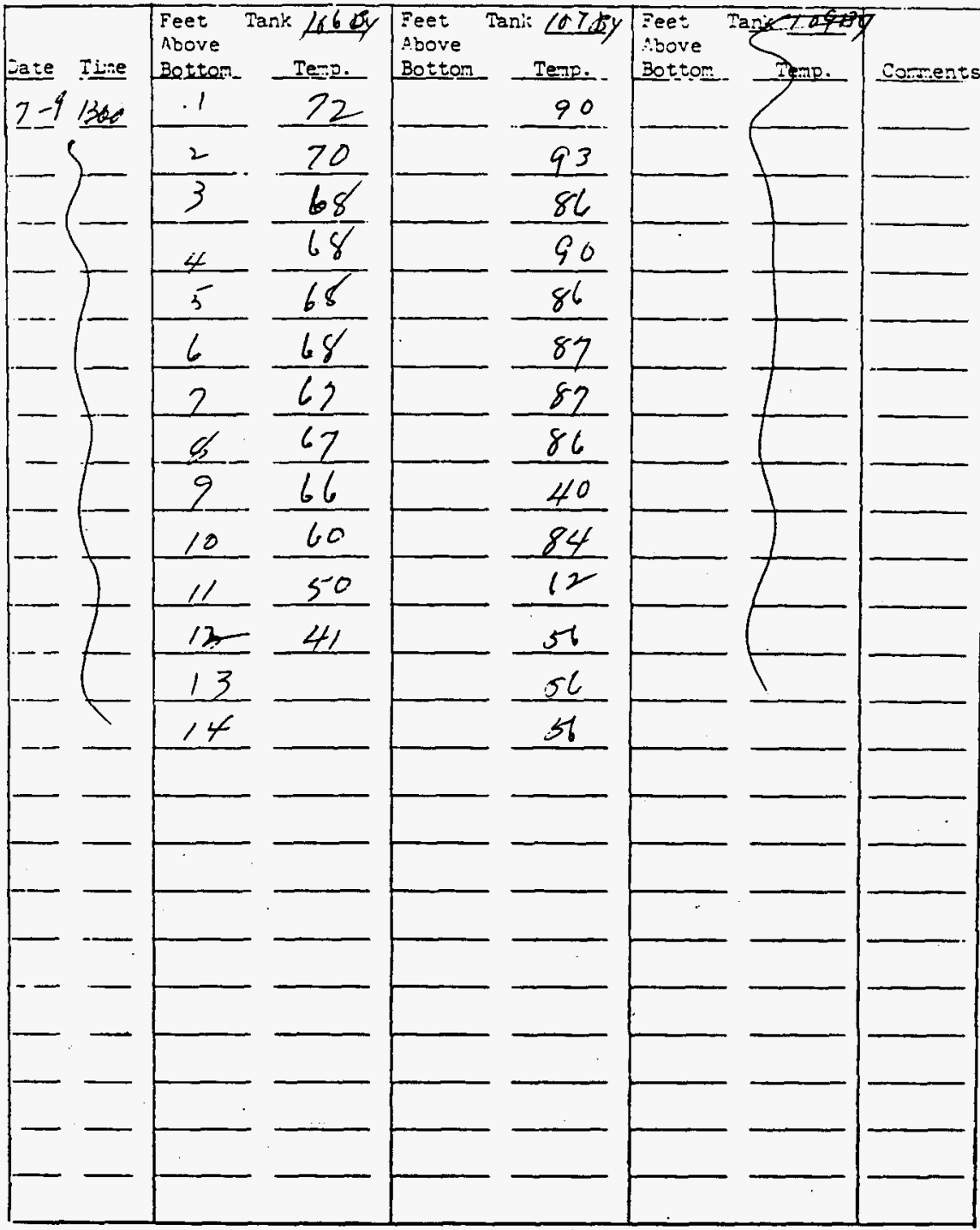

Irjir:zions ar coments: -Take profule temperatures weekly in each battons 
Title: FROEILE TZTFERATURES TI ITS-2 BOTTONS TAMKS

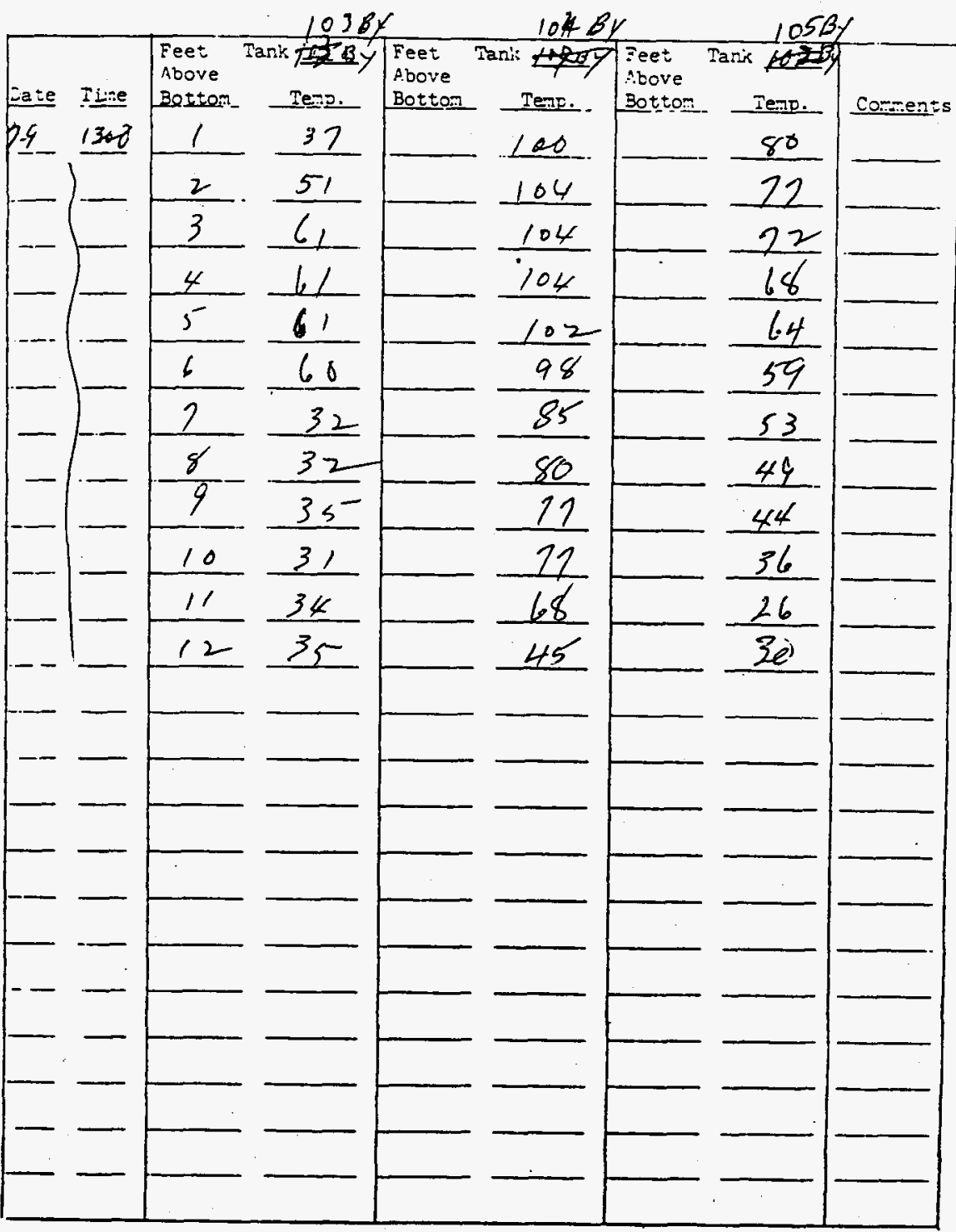

Ir:str:itions ar coments: - Take profile temperatures veekly in each bottons 
Title: FROFILE TERERATURES II ITS-2 BOTIONS TAIRS

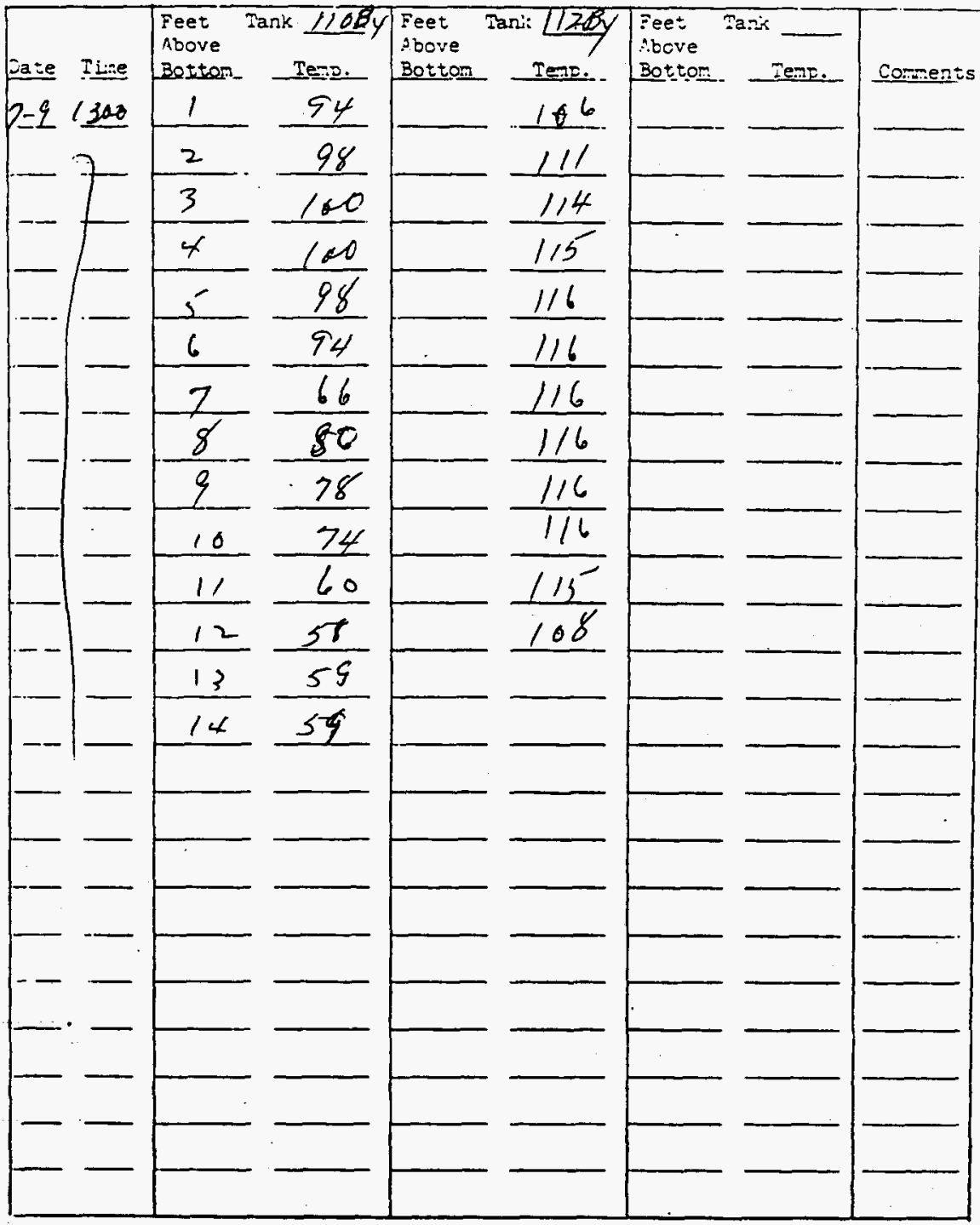

Irstr:sions or coments: - Take proryle temperatures veekly in each hottons 
Title:

PROFILE TEFERATURES IV ITS-2 3OTTOMS IANKS
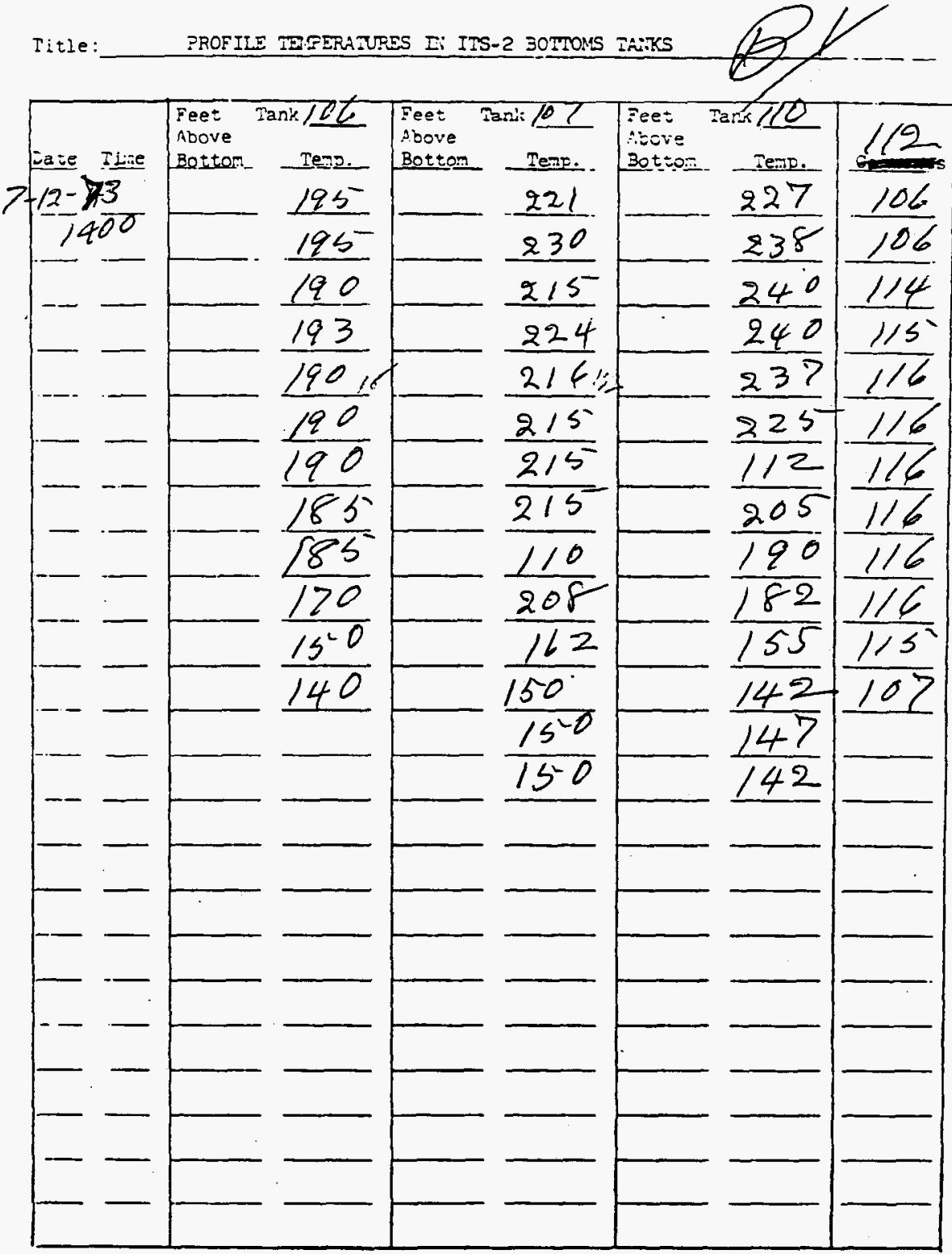

Instriations ar coments: - Take profile temperatures veekly in each battoms 
Title: PROFILE TEFERATUFES IN ITS-2 BOTIOYS FANKS

Feet Tank 104 Fee Tani 83 Fee:

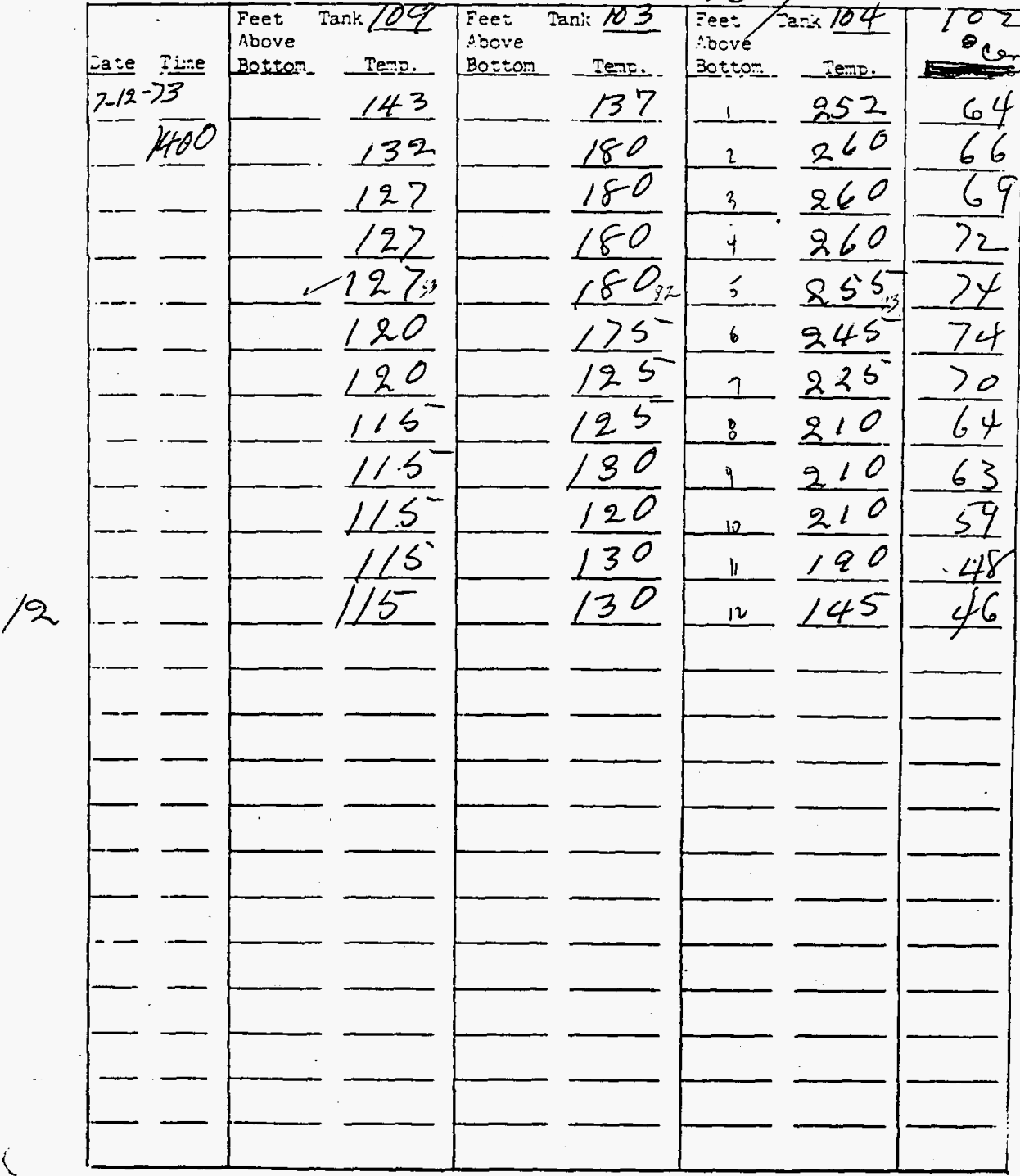

Ir:3ir:-zisns $=r$ coments: - Take erofile temperatures weekly in each hottoms 
Title: PROFILE TEPERATURES II ITS-2 BOTTONS TANKS

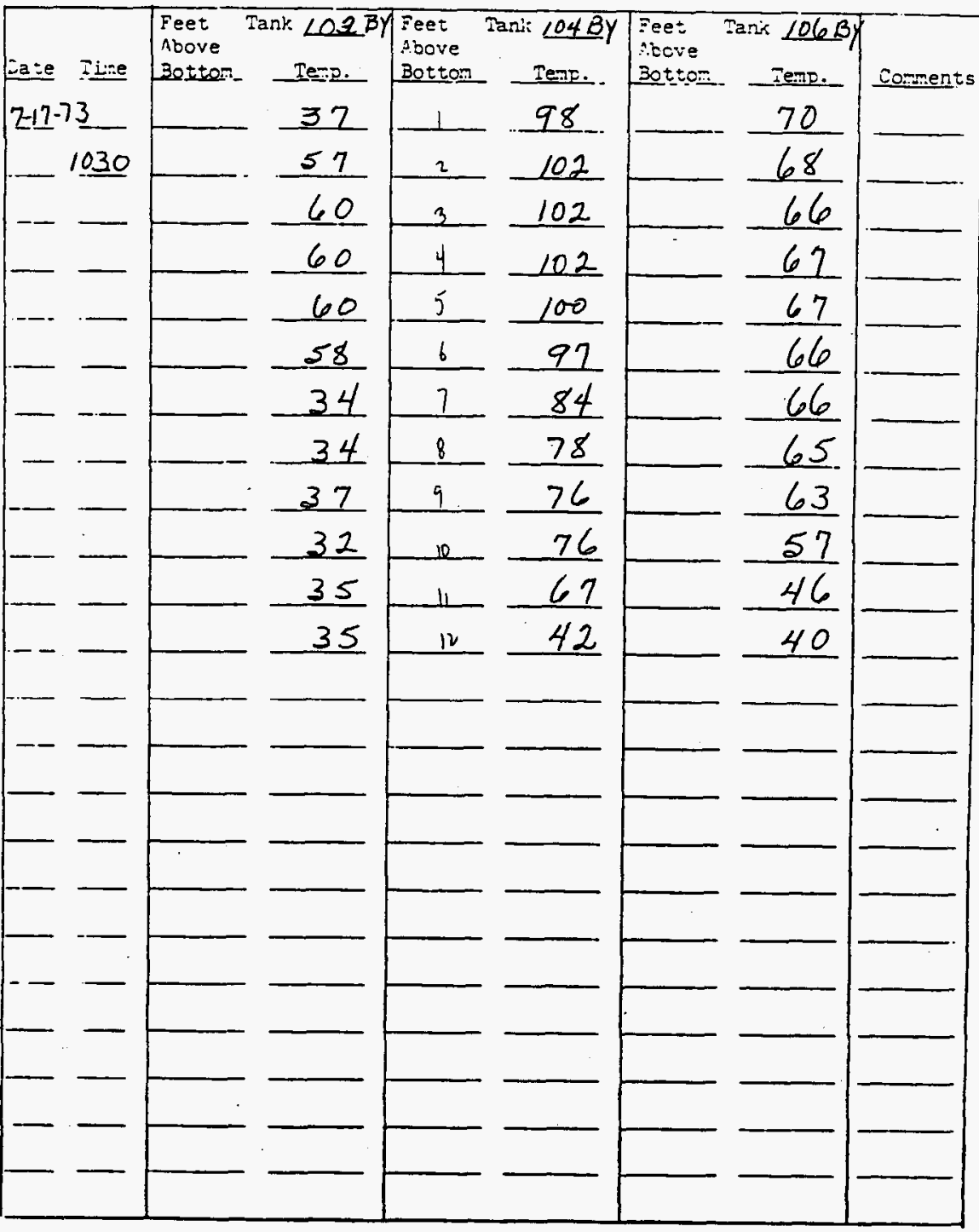

Injtr:stions is coments: - Take proflle temperetures weekly in each bottoms tank. Attach conpleted form to Monday and Thursday's Data Sheets. 


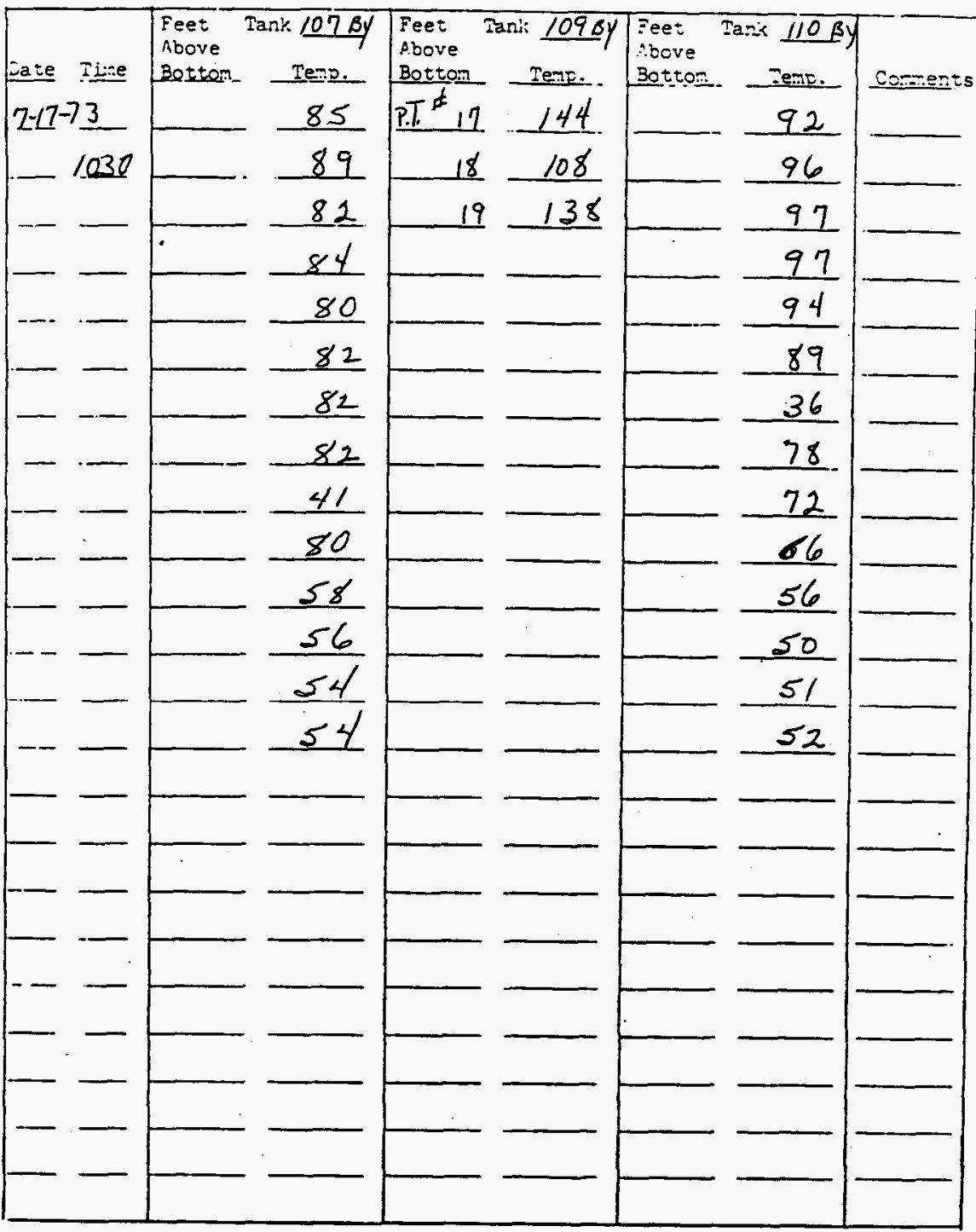

Ir3tr:0:fiss =r coments: - Take profile temperatures veekly in each bottoms tark. Attech completed forz to Monday and Thursday's Deta Sheets. 
Title: FROFILE TEIFERATURES I: ITS-2 BOTTOMS TAUKS

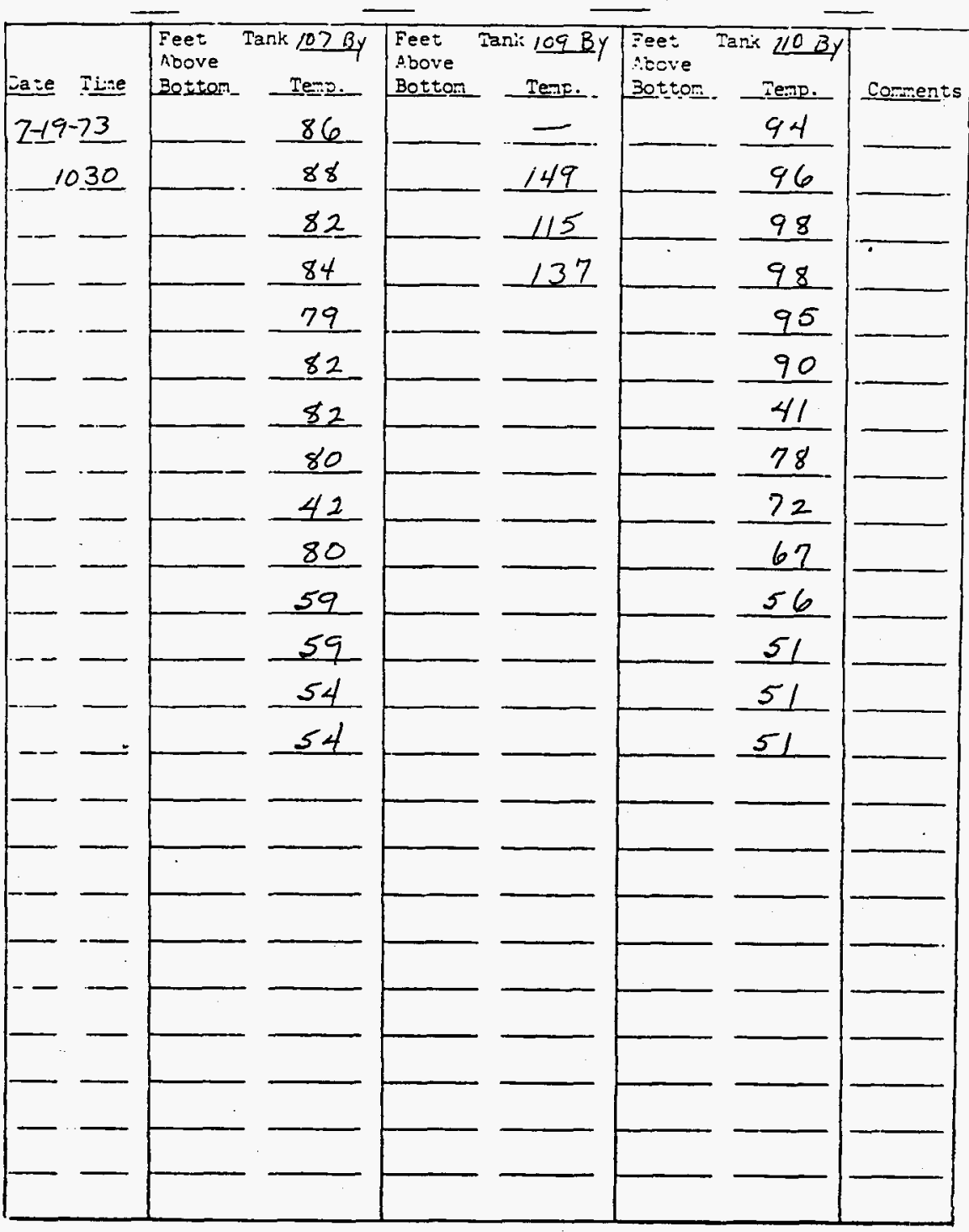

Insiratisns ar coments: - Take proflie temperatures weekly in mach bottoms 
Title: PROFILE TETERATURES IF IIS-2 BOTMONS FAMKS

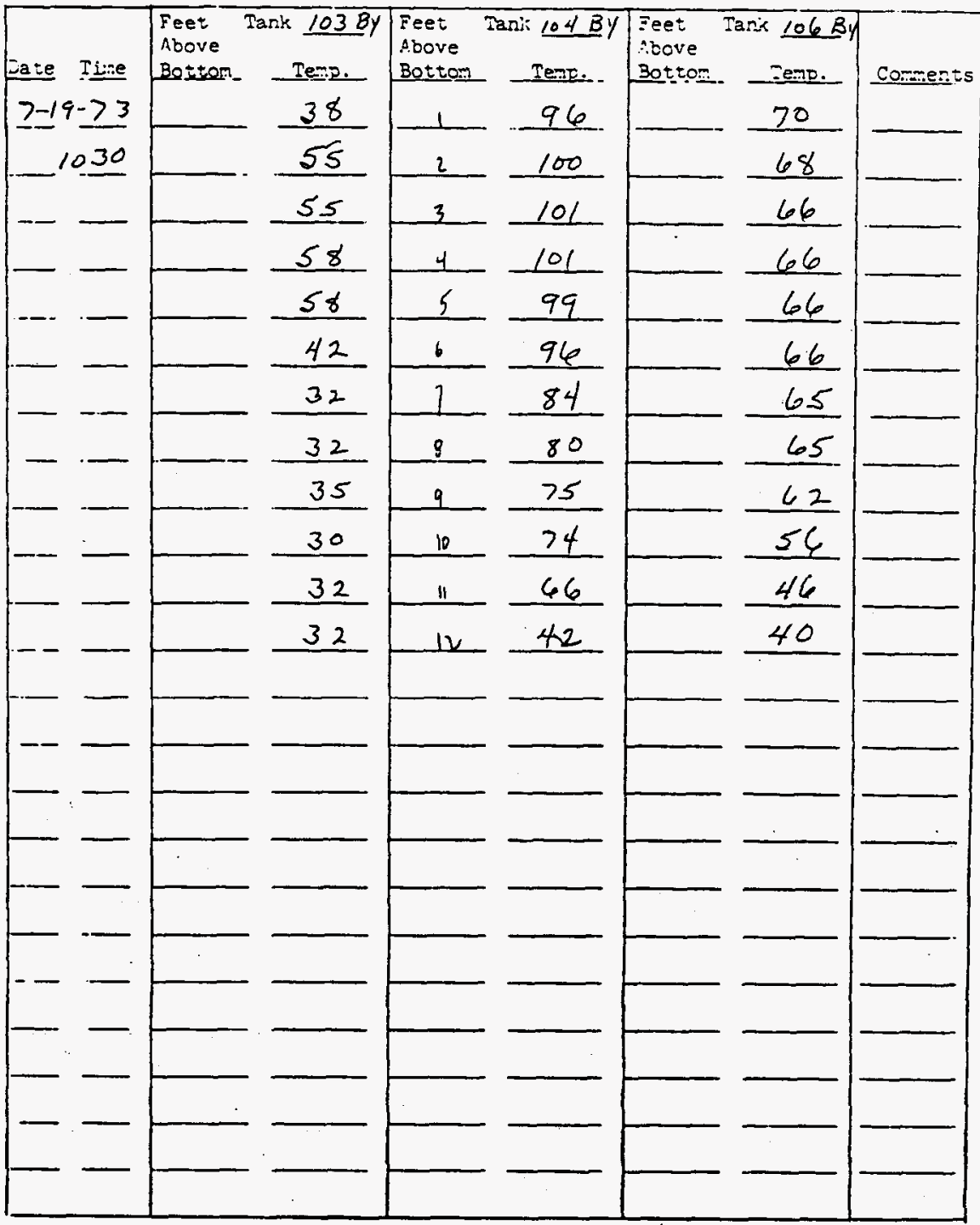

Instrations or conmenss: - Take profile temperatures veekly in each bottops. 
Title: FROFILE TEQFERATUGES I: ITS-2 BOTMOMS TANTS

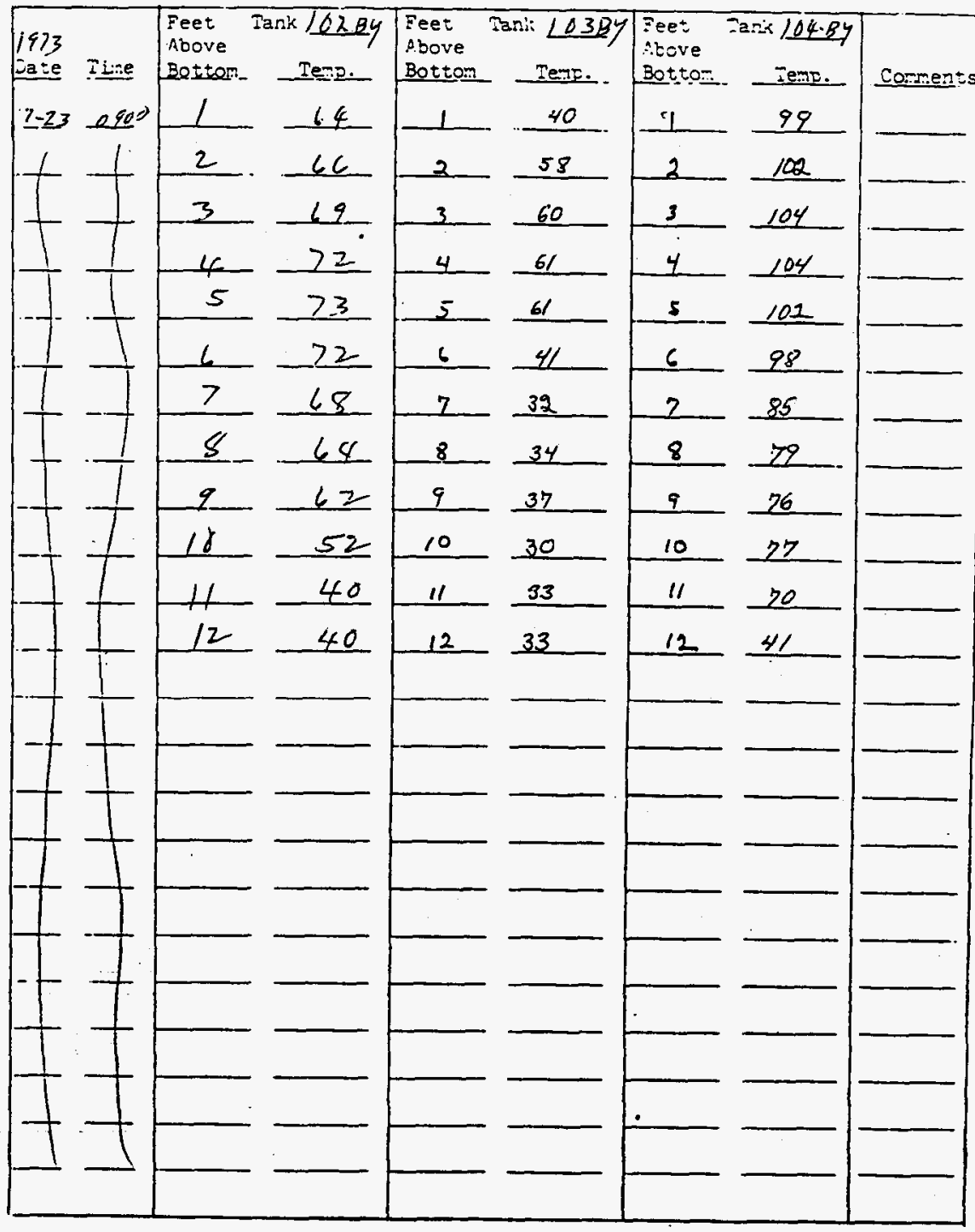

Instr:atisns ar comenss: - Take prof lle temperatures weckly in asch bottons. tank. Attach completed forg to Monday and Thursday's Data sheets. 
Title:

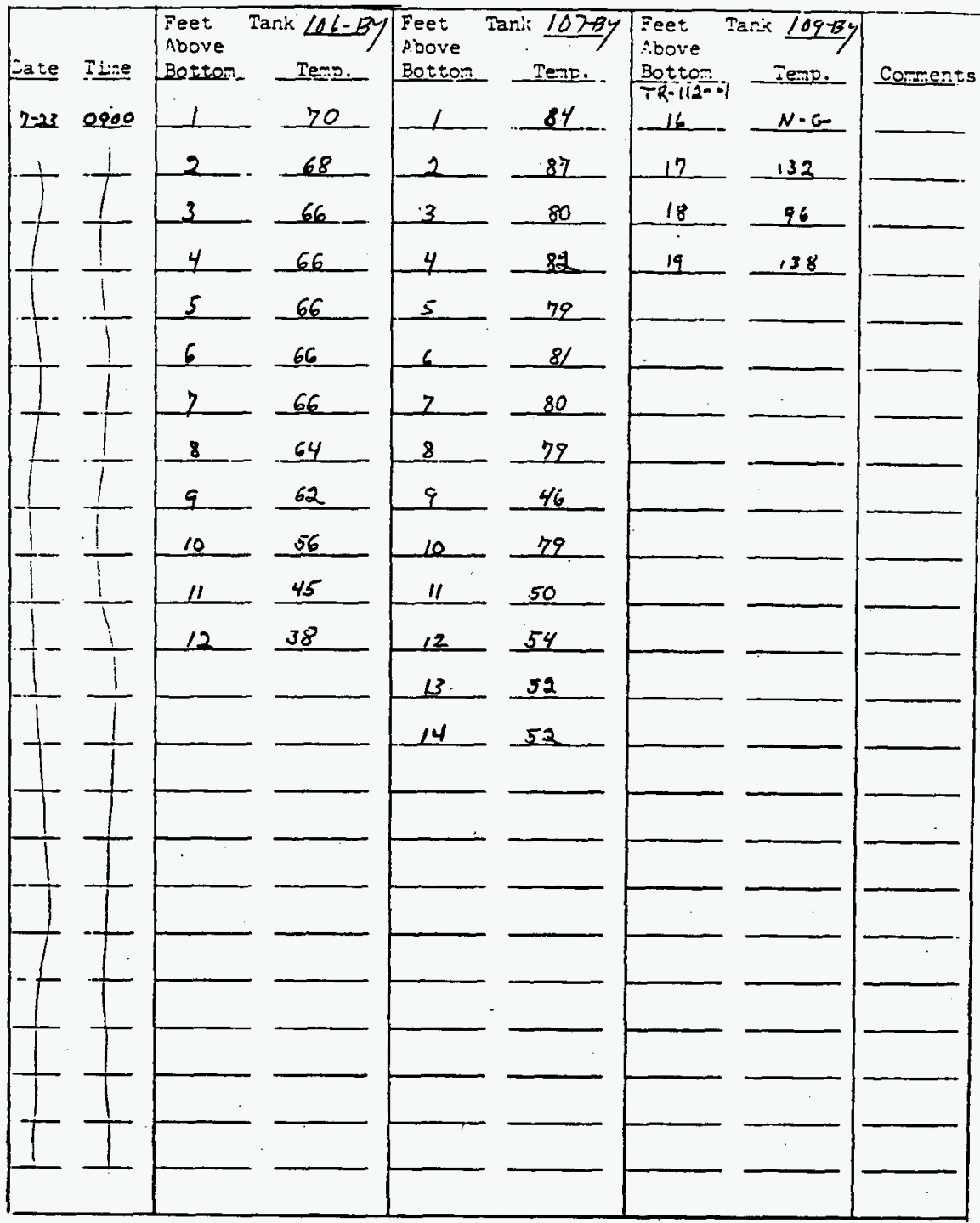

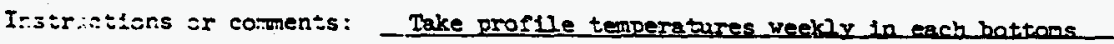
tank. Attach completed forn to Monday and Thursday's Data Sheets. 
Title: PROFILE TERERATURSS IV IIS-2 BOTTOMS TAIKS

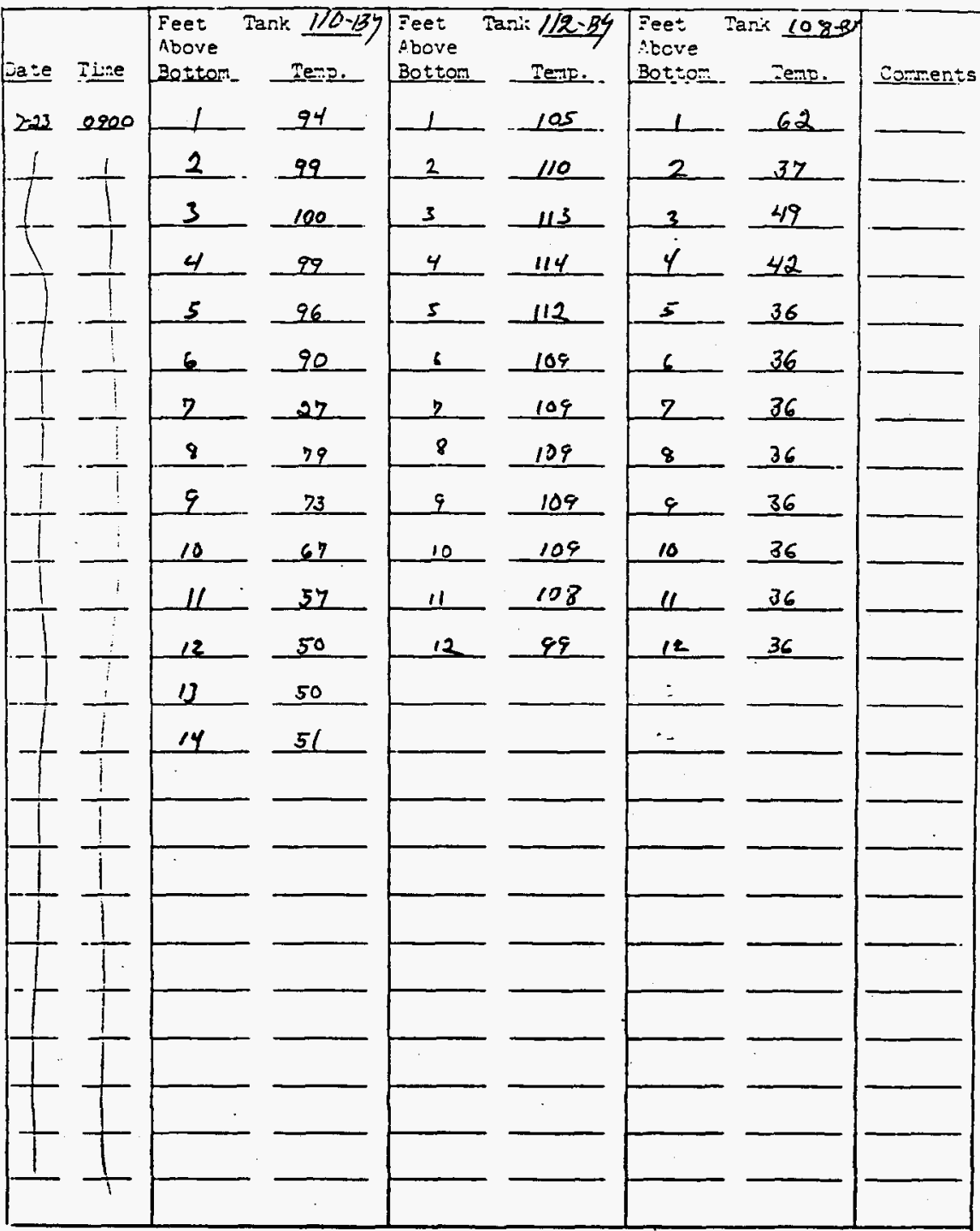

Irstr:stions or coments: Take profile temperatures weekly in pach bottoms terk. Attach conpleted form to Monday and Thursday's Data Sheets. 
Title: PROFILE TQPERATURES II ITS-2 BOTTOMS TAKTS

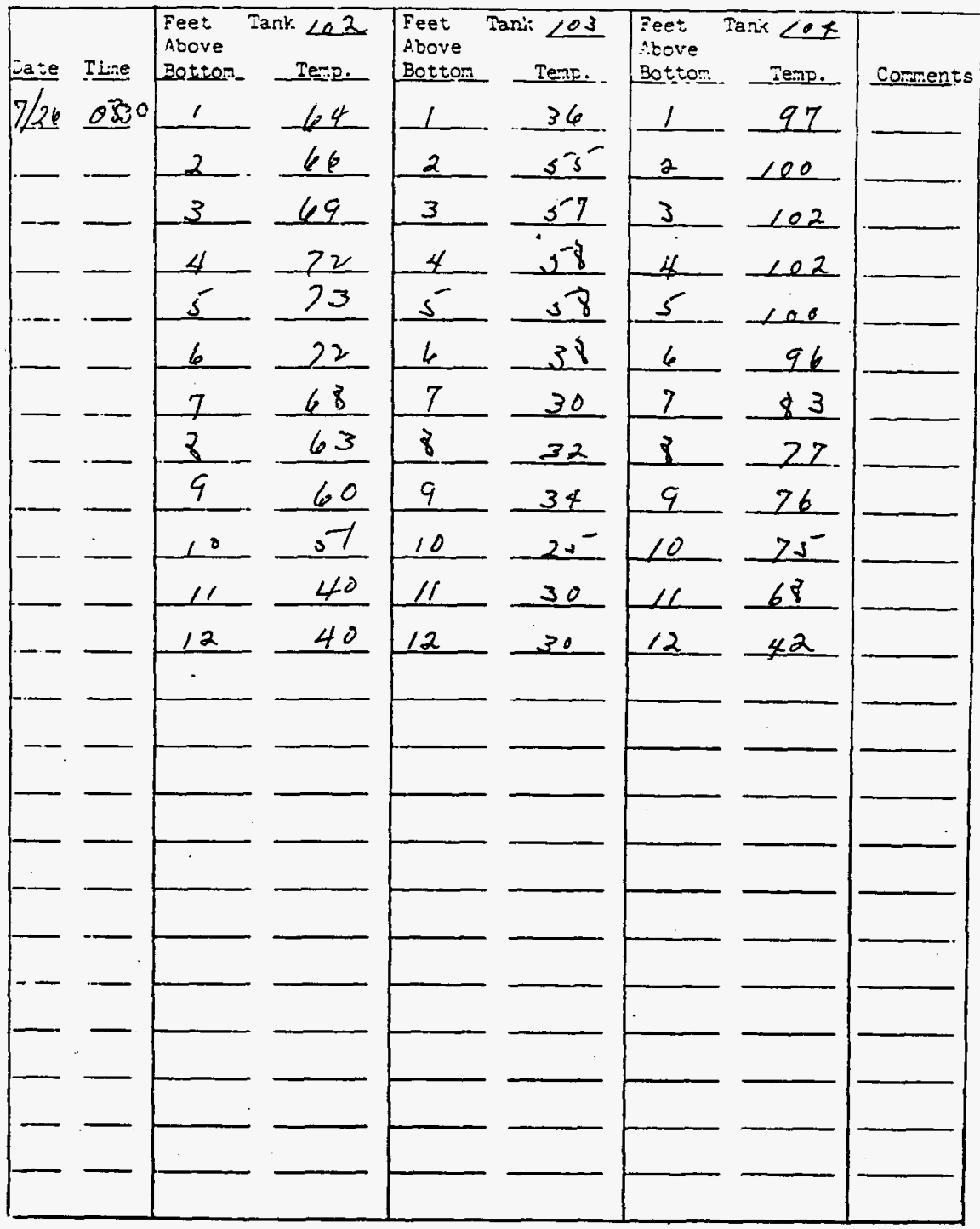

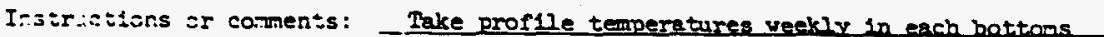


Title: PROFILE TERERAIURES I: IAS-2 EOTTOMS TAMKS

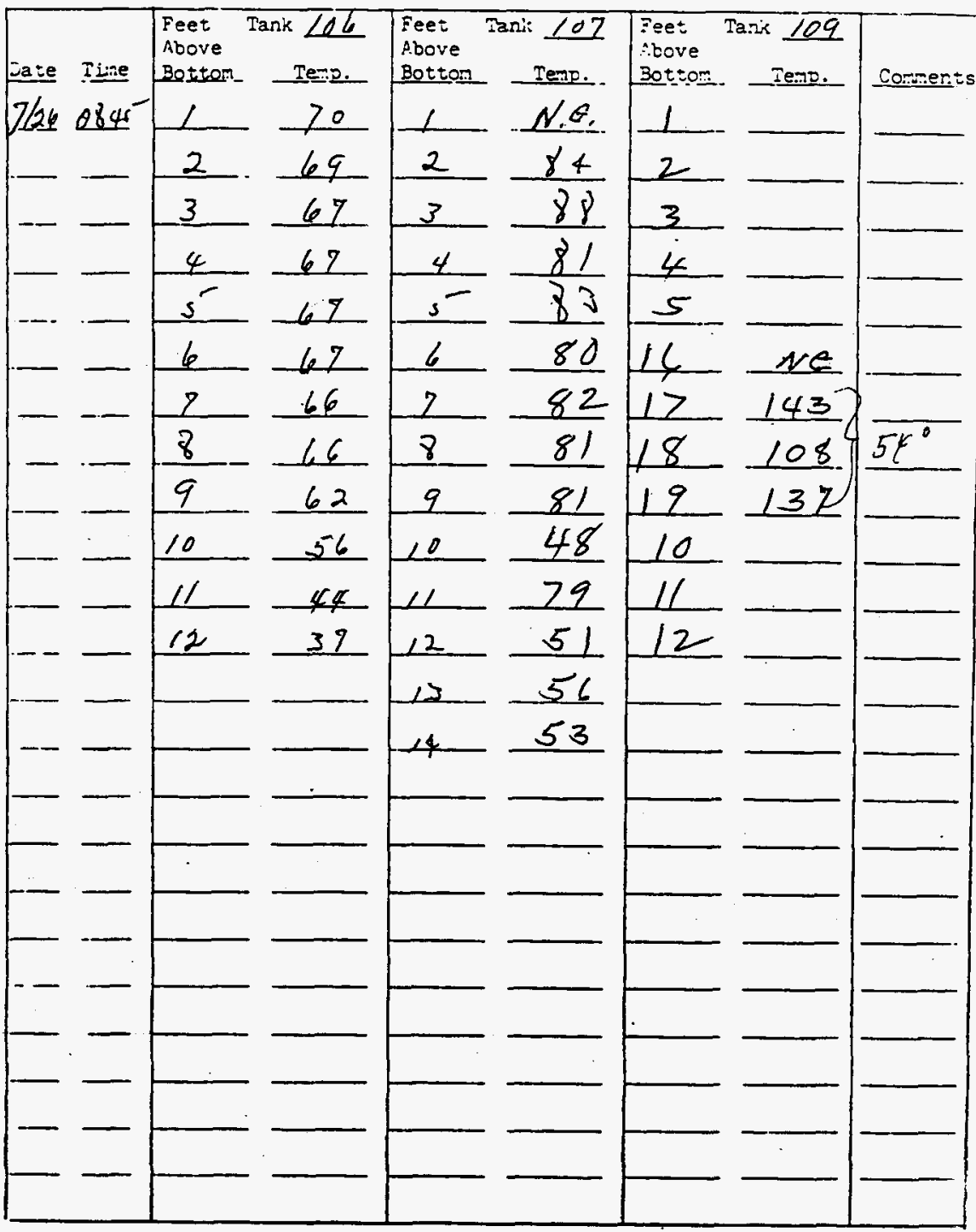

Insirisifins ir camens: - Bake profile temperatures weekly in each bottons 
Title: FROFILE TETERATURES II ITS-2 SOTTOMS IAITS

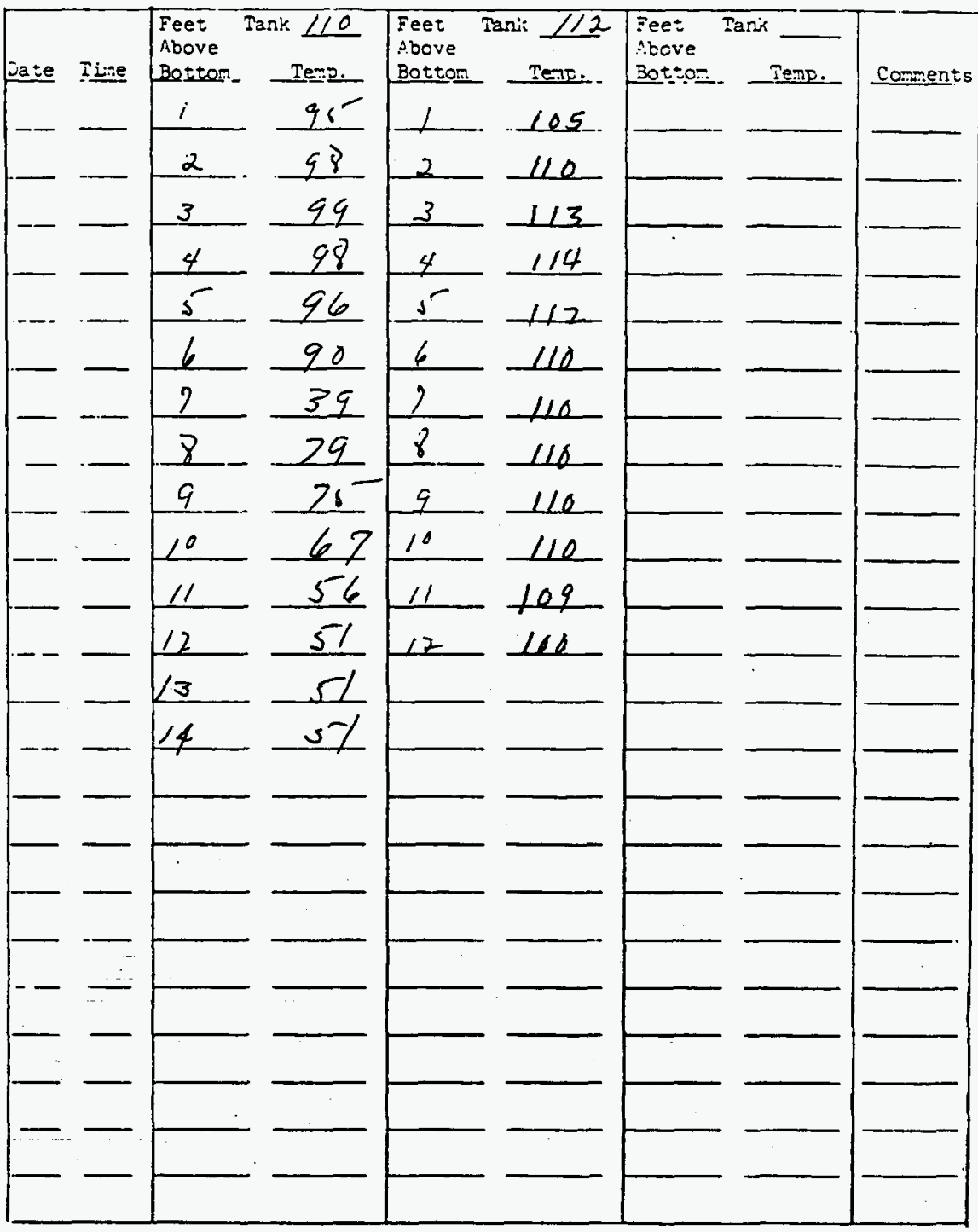

Ir:str:istons or coments: - Take profile temperstures weekly in each bottoms 
Title: PROFILE TEEERATURES IT ITS-2 BOTTOMS TANKS

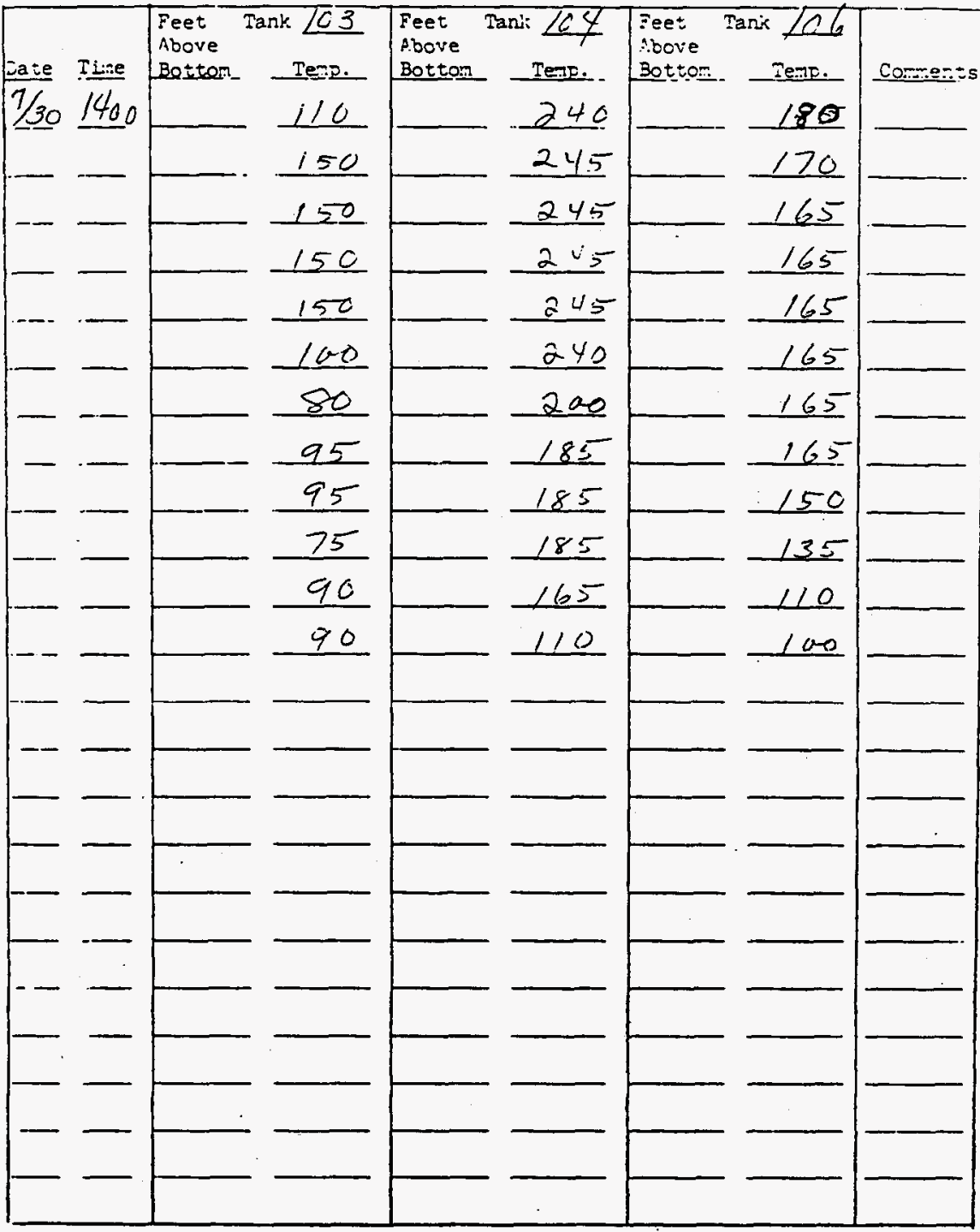

I:3:r:E:scr.s or comen:s: - Take proflle temperetures weekly in each battoms 
Title: PROFILE TEFERAIURES IV ITS-2 SOTIONS TAMTS

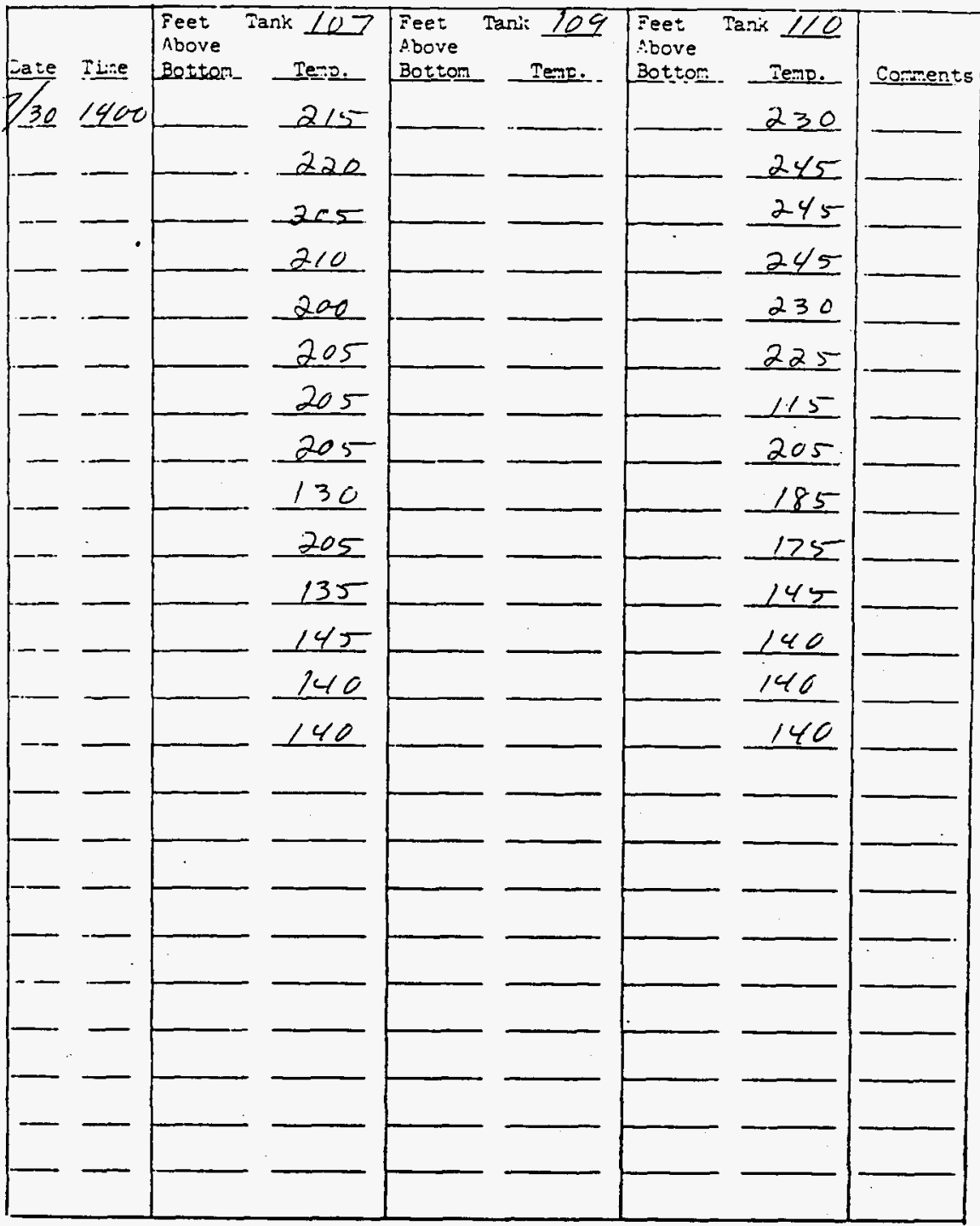

Instr:atlons ir coments: - Pake proflle temperatures veekly in each bottoms 
UHC-SD-LM-DPP 207 , Rev. 0

$$
8-4>8-6-73
$$

Title: PROFILE IDRERATURES II ITS-2 3OTTOMS TATTS

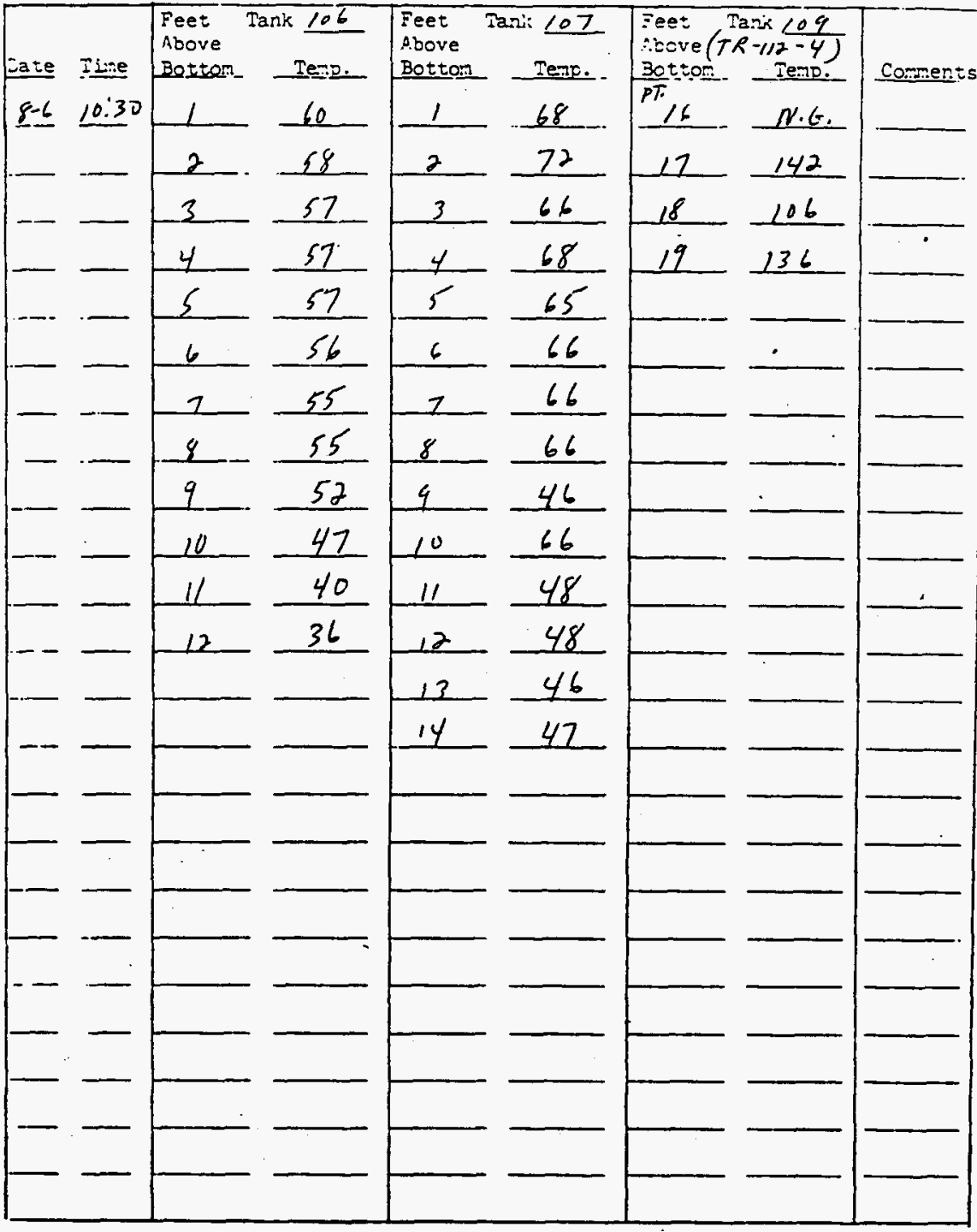

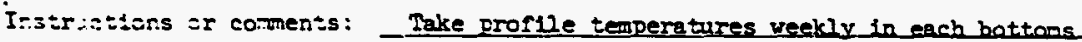


LHC-SD-LM-DPP-207, Ŕev. O

Title: PROFILE TDPERATURES IN ITS-2 3OMOMS TAUKS

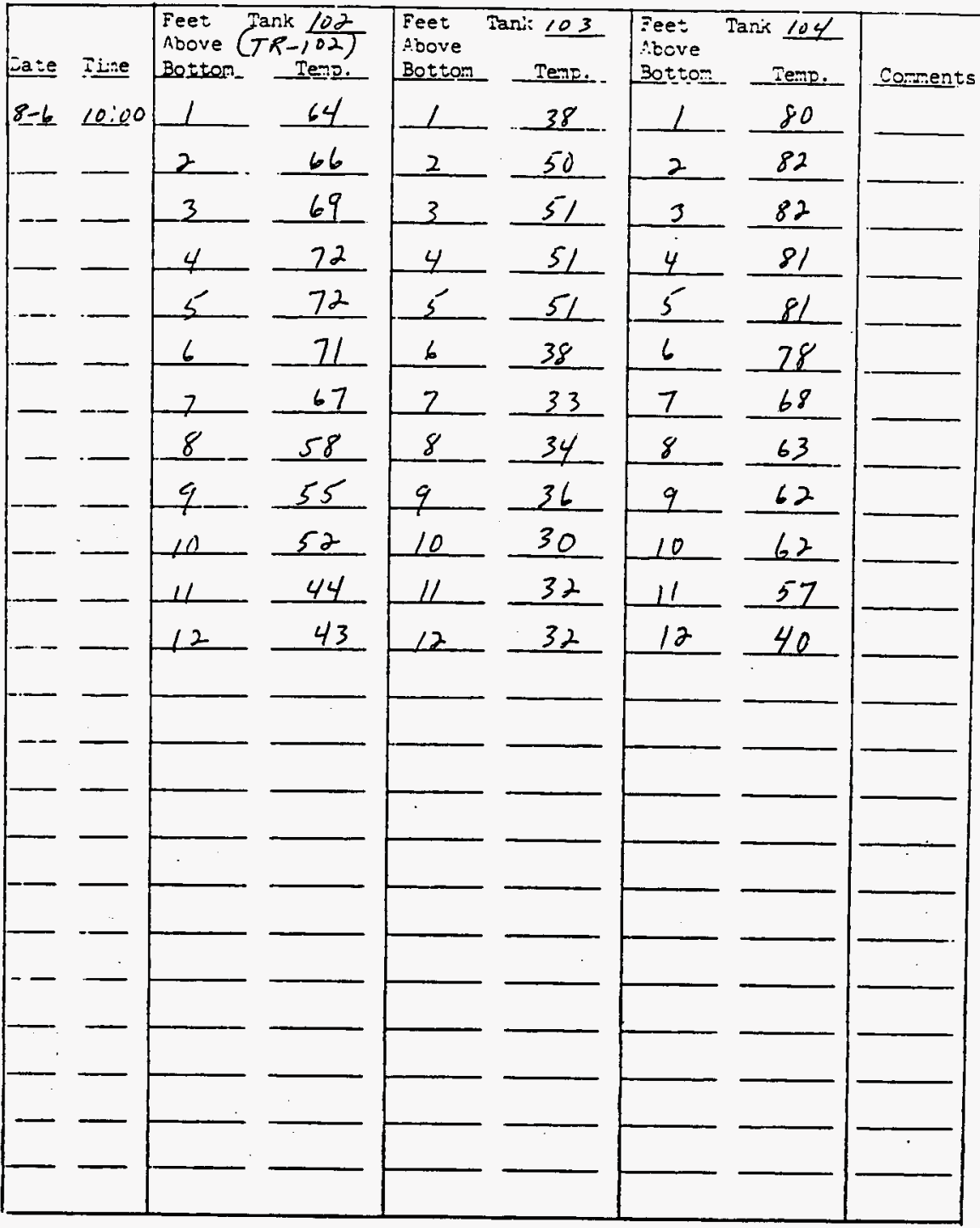

I:str:zisons ir caments: - Take Fror1le temperatures reekly in each bottoms. 


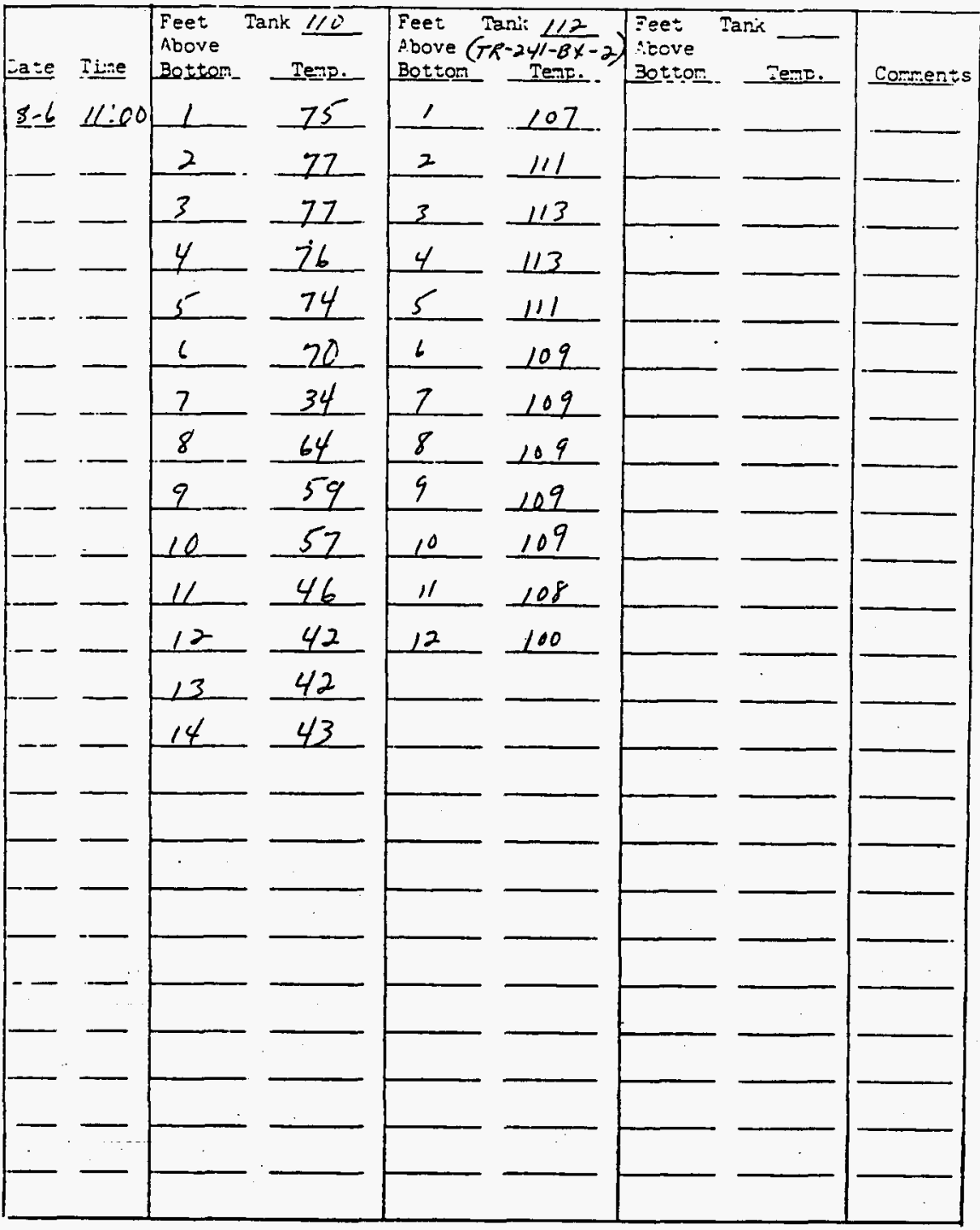

Instristions ir coments: - Take proflle temperatures veekly in each bottoms 
Title:

PROFIIE TZIPERATURES II ITS-2 BOTTONS TAUKS

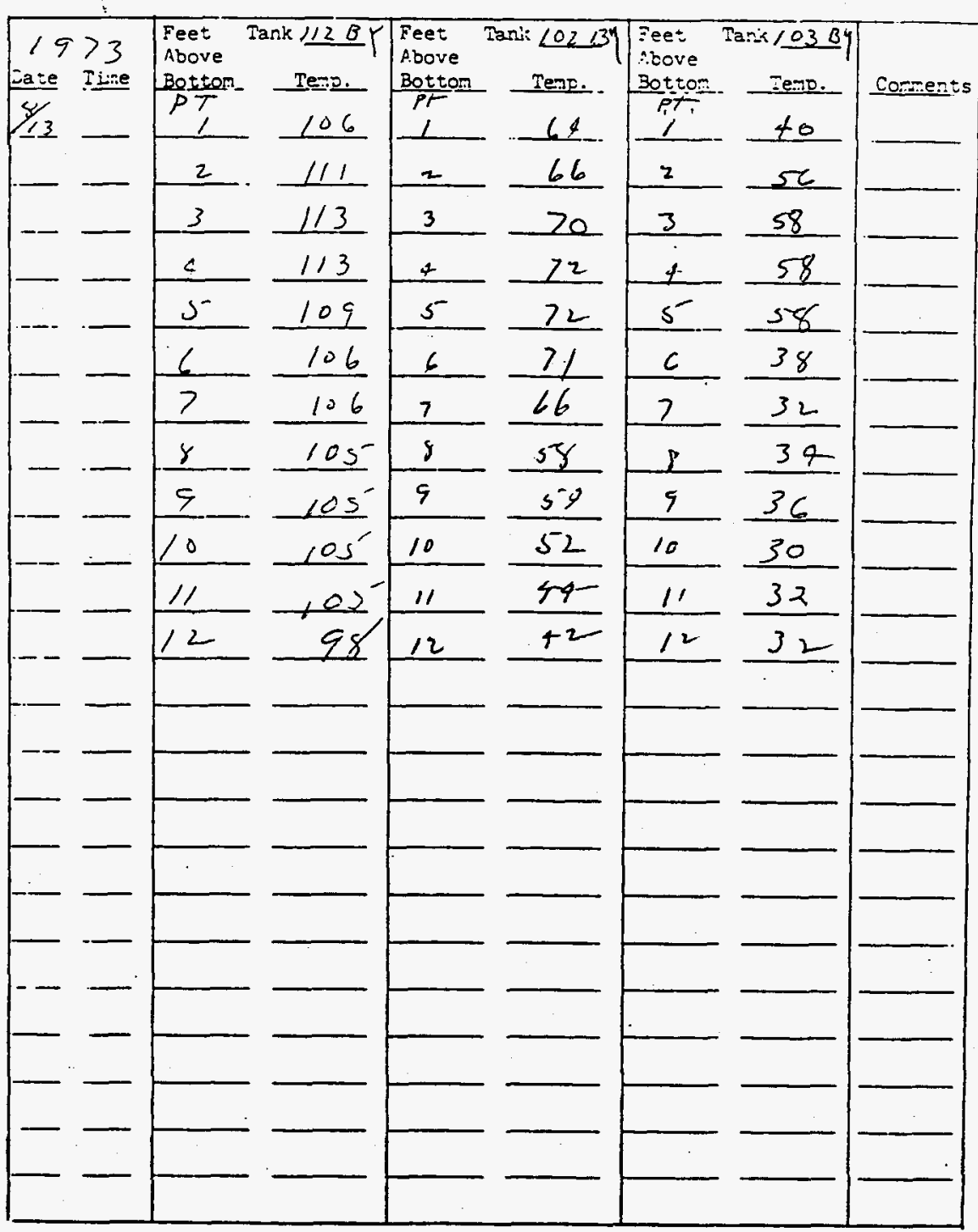

Ir3:r.:itions =r comen=s: - Take profile temperatures reekly in each bottons tank. Attach conpleted forn to Monday and Thursday's Data Sheets. 
Title: PROFILE TEPERATURES II ITS-2 BOTIOMS FAHKS

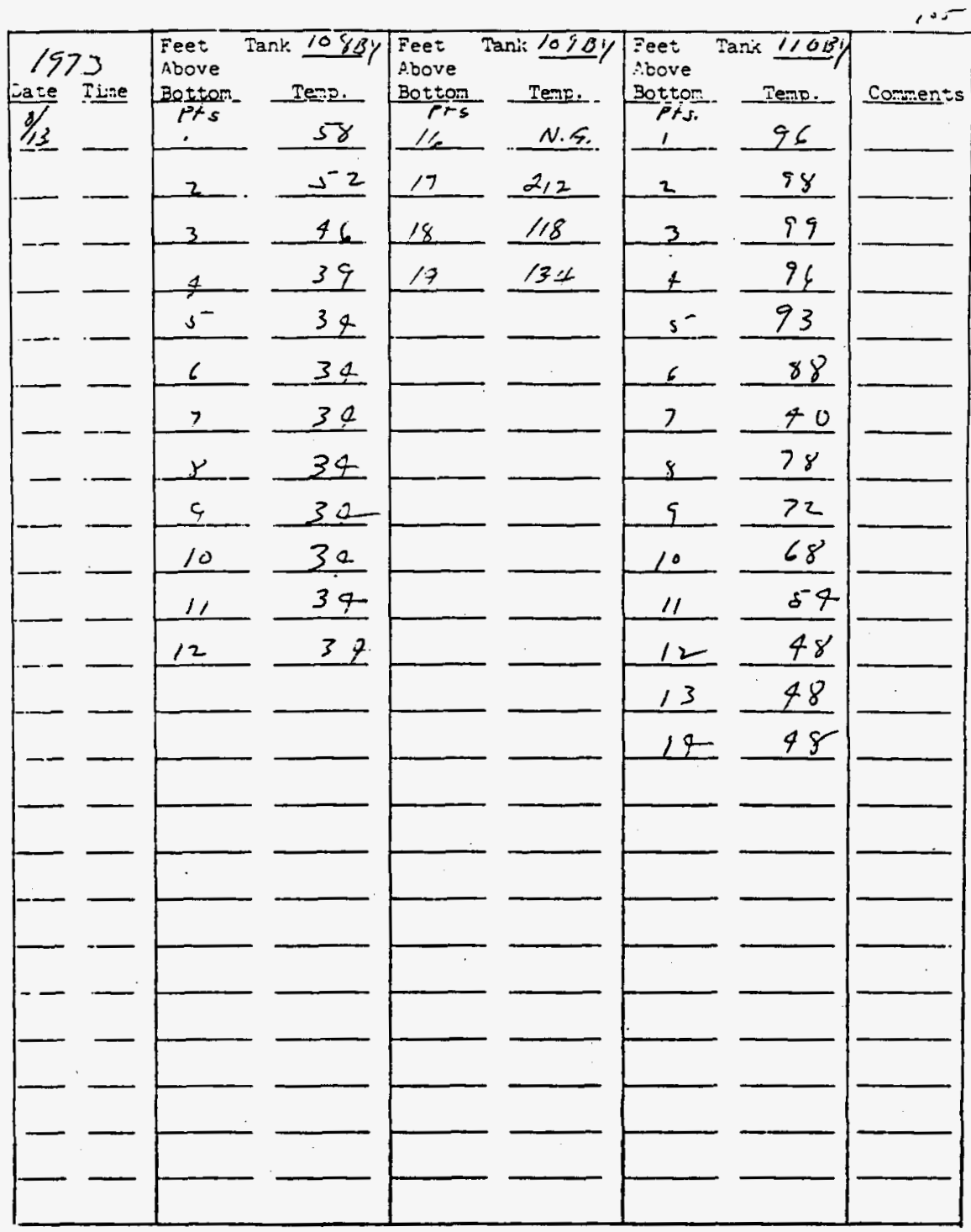

I:35r:ations ar caments: - Take profile temperatures weekly in each bottons tank. Attach completed forg to Monday and Thursday's Dats Sheets. 
Title:

PROFILE TEFERATURES IE: ITS-2 BOTROMS TAITS

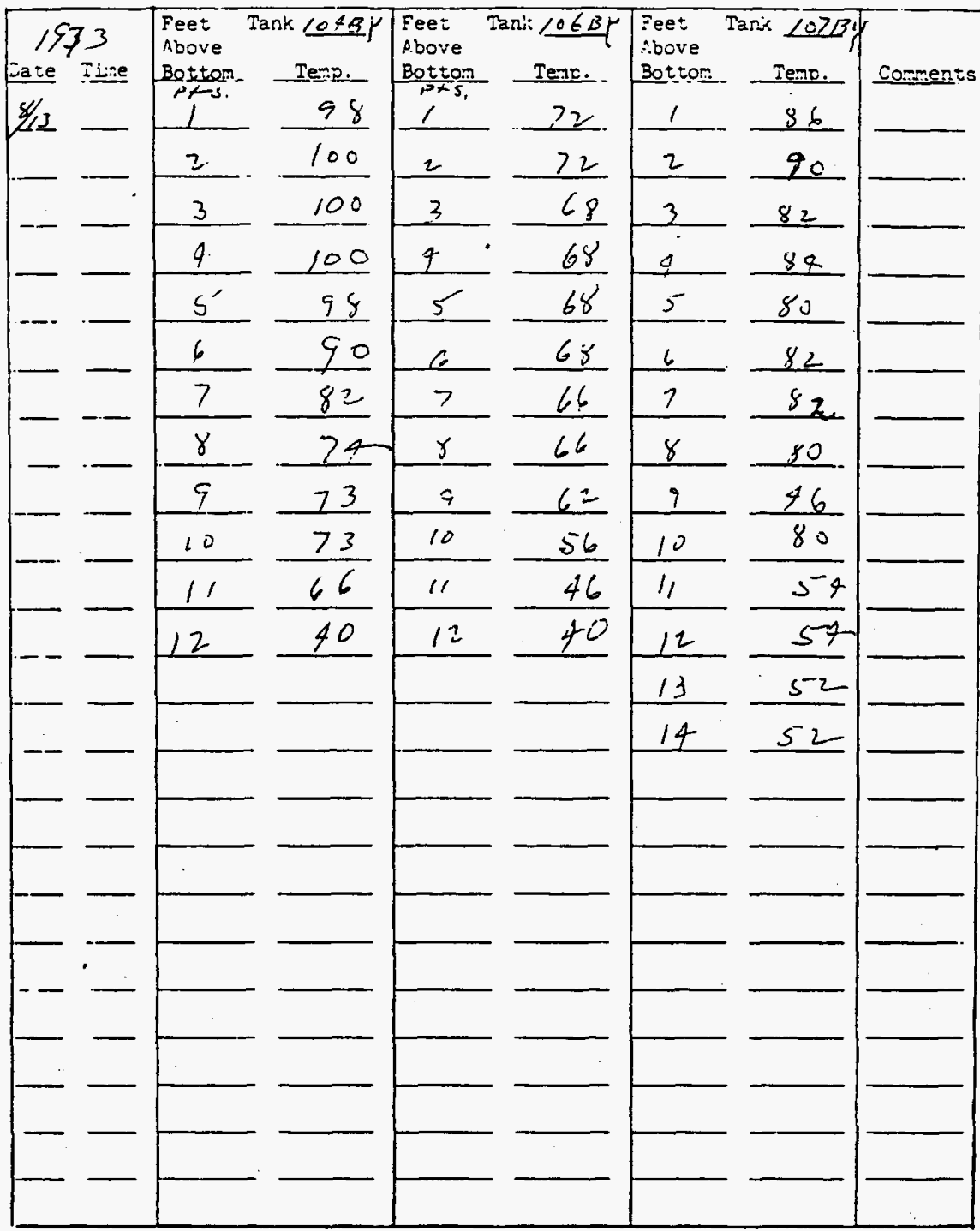

Irstr:stisns ar caments: - Thke Fror lle temperatures veekly in each bottoms tank. Attach conpleted for to Monday and Thursday's Data Sheets. 
Iitle: PROFILE TEPERATURES IF ITS-2 BOTTOMS TANKS

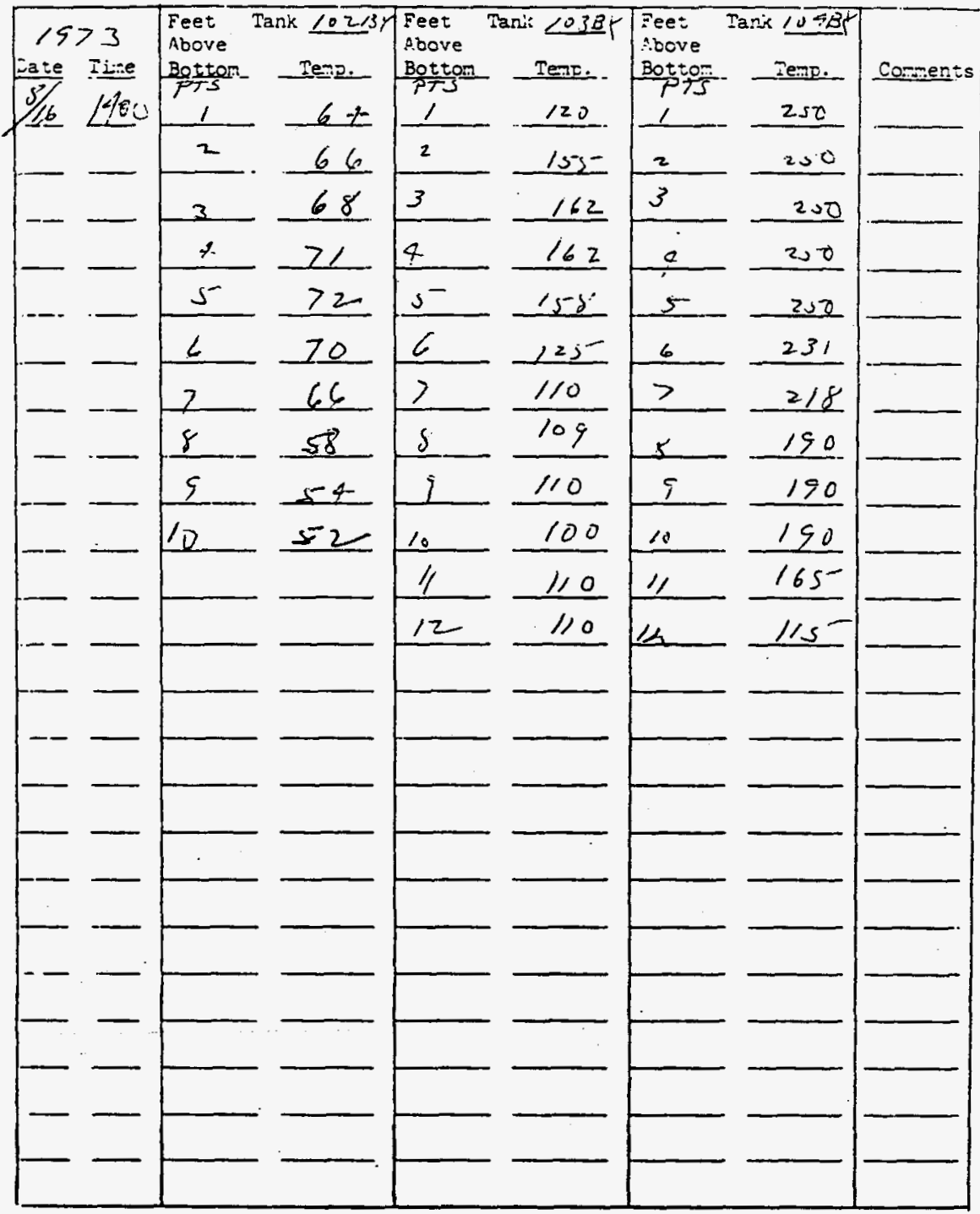

Instr:=isos ar conents: - Take proflle temperatures yeekly in each bottons tank. Attach completed form to Monday and Thursday's Dato Sheets. 
Title:

PROFILE TEPERATURES Li ITS-2 BOTMONS TANKS

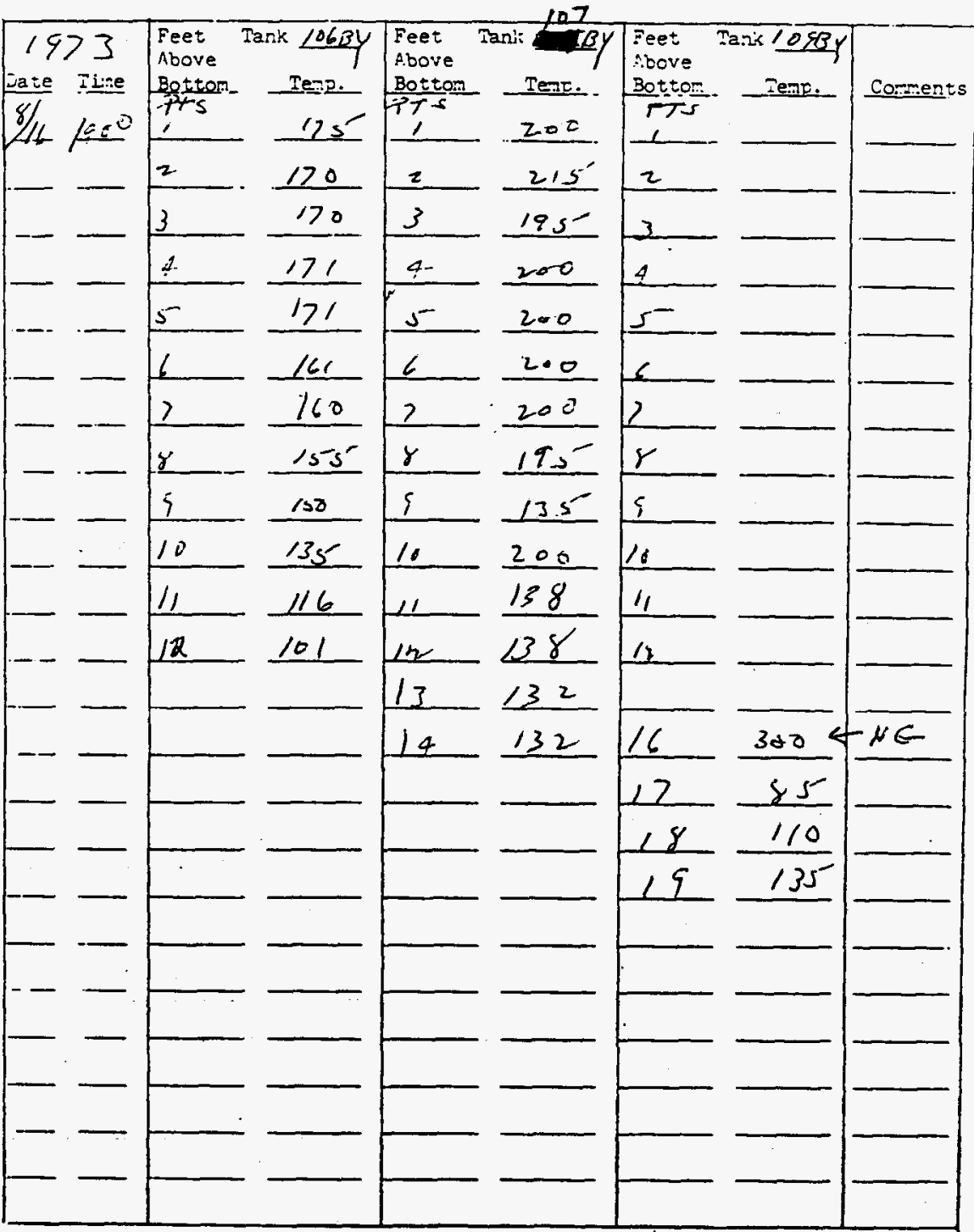

Insiris:ions ir comen's: - Take proflle temperatures weekly in each bottoms tank. Attach completed form to Monday and Thursday's Data Sheets. 
Title:

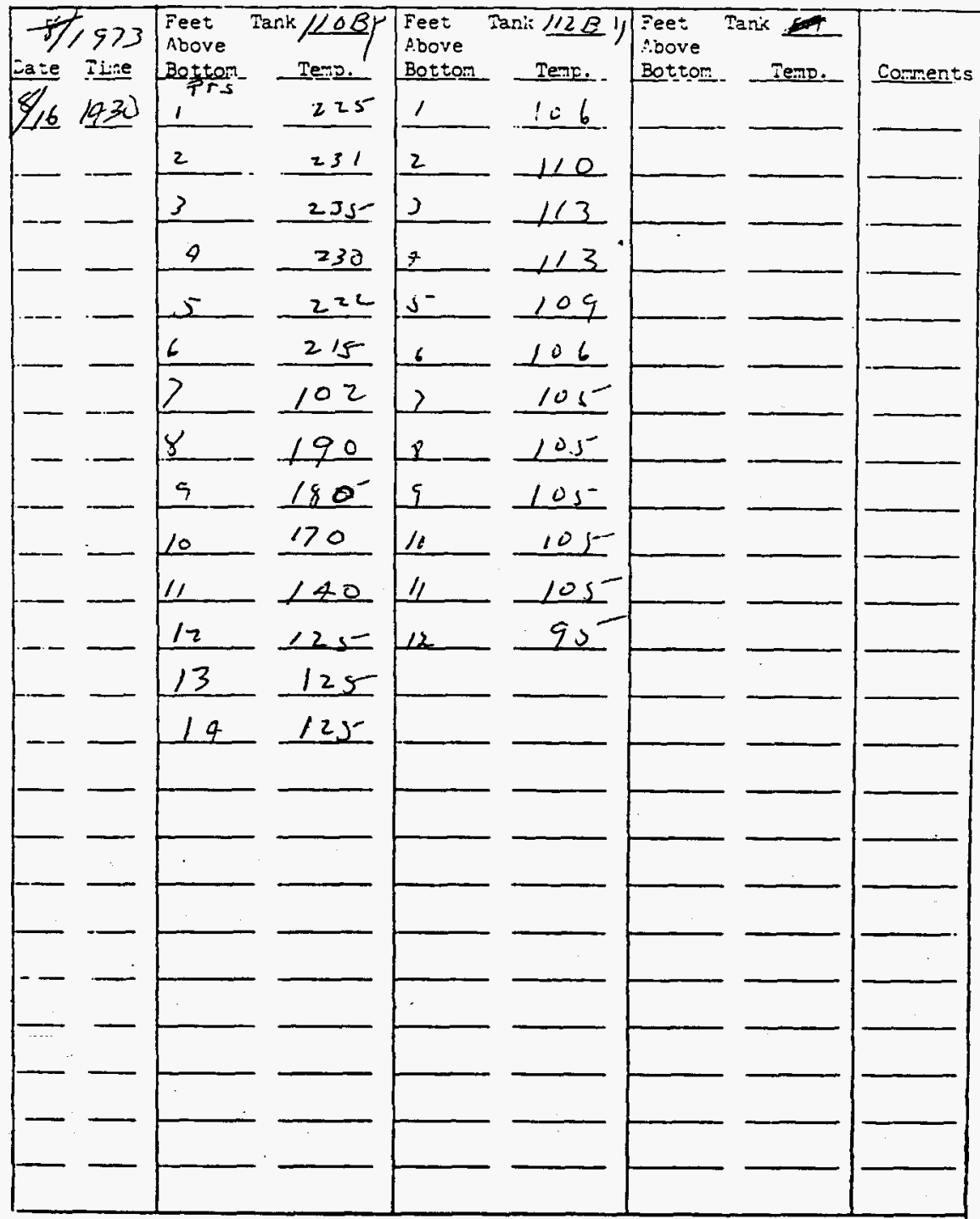

Instr:stisns =r coments: - Take proflle temperatures veekly in each bottons tank. Attach completed form to Monday and Thursday's Dats Sheets. 
Title: PROEILE TERERATURES IN ITS-2 BOTTONS IATKS

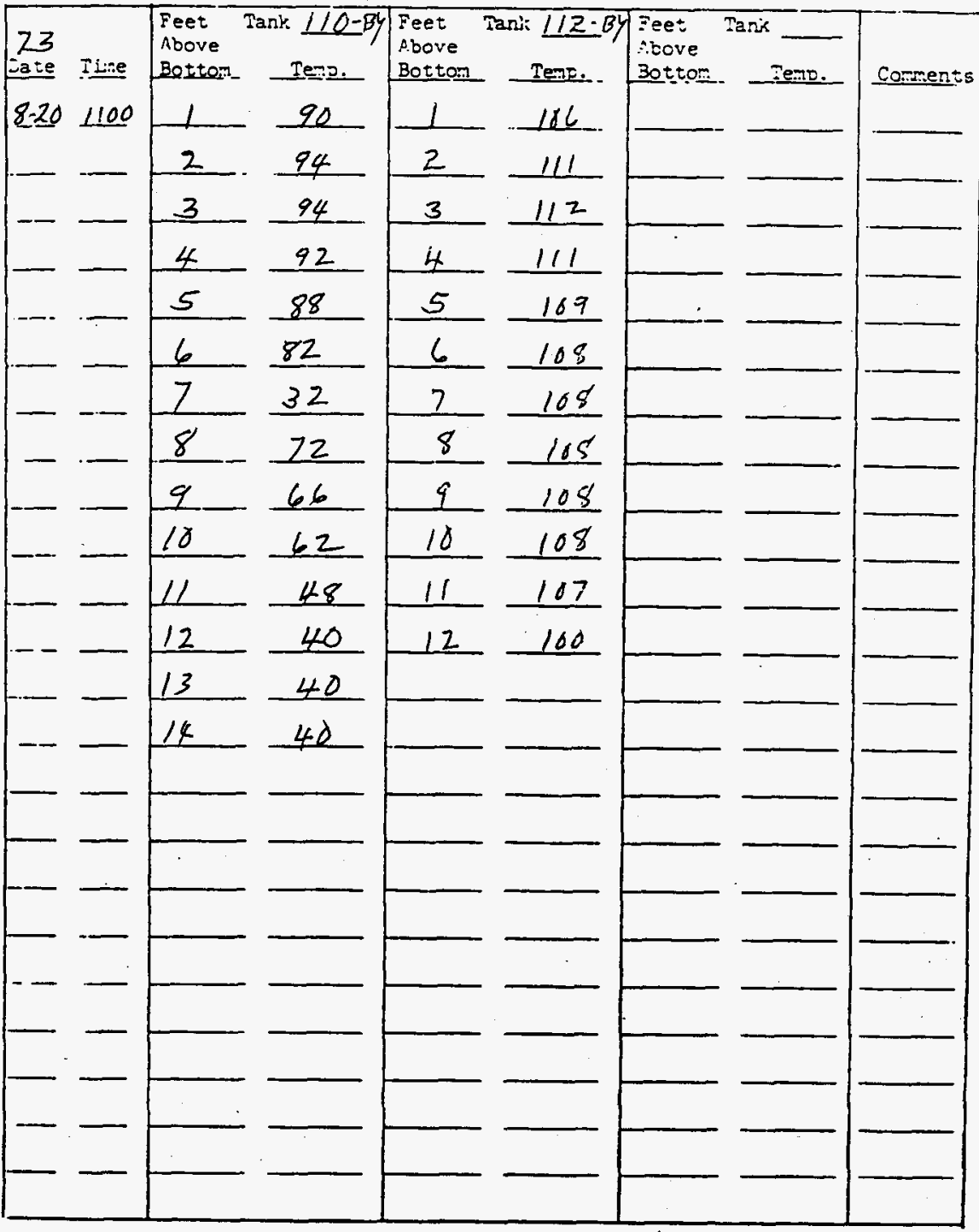

Instr:otions or coments: - Take grorlle temperatures weekly in each bottoms tank. Attach completed form to Monday and Thuxsday's Dats Sheets. 
Title:

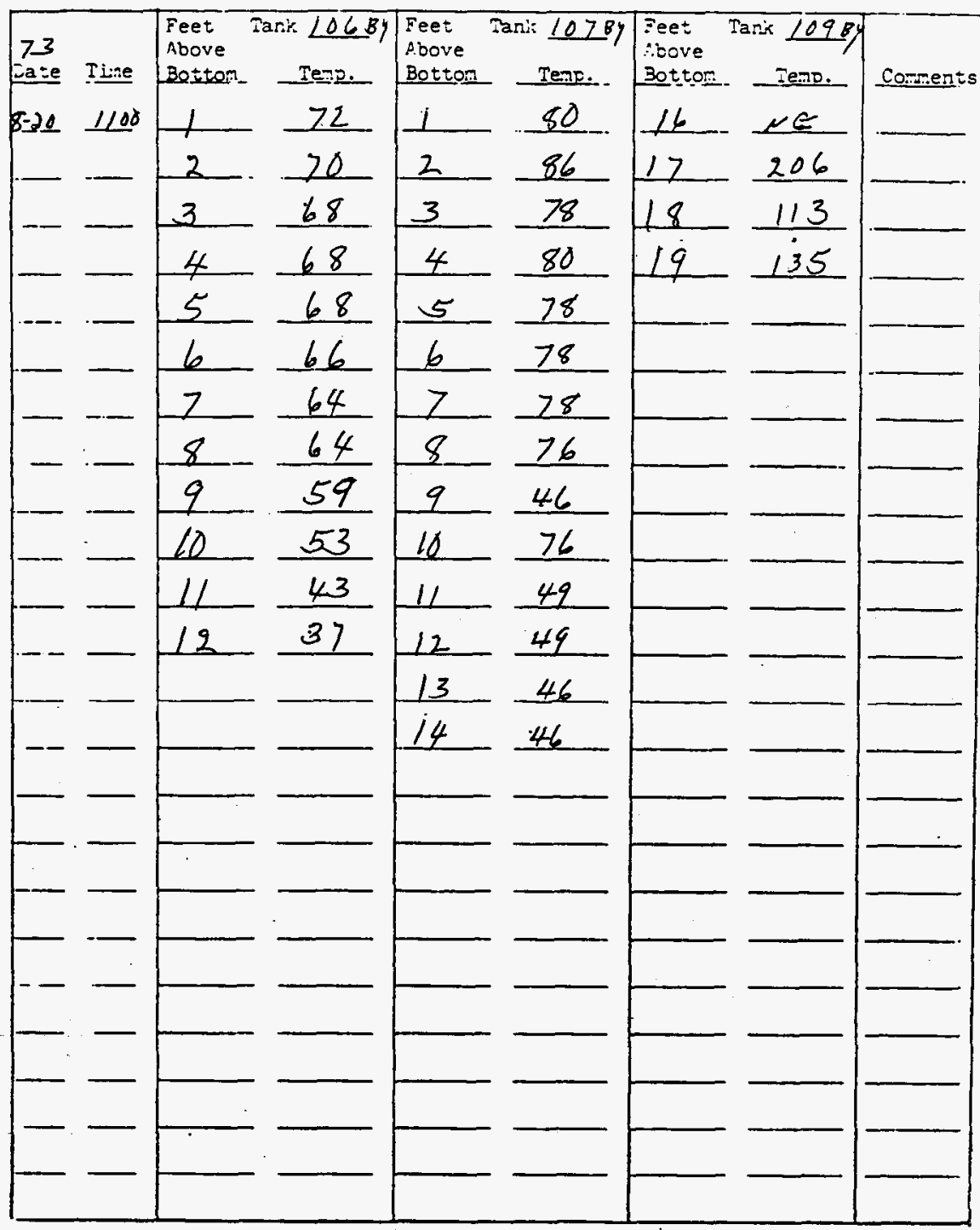

Instr:sitsrs or coments: - Take profile temperetures veekly in each battoms tank. Attach conpleted for to Monday and Thursday's Data Sheets. 
Title: FROFILE TERERATURES IN ITS-2 BOTTOMS TAMTS

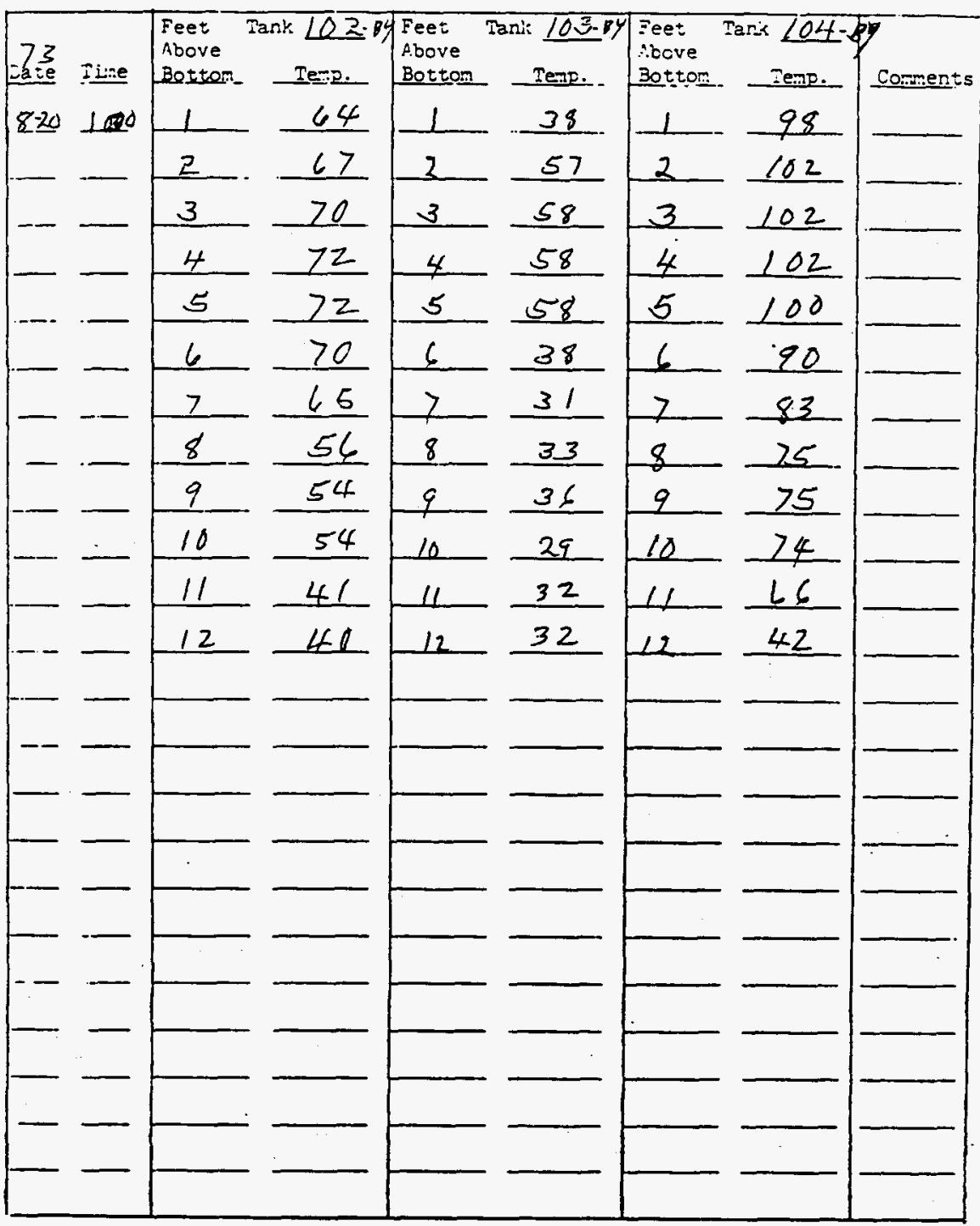

Instristises ir coments: - Take grofile temperatures yeekly in each hattoms tank. Attach conpleted forg to Monday and Thursday's Data sheets. 
Title:

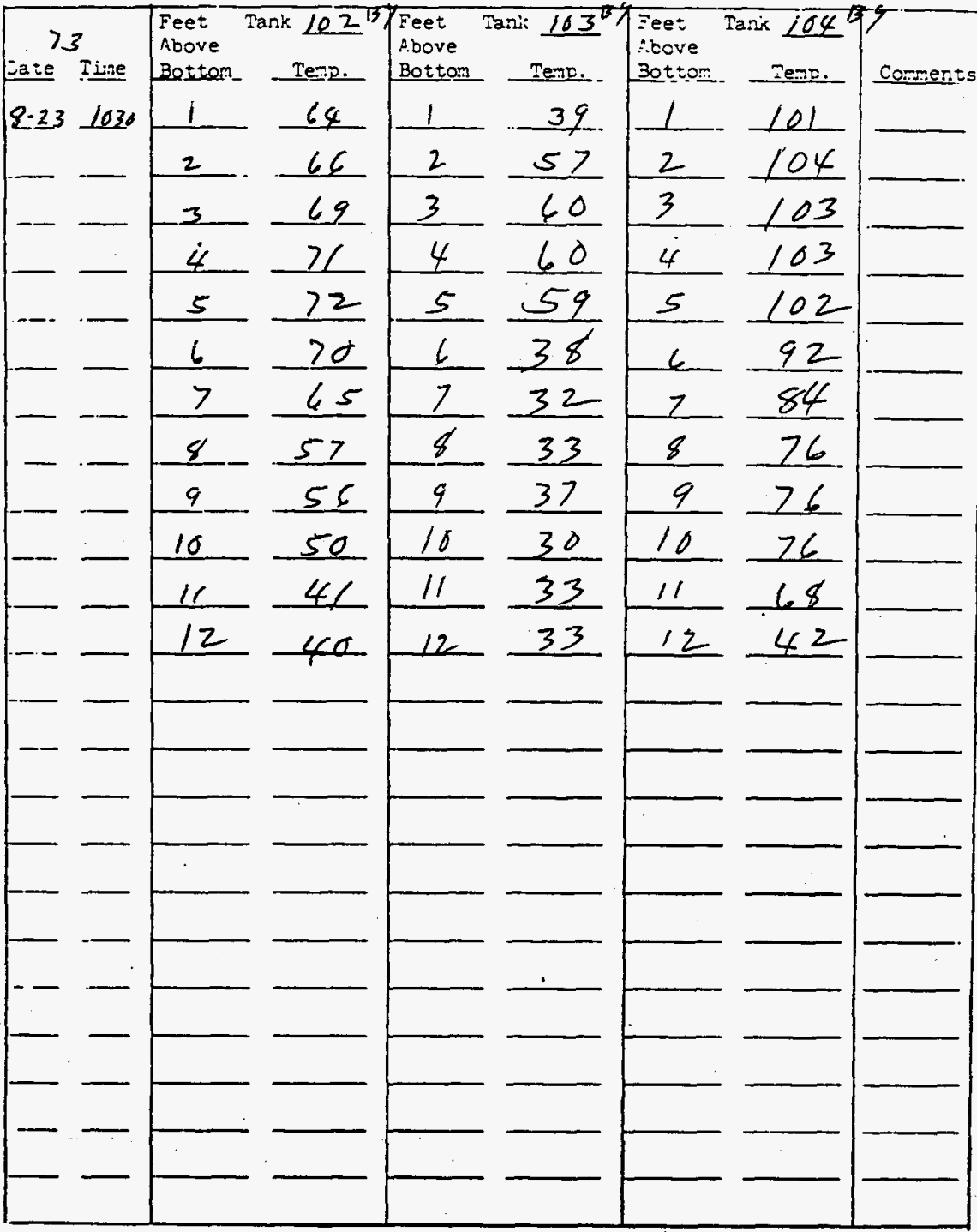

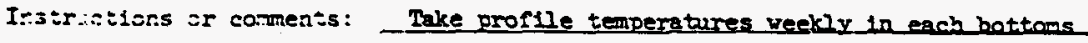
tank. Attech conpleted form to Monday and Thursday's Data sheets. 
Title: FROFILE TEPERATURES IF ITS-2 30TMOMS TATKS

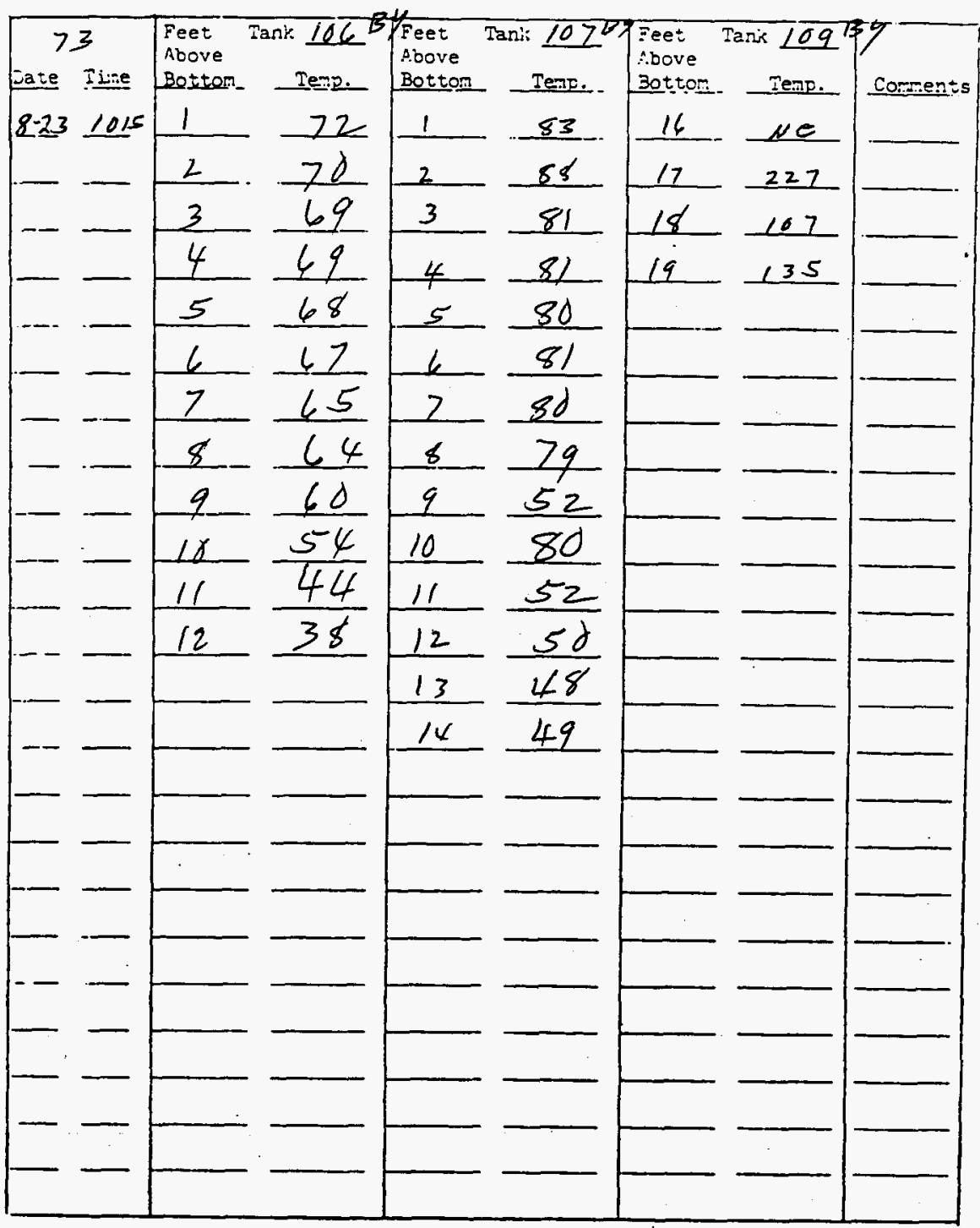

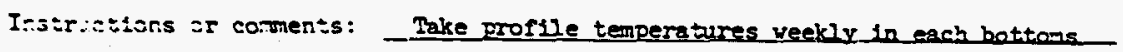
tank. Attach corpleted form to Monday and Thursday's Data Sheets. 
Title: PROFILE TERTERATURES IV ITS-2 ECTTOMS TAMRS

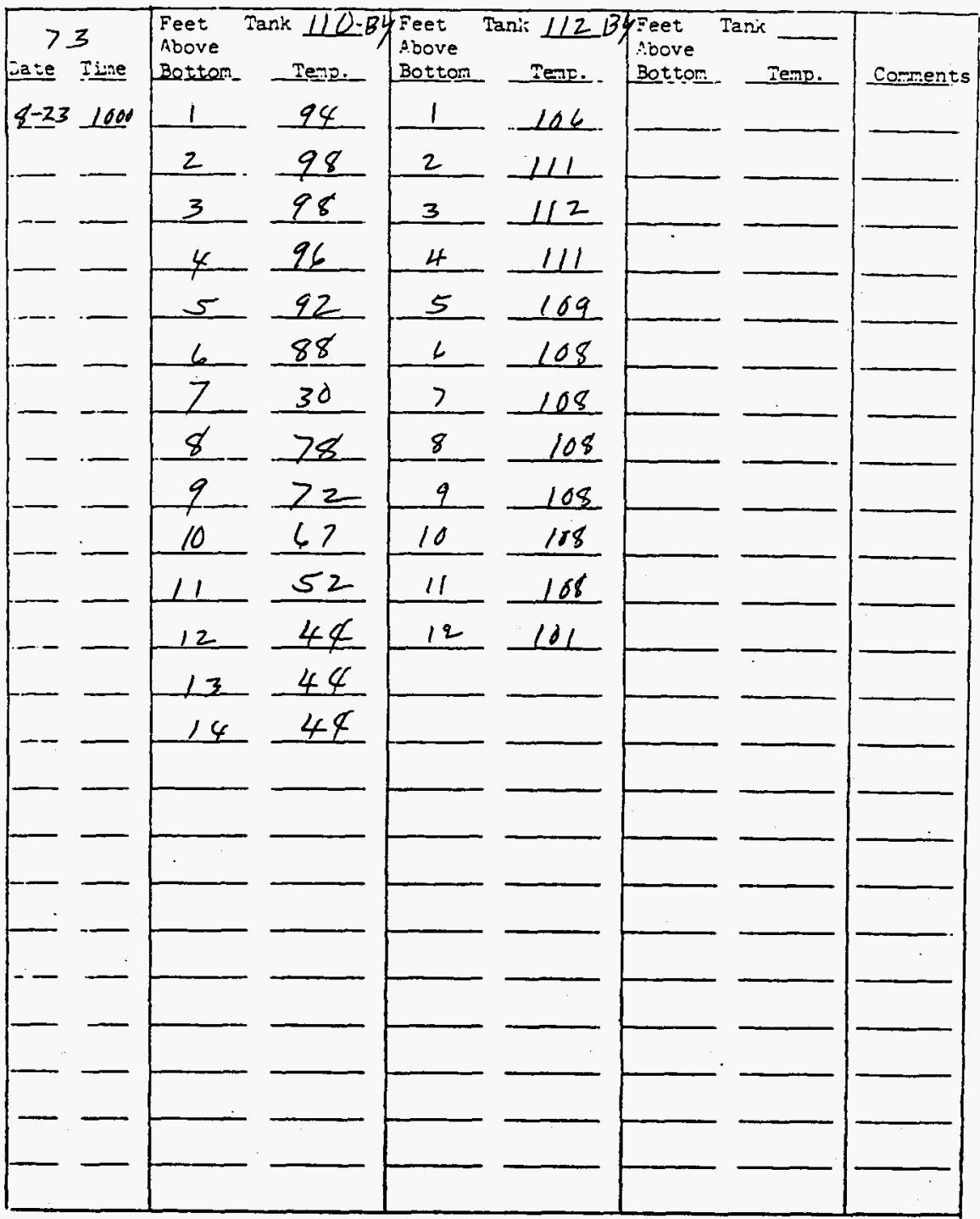

Instr:stians =r coments: - Thke pror1le temperatures veekly in each hottoms tank. Attech completed form to Monday and Thursday's Data Sheats. 
Title: PROFILE TEEERATUEES IF ITS-2 BOTTONS TAKS

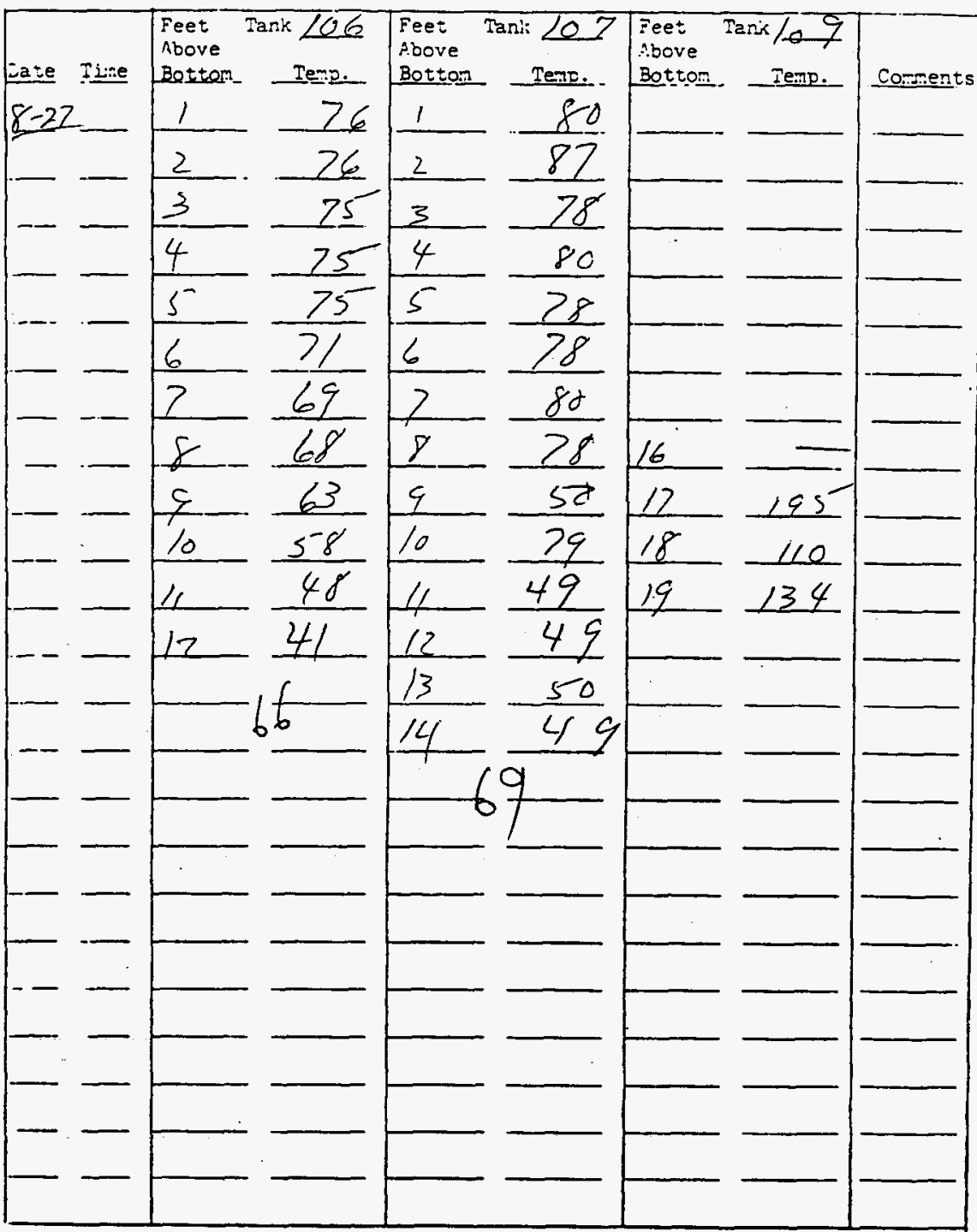

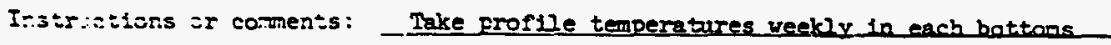
tank. Attach conpleted form to Monday and Thursday's Data Sheats. 
Title: PROFILE TEPERAIURES II ITS-2 3OTTONS TARKS

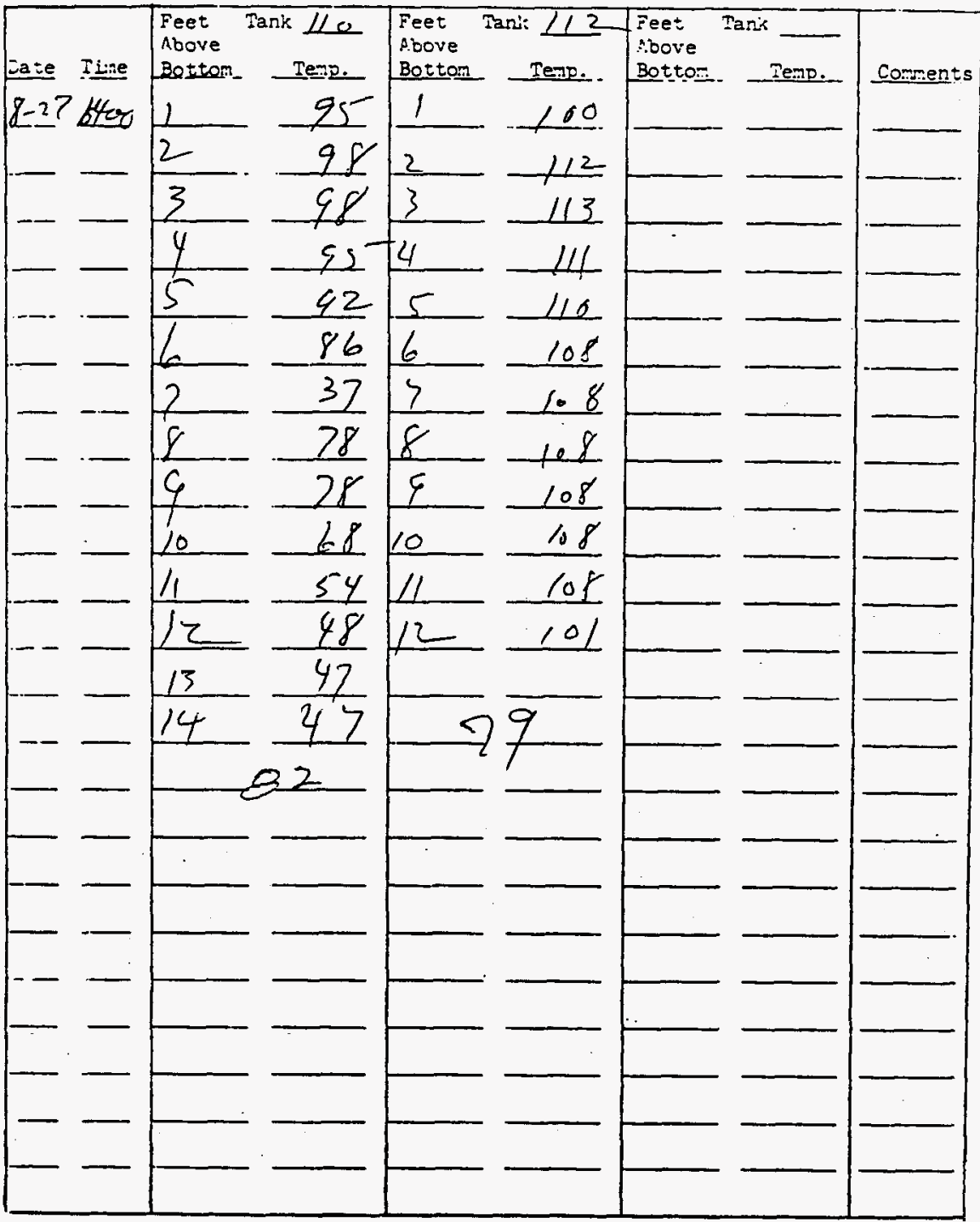

Irstr:ivisns ar caments: - Pake proflle temperetares weekly in each hattoms tank. Attach completed forg to Monday and Thursday's Dats sheets, 
Title: PROFIIE TQRERATURES II ITS-2 BOTTONS TAIKS

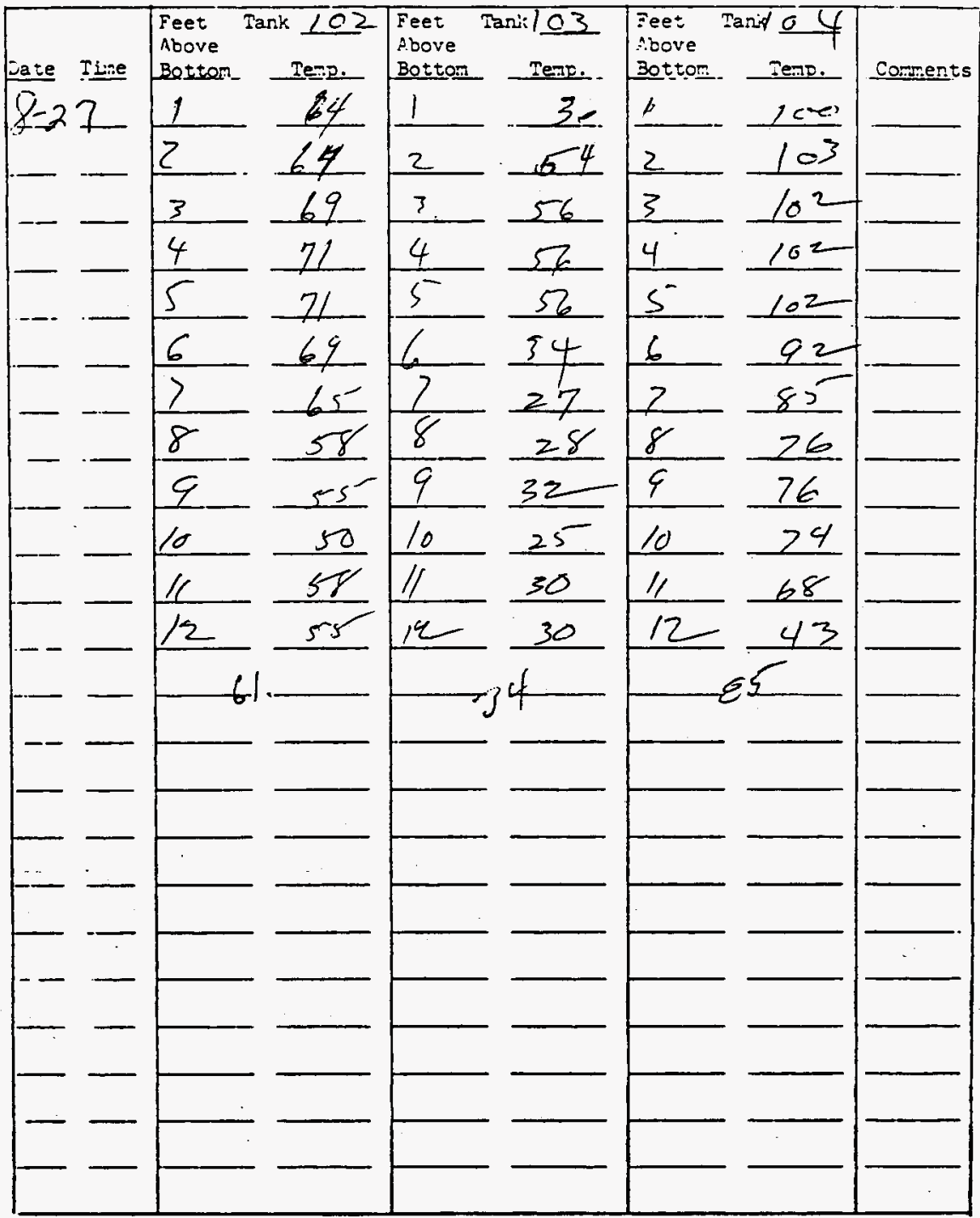

Ir:stristisns $=r$ camen's: - Take profile temperetares veekly in each bottoms tank. Attach conpleted for to Monday and Thursday's Data sheets. 
Title:

PROFIIE TEPERATURES IV ITS-2 BOTTOMS TANKS

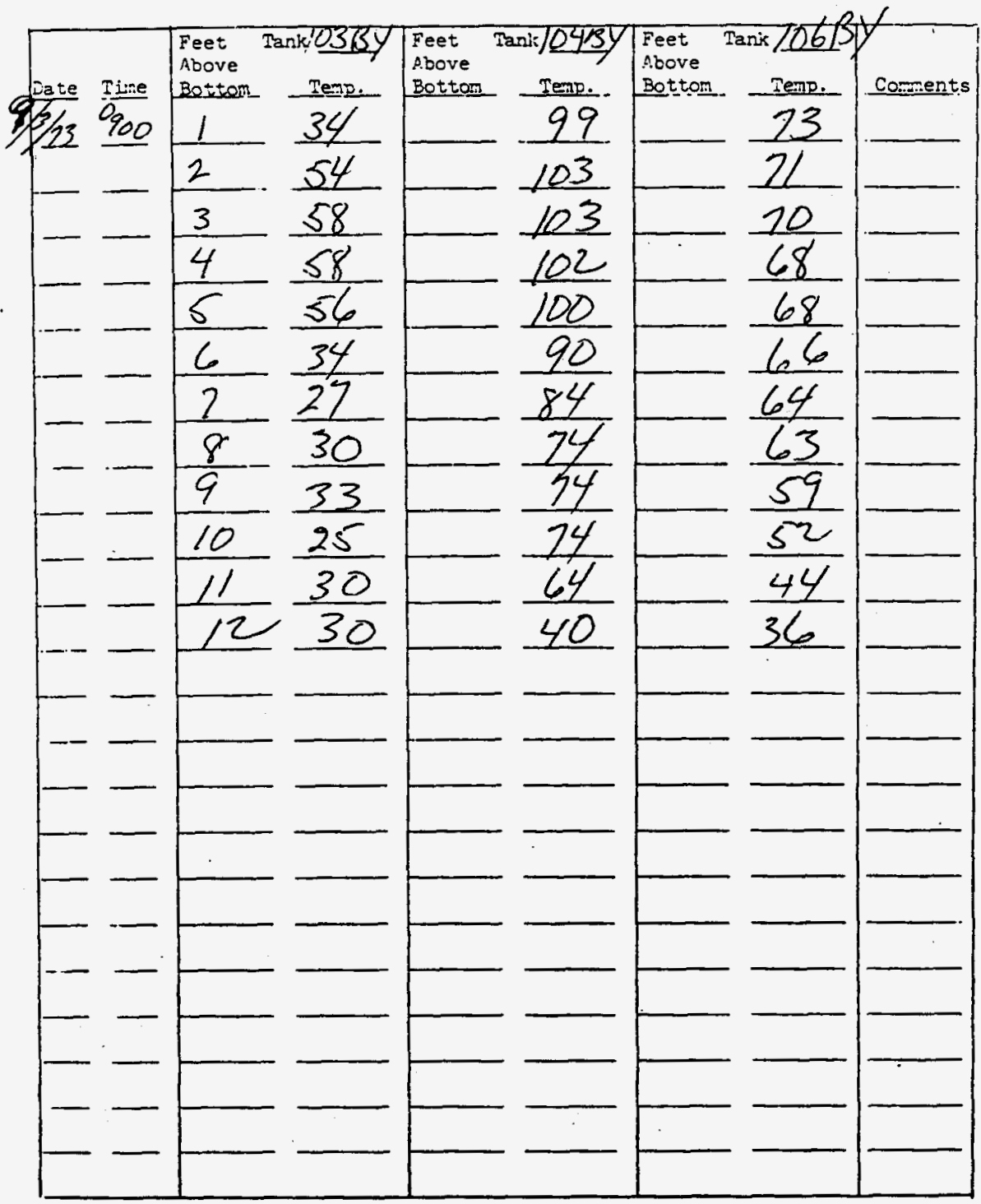

Instrictions ar coments: The proflle temperabures weekly in each bottoms tank. Attach completed fors to Monday and Thursday's Data Sheets. 
Title: PROFIIE TERERATURES II IIS-2 BOTTOMS TAIKS

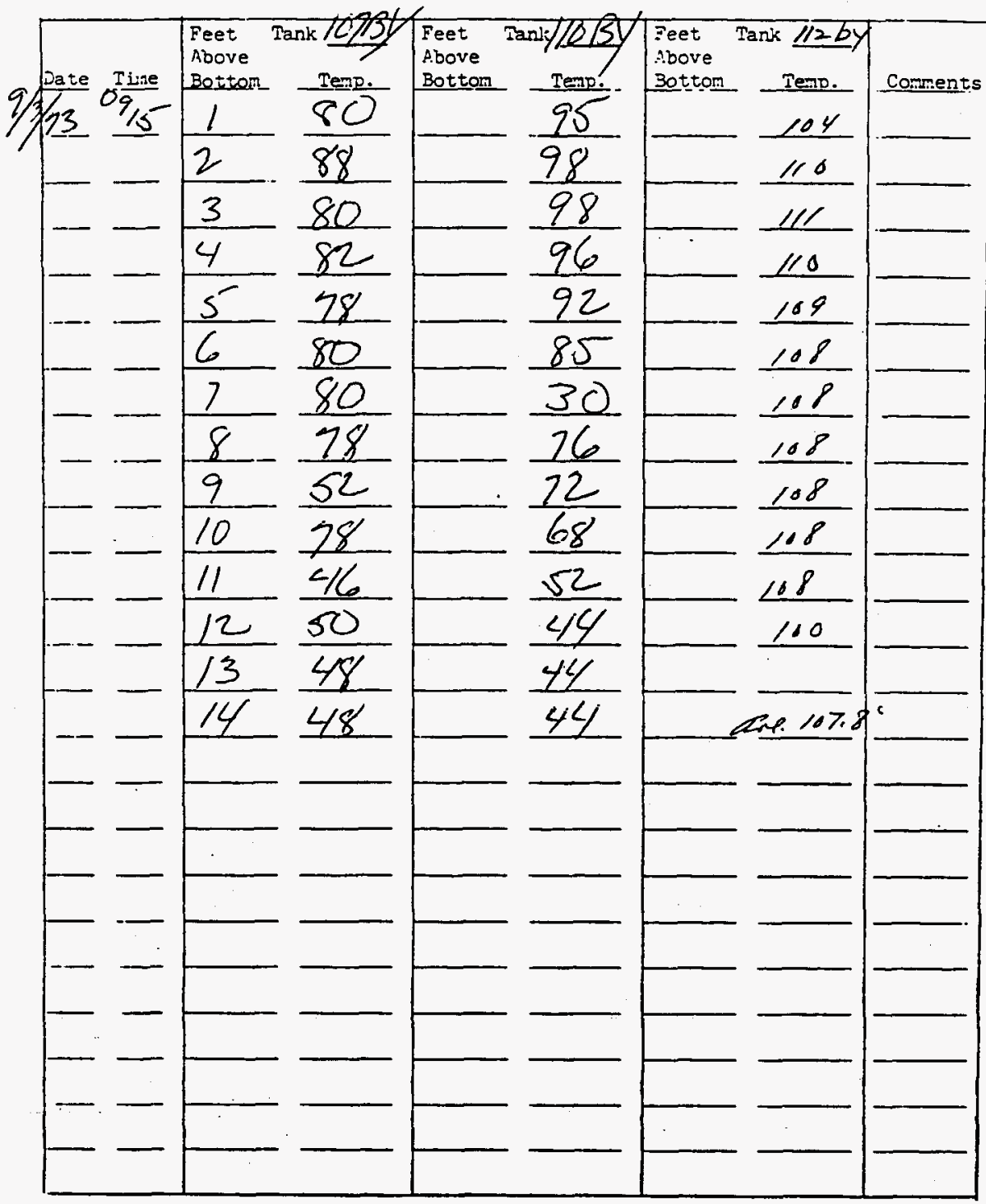

Instristions or conments: - Take profyle temperewres weekly in each battoms tank. Attach conpleted form to Monday and Thursday's Date sheets. 
Title: PROFILE TDPERATRES I: IIS-2 BOTTOMS TAIKS

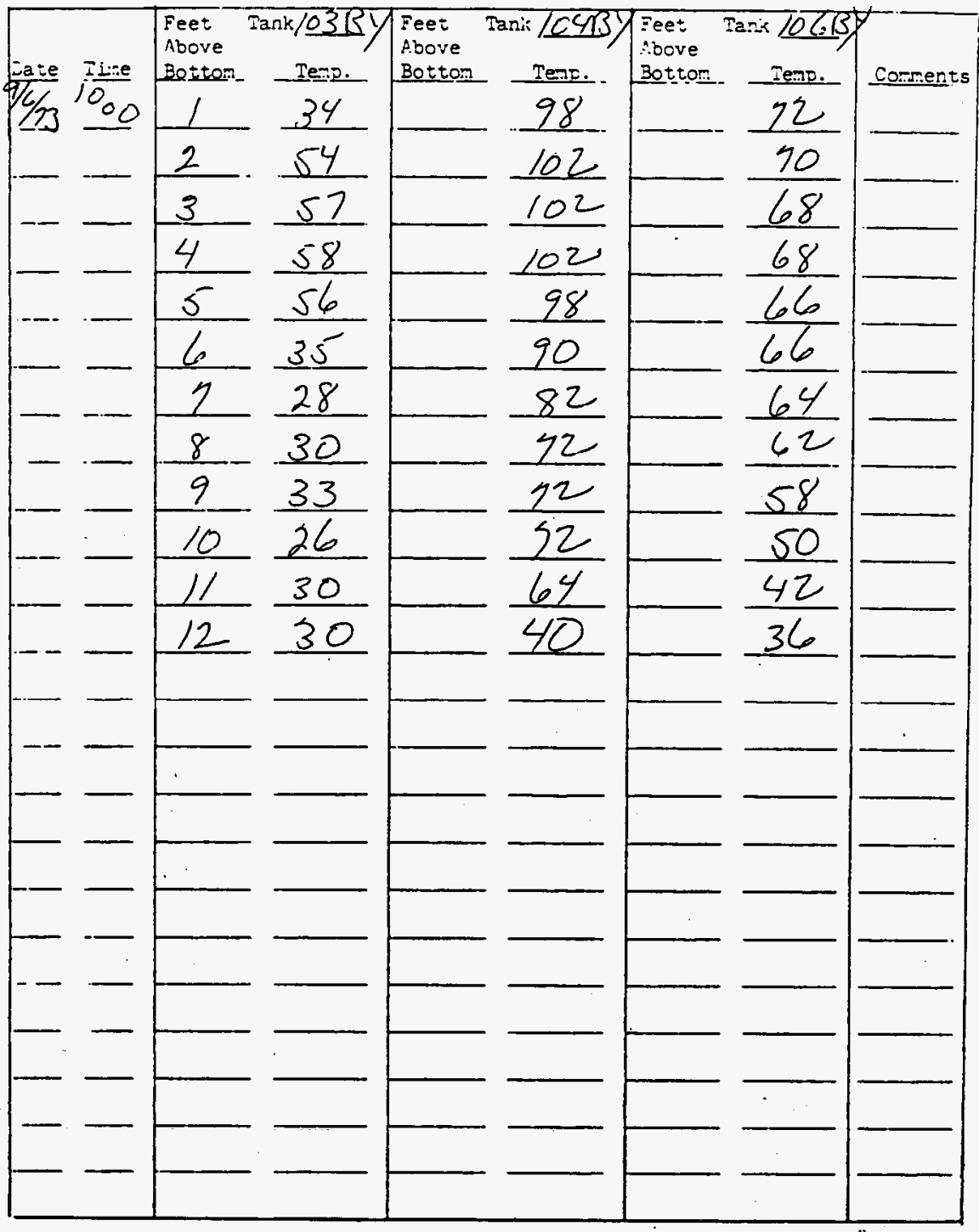

Instratisns or coments: - Take proflie temperawures veekly in each bottoms tank. Attech conpleted forr to Monday and Thursday's Data Sheets. 
Title: TROFIIE TEIERATURES $\mathbb{E}$ IIS-2 BOTIOMS TAMKS

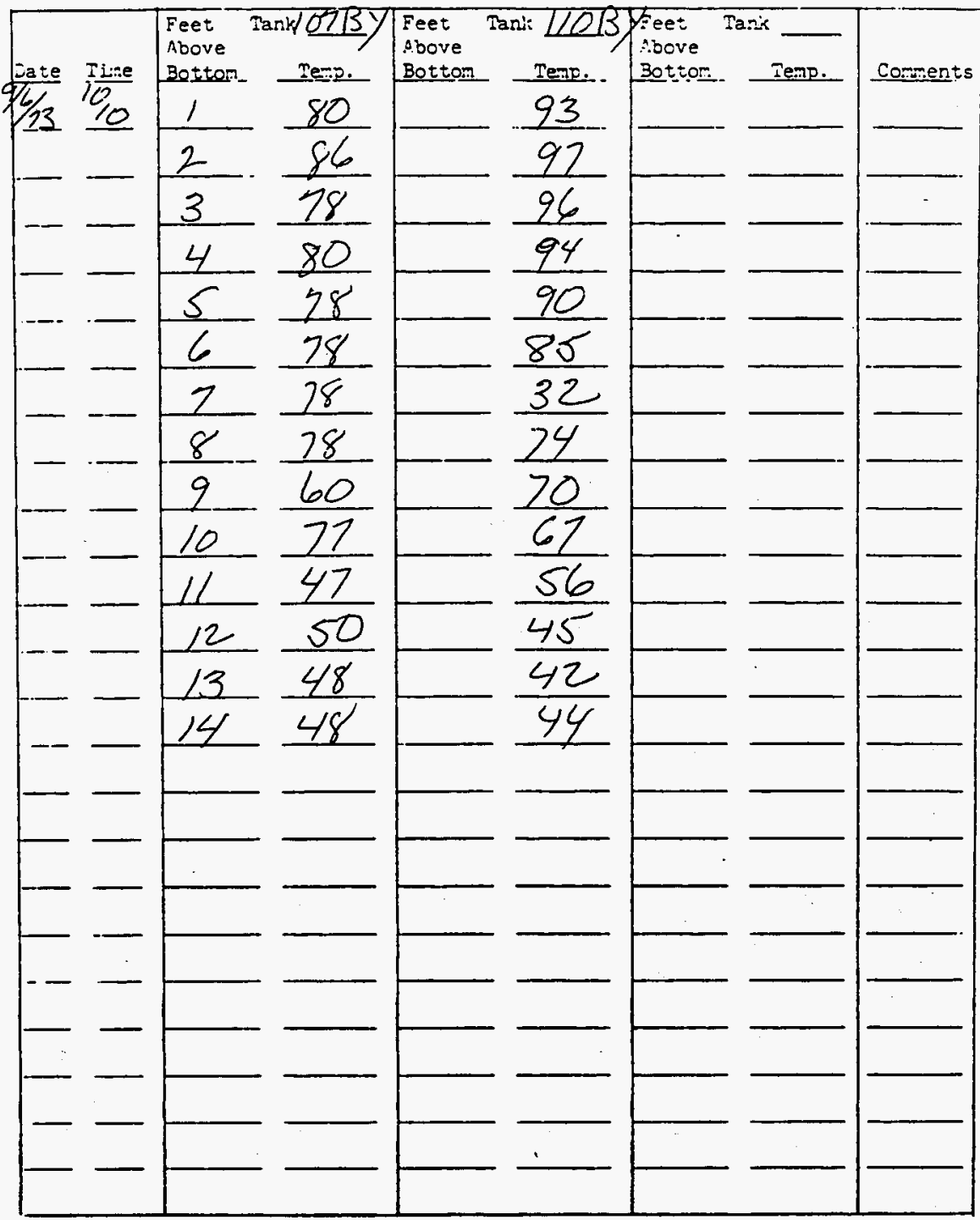

I-strictions $=r$ coments: -Take proflie temperatures veekly in each battons tank. Attach completed forn to Monday and Thursday's Data Sheets. 
Title: TROFILE TEFERATUFES IF ITS-2 BOTTONS TALKS

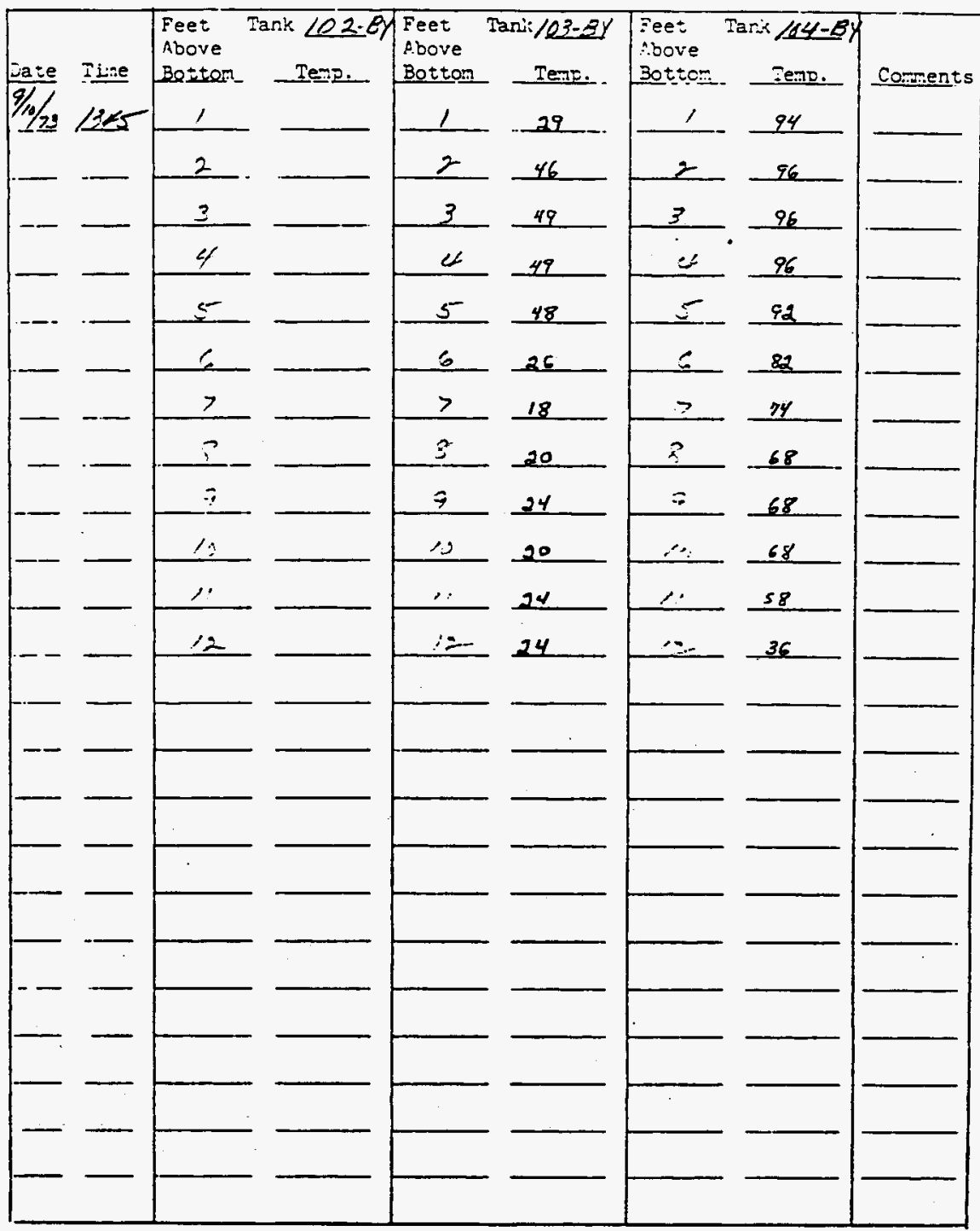

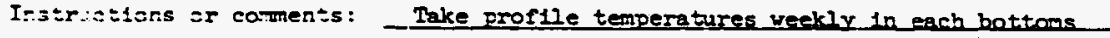
tank. Attach conpleted form to Monday and Thursday's Data sheets. 
Title: PROFILE TEIFERATURES II ITS-2 3OTTONS TAITS

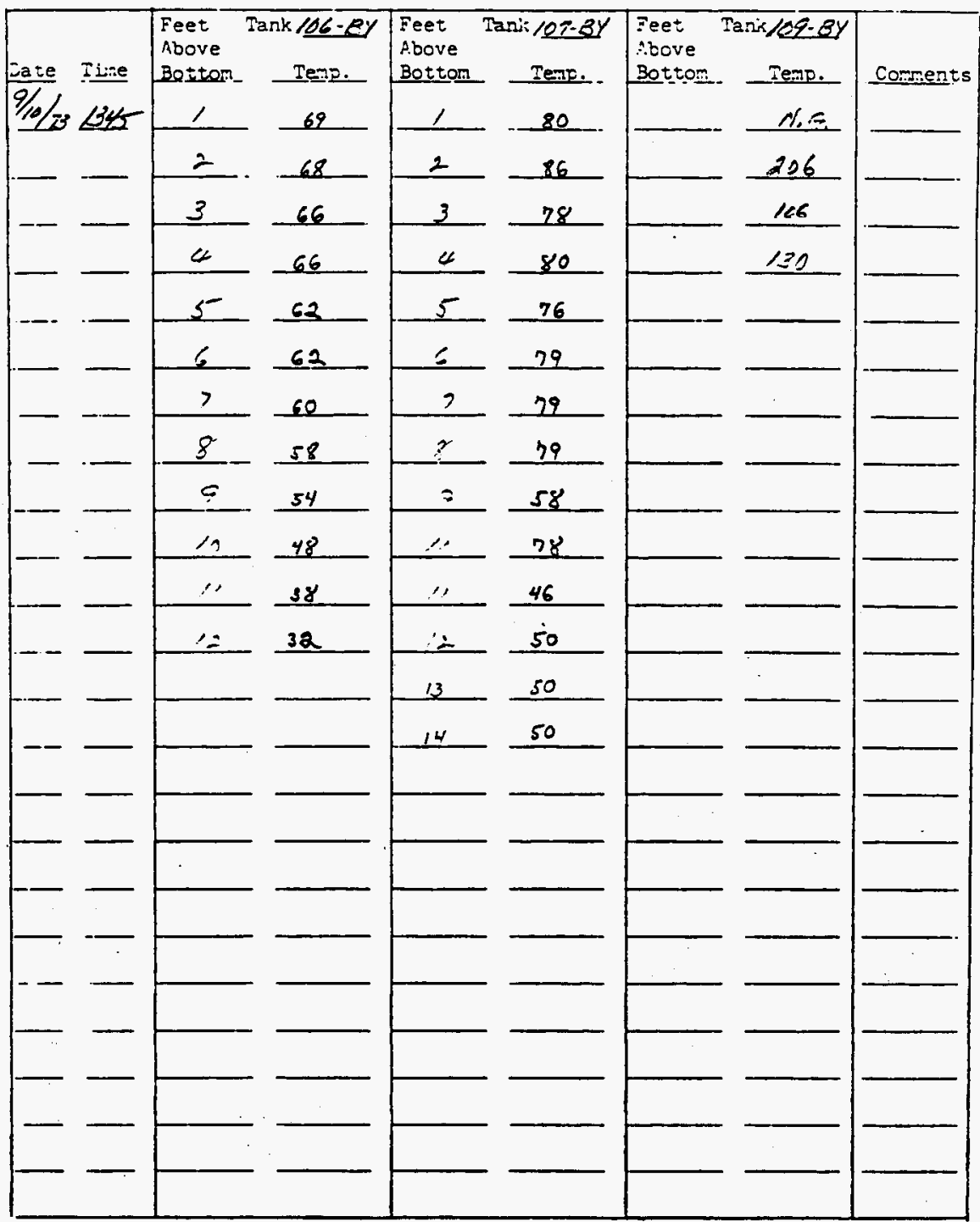

I:str:sisns sr connents: - Take proryle temperatures weekly in sach bottoms tank. Attach canpleted form to Monday and Thursday's Datg sheets. 
Title: PROFILE TEEERATURES IN ITS-2 BOTTONS FANTS

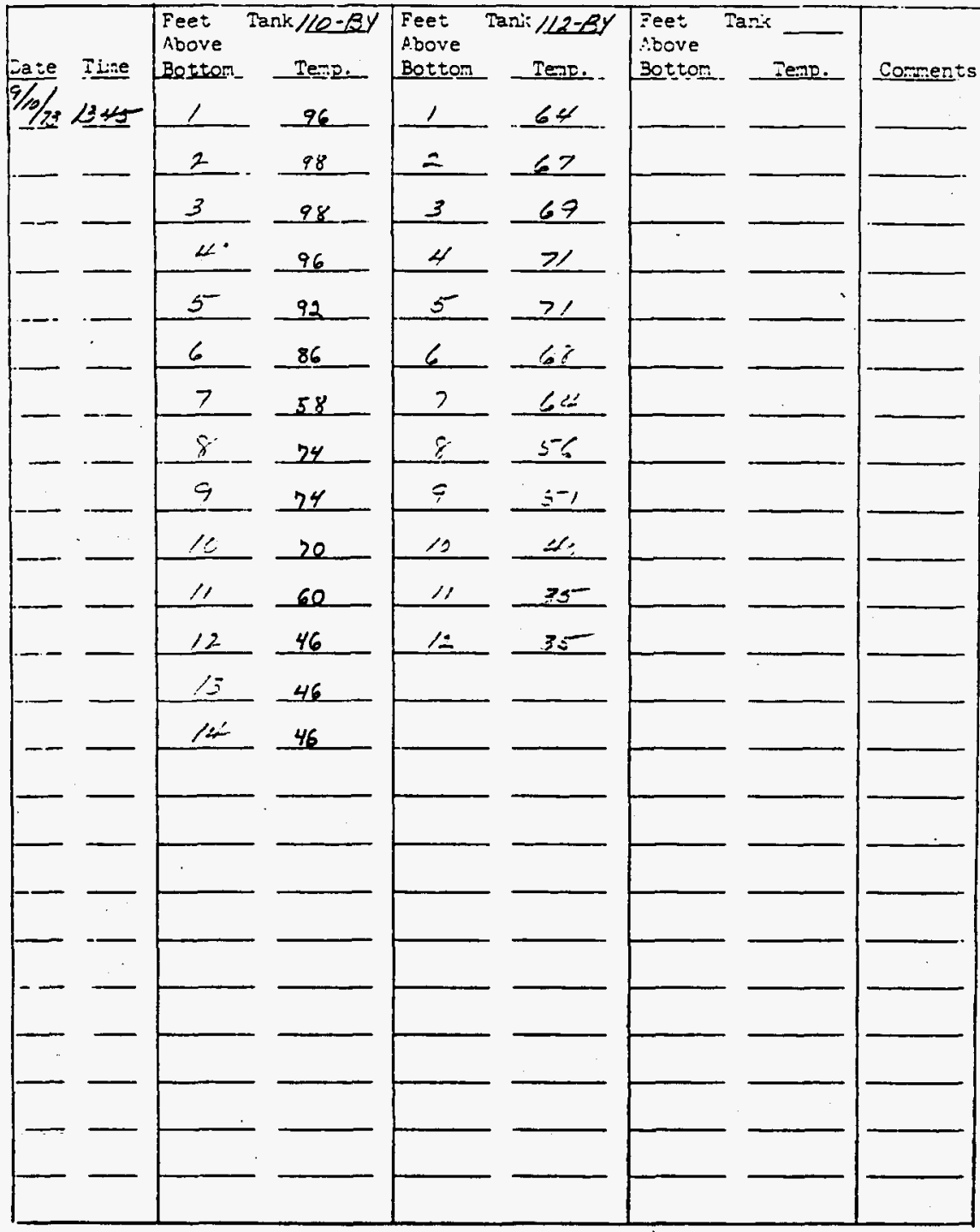

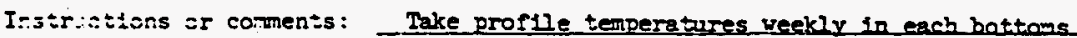
tank. Attech completed for to Monday and Thursday's Data Sheets. 
Title: PROFILE TERERATURES I: ITS-2 BOTMOAS TAIKS

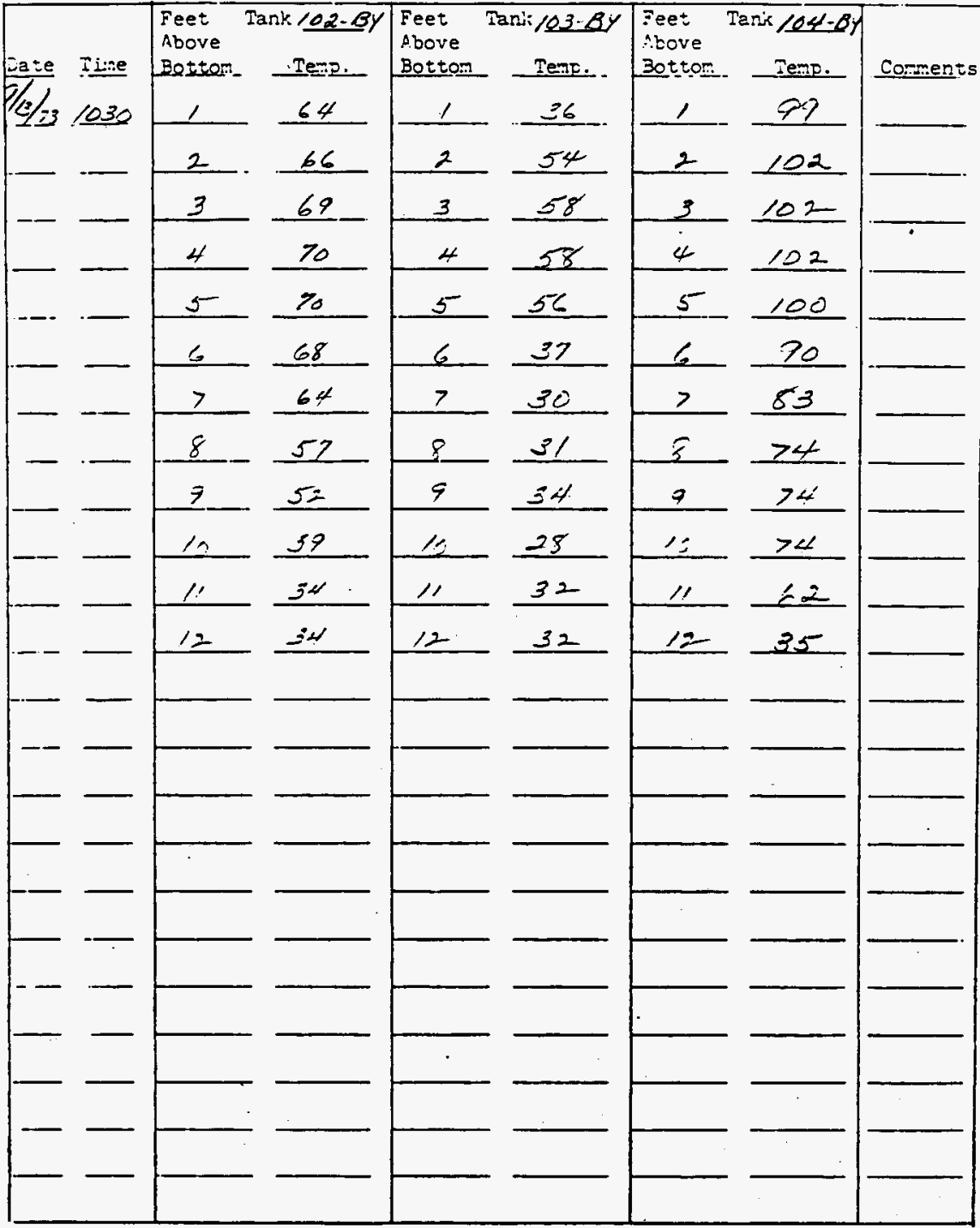

Insiricisons ar coments: - Take frofyle temperstures veekly in each hottoms tank. Attach conpleted forr to Monday and Thursday's Data Sheets. 
Title: PROFILE TETEERATURES II ITS-2 SOTTONS TATKS

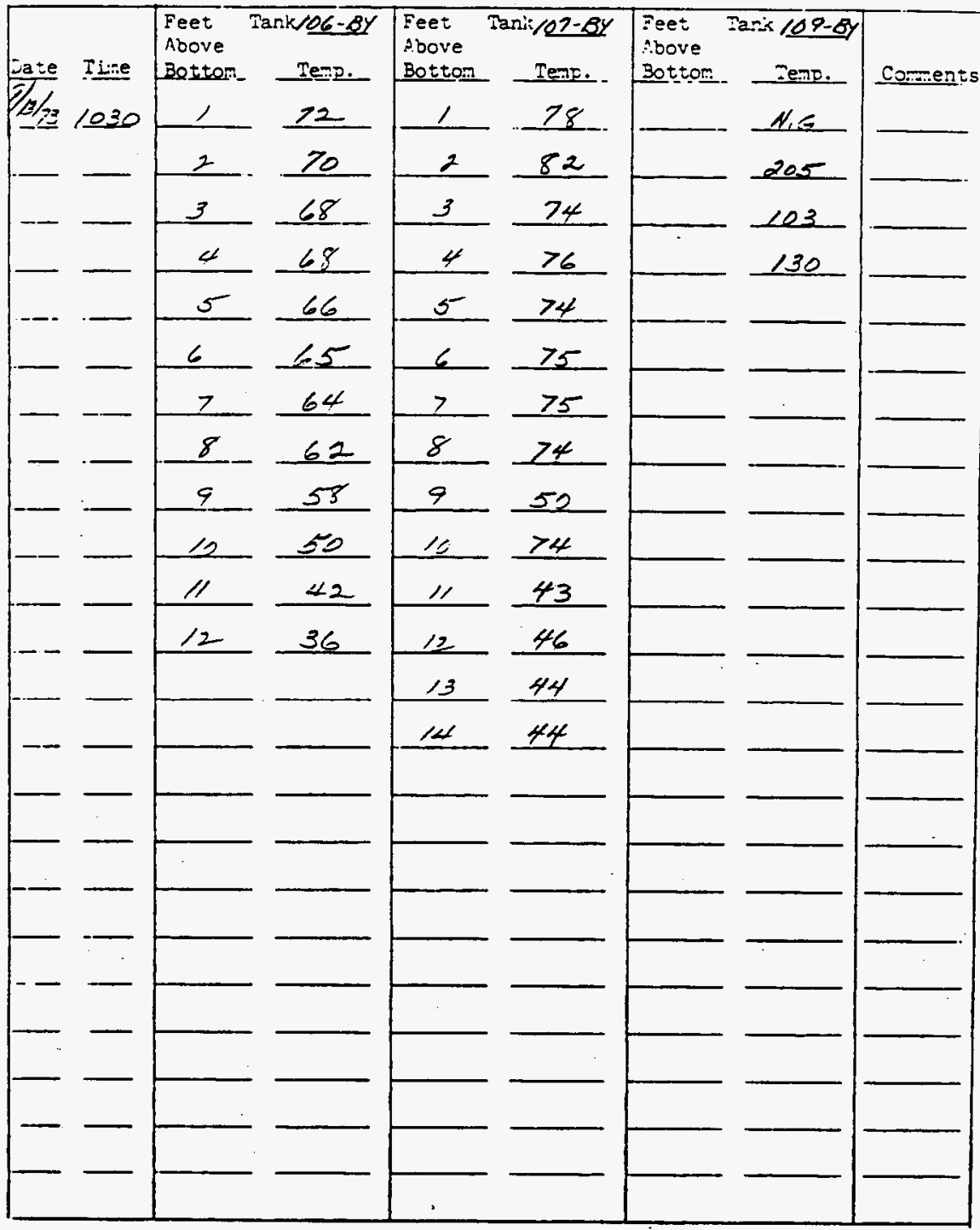

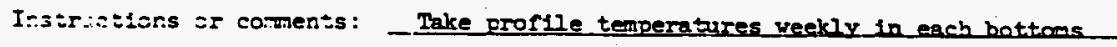
tank. Attach corpleted form to Monday and Thursday's Data sheets. 
Title:

PROFILE TEPERATURES LE ITS-2 BOTMONS TARKS

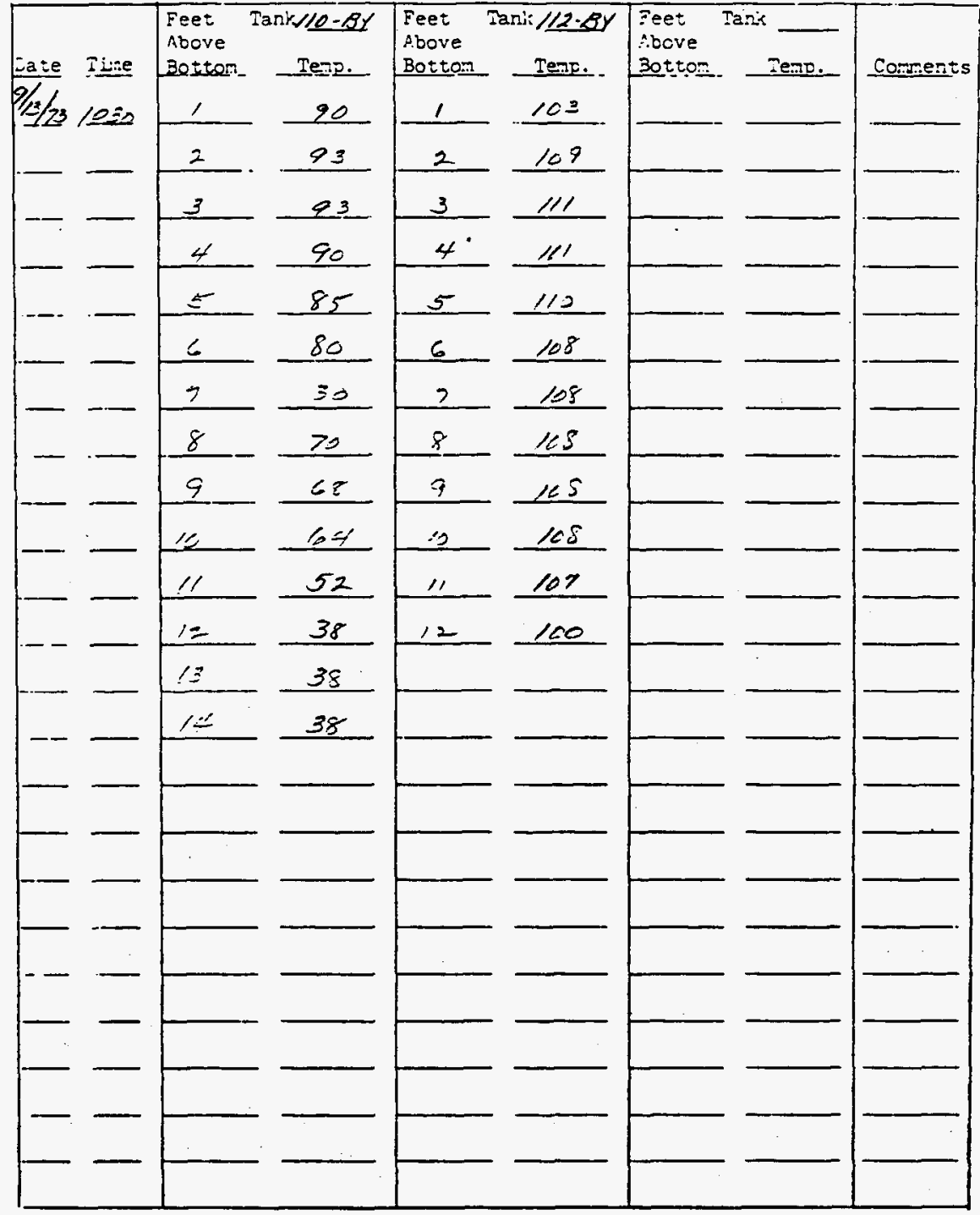

Instr:t:isns sr coments: - Take prorile temperatures veekly lo each hottoms tank. Attach completed form to Monday and Thursday's Data Sheets. 
Title: PROFILE TERERATURES I: ITS-2 BOTIOMS IAIKS

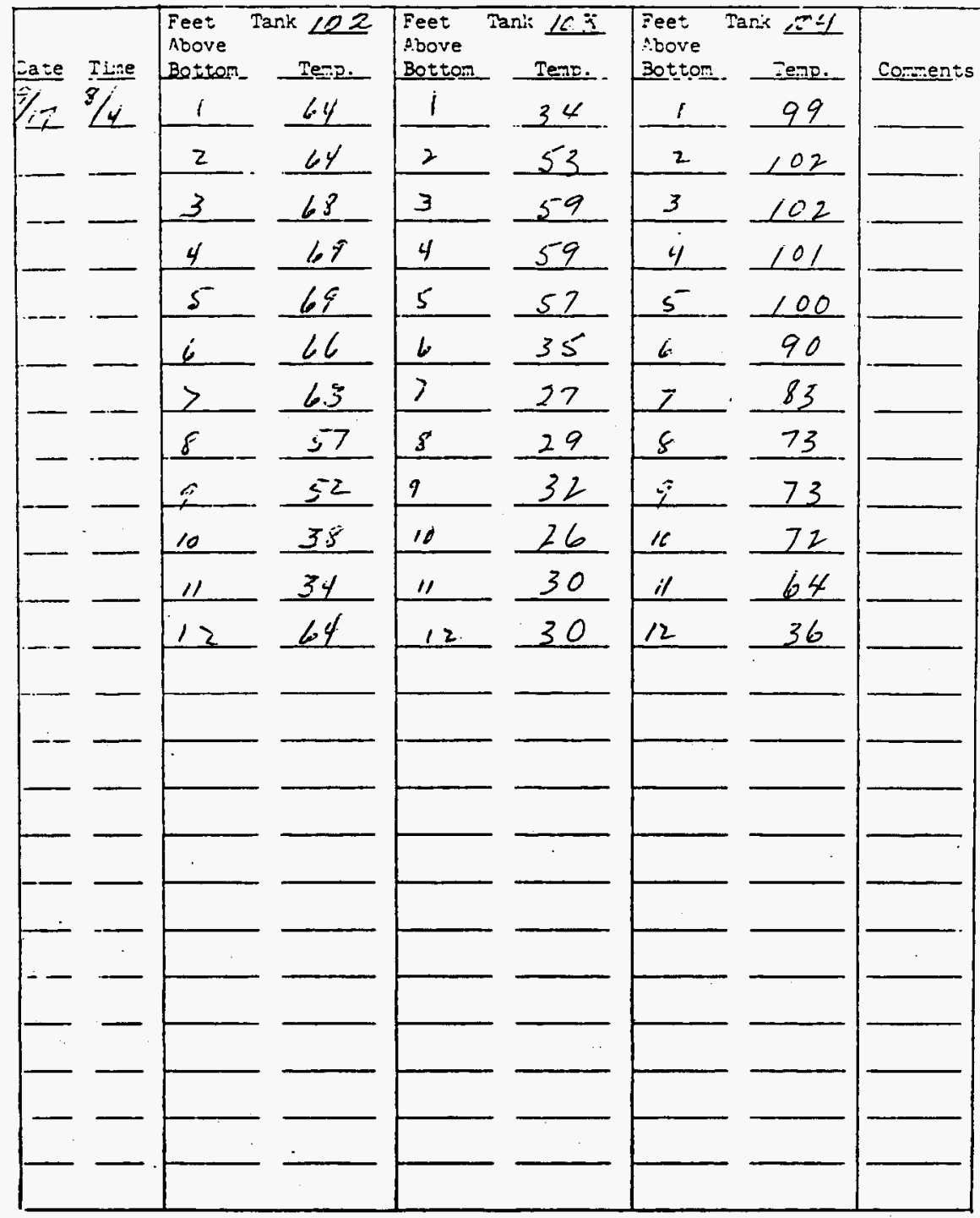

Ir:str:atisrs ir coments: - Take prorlle temperatures veekly in each battoms tank. Attach completed foren to Monday and Thursday's Data sheets. 
Title: PROFIIE TEFERATURES II ITS-2 3OTMOMS TAITKS

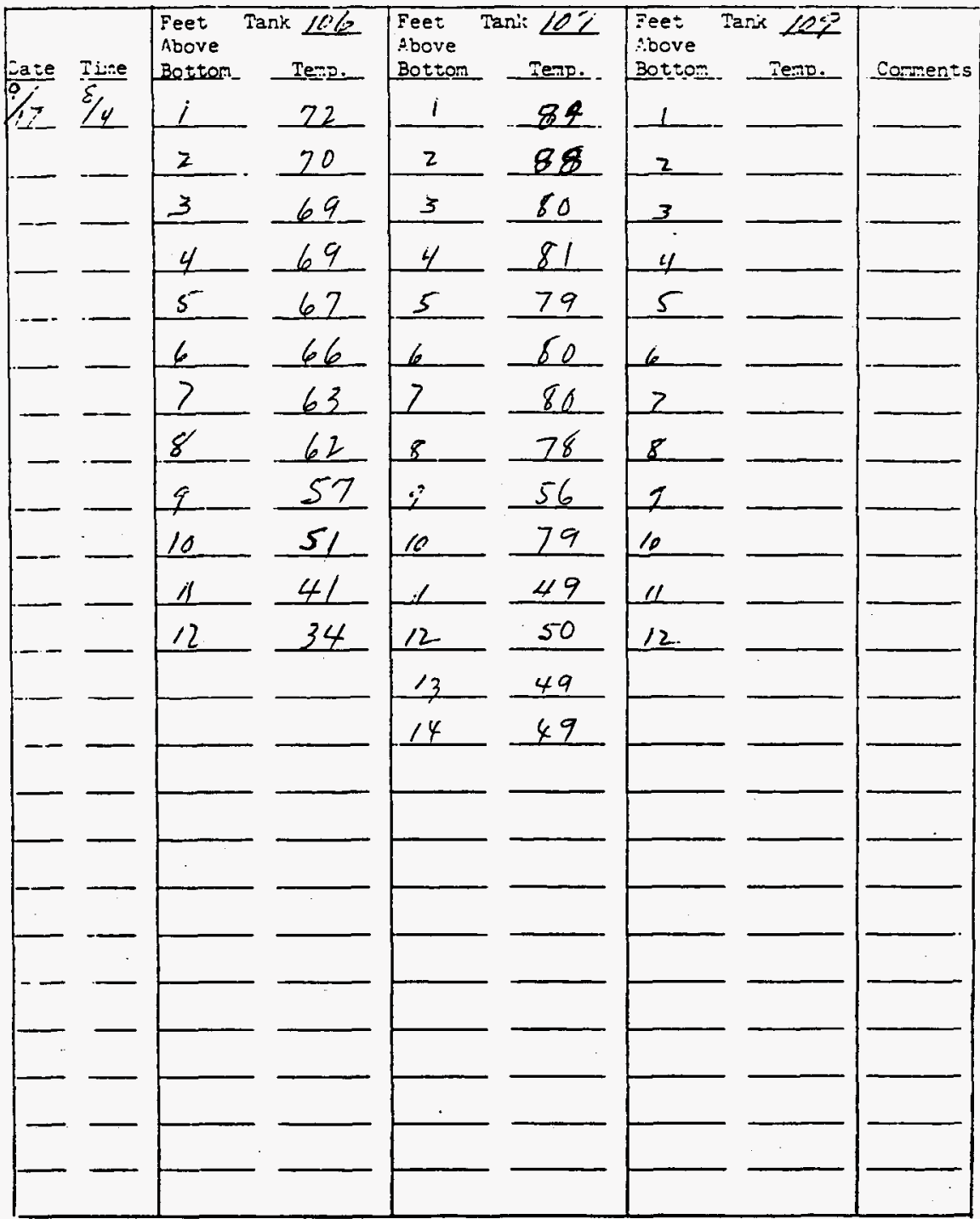

Irstr.:tisns or contnents: - Take proflle temperatures weekly in each battons tank. Attach conpleted forg to Monday and Thursday's Data sheets. 
Title: PROFIIE TETERATURES II ITS-2 BOTTOMS TANS

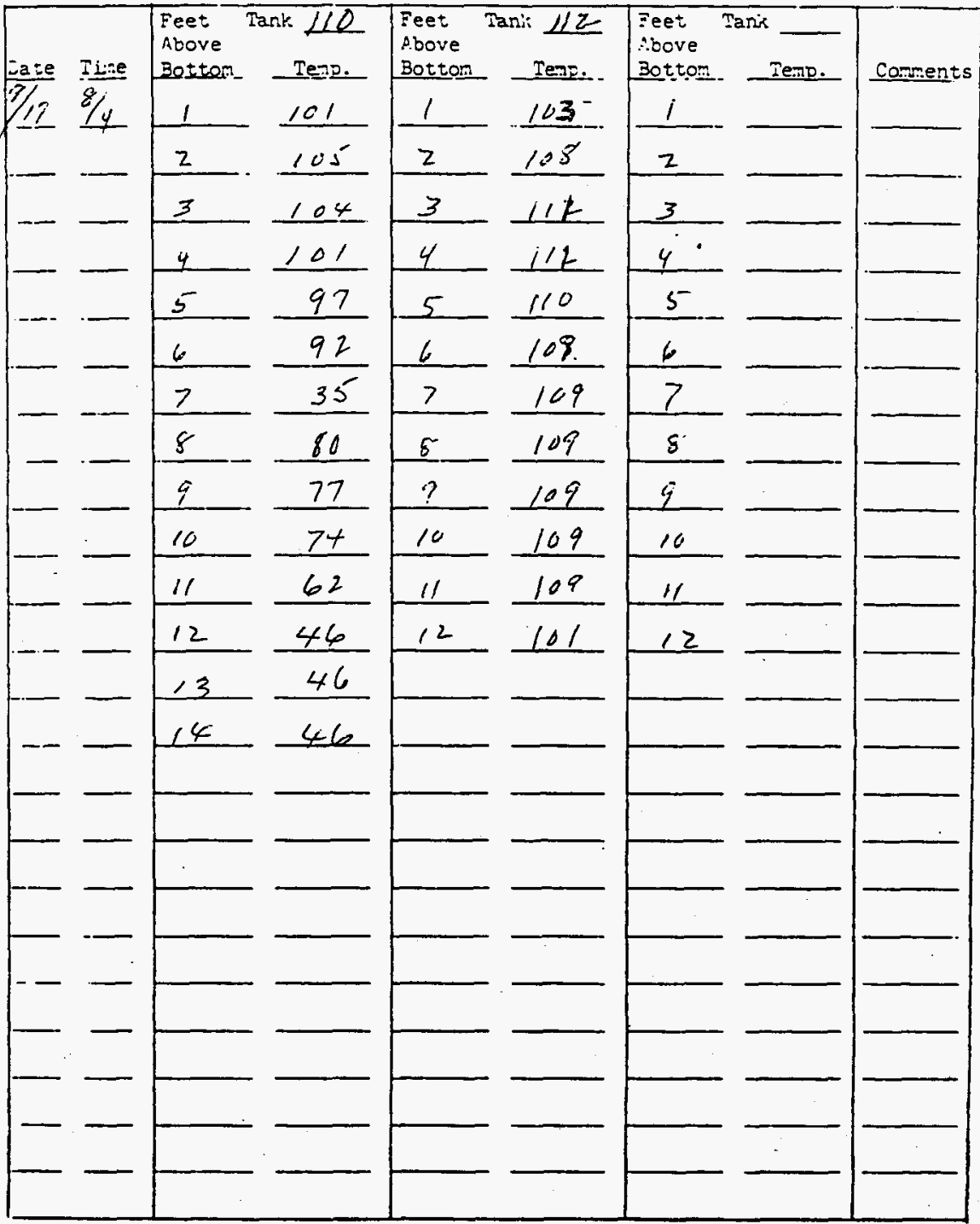

Ins:r:stions ir caments: - Take proflle temperatures weekly in each bottoms tank. Attach conpleted form to Monday and Thursday's Data Sheets. 
Title: PROFILE TRTERAIURES I: ITS-2 BOTTOMS TARTS

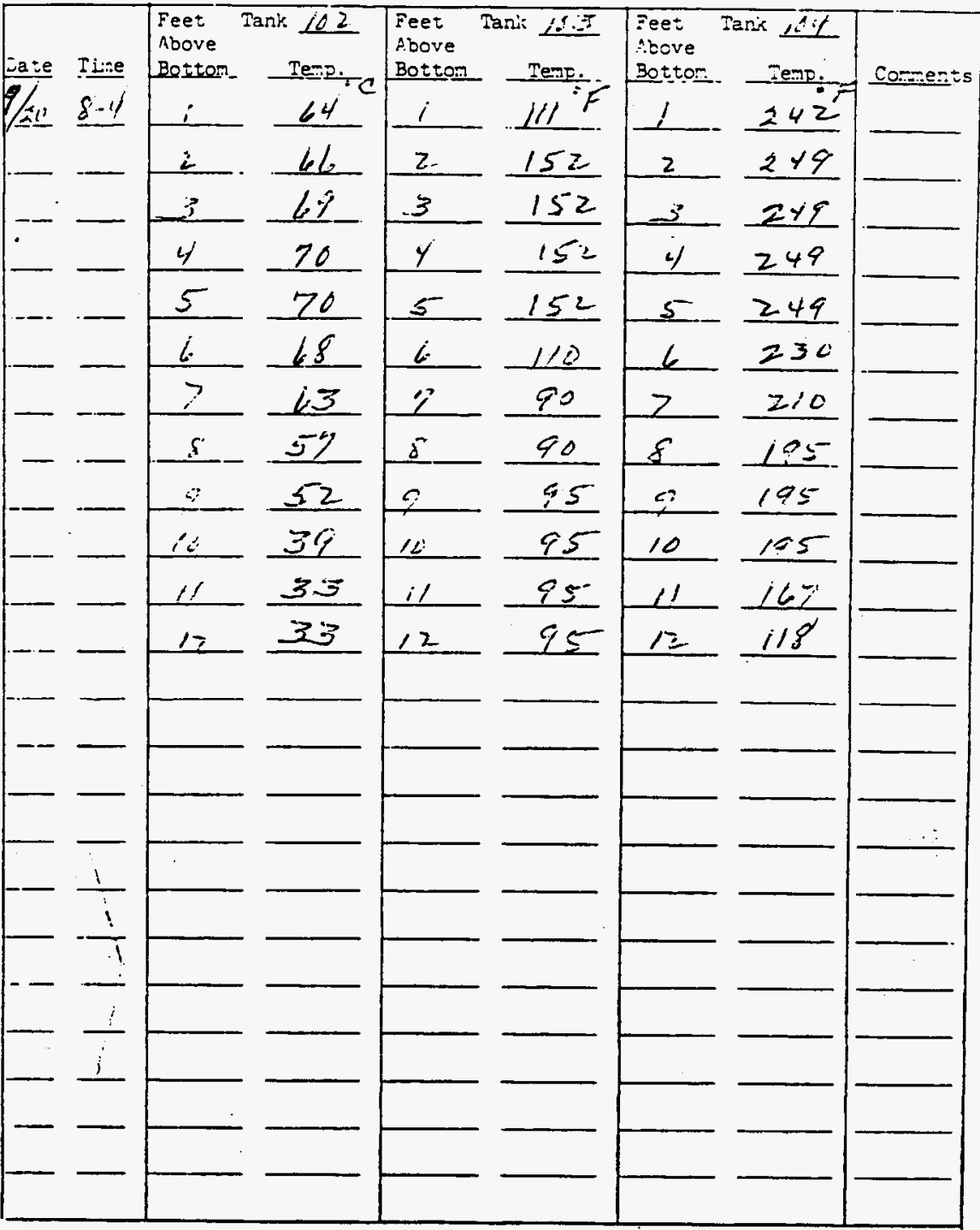

Irstr:-ticrs ar comen:s: - Take proflle temperatures weekly in each bottoms tank. Attach conpleted form to Monday and Thursday's Data Sheets 
Title:

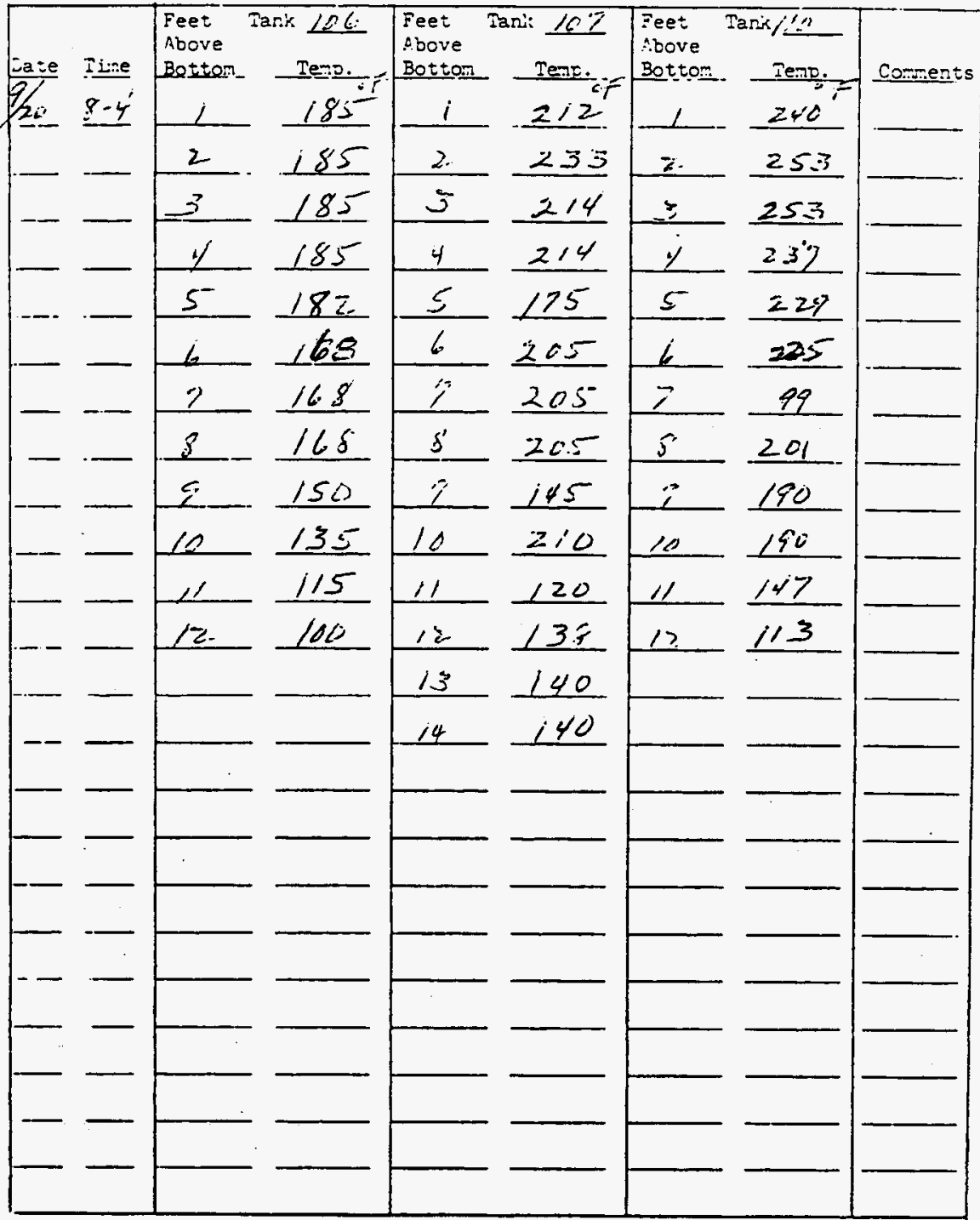

Ins:r:0:tons or conments: - Take prof lle temperatures veekly in each battoms tenk. Attach conpleted form to Monday and Thursday's Data Sheets. 


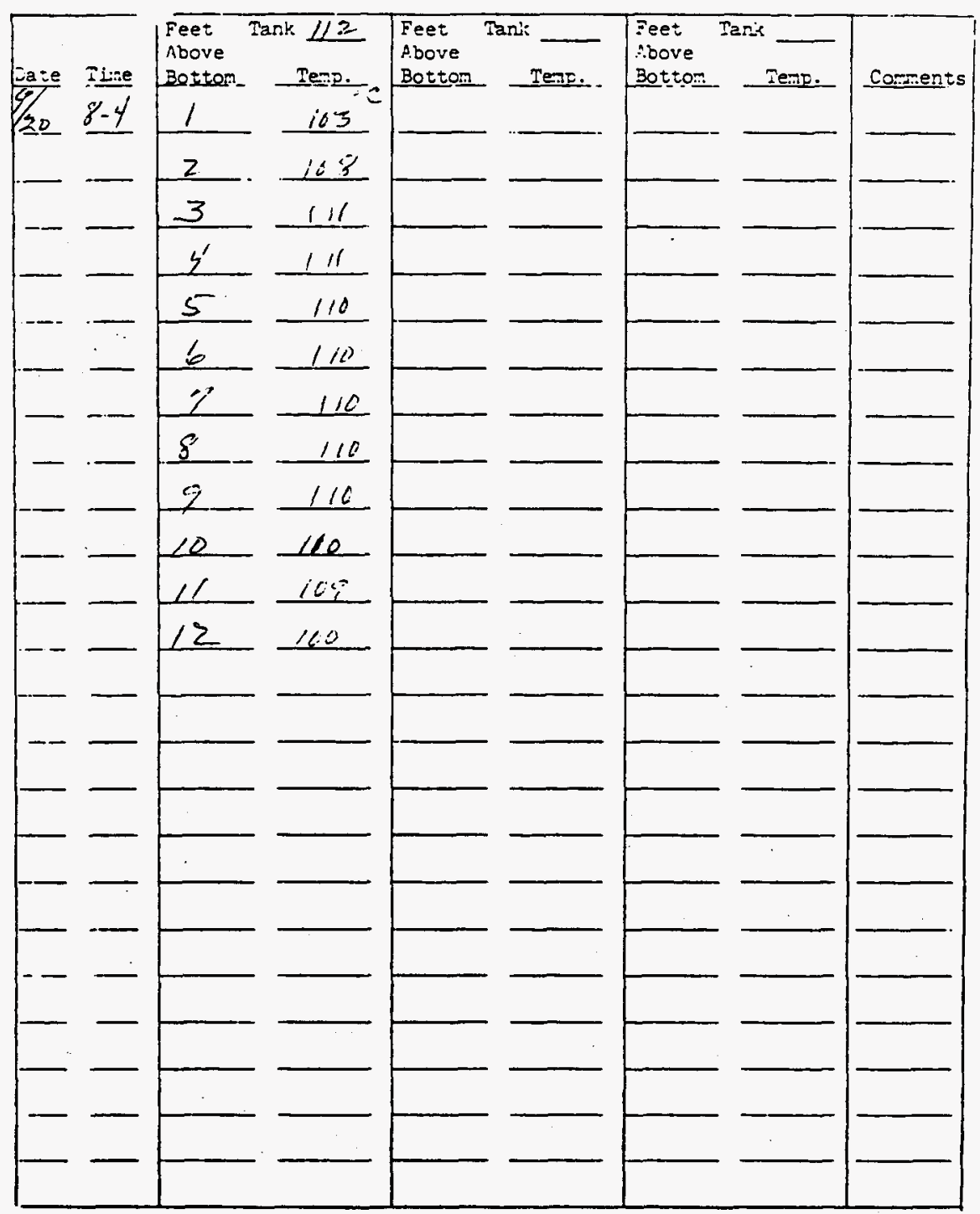

I-:sir:ations ar conments: - Take prof lle temperatures weekly in each bottoms tank. Attach conpleted ford to Monday and Thursday's Data Sheets. 
Title: PROFILE TEIPERATURES IN ITS-2 BOTTOMS TANTS

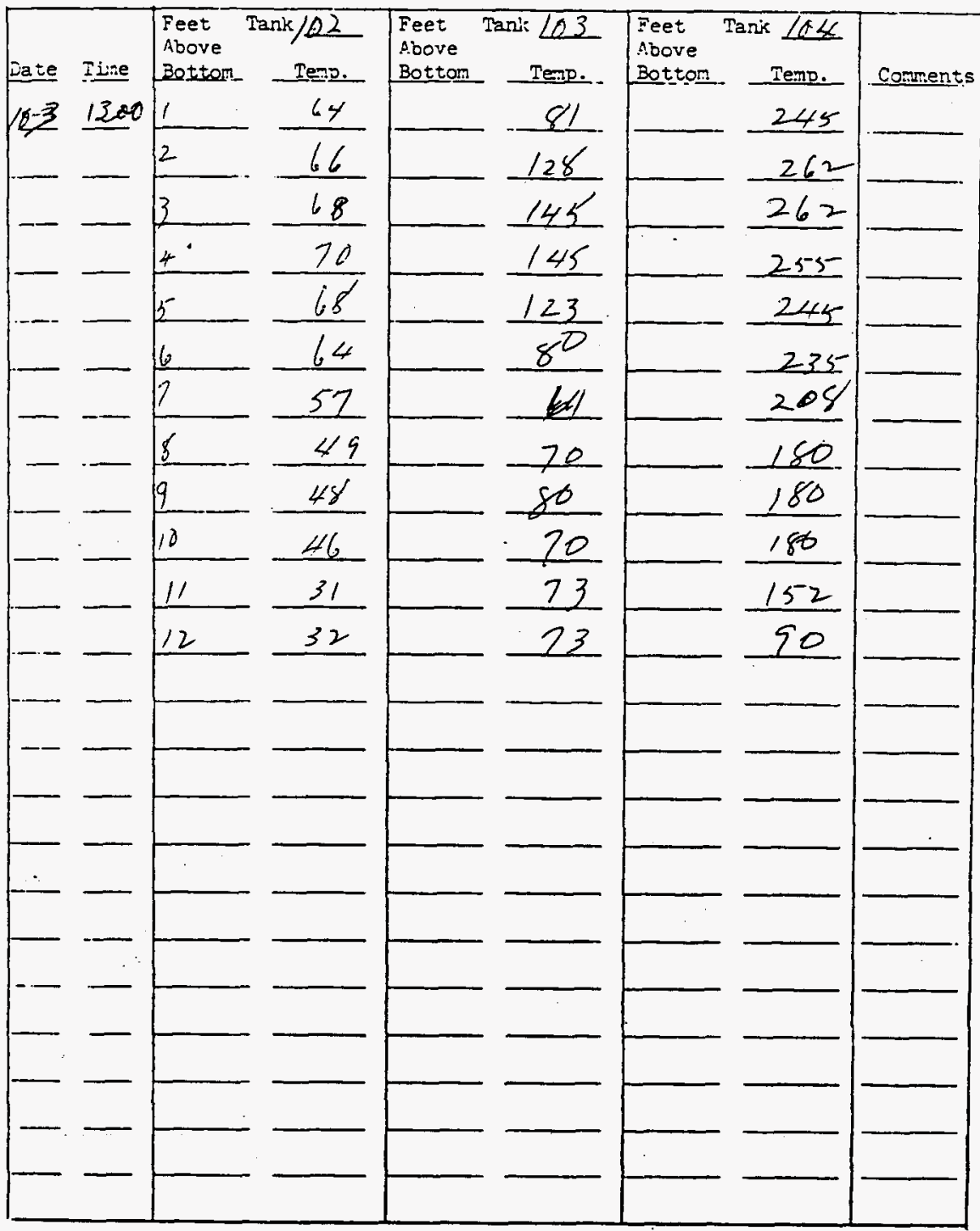

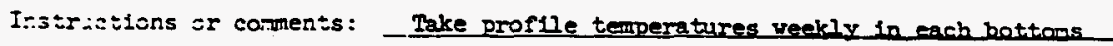
tank. Attach completed form to Monday and Thursday's Data Sheets. 
Title: PROFILE TEPERATURES TV ITS-2 BOTIOMS TARKS

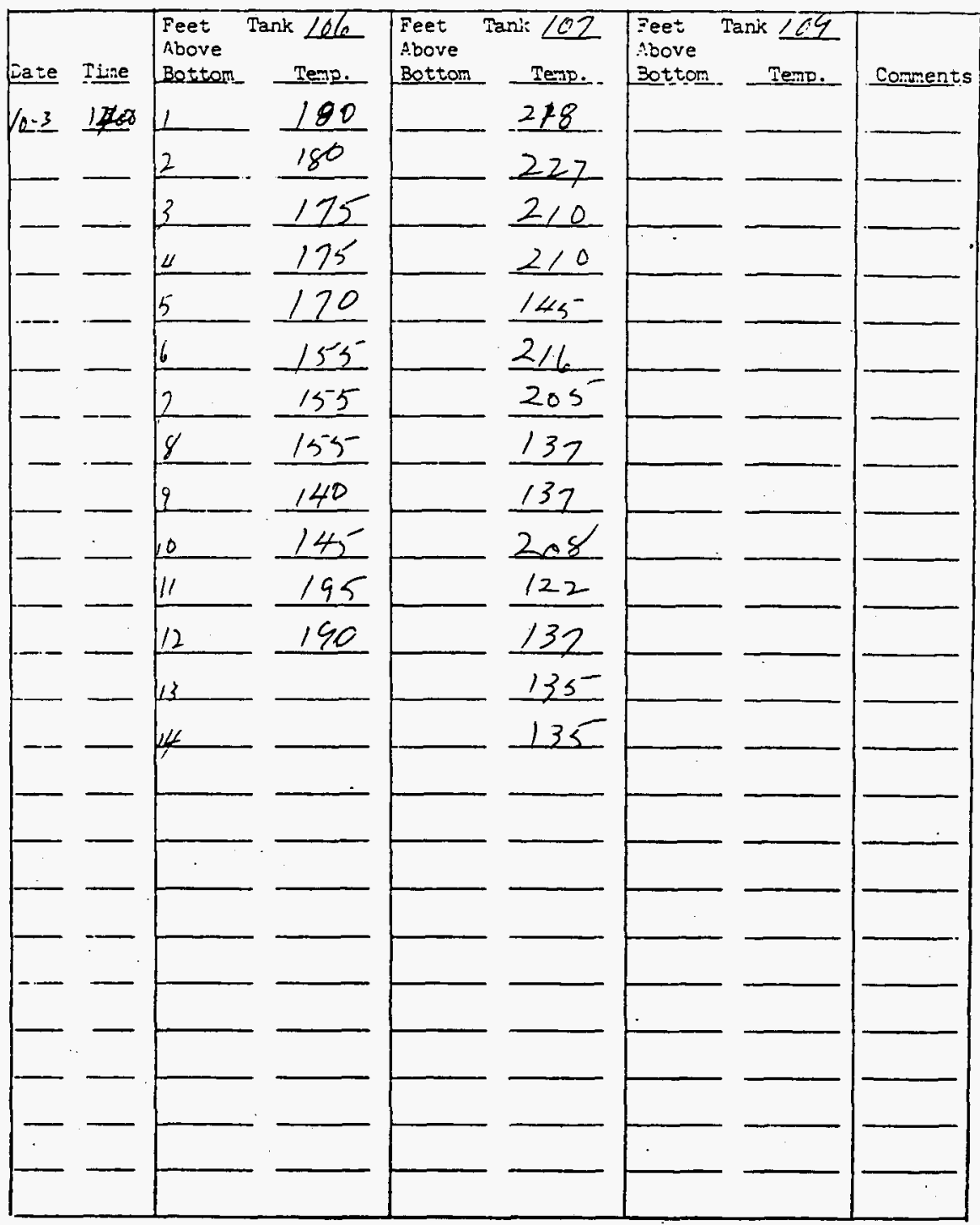

Irsir:atisns or coments: - Take proftle temperatures veekly in mach battoms tank. Attach conpleted form to Monday and Thursday's Data sheets. 
Title: PROFILE TEMPERATURES II ITS-2 BOTTOMS TAITS

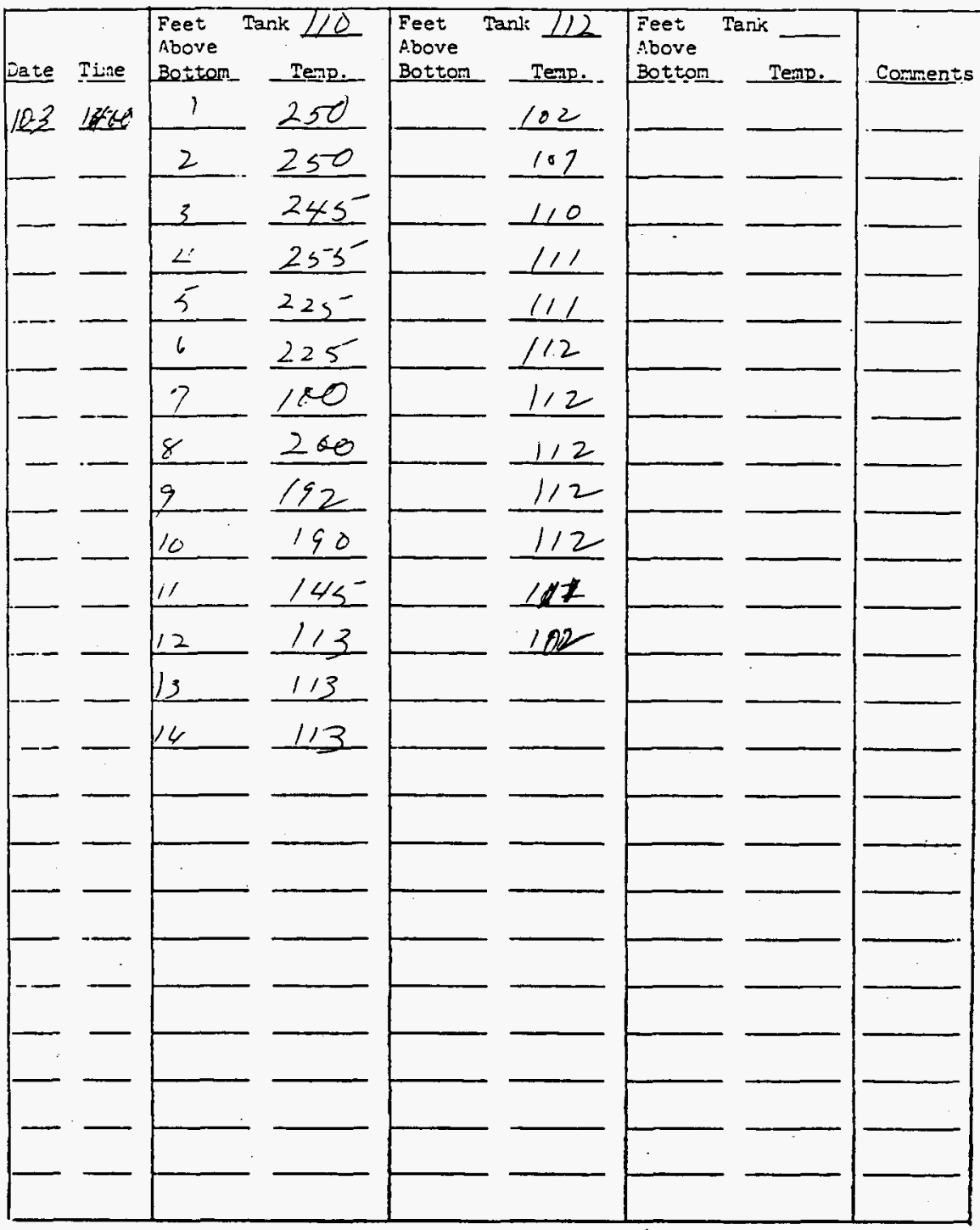

Irstristions or carments: - Take prof 11 e temperatures veekly in each hattoms tonk. Attach conpleted form to Monday and Thursday's Datg Sheets. 
inc-so-1m-DP-207, Rev. O $10-8-73 \quad$ DAYS: (M,ke + Jerry)

\begin{tabular}{|c|c|c|c|c|c|c|c|c|c|c|c|c|c|c|c|c|}
\hline K & $102 B \bar{Y}$ & $x$ & $1038 Y$ & $x$ & $104 B Y$ & $x$ & $106 B Y$ & $x$ & $10>B Y$ & $x$ & $110 B Y$ & $\underline{x}$ & $112 B Y$ & $x$ & \multicolumn{2}{|c|}{$109 \mathrm{BY}$} \\
\hline 1 & 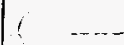 & -1 & 27 & 1 & 96 & $\perp$ & 74 & 1 & 80 & $L$ & 90 & 1 & 102. & 1 & -0 & 6 \\
\hline 2 & 60 & 2 & 48 & -2 & 98 & -2 & 24 & 2 & 83 & 1 & 92 & 2 & 102 & 2 & & \\
\hline 3 & $\because ?$ & 3. & -55 & 3 & 99 & 3 & 22 & 3 & 28 & 3 & 90 & 3 & 410 & 2 & 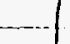 & $\ldots$ \\
\hline 4 & 69...... & 4 & 55 & -4 & -89 & -4 & 32 & 4 & 78 & 1 & -88 & 4 & IIIL & 4 & $\ldots$ & $\ldots$ \\
\hline 5 & $\therefore 8$ & 5 & -24 & 5 & 98 & 5 & 70 & $=$ & 56 & 5 & 84 & $\underline{z}$ & $\mu$ & $z$ & 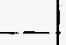 & $\ldots$ \\
\hline 6 & 64 & 6 & -52 & 16 & 91 & 6 & 67 & 6 & 80 & + & 78 & 6 & 109.5 & 6 & & \\
\hline í & 57 & $z$ & 20 & $\neq$ & -83 & 7 & -64 & 2 & -82 & 3 & 20 & 2 & 109 & $z$ & & $\ldots$ \\
\hline$\gamma$ & 50 & $x$ & $-20:$ & 8 & .72 & s. & 61 & 8 & 54 & 8. & 68 & $y$ & 109 & 8. & & $\ldots$ \\
\hline 7 & $48 \ldots$ & 9 & 20 & 4. & 20 & -9 & 56 & $\varepsilon$ & 542 & $\varepsilon$ & 68 & s. & 102 & .2. & 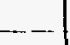 & $\ldots$ \\
\hline & 46 & 10. & 20 & 10 & -20 & 10 & 50 & 10 & 72 & 10 & 65 & 2 & 109 & se & $\therefore$ & $\ldots$ \\
\hline & - & $\|$ & $23 \div$ & " & 62 & "t. & 40 & $k$ & 52 & 4 & -52 & 4 & 109. & $11-$ & $\ldots$ & $\ldots$ \\
\hline & $\therefore$ & 12 & 23 & 12 & 36 & 12 & 34 & 12 & 47 & 12. & 35 & nt & 100,5 & 12 & $\ldots$ & \\
\hline & $<\ldots$ & 13. & $\therefore$ & D & -- & 13 & - - - & 6 & 46 & 13. & 34 & 2 & $-\ldots$ & $\theta$ & $\ldots$ & $1-\ldots$ \\
\hline & $\cdots$ & 14 & -1. & 19 & & $y$ & & 14 & 46 & $2 y$ & 3.4 & $2 \%$ & $-\ldots \ldots$ & 4 & & $\cdots$ \\
\hline & & & & & & & & & & & & & & - & & . \\
\hline
\end{tabular}


DATA SHEET

Temperatures of Tank ITS-2 Bottoms Tanks

\begin{tabular}{|c|c|c|c|c|c|c|c|c|c|c|c|}
\hline Temp. & $\begin{array}{l}\text { Date } \\
10-\mu\end{array}$ & ${ }_{3}$ Date & $\rightarrow^{\text {Date }}$ & Date & Date & Date & Date & Date & Date & Date & \\
\hline$n t$ & 102 & 103 & 104 & 106 & 110 & 109 & 107 & 112 & & & \\
\hline$\underline{I}$ & 64 & 30 & 99 & 73 & 94 & 4 & 82 & 102 & & & \\
\hline 2 & 66 & 51 & 102 & 71 & 97 & I & 85 & 107 & & & \\
\hline$\overline{3}$ & 67 & 58 & 109 & 10 & 96 & & 27 & 110 & & & \\
\hline 4 & 69 & 58 & 101 & 57 & 9 & & 78 & 111 & & & \\
\hline 5 & .8 & 24 & 98 & $\frac{16}{6}$ & 99 & & 52 & 111 & & & \\
\hline$\overline{6}$ & 64 & 54 & 89 & 64 & 83 & & 39 & 108 & & & \\
\hline 7 & 58 & 22 & 82 & 62 & 26 & & 76 & 108 & & & \\
\hline$\overline{8}$ & 48 & 20 & 72 & 60 & 22 & & 50 & 108 & & & \\
\hline$\underline{9}$ & 43 & 23 & 21 & 55 & 70 & & 46 & 108 & & & \\
\hline 10 & 38 & 25 & 71 & 48 & $i 6$ & & 74 & 108 & & & \\
\hline 11 & $\pi$ & 27 & 60 & 39 & 46 & & 46 & 108 & & & \\
\hline 12 & & 28 & 3.5 & 13 & 46 & & 45 & 101 & & & \\
\hline 13 & & $\Lambda$ & 4 & 1 & 35 & & 44 & 7 & & & \\
\hline 14 & & & 1 & & 36 & & 46 & & & & \\
\hline$\sqrt{5}$ & & $T$ & 7 & & 1 & \pm & $x$ & & & & \\
\hline 16 & $t$ & 7 & 7 & & & $N G$ & & & & & \\
\hline$\pi$ & & & 7 & & 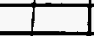 & 215 & & & & & \\
\hline 18 & & 7 & & & & 24 & 1 & 1 & & & \\
\hline$\sqrt{9}$ & & & $E$ & & & 129 & & & & & \\
\hline 20 & & 7 & 1 & & $T$ & 1 & $T$ & & & & \\
\hline 21 & & & 1 & & & 5 & & & & & \\
\hline 22 & & & & & $I$ & & & & & & \\
\hline$\frac{23}{24}$ & 7 & & & & 7 & & & & & & \\
\hline$\frac{24}{25}$ & & 1 & & $f$ & 1 & - & & & & & \\
\hline$\frac{56}{26}$ & & & 1 & $f$ & $\frac{1}{1}$ & - & 7 & & & & \\
\hline 27 & & I & 7 & $f$ & 1 & & $t$ & 1 & & & \\
\hline 28 & & & $L$ & $L$ & I & 1 & & I & & & \\
\hline 29 & & & & & 1 & & 7 & 1 & & & \\
\hline$\frac{30}{31}$ & & & & & $I$ & & & 1 & & & \\
\hline$\frac{31}{32}$ & & & & & & 7 & \pm & & & & \\
\hline$\frac{32}{\text { Probe }}$ & $I$ & \pm & 5 & 7 & $\nabla$ & 7 & 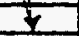 & 5 & & & \\
\hline $\begin{array}{l}\text { Probe } \\
\text { No. }\end{array}$ & & & & & & & & & & & \\
\hline & & & & & & & & & & & \\
\hline Time & $D$ & 15 & & . & & & & & & & \\
\hline
\end{tabular}

This sheet is for recording temperatures of underground tanks for those situations which are not covered by routine S.O.P. data sheets. Transfers between tanks is frequently a situation where temperature monitoring is needed and a uniform data sheet form is conventent for the operator.

MC Fraser 12-18-71 


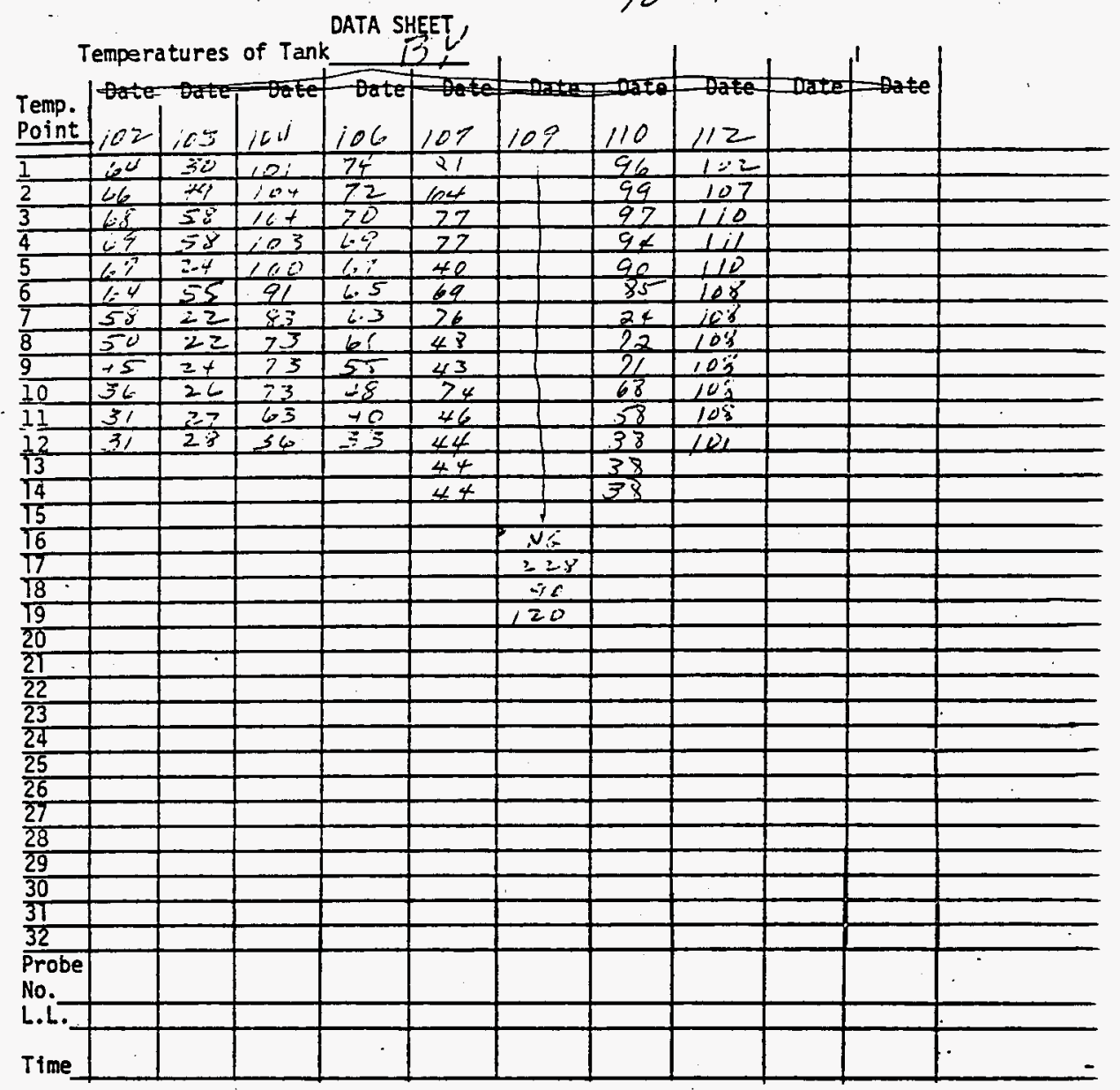

This sheet is for recording temperatures of underground tanks for those situations which are not covered by routine S.O.P. data sheets. Transfers between tanks is frequently a situation where temperature monitoring is needed and a uniform data sheet form is conventent for the operator.

MC Fraser 12-18-71 
Title: FROFIIE TOTERATURES IV ITS-2 BOTTOMS TAIKS

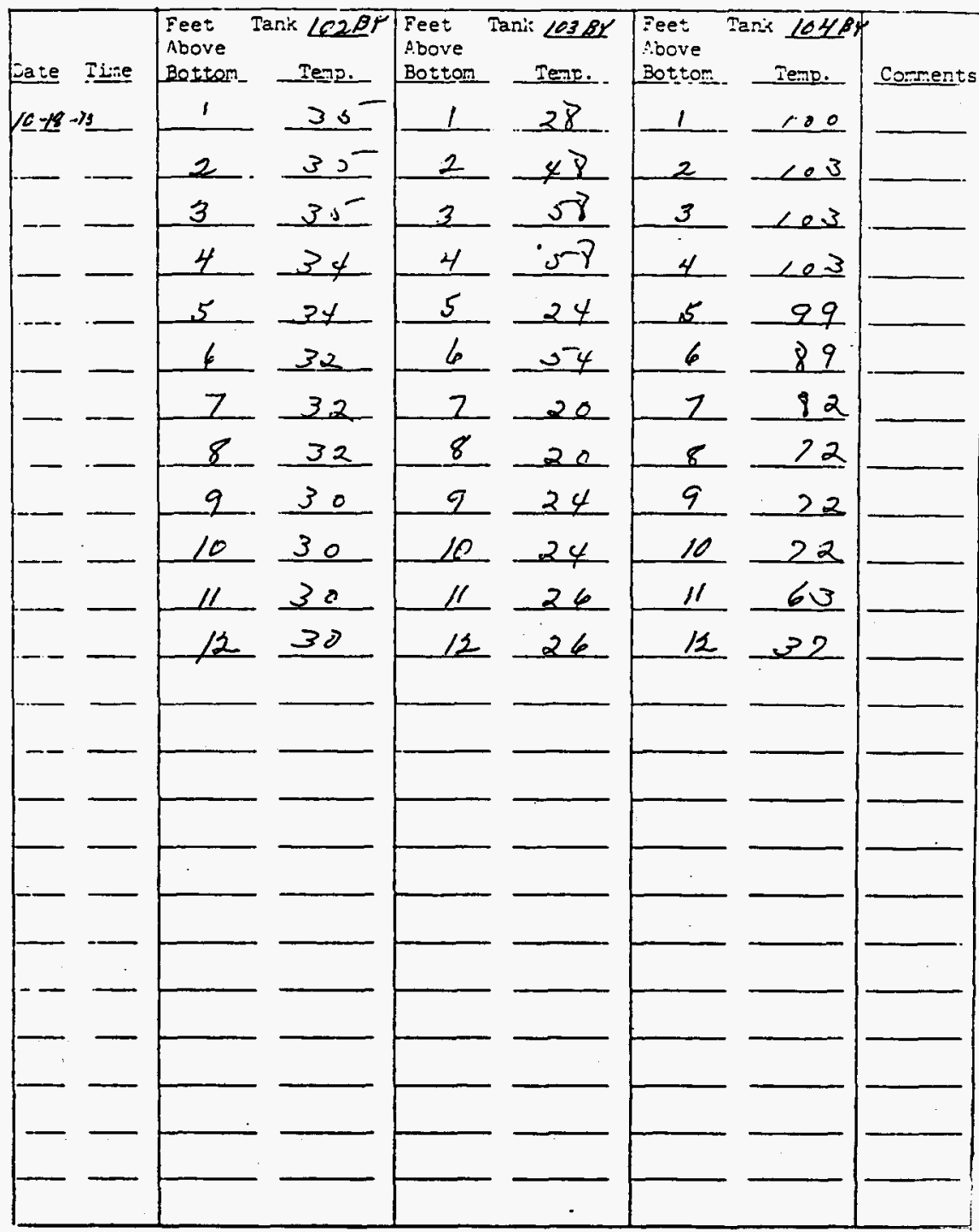

Ir:s:r:e:tans or coments: - Take profile temperatures veekly in each bottoms tenk. Attach conpleted forg to Monday and Thursday's Data sheets. 
Title: PROFILE TERERATURES IN ITS-2 SOTTOMS TAHTS

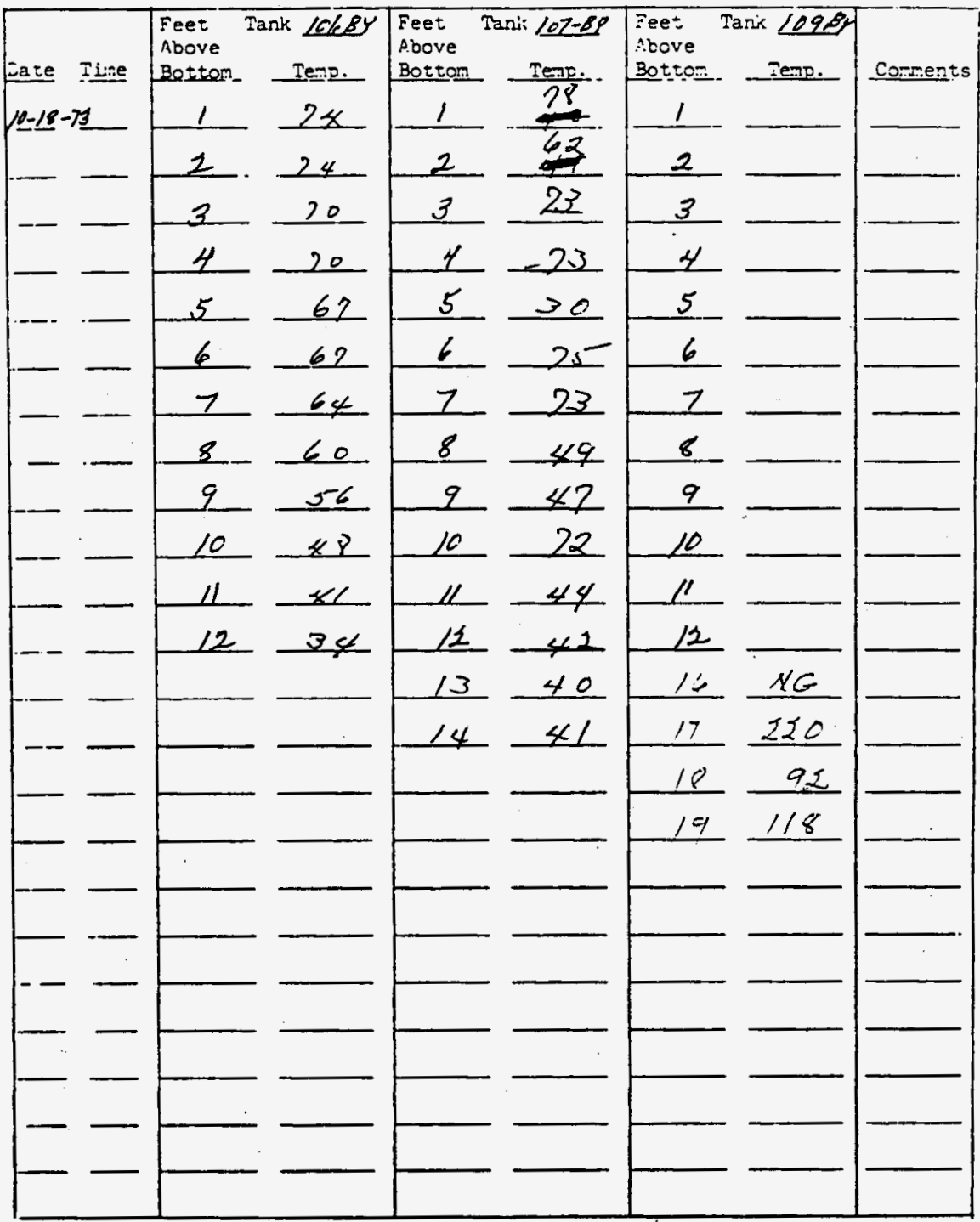

Ir:j:rations ar comen's: - Pake proflie temperatures veekly in each bottons tank. Attech conpleted forz to Monday and Thursday's Date Sheets. 
Title: PROFILE TERERATURES IN ITS-2 BOTTOMS TANKS

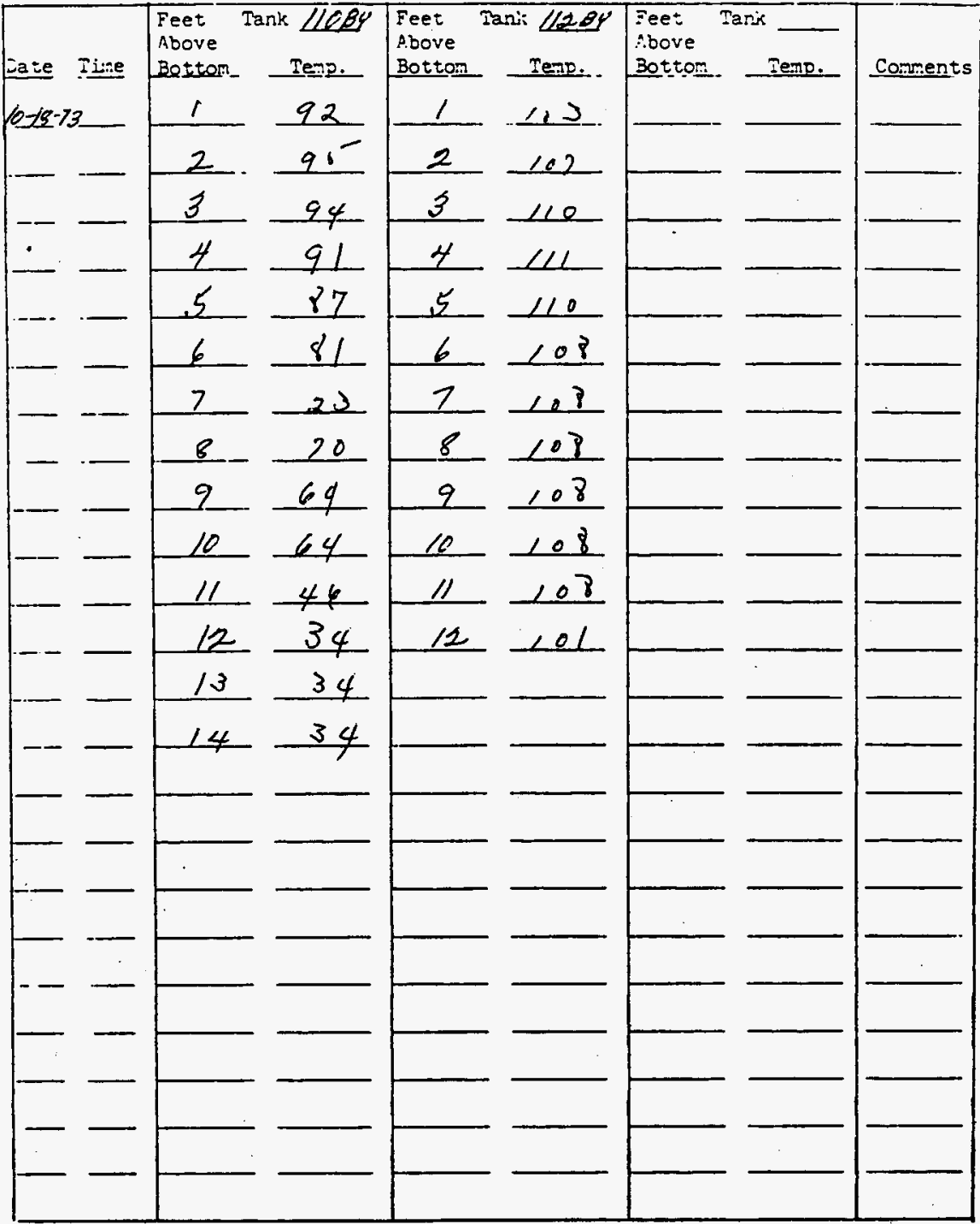

Insirations or connenss: Take prorlle temperatures veekly in each bottoms tank. Attach conpleted form to Monday and Thursday's Data Sheats. 
Title: PROFILE TERERATURES IV ITS-2 BOTTONS TANKS
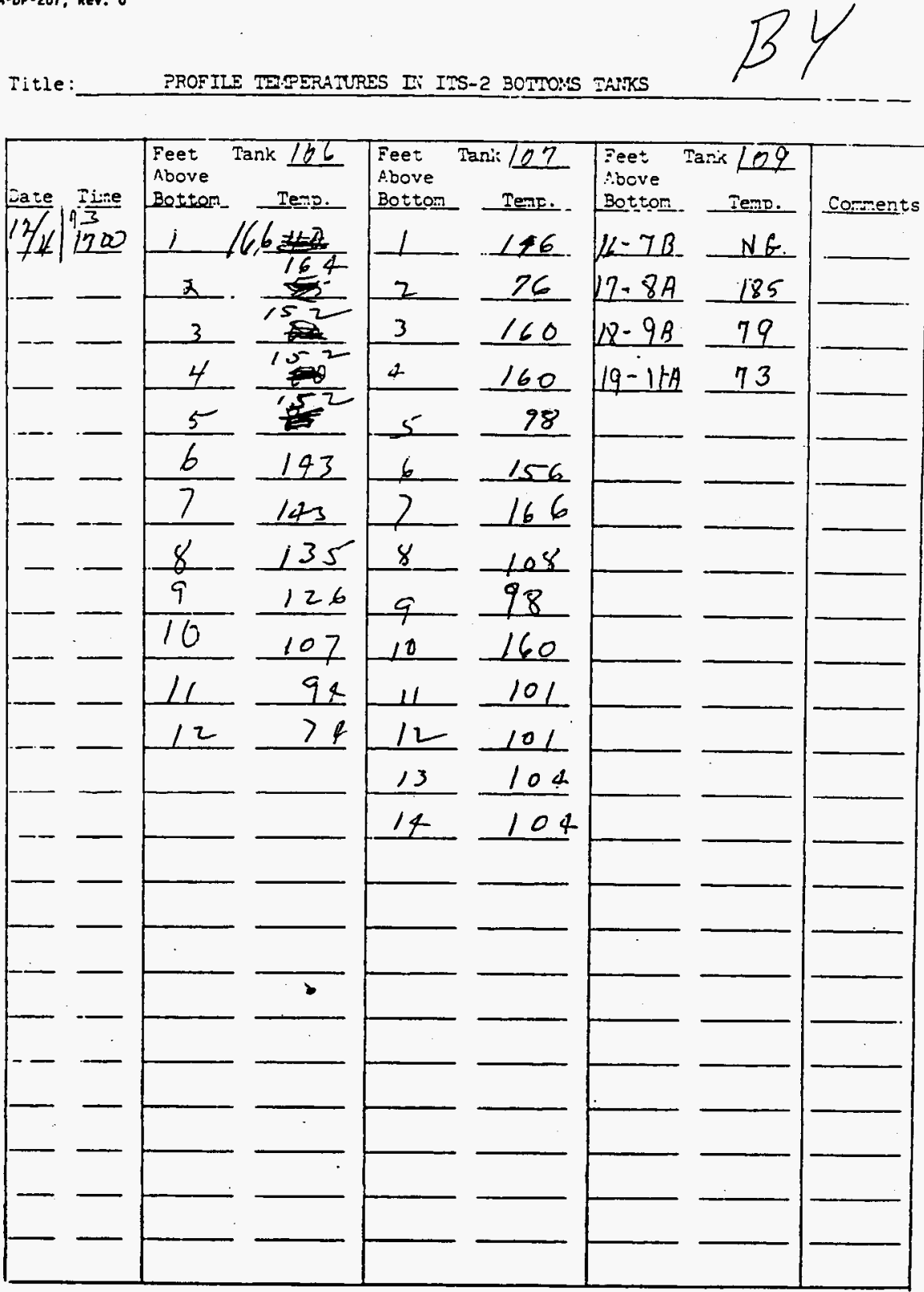

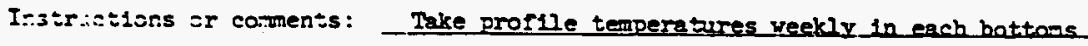
tank. Attach conpleted forit to Monday and Thursday's Data Sheets. 
Title:

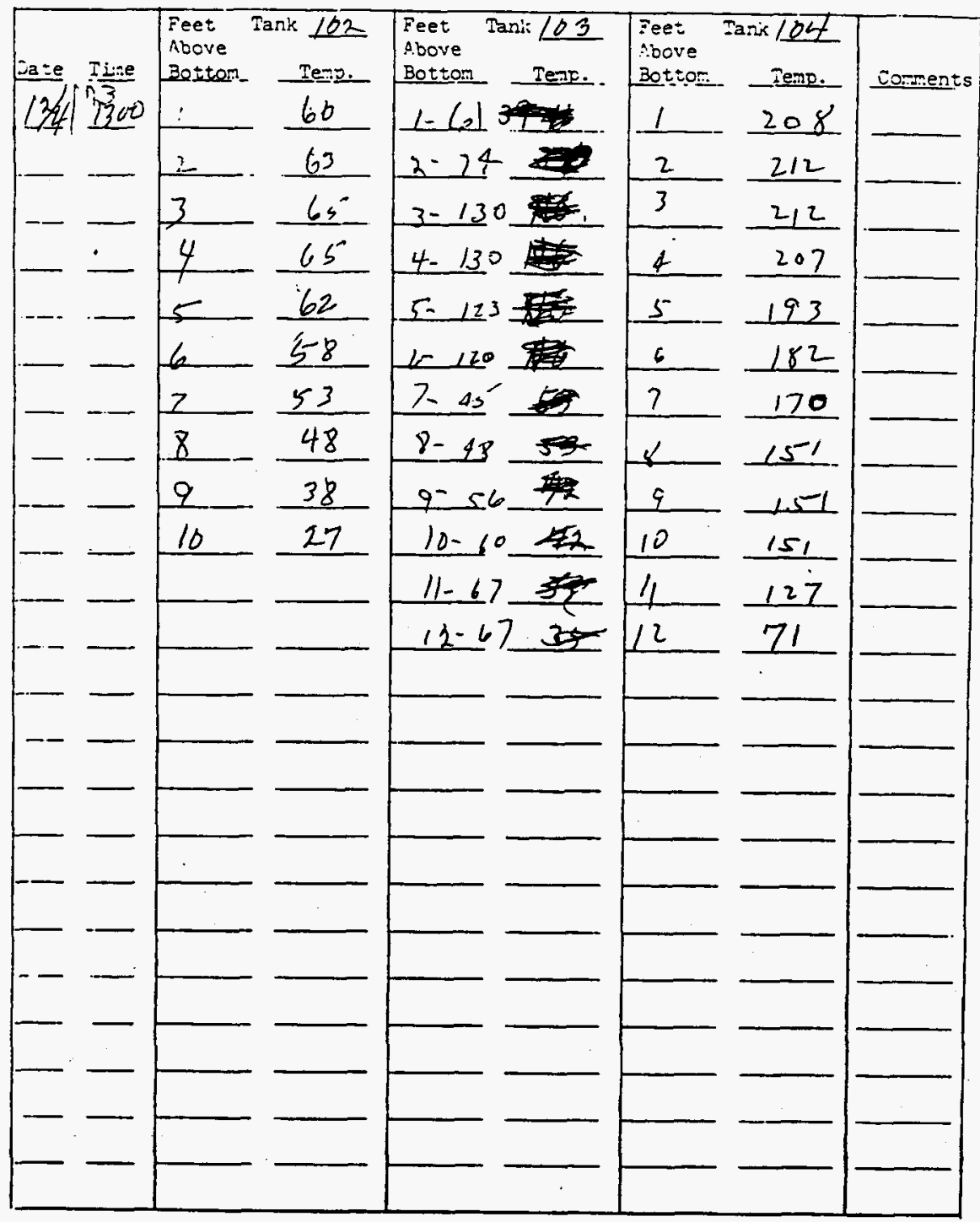

Instr:sizns or coments: - Take proflle temperatures weekly in each battoms tank. Attach conpleted form to Monday and Thursday's Data Sheats. 
Title: PROFIIE TDPERAIURES IH ITS-2 BOTTONS TAITS

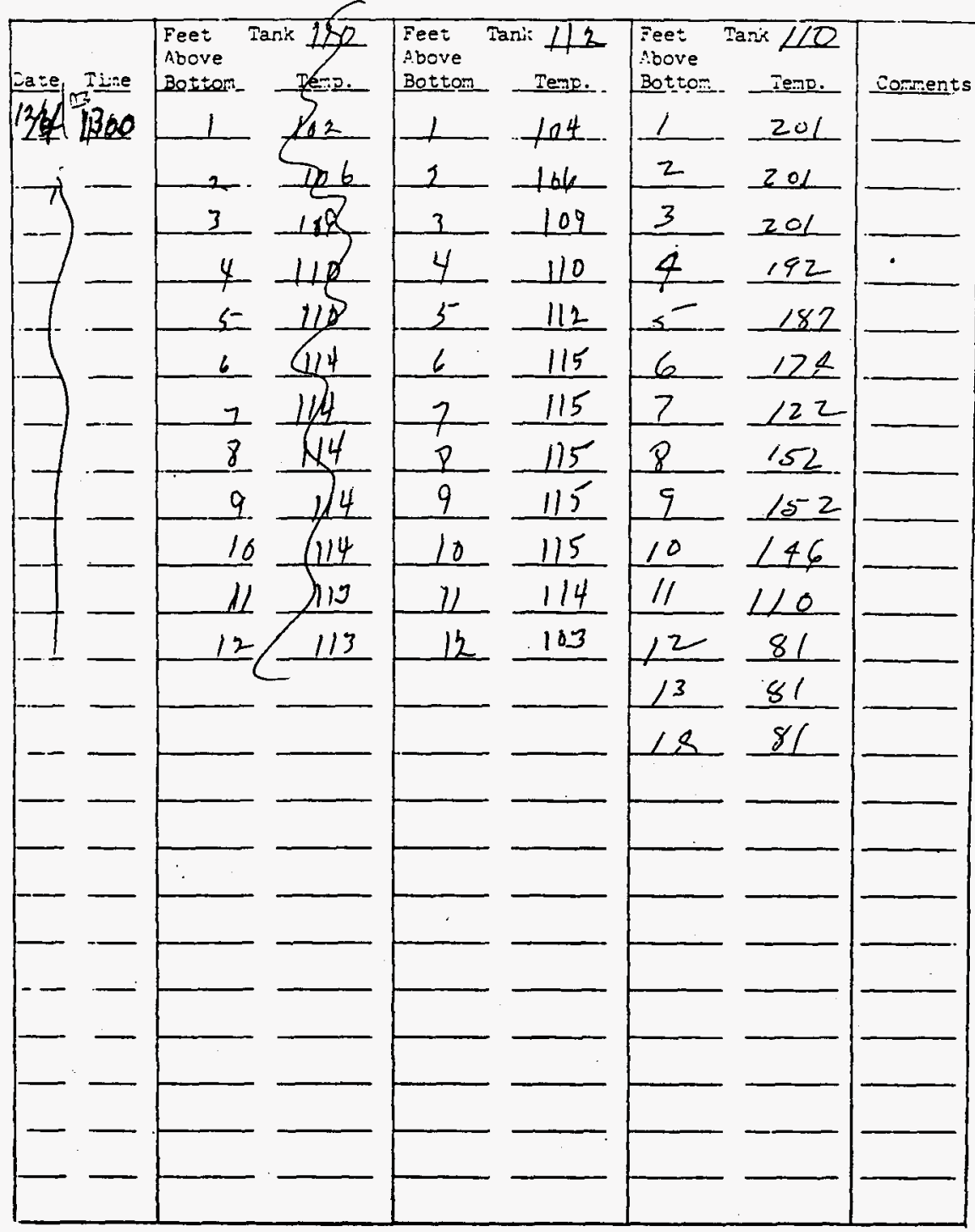

(' Irstrietions ar comen's: - Take froflie temperatures veekly in each bottoms tank. Attach completed form to Monday and Thursday's Data sheets. 
Title: PROFILE TEPERATURES IR ITS-2 BOTTOMS TAMKS

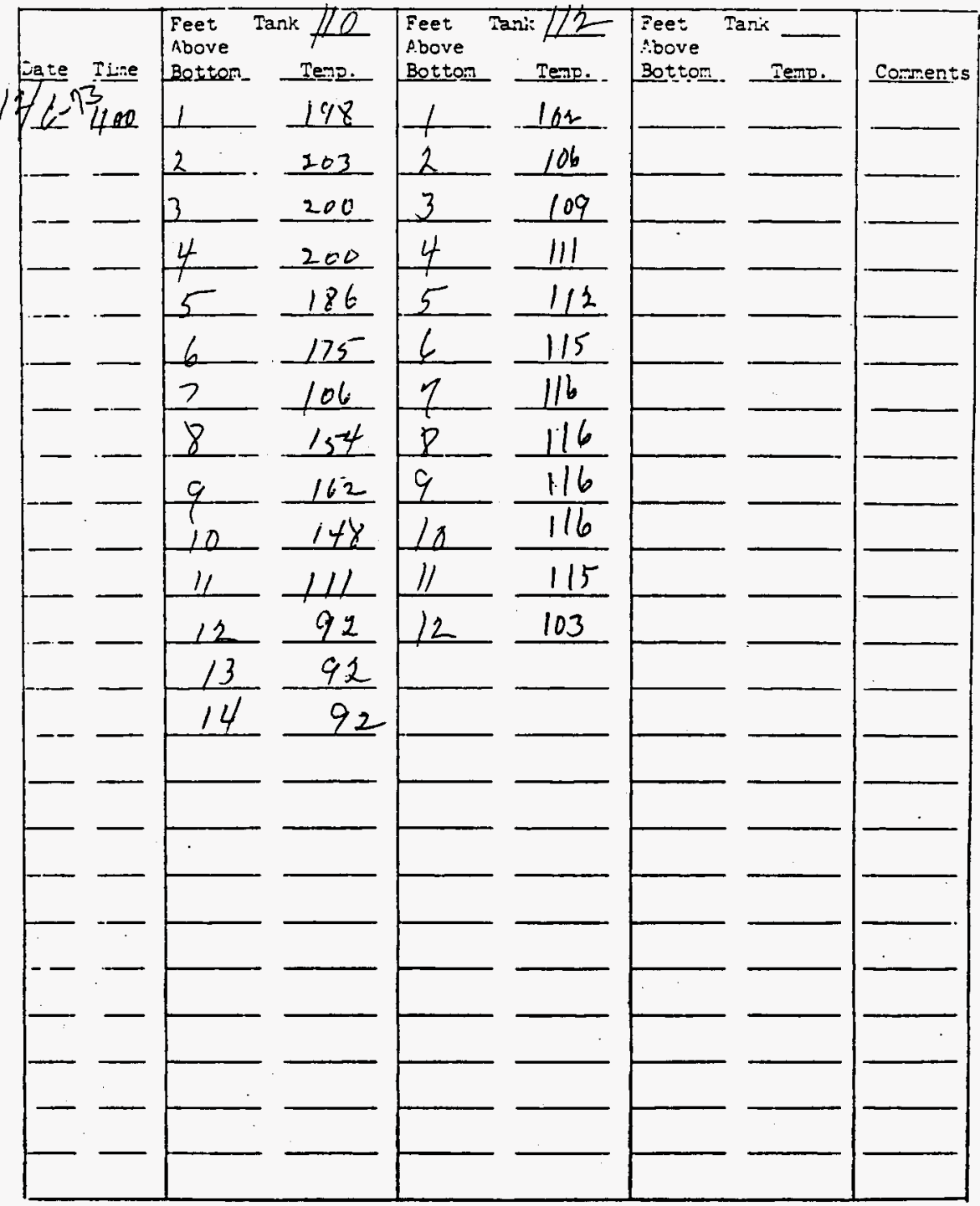

In:3is:tisns sr coments: - Take proflie temperatures weekly in each battoms tank. Attach corpleted form to Monday and Thursday's Data Sheets. 


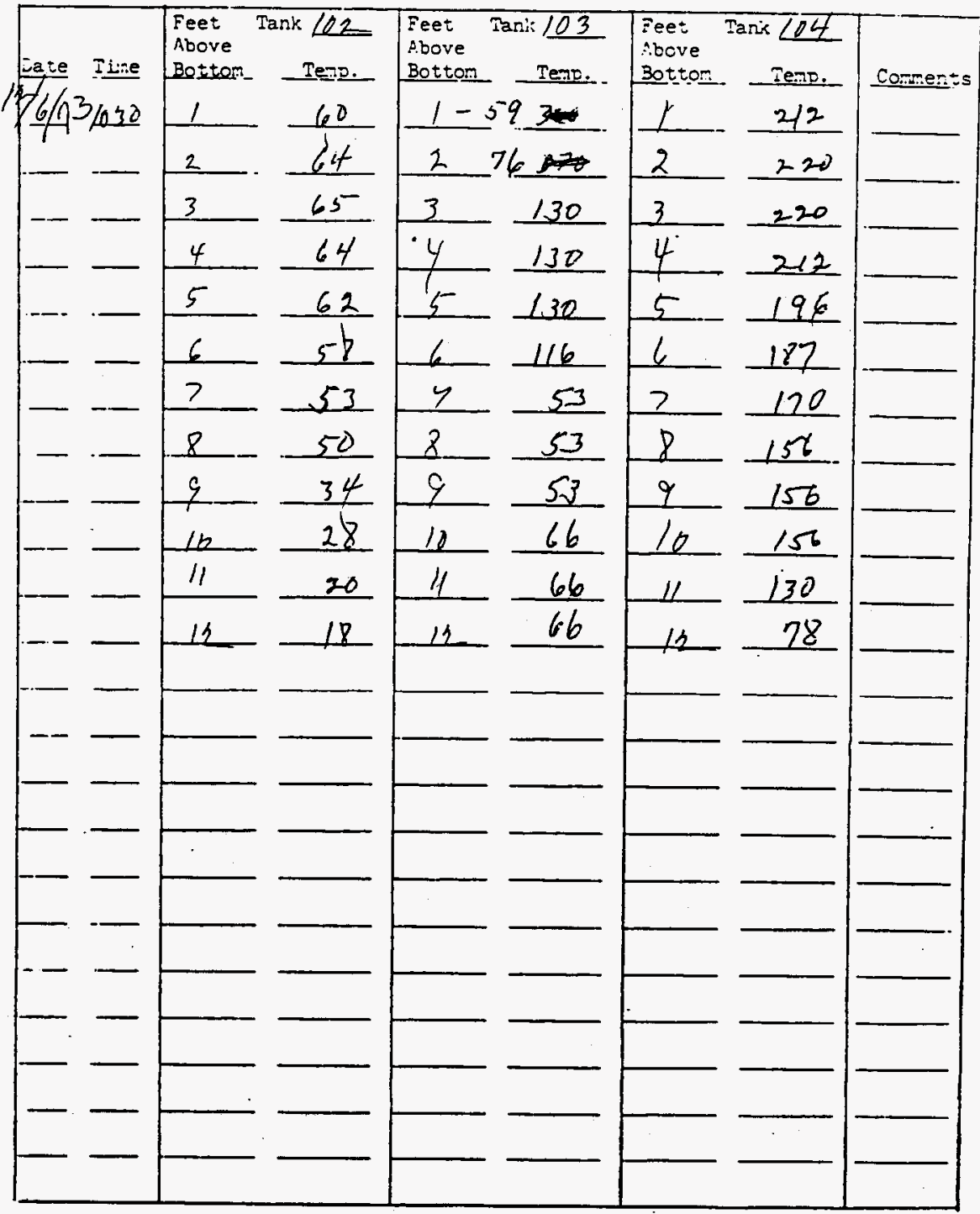

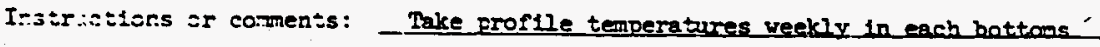
tank. Attach conpleted for to Monday and Thursday's Date Sheets. 
Titie : PROEILE TZPERATURES II ITS-2 BOTMONS TANKS

(.

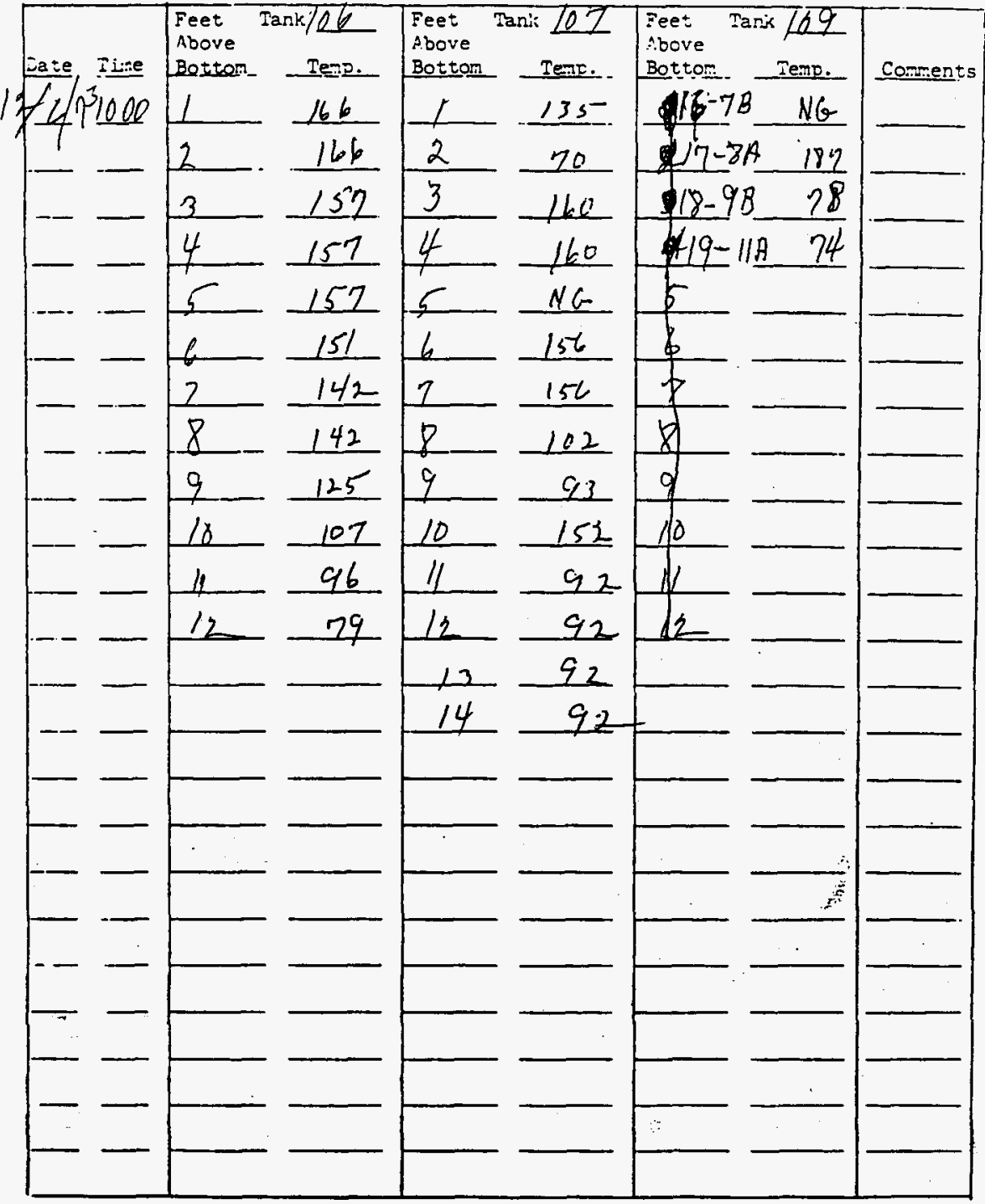

Irstristizns ar conmenis: - Take profile temperatures veekly in each battoms tenk. Attech completed form to Monday and Thursday's Date Sheets. 
Title: PROFIIE TEFERATURES II ITS-2 BOTTOMS TANKS

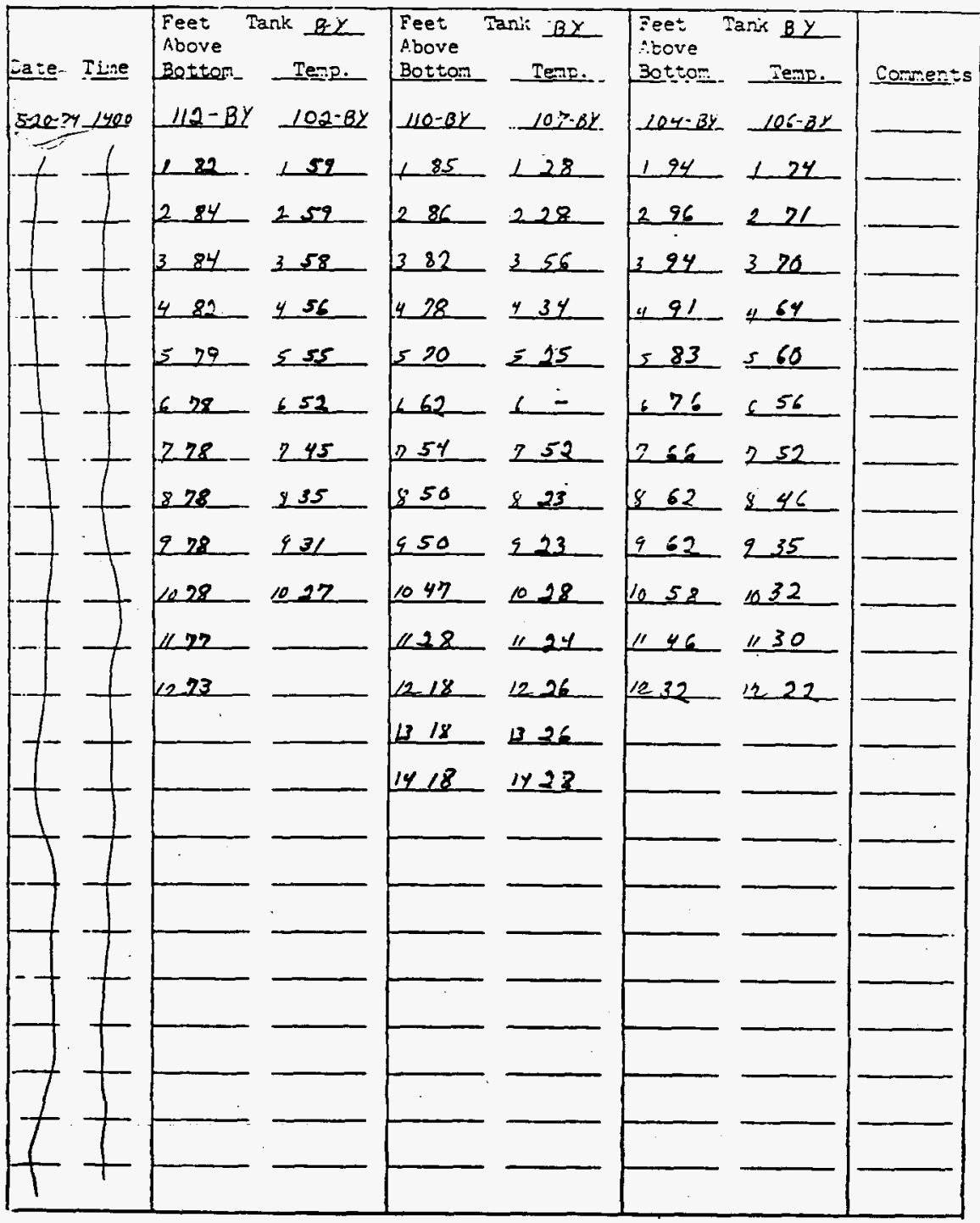

Irsir.itions or coments: - Take proryle tempergtares yeekly in each botitoms. tank. Attach corpleted form to Monday and Thursday's Data Sheets. 


\section{DATA SHEET}

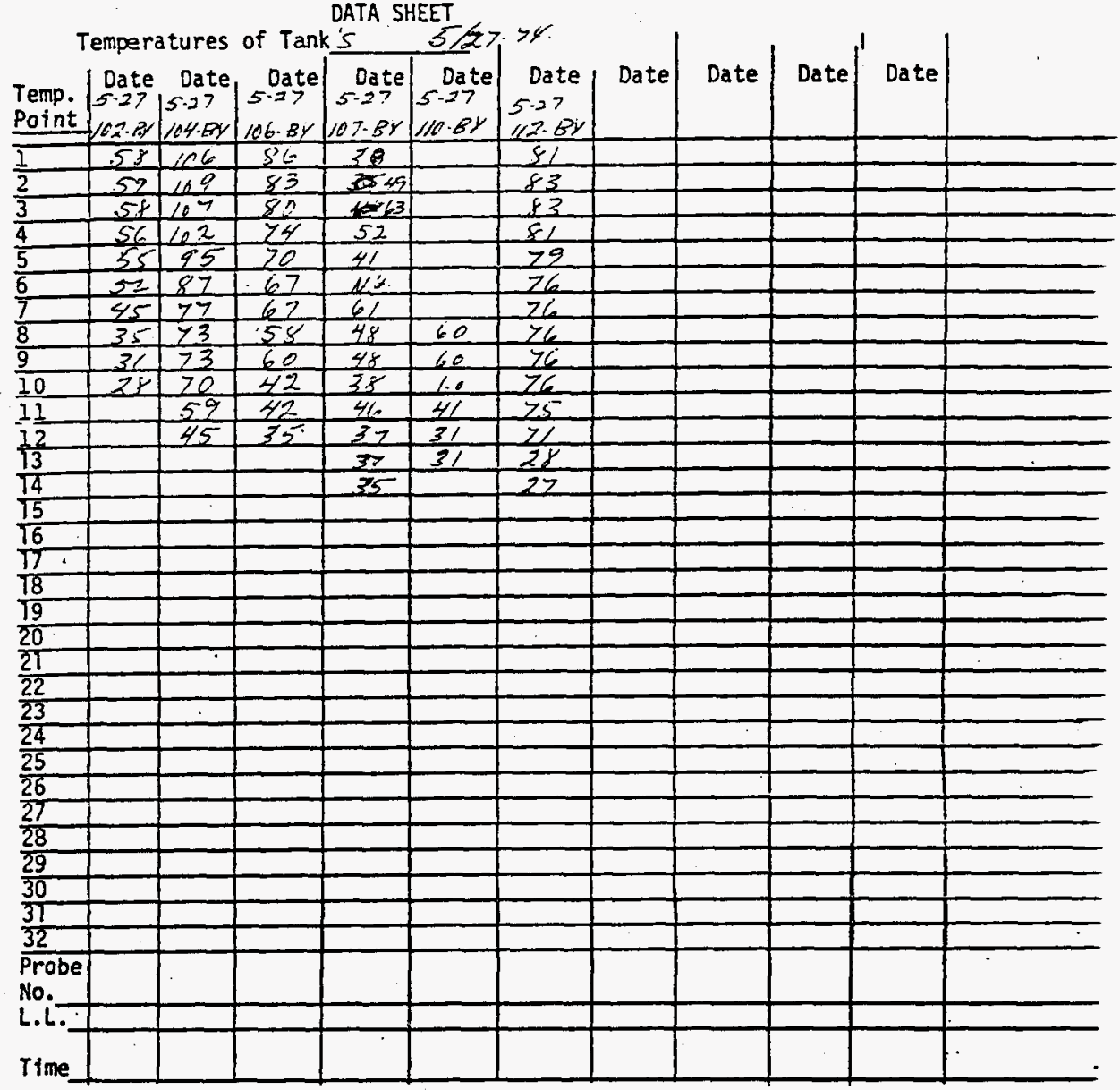

This sheet is for recording temperatures of underground tanks for those situations which are not covered by routine S.0.P. data sheets. Transfers between tanks is frequently a situation where temperature monitoring is needed and a uniform data sheet form is conventent for the operator.

\section{Fraser 12-18-71}




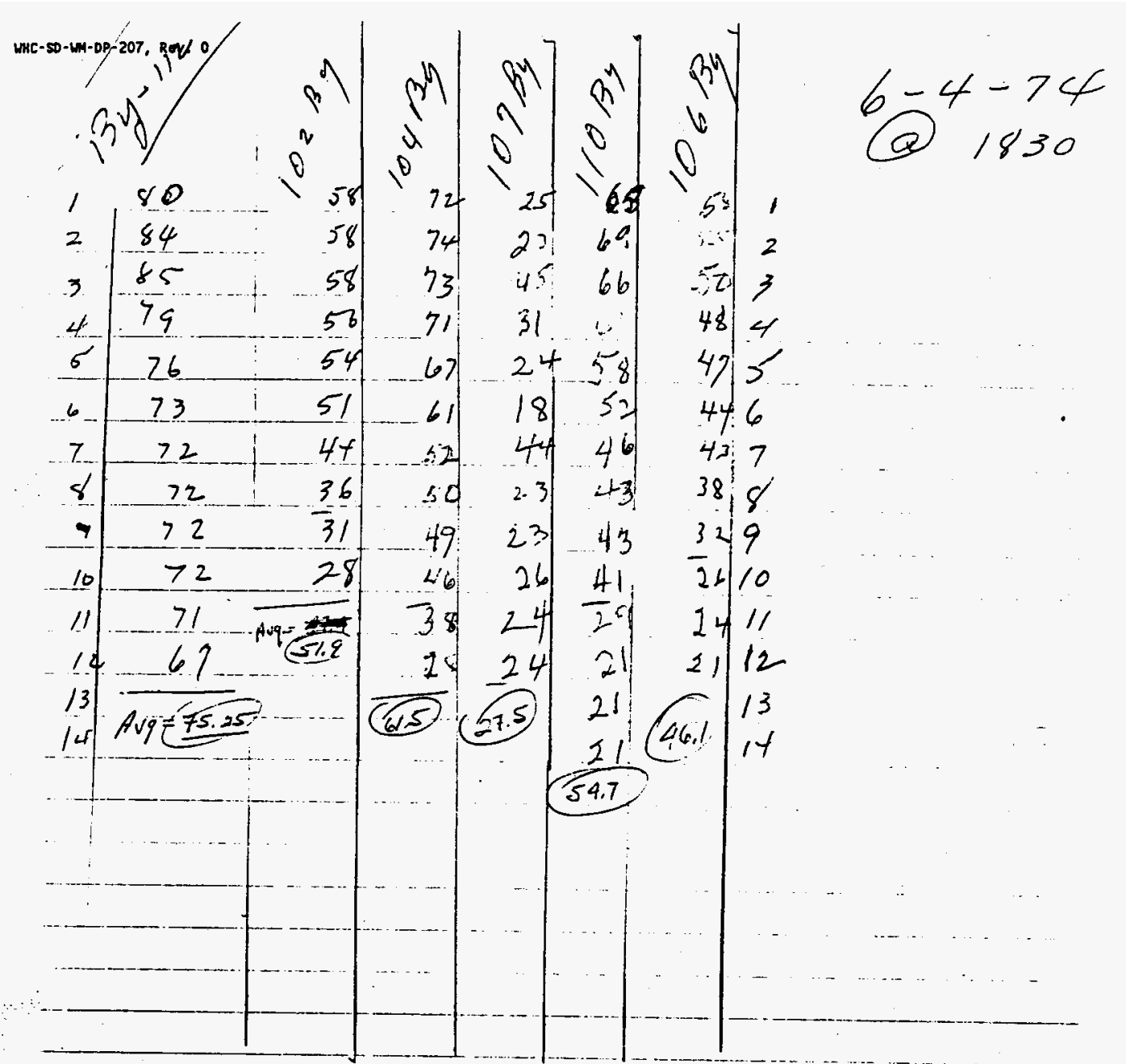


Title: FROFILE TERTERATURES III ITS-2 BOTTOMS TANKS

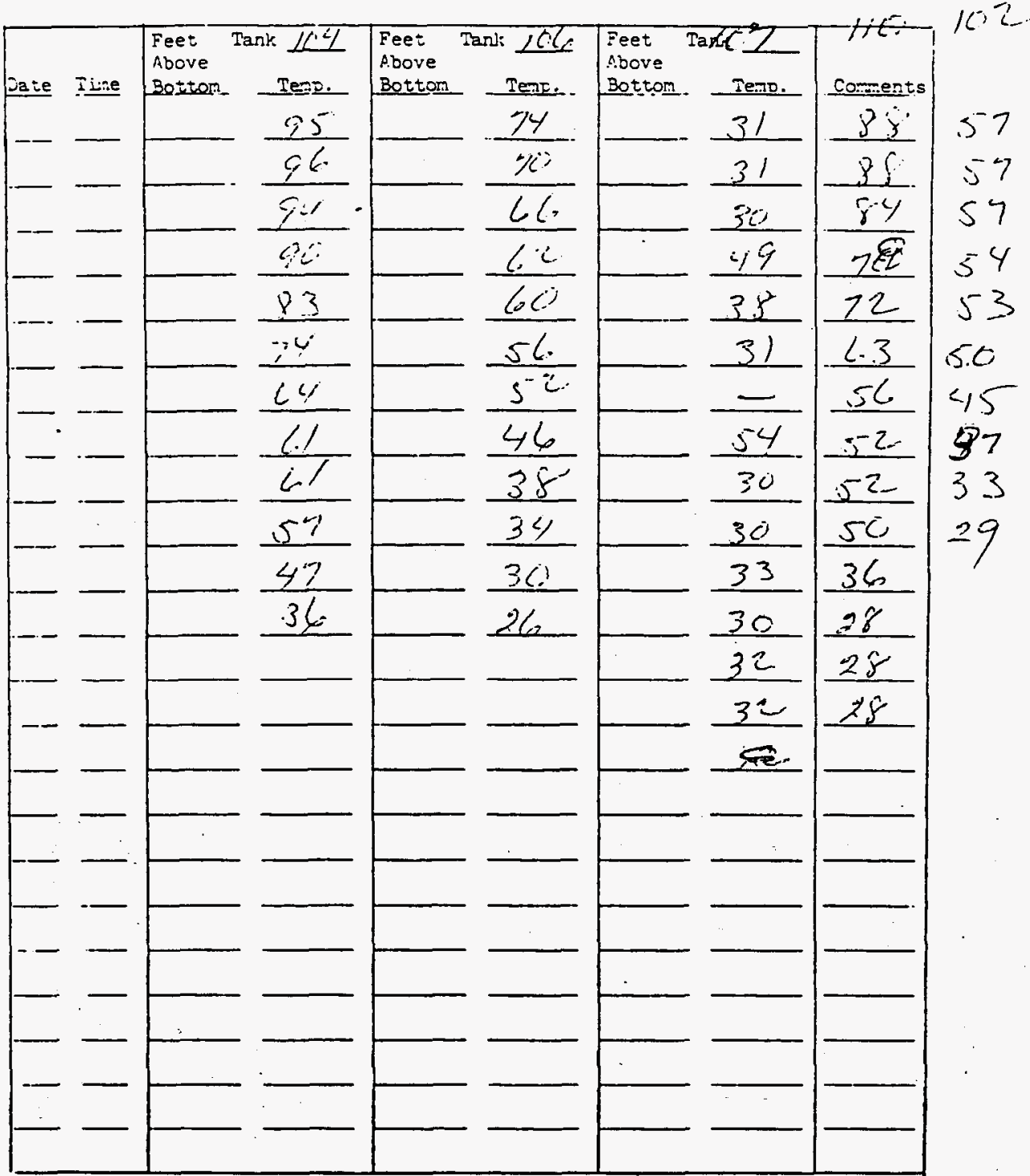

Instr:sticrs ar caments: - Take profile temperatares weekly in mach bottoms tank. Attach conpleted fora to Monday and Thursaay's Data Sheots. 
Title: FROFILE TEFERAZUESS II ITS-2 SOTTOMS TAIKS

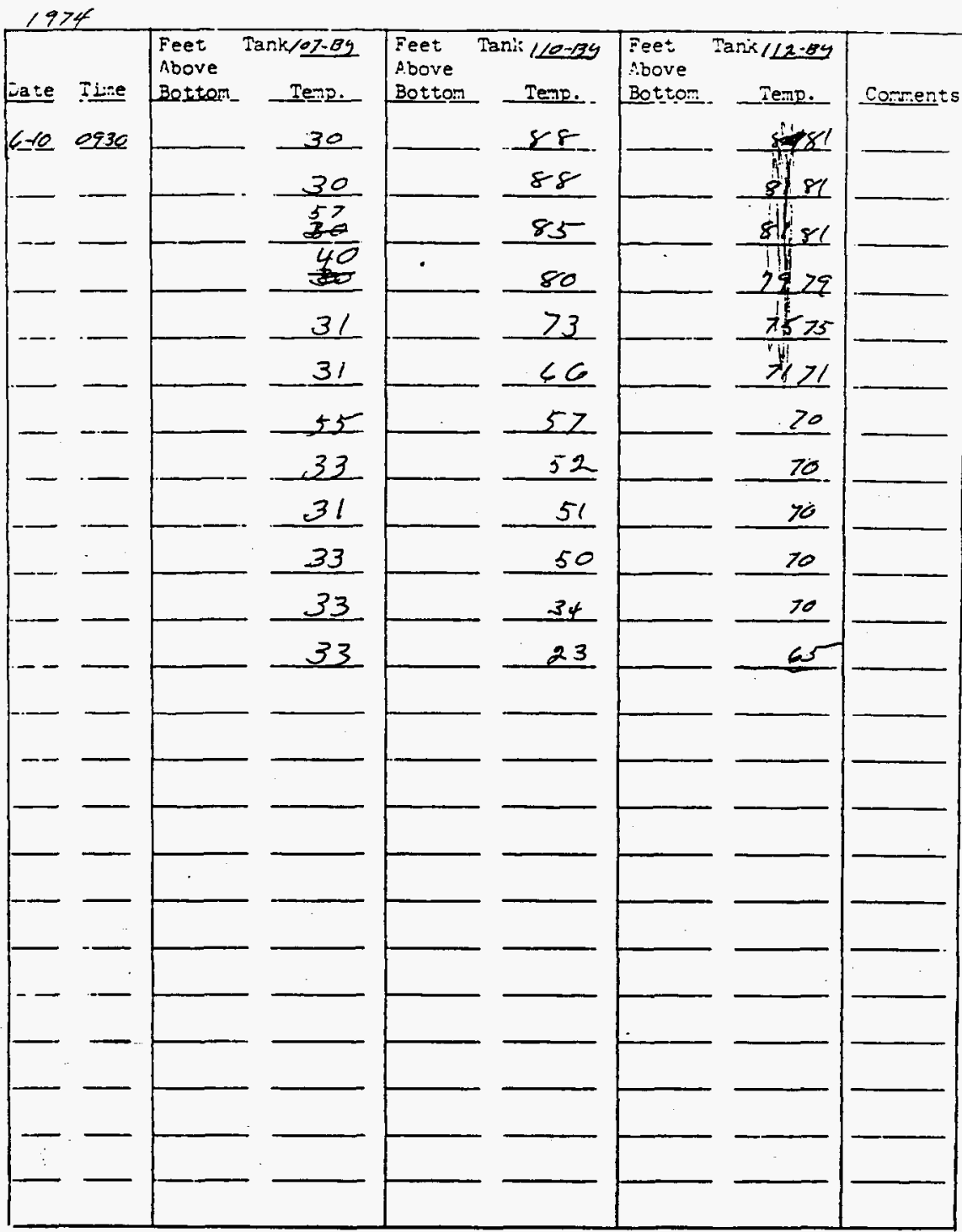

Ins:ratisrs or coments: - Take proflle temperatures veekly in each bottoms tank. Attach completed form to Monday and Thursday's Data Sheets. 
Title: PROFILE TIRERATURES TV ITS-2 BOTTONS TANKS

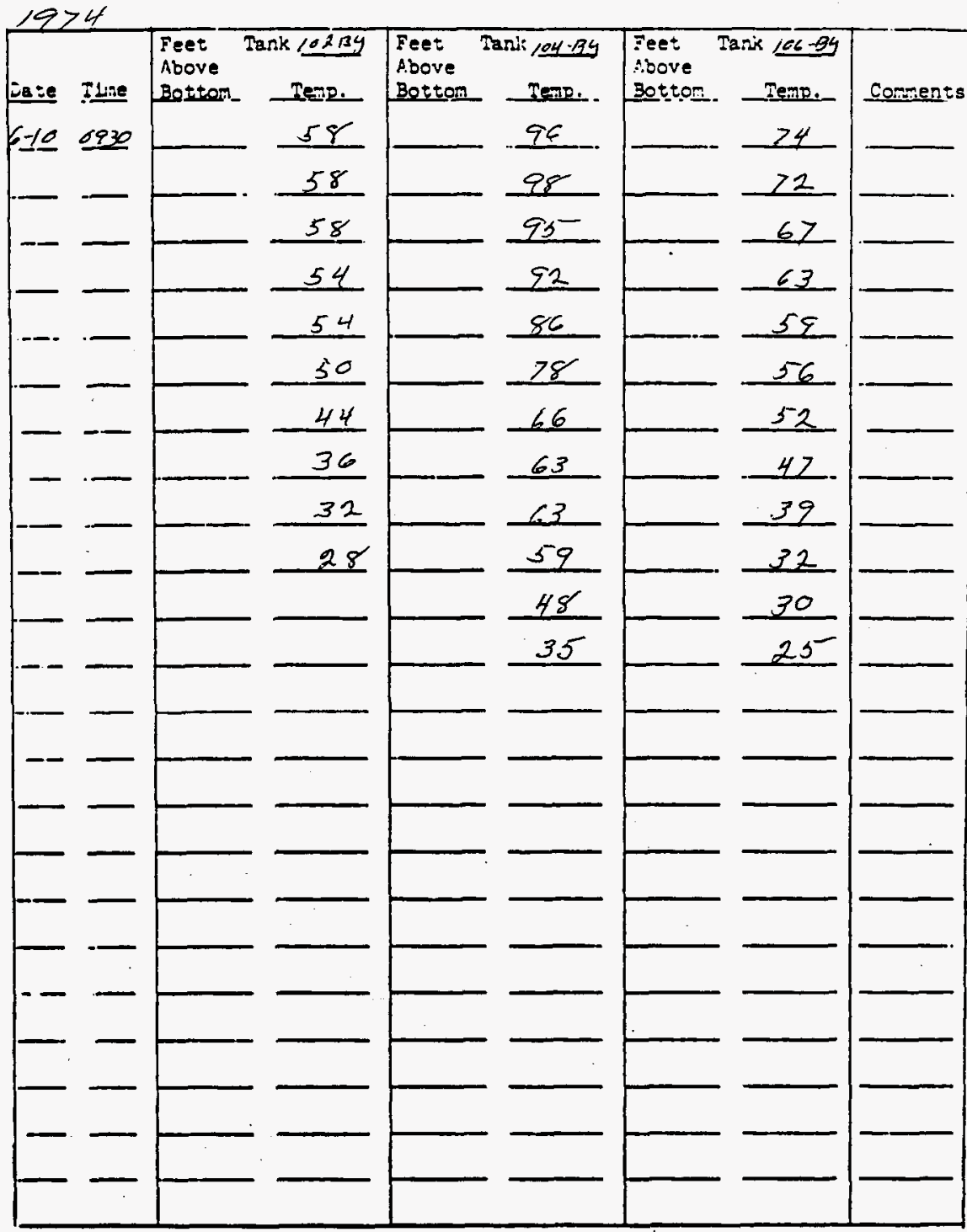

Ir:3:r:stisns or coments: - Trke proplile temperaturen veekly in ench hottoms 
Title: PROFILE TERPERATURES IN ITS-2 BOTTOMS TAITS

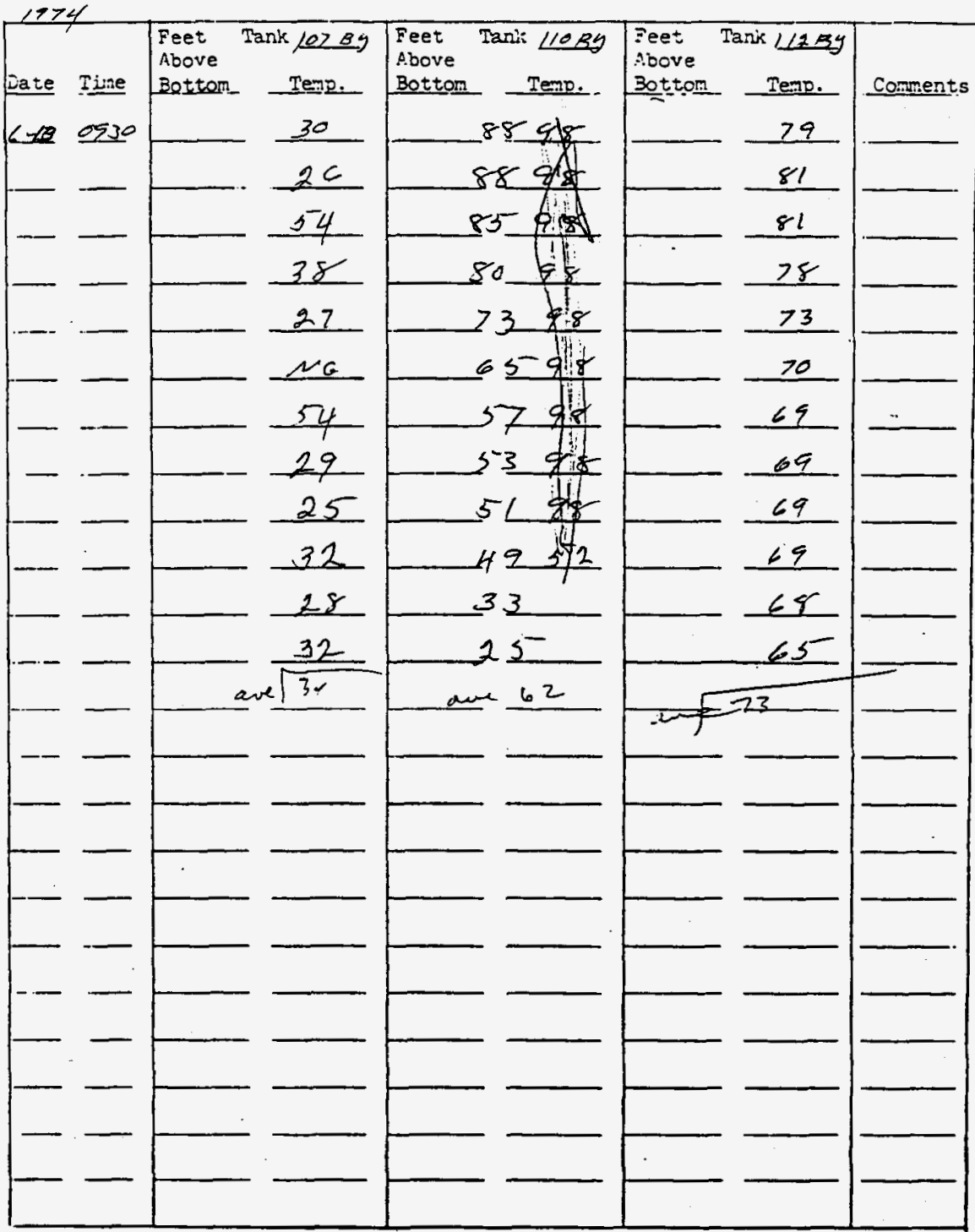

I.stristions or coments: Take proflle temperatures weekly in each bottons tank. Attach completed form to Monday and Thursday's Data sheets. 
Title :

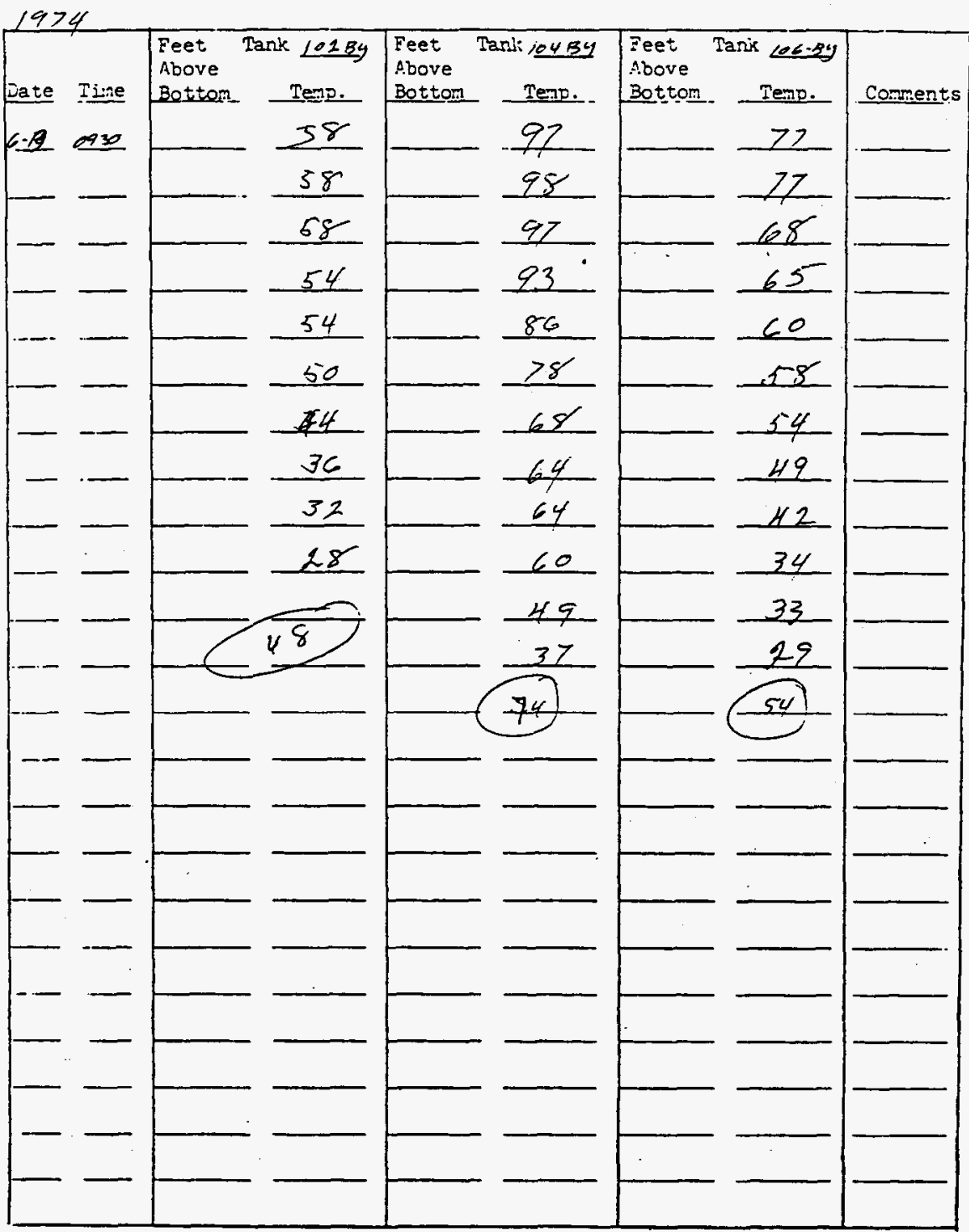

Instrictions or coments: - Take profile temperetures weekly in rach bottoms

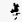

tank. Attach completed forr to Monday and Thursday's Data sheets. 
Titie: PROFIIE TRIPERATURES IN ITS-2 BOTTOMS TANKS

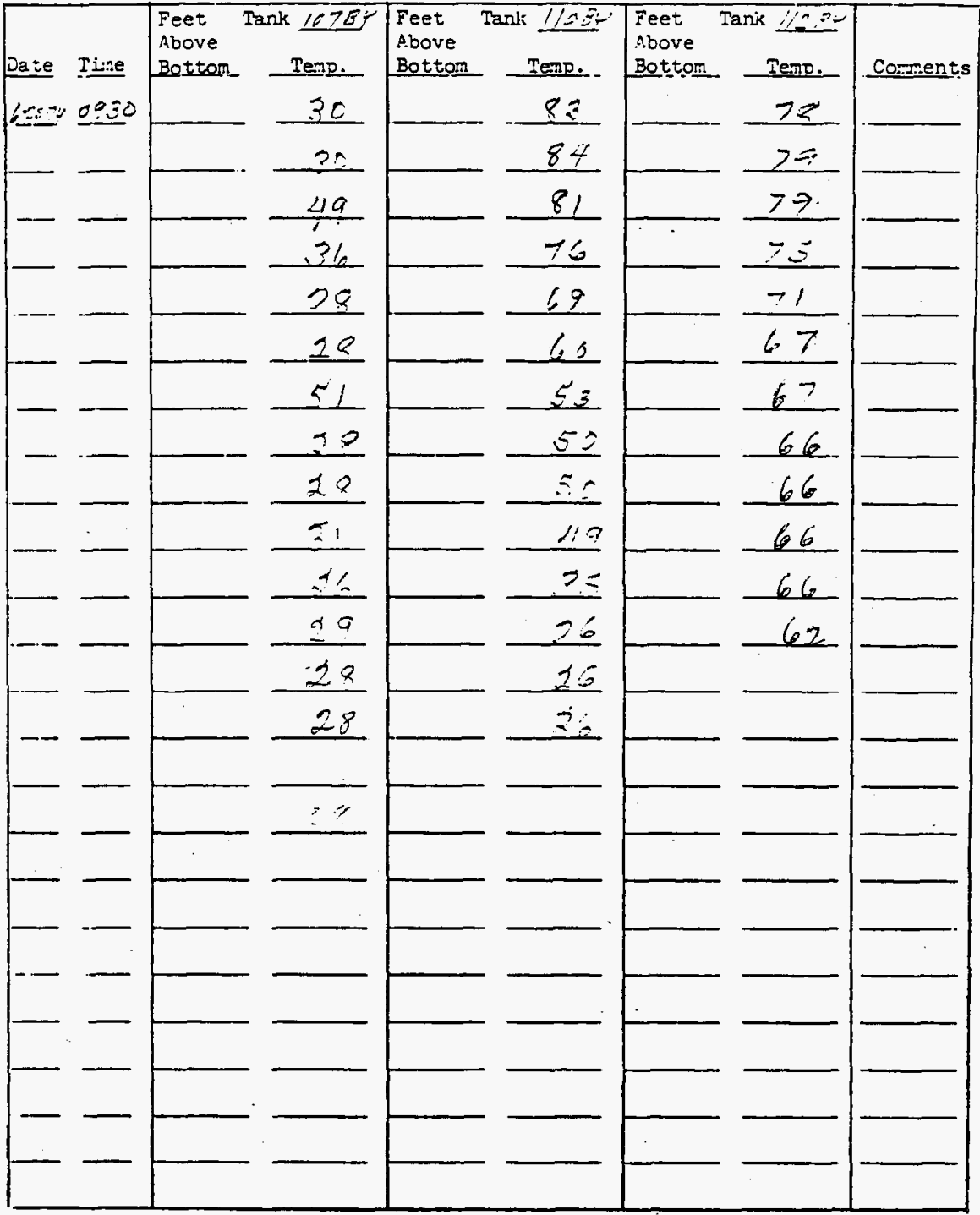

Irstriations ar coments: - Take profile temperetures weekly in each battoms tank. Attach completed forn to Monday and Thursday's Data Sheets. 
Title: PROFILE TERERATURES IN ITS-2 SOTTOMS TANKS

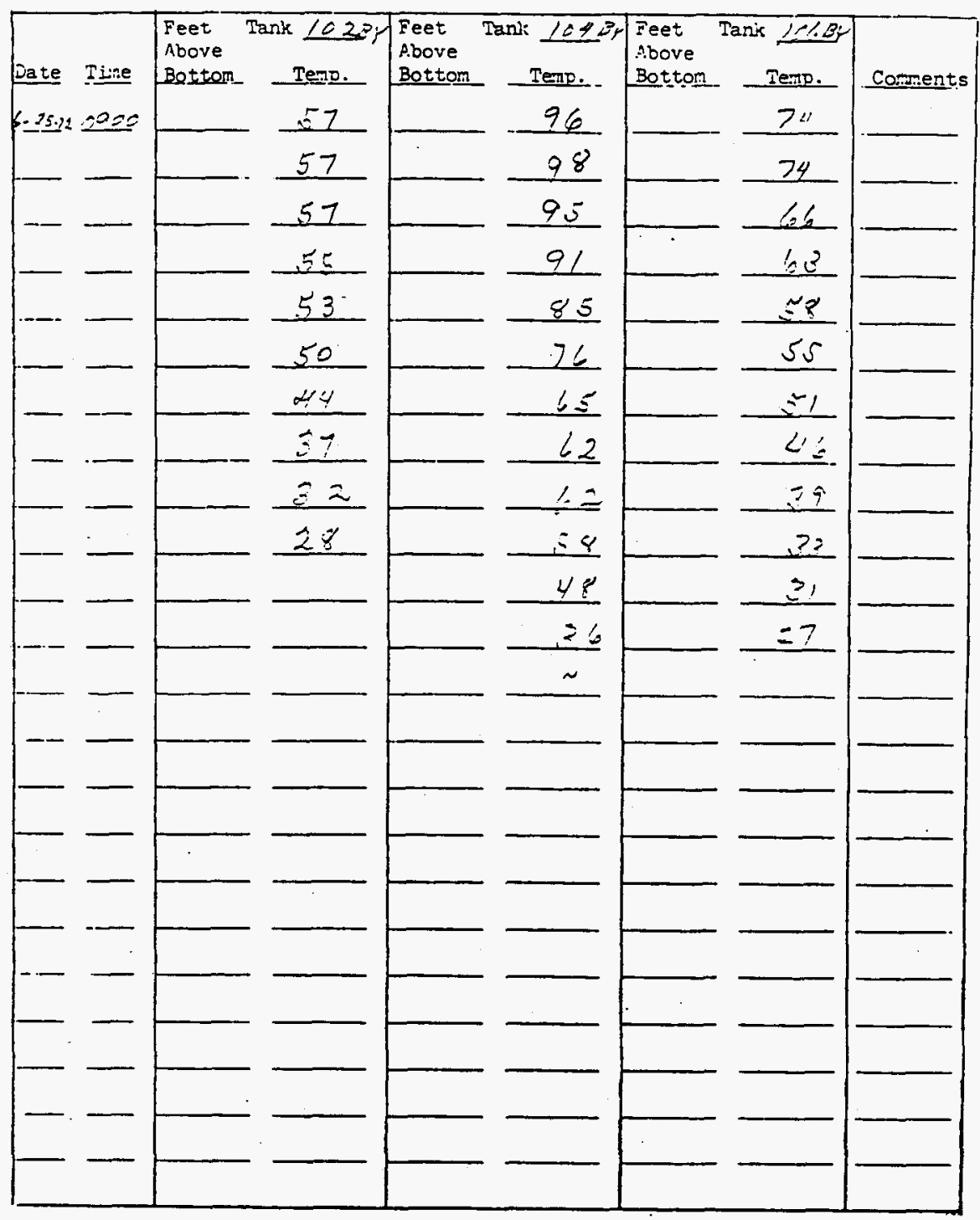

I::3triations or conments: - Take prof lle temperetures weekly in each battoms tank. Attach conpleted form to Monday and Thursday's Data Sheets. 
Title:

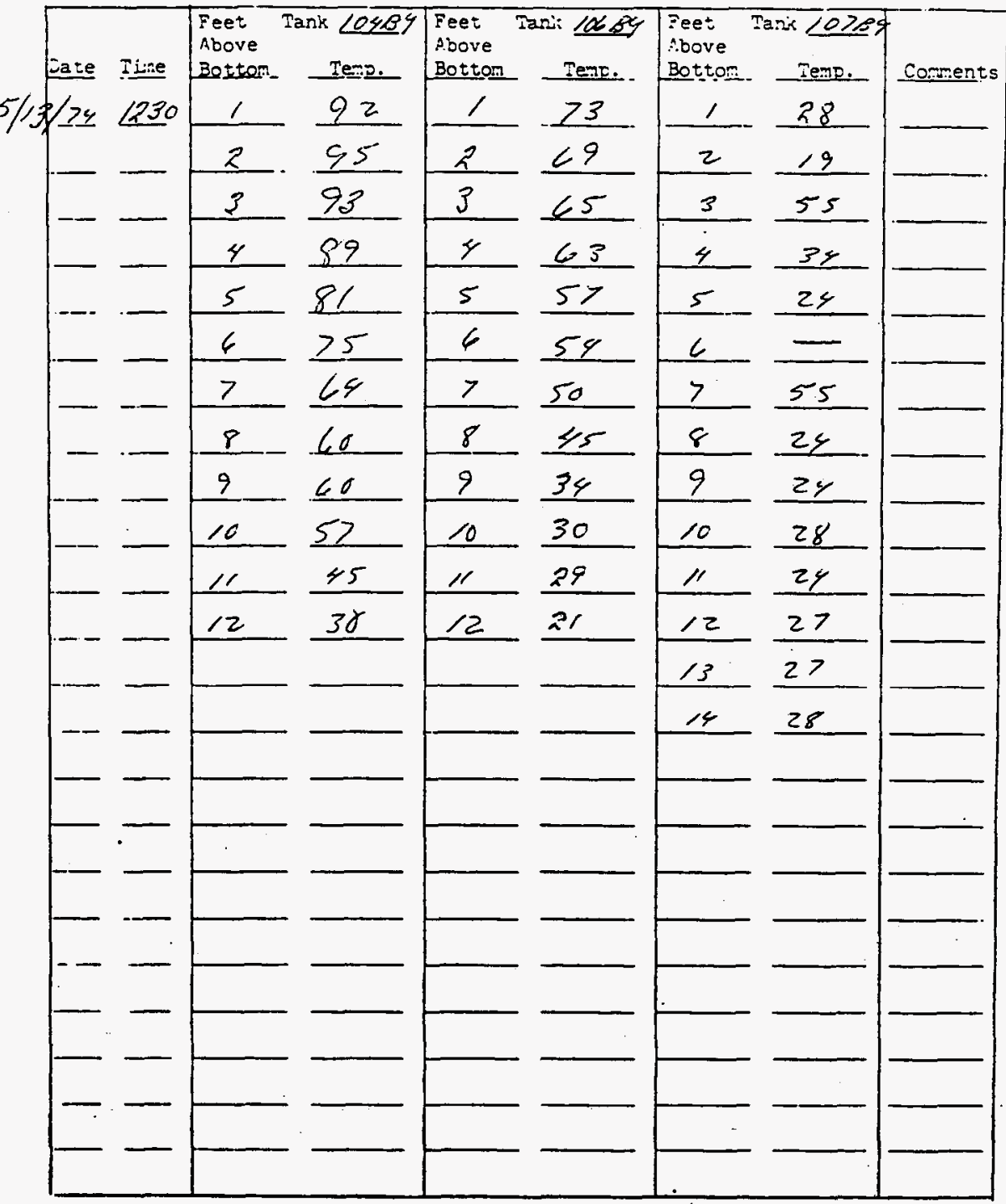

I-3tr:-isons or comenss: - Take prorile temperetures weekly in each battoms tank. Attach conpleted form to Monday and Thursday's Data Sheets. 
Title: PROFIIE TETERATURES II ITS-2 BOTTOMS IAIRS

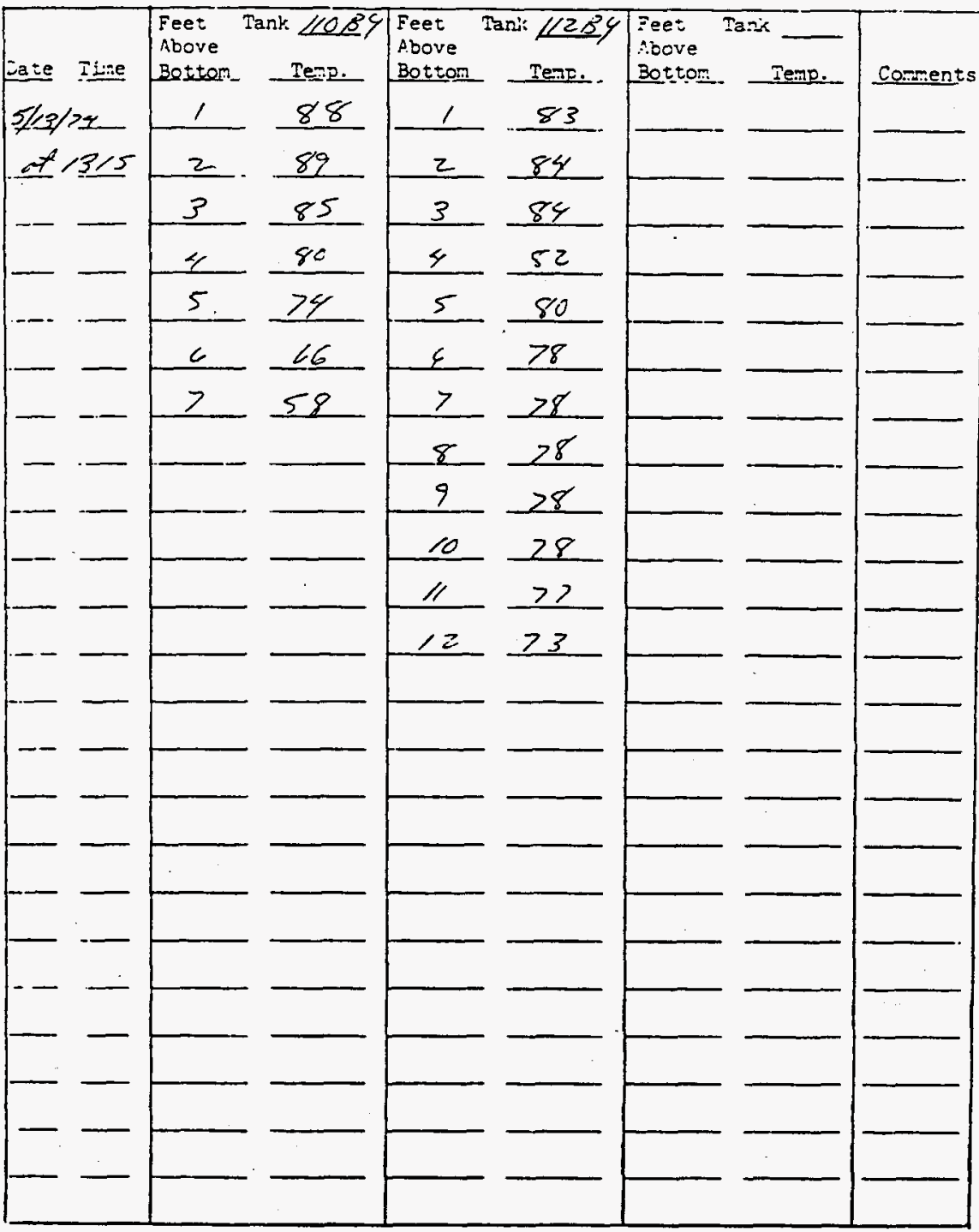

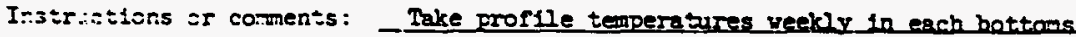
tank. Attach completed form to Monday and Thursday's Data Sheets 
Title: FROFILE TEFERATURES II ITS-2 BOTTOMS IAIKS bVR-C

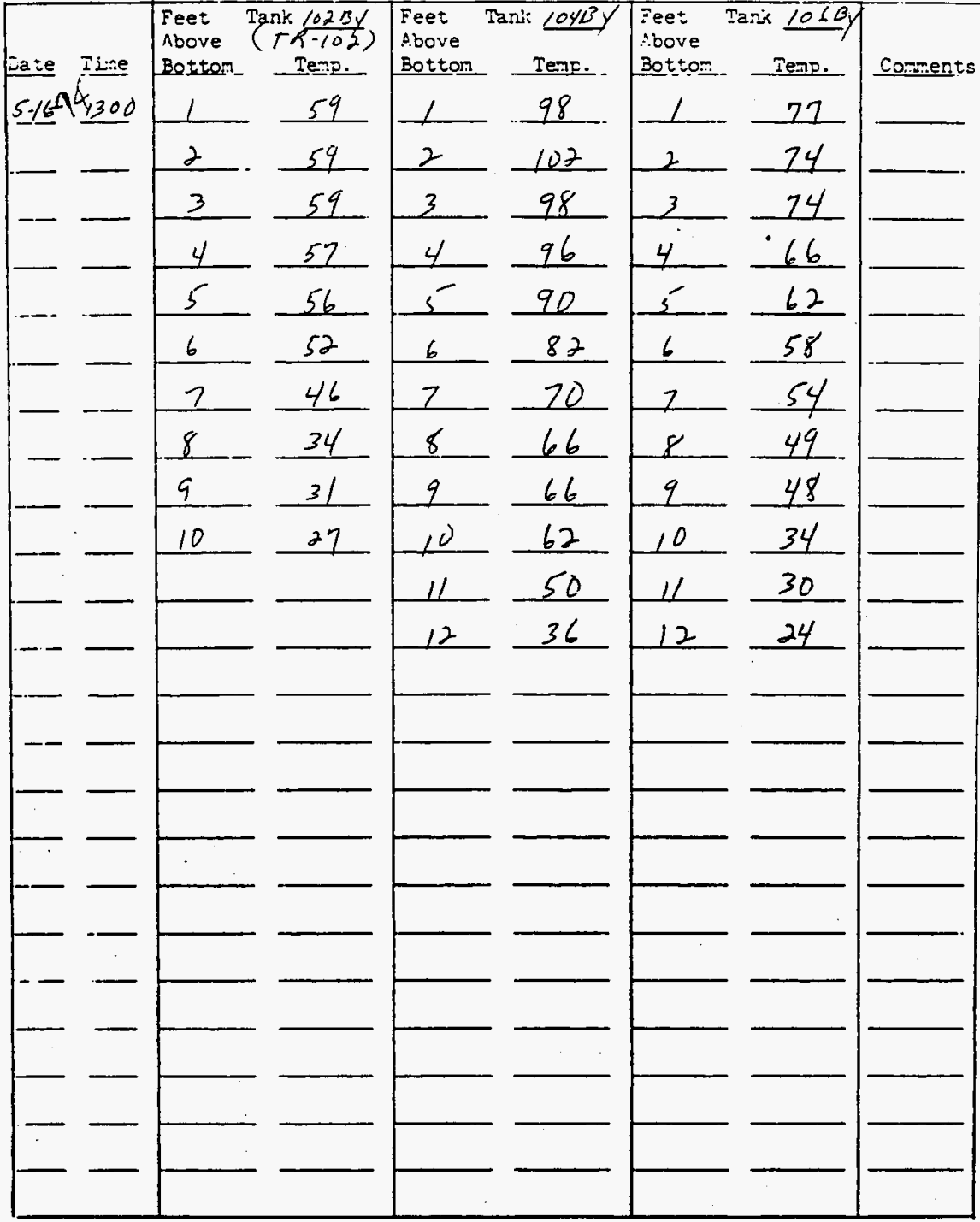

Instristions ar caments: - Take crofile temperatures veekly in each hottams tank. Attach conpleted form to Monday and Thursday's Dats Sheets. 
Title: ___ PROFIIE TQPERAIURES $\mathrm{n}$ IIS-2 BOTTOMS TANXS $B A R-C$

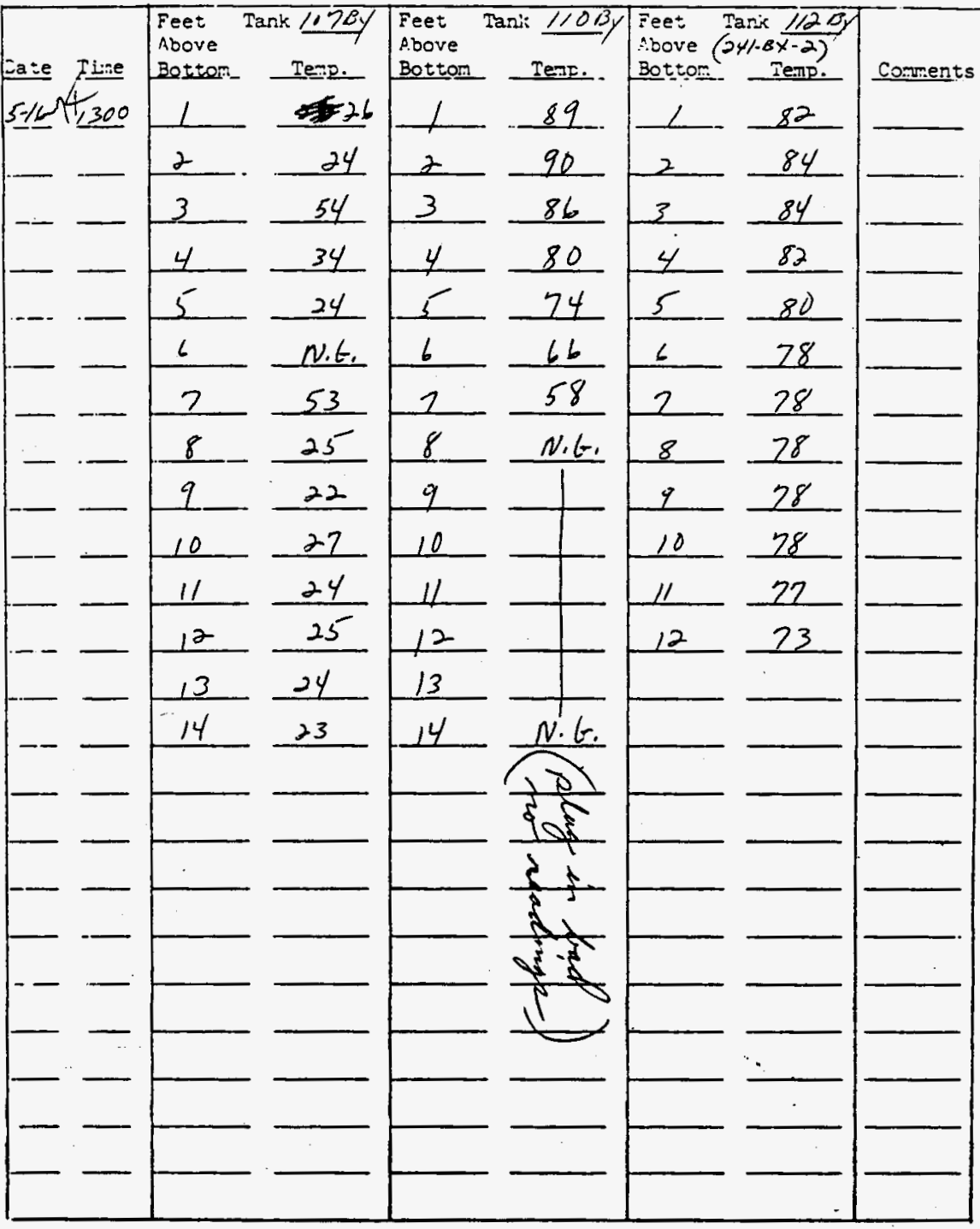

Instr:cilins $=r$ camenss: - Take prorile temperatures veekly in each nottoms tank. Attach conpleted forn to Konday and Thursday's Data sheets. 
Title: PROFIIE TEPERATURES IN ITS-2 BOTIOMS TATKS

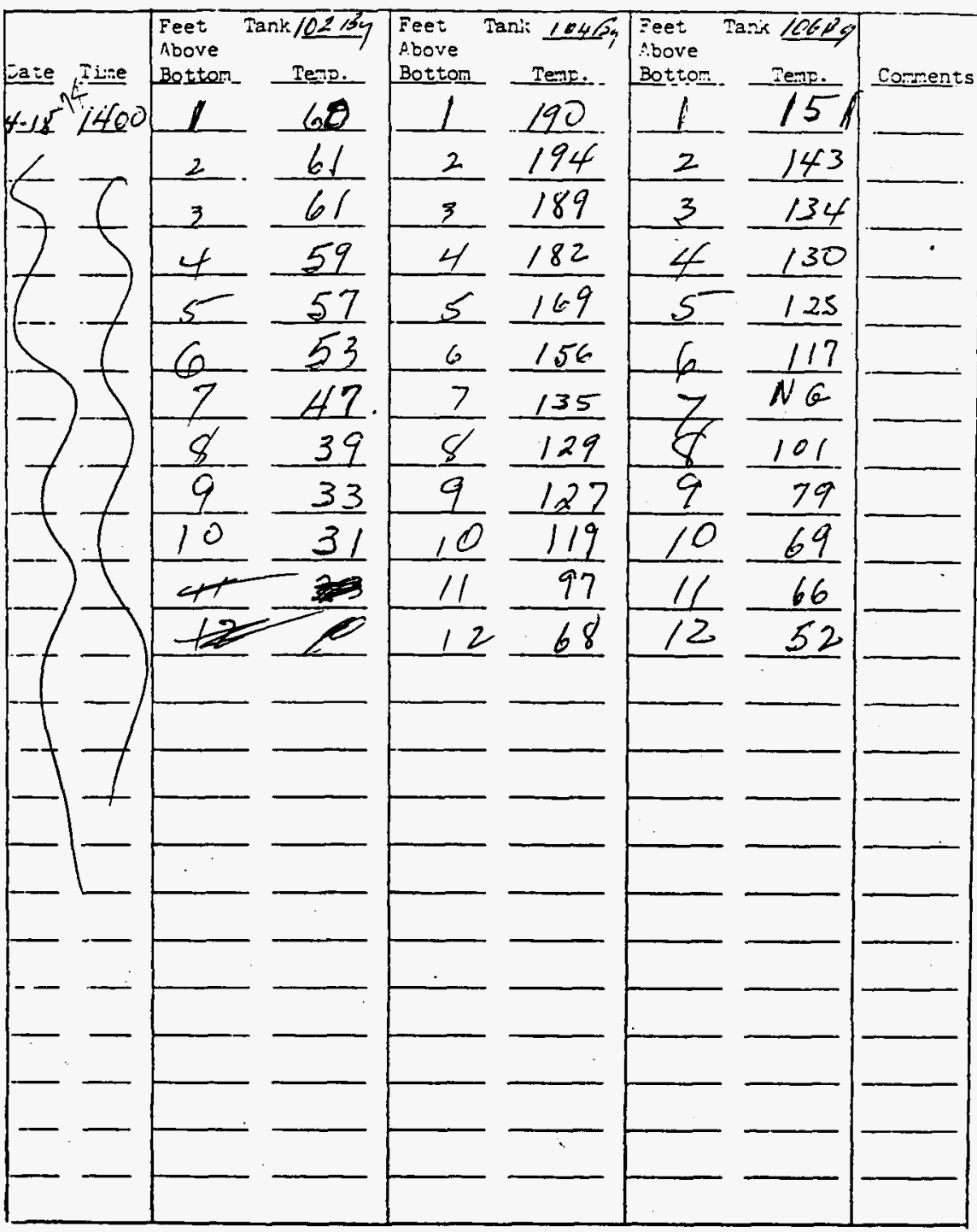

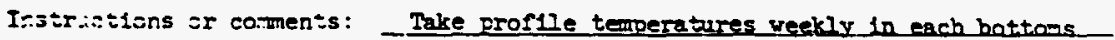
tank. Attach completed form to Monday and Thursday's Data Sheets. 
Title: PROFILE TERERAZURES IN IZS-2 BOTTONS TANKS

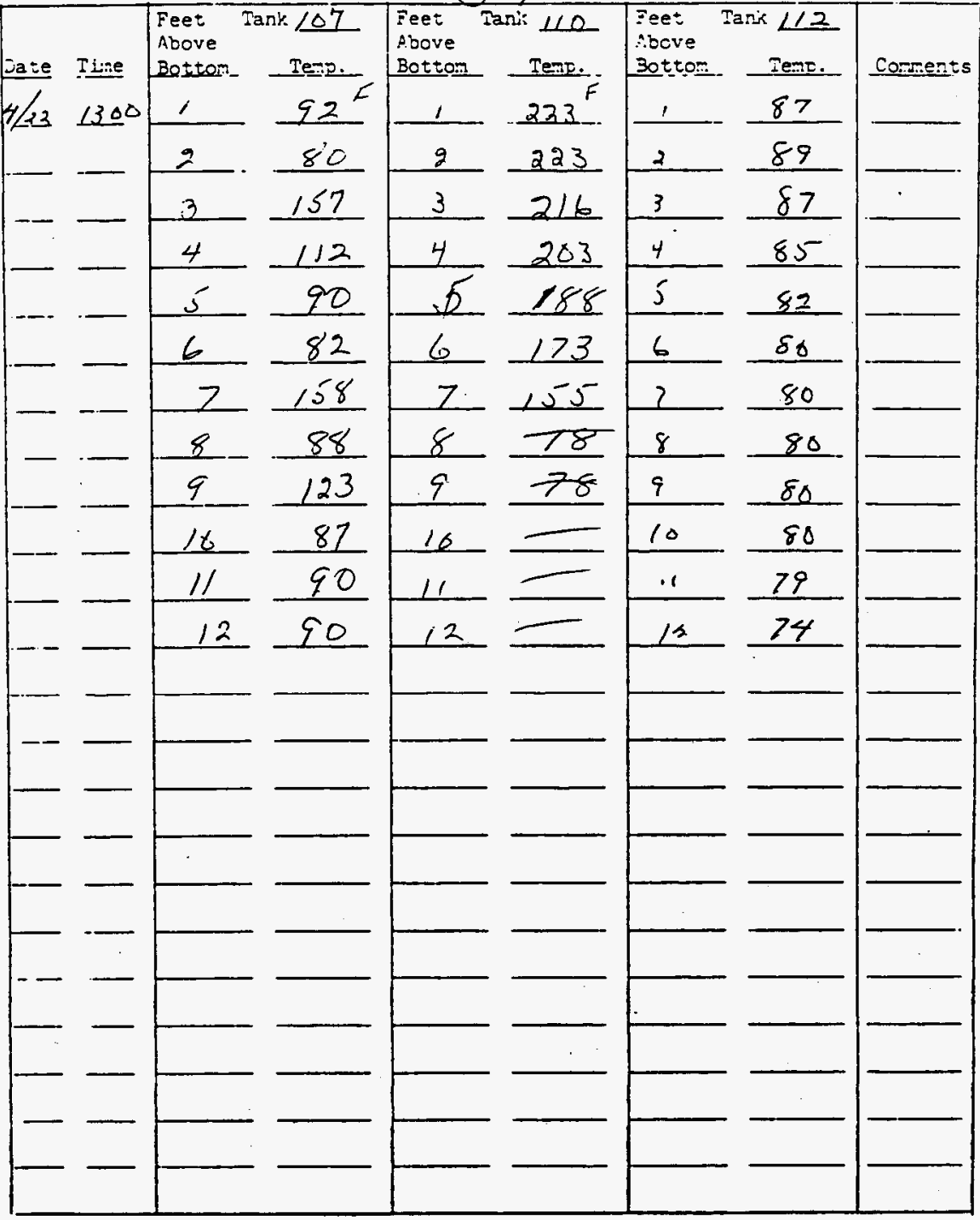

I:3tr:silons or coments: - Take froflle temperatures weekly in each bottons tank. Attach conpleted form to Monday and Thursday's Data Sheets. 
Title :

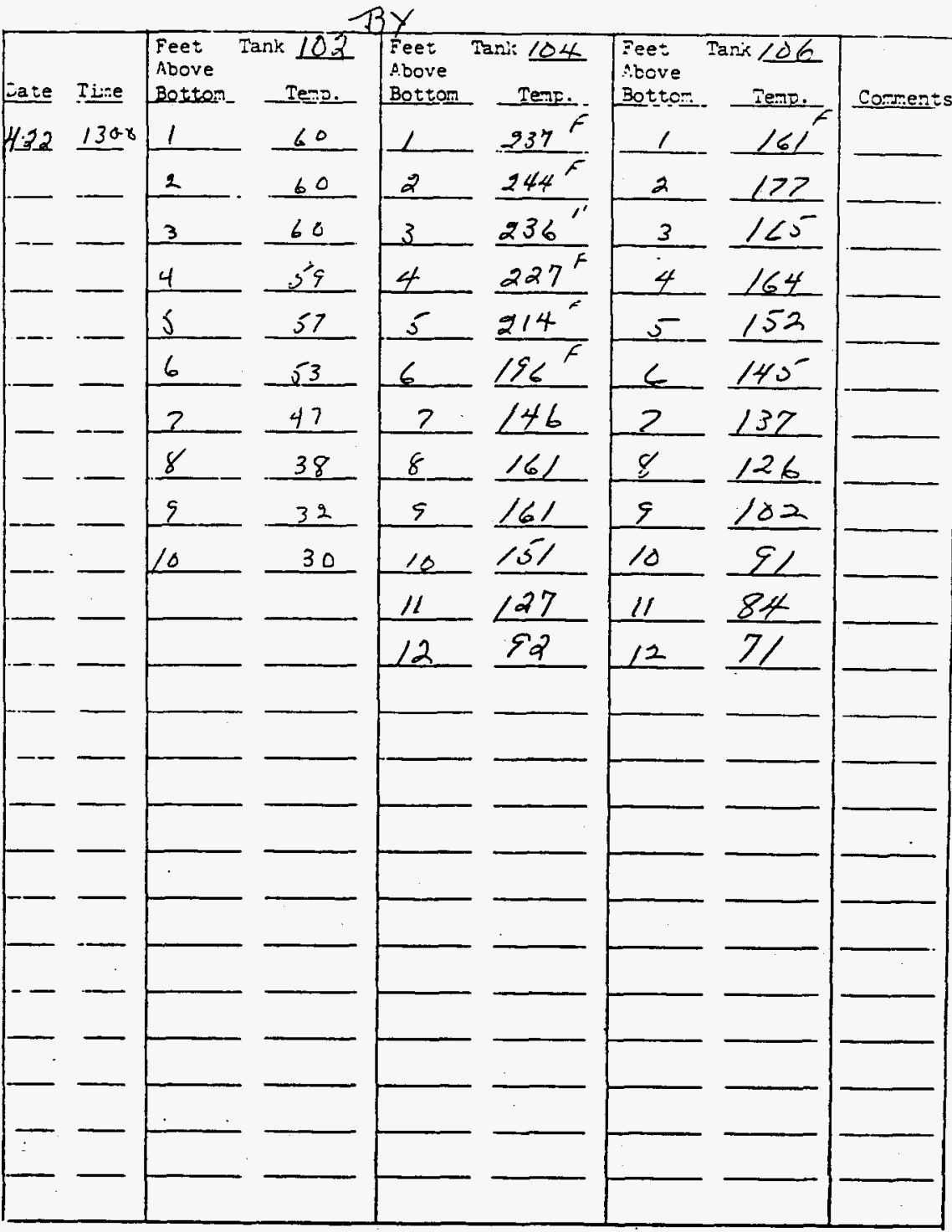

Instr:-isiss ir coments: - Pake proflle temperatures yeekly in each hottoms tank. Attach completed forz to Monday and Thursday's Data Sheets. 
Title: FROFIIE TRPERAIURES II ITS-2 BOTTONS TAMTS

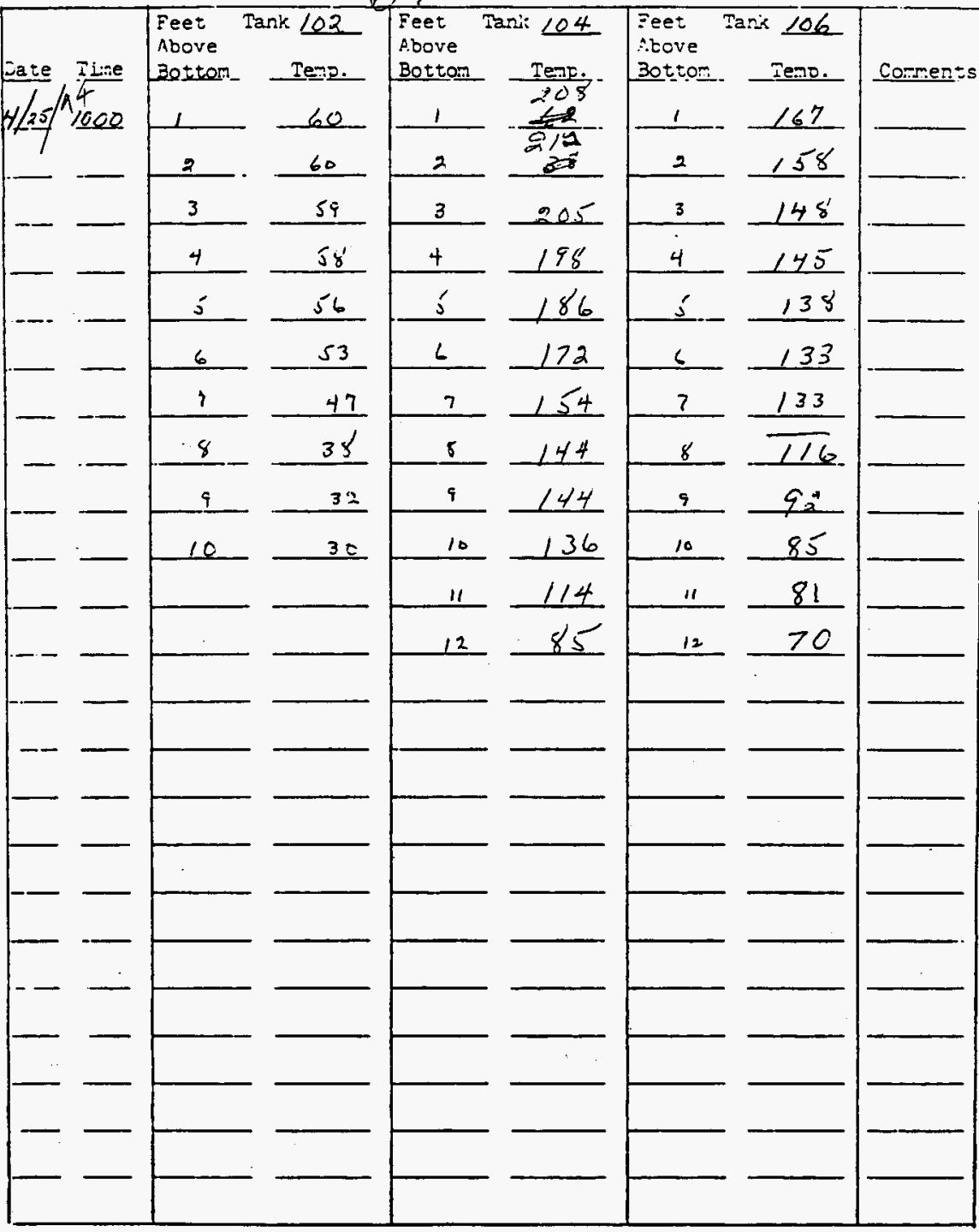

Irsir:tisns ar conmen:s: - Telce profile temperatures veekly in each bottoms tank. Attach completed for to Monday and Thursday's Data Sheets. 
Title: PROFILE TRTERATURES II ITS-2 BOTTONS TAMTS

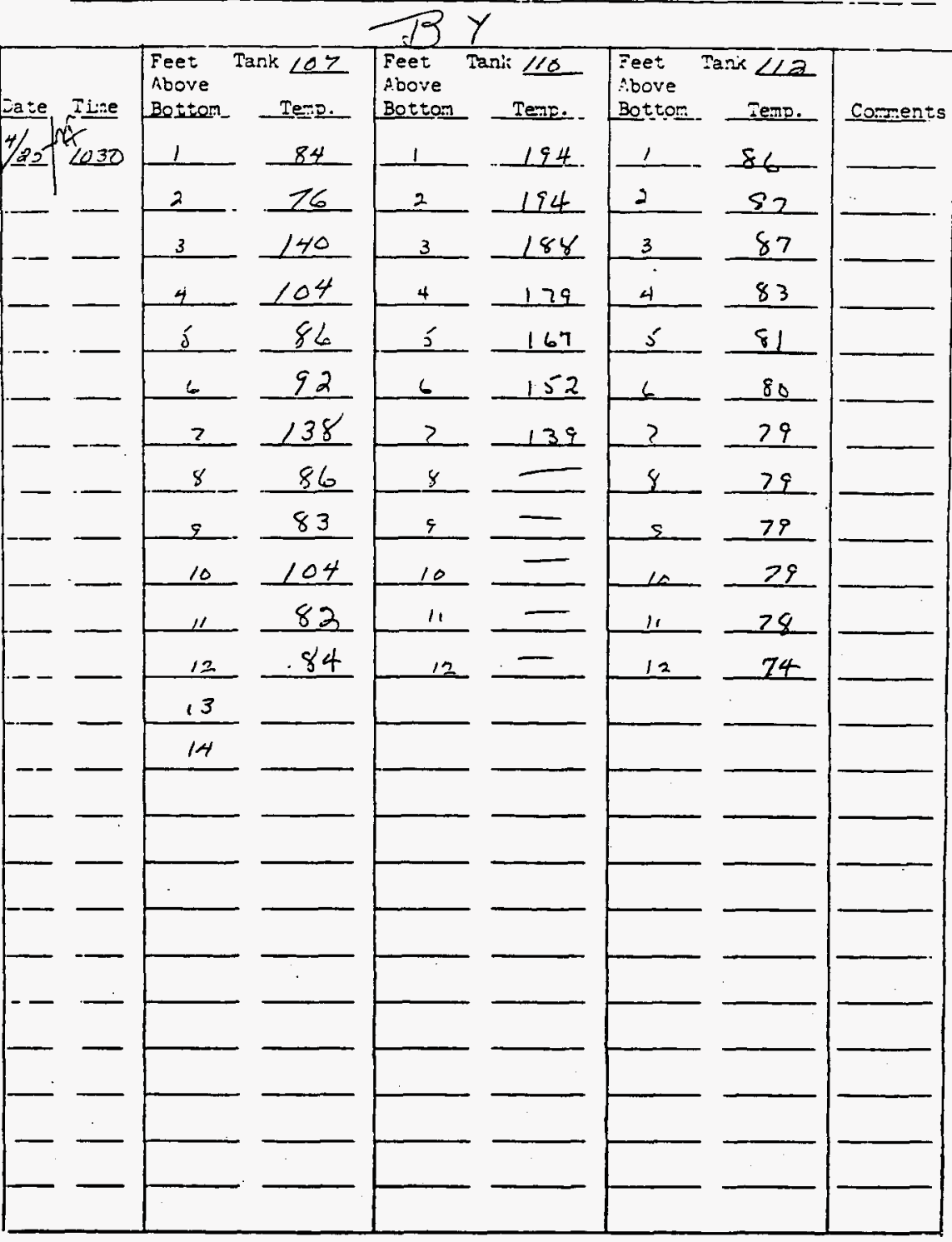

I:3:ristisns ar coments: - Take prorile tomperatures weekly in each bottoms tank. Attach conpleted form to Monday and Thursday's Data Sheets. 


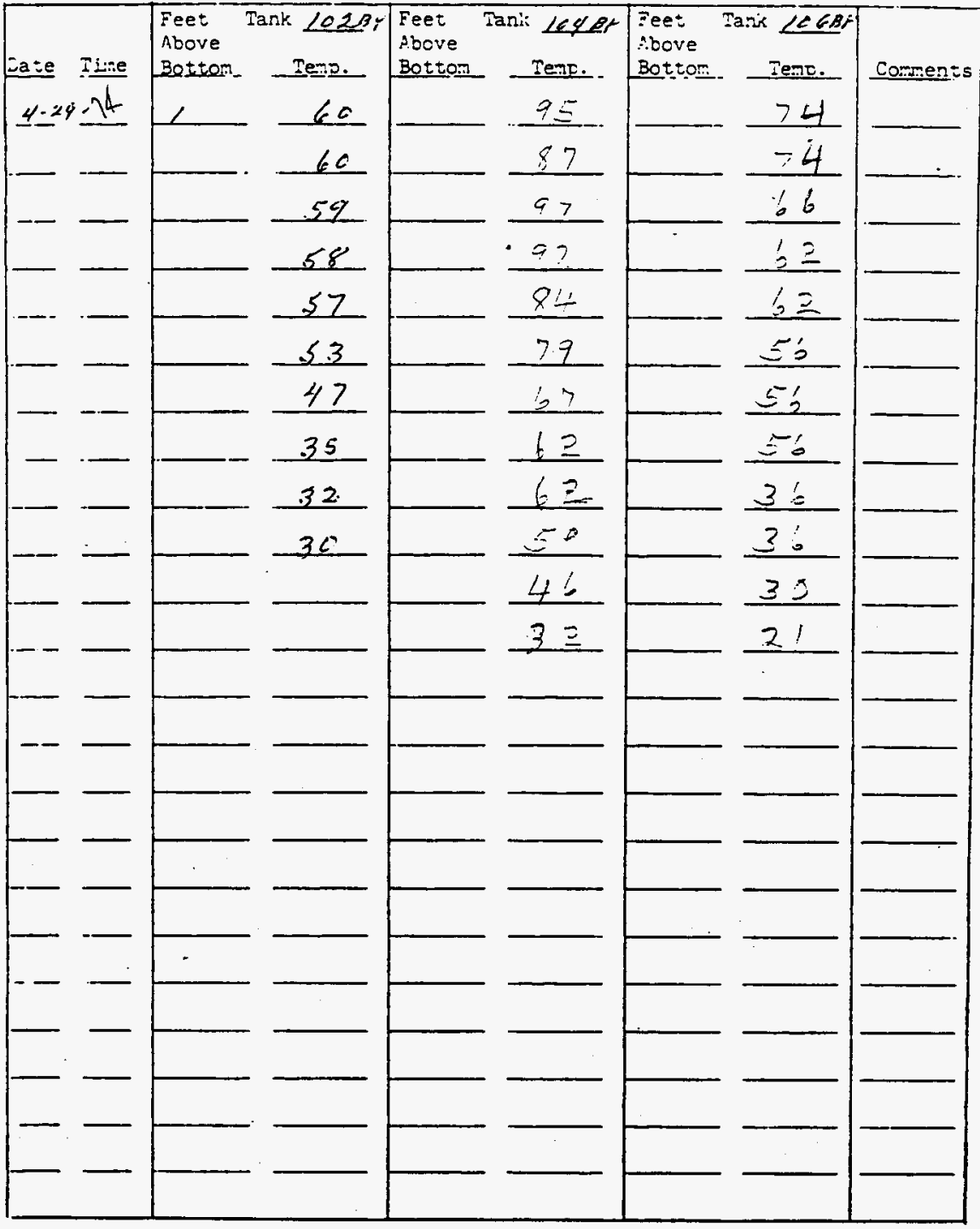

I:35::2510rs or conments: - Take profile tepperatures weekly in each hottoms tank. Attach conpleted fors to Monday and Thursday's Data Sheets. 
Title:

PROFILE TERERATURES II ITS-2 BOTOMS TAMKS

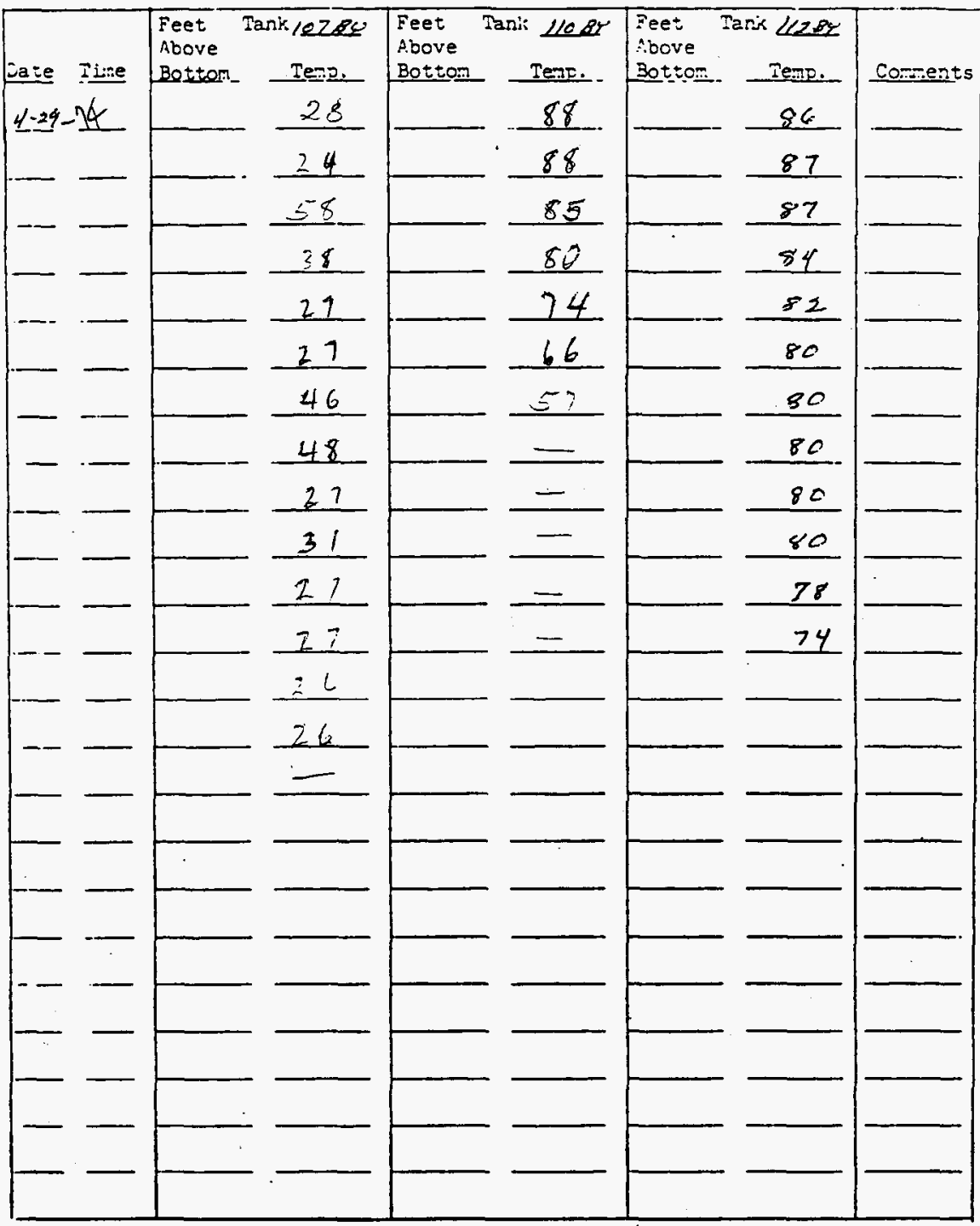

In:str:e:tons ar coments: - Take proflle temperetures weekly in each bottoms tank. Attach completed forf to Monday and Thursday's Deta sheets. 
Title: PROFILE TEPERATUKES IK ITS-2 BOTTOMS TAIKS

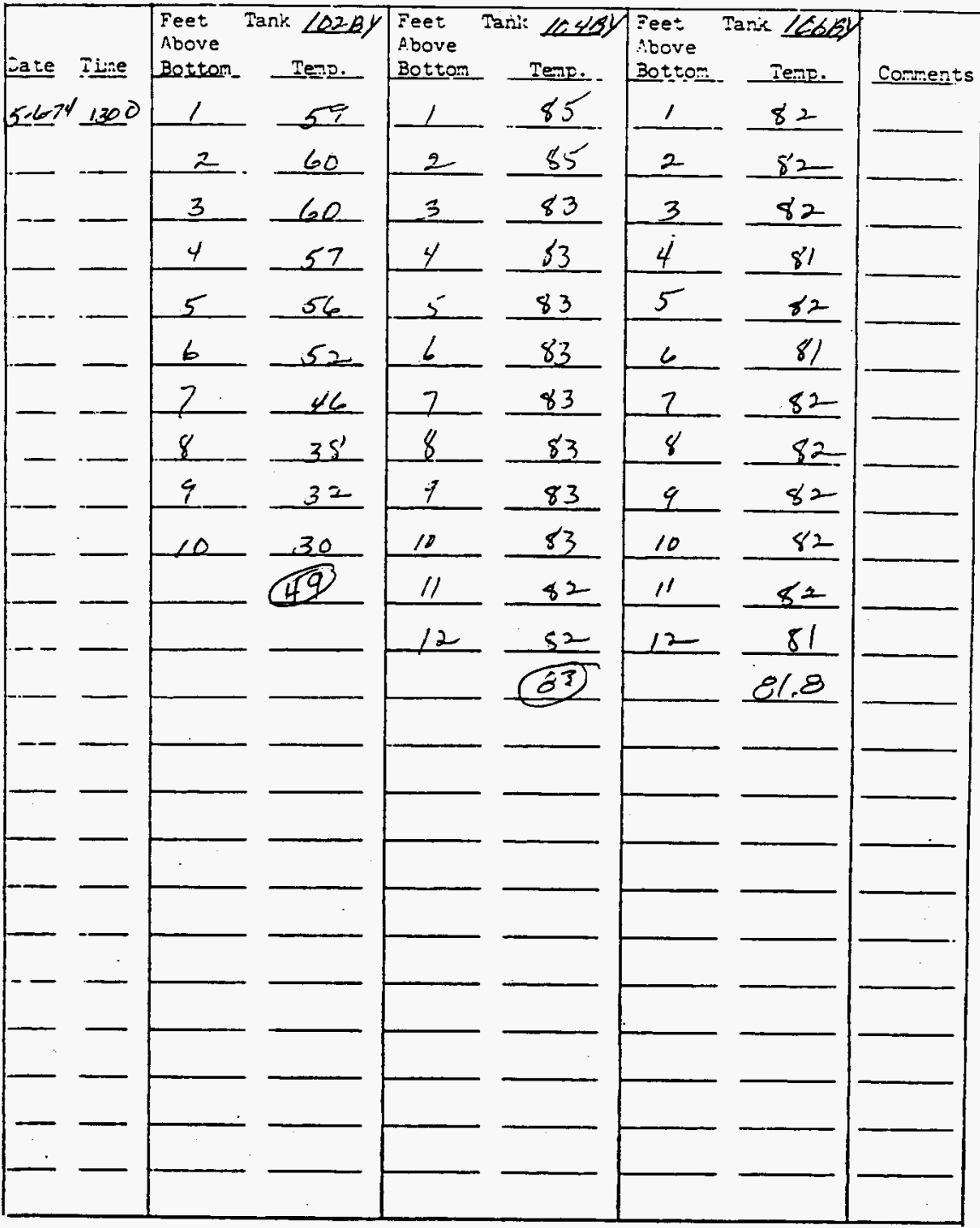

Irstriations ar caments: - Take grofile temperatures veelaly in each bottams tank. Attach conpleted form to Monday and Thursday's Dats sheets. 
Title: PROFILE TERERATURES II: ITS-2 BCTTOMS TAITS

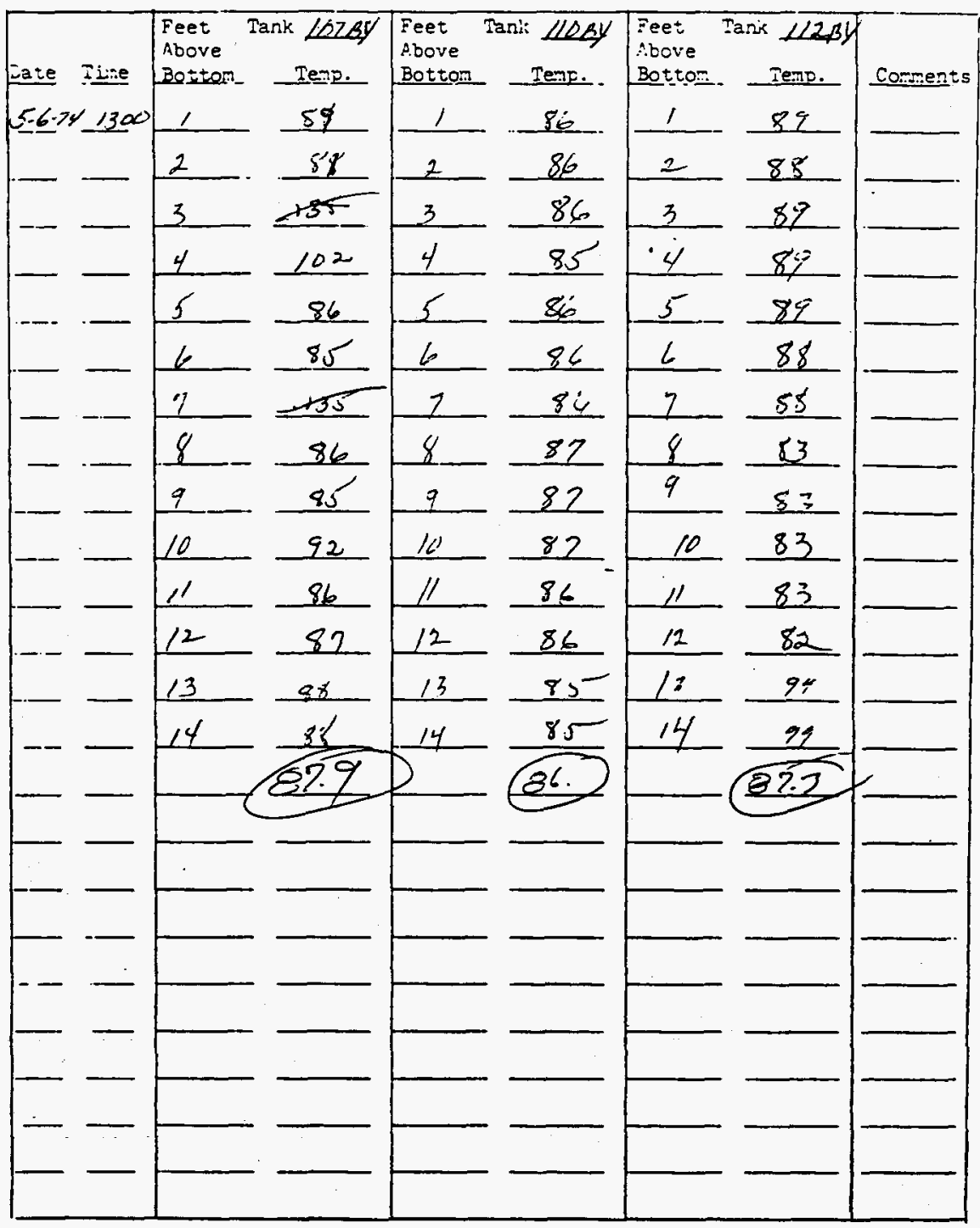

Ir:3:I:0:12ns $=r$ camen:s: - Take profile temperatures veekly in each bottoms tank. Attech completed for to Monday and Thursday's Data Sheets. 
Title:

PROFILE TERERATURES II ITS-2 BOTIOMS TAMKS

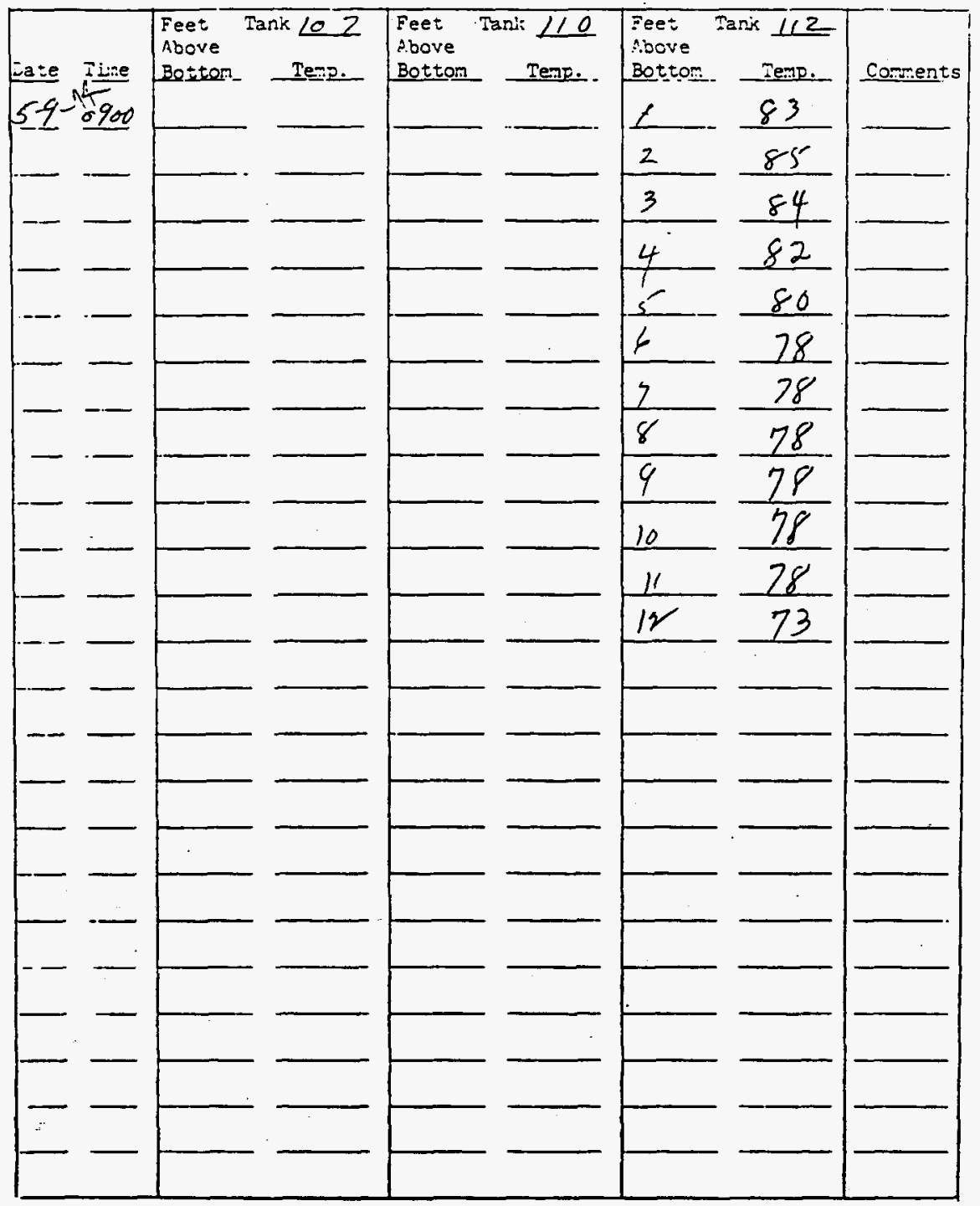

Irstr:stiors ar coments: - Take proflle temperetures weekly in each battams tank. Attach conpleted fors to Monday and Thursday's Data Shegts. 
Title:

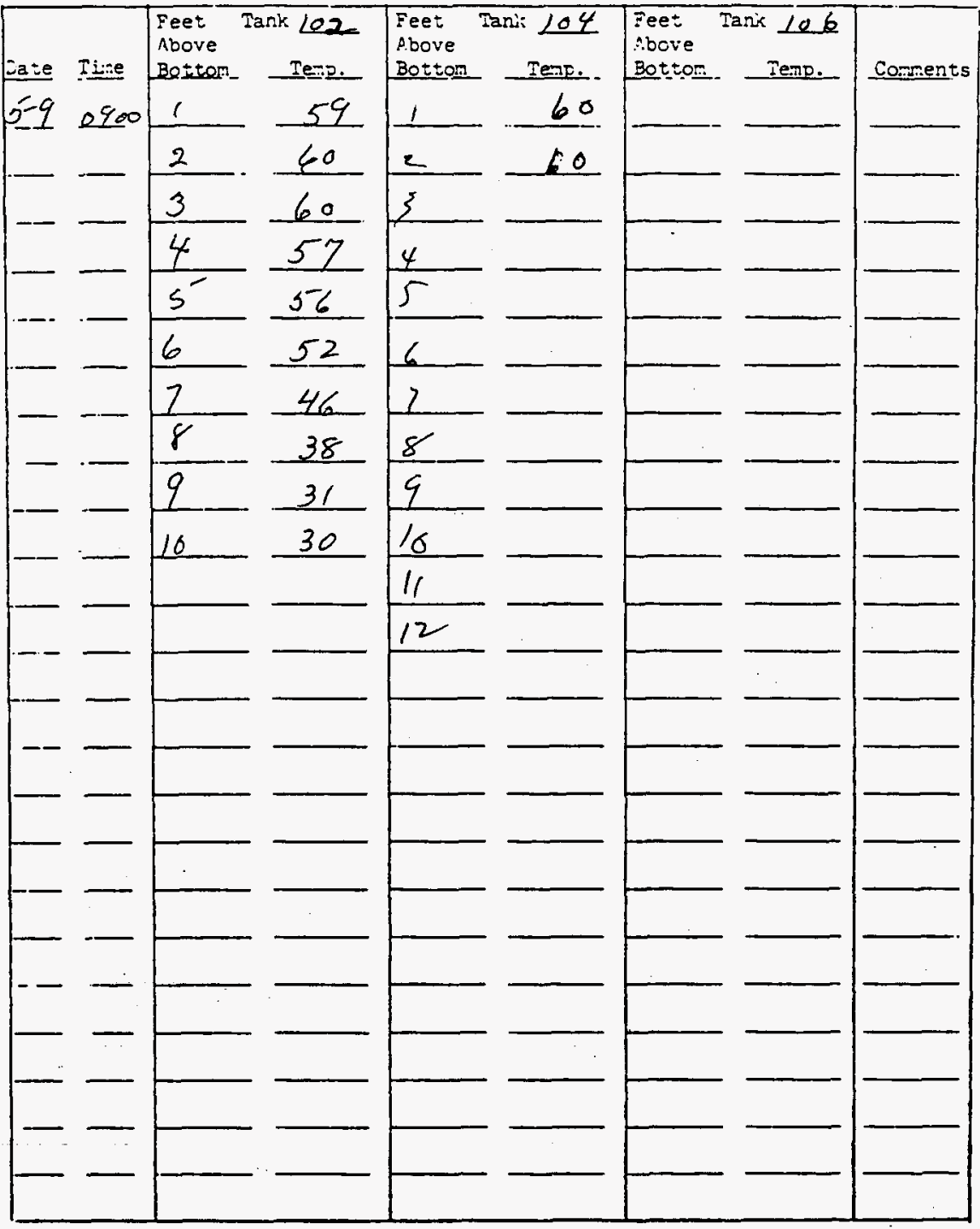

Irstr:s:isns $=r$ caments: - Take proflle temperatures weekly in each hottoms. tank. Attach conpleted form to Monday and Thursday's Data Sheets. 
Title: FROFILE TQPERATURES TI ITS-2 3OTHOMS TANKS

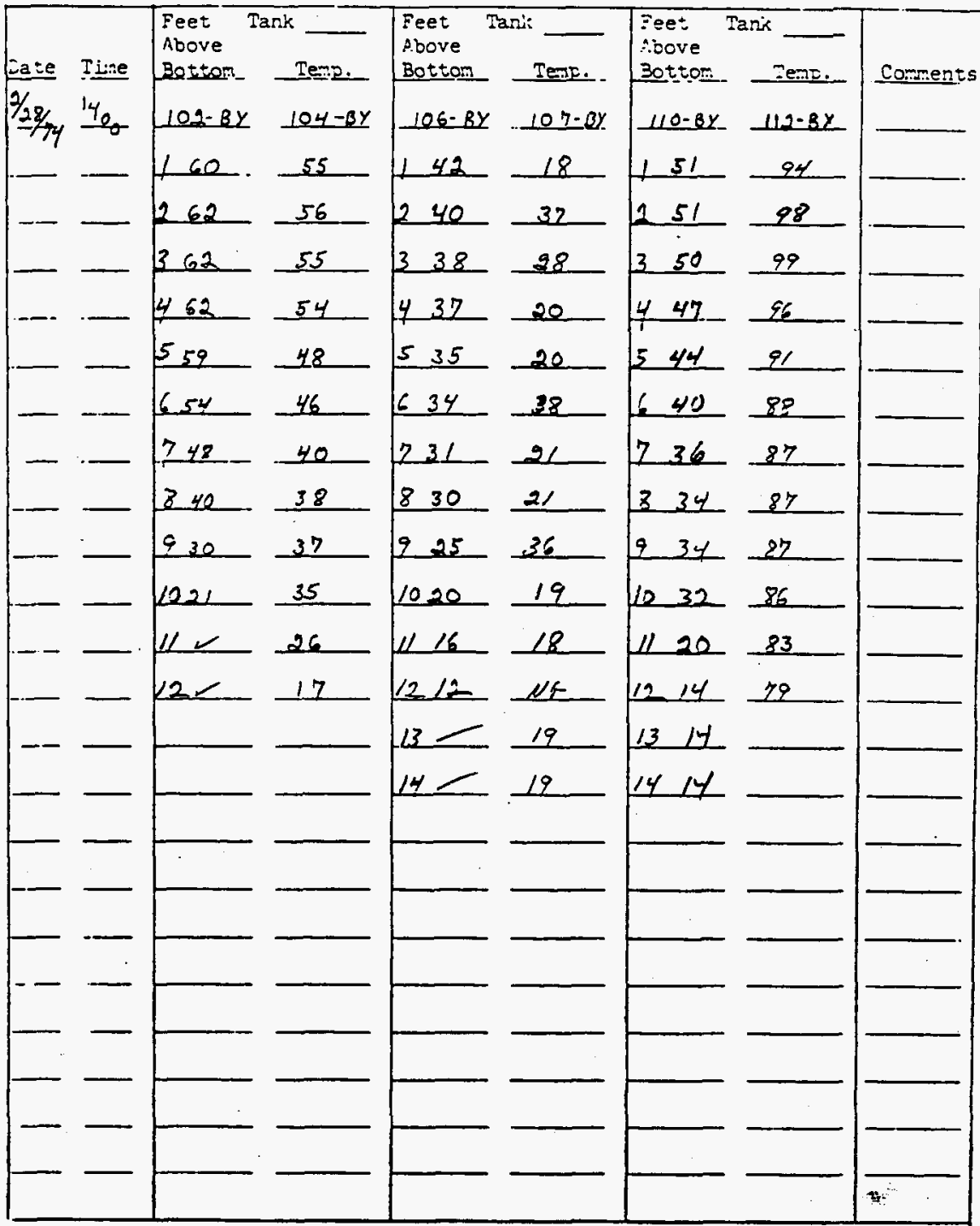

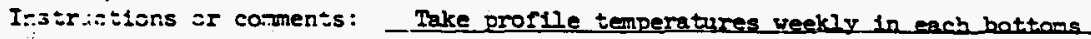
tank. Attach conpleted form to Monday and Thursday's Data Sheets. 
Title: PROFILE TERERATURES LV ITS-2 BOTMOMS TANRS

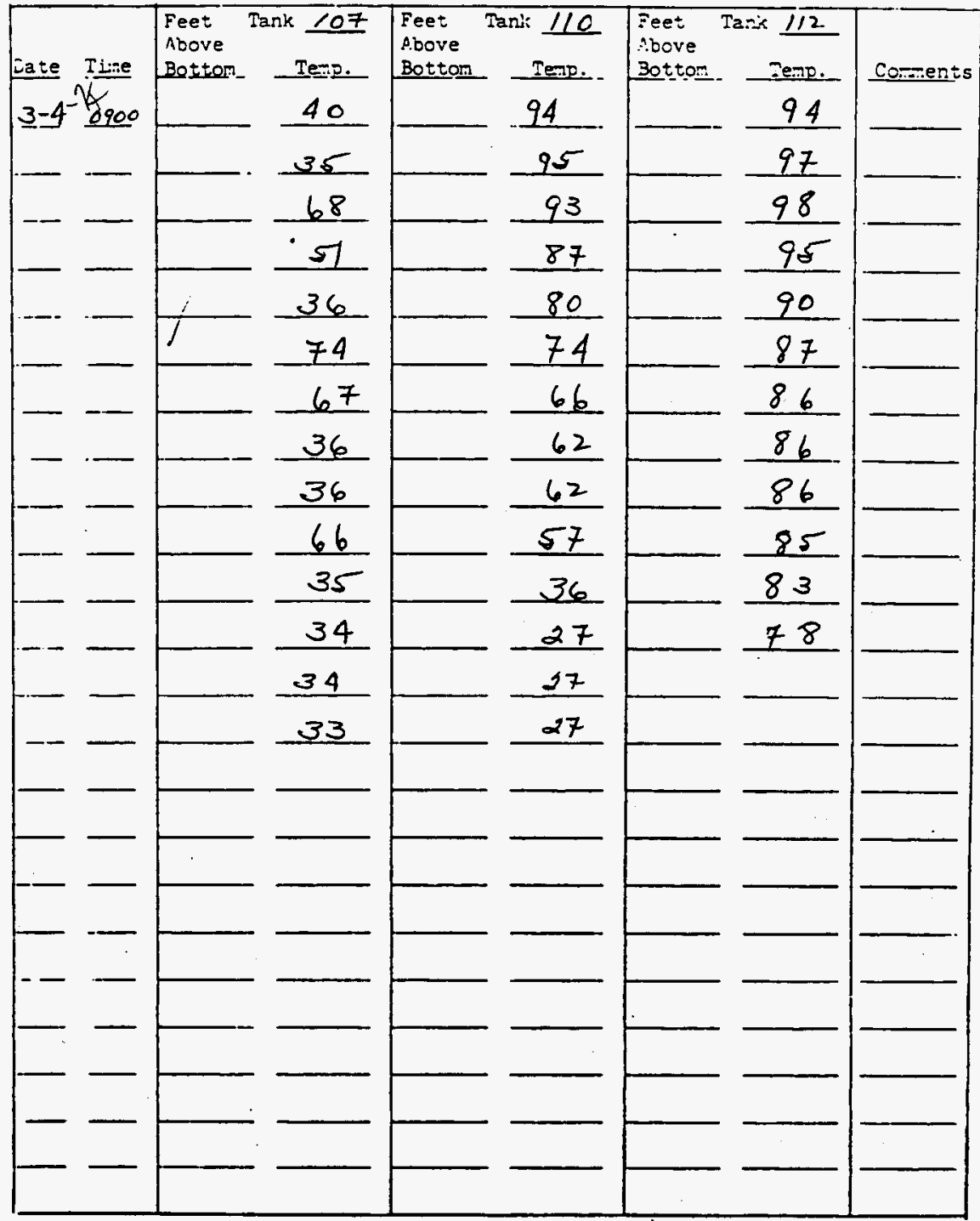

Instrisilons is coments: - Take proflle temperatures veekly in each hottoms tank. Attach completed fora to Monday and Thursday's Data Sheets. 
Title:

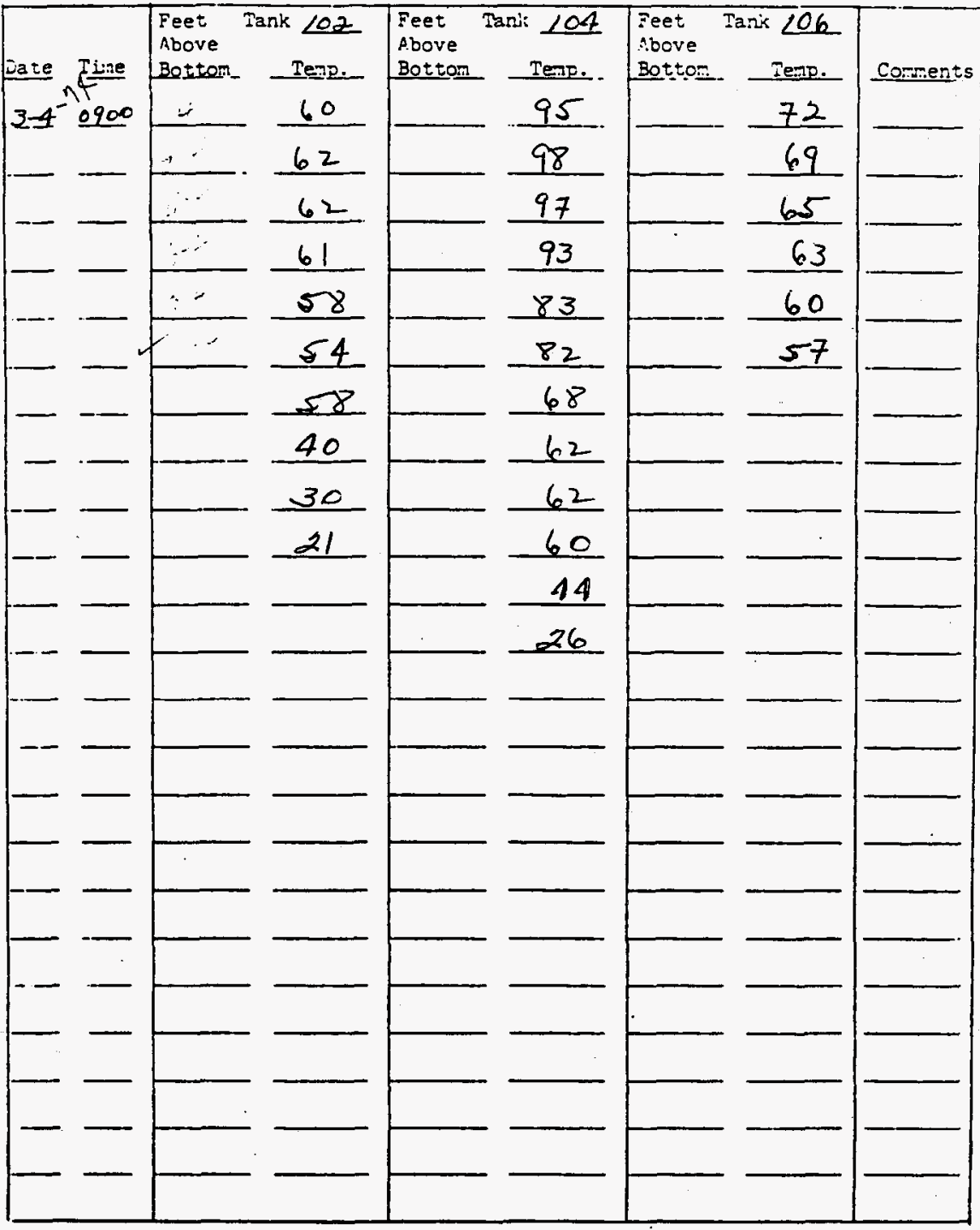

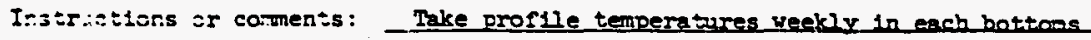


Title: PROFIEE TIPERATURES DN ITS-2 BOTTOMS TAMKS

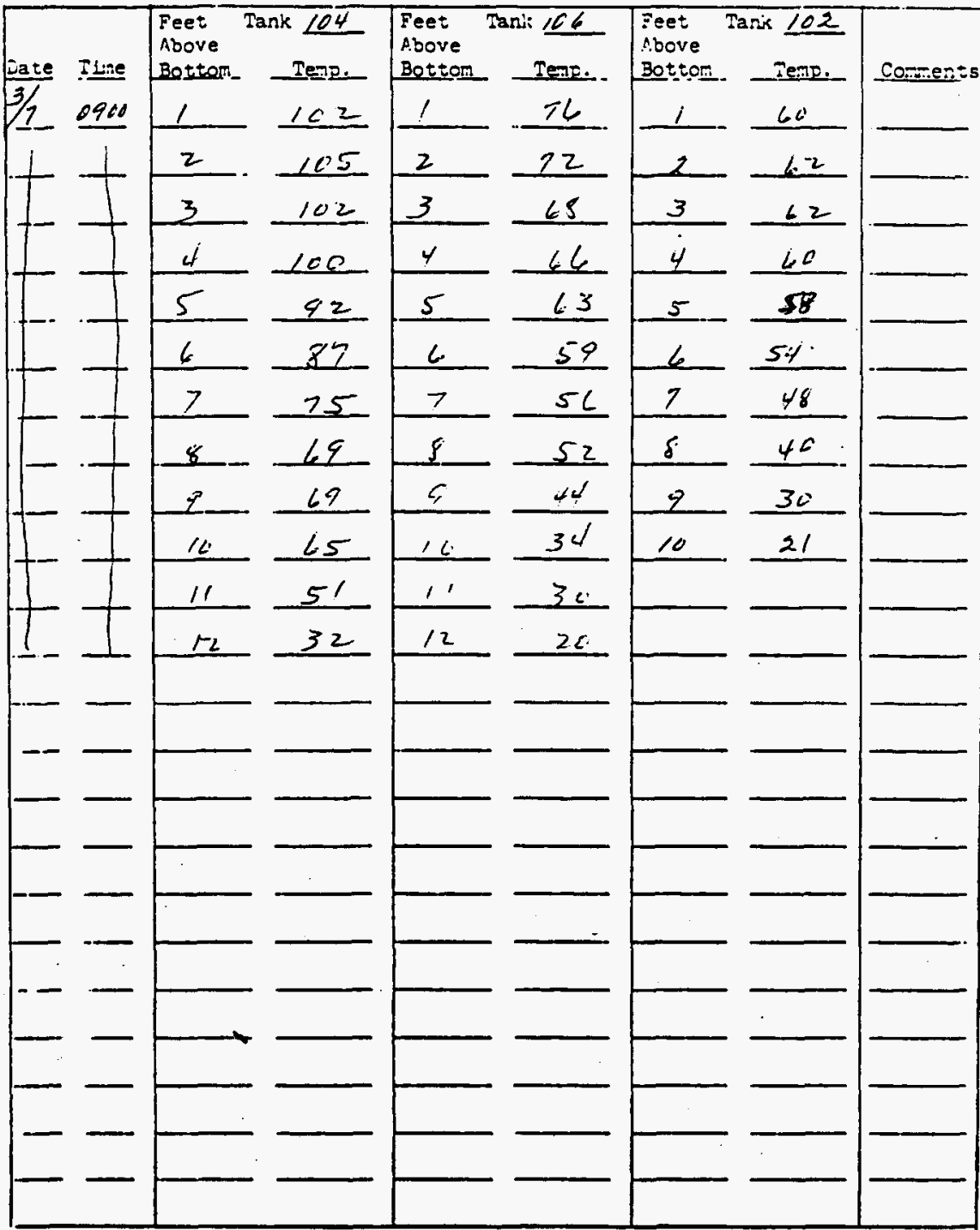

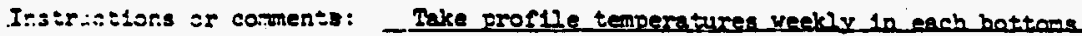


Title: PROFILE TERERATRRES Di ITS-2 BOTTOMS TAMKS

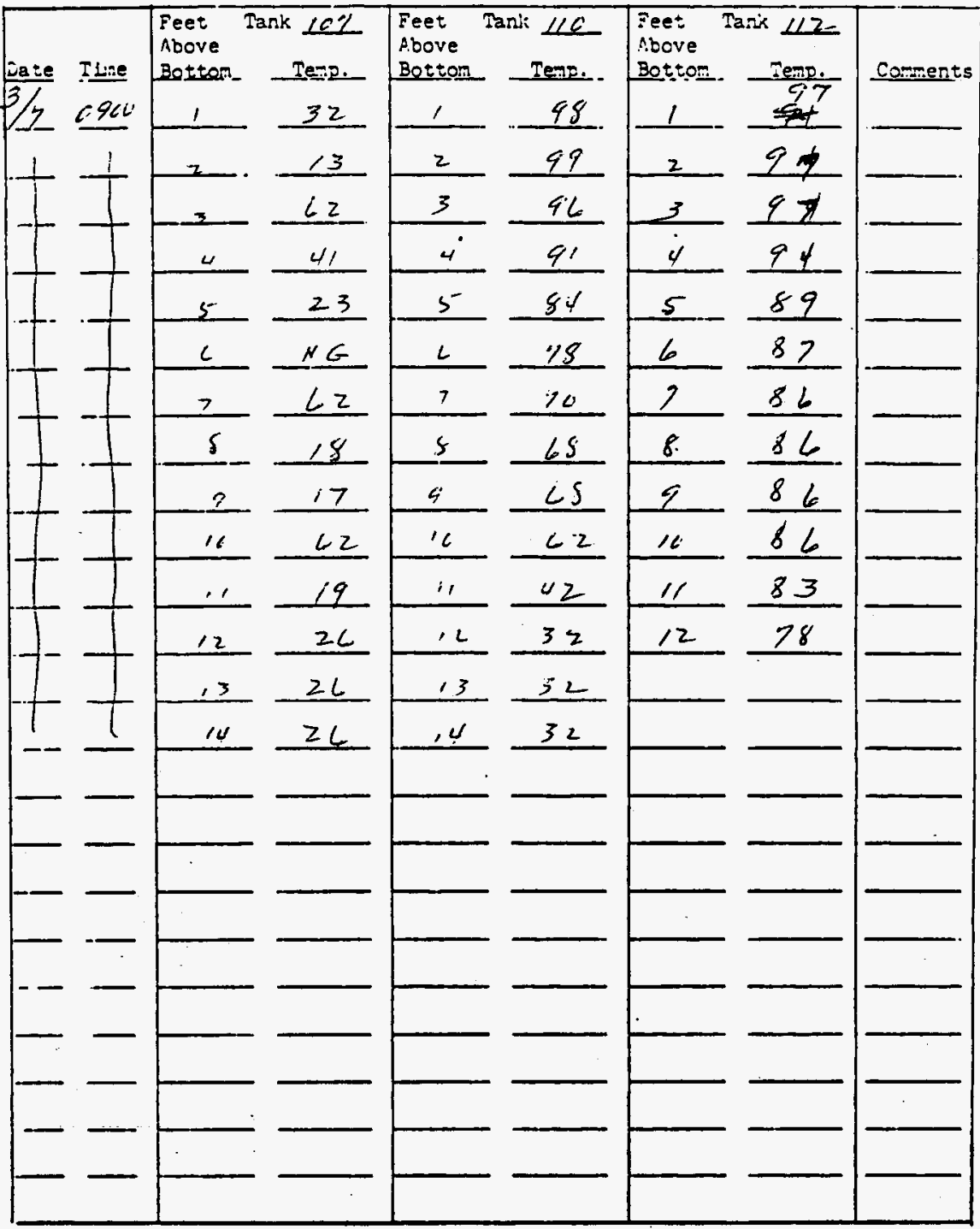

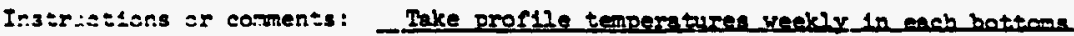
tenk. Attech completed forn to Monday and Thurnday's Data shente. 
Title:

PROFILE TEPERATURES LV ITS-2 BOTTONS TAMRS

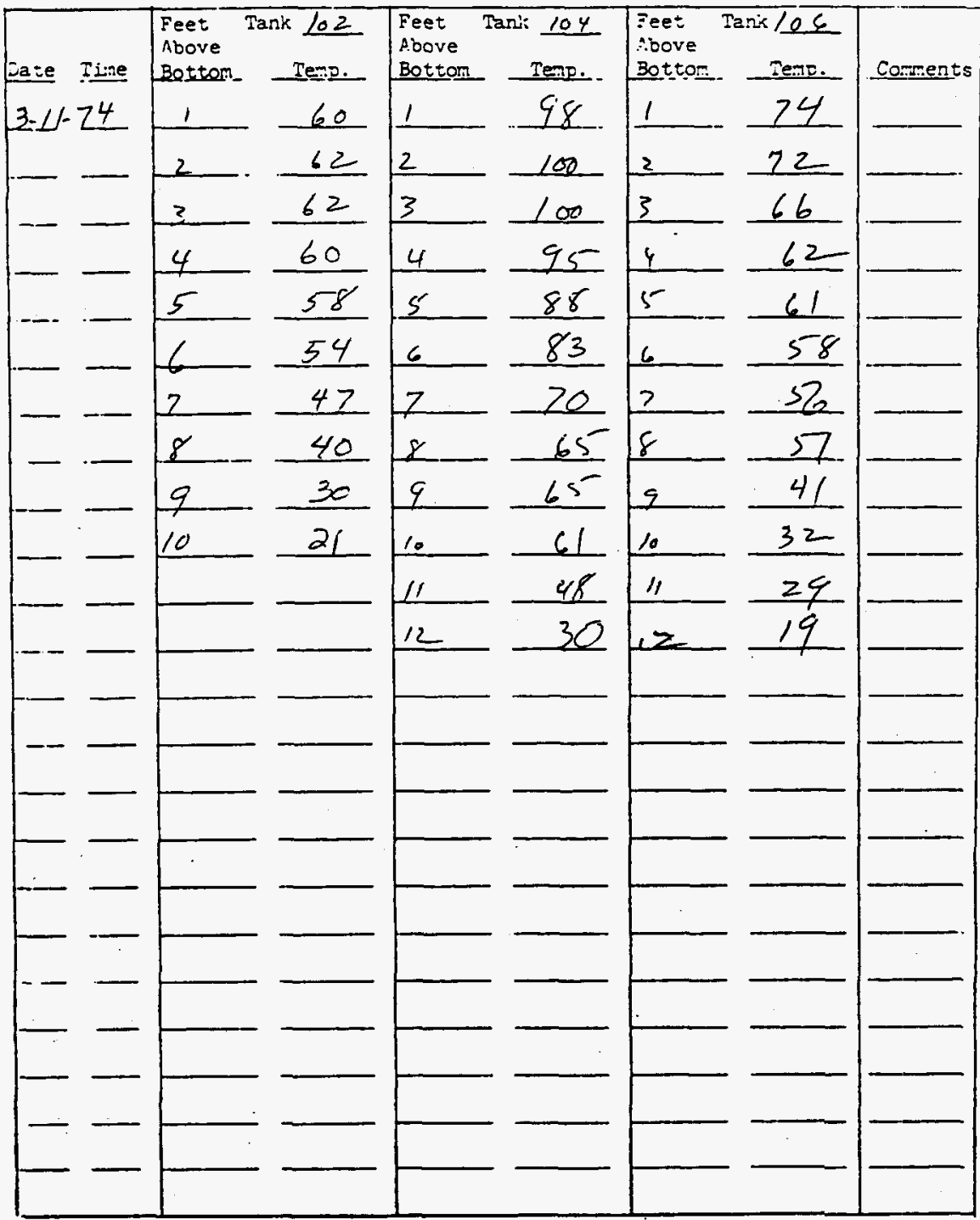

I=3:xis:isns sr coments: - Take proflle temperatures weekly in each bottoms tank. Attach conpleted fore to Monday and Thursday's Data Sheets. 
Title:

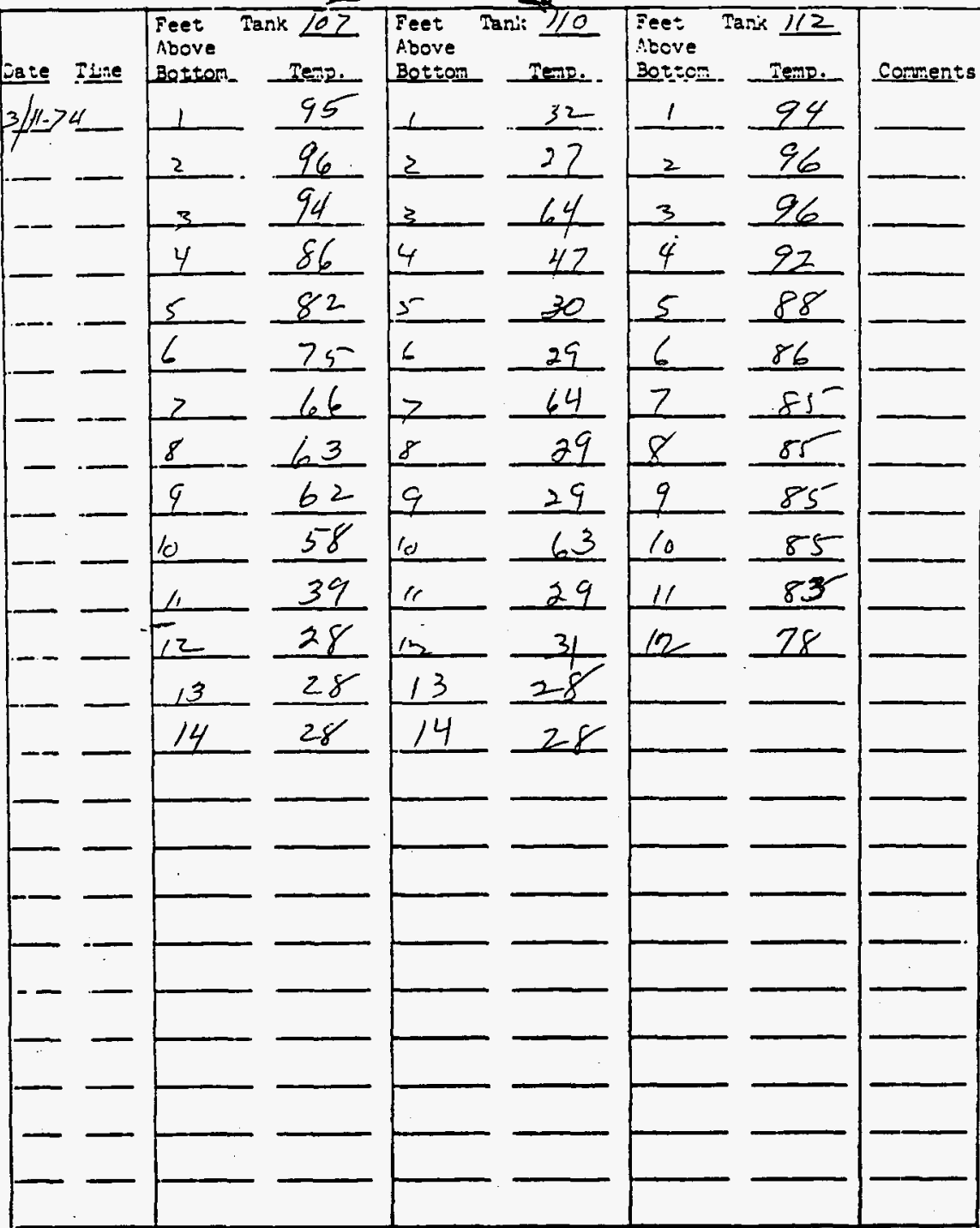

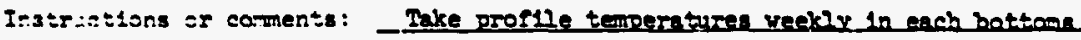
tank. Attech conpleted form to Monday and Murgday's pate shants. 
Title:

PROFILE TZMPERATURES IN ITS-2 BOTTOMS TANKS

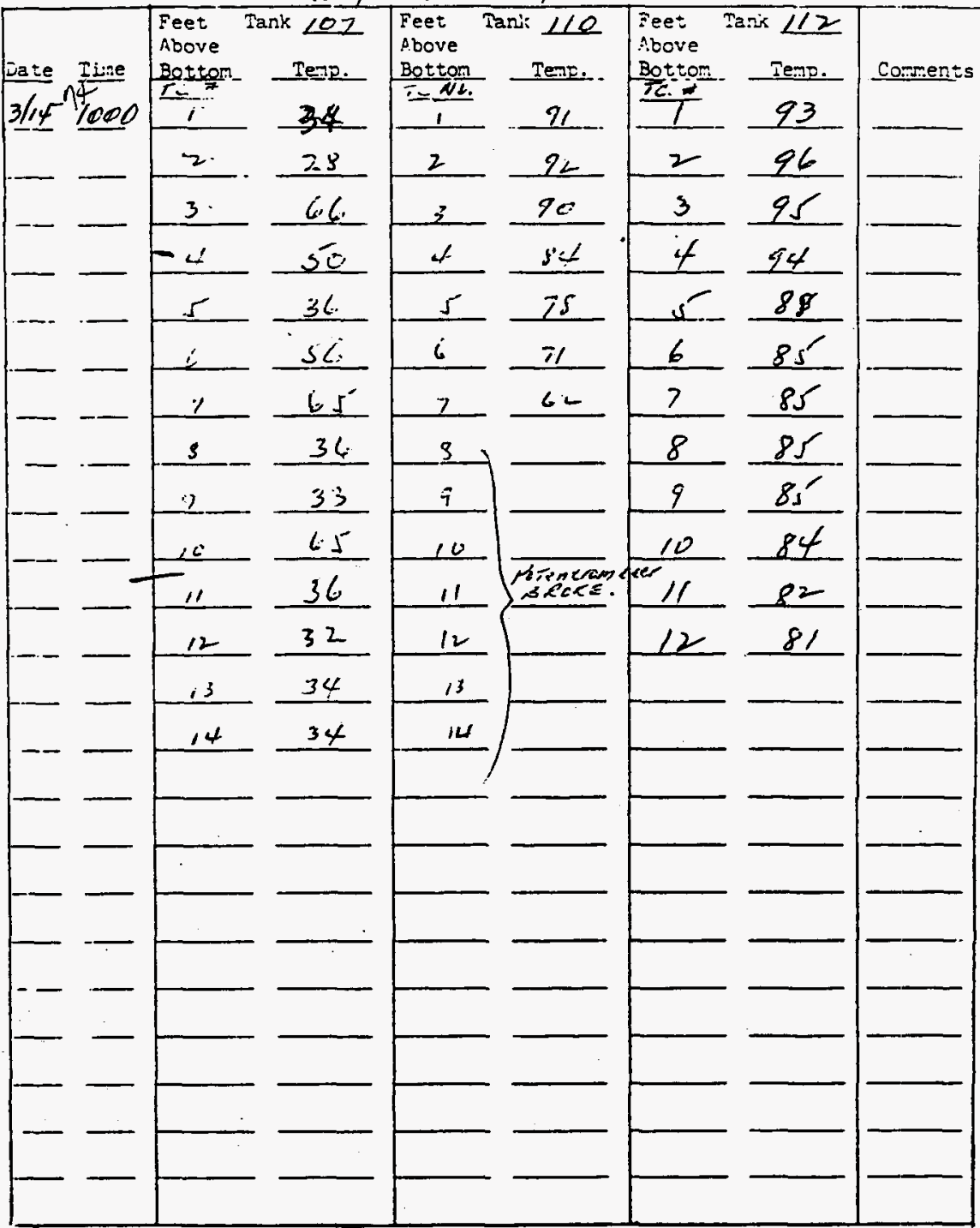

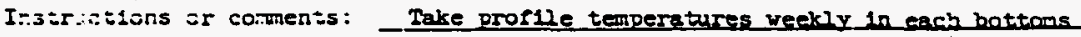
tank. Attach conpleted form to Monday and Thursday's Data Sheets. 
Title:

PROFILE TERERATURES IN IIS-2 BOTMOMS TAIKS

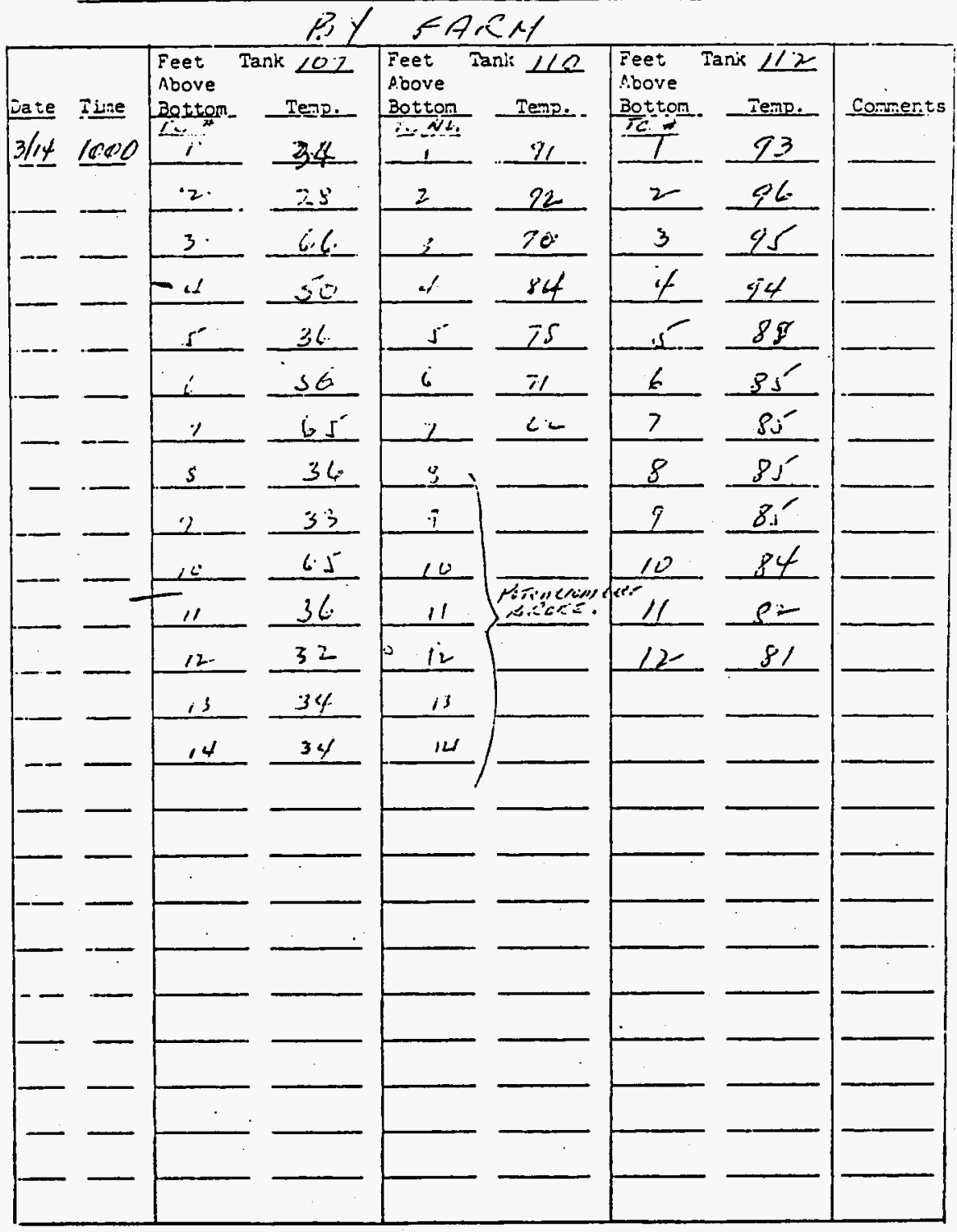

Insir:etions or coments: - Take proflle temperatures weekly in each bottoms tank. Attach completed form to Monday and Thuesday's Data Sheets. 
Title:

PROFIIE TRPERATURES II ITS-2 BOTTONS TAIRS

$$
\text { BY PACH }
$$

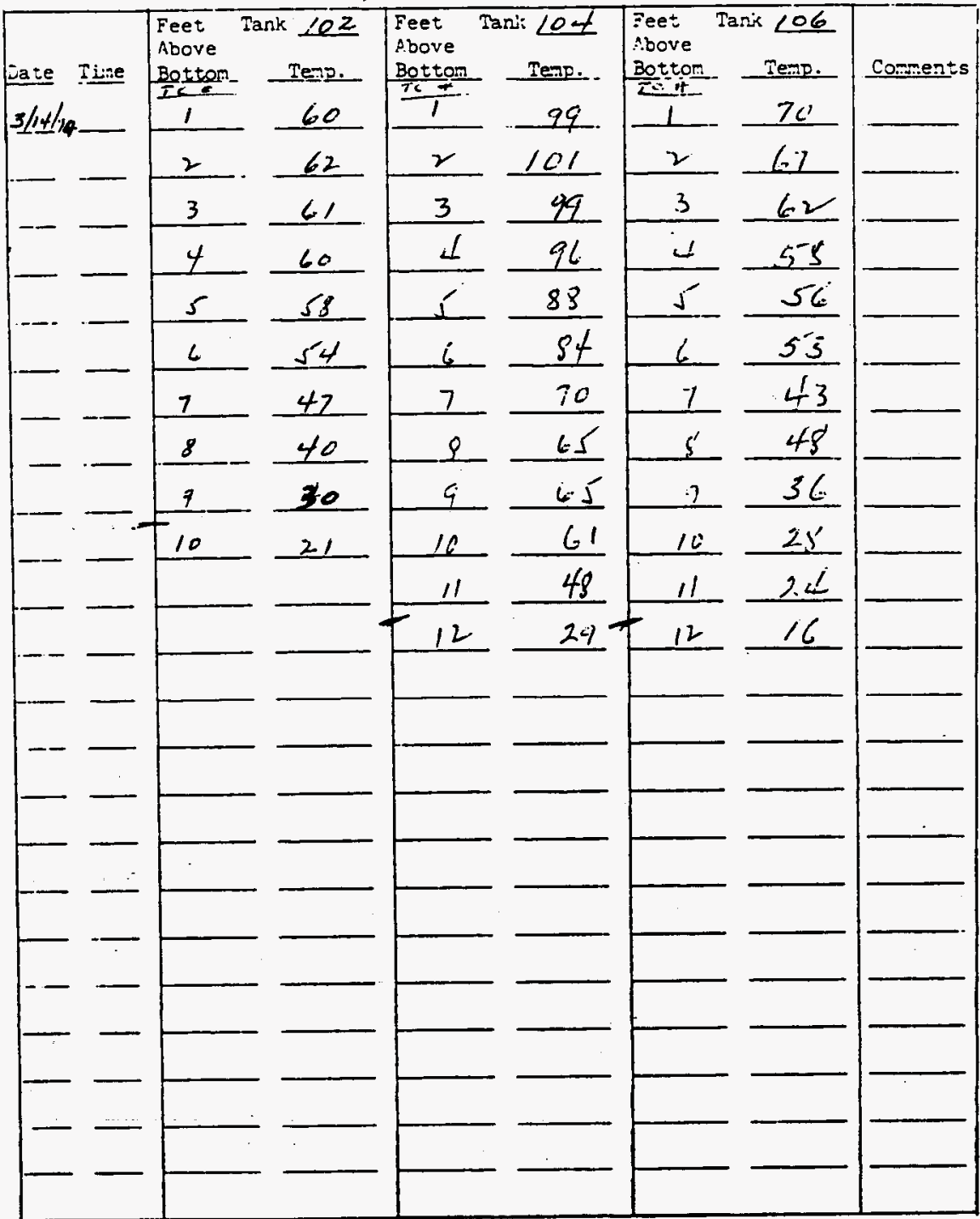

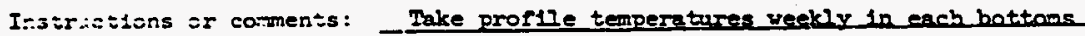
tank. Attach completed form to Monday and Thursday's Data Sheets. 
Title: PROFILE TEIPERATURES IN ITS-2 BOTTOMS TANKS

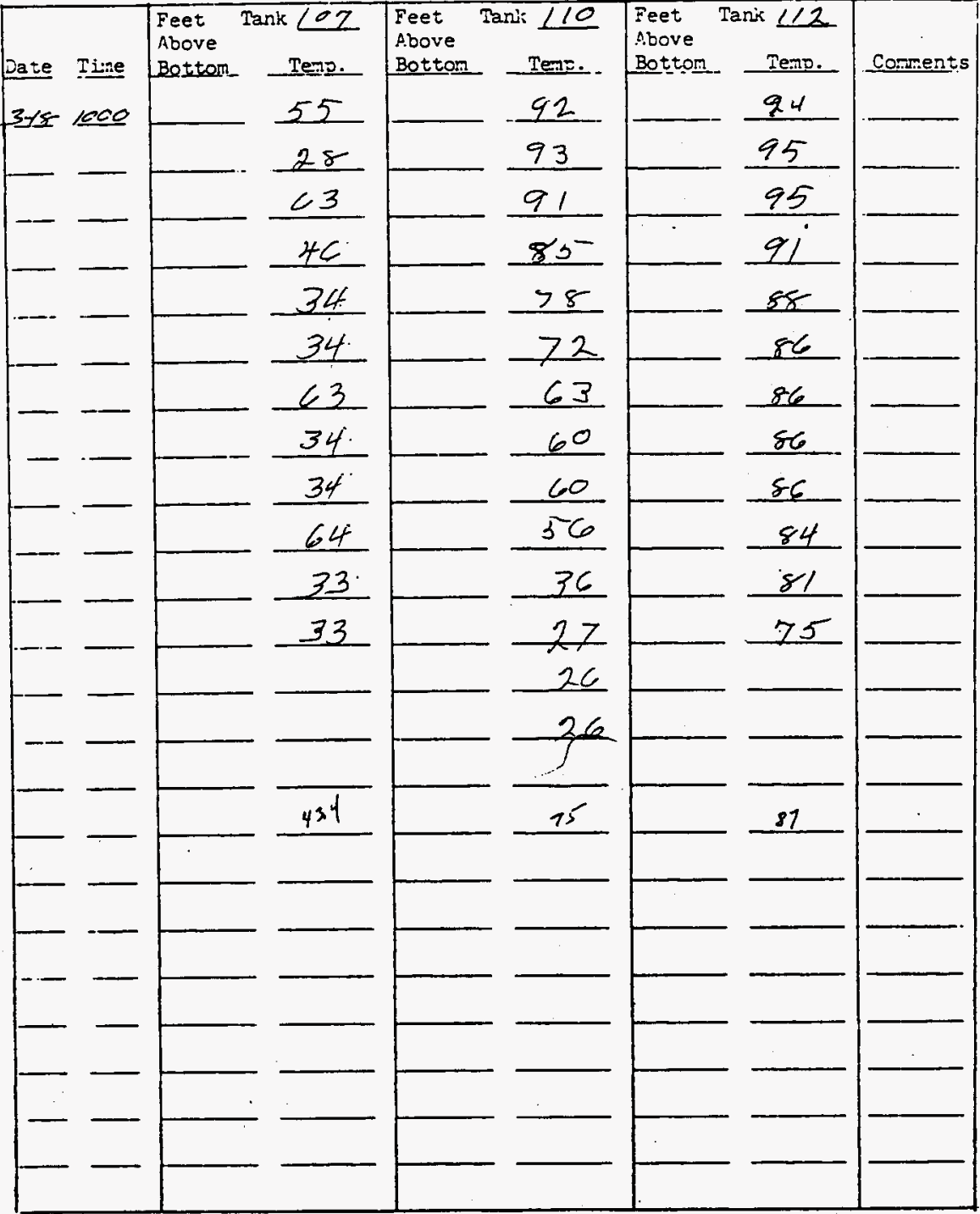

Instristions or conments: - Take profile temperetures weekly in each hottoms tack. Attach completed forn to Monday and Thursday's Data sheets. 
Title: FROFIIE TQRERATURES II ITS-2 BOTTOMS TAIKS

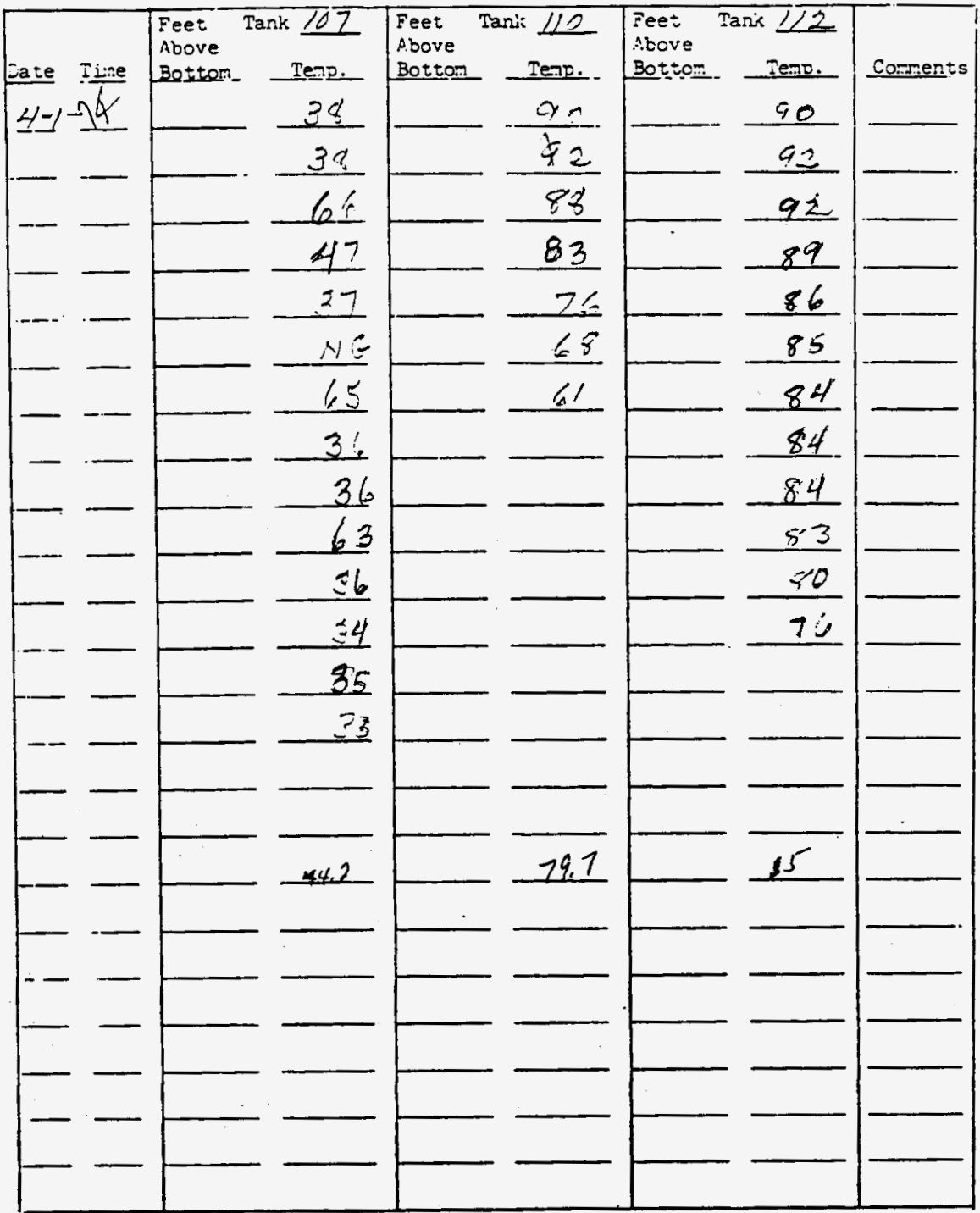

Instrintisns ar coments: - Take profile temperatures yeekly in each battoms tank. Attach completed form to Monday and Thursday's Data Sheets. 
Title : BROEILE TERERATURES DI ITS-2 BOTTONS TAMKS

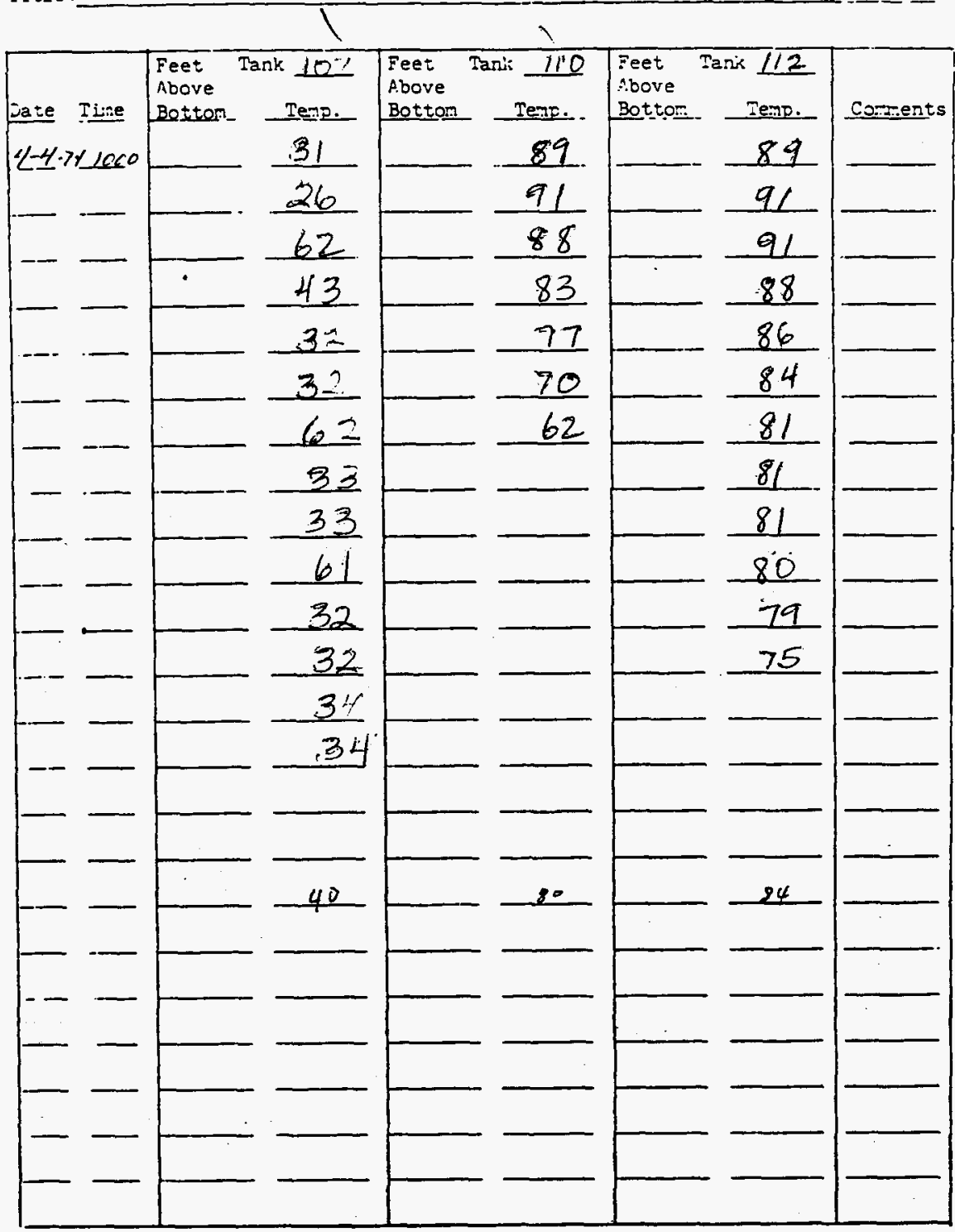

Instristisns or coments: Thake prorlle temperatures weekly in each bottons tank. Attach completed form to Monday and Thursday's Data Sheets. 
Title:

FROFILE TRPERATURES IN IIS-2 BOTTOMS TANTS

$4-15-74$

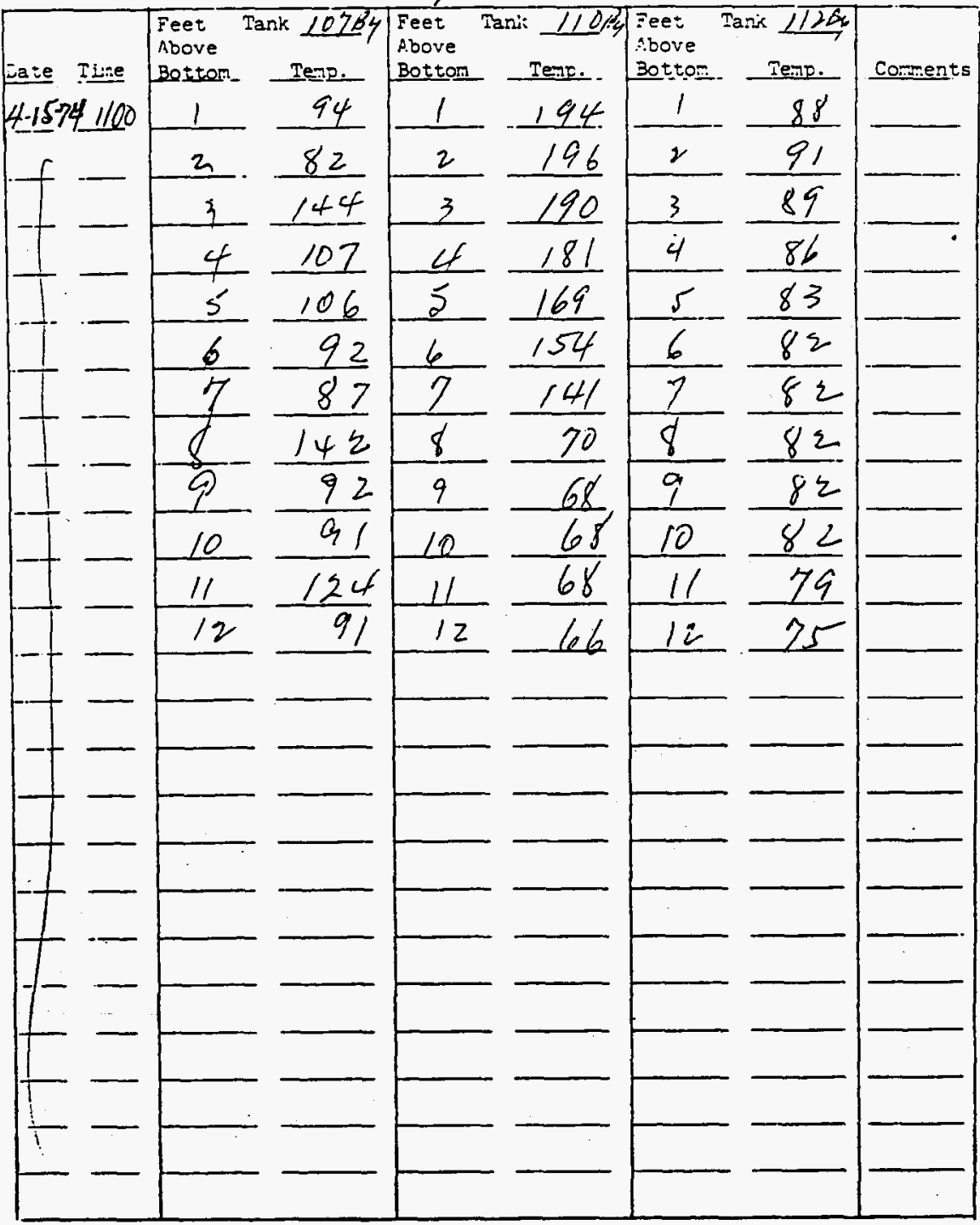

Ir:s:r:s:isns ar coments: - Take profile tenperatures weekly in each bottoms tank. Attach corpleted forn to Monday and Thursday's Data Sheets. 
Title: PROFILE TREREATURES IN ITS-2 BOTTOMS TANKS

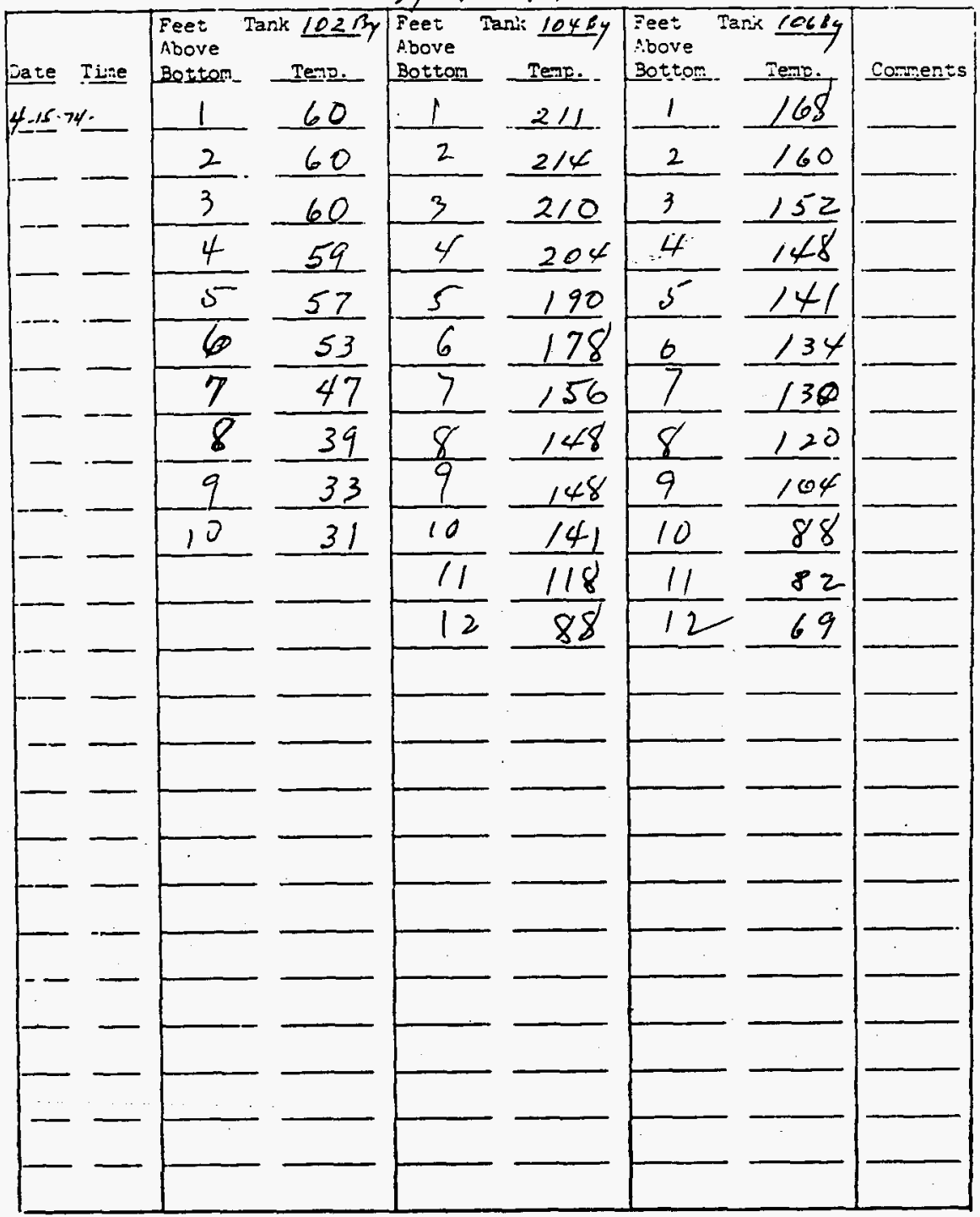

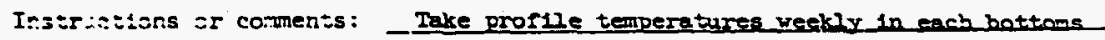
tanik. Attach completed form to Monday and Thursday's Data Sheets. 
Title: FROFILE IETERATURES II ITS-2 BOTTOMS IATKS

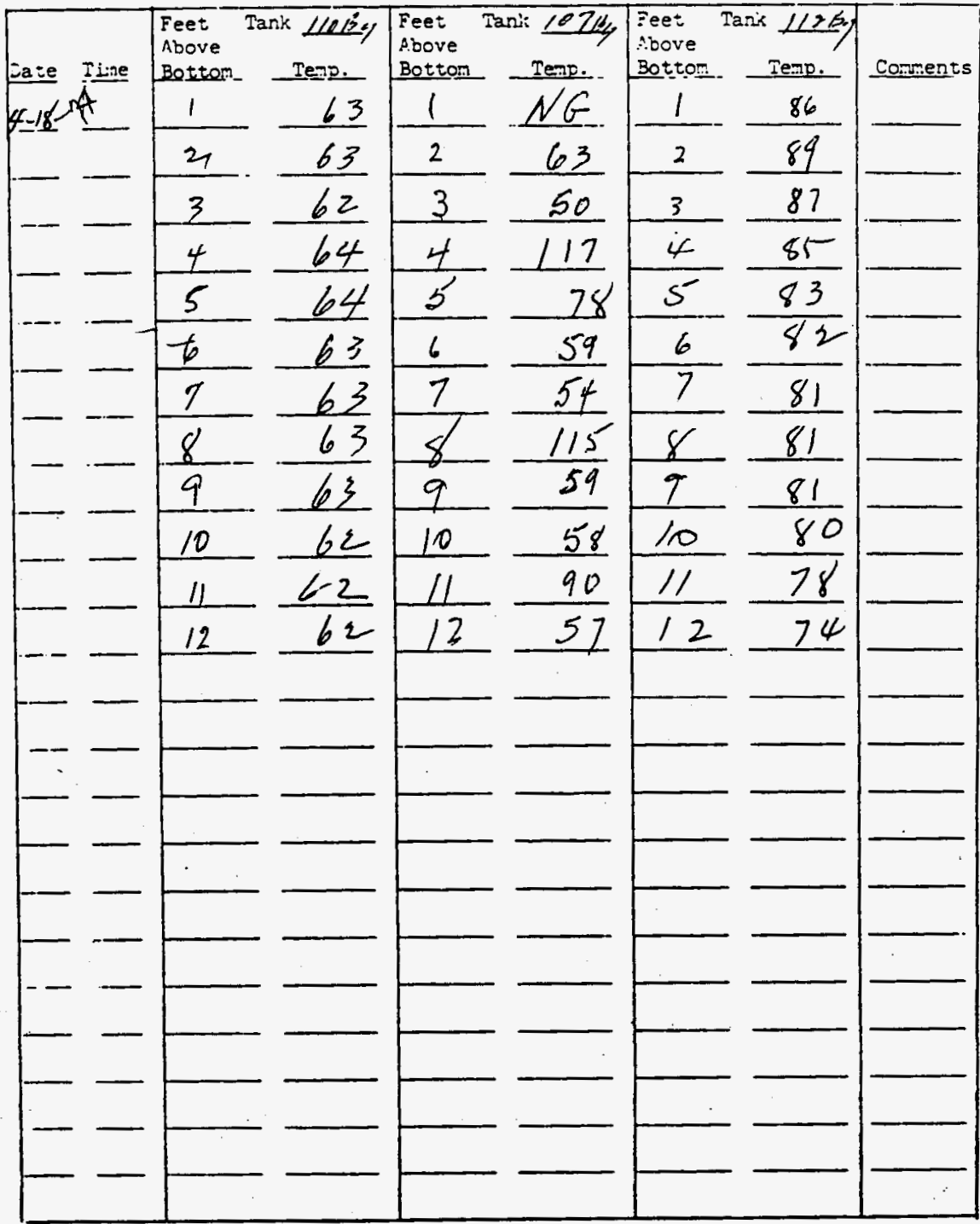

Ir:5tr:ajisns ar corments: -Take profile temperetures veekly in each bottoms. tark. Attach completed form to Monday and Thursday's Data Sheets. 
Title: FROFILE TERERATURES DI ITS-2 BOTTONS TARKS

TY

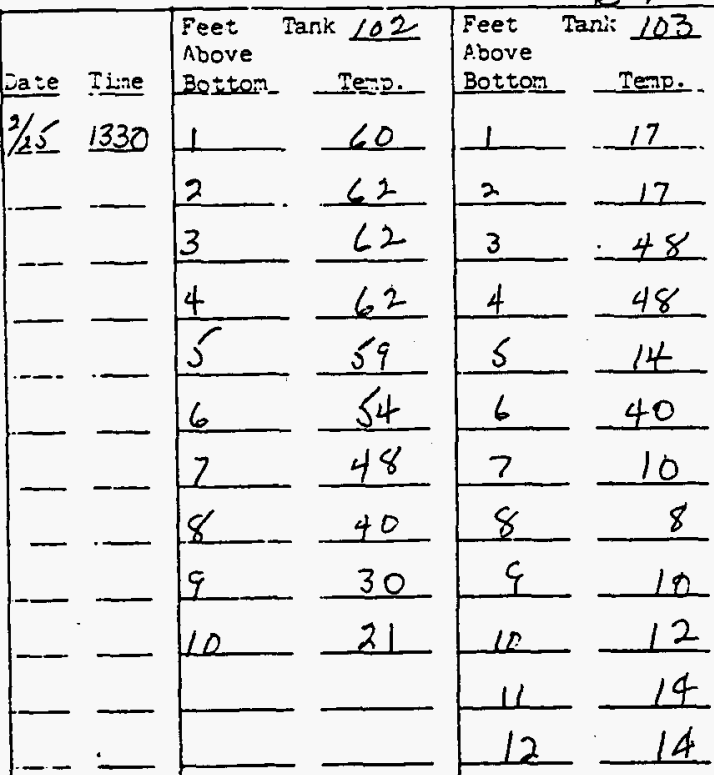

Itts II

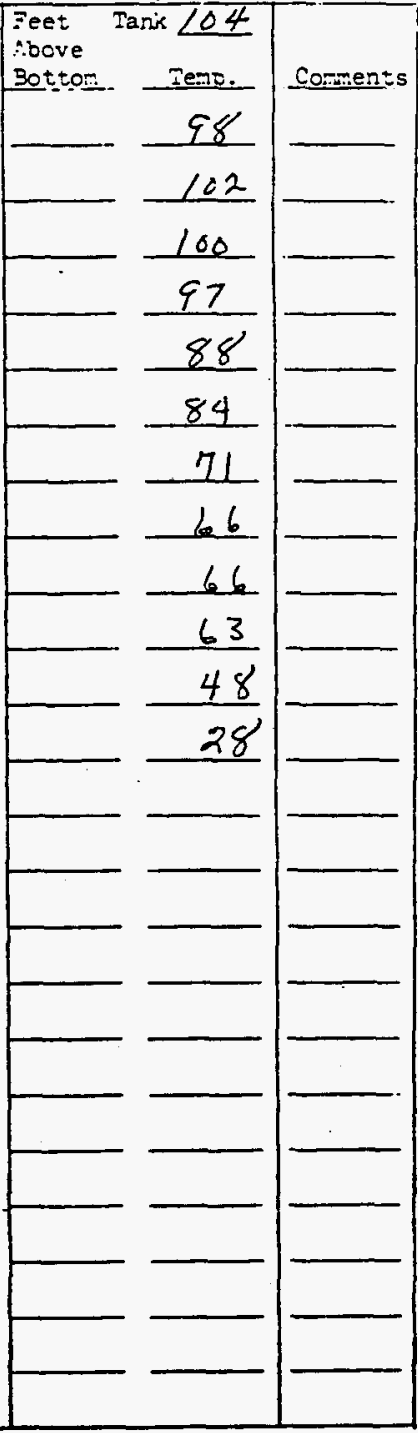

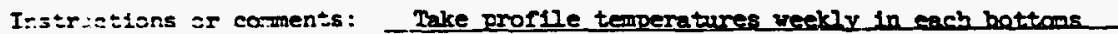
tank. Attach conpleted form to Monday and Thursday's Date sheets. 
Title: PROFILE TEIFERATURES IN ITS-2 BOTTOMS TANTS

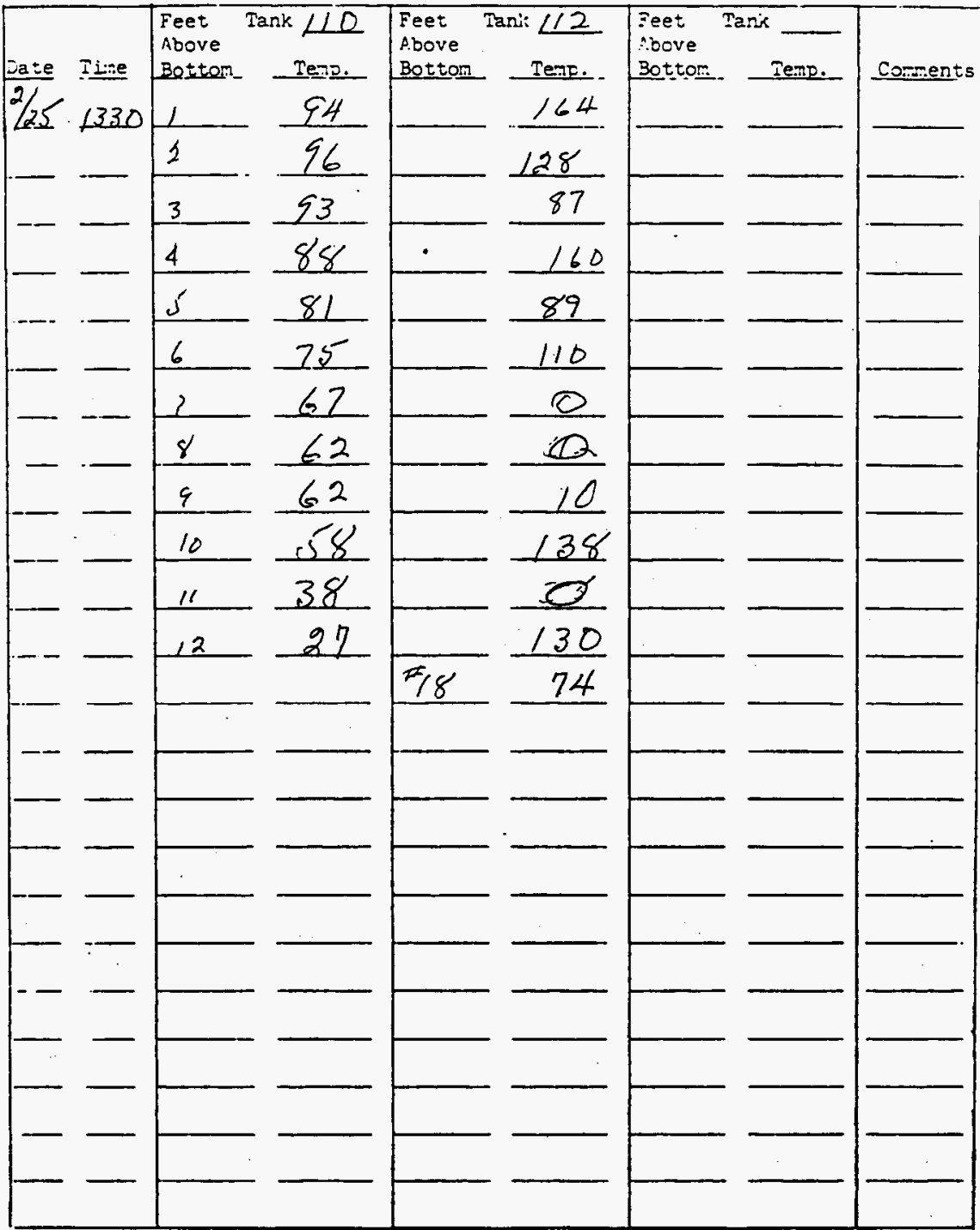

I:3tr:ations sr comen's: - Teke profile temperetures veekly in each hottoms tank. Attach completed form to Monday and Thursday's Data sheets. 


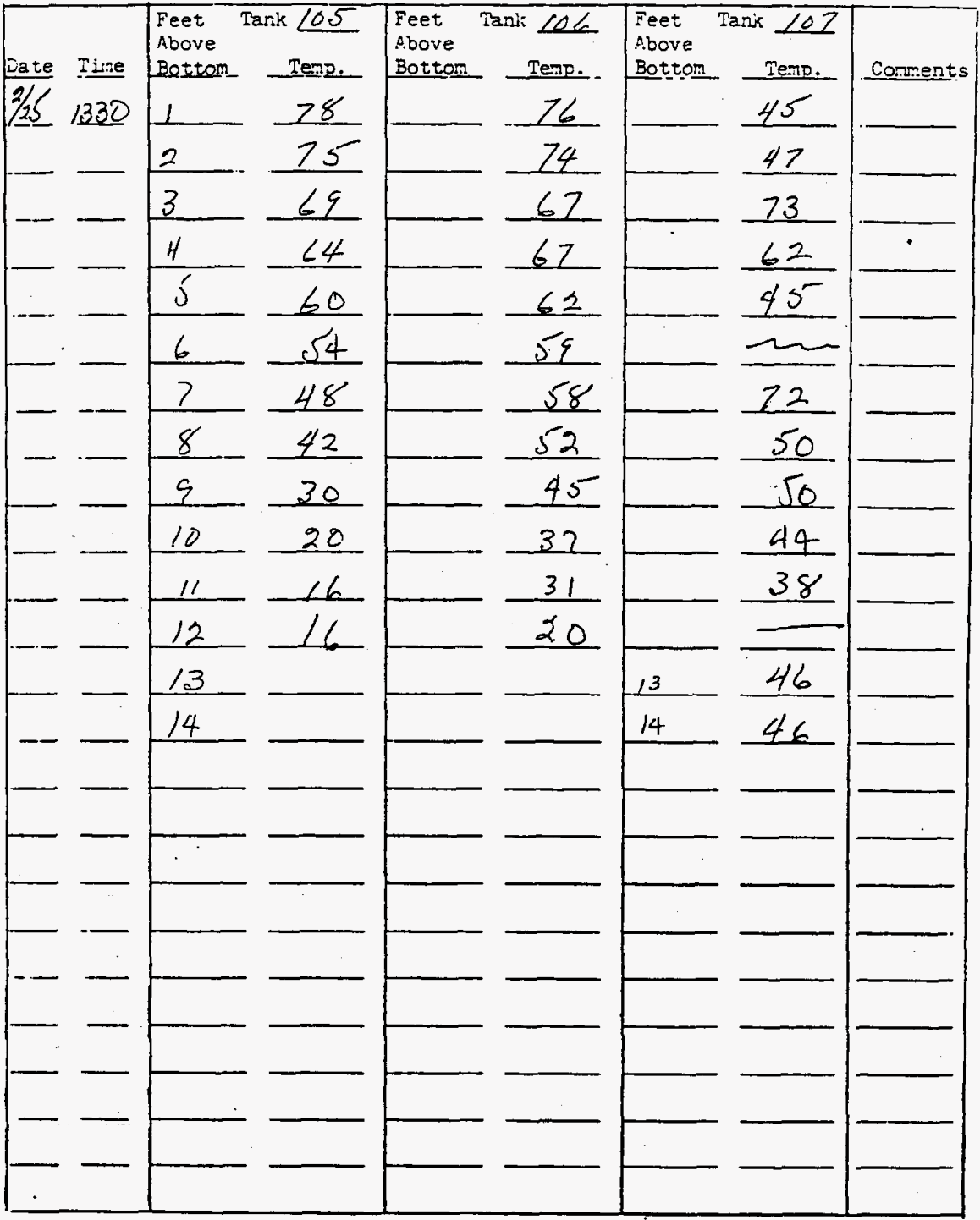

Instrictions or coments: - Thke profile temperazures reekly in each bottoms tanik. Attach conpleted forz to Monday and Thursday's Data Sheets. 
Title:

PROFIIE TEIRERATURES IN ITS-2 BOTTOMS TANKS

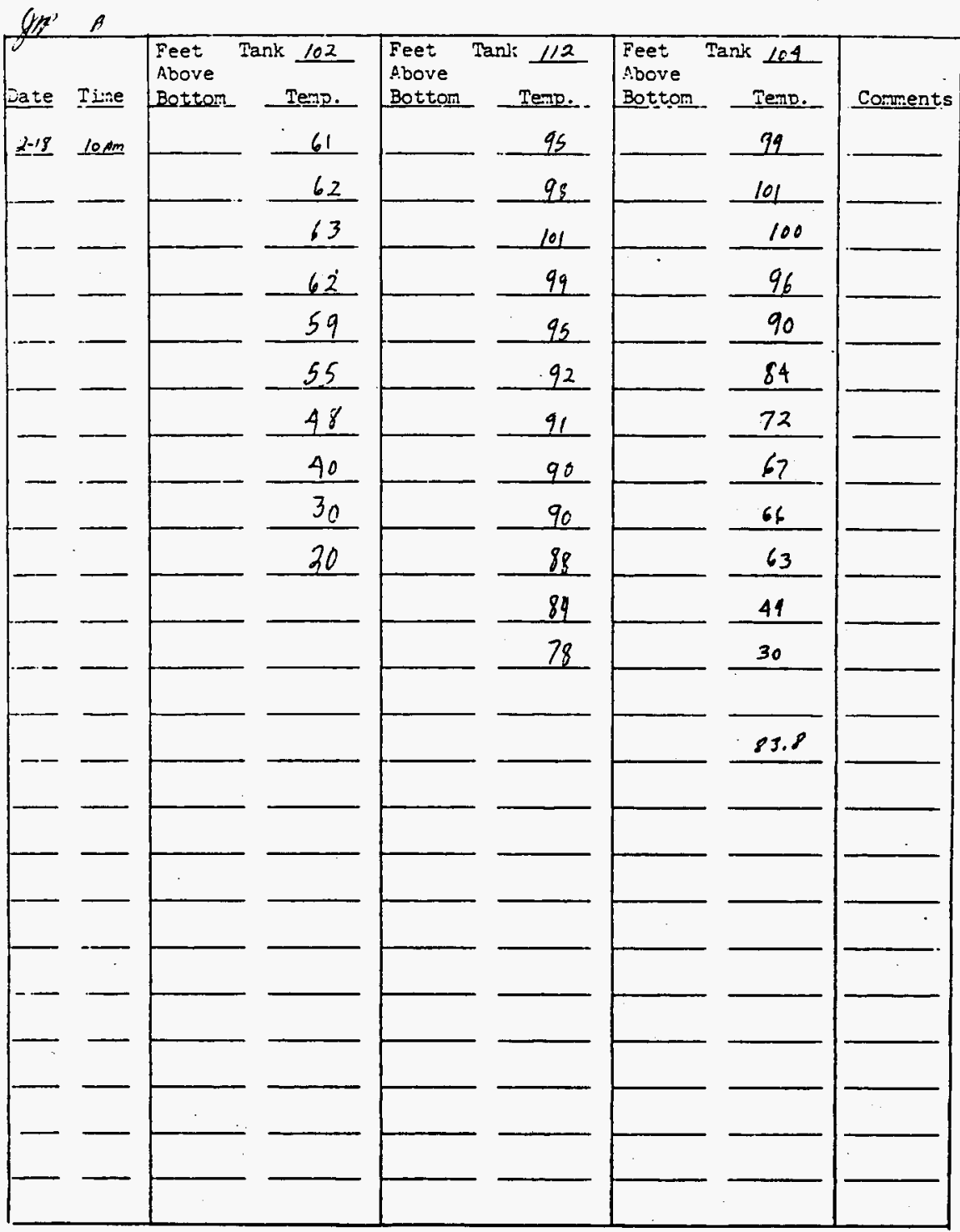

Ir:3tristisns or coiments: - Take profile temperatures weekly in sach bottoms tank. Attach completed form to Monday and Thursday's Data Sheets. 
UHC-SO-LWH-DP-207, Rev. 0

Title: PROFIIE TEMERATURES IN ITS-2 BOTTOMS TAIKS

$\zeta$

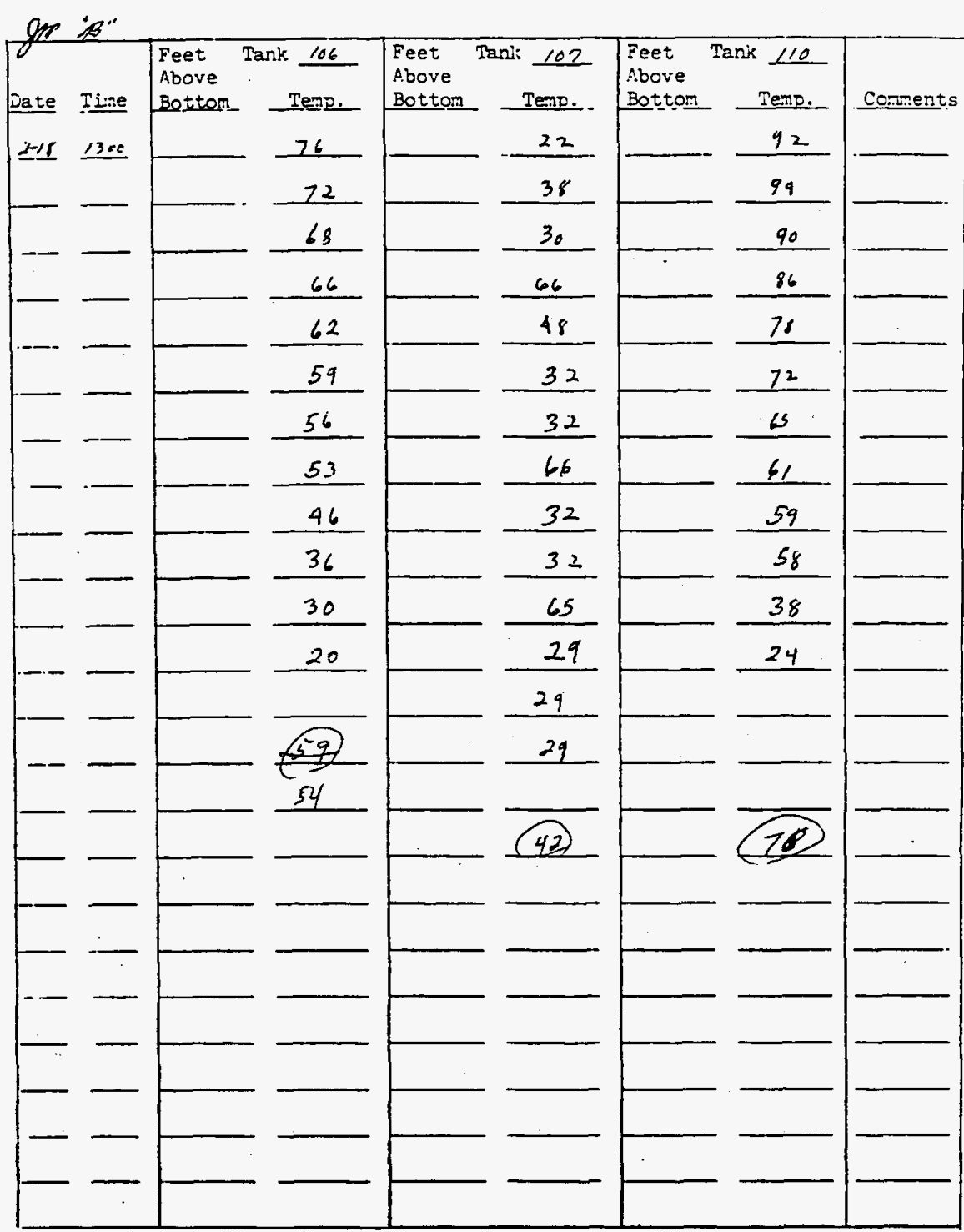

Instrictions or caments: - Take proflie temperetares veekly in each bottoms tank. Attach conpleted fors to Monday and Thursday's Data Sheets. 
Title: FROFILE TETERATURES IN ITS-2 3OTROAS TANTS

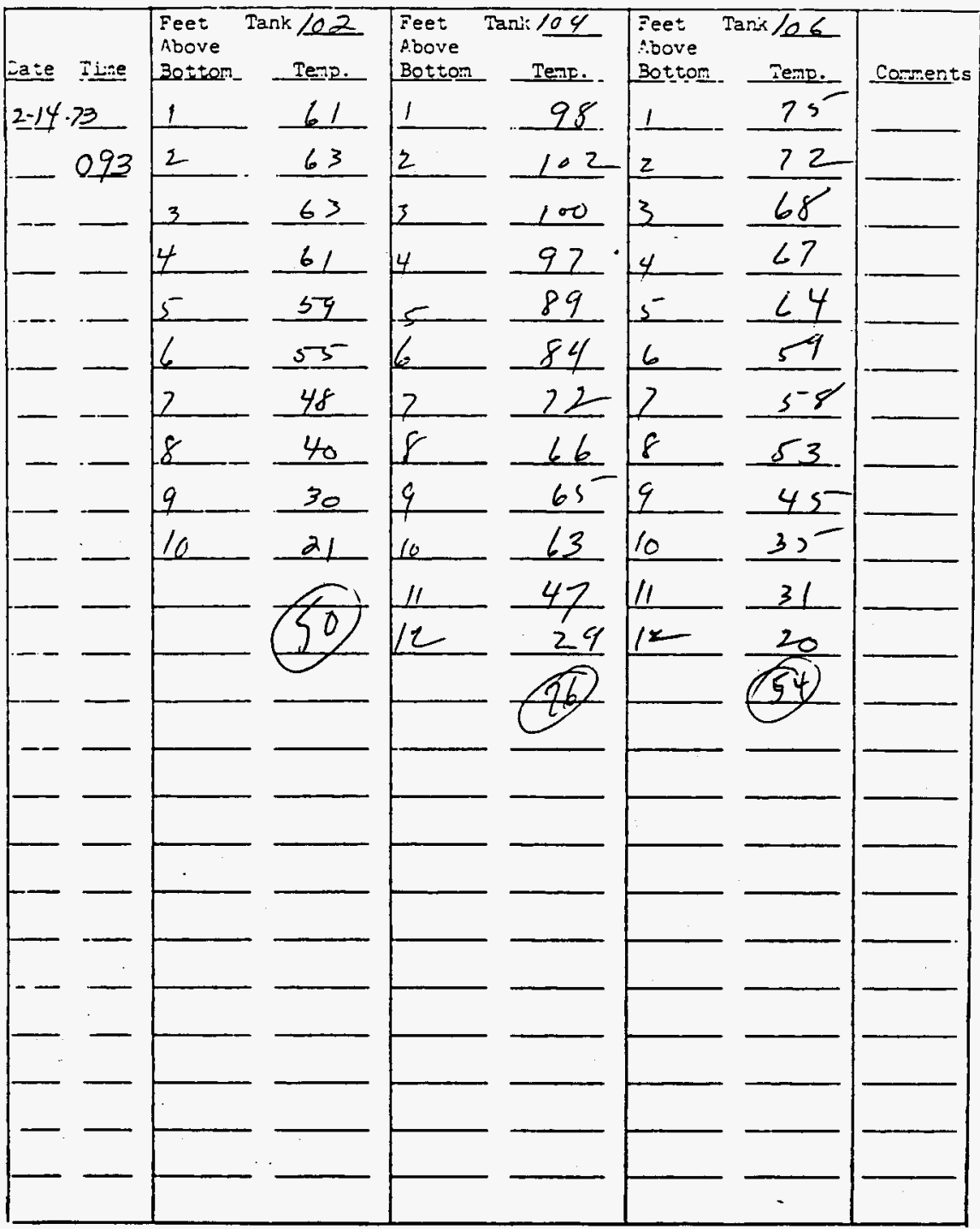

I-s:r:s:10r.s sr coments: - Take prorlie temperatures weekly in pach battoms. tank. Attach conpleted form to Monday and Thursday's Data Sheets. 
Title: PROFILE TEPERATURES IN ITS-2 BOTTOMS TAIKS

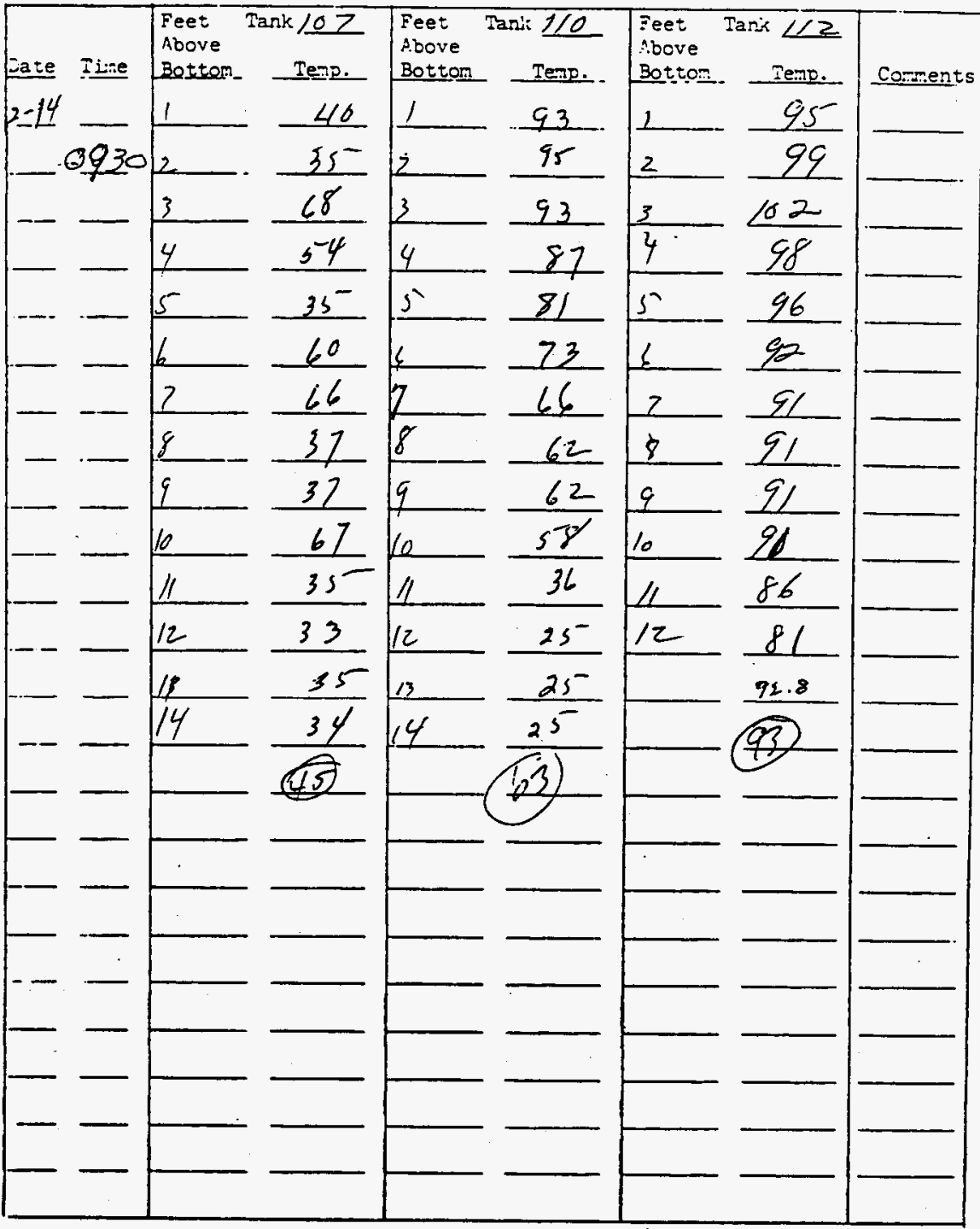

Instristians ar coments: - Take prorlle tenperatures veekly in each bottoms tenk. Attach completed form to Monday and Thursday's Data Sheets. 
Title: PROFILE TEPERATURES LI ITS-2 BOTTOMS TAUKS

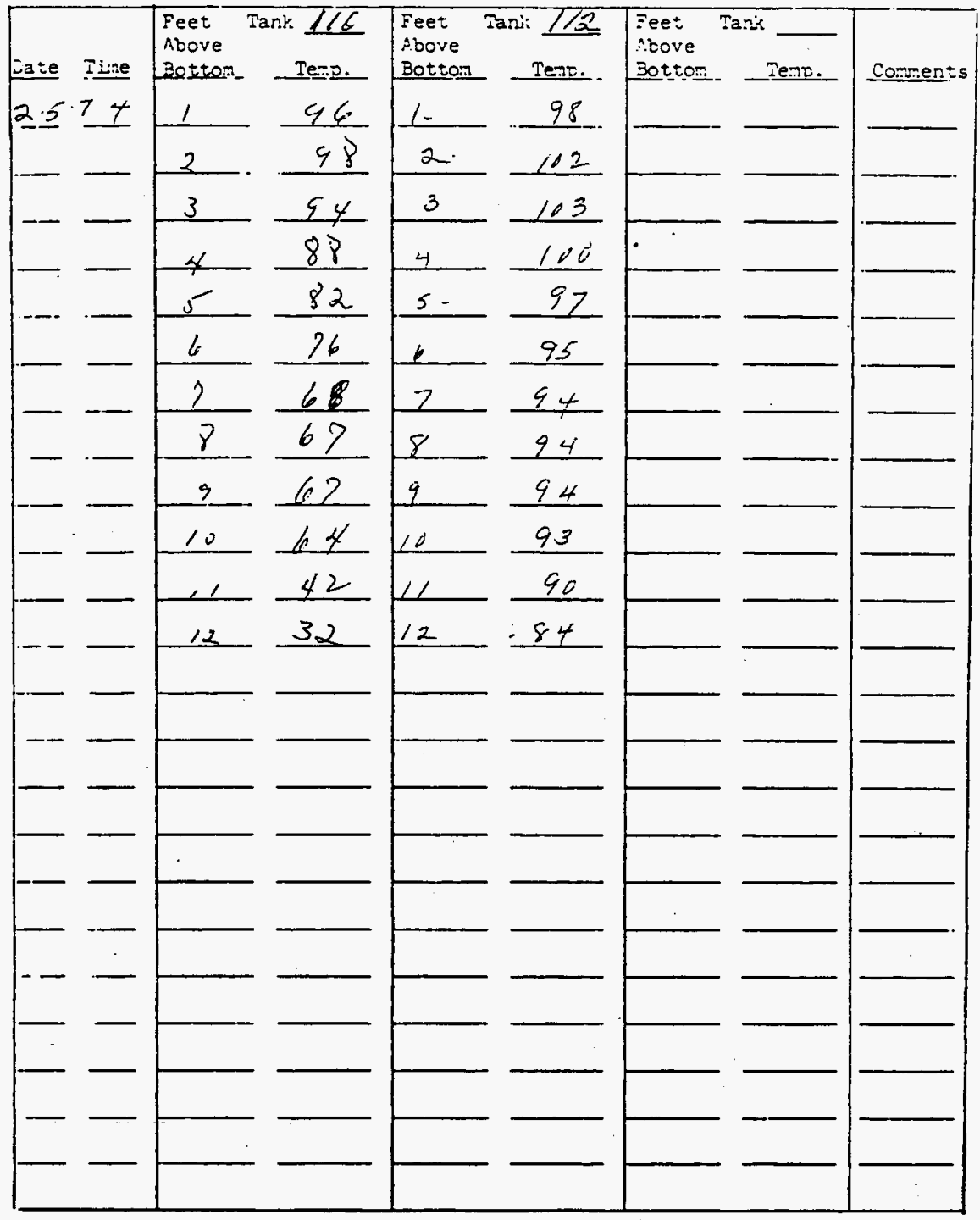

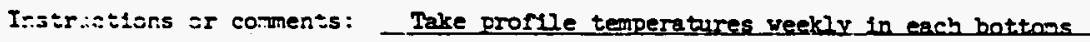
tank. Attach conpleted for to Monday and Thursday's Data sheets. 
Title:

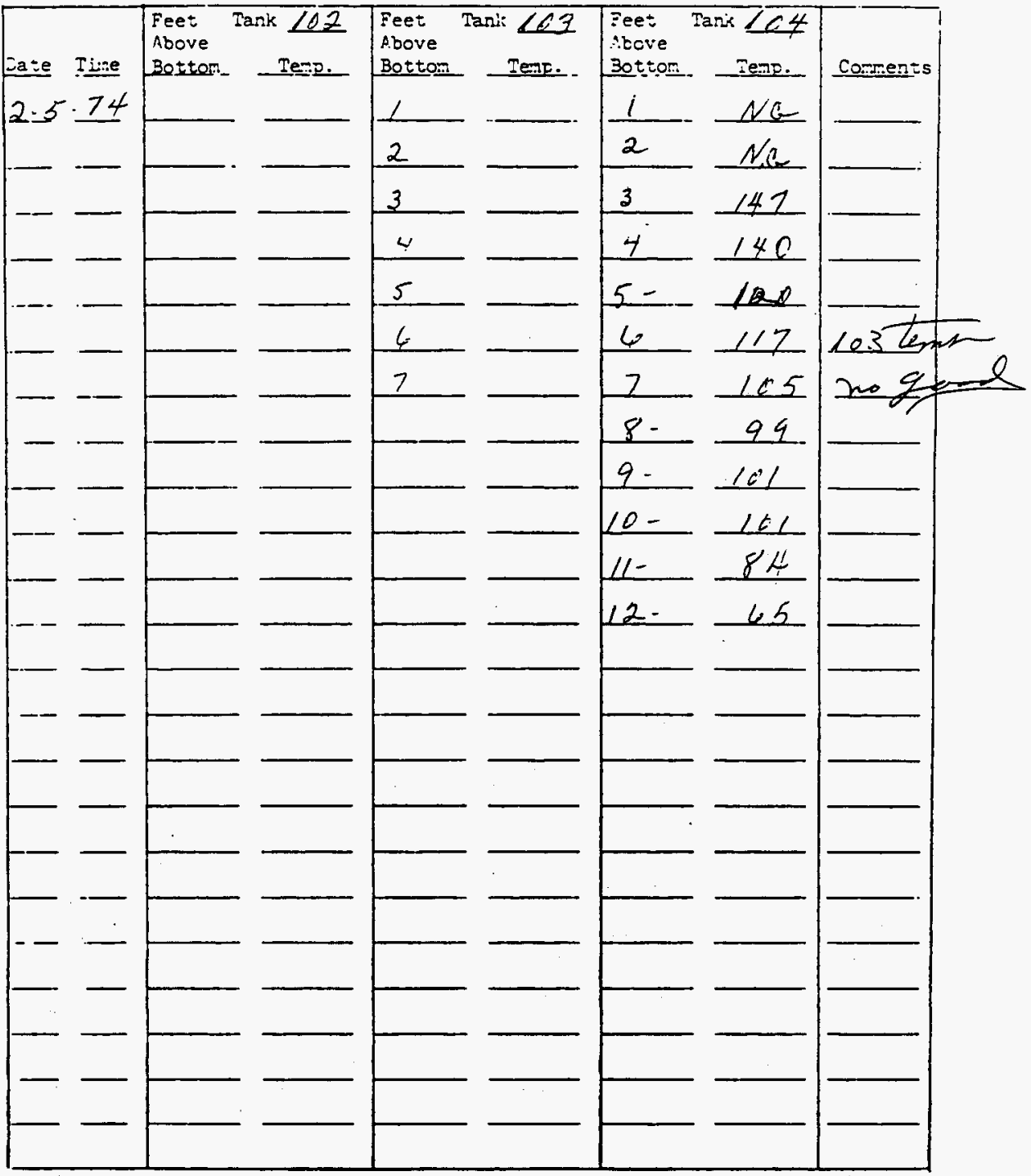

Irstristions or coments: - Take proflile temperatares reekly in each bottoms tank. Attach conpleted forg to Monday and Thursday's Dats sheets. 
Title: PROFILE TERERAIURES IH ITS-2 SOTMOMS TAIKS

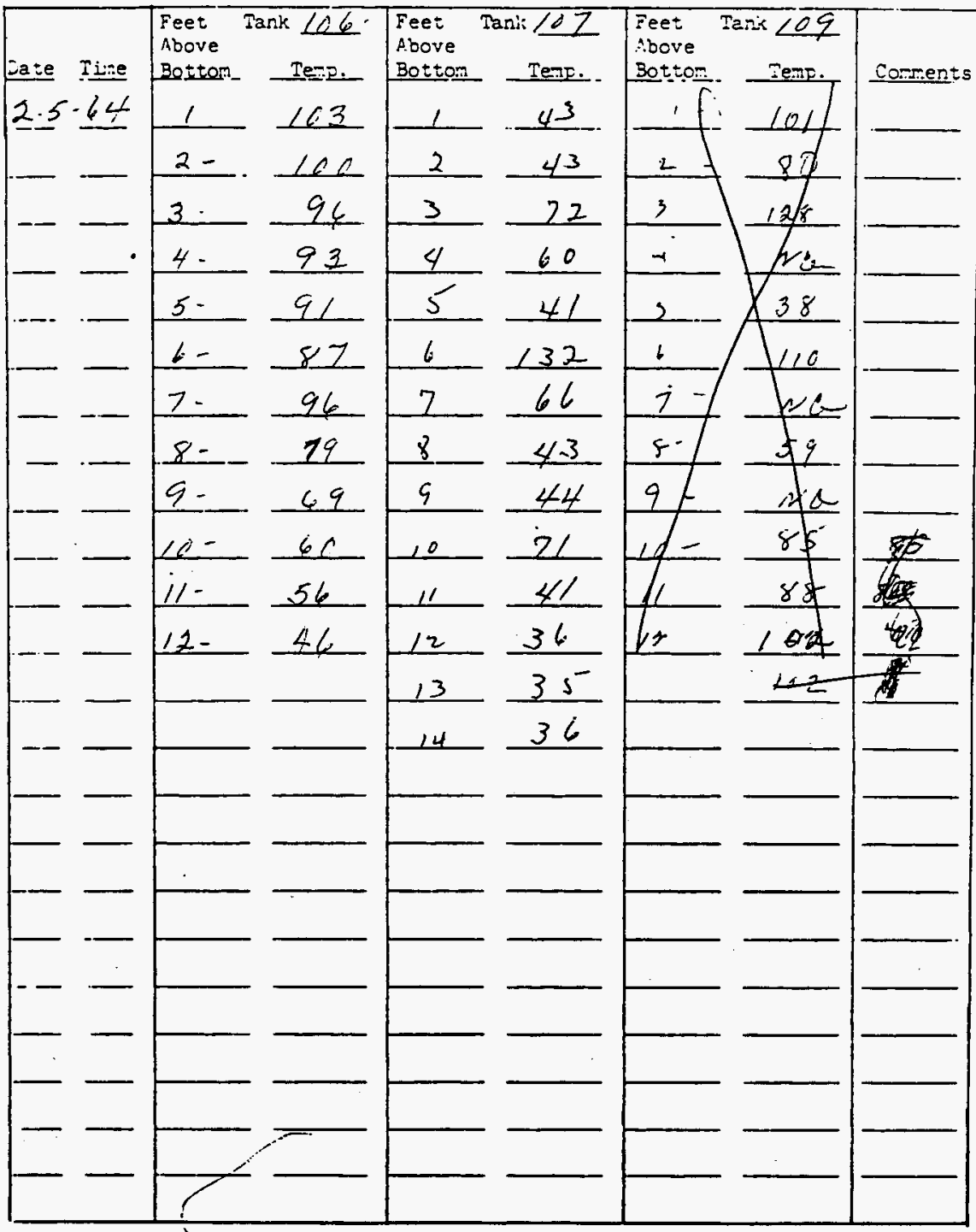

Ir.jur.itions or coments: - Take profile temperetures veekly in each bottoms tank. Attach conpleted form to Monday and Thursday's Data sheats. 
Title:

PROFILE TEFERATURES IF ITS-2 3OTTOMS TAIKS

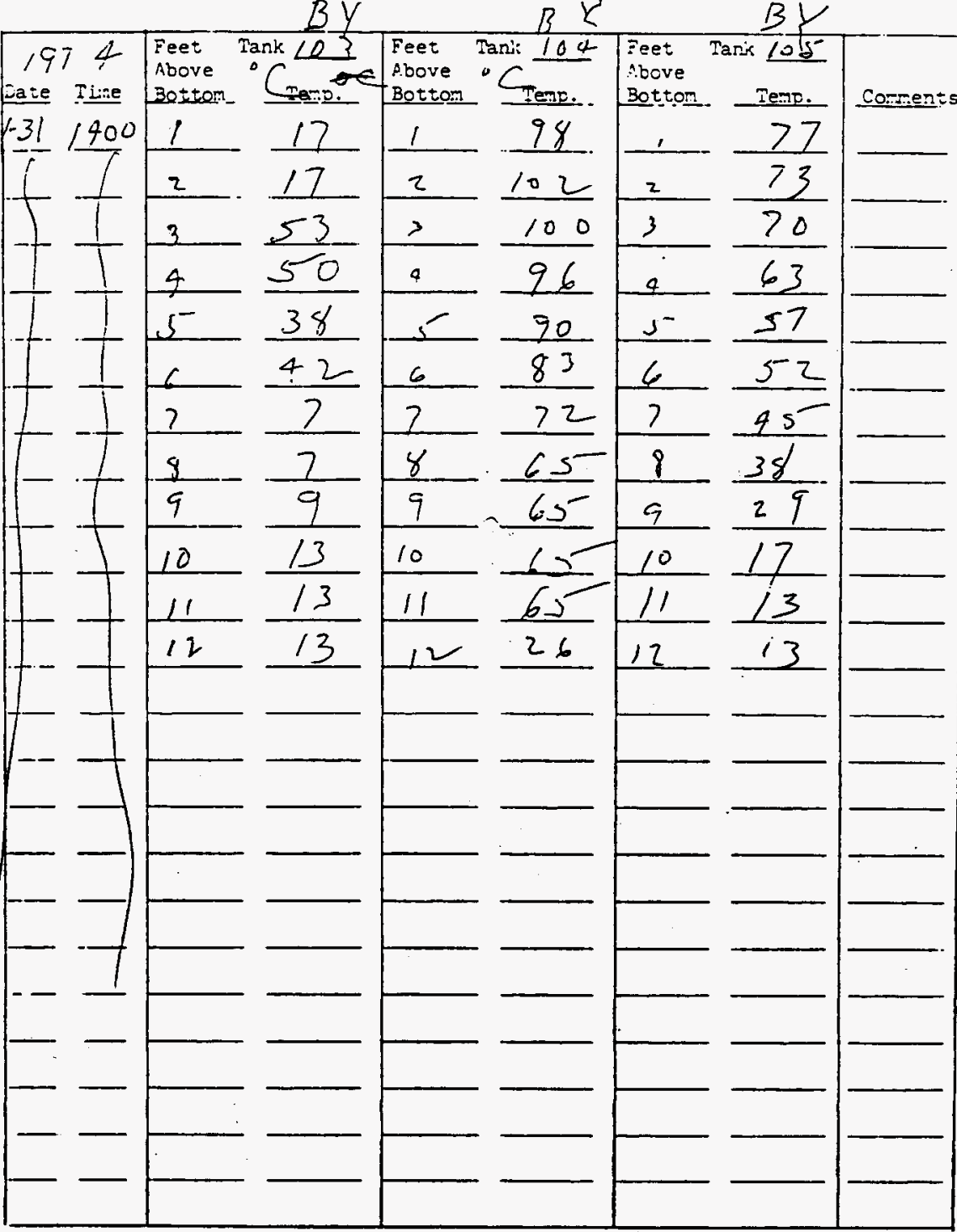

Ir:3:r:0:10rs or connents: - Take proflle temperatares weekly in each bottoms tank. Attach conpleted for to Monday and Thursday's Data Sheets. 
Title:

PROFILE TERERATURES IN ITS-2 BOTTOMS TANKS

BY

$197 \&$ Feet Tank $\angle 0$ C

Eate Ijase

$1-3110301$

$\frac{-31}{5} \frac{1930}{-1}$

$+1.1$

$\rightarrow+$

$7-1$

$+1$

$-+-1$

$\rightarrow-$

$-\rightarrow \frac{10}{11} \frac{33}{12}$

$\frac{1}{1}-\frac{1}{1}$

$-1$

$+$
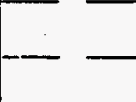

$-$
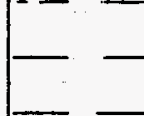

$\frac{2}{3}$.

$\frac{3}{4} \cdot \frac{66}{65}$

$5-\frac{65}{61}$

$6-58$

2

8

9
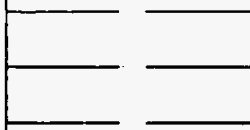

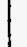
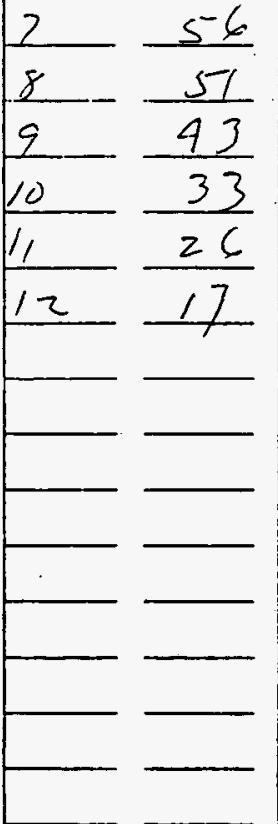

Feet Pani 107

Above $C \mathrm{C}$

Bottom.

Iemp.

Feet $\quad B$ Tani

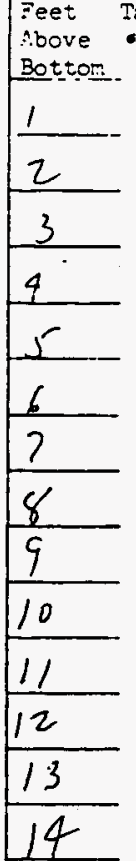

$C \operatorname{Con} \pi$

43

39

$2-\frac{39}{69}$

$\frac{69}{58}$

$\frac{4}{4} \frac{58}{44}$

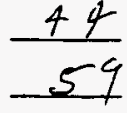

7

4

76

40

5

\begin{tabular}{|l}
\hline 10 \\
\hline$\frac{12}{13}$ \\
\hline 14 \\
\hline
\end{tabular}

$\frac{40}{69}$

$\frac{39}{36}$

temp.

Conrents

$\frac{92}{86}$

$\frac{\frac{86}{83}}{77}$

70

62

60

$\frac{60}{60}$

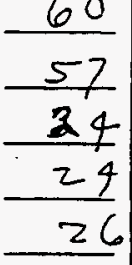


Title:

FROFILE TETERATUFES EF ITS-2 3OTTOMS TAMKS

\section{$"$ "BY-FARY"}

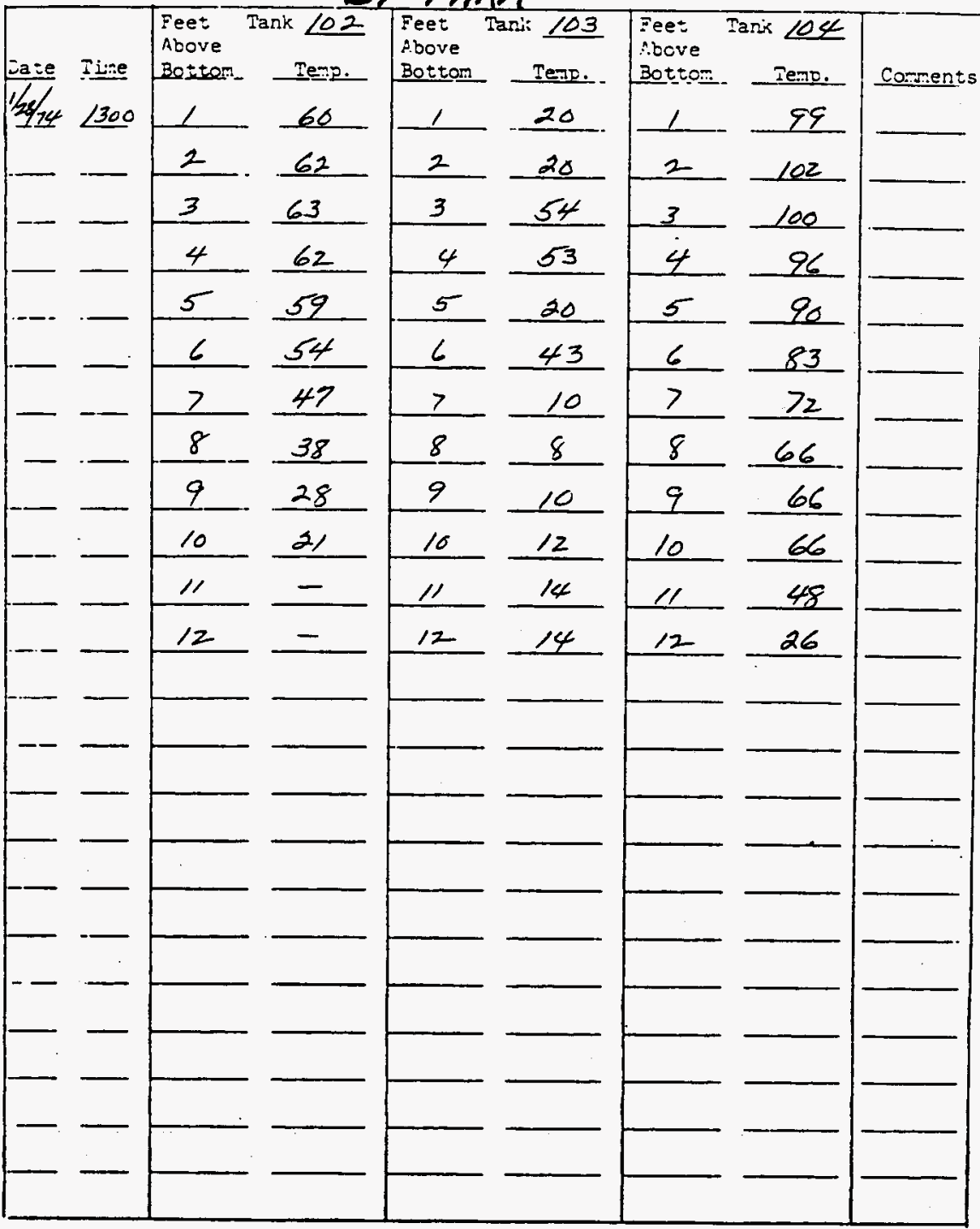

Ir:3tr:: itons or coments: - Take proflie temperatures veekly in each battoms tank. Attach conpleted form to Monday and Thursday's Data Sheets. 
Title:

PROFILE TEPERATURES DI ITS-2 BOTTOMS TAITS

\section{"BY-FARM}

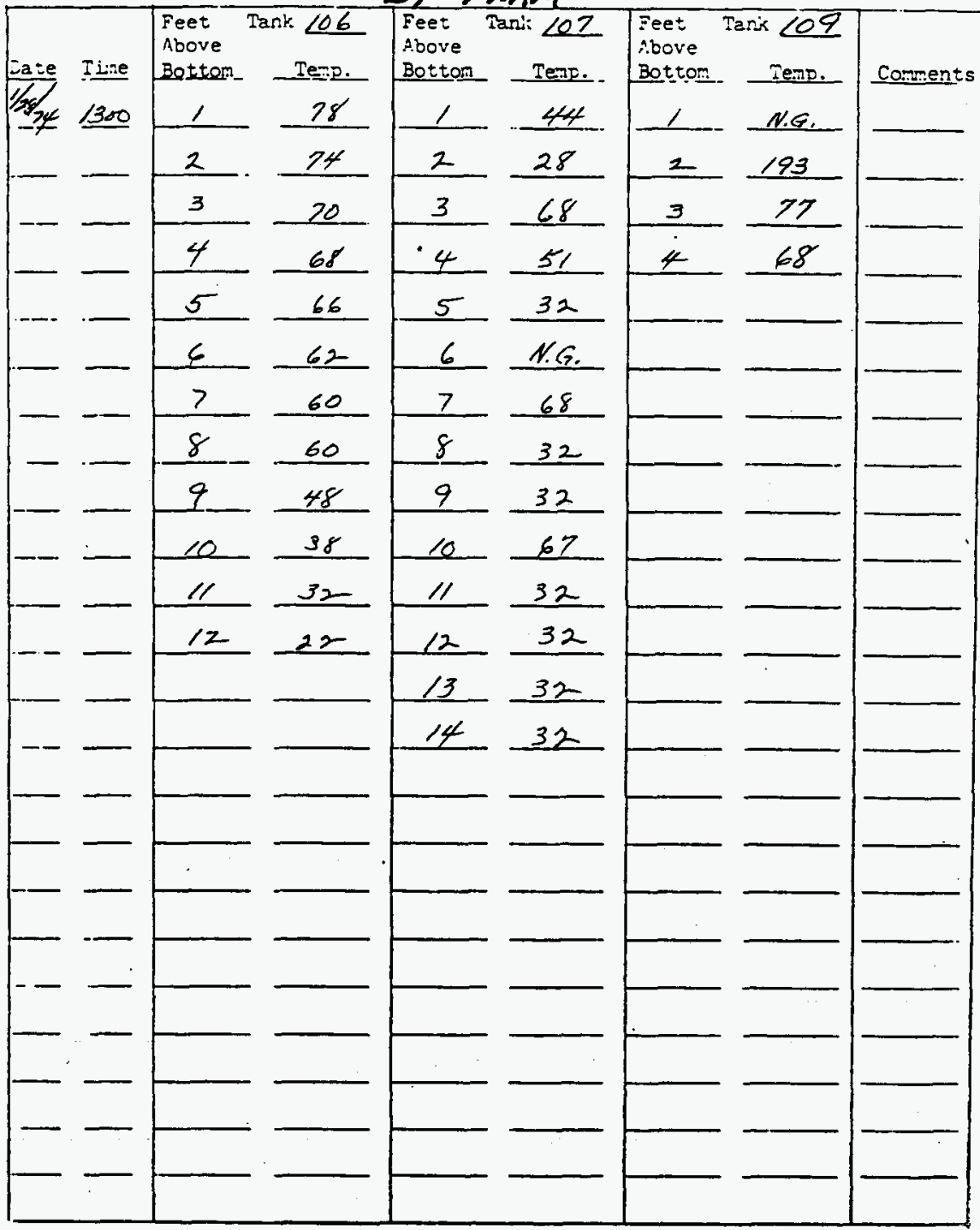

I:3:r:e:isns or comenss: - Take profile temperatares veekly in each battoms tank. Attach coapleted form to Monday and Thursday's Data sheets. 
Title:

PROFILE TEIFERATURES IN ITS-2 BOTTOMS IANTS

\section{"By-FARM}

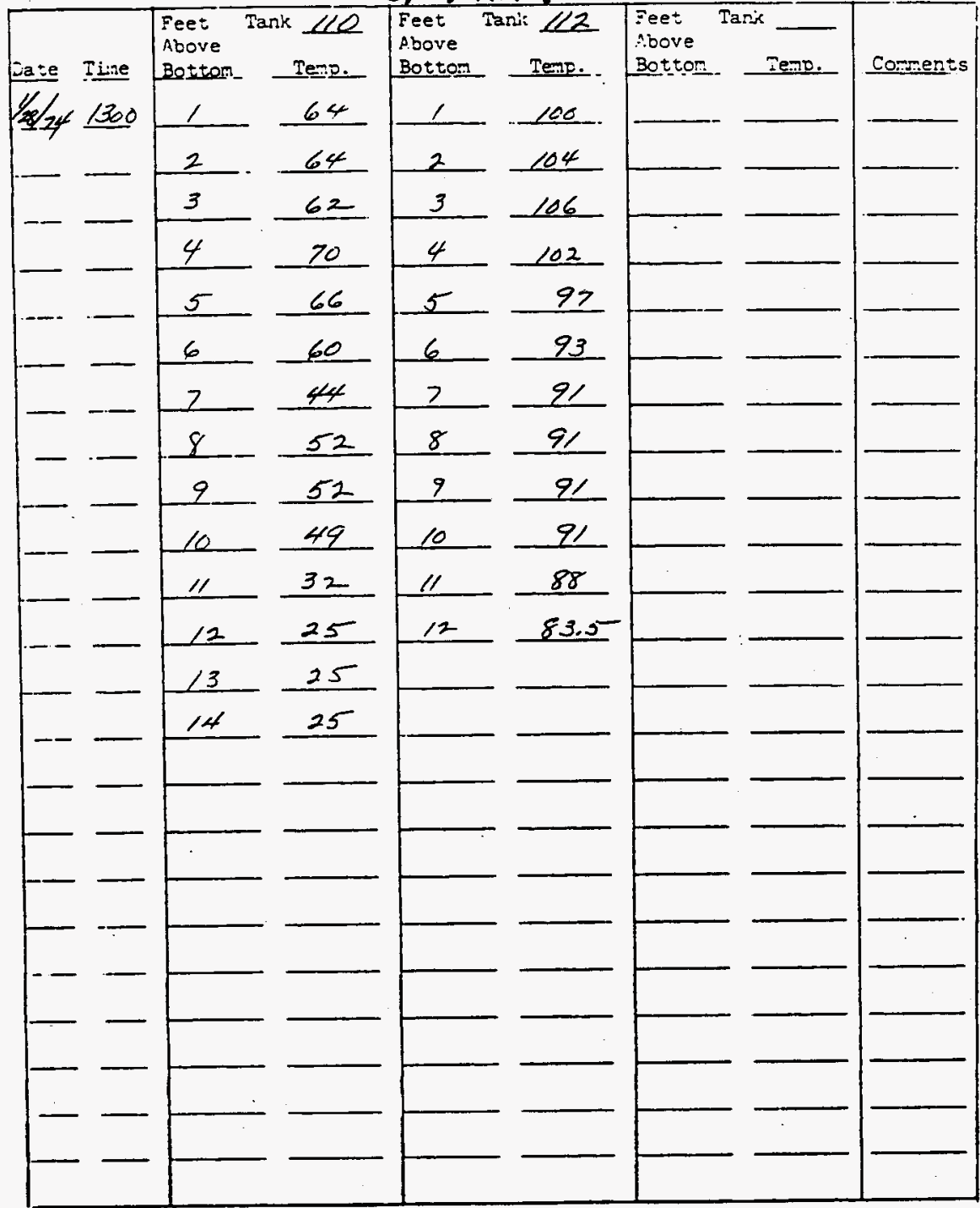

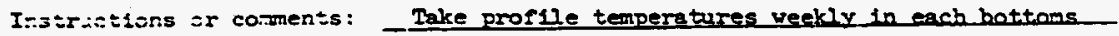
tank. Attach copleted fore to Monday and Thursday's Data Sheets. 
Title: PROFIIE TERERATURES II ITS-2 BOTMOMS TANKS

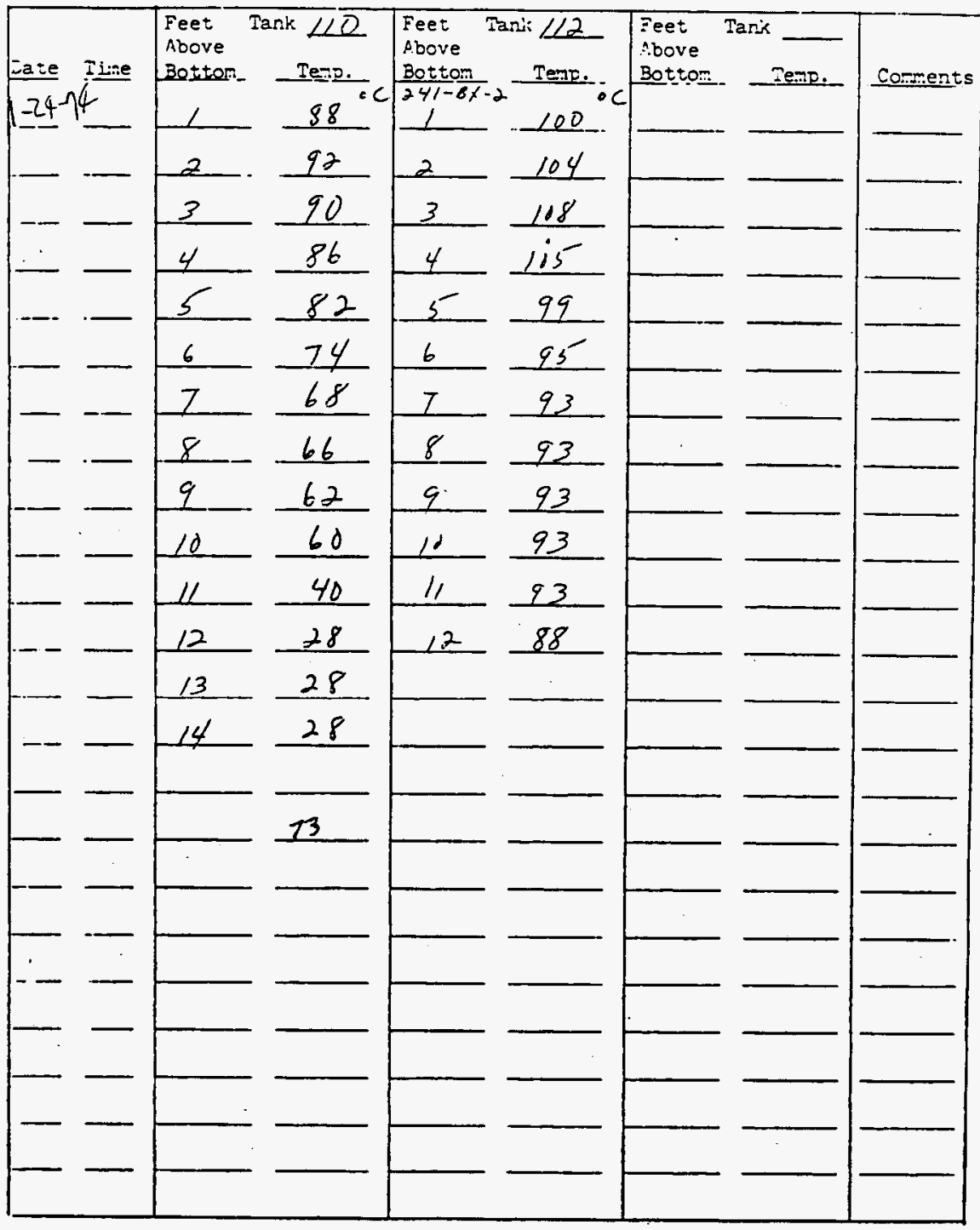

Irstristisss or conments: - Take profile temperatures yeekly in each bottoms tank. Attach conpleted forz to Monday and Thursday's Data Sheets. 
By $\quad 1-24-74$

Title:

PROFIIE TQFERATURES II ITS-2 BOTTOMS TARTS

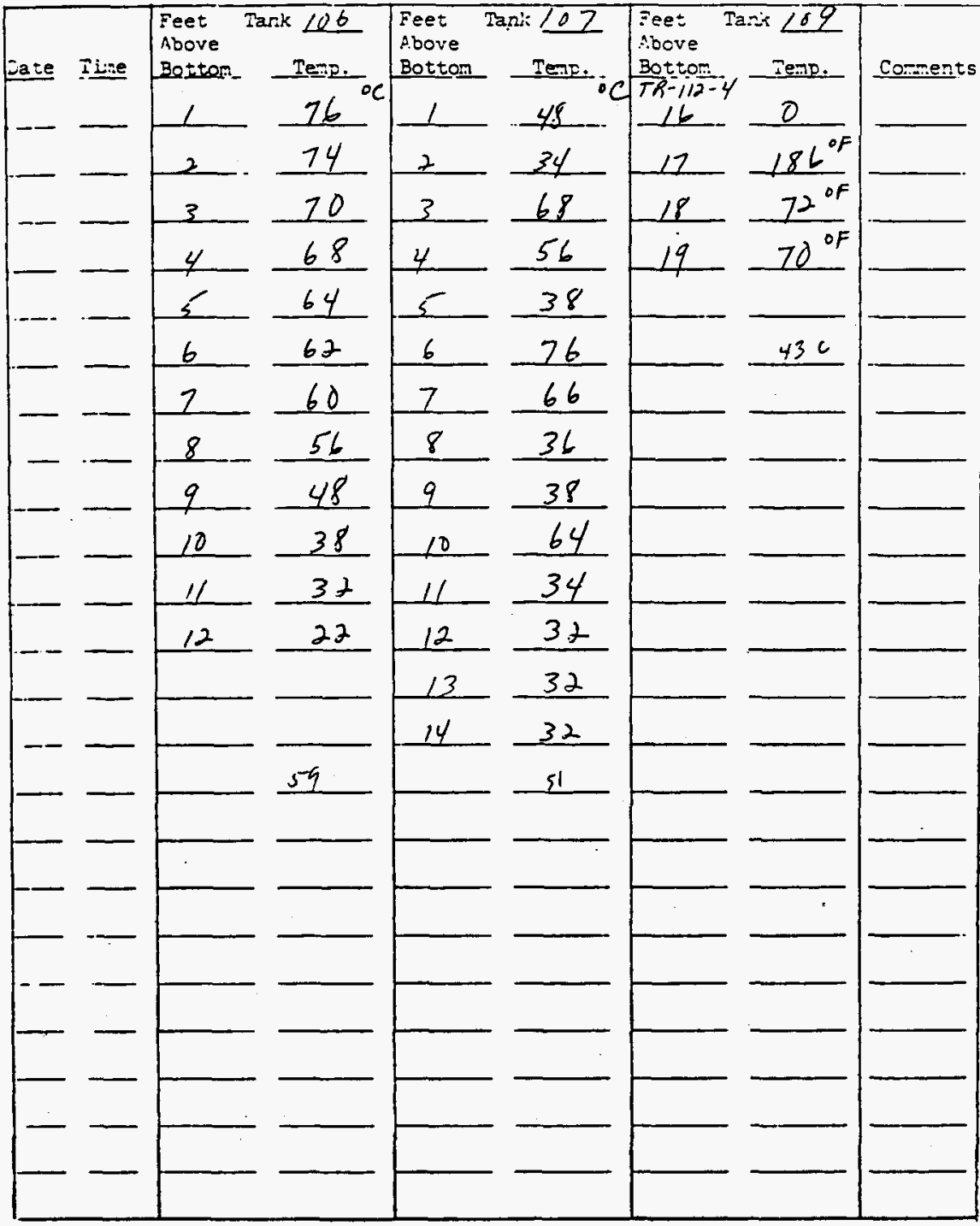

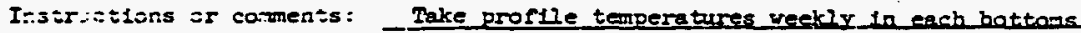


Title:

PROFIIE TERERATURES Li ITS-2 BOTTOMS TAMKS

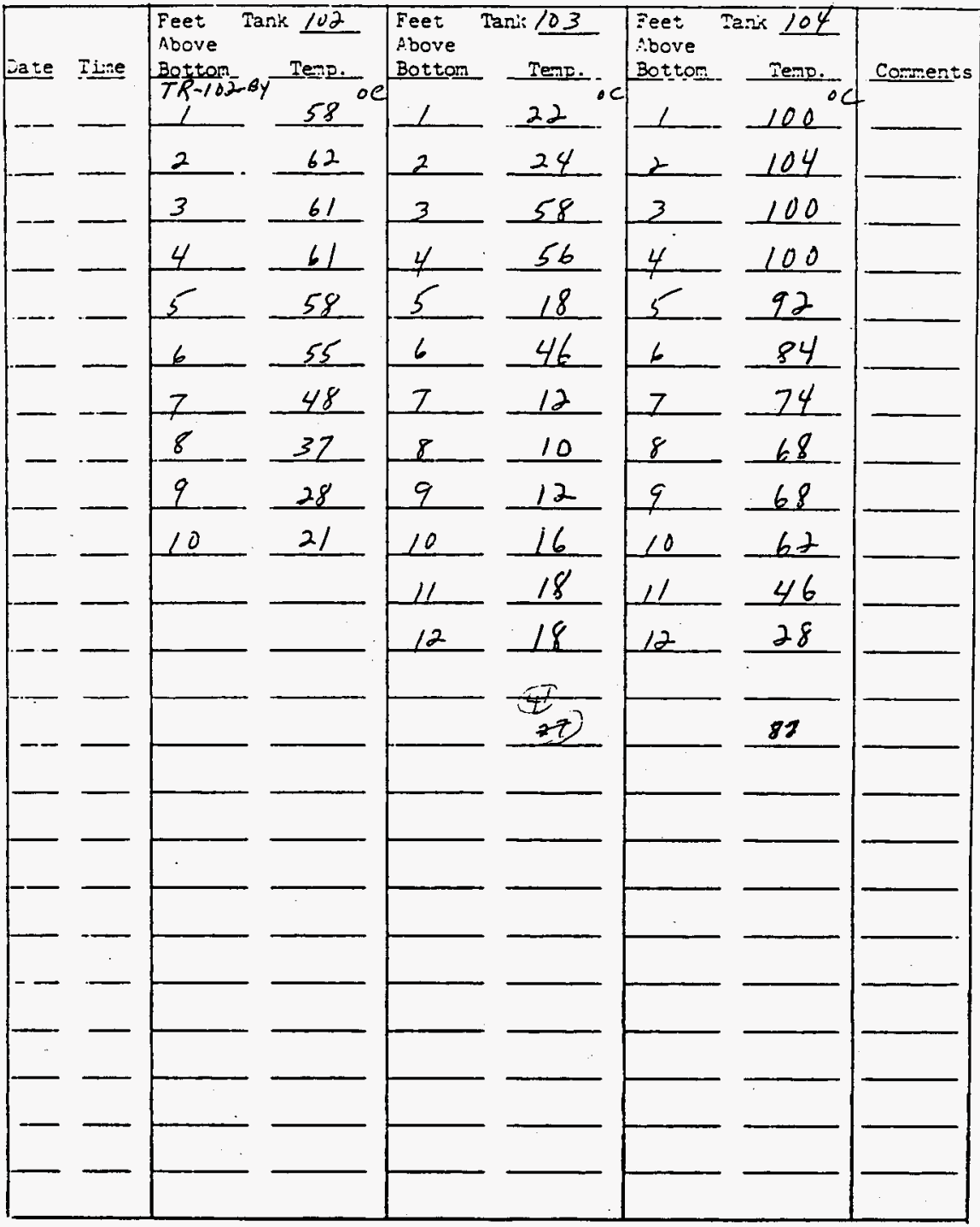

I-:3ir:ilions or coments: - Take proflle temperatures weekly in each bottoms.; tank. Attach conpleted form to Monday and Thursday's Data sheats. 
WHC-SD-LH-DP-207, Rev. $\ddot{0}$

Title: PROFILE TERERATURES IN ITS-2 BOTTOMS IATKS

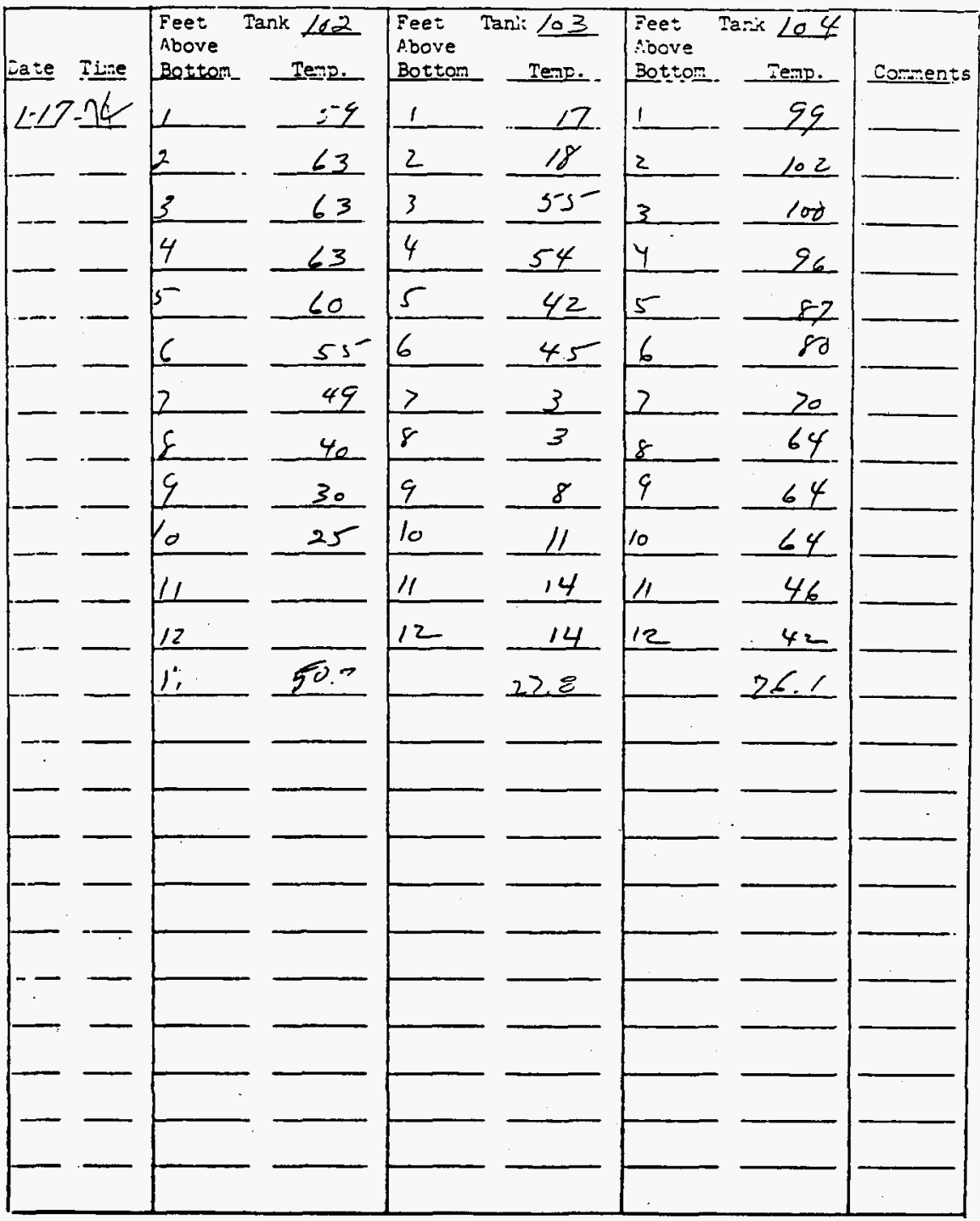

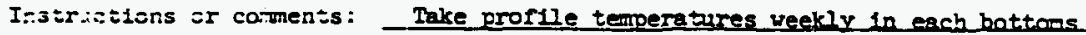
tank. Attach conpleted form to Monday and Thursday's Data sheets. 
Title: PROFILE TE.FERATURES II ITS-2 BOTTOMS IAIKS

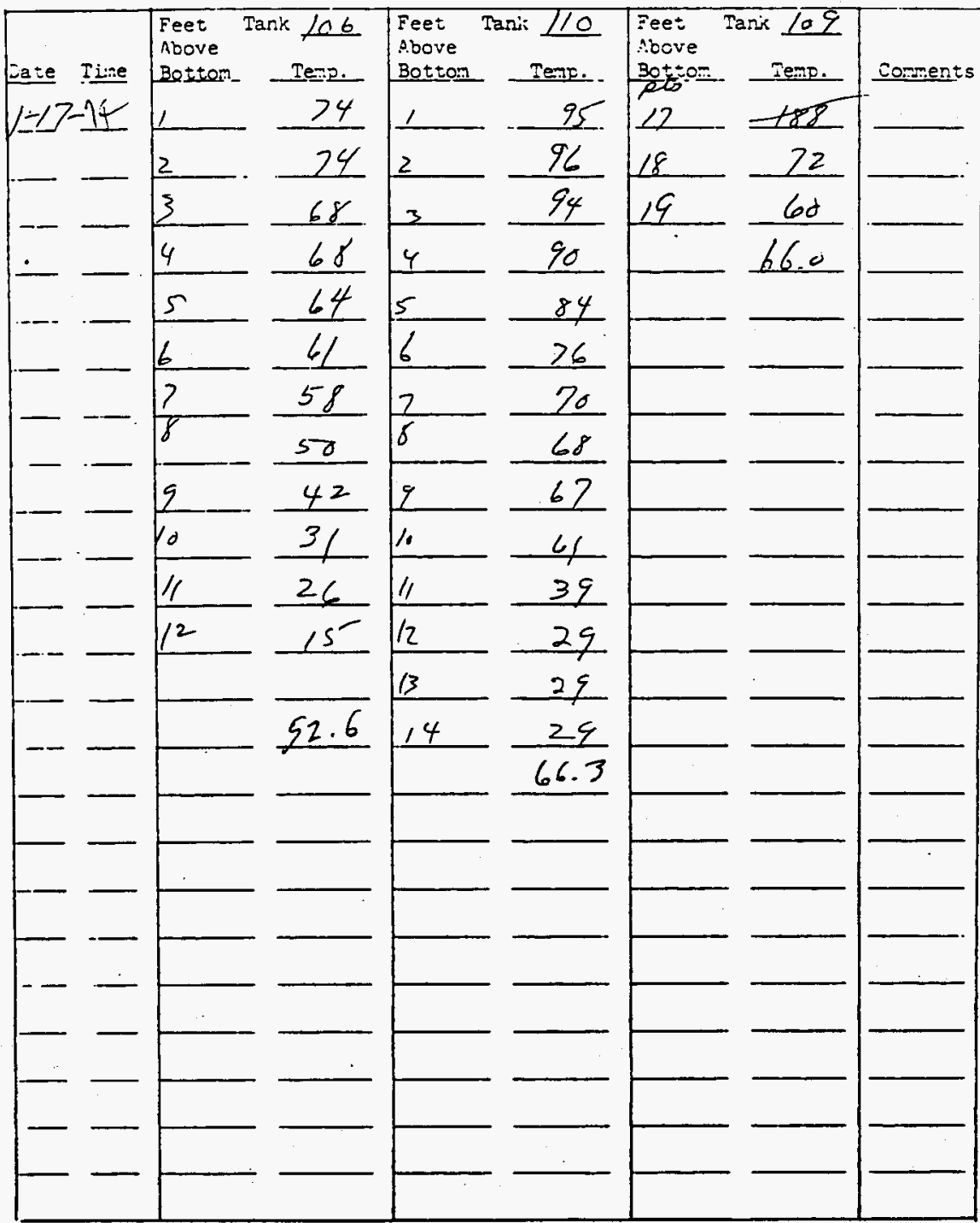

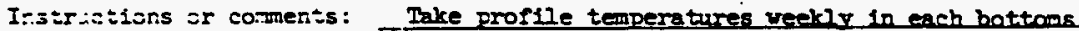
tank. Attach conpleted fors to Monday and Thursday's Data Sheets. 
Title: PROFILE TEPERATURES II ITS-2 BOTTOMS TARKS

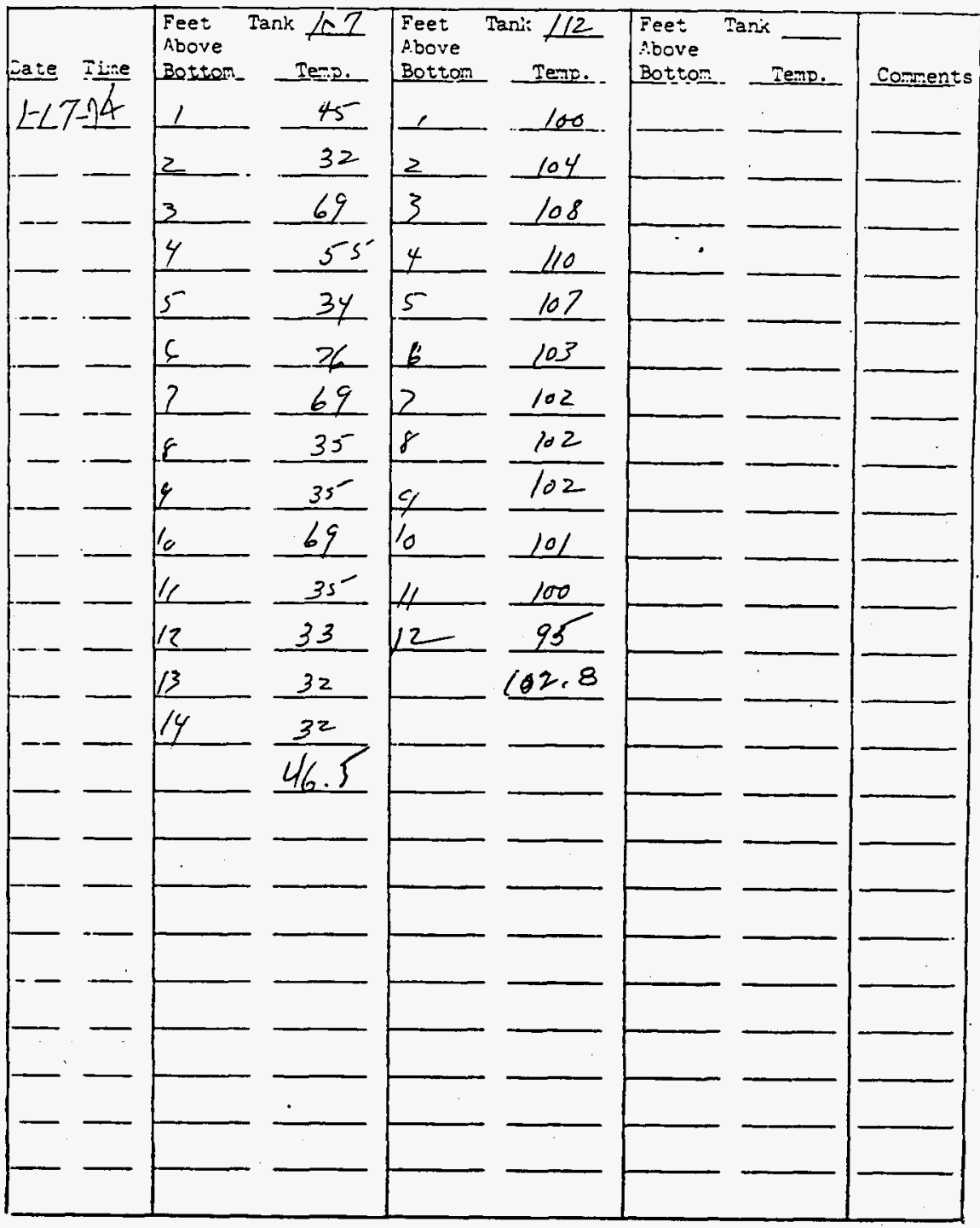

I-3:r:stisns ir comenss: - Take proflle temperatures reekly in each hottoms. tank. Attach conpleted form to Monday and Thursday's Data Sheets. 
Title:

PROFIIE TERERATRES IF ITS-2 BOTTOMS TANKS

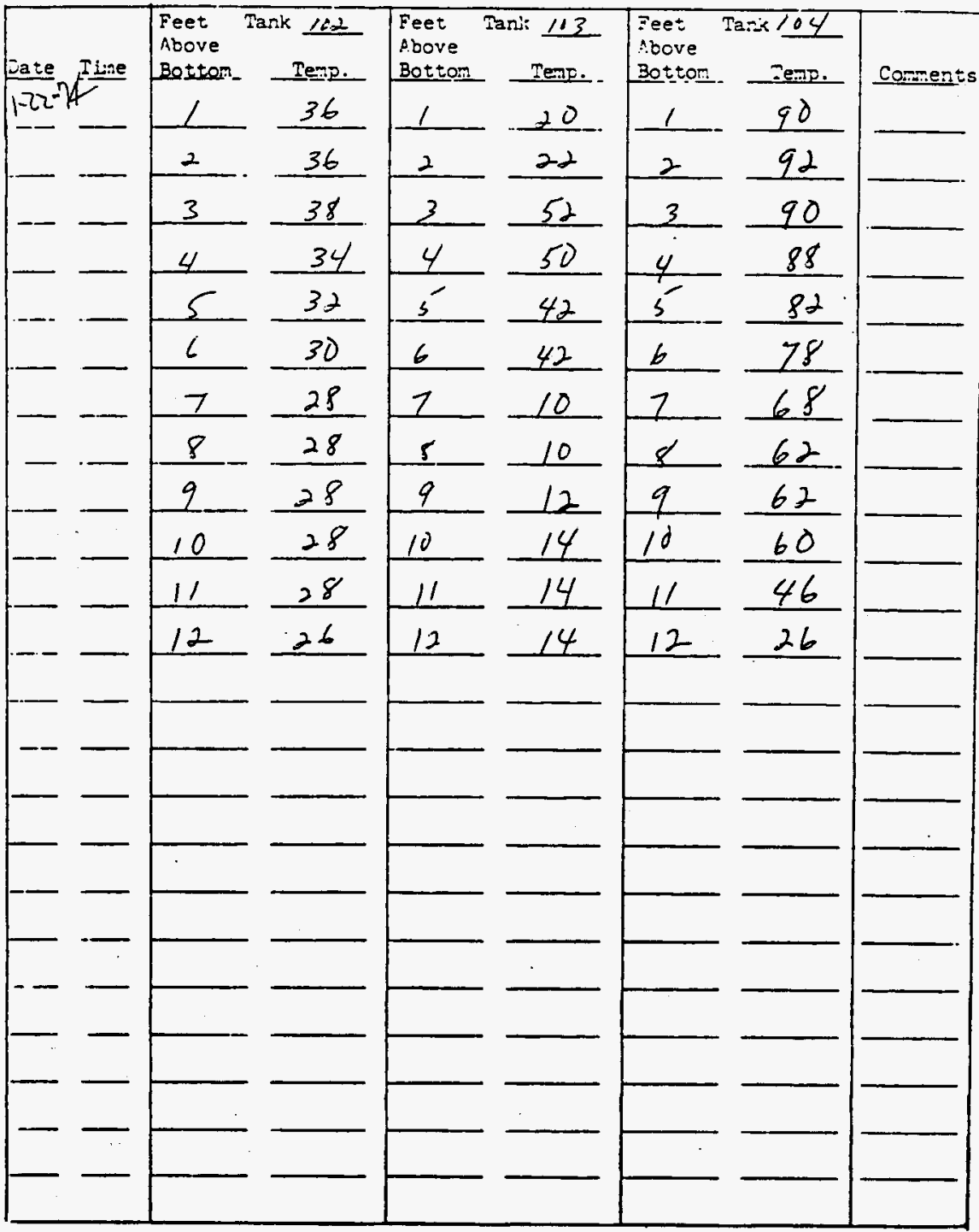

Instr.:01srs ar caments: - Take prorile temperatures weekly in each bottoms tank. Attach completed forf to Monday and Thuisday's Data Sheets. 
Title:

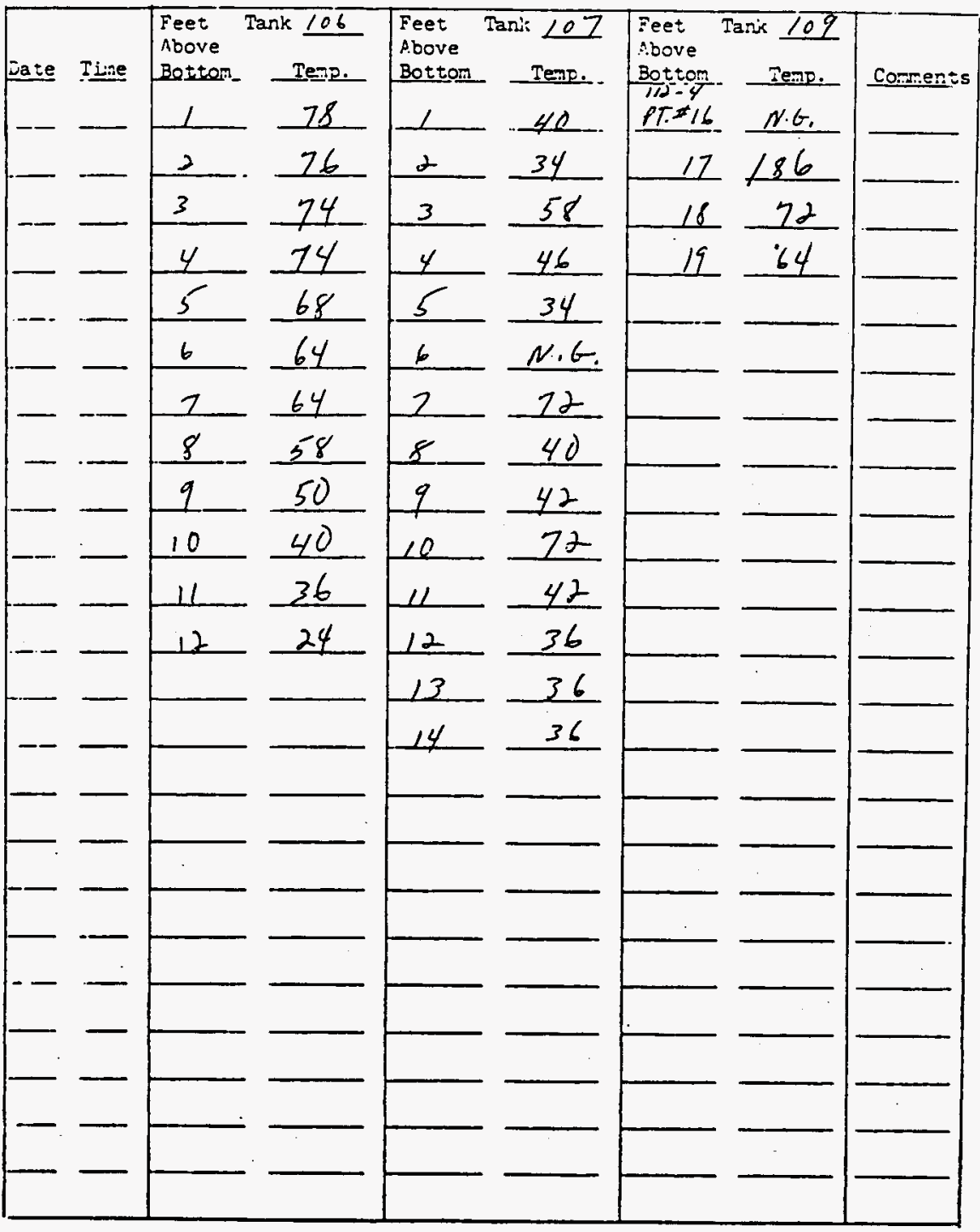

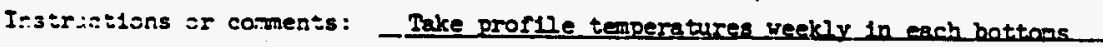
tank. Attach conpleted form to Monday and Thurgday's Data sheats. 
Title:

PROFILE TERERATURES IN ITS-2 BOTTOMS TATKS

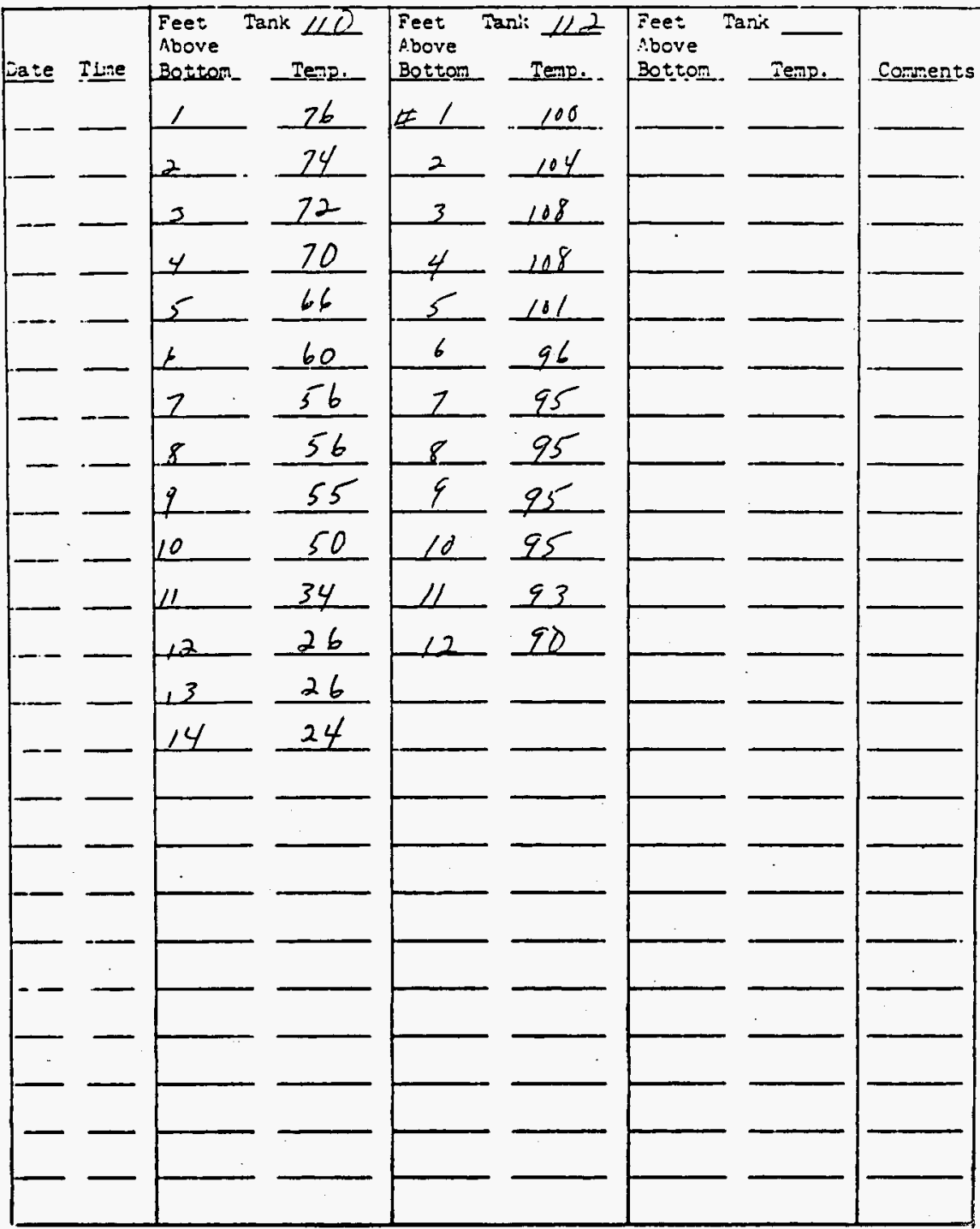

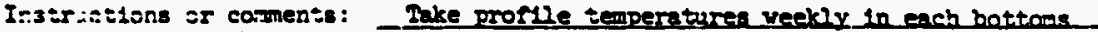
tank. Attach completed form to Monday and Mhurgdax's Data Sheats. 


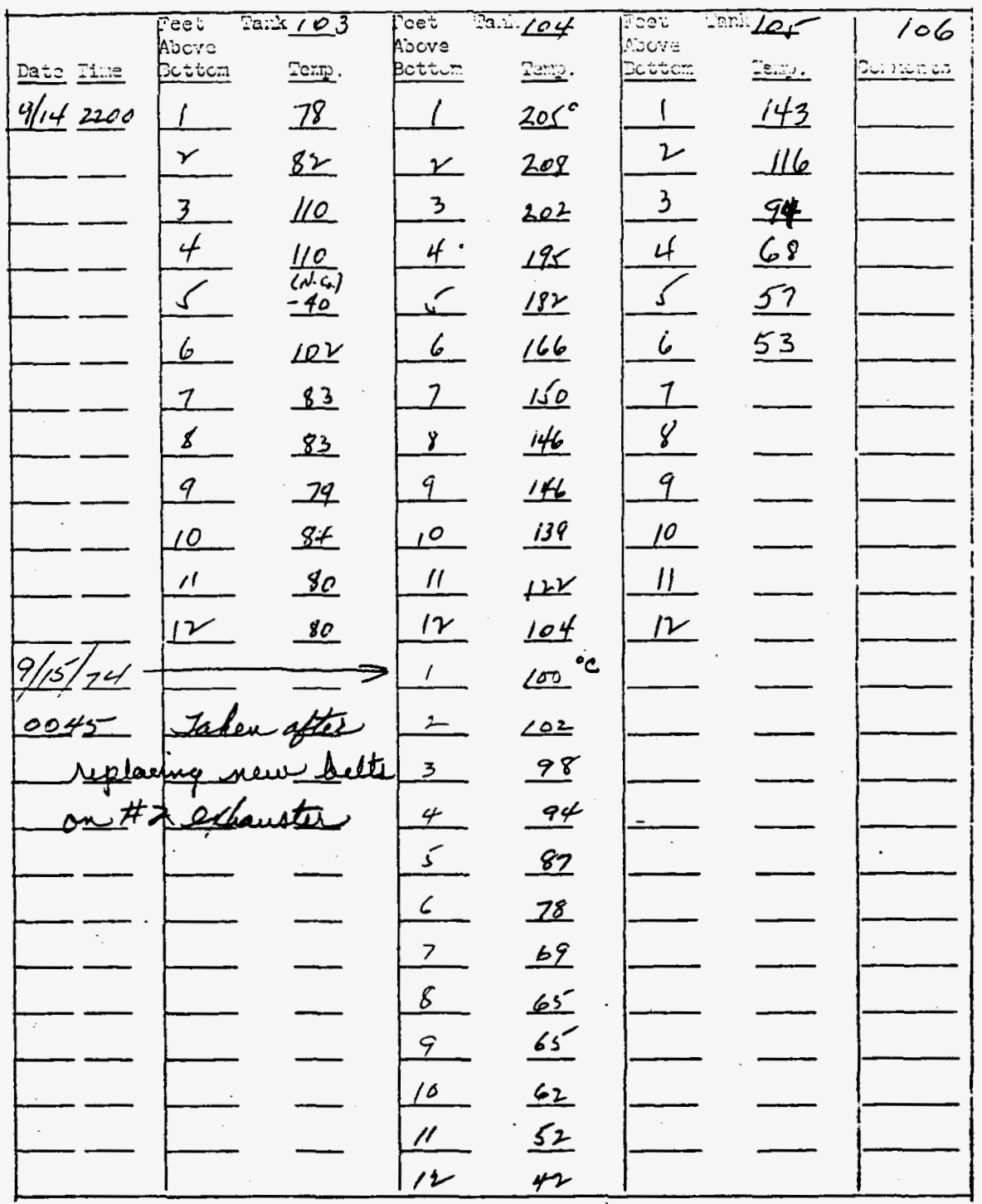

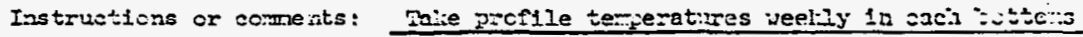
tari: Attach completed form to lonciay and mursolay's Data Sheats. 
raำ:

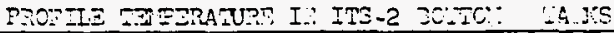

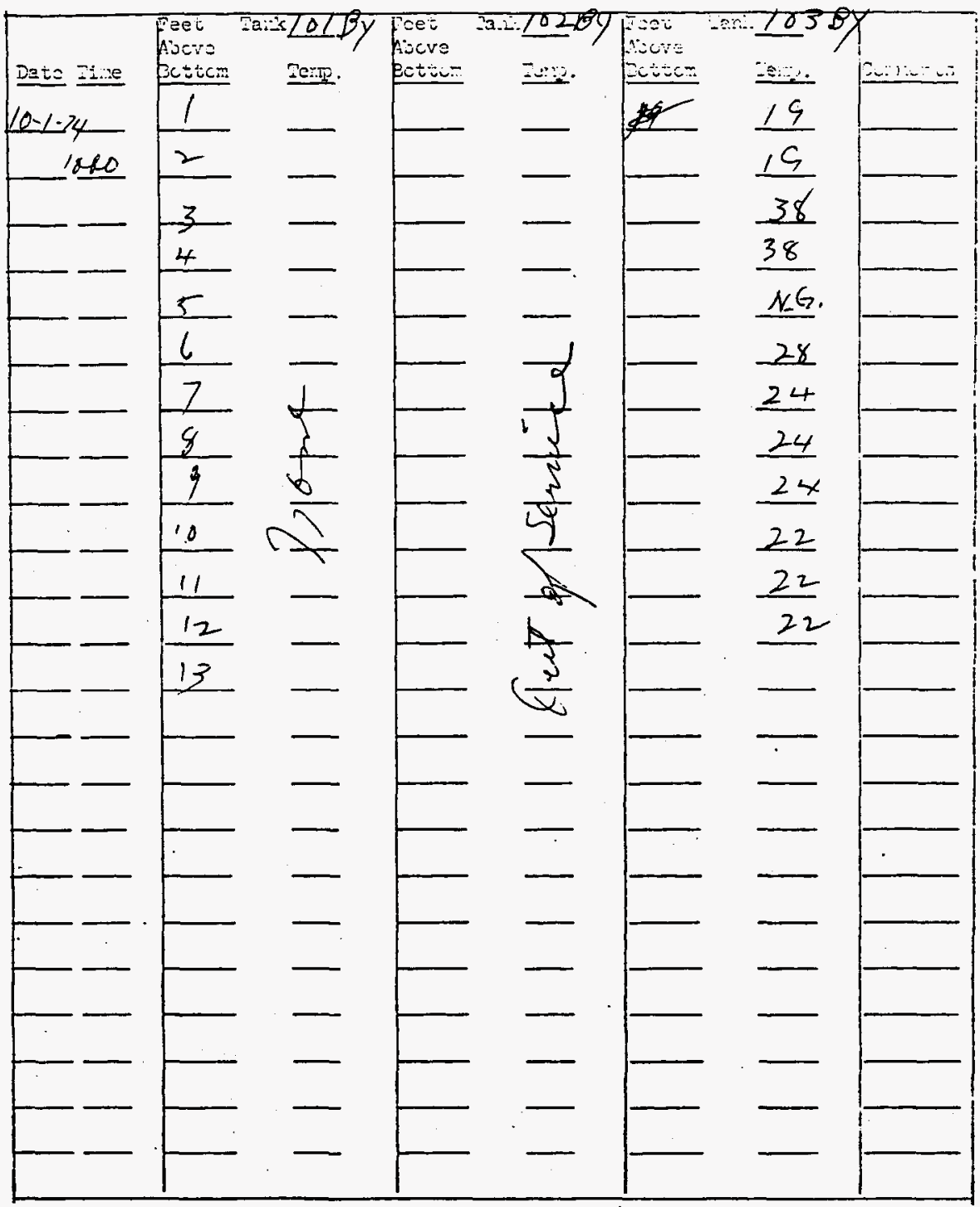

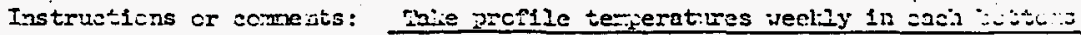
tari. Attech cosiletej furm to lonciay and Fursday's Data S.acetz. 
Pile:

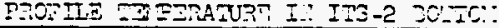

$\because 4.95$

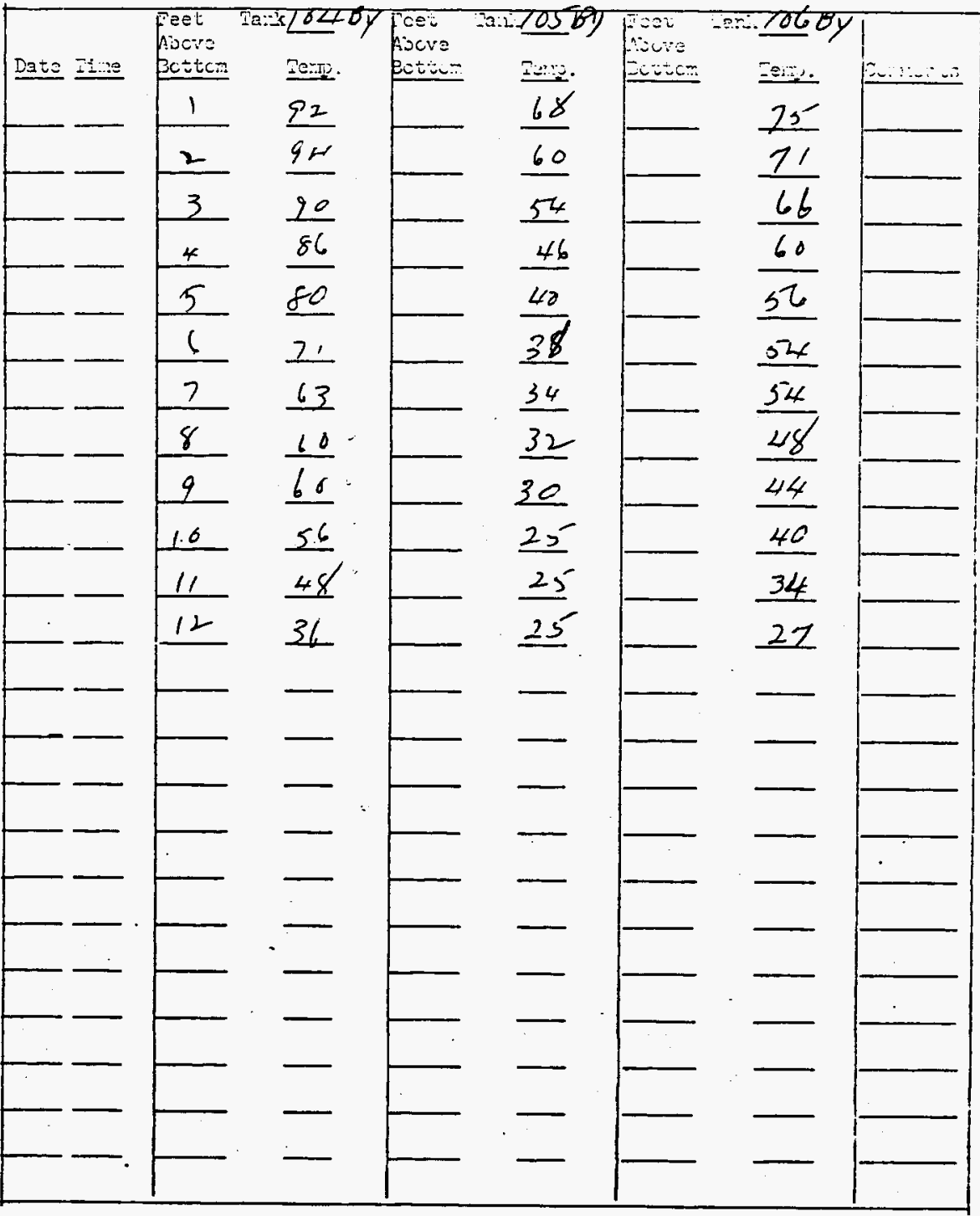

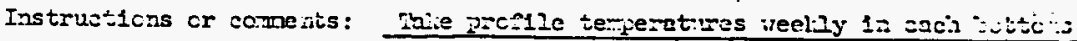
taxi. Attach corpleted form to lonciay an: Fursiay's Data Sreats. 
İle:

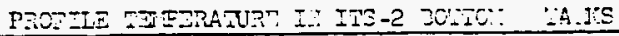

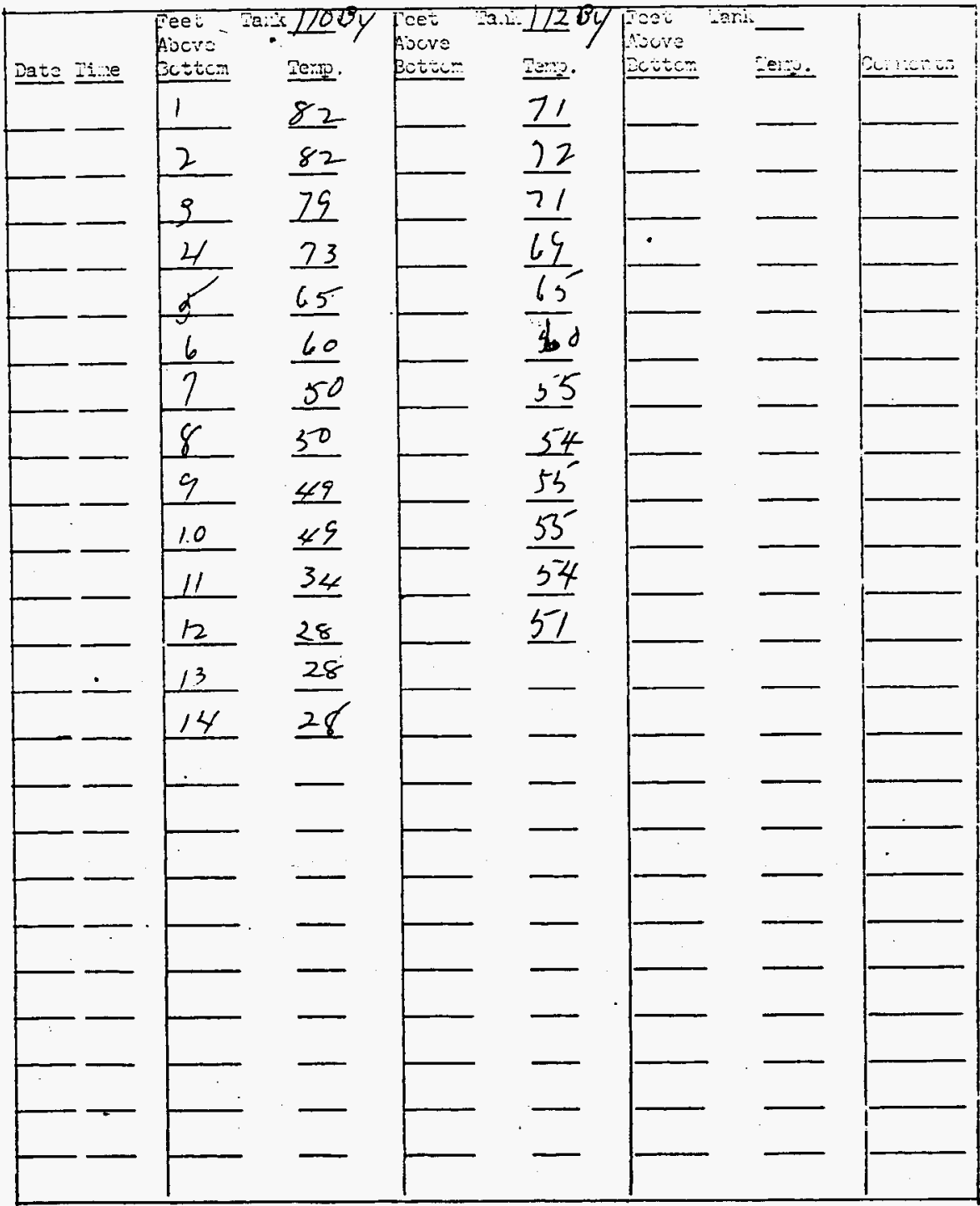

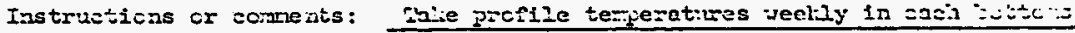

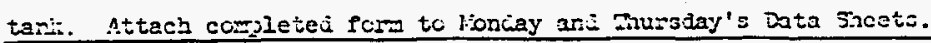


Ttile:

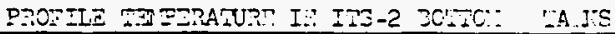

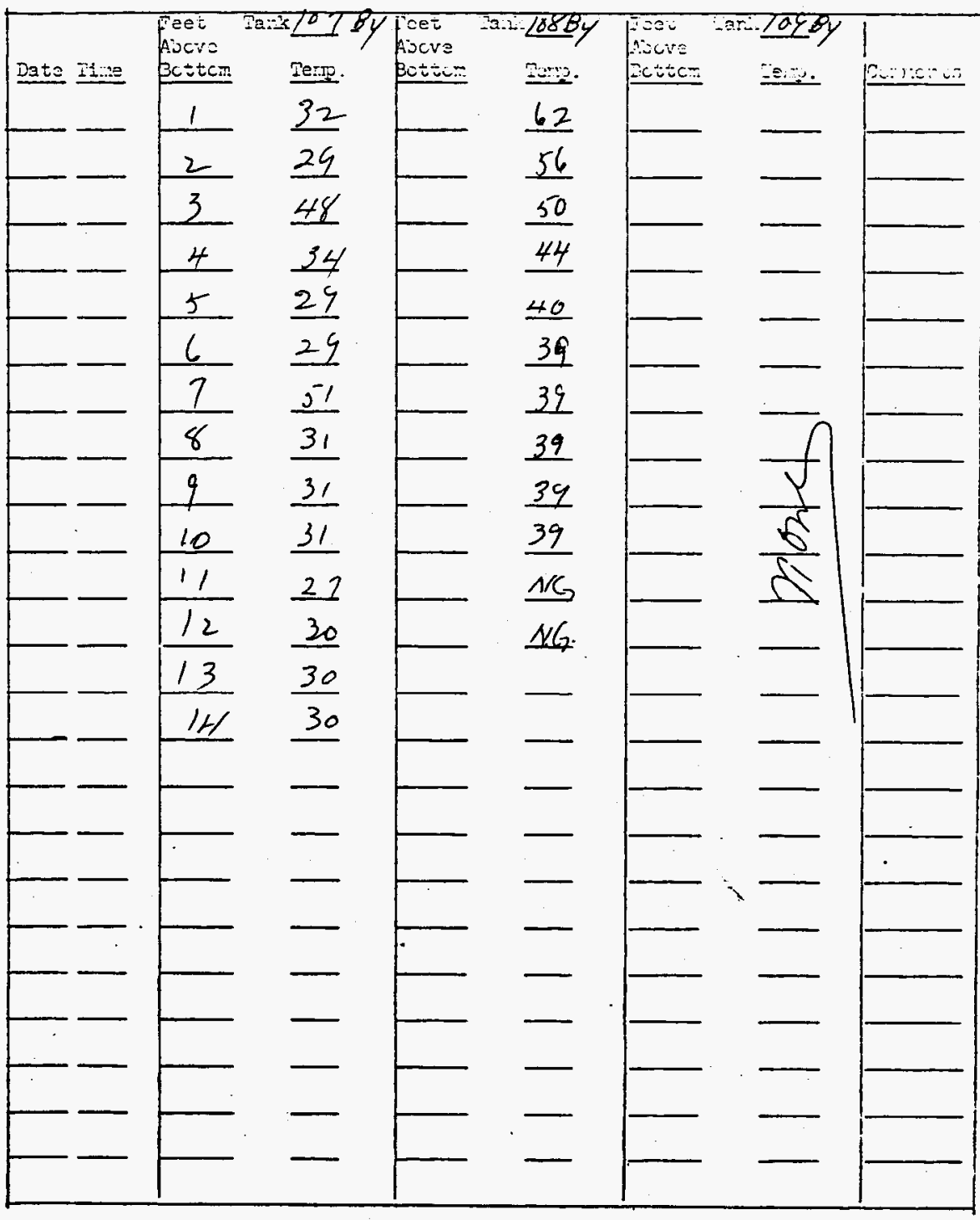

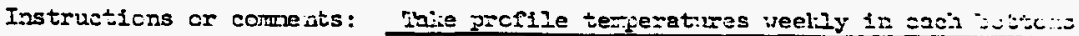
tacis. Attach corpleted form to loncay and Furstay's Data Shcets. 
WHC-SD-LW-DP-207, Rev. 0

- rite: 101-B. Profile Temp weekly :

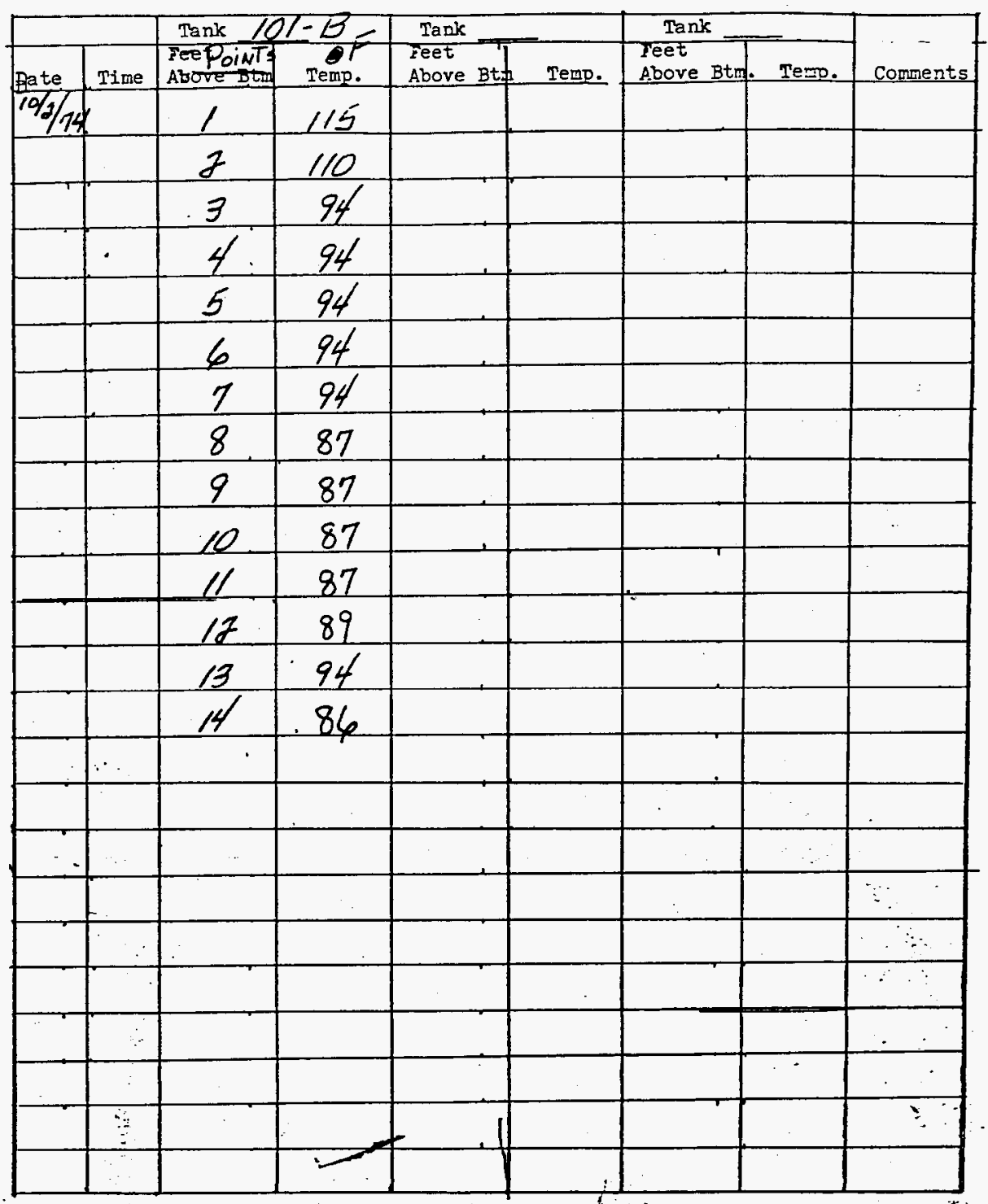

Instructions or comments; 251 
HAC-SD-in-Dp-207, Rev. 0

ritie: LN-B PROFile Temp.

\begin{tabular}{|c|c|c|c|c|c|c|c|c|}
\hline & & Tank 10 & & Tank & & Tank & & \\
\hline te & Time & $\begin{array}{l}\text { Fepoin } 15 \\
\text { Above Btm }\end{array}$ & $\begin{array}{l}\text { of } \\
\text { Temp. }\end{array}$ & $\begin{array}{l}\text { Peet } \\
\text { Above Bt }\end{array}$ & Iemp. & $\begin{array}{l}\text { Teet } \\
\text { Above Btn }\end{array}$ & Temp. & Comments \\
\hline $10 \% / 24$ & $134 / 5$ & $L$ & 173 & & & & & \\
\hline & & $f$ & 116 & & & & & \\
\hline & & 3 & 100 & & & & & \\
\hline & & 4 & 100 & & & : & . & \\
\hline & & 5 & 100 & & & & & \\
\hline & & 6 & 100 & & & & & \\
\hline & & 7 & 100 & & & & & \\
\hline & & 8 & 90 & & & & & \\
\hline & & 9 & 90 & & & & & \\
\hline & & 10 & 90 & & & & & \\
\hline & & 11 & 90 & & & & & \\
\hline & & 12 & 92 & & & & & \\
\hline & & 13 & 94 & & & & & \\
\hline & & 14 & .94 & & & & & \\
\hline & & & & & & & & \\
\hline & & & & & & . & & \\
\hline & & & & & & & & \\
\hline & & & & & & & & \\
\hline & & & & & & & & \\
\hline & & & & & & & & \\
\hline & & & & & & & & \\
\hline & & & & & & & & \\
\hline & & & & & & & & \\
\hline & & & & & & & & \\
\hline
\end{tabular}

Instructions or comments; 


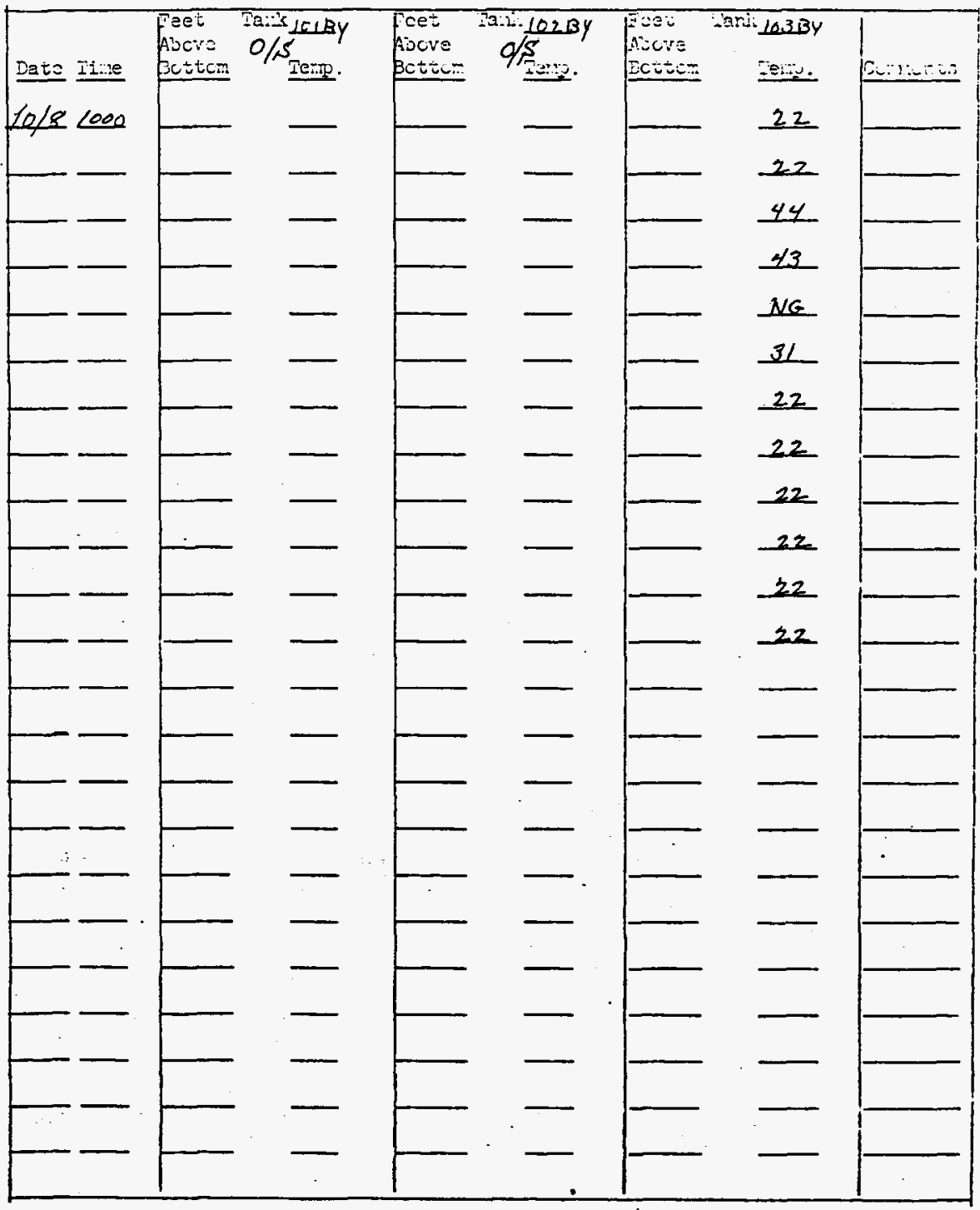

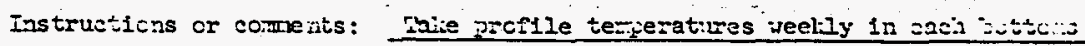
tari. Attach completeci fer tc lonciay anc Giursiay's Data Sreets. 


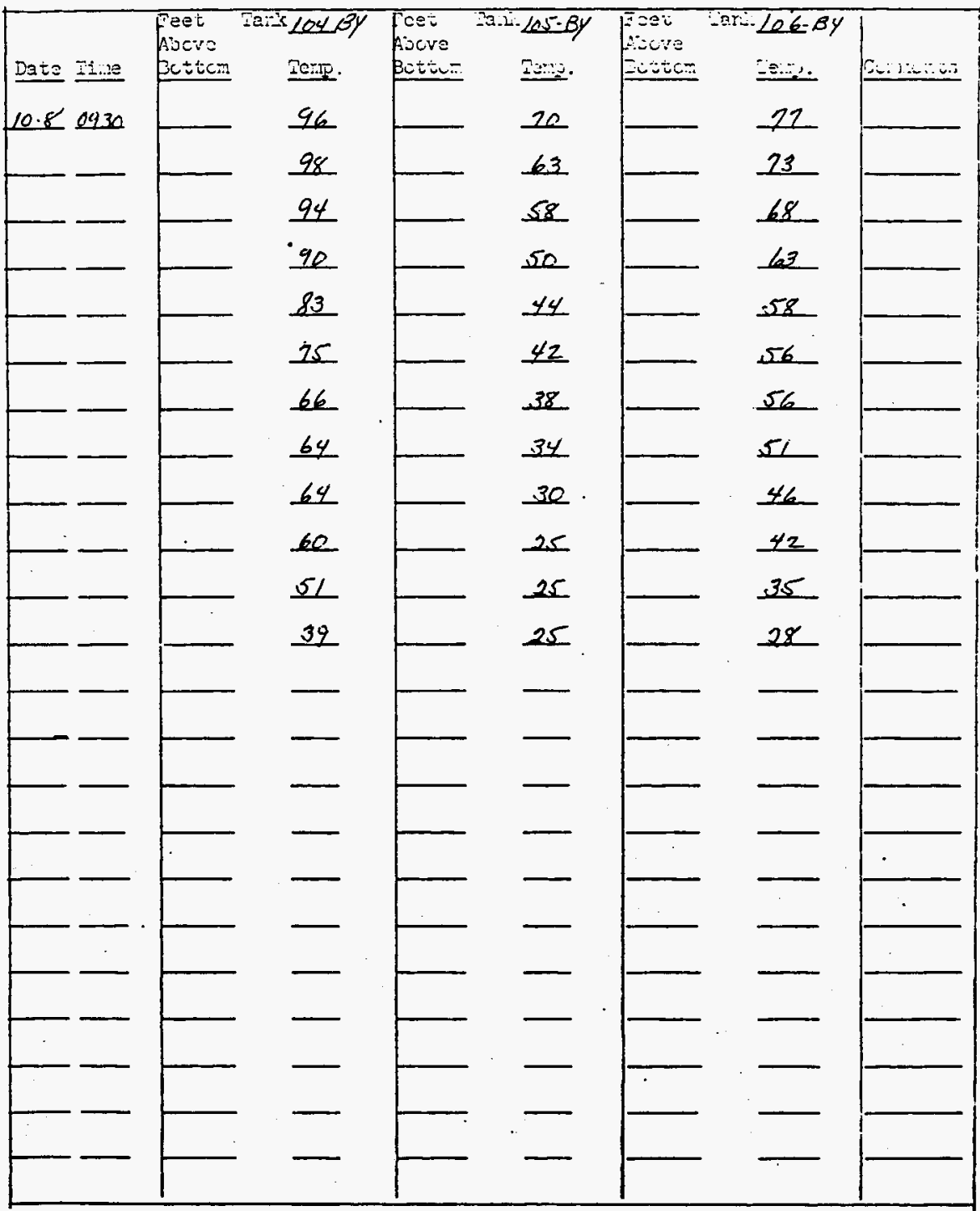

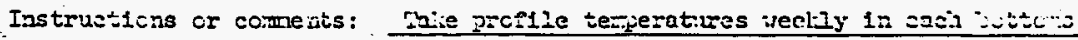

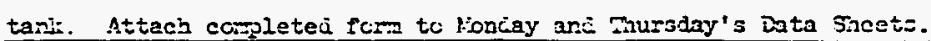


Zile:

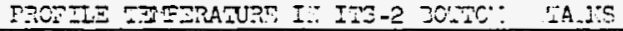

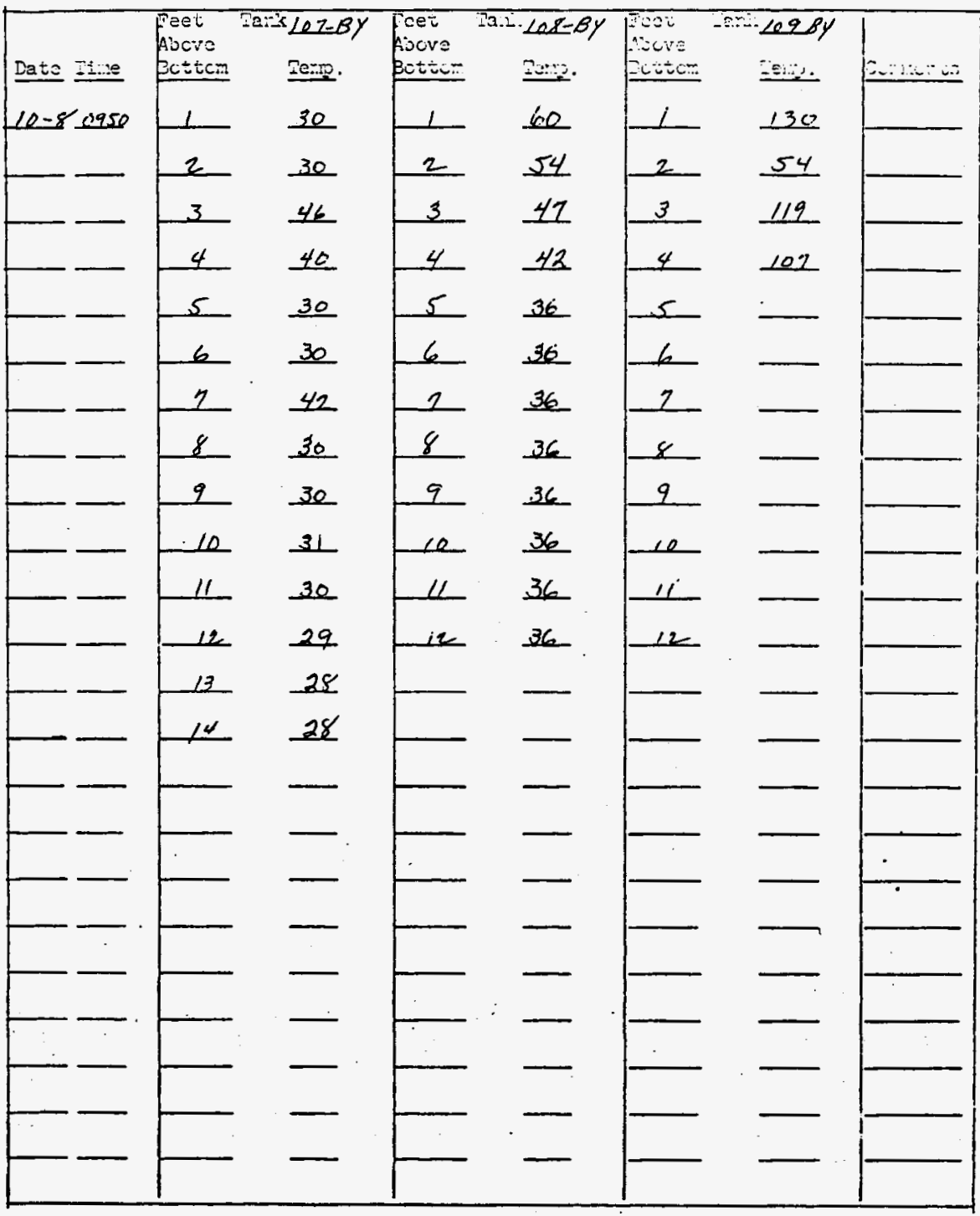

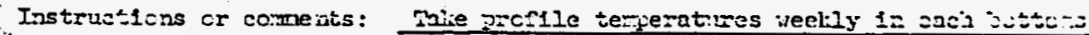
tari. Attach cospleted fors to Vonciay ans fursiay's Data Sucets. 
anle:

PROFILE TOFERATUPS IH ITS-2 30TC:

$r^{\prime}$

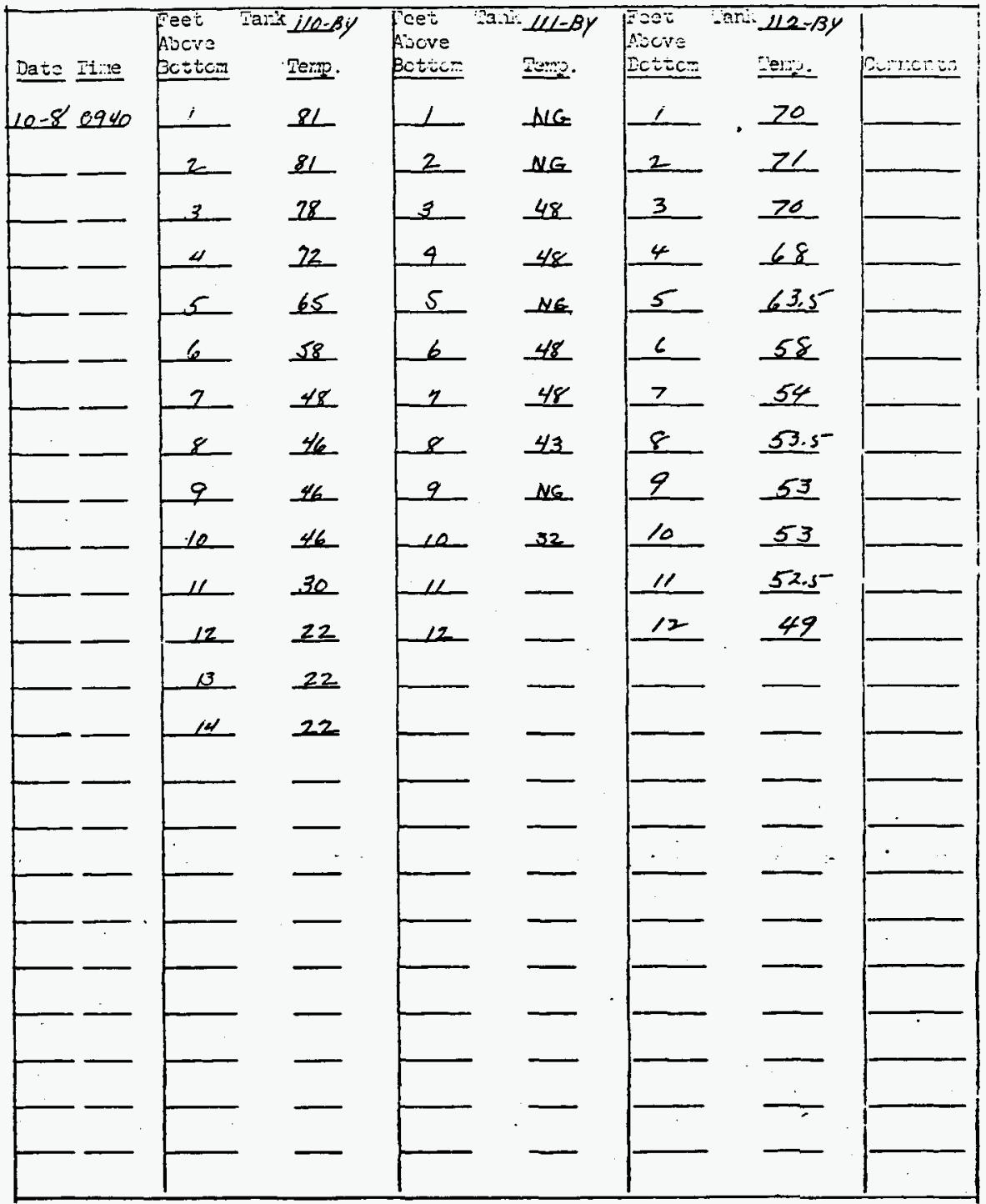

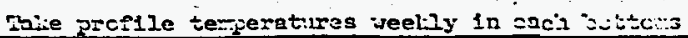




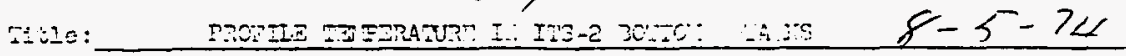

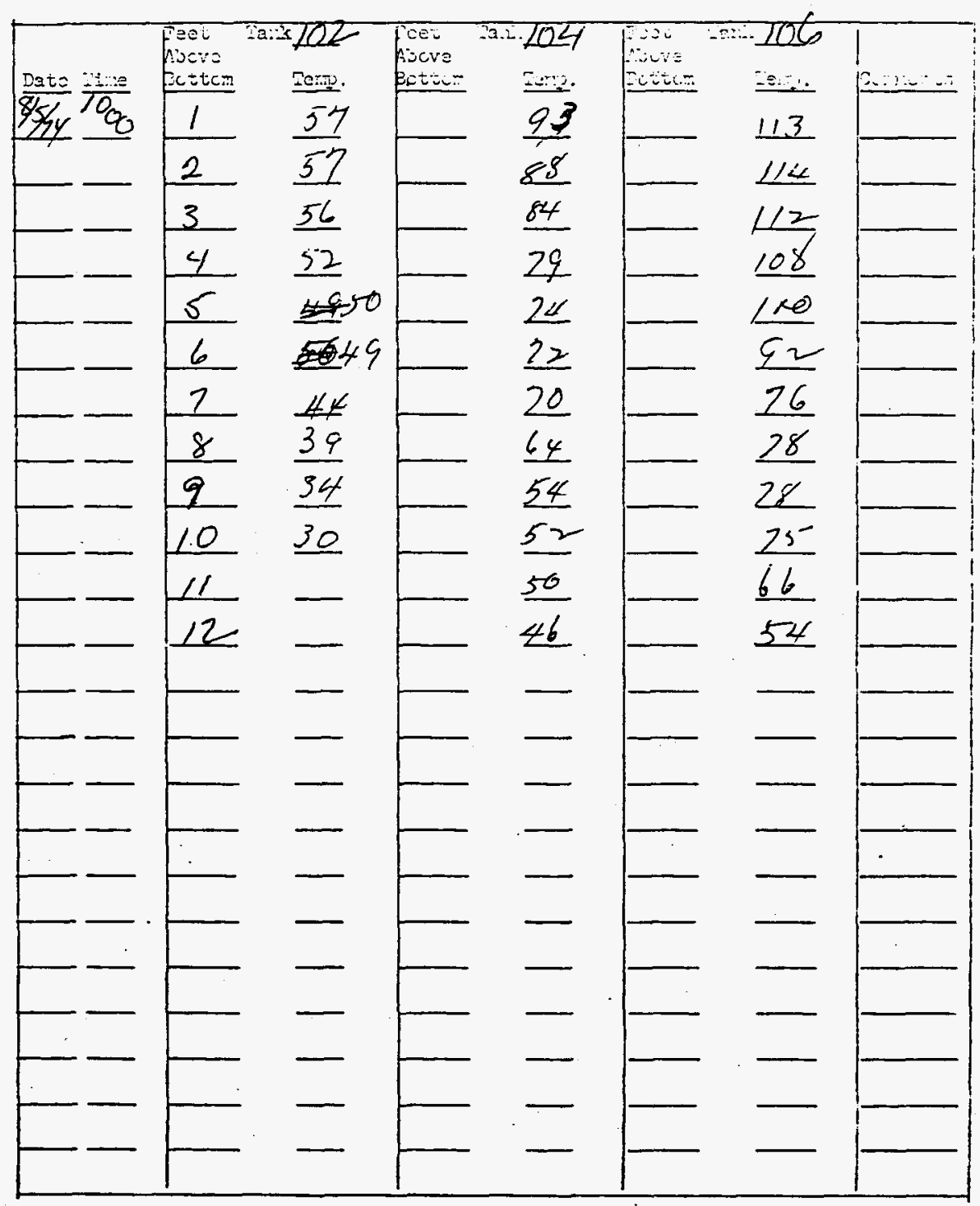

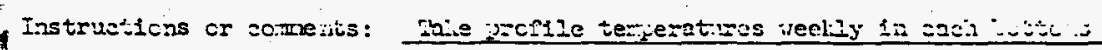

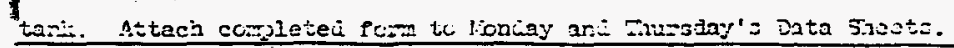




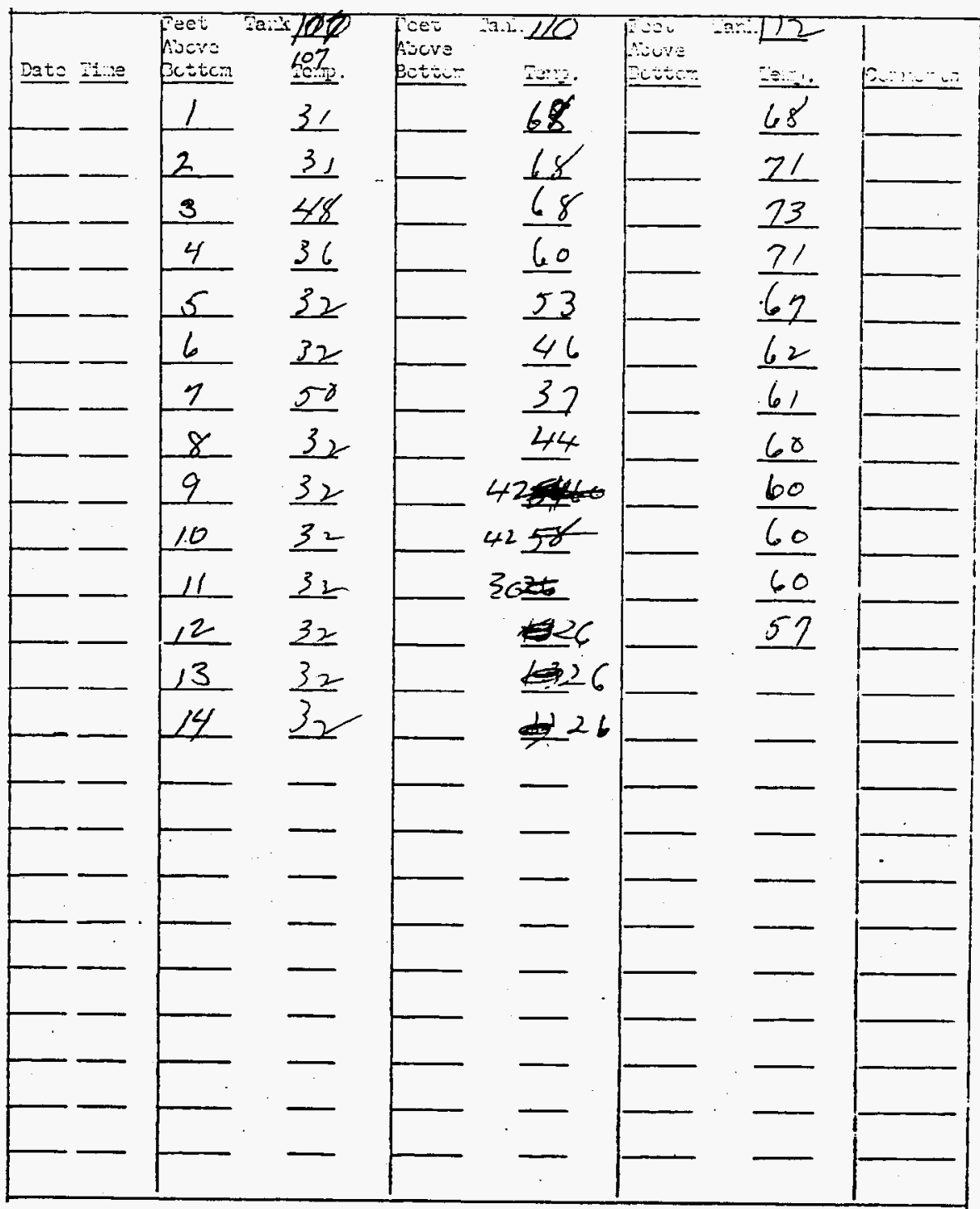

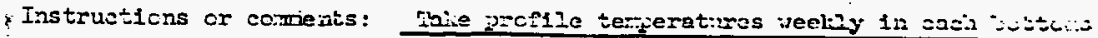

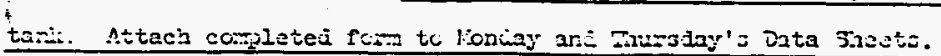




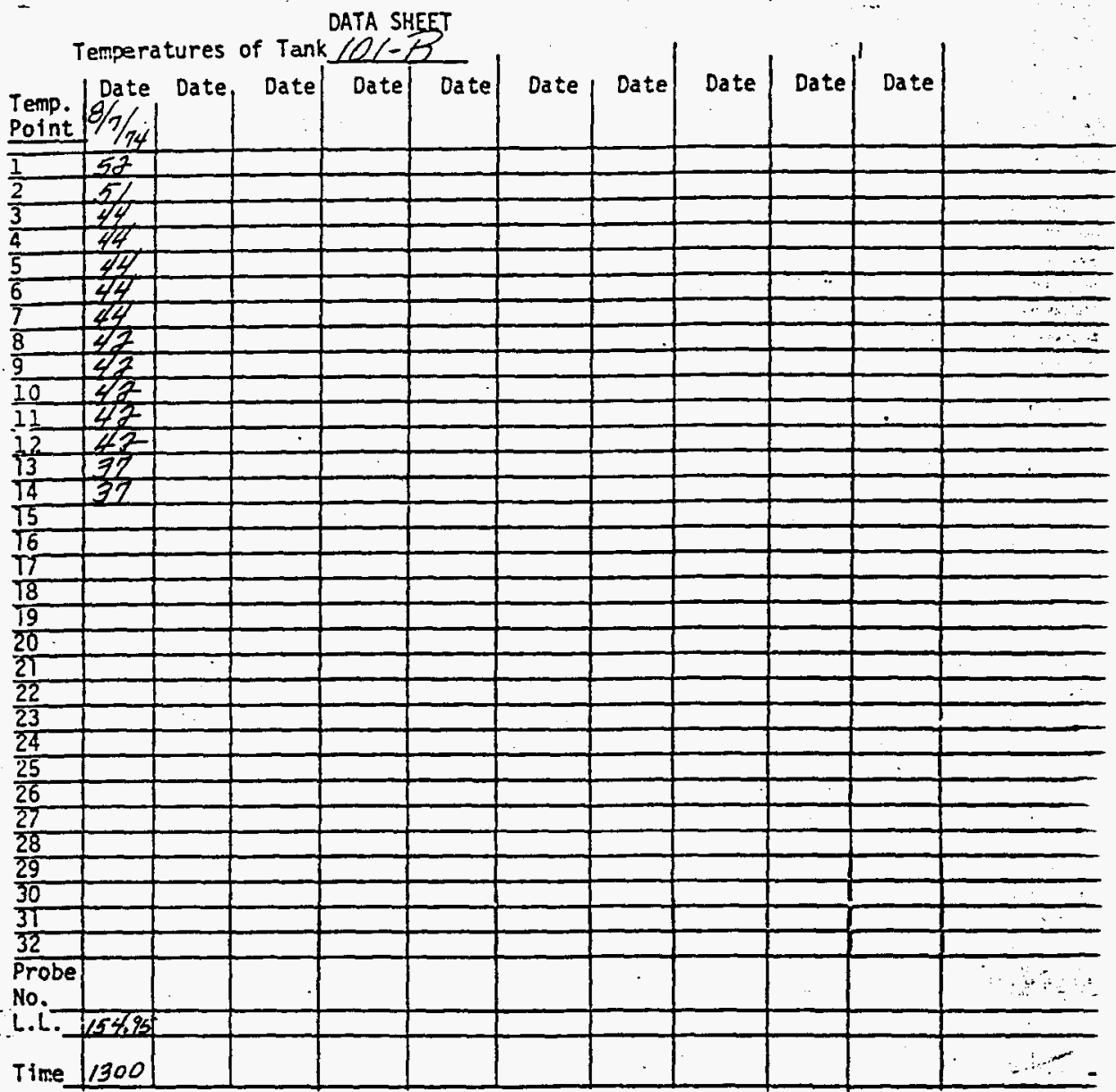

This sheet is for recording temperatures of underground tanks for those

situations which are not covered by routine S.0.P. data sheets. Transfers between tanks is frequentiy a situation where temperature monitoring is.needed and a uniform data sheet form is convenient for the operator. :

MC Fraser 12-18-71 


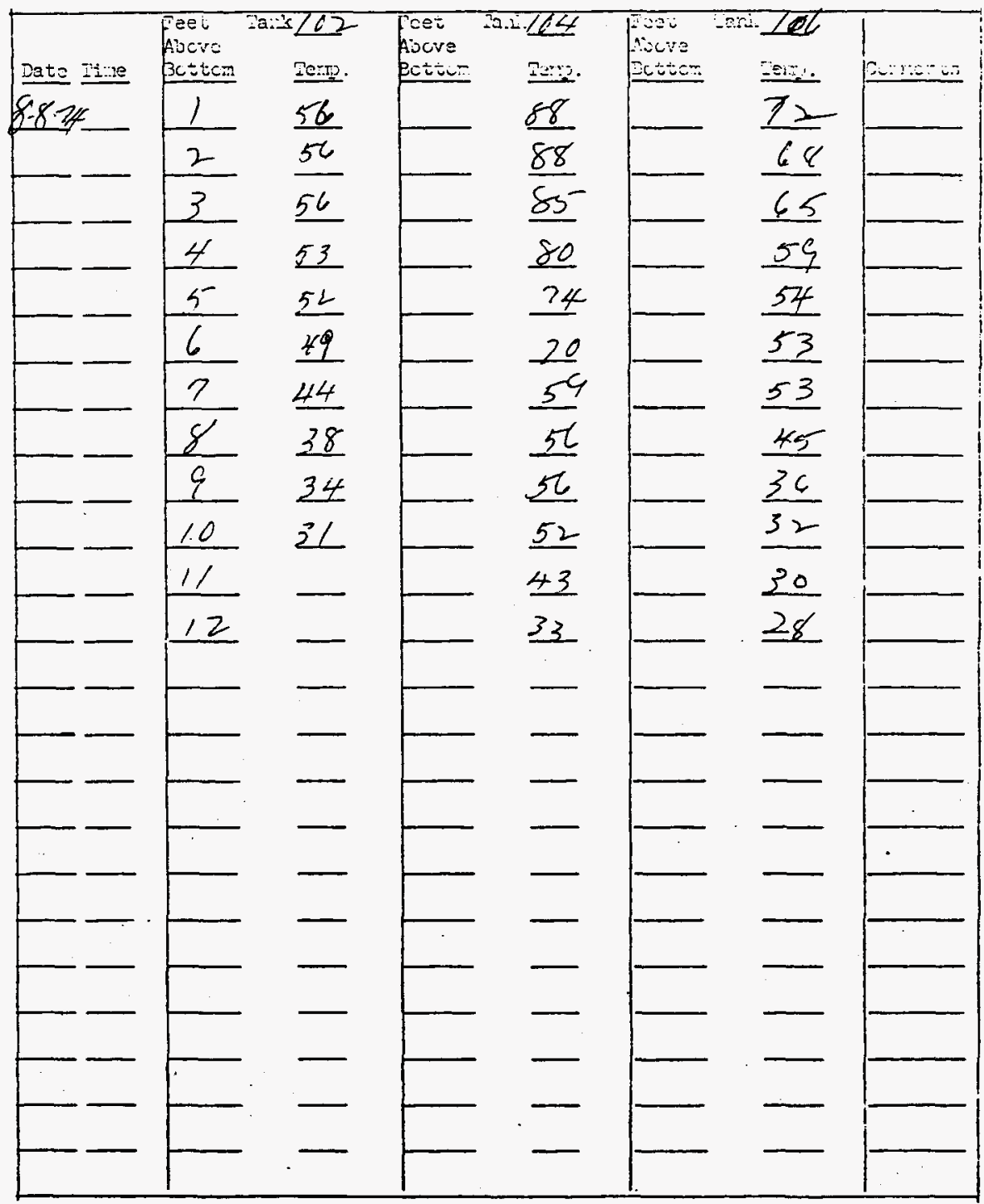

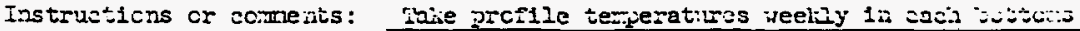

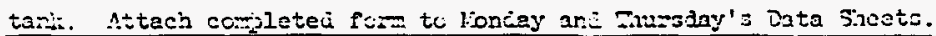




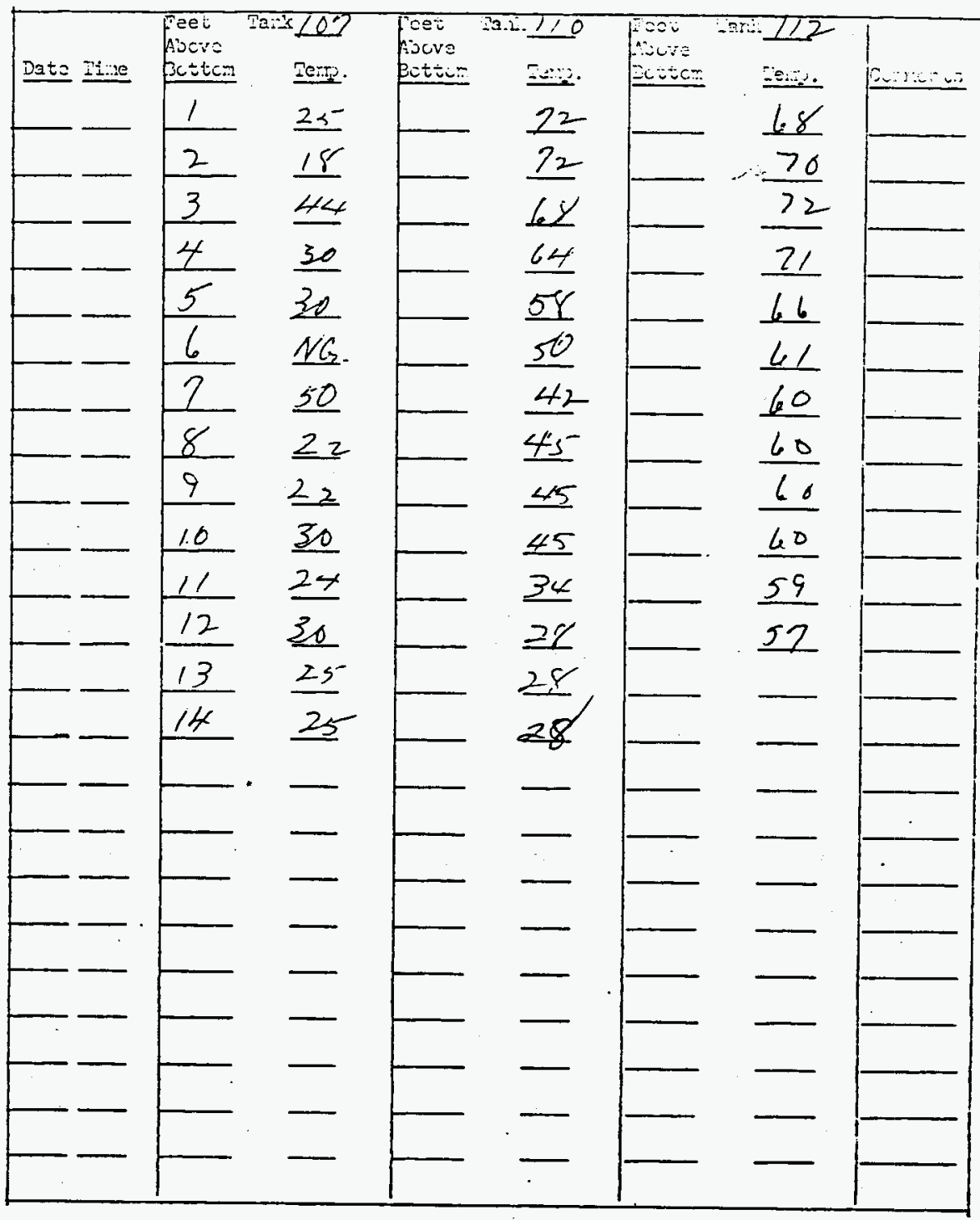

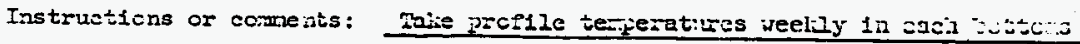
taris. Attaci completei for tc lioniay ari Furstay's Data Sheets. 
Tlte: IROFILE TEGERATUKES IN ITS-2 BOTHONS TATKS

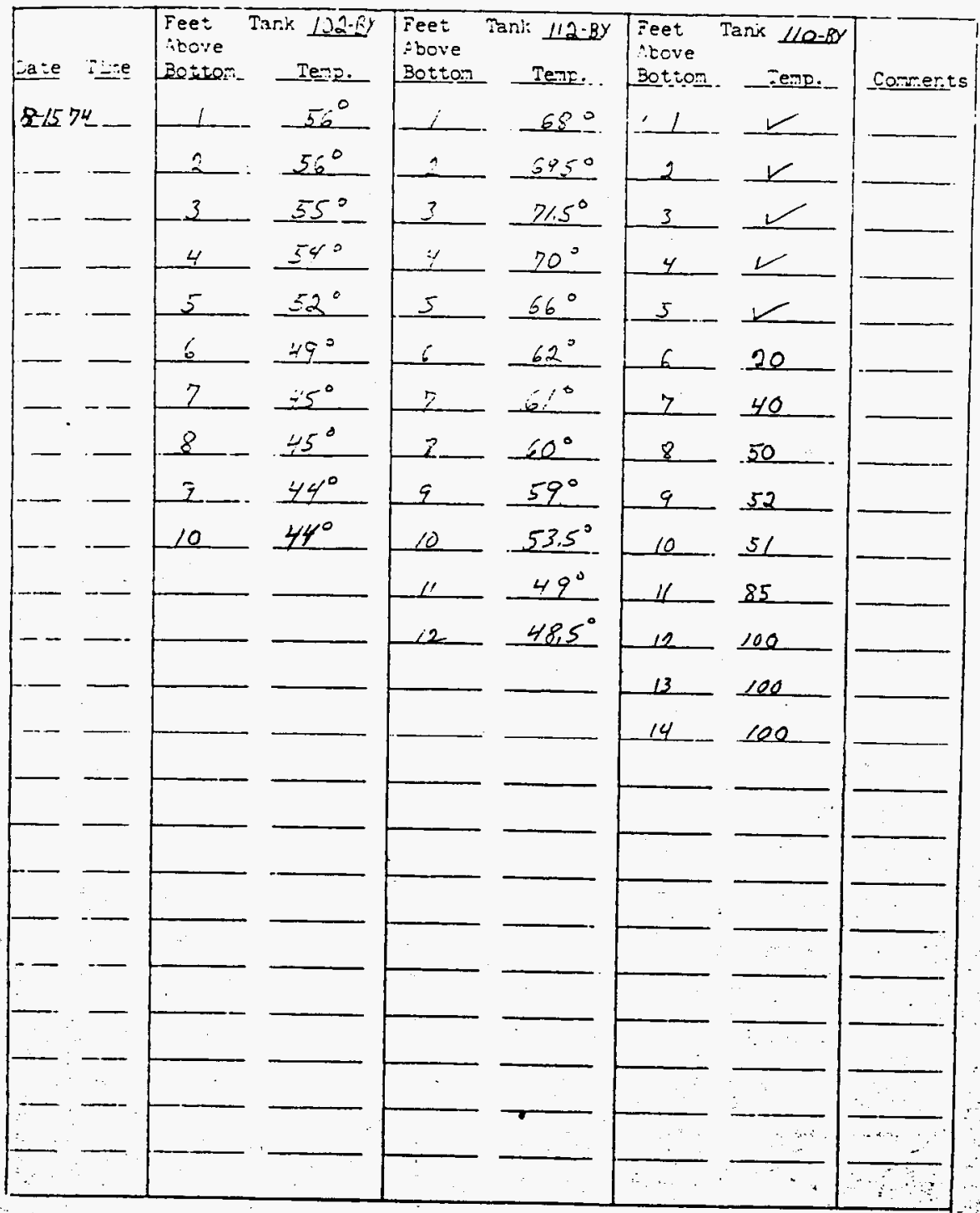

Iristratiors ar coments: - Take proflle temperatures weekly in each bottoms tank. Attach completed form to Monday and Thursday's Data Sheets: 
Title:

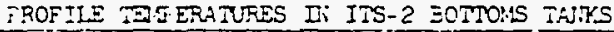

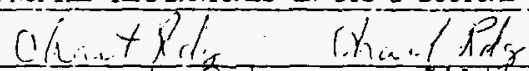

Eaie Ijie Aotore Tem.

Feet anill/PX sbove

$10+4$

$-\cdots$

2

$\frac{70}{71}$

Bottom Tenc.

Feet Taris L1D
bove

$-\cdots$

3

71

$\frac{13 i}{142}-\frac{26}{27}$

Sottom.

Zemo. Eonerts

$-1-$

4

$\frac{7 i}{66}$

$15-11 \frac{\gamma \delta}{7 \pi}$

$\frac{18}{17 / 6} \frac{7-9}{2-8}$

\begin{tabular}{|l}
$\frac{1}{3}$ \\
\hline$\frac{4}{5}$ \\
\hline 6 \\
\hline 7 \\
\hline$\frac{5}{4}$
\end{tabular}

28

2.6

26

$\frac{26}{1}$

-...

6

63

7

$\frac{57}{57} \frac{17 / 9}{76 / 2}$

$\frac{\frac{33}{57}}{\frac{33}{45}}$

$26 / 2 \quad 27$

$\frac{3}{10}$
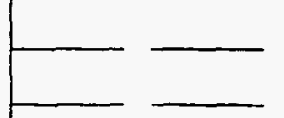

$\frac{10}{11}$

23

20

22

24

$--\longrightarrow$

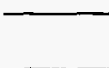

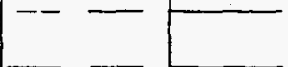
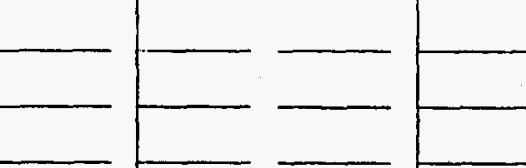

$\frac{24}{2.6}$

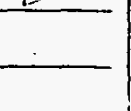


I:tle: I ROFILE TIESAILES II ITS-2 SOTHOMS IAIKS

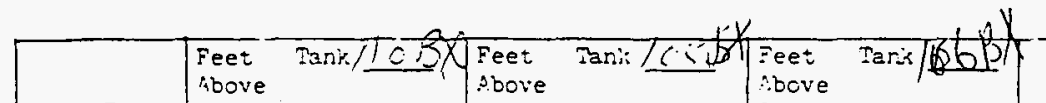

Ease Iine Botton Tem.

$3=2$

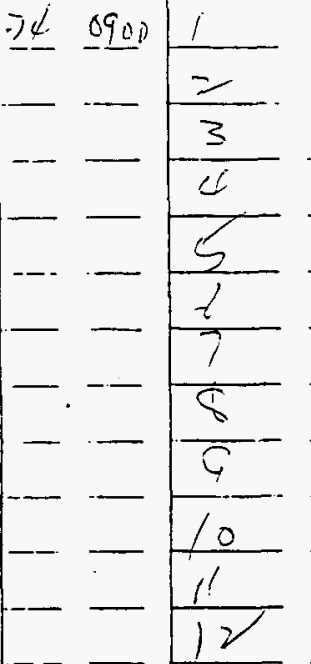

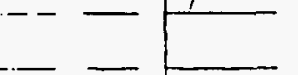

$$
16
$$$$
57
$$$$
38
$$$$
\overline{5}
$$$$
\overline{5}
$$$$
25
$$$$
35
$$$$
35
$$$$
34
$$$$
\begin{aligned}
& 35 \\
& 35 \\
& 25 \\
& 56
\end{aligned}
$$

- -

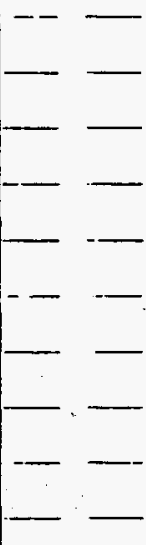

Botrom
Bottom Tent.

$\frac{17}{47}$

197

49

48

413

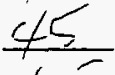

$4<$

$4=$

4

$\frac{46}{46}$

Sottom. Iemp.
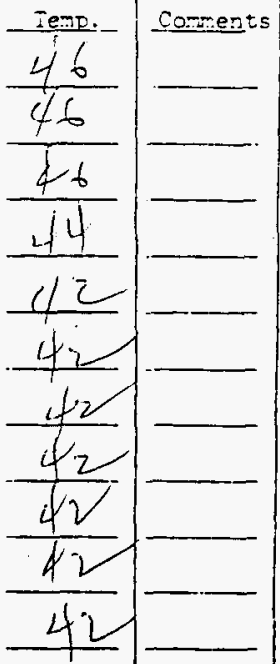

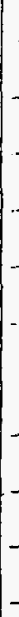




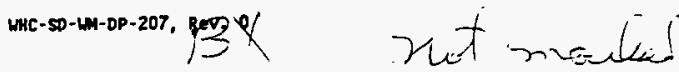

Title:

IROFILE TEI ERATIES IN: ITS-2 EOTTOMS TESTS
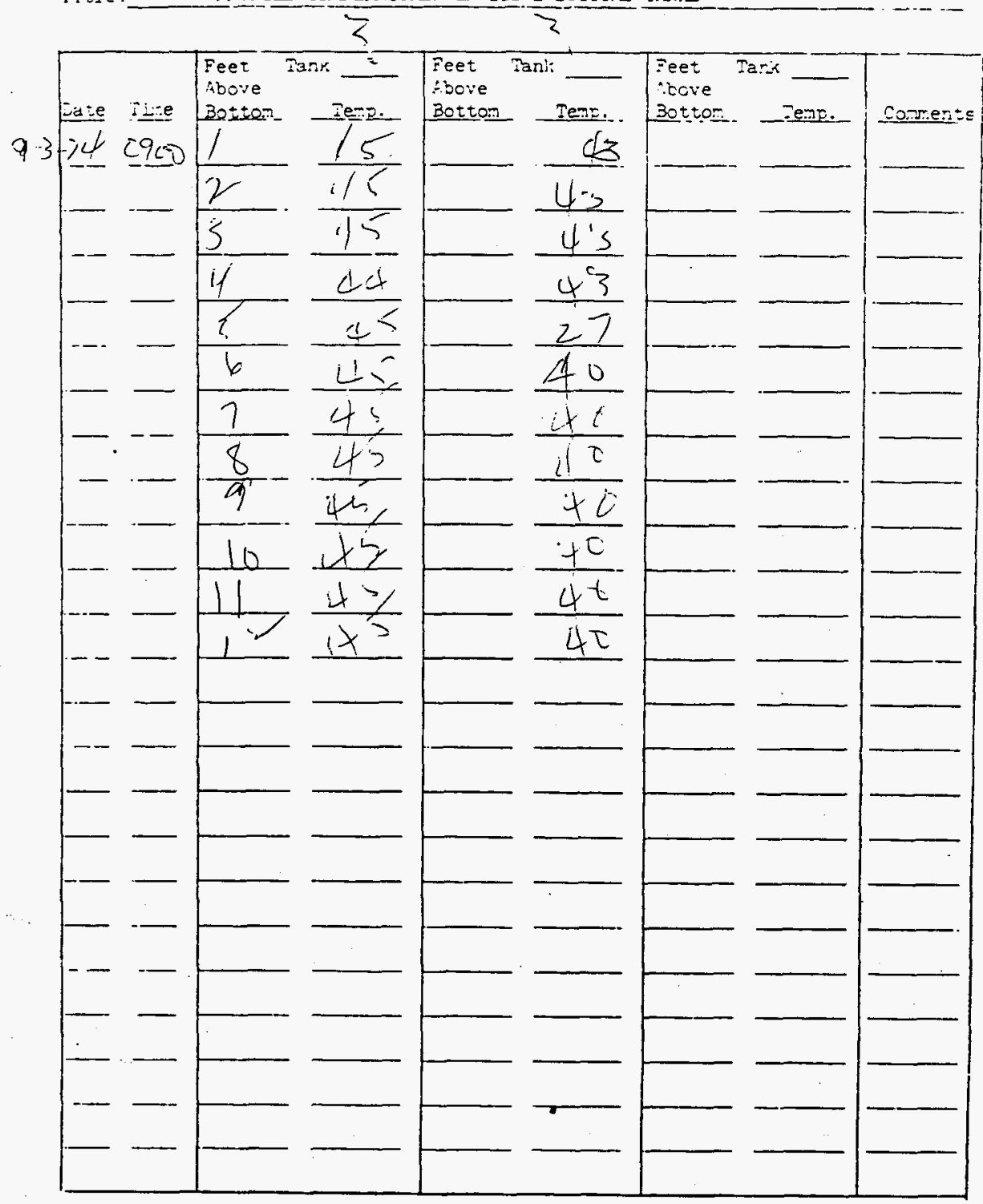

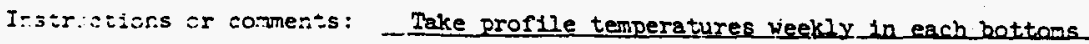
tank. Attach conpleted form to Monday and Thursday's Data Sheets. 
$\therefore \therefore ?$

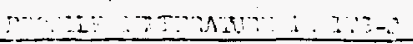

$\therefore \cdots$

$2 \ldots>i$

7

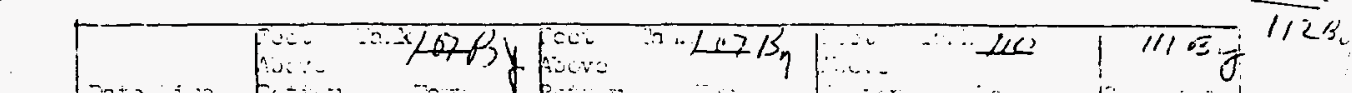

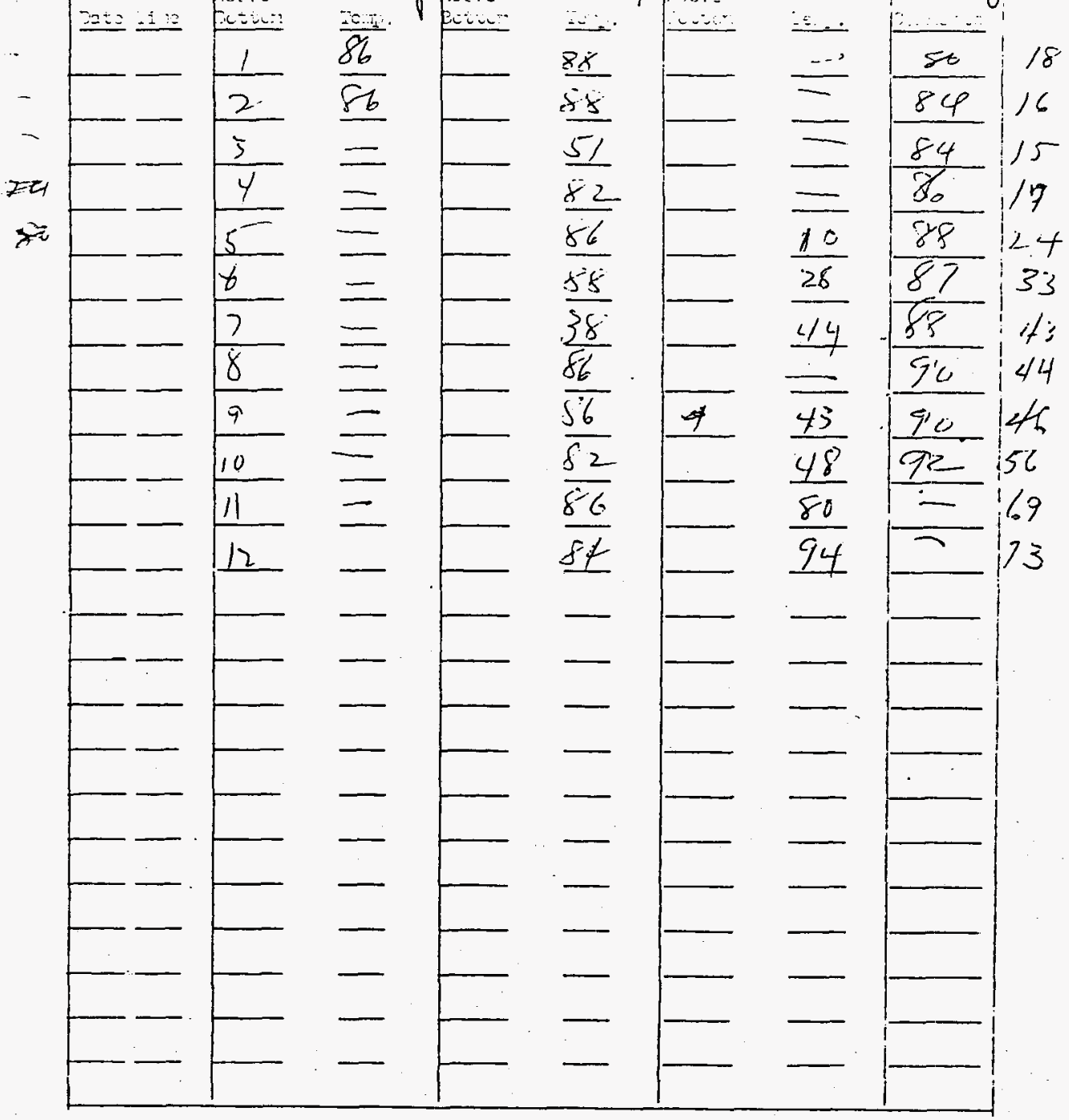

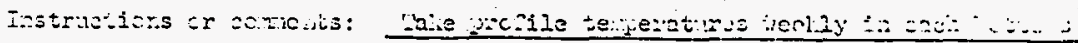




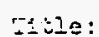

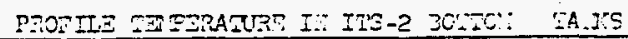

$9-3-74$

\section{$N_{0}+M$ intep}

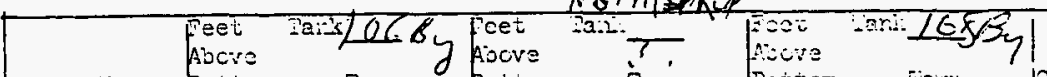

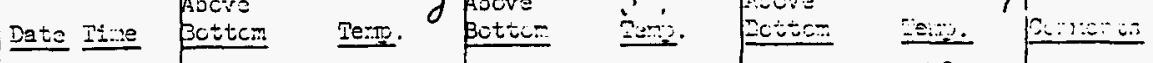

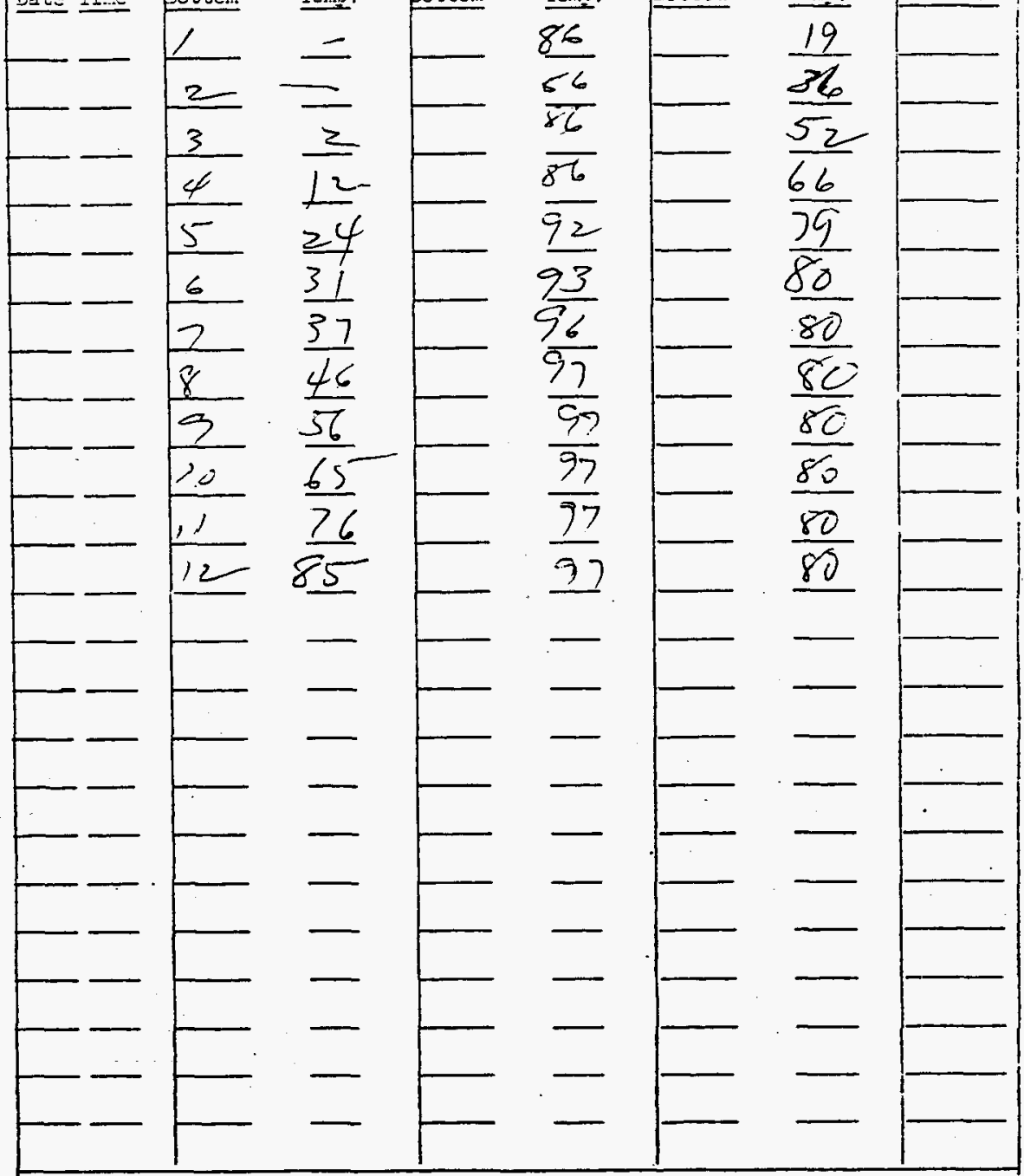

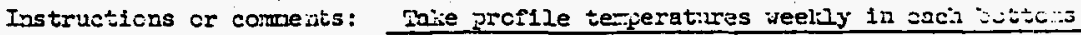
tani. Attach cospleteú fcre to loncay and Fursday's Data Sheets. 
Title:__ PROFIIE TERERATUFES IN ITS-2 BOTIOMS TANKS $9-5$ $\mathrm{XC} \quad 093$

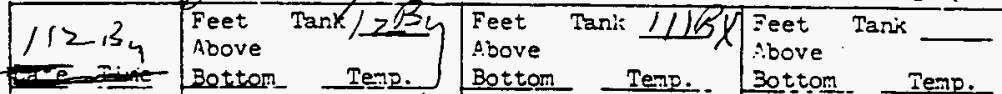
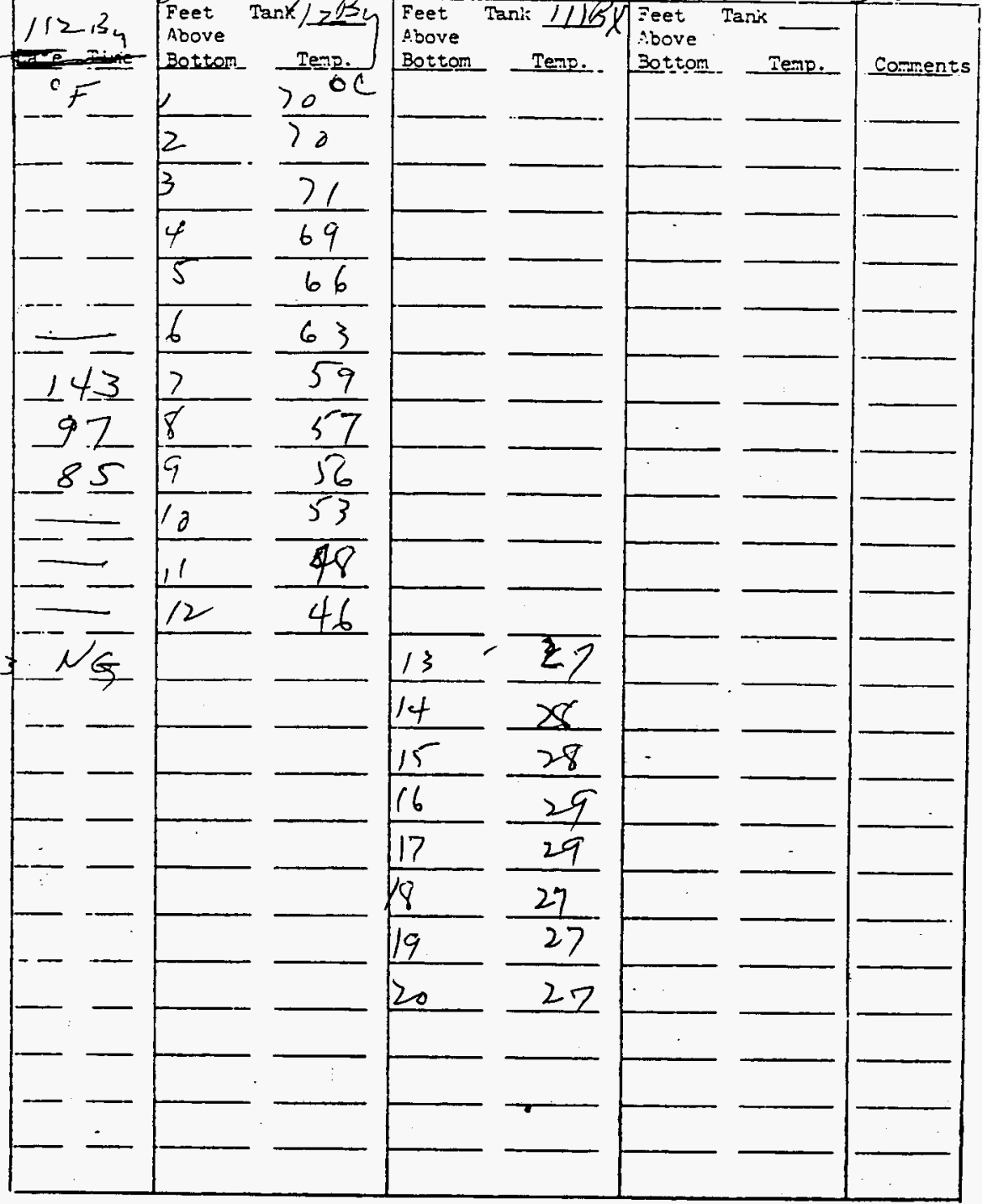

Injirations or coments: - Take profile temperatures veekly in each bottoms tank. Attach completed form to Monday and Thursday's Data sheets. 
misle:

PROFILE TETISATURT I:O ITE-2 30IC:: TA.JS

$$
9-5.76 \% \text { Sile }
$$

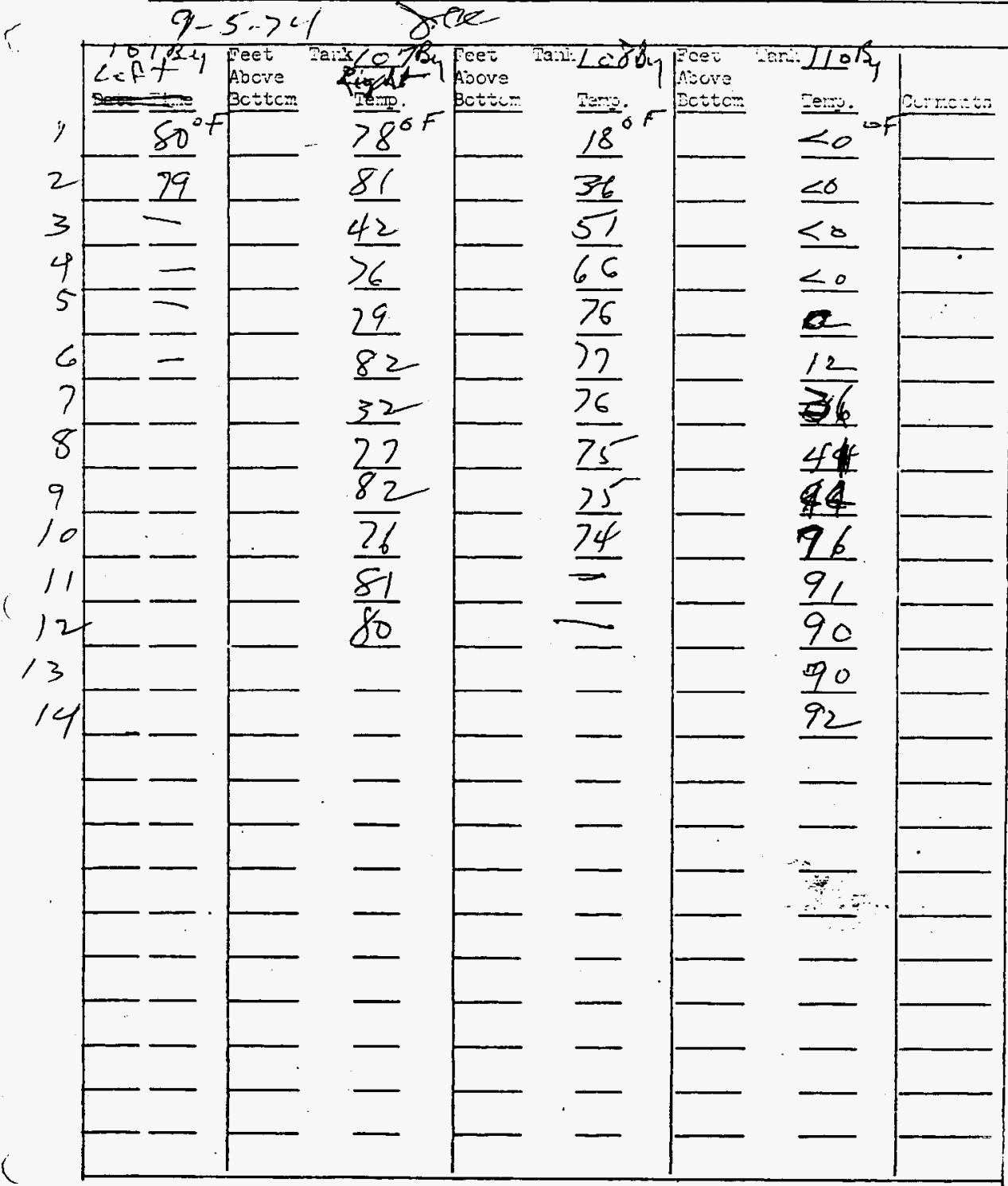

Instructions or coments: Take profile temperatures weekly in cacis bottcrs tani. Attach corpleted form to Honcay and Fursday's Data Sinets. 
Tisle:

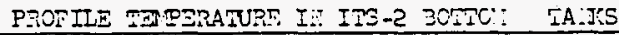

$$
9-5-74
$$

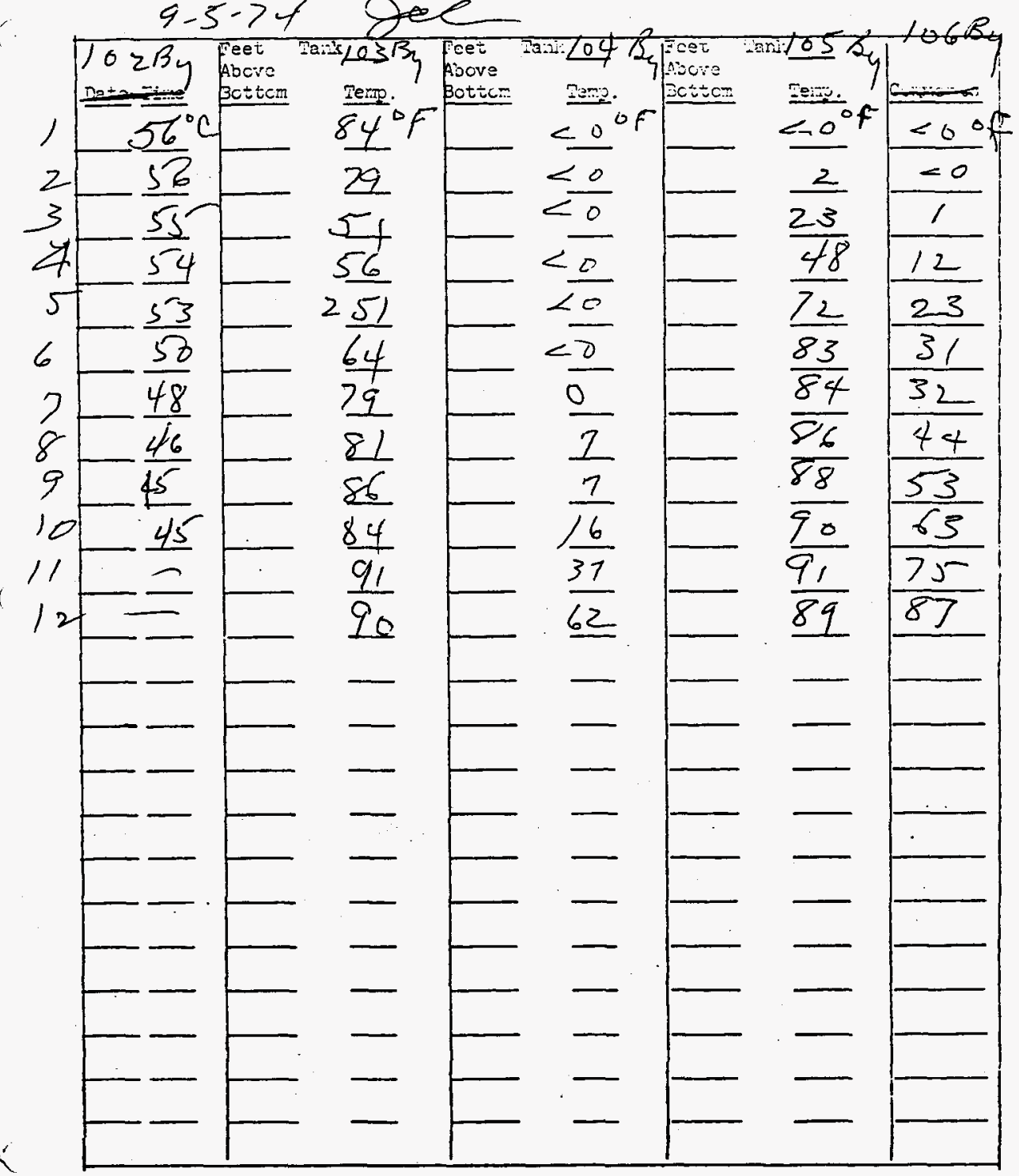

Instructions or cormeits: Tabe proffle terperatires veekly in caci soticis taris. Attaci corpleted form to loncay and Tursday's Data Sincets. 
WHC-SD-LMU-DP-207, ReV. O

Title:

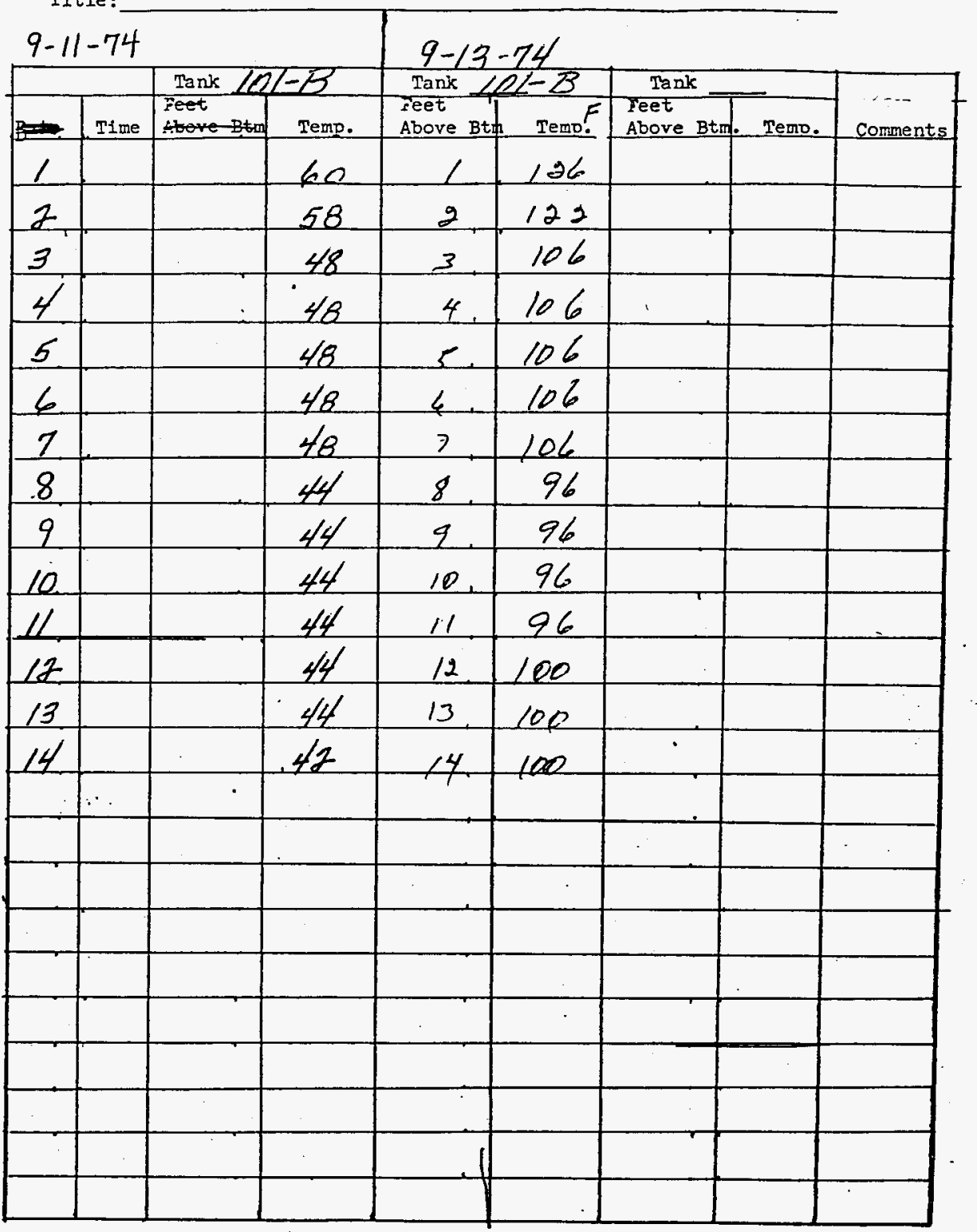

9-11-74 Instructions or comments? Inst, seems to Read about 8 . high, 
Ifle:

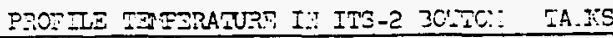

$B Y-7 A R M$

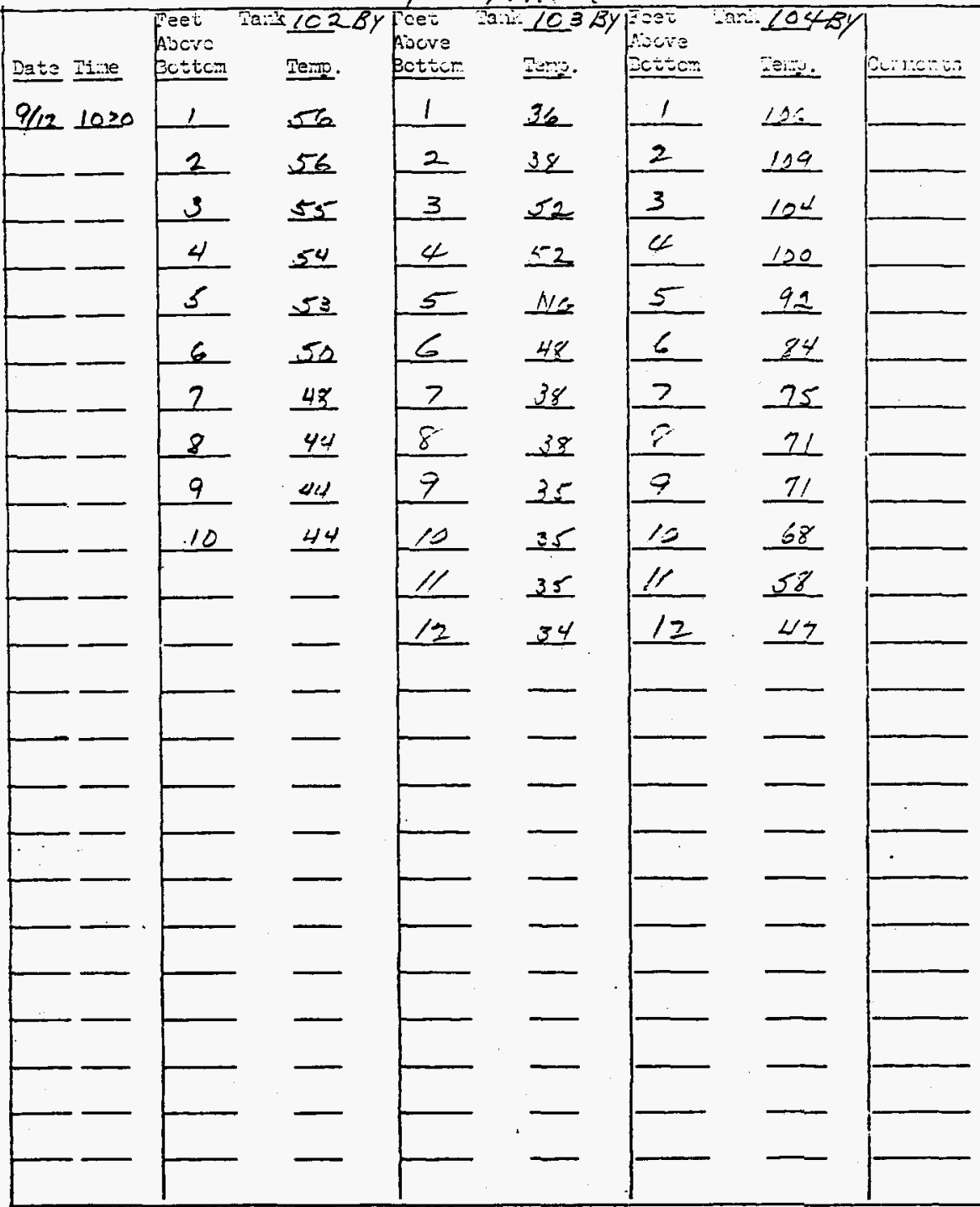

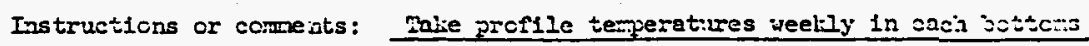
tani. Attach completed fors to Voncay and Fursday's Data Sicets. 
Zitole:

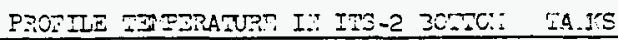

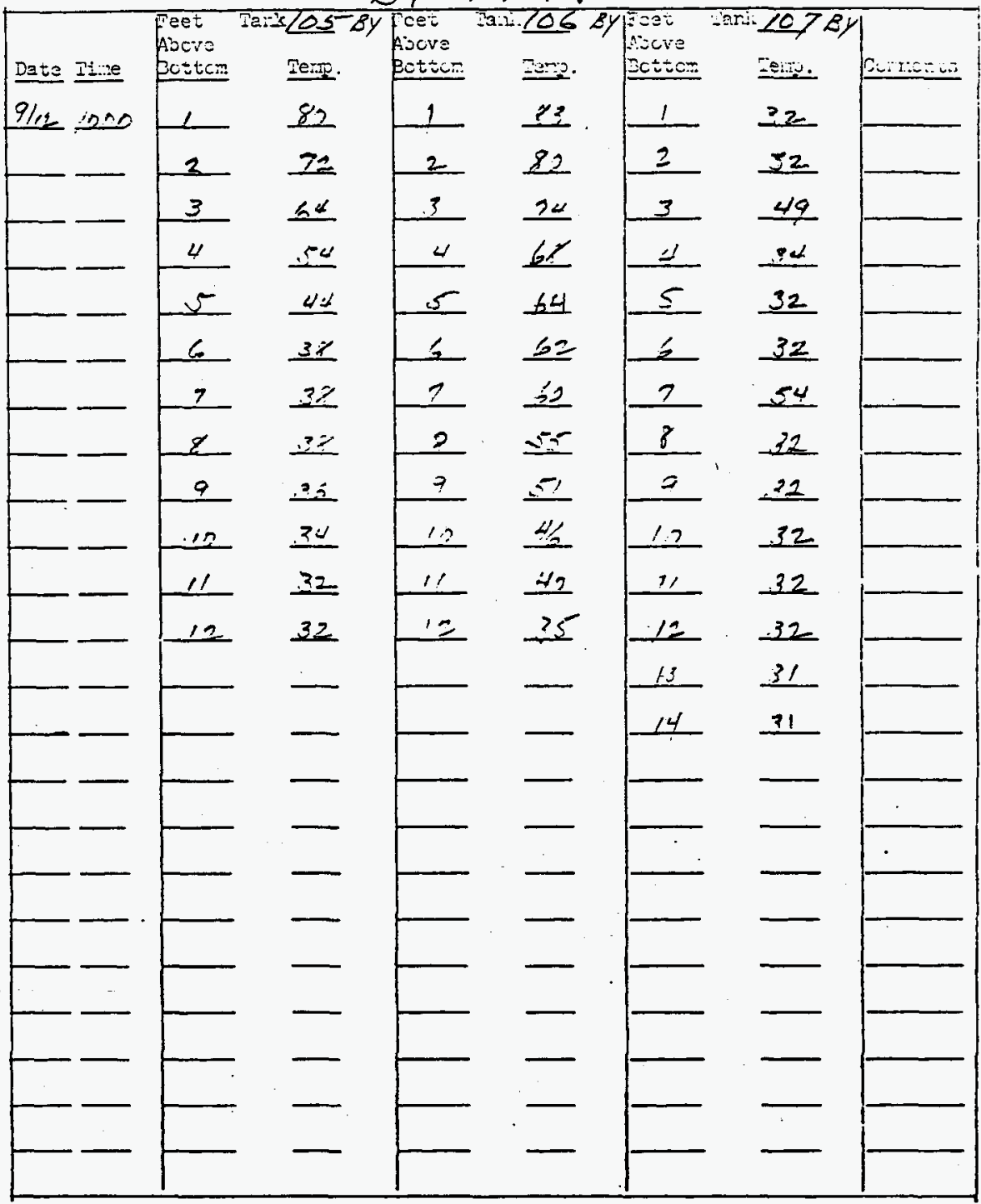

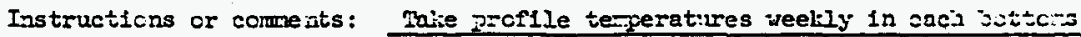
tanit. Attach completec fcrm to licncay and Tausday's Data S.aests. 


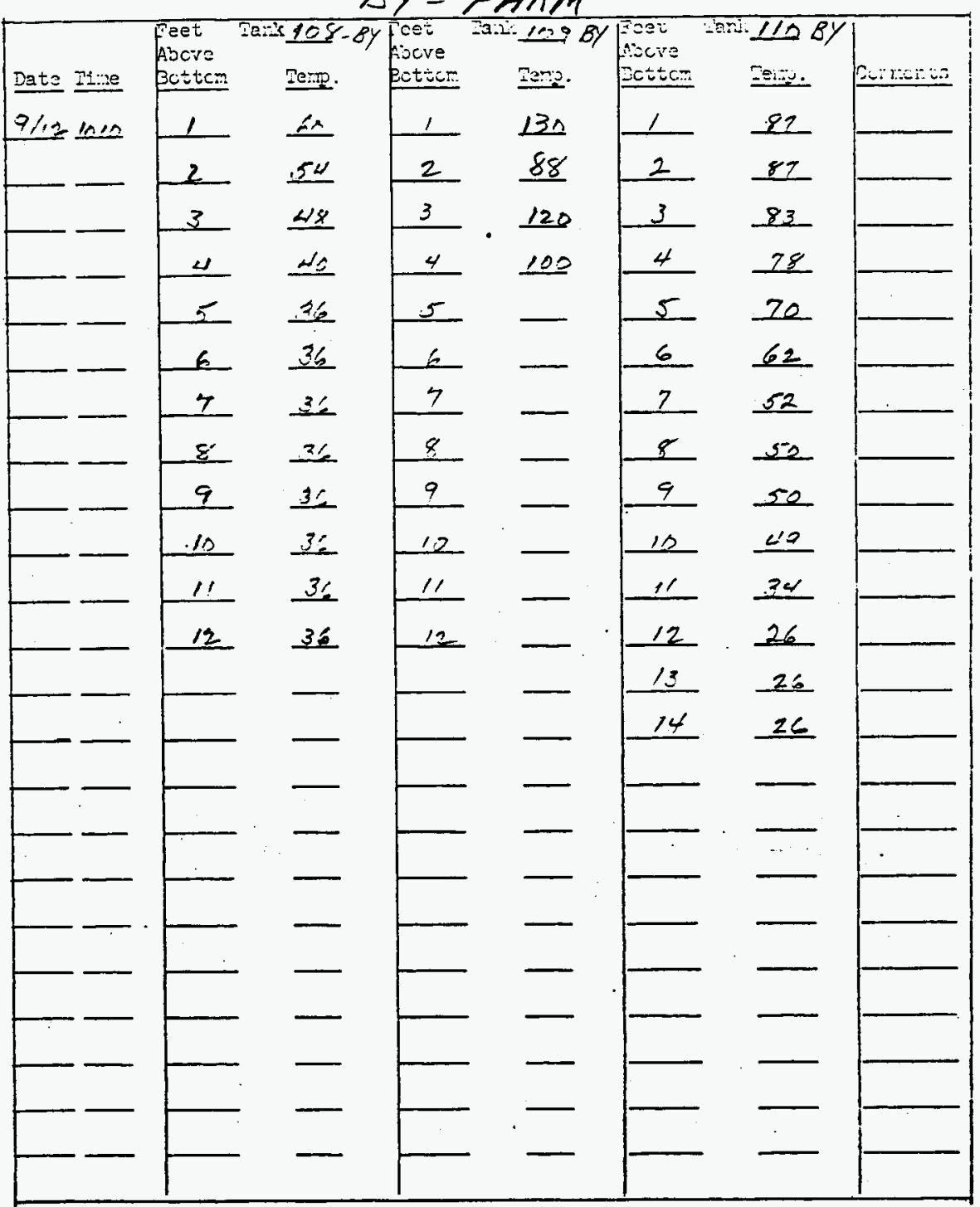

Instructions or cormeats: "Taite proflle temperat:ures weel-ly in eacia sutscis tani. Attach completed form to lioncay and Mursday's Data Sacets. 
Itile:

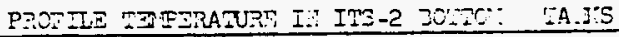

\section{BY - FAPM}

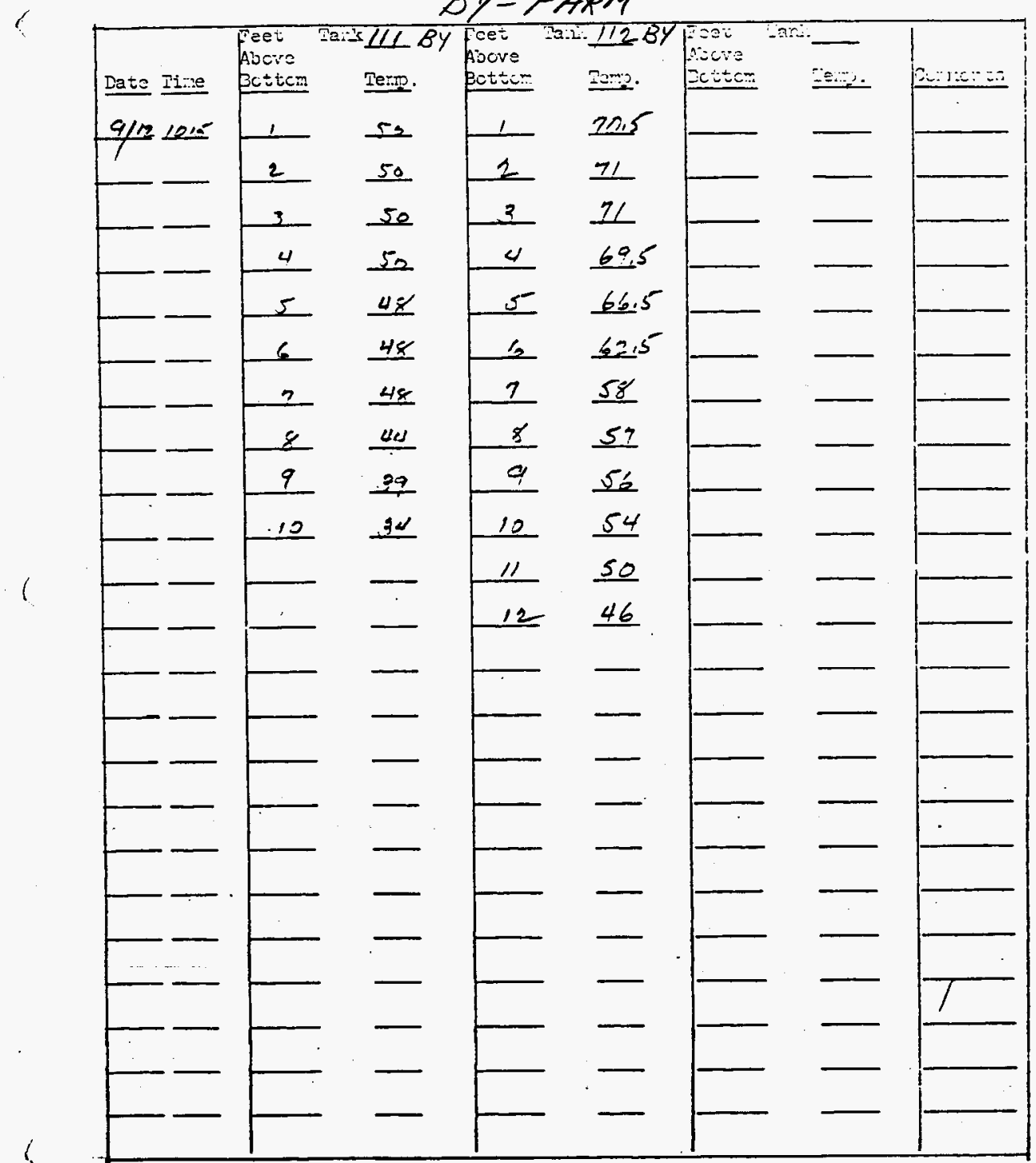

Instruetions or comeats: Taie propile teperat:ues veelily in sacis sotuctis tani. Attach ccosleted fcre tc lionciay and Jursday's Data Srests.

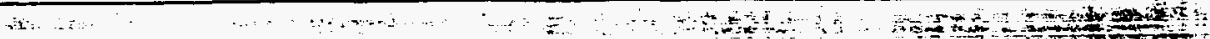


Title:

PROFTIE TERERATURES IN ITS-2 BOTTOMS TANKS

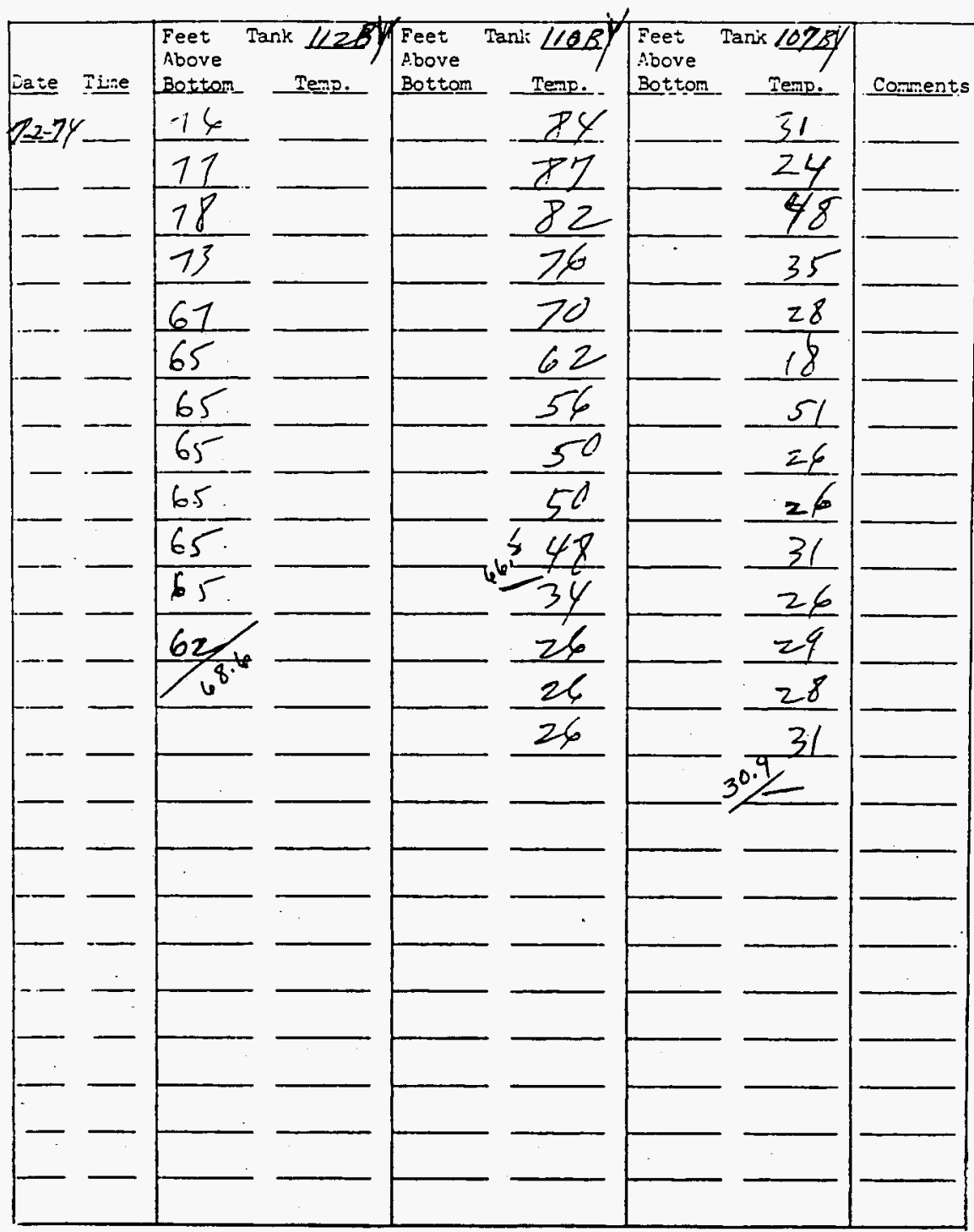

Instratilans ar conments: - Take proflle temperatures reekly in each bottoms tank. Attach conpleted form to Monday and Thursday's Data' Sheets. 
Title: PROFIIE TERPERATURES IN ITS-2 BOTTOMS TAINS

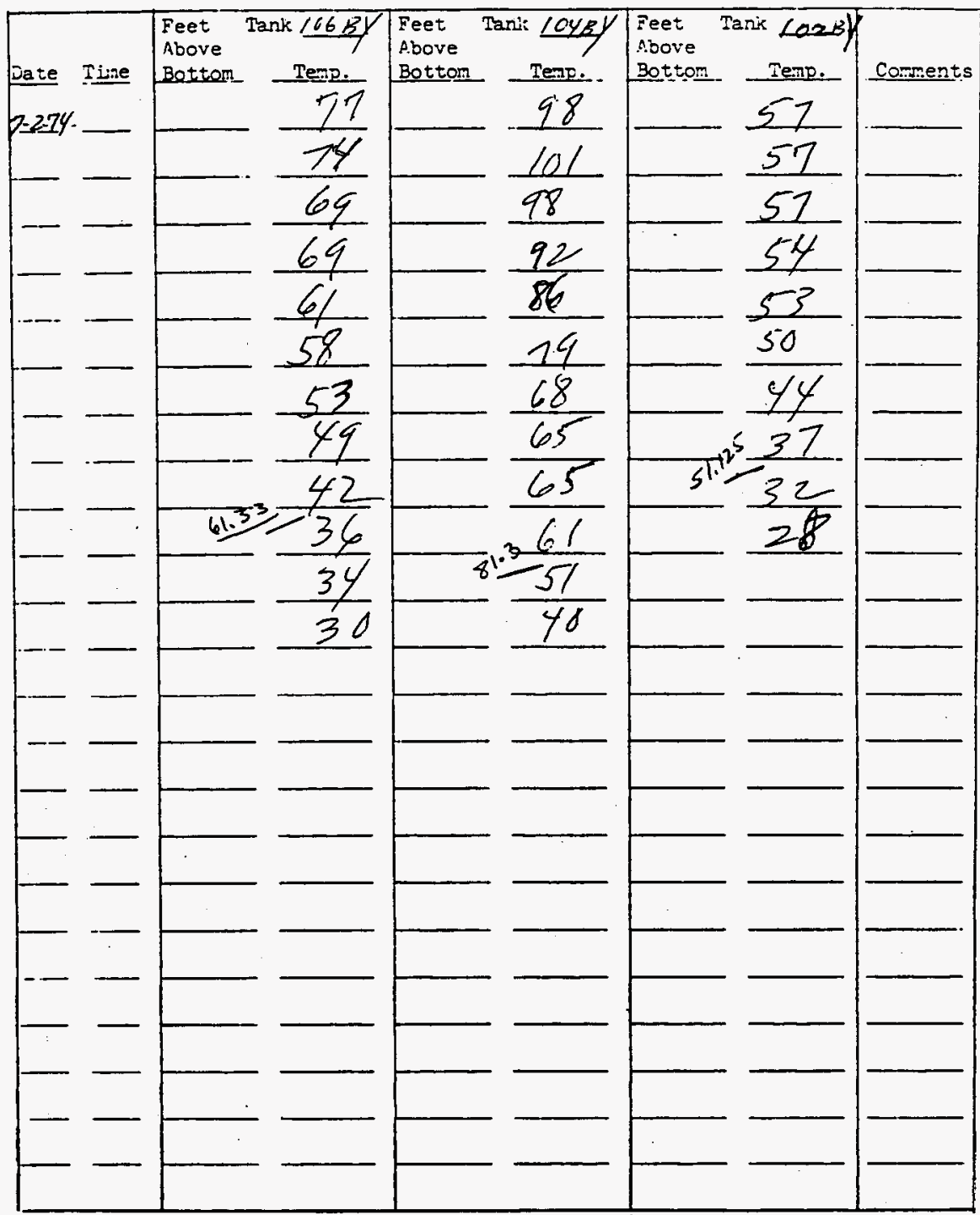

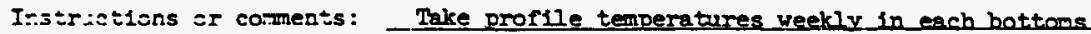


Title:

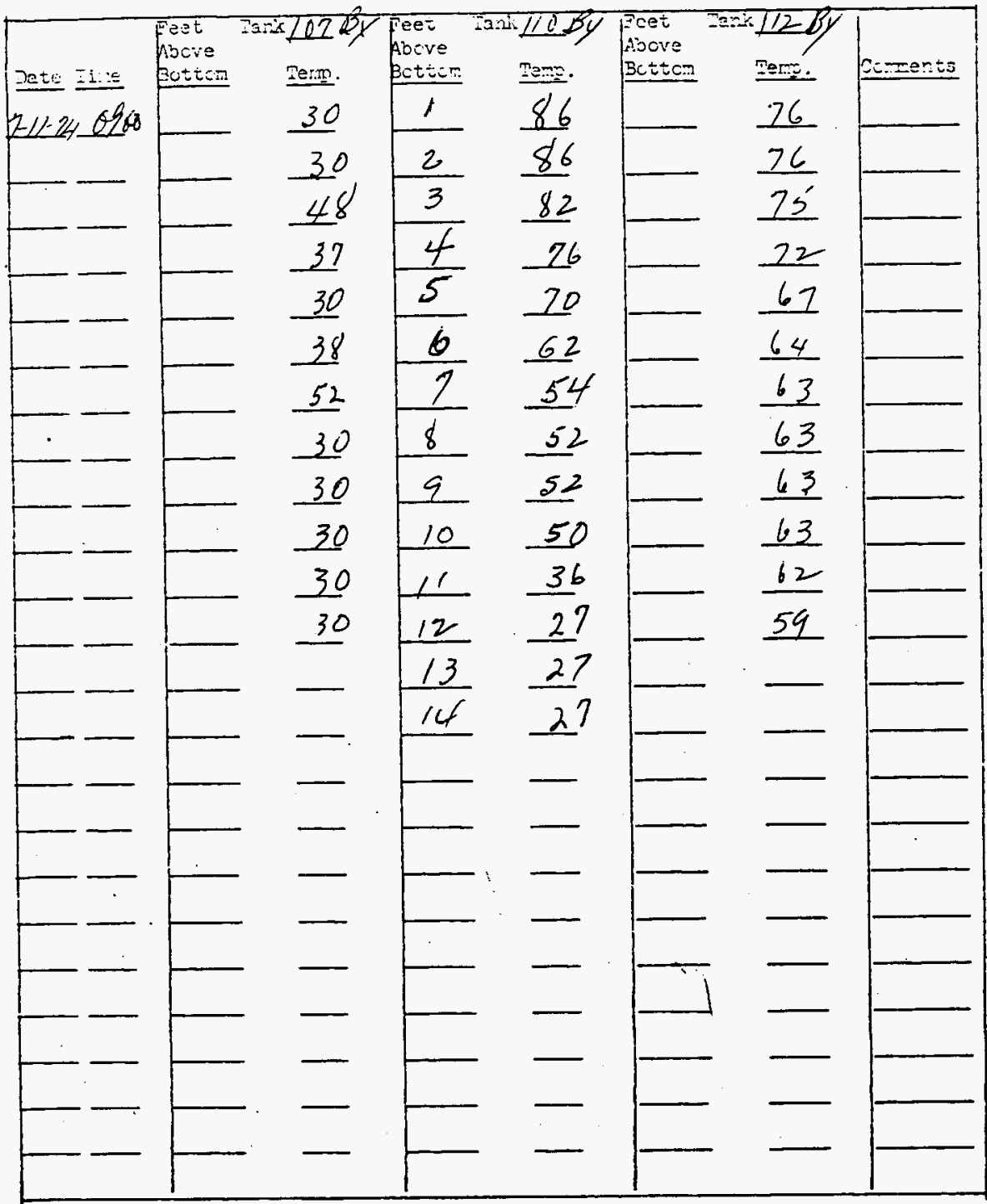

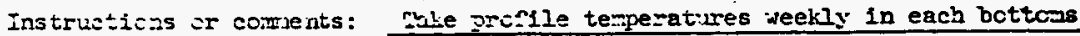
tark. Attaci sompleteu form to Honiey and Thursay's Data Sheets. 


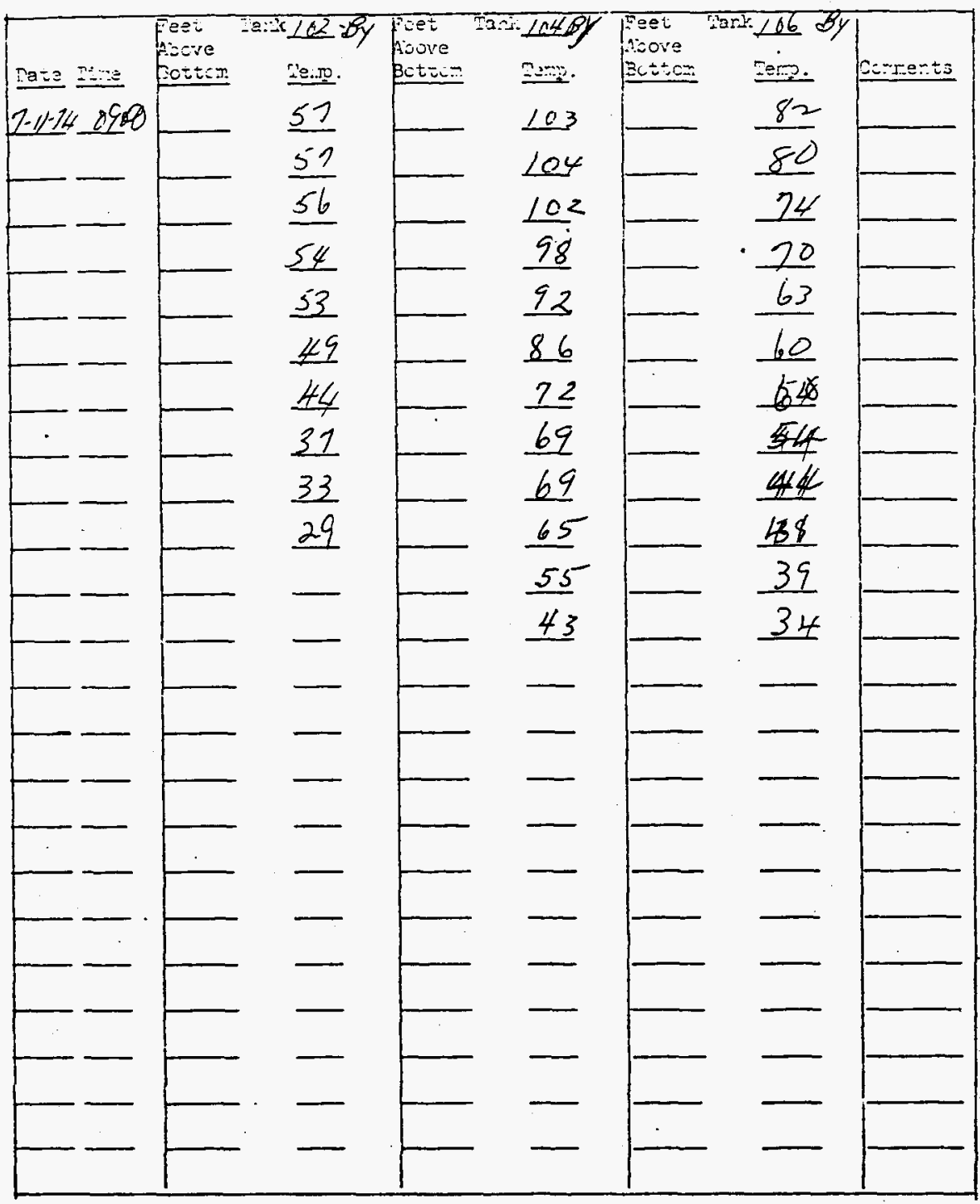

Instructicns cr colments: Thke pacfle temperat:ures weeliy in each bcttcus tani. Atiaci sorpleted form to Kentay and Thursday's Data Sheets. 


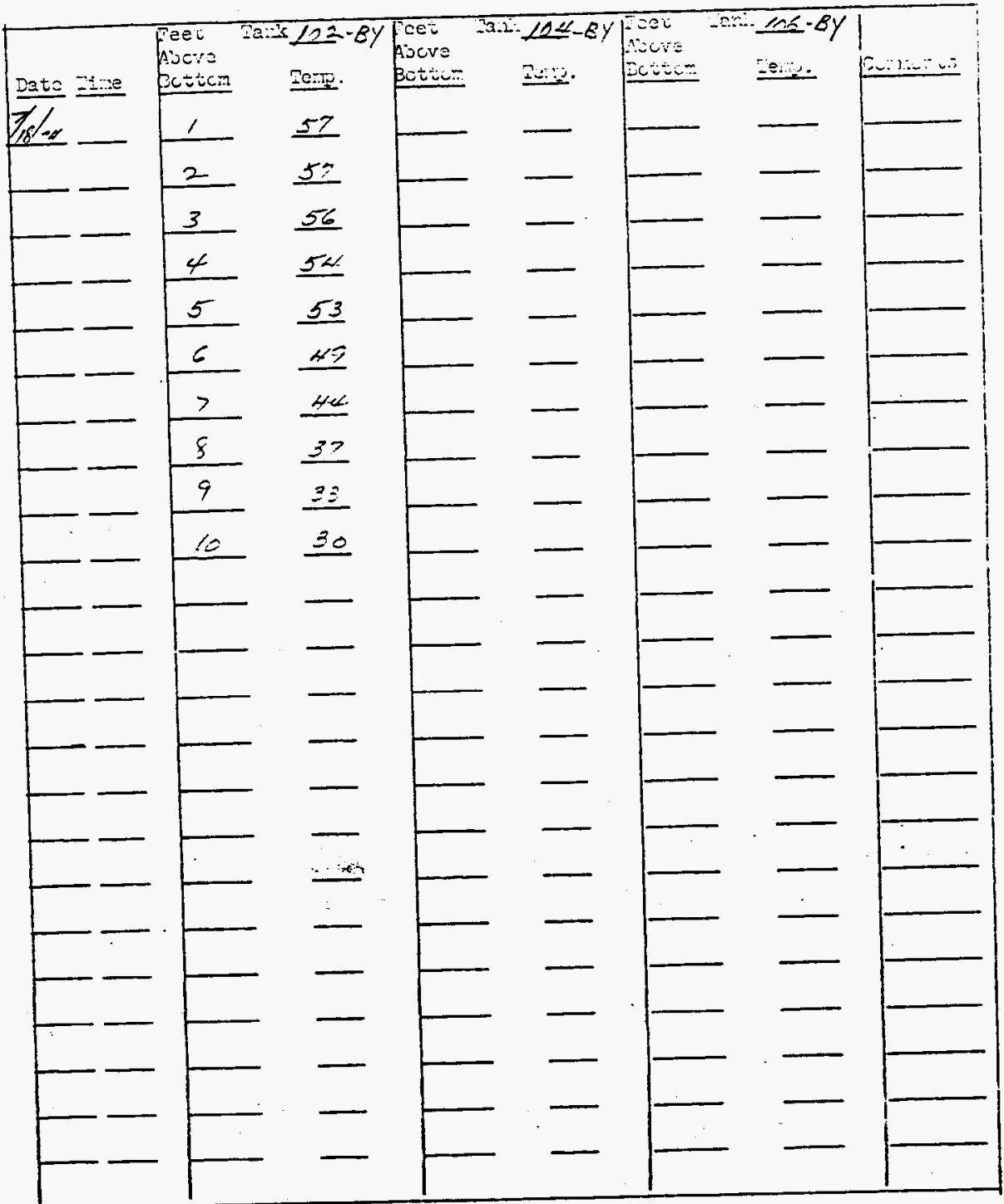

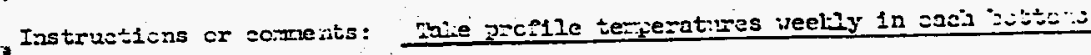
(ton

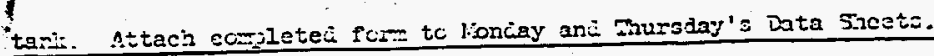




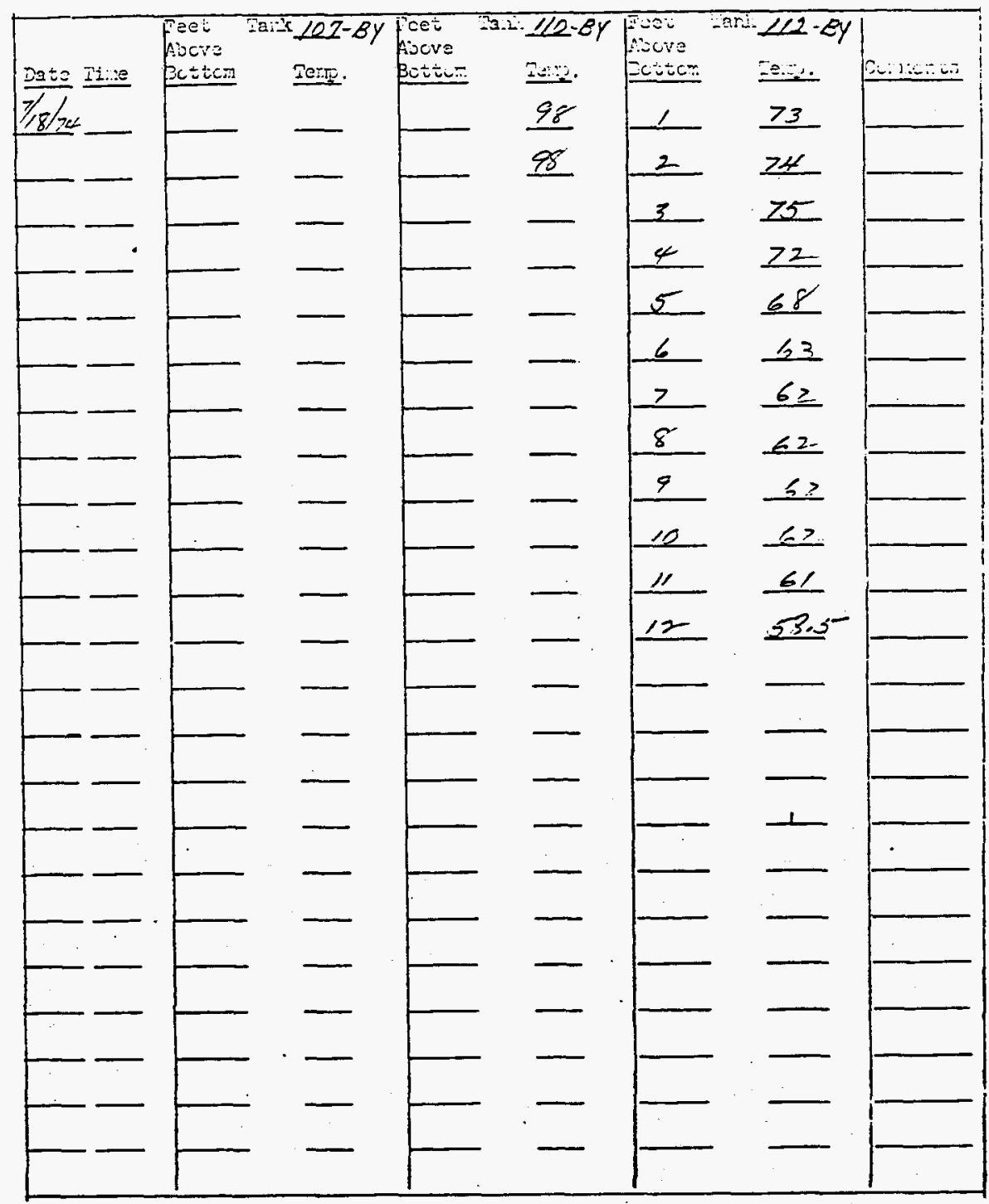

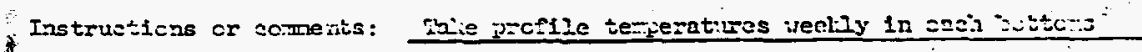




\begin{tabular}{|c|c|c|c|c|c|c|}
\hline \multicolumn{7}{|c|}{ DISTRIBUTION SHEET } \\
\hline To & \multicolumn{4}{|c|}{ From } & \multicolumn{2}{|c|}{ Page 1 of 1} \\
\hline $\begin{array}{l}\text { Remote System and Sensor } \\
\text { Applications }\end{array}$ & \multicolumn{4}{|c|}{$\begin{array}{l}\text { Remote System and Sensor } \\
\text { Applications }\end{array}$} & \multicolumn{2}{|c|}{ Date $7 / 29 / 96$} \\
\hline \multirow{2}{*}{\multicolumn{5}{|c|}{$\begin{array}{l}\text { Project Title Work Order } \\
\text { Sensor/Analytical Techno }\end{array}$}} & \multicolumn{2}{|c|}{ EDT No. 617410} \\
\hline Sensor/Analytical Technology & & & & & \multicolumn{2}{|c|}{ ECN No. } \\
\hline Name & & MSIN & $\begin{array}{c}\text { Text } \\
\text { With All } \\
\text { Attach. }\end{array}$ & Text Only & $\begin{array}{l}\text { Attach./ } \\
\text { Appendix } \\
\text { Only }\end{array}$ & $\begin{array}{l}\text { EDT/ECN } \\
\text { Only }\end{array}$ \\
\hline $\begin{array}{l}\text { H. Babad } \\
\text { W. B. Barton } \\
\text { C. H. Brevick } \\
\text { R. J. Cash } \\
\text { M. D. Crippen } \\
\text { D. R. Dickinson } \\
\text { D. W. Jeppson } \\
\text { N. W. Kirch } \\
\text { D. J. McCain } \\
\text { J. E. Meacham } \\
\text { F. R. Reich } \\
\text { D. A. Reynolds } \\
\text { Central Files (original +1) }\end{array}$ & & $\begin{array}{l}S 7-14 \\
R 2-11 \\
S 3-10 \\
S 7-14 \\
\text { L5-31 } \\
\text { L5-31 } \\
\text { L5-31 } \\
\text { R2-11 } \\
\text { R2-12 } \\
S 7-14 \\
\text { L5-55 } \\
\text { R2- } 11 \\
\text { A3-89 }\end{array}$ & $\begin{array}{l}x \\
x \\
x \\
x \\
x \\
x \\
x \\
x \\
x \\
x \\
x \\
x \\
x\end{array}$ & & & \\
\hline
\end{tabular}

